\title{
WRR
}

WETENSCHAPPELIJKE RAAD VOOR HET REGERINGSBELEID

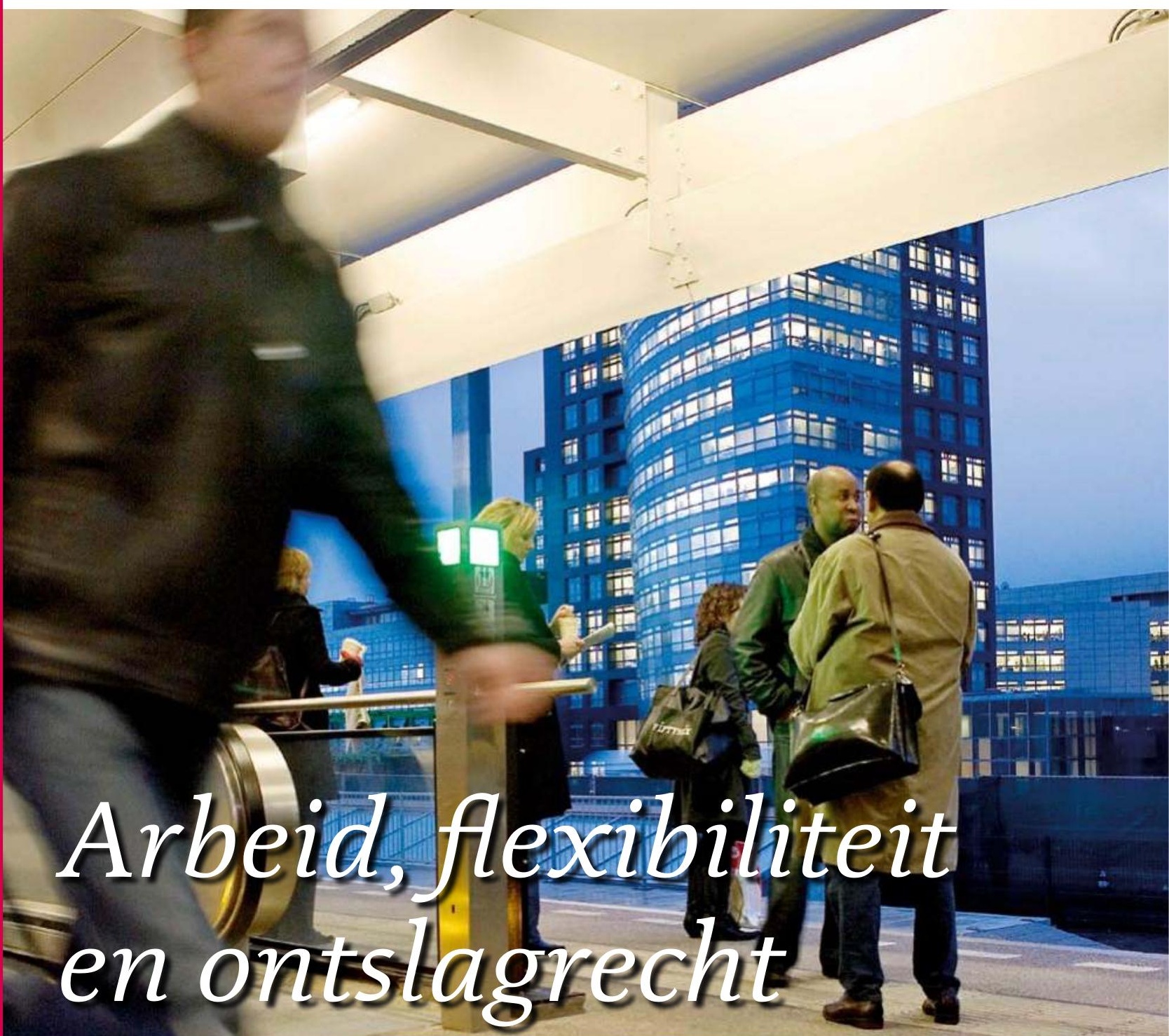


Arbeidsflexibiliteit en ontslagrecht 
De serie 'Verkenningen' omvat studies die in het kader van de werkzaamheden van de WRR tot stand zijn gekomen en naar zijn oordeel van zodanige kwaliteit en betekenis zijn dat publicatie gewenst is. De verantwoordelijkheid voor de inhoud en de ingenomen standpunten berust bij de auteurs.

Wetenschappelijke Raad voor het Regeringsbeleid De WRR is gevestigd:

Lange Vijverberg 4-5

Postbus 20004 2500 EA 's-Gravenhage

Telefoon $070-35646$ oo

Telefax 070-356 4685

E-mail info@wrr.nl

Website http://www.wrr.nl 


\section{Arbeidsflexibiliteit en ontslagrecht}

D. Scheele, J.J.M. Theeuwes en G.J.M. de Vries (red.) 
Omslagfoto: (C) WRR / Chantal Ariëns

Omslagontwerp: Studio Daniëls, Den Haag

Vormgeving binnenwerk: Het Steen Typografie, Maarssen

ISBN $\quad 9789053569931$

NUR $741 / 754$

(C) WRR/Amsterdam University Press, Den Haag / Amsterdam 2007

Alle rechten voorbehouden. Niets uit deze uitgave mag worden verveelvoudigd, opgeslagen in een geautomatiseerd gegevensbestand, of openbaar gemaakt, in enige vorm of op enige wijze, hetzij elektronisch, mechanisch, door fotokopieën, opnamen of enige andere manier, zonder voorafgaande schriftelijke toestemming van de uitgever.

Voor zover het maken van kopieën uit deze uitgave is toegestaan op grond van artikel 16B Auteurswet 1912 jo het Besluit van 20 juni 1974, Stb. 351, zoals gewijzigd bij het Besluit van 23 augustus 1985, Stb. 471 en artikel 17 Auteurswet 1912, dient men de daarvoor wettelijk verschuldigde vergoedingen te voldoen aan de Stichting Reprorecht (Postbus 3051, 2130 KB Hoofddorp). Voor het overnemen van gedeelte(n) uit deze uitgave in bloemlezingen, readers en andere compilatiewerken (artikel 16 Auteurswet 1912) dient men zich tot de uitgever te wenden. 


\section{INHOUDSOPGAVE}

Ten geleide

Arbeidsflexibiliteit en ontslagrecht: een introductie van deze verkenning

Dirk Scheele, Jules Theeuwes en Gerard de Vries

Mobiliteit, interne arbeidsmarkten en arbeidsverhoudingen - naar een nieuwe dynamiek?

Jelle Visser en Marc van der Meer

2.1 Inleiding

2.2. Baanmobiliteit en het Nederlands mobiliteitsregime 18

$\begin{array}{ll}\text { 2.2.1 Bedrijfsdynamiek en mobiliteit } & 18\end{array}$

2.2.2 Baanmobiliteit en economische conjunctuur 19

$\begin{array}{ll}2.2 .3 & \text { Baanwisselingen } 20\end{array}$

$\begin{array}{ll}\text { 2.2.4 Mobiliteitsregimes } & 23\end{array}$

2.3 Veranderende interne arbeidsmarkten en het nieuwe psychologisch $\begin{array}{ll}\text { contract } & 25\end{array}$

2.3.1 Van internalisering naar externalisering als dominante bedrijfs$\begin{array}{ll}\text { strategie } & 25\end{array}$

$\begin{array}{ll}\text { 2.3.2 Interne arbeidsmarkten } & 26\end{array}$

2.3.3 Tijdelijke contracten en uitzendwerk 40

2.3.4 Perceptie van toegenomen baanonzekerheid 42

2.3.5 Gemiddelde of modale baanduur van werknemers 44

2.3.6 Naar een nieuw psychologisch contract? 45

$\begin{array}{ll}2.4 & \text { Beleid ten aanzien van mobiliteit: enkele voorbeelden }\end{array}$

2.4.1 Jongeren: kwetsbaar zonder startkwalificaties 50

2.4.2 Mannen en vrouwen: opleidingsverschillen en uiteenlopende keuzen 51

2.4.3 Laag productieve werknemers en ouderen: over de mogelijkheden van een tijdige loopbaanverandering $\quad 52$

2.5 Conclusies: naar een nieuwe arbeidsverhouding 54

3 Menselijk kapitaal en het proces van creatieve destructie 65

Arie Gelderblom en Jaap de Koning

$\begin{array}{lll}3.1 & \text { Inleiding } & 65\end{array}$

3.2 Werkgelegenheid en menselijk kapitaal: een beschrijvende analyse $\quad 67$

$\begin{array}{ll}\text { 3.2.1 Inleiding } & 67\end{array}$

$\begin{array}{lll}\text { 3.2.2 Indicatoren voor menselijk kapitaal } & 67\end{array}$

$\begin{array}{lll}\text { 3.2.3 Technologie-indicatoren } & 71\end{array}$

$\begin{array}{lll}\text { 3.2.4 Prestatie-indicatoren } & 71\end{array}$

$\begin{array}{lll}3.2 .5 & \text { Indicatoren baanmobiliteit } & 73\end{array}$

$\begin{array}{lll}\text { 3.2.6 Conclusies } & 75\end{array}$ 
3.3 Zijn beter opgeleiden meer opgewassen tegen veranderingen in de arbeidsmarkt?

3.3.1 Inleiding

3.3.2 Het initiële opleidingsniveau

3.3.3 Scholing van werkenden

3.3.4 Scholing van werklozen

3.4 Effecten van menselijk kapitaal op werkgelegenheid en economische groei $\quad 97$

3.4.1 Inleiding

3.4.2 Initieel onderwijs

3.4.3 Scholing van werkenden

102

3.4.4 Scholing van werklozen

105

3.4.5 Conclusies

3.5 Samenvatting en conclusies

108

3.5.1 Samenvatting

108

3.5.2 Gevolgen voor het beleid

112

Bijlage 3.1 volledige tabellen van paragraaf 3.2 met alle landen

126

$4 \quad$ Flexibiliteit en ontslagrecht

131

Alexandra Baris en Evert Verhulp

I SCHOLING EN ONTSLAG

4.1 Kabinetsstandpunt en arbeidsmarktbeleid

4.1.1 Inleiding

4.1.2 WW en ontslagrecht

135

4.1.3 Ontslagbescherming

137

4.1.4 Employability en ontslag

138

4.1.5 Scholing

139

4.1.6 Conclusie

140

Scholing

4.2.1 Inleiding

140

4.2.2 Overheid

140

4.2.3 Sociale partners

142

4.2.4 Werkgevers

146

4.2.5 Werknemers

150

4.2.6 Knelpunten en conclusie

II SCHOLING EN ONTSLAGRECHT

4.3 Het ontslagrecht als stimulans voor scholing $\quad 155$

4.3.1 Ontwikkelingen in het ontslagrecht de afgelopen 25 jaar $\quad 155$

4.3.2 Ontslagrecht en scholing $\quad 156$

$\begin{array}{ll}4.3 .3 \quad \text { Verantwoordelijkheid } & 158\end{array}$

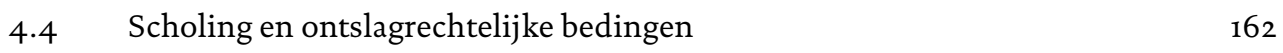

$\begin{array}{lll}4.4 .1 & \text { Inleiding } & 163\end{array}$

$\begin{array}{ll}4.4 .2 & \text { Studiekostenbeding } \\ & 163\end{array}$ 
$\begin{array}{ll}4 \cdot 4 \cdot 3 \text { Concurrentiebeding } & 165\end{array}$

$\begin{array}{ll}\text { 4.4.4 Minimumverblijftijd } & 167\end{array}$

$\begin{array}{ll}4.4 .5 & \text { Conclusie } \\ & 169\end{array}$

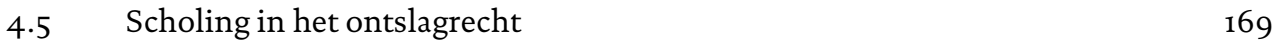

$\begin{array}{lll}4 \cdot 5.1 & \text { Inleiding } & 169\end{array}$

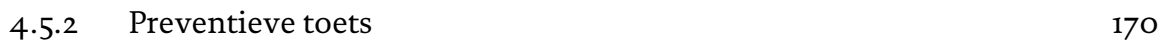

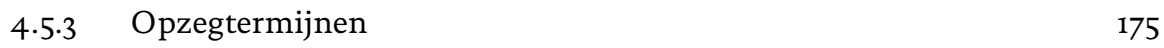

4.5.4 Kennelijk onredelijk ontslag $\quad 178$

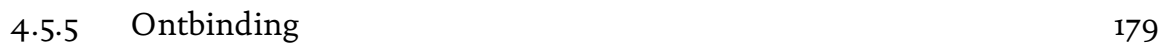

4.5.6 Scholing en ontslagvergoedingen, motie Verburg en Bussemaker $\quad 181$

$\begin{array}{lll}4.5 .7 & \text { Ontslagrecht en Ww } & 182\end{array}$

4.5.8 Naar een activerend ontslagrecht? $\quad 184$

$\begin{array}{lll}4.6 & \text { Conclusies } & 185\end{array}$

$\begin{array}{ll}\text { III ONTSLAGRECHT EN OUDERE WERKNEMERS } & 188\end{array}$

5 Ontslagregels: een rechtseconomische analyse 209

Ann-Sophie Vandenberghe

$\begin{array}{ll}5.1 & \text { Inleiding }\end{array}$

$\begin{array}{ll}5.2 & \text { De rechtseconomische benadering }\end{array}$

5.2.1 De rechtseconomische benadering 212

5.2.2 Typische kenmerken van de arbeidsrelatie 213

$\begin{array}{ll}\text { 5.2.3 Ontslagregimes } & 215\end{array}$

5.3 De rechtseconomische analyse van de regels met betrekking tot de gron-

den voor ontslag 217

5.3.1 Ontslagbescherming en de reallocatie van arbeid via de externe arbeidsmarkt 218

5.3.2 Ontslagbescherming en het gezamenlijke belang van de individuele arbeidspartijen $\quad 224$

5.3.3 Ontslagbescherming en het algemene en sociale zekerheidsbelang 229

5.3.4 Versoepeling ontslagrecht 232

5.4 De rechtseconomische analyse van ontslagvergoedingen 235

5.4.1 De huidige Nederlandse regels met betrekking tot de ontslag-

$$
\text { vergoeding } 235
$$

5.4.2 Economische veranderingen en de kosten van ontslag 236

5.4.3 Ontslagvergoedingen als substituut voor de collectieve werkloosheidsverzekering $\quad 237$

5.4.4 De ontslagvergoeding als vergoeding voor het verlies aan relatiespecifieke investeringen

5.4.5 De ontslagvergoeding als vergoeding voor het verlies aan uitgestelde beloning 241

5.4.6 De ontslagvergoeding als spaarsysteem 242

5.4.7 Beoordeling van de Nederlandse regels met betrekking tot de 242 ontslagvergoeding

$\begin{array}{ll}5.5 & \text { Conclusies en aanbevelingen } \\ & 244\end{array}$

$\begin{array}{lll}\text { 5.5.1 Conclusies } & 251\end{array}$

5.5.2 Aanbevelingen 253 
6 Arbeidsmarktinstituties en arbeidsmarktdynamiek 261

Michèle Belot en Jan van Ours

$\begin{array}{lll}6.1 & \text { Inleiding } & 261\end{array}$

$\begin{array}{lll}6.2 & \text { Globale empirie } & 262\end{array}$

6.2.1 Arbeidsmarktinstituties $\quad 263$

$\begin{array}{lll}6.3 & \text { Arbeidsmarktprestaties } & 269\end{array}$

6.3.1 Werkgelegenheid en werkloosheid 269

6.3.2 Groei, baancreatie en baanvernietiging 272

6.3.3 Arbeidsmarktinstituties en arbeidsmarktprestaties $\quad 275$

6.4 Arbeidsmarktinstituties - theoretisch en empirisch onderzoek 277

6.4.1 Afzonderlijke instituties en reallocatie $\quad 278$

6.4.2 Combinatie van instituties $\quad 286$

6.4.3 Instituties, arbeidsmarktdynamiek en welvaart $\quad 287$

$\begin{array}{ll}\text { 6.5. Perspectief op instituties en dynamiek } & 289\end{array}$

Bijlage 6.1 294

$\begin{array}{ll}\text { Over de auteurs } & 295\end{array}$ 


\section{TEN GELEIDE}

De voor $\mathrm{u}$ liggende studies zijn verricht ter onderbouwing van het WRR-advies Investeren in werkzekerheid. De vraag die voor heeft gelegen betreft de mogelijkheden van de Nederlandse arbeidsmarkt om zich aan te passen aan een steeds veranderlijker omgeving. In dat verband zijn allereerst de studies van Arie Gelderblom en Jaap de Koning en die van Michèle Belot en Jan van Ours verricht. Is het kennisniveau van de beroepsbevolking adequaat en zijn de arbeidsmarkt-instituties verstarrend? De studie van Jelle Visser en Marc van der Meer is verricht om een kennislacune te dichten over de relatie tussen interne en externe arbeidsmarkten. Zijn aanpassingen via de interne arbeidsmarkt functioneel equivalent met aanpassingen via de externe arbeidsmarkt? De studies van Ann-Sophie Vandenberghe en van Alexandra Baris en Evert Verhulp concentreren zich op de arbeidsmarktinstitutie van het ontslagrecht. De laatstgenoemde auteurs onderzoeken nauwgezet de relatie die tussen scholing en het ontslagrecht gelegd kan worden.

De projectgroep die de voorbereiding van het advies Investeren in werkzekerheid heeft voorbereid, is de auteurs van de voorliggende studies dankbaar voor de inspirerende discussies die bij de totstandkoming van de teksten zijn gevoerd. Het advies heeft zeer kunnen profiteren van de inzichten die naar voren zijn gebracht. De studies bieden een goede inleiding op de thema's flexibiliteit, scholing en ontslagrecht. Rond deze thema's is er een samenhang en vullen de studies elkaar aan. De raad wil door middel van deze uitgave de studies voor een breder publiek toegankelijk maken.

Prof. dr. Wim van de Donk Voorzitter WRR 


\title{
ARBEIDSFLEXIBILITEIT EN ONTSLAGRECHT: EEN INTRODUCTIE VAN DEZE VERKENNING
}

\author{
Dirk Scheele, Jules Theeuwes en Gerard de Vries
}

Ingrijpende veranderingen op de productmarkten dwingen tot veranderingen in de inzet van arbeid. Arbeidsflexibiliteit stelt bedrijven en instellingen in staat om de inzet van arbeid te laten meebewegen met de onrust op productmarkten waarop zij zich waar moeten maken. Die arbeidsflexibiliteit ontstaat niet vanzelf. Het arbeidsaanbod kan aan flexibiliteit winnen door het opdoen van arbeidsvaardigheden door scholing en ervaring. Het is daardoor beter in staat om zich aan te passen aan veranderende omstandigheden. Het arbeidsaanbod kan ook tot flexibiliteit gebracht worden door aanpassingen in de arbeidsmarktinstituties. Ontwikkelingen in het arbeidsrecht brengen werknemers ertoe om meer oog te hebben voor de toekomst van hun loopbaan en voor de kansen die zich in de loop van de tijd voordoen. In het bijzonder is het ontslagrecht van invloed op de flexibiliteit van werknemers.

In deze WRR-verkenning brengen we onderzoeksrapporten samen die als achtergrond en inspiratie hebben gediend bij het schrijven van WRR-advies Investeren in werkzekerheid. Drie kernbegrippen staan centraal in deze verkenning: flexibiliteit, scholing en ontslagrecht. Flexibiliteit vormt de aanleiding om na te denken over scholing en ontslagrecht. De studie van Visser en Van der Meer vormt daarom een startpunt (hoofdstuk 2). Zij verkennen de verandering in de dominante bedrijfsstrategie waaruit de noodzaak voor meer flexibiliteit naar voren komt. Een vervolgvraag is hoe deze flexibiliteit tot stand gebracht kan worden. Scholing of breder genomen employability wordt dikwijls naar voren geschoven als middel om de flexibiliteit van arbeid te verhogen. In de tweede opgenomen studie verkennen Gelderblom en De Koning de relatie tussen de versterking van het menselijk kapitaal en de mogelijkheid van werknemers om zich daardoor op de arbeidsmarkt staande te houden (hoofdstuk 3). Ook Baris en Verhulp hebben het over scholing. Hun studie is als derde opgenomen (hoofdstuk 4). Het huidige ontslagrecht laat kansen onbenut om flexibiliteit op de arbeidsmarkt te creëren en tegelijkertijd zekerheid voor de werknemer overeind te houden. Baris en Verhulp verkennen door een juridische bril de relatie tussen scholing en het ontslagrecht. Vervolgens wordt in deze verkenning geheel ingezoomd op het ontslagrecht. In de vierde studie neemt Vandenberghe voor de individuele werknemer en werkgever de werking van het ontslagrecht onder de loep, dit keer vanuit een economische invalshoek (hoofdstuk 5). In de laatste studie verkennen Belot en Van Ours ten slotte in samenhang met andere arbeidsmarktinstituties de gevolgen van het ontslagrecht voor macro-economische grootheden zoals de werkgelegenheid en de dynamiek op de arbeidsmarkt (hoofdstuk 6).

De gedachte dat de inspanningen die de werkgever doet om de inzetbaarheid van de werknemer te verbeteren, gevolgen moet hebben voor de ontslagbescherming, is een thema waar met name de bijdrage van Baris en Verhulp aan raakt. 
Visser en Van der Meer zijn op zoek naar veranderingen in de relatie tussen de interne en de externe mobiliteit op de arbeidsmarkt. Vinden er merkbare veranderingen plaats? Zij maken aannemelijk dat er een verschuiving heeft plaatsgevonden in de dominante bedrijfsstrategie. Terwijl in de vorige eeuw de bedrijfsstrategie vooral gericht was op internalisering van de relevante processen om de onzekerheid in de omgeving te beheersen (ontstaan van verticale geïntegreerde onderneming), is vanaf de jaren tachtig van de vorige eeuw de dominante bedrijfsstrategie in de richting gegaan van externalisering (ontstaan van op kernactiviteiten gerichte netwerkonderneming). Er worden bedrijfsonderdelen en -activiteiten afgestoten en er vinden veranderingen plaats in de interne aansturing van bedrijfsonderdelen. Deze veranderingen hebben gevolgen voor de mobiliteit van de werknemer. Het 'impliciete contract' tussen werkgevers en werknemers, waarbij baanzekerheid wordt geboden in ruil voor loyaliteit en inzet, komt onder druk te staan. De erosie van de interne arbeidsmarkt lijkt haar intrede te hebben gedaan. Aanwijzingen daarvoor zoeken zij in de groei van tijdelijke contracten en uitzendwerk, in de perceptie van baanonzekerheid en in de ontwikkeling van de modale baanduur.

De omslag in de dominante bedrijfsstrategie heeft op tal van terreinen gevolgen voor de arbeidsverhoudingen. Automatismen in beloningssystemen worden ter discussie gesteld. De positie van de vakbonden is enorm veranderd. De oude verhouding tussen insiders en outsiders komt onder druk te staan. De vraag naar arbeidsvaardigheden is aan verandering onderhevig. Met inachtneming van beduidende internationale verschillen is er een beweging in de richting van een brede competentieontwikkeling. In het nieuwe psychologische contract tussen werkgevers en werknemers neemt de werkgever verantwoordelijkheid om zijn werknemer te ondersteunen in zijn loopbaanontwikkeling, ook wanneer die buiten het bedrijf zelf zal plaatsvinden. Hij biedt daarvoor gelegenheid tot scholing en tot deelname aan relevante netwerken. De praktijk van dit nieuwe psychologische contract is nog verre van uitontwikkeld. In een open kenniseconomie is het noodzakelijk om regelingen te treffen over de beschikkingsrechten op voorheen opgedane kennis. Visser en Van der Meer identificeren groepen die onder de nieuwe arbeidsverhoudingen een kwetsbare positie lijken in te nemen: jongeren zonder startkwalificaties, laagproductieve werknemers en oudere werknemers. Ook vrouwen kunnen door beroepssegregatie of door een geringe verticale doorstroom in een nadelige positie verkeren. Al met al suggereren de beschikbare arbeidsmarktstatistieken geen einde van de vaste aanstelling. Wel ontstaat er een nieuwe arbeidsverhouding waarin het onderhoud van de arbeidskwalificatie primair als een eigen verantwoordelijkheid van de werknemer wordt gezien. De werkgever heeft daarbij de secundaire verantwoordelijkheid en dient tijd en middelen beschikbaar te stellen voor het onderhoud van de arbeidvaardigheden van de werknemer en van diens brede inzetbaarheid. De overheid heeft hiervoor ten slotte voorwaardenscheppende verantwoordelijkheden.

Gelderblom en De Koning stellen de vraag aan de orde of werknemers door scholingsinspanningen beter gewapend zijn wanneer de noodzaak van mobiliteit op de arbeidsmarkt zich voordoet. In vergelijking met andere oEso-landen scoort Nederland evenmin als zijn directe buurlanden hoog als kenniseconomie. Er valt 
hier winst te boeken. Gelderblom en De Koning vinden positieve effecten van het initiële opleidingsniveau op de kans om zich op de arbeidsmarkt staande te houden. Ook bedrijfsopleidingen hebben een positief effect op de arbeidsmarktkansen. Scholing vergroot de kans op interne mobiliteit en verkleint de kans om werkloos te worden. Deze bevindingen lijken ook voor oudere werknemers te gelden. Toch volgen oudere werknemers minder vaak een bedrijfsopleiding. De vraag of scholing van werklozen eveneens een positief effect heeft op hun arbeidsmarktkansen wordt door de beschikbare studies vaker positief dan negatief beantwoord. Op de lange termijn zijn eventuele positieve effecten echter gering. Een tweede vraag die Gelderblom en De Koning aan de orde stellen is in hoeverre een beter opgeleide beroepsbevolking leidt tot meer economische groei, meer innovatie en meer werkgelegenheid. Het positieve inkomensrendement van onderwijs dat uit micro-economisch onderzoek naar voren komt, is waarschijnlijk gerelateerd aan het positieve verband tussen onderwijs en productiviteit dat uit macro-economisch onderzoek blijkt. Minder duidelijk is dat een grotere voorraad menselijk kapitaal leidt tot een hogere groei van de productiviteit. Gelderblom en De Koning beëindigen hun bijdrage met de opmerking dat investeringen in scholing nooit geheel kunnen voorkomen dat werknemers werkloos worden.

Baris en Verhulp constateren in een bijdrage vanuit een juridische invalshoek dat ontslagrecht en scholing hoog op de politieke agenda staan. Er bestaat druk om het ontslagrecht te versoepelen zonder dat daarmee een afwenteling op de ww ontstaat. De scholing van de bevolking moet worden bevorderd, niet alleen ter voorkoming van werkloosheid maar ook ter stimulering van de kenniseconomie. Zij benadrukken de onderlinge samenhang van arbeidsmarktinstituties en van scholingsarrangementen. De overheid richt zich in haar verantwoordelijkheid voor postinitiële scholing vooral op de scholing voor werkzoekenden. Daarnaast zijn ook middelen uitgetrokken voor de scholing van werkende personen. Naast de overheid worden in het overleg tussen werkgevers en werknemers middelen vrijgemaakt voor scholing. Deze middelen zijn hoofdzakelijk gericht op de scholing van werkende personen. Het blijkt dat aan gemaakte afspraken over scholing in de praktijk nog weinig vervolg wordt gegeven. Baris en Verhulp zien ondanks de bezwaren die hiertegen bestaan ook voordelen van meer dwingend rechtelijke regelingen voor scholing. Zij bespreken de verantwoordelijkheden die de sociale partners kunnen nemen op dit vlak. Een interessante mogelijkheid om werknemers tot eigen regie over hun loopbaan aan te zetten is hen de beschikking te geven over overdraagbare scholingsgelden. Van een postcontractuele zorgplicht van de werkgever voor zijn werknemer is in het huidige ontslagrecht althans voor langere tijd geen sprake. Hooguit bestaat er oog voor een zorgplicht in het kader van situaties waarin de dreiging van ontslag manifest is. Het is volgens Baris en Verhulp denkbaar dat met het oog op scholing en employability van werknemers bij cao wordt afgeweken van de preventieve ontslagtoets. Een marginaal ingevulde bezwaarprocedure onder verantwoordelijkheid van de sociale partners zou de scholing door werknemers afdwingbaar moeten maken. Bij gegrond bezwaar zou dan voor het concrete geval de mogelijkheid van afwijking bij cao vervallen. 
De invulling van een 'zoekperiode' na opzegging van de arbeidsrelatie met een scholingsverplichting maakt volgens Baris en Verhulp weinig kans. Daarvoor zou nodig zijn dat de ontslagvergoeding bij een dergelijke regeling wordt betrokken.

Vandenberghe gaat in een rechtseconomische benadering in op de doelmatigheid van het ontslagrecht. Zij behandelt daarbij afzonderlijk de doelmatigheid van het ontslag en de doelmatigheid van de ontslagvergoeding. De doelmatigheid van een ontslag hangt gegeven een bepaald loonniveau af van de productiviteit van een werknemer in zijn huidige baan en van de productiviteit in een alternatieve baan. Daarnaast worden er voor de beëindiging van een arbeidsrelatie transactiekosten gemaakt. Vandenberghe komt met een voorstel voor een arbeidsovereenkomst voor onbepaalde tijd met de vrijheid om de overeenkomst eenzijdig op te zeggen. Hier kan een beding mee verbonden zijn dat de werkgever de werknemer helpt zoeken naar een nieuwe baan. Vanwege de vrijheid om de overeenkomst eenzijdig op te zeggen kan er geen schadevergoeding worden gevraagd voor het beëindigen van de arbeidsrelatie. Vanuit rechtseconomisch perspectief is er een aantal redenen om een ontslagvergoeding toe te kennen aan ontslagen werknemers. Het motief dat de werknemer zijn productiviteit in belangrijke mate ontleent aan bedrijfsspecifieke investeringen en dat ontslag inbreuk maakt op de verdiencapaciteit van de werknemer, staat daarbij centraal. De vraag is hoe de werknemer het best tegen een inkomstenderving als gevolg van ontslag verzekerd kan zijn. Vandenberghe plaatst een verzekering via het systeem van ontslagvergoedingen tegenover een verzekering via eigen besparingen en bespreekt hier de voor- en nadelen van.

Belot en Van Ours bespreken de beïnvloeding van de flexibiliteit van de arbeidsmarkt door het ontslagrecht in samenhang te bezien met de effecten van een aantal andere arbeidsmarktinstituties. Met name kijken zij naar het wettelijk minimumloon, de werkloosheidsverzekering en het activerend arbeidsmarktbeleid. Zij concluderen dat van al deze arbeidsmarktinstituties het minimumloon het minst van invloed is op de arbeidsmarktflexibiliteit. De groep die er door geraakt wordt is betrekkelijk klein. Het activerend arbeidsmarktbeleid heeft de meeste invloed op de arbeidsmarktflexibiliteit. De werkloosheidsverzekering en het ontslagrecht nemen een tussenpositie in. Belot en Van Ours vergelijken combinaties van arbeidsmarktinstituties van een aantal landen in termen van hoge en lage niveaus. In Nederland zijn de genoemde instituties royaal bemeten en in de Verenigde Staten is het tegengestelde het geval. Opvallend is dat op één uitzondering na de arbeidsmarktprestaties (werkgelegenheidsgroei, langdurige werkloosheid, werkgelegenheidsgraad van ouderen) zowel in de Verenigde Staten als in Nederland hoog zijn. Die uitzondering betreft de langdurige werkloosheid in Nederland. Deze ligt op een hoog niveau, zij het dat er de laatste tijd een daling gerealiseerd is.

Theoretisch wordt verwacht dat ontslagbescherming een negatief effect heeft op de reallocatie van banen. Inefficiënte banen blijven lang bestaan en nieuwe banen worden minder snel geschapen. Empirisch onderzoek wijst vooral op een effect van ontslagbescherming op de baancreatie. Een hoog niveau van ontslagbescher- 
ming leidt ertoe dat minder snel nieuwe banen worden geschapen, dat de toetreding van nieuwe bedrijven minder snel plaatsvindt en dat werknemers langer werkloos blijven. De langdurige werkloosheid in Nederland in vergelijking met die in de Verenigde Staten heeft dus mogelijk te maken met het hoge niveau van ontslagbescherming. 

NIEUWE DYNAMIEK?

\author{
Jelle Visser en Marc van der Meer ${ }^{1}$
}

\title{
$2.1 \quad$ INLEIDING
}

Mobiliteit is eigen aan de arbeidsmarkt. Elke maand zoeken nieuwkomers een plek, veranderen mensen van baan bij dezelfde of een andere werkgever, beginnen ze een eigen bedrijf, gaan bedrijven failliet, gaan mensen al of niet vervroegd met pensioen, worden ze werkloos of arbeidsongeschikt en zo verder. Dit essay analyseert de aard en omvang van deze dynamiek en de instituties en het beleid die haar beïnvloeden. We richten ons met name op drie hoofdvragen. (1) Hoe dynamisch, rechtvaardig en efficiënt werkt het Nederlandse mobiliteitsregime? (2) In hoeverre staan 'interne arbeidsmarkten' en het 'psychologisch contract' van duurzame arbeidsrelaties onder druk en wat komt ervoor in de plaats? (3) Hoe kan bevorderd worden dat meer mensen halverwege hun werkzame leven aan een tweede carrière beginnen?

Dit essay beperkt zich in hoofdzaak tot de mobiliteit van werknemers die van baan veranderen bij dezelfde (interne mobiliteit) of bij een andere werkgever, dan wel voor zichzelf beginnen (externe mobiliteit). Deze baanmobiliteit bestrijkt maar een deel van de totale arbeidsmarktdynamiek, die immers ook de stromen omvat van mensen die de arbeidsmarkt verlaten of betreden en mensen die werkloos worden of werk vinden. Daarmee zullen we ons zijdelings bezighouden, voor zover het met baanmobiliteit verband houdt. Met name de relatie tussen de dynamiek (groei en krimp, oprichting en ondergang) van bedrijven, bedrijfstakken en beroepen enerzijds en de interne en externe baanmobiliteit is van belang. Nieuwe en groeiende bedrijven, beroepen en bedrijfstakken scheppen nieuwe kansen voor promotie en banen voor buitenstaanders; verdwijnende en krimpende bedrijven, beroepen en bedrijfstakken dwingen tot omschakeling en duwen mensen naar buiten. Idealiter vindt omschakeling plaats via interne en externe baanmobiliteit, zonder werkloosheid, met behoud van capaciteiten en zonder voortijdig vertrek van de arbeidsmarkt. Er zijn vele institutionele en beleidsmatige factoren die dat kunnen beïnvloeden. In hun vergelijkende studie van mobiliteitsregimes noemen DiPrete e.a. (1997) er vier: (1) de aanwezigheid van schotten tussen de 'interne' arbeidsmarkten van bedrijven, beroepen of bedrijfstakken; (2) de mate van ontslagbescherming; (3) de inkomenssteun voor werknemers die de arbeidsmarkt (voortijdig) verlaten; en (4) de mate waarin werknemers ondersteund worden bij het zoeken naar nieuwe banen.

Deze instituties en hun gevolgen voor baanmobiliteit komen in het vervolg van dit essay aan de orde. Na een kort overzicht van de aard en omvang van de mobiliteit in Nederland, typeren we het institutionele mobiliteitsregime in ons land in 
vergelijking met andere landen en gaan we in op enkele gevolgen van dat regime. Vervolgens richten we onze blik op de interne arbeidsmarkt en bezien we de mate waarin deze per bedrijf, bedrijfstak of beroep is afgeschermd van de werking van vraag en aanbod op de externe arbeidsmarkt. Na een korte bespreking van het hoe en waarom van interne arbeidsmarkten traceren we enkele kenmerkende internationale verschillen en veranderingen. De centrale gedachte is dat het 'impliciete contract' van baanzekerheid in ruil voor gemiddelde of voldoende prestatie dat aan de standaardarbeidsverhouding ten grondslag lag aan het verdwijnen is, maar dat het nog niet zo duidelijk is wat daarvoor in de plaats komt. Wat lossere arbeidsrelaties en grotere multi-inzetbaarheid bij eigen en vooral andere werkgevers (employability) voor het psychologische en juridische contract tussen werknemers en werkgevers betekent, lijkt bij de partijen zelf allerminst duidelijk en die onduidelijkheid kan nieuw beleid met betrekking tot ontslagbescherming, employability, vernieuwing van de arbeidsverhoudingen en scholing in de weg staan. We sluiten af met een antwoord op onze laatste vraag, over de mogelijkheden van een tweede carrière en de instituties die bij zo'n overstap of transitie kunnen helpen. In dat verband bezien we afzonderlijk de positie van enkele groepen die het moeilijk hebben op de arbeidsmarkt en deze vaak vroegtijdig verlaten. Door het hoofdstuk heen zullen we een vergelijking maken met instituties en ontwikkelingen in arbeidsmarkten in andere landen, in het bijzonder de Verenigde Staten, het Verenigd Koninkrijk, Denemarken, Zweden, Duitsland, Frankrijk en Japan.

\subsection{BAANMOBILITEIT EN HET NEDERLANDS MOBILITEITSREGIME}

\subsubsection{BEDRIJFSDYNAMIEK EN MOBILITEIT}

Interne en externe baanmobiliteit hangen nauw samen met de bedrijfsdynamiek, bedrijven die komen en gaan, opgericht worden of ophouden, krimpen of groeien. De Amsterdamse arbeidsmarkt in 2004 kan als voorbeeld dienen. Op het eerste gezicht was er sprake van stilstand. Op een totaal van 410.264 banen van twaalf uren per week en meer in januari 2004 kwamen er dat hele jaar niet meer dan 74 banen bij. Daarachter gaat echter een aanzienlijke dynamiek schuil van 37.650 nieuwe banen en 37.576 die verdwenen. Tweederde van de nieuwe banen ontstond door uitbreiding bij ruim 3.500 bedrijven, terwijl eenderde het gevolg was van de komst of oprichting van liefst 5 .00o nieuwe doorgaans zeer kleine bedrijven of bedrijfsvestigingen. Bij de banen die verdwenen zien we het omgekeerde: van de banen die verdwenen was tweederde het gevolg van sluiting of vertrek van 4.660 bedrijven of vestigingen uit Amsterdam, terwijl eenderde het gevolg was van krimp bij 3.262 bedrijven of vestigingen. ${ }^{2}$ Aan de bewegingen op de arbeidsmarkt ligt dus een aanzienlijke dynamiek van bedrijven ten grondslag. Uit deze cijfers valt verder af te leiden dat de Amsterdamse economie - wellicht typisch voor de media, kunsten, informatica en commerciële dienstenmarkt? wordt gekenmerkt door kleine bedrijven (gemiddeld 2,6 werknemers). In Nederland als geheel zijn er in 200467.000 nieuwe bedrijven (starters en dochterondernemingen) opgericht, een stijging van 15 procent ten opzichte van 2003 . Bij 
deze startende bedrijven werken per bedrijf gemiddeld 1,4 personen. De overlevingskansen van bedrijven zijn de afgelopen decennia vrij stabiel gebleven, ongeveer 93 procent overleeft het eerste jaar en 70 procent bestaat drie jaar later nog. In hetzelfde jaar 2004 verdwenen 47.400 bedrijven door vertrek naar het buitenland, overname of beëindiging. De nieuw opgerichte bedrijven waren verantwoordelijk voor een totaal van 119.000 nieuwe banen, terwijl de werkgelegenheid als geheel in 2004 kromp met 129.000 banen. Het merendeel van de banen ging verloren als gevolg van personeelskrimp bij bestaande bedrijven (Verhoeven et al. 2005). Dankzij de enquêtes van de Organisatie voor Strategisch Arbeidsmarktonderzoek (OSA) en het Centraal Bureau voor de Statistiek (CBS) bij bedrijven en huishoudens beschikken we over flink wat gegevens over baanmobiliteit. Het Sociaal en Cultureel Planbureau heeft verschillende OsA-data bijeengebracht in de studie Arbeidsmobiliteit in goede banen (Gesthuizen en Dagevos 2005). Daaruit blijkt dat over een periode van twee jaar van alle mensen die zijn blijven werken, bijna driekwart (64,1 procent) dit bij de dezelfde werkgever en in dezelfde functie doet; 11,7 procent heeft een andere functie binnen hetzelfde bedrijf gekregen en 17,3 procent is overgestapt naar een andere werkgever. Uit diezelfde gegevens blijkt dat bijna vier van de vijf werknemers die van baan wisselen aangeven dit vrijwillig te doen, terwijl 21,5 procent van de werknemers zegt daartoe gedwongen te zijn. Desgevraagd zegt volgens het arbeidsaanbodpanel van 2004 ongeveer tien procent van alle werknemers dat zij 'op zoek zijn naar een andere baan'. Dat geldt vooral voor jongeren en werknemers tot 35 jaar en voor werknemers met een hogere opleiding. Als motief wordt opgeven de wens om meer of juist minder uren te willen werken, een hoger loon, meer carrièremogelijkheden en betere aansluiting bij eigen opleiding of capaciteiten. Bij oudere werknemers speelt bij de wens naar een andere baan de verwachting dat de bestaande baan zal verdwijnen.

\subsubsection{BAANMOBILITEIT EN ECONOMISCHE CONJUNCTUUR}

De baanmobiliteit wordt sterk beïnvloed door de economische conjunctuur (zie figuur 2.1). In de voorbije vijftien jaren werden de hoogste cijfers voor de totale baanmobiliteit bereikt in jaren van hoogconjunctuur (1989-1990 en 1999-2000) terwijl het dieptepunt bij de korte recessie van 1993-1994 lag. Ook in de recente recessie (2002-2004) daalde de mobiliteit. Bij economische voorspoed stijgt de werkgelegenheid, gaan veel werknemers op zoek naar een betere 'match' (een baan die past bij hun capaciteiten, betere beloning, minder reistijd, enz.) en neemt vooral de externe mobiliteit toe. In goede tijden verandert jaarlijks gemiddeld ruim een op de tien werknemers van werkgever, terwijl dit in slechte tijden daalt tot een op de zestien. In een groeiende economie gaat ook de interne mobiliteit iets omhoog, onder meer omdat uitbreidende bedrijven meer promotiemogelijkheden zullen bieden, waardoor ook de kansen voor externe mobiliteit (voor werknemers van andere bedrijven en uiteraard voor nieuwkomers) stijgen. Bij economische tegenwind daalt de (vrijwillige) externe mobiliteit en lijkt het motto: blijf zitten waar je zit. Bij een conjuncturele omslag kan aanvankelijk de interne mobiliteit nog wat toenemen. Als werknemers vanwege ontslagbescher- 
ming moeilijk kunnen worden ontslagen en geen reden hebben vrijwillig te vertrekken naar banen die er niet zijn, zal er wellicht naar nieuw werk binnen de bestaande arbeidsorganisatie gezocht worden. Vooral aan het begin van een recessie, als er onzekerheid bestaat of de economie weer zal aantrekken, kan het oppotten van arbeid (labour hoarding) een rationele bedrijfsstrategie zijn om waardevol personeel vast te houden. Het kan ook duiden op het bestaan van een interne arbeidsmarkt die door haar regels enigermate van de buitenwereld, lees: de externe arbeidsmarkt van vraag en aanbod, is afgeschermd. Over de interne arbeidsmarkt straks meer. Nadere beschouwing van figuur 2.1 suggereert overigens wel dat dit effect in de recent recessie na 2001 veel geringer was dan in 1991. Destijds ging de scherpe daling in externe mobiliteit nog gepaard met een groeiende interne mobiliteit, terwijl in de recente periode de interne mobiliteit eerder en scherper daalde dan de externe mobiliteit. Dat zou kunnen wijzen op een afname van de betekenis van interne arbeidsmarkten.

Figuur 2.1 Interne en externe mobiliteit in Nederland 1987-2002

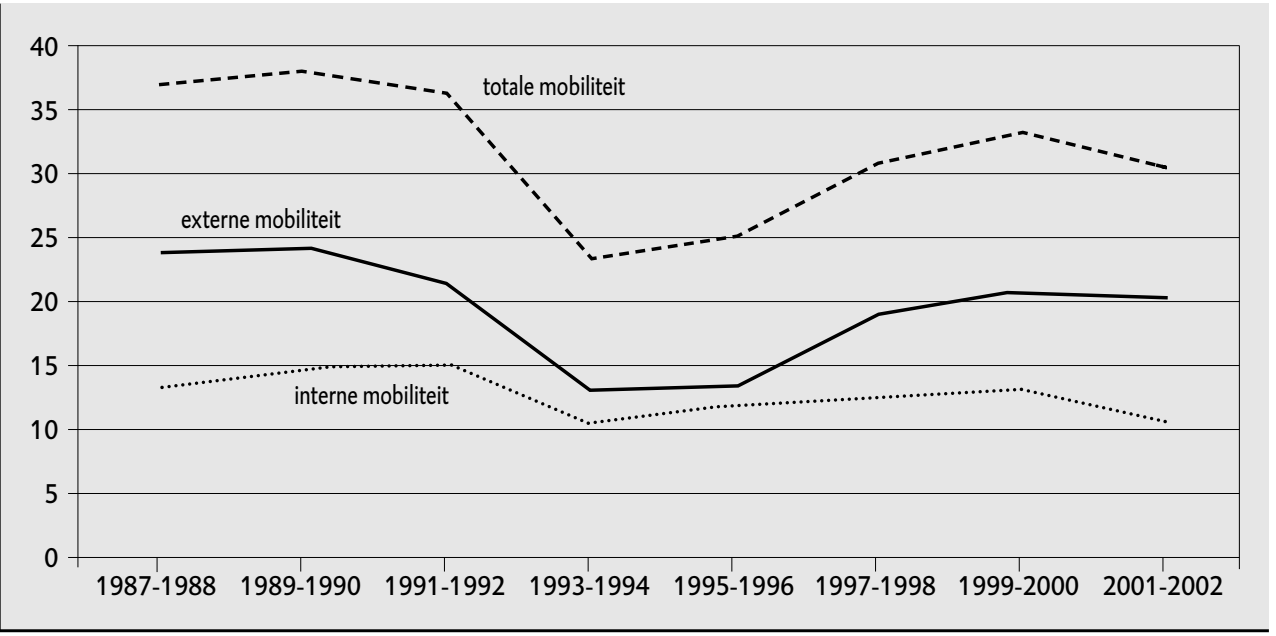

Bron: OsA (Arbeidsaanbodpanel 1988, 1990, 1992, 1994, 1996, 1998, 2000 en 2002)

Bron: Gesthuizen en Dagevos 2005

\subsubsection{BAANWISSELINGEN}

Uit figuur 2.1 blijkt ook dat over een periode van vijftien jaar gemiddeld genomen zowel de interne als de externe mobiliteit enigszins is gedaald. Deze trend naar minder mobiliteit staat haaks op veel beschouwingen over 'het einde van de vaste baan' en de 'ondernemende werknemer' die steeds op zoek zou zijn naar nieuwe uitdagingen. Ook de gegevens over de gemiddelde duur van banen duiden op stabiliteit. Dit gemiddelde is in de genoemde periode licht gestegen (zie tabel 2.1) en suggereert dat, gemiddeld genomen, werknemers over een werkend leven van veertig jaren vier keer van baan veranderen. Met dit gemiddelde bevindt Nederland zich in de middenmoot: in de Verenigde Staten wisselt een werknemer zes of zeven keer van baan, het dubbele van Japan. Met andere Europese landen 
vergeleken is de dynamiek in Nederland geringer dan in het Verenigd Koninkrijk en Denemarken, maar groter dan in Duitsland, Frankrijk of Zweden. Ook het aandeel van werknemers die 20 jaar of langer bij dezelfde werkgever in dienst zijn - bijna twaalf procent in 1995 - is in Nederland hoger dan in de vs of in het Verenigd Koninkrijk, maar vergelijkbaar met Denemarken en beduidend lager dan in Duitsland, Frankrijk, Zweden of Japan. Het aandeel van contracten van korte duur, van zes maanden of minder, lag in 1995 net onder tien procent, hoger dan in Zweden, Duitsland of Japan, even hoog als in Frankrijk of Engeland, lager dan in de vs en vooral lager dan in Denemarken. Uit deze cijfers komt Nederland als middenmoter tevoorschijn als het gaat om banendynamiek.

Tabel 2.1

Baanwisselingen, internationale cijfers

\begin{tabular}{|c|c|c|c|c|c|c|c|c|c|}
\hline & & NL & DK & $\mathbf{S}$ & D & $\mathbf{F}$ & UK & US & $J$ \\
\hline \multicolumn{10}{|l|}{ Gemiddelde baanduur } \\
\hline \multirow[t]{2}{*}{ werknemers (in jaren) } & 2000 & 9,9 & 8,4 & 11,5 & 10,7 & 11,3 & 8,1 & 6,6 & 12,2 \\
\hline & $\Delta 1992-2000$ & 1,0 & $-0,4$ & 1,0 & 0,0 & 0,9 & 0,0 & 0,1 & 1,3 \\
\hline \multicolumn{10}{|l|}{ Aandeel contracten } \\
\hline 20 jaar of langer & 1995 & 11,9 & 11,4 & 17,0 & 17,0 & 18,7 & 9,4 & 9,0 & 21,4 \\
\hline \multicolumn{10}{|l|}{ Aandeel contracten } \\
\hline 6 maanden en korter & 1995 & 9,8 & 15,5 & 8,6 & 7,9 & 10,1 & 10,5 & 12,6 & 7,0 \\
\hline
\end{tabular}

Bron: Bewerking gegevens OESO

Dankzij de OSA-data beschikken we ook over gegevens over gedwongen en vrijwillige, interne en externe mobiliteit voor groepen werknemers met verschillende kenmerken. De cijfers in tabel 2.2 zijn berekend over de hele periode 1986-2002.

Gemiddelden kunnen grote verschillen verbergen en doen dat in dit geval ook (zie tabel 2.2). Jongeren veranderen veel vaker van baan dan ouderen en willen ook vaker veranderen. Bijna eenderde van alle werkenden onder de 25 jaar met een baan van ten minste 12 uur per week wisselt binnen twee jaar minimaal eenmaal van werkgever. De externe mobiliteit daalt naarmate men ouder wordt; boven de 45 jaar wisselt, gerekend over twee volle jaren, nog slechts zeven procent van de werknemers van baan. Per jaar ligt dit in de buurt van 1 op de 30 werknemers, vergeleken met 1 op de 6 baanwisselaars onder jongeren. Het is dus heel goed mogelijk dat de langzame afname van de externe baanmobiliteit, zoals weergegeven in figuur 2.1, samenhangt met het ouder worden van de werkende bevolking en dat de komende vergrijzing een nog grotere afname van de externe mobiliteit zal betekenen. Deze daling geldt vooral voor de vrijwillige mobiliteit. Tabel 2.2 laat zien dat de vrijwillige mobiliteit juist in de categorie boven de 35 jaar afneemt en in de leeftijdsgroep van $45-54$ het laagst is. In de nog oudere groep is de vrijwillige mobiliteit weer wat hoger, mogelijk een selectie-effect, omdat lager opgeleiden en mensen met weinig kansen de arbeidsmarkt dan al hebben verlaten. Indien dit scenario juist is en vergrijzing de externe baan mobi- 


\begin{tabular}{|c|c|c|c|c|c|}
\hline & $\begin{array}{r}\text { Totale } \\
\text { mobiliteit }\end{array}$ & $\begin{array}{r}\text { Interne } \\
\text { mobiliteit }\end{array}$ & $\begin{array}{r}\text { Externe } \\
\text { mobiliteit }\end{array}$ & $\begin{array}{r}\text { Gedwongen } \\
\text { mobiliteit }\end{array}$ & $\begin{array}{l}\text { Vrijwillige } \\
\text { mobiliteit }\end{array}$ \\
\hline \multicolumn{6}{|l|}{ Geslacht } \\
\hline Man & 24.9 & 11.9 & 12.7 & 22.0 & 78.0 \\
\hline Vrouw & 31.4 & 12.4 & 18.4 & 20.8 & 79.2 \\
\hline \multicolumn{6}{|l|}{ Leeftijd } \\
\hline $16-24$ jaar & 43.9 & 10.8 & 32.5 & 23.7 & 76.3 \\
\hline 25-34 jaar & 34.8 & 14.8 & 19.6 & 17.3 & 82.7 \\
\hline 35-44 jaar & 27.3 & 12.9 & 14.0 & 20.6 & 79.4 \\
\hline 45-54 jaar & 17.0 & 8.9 & 7.9 & 32.7 & 67.3 \\
\hline $55-65$ jaar & 15.4 & 9.6 & 5.7 & 25.0 & 75.0 \\
\hline \multicolumn{6}{|c|}{ Hoogst voltooide opleiding } \\
\hline Basisonderwijs & 19.1 & 7.5 & 11.6 & 35.7 & 64.3 \\
\hline Vbo, mavo & 25.3 & 10.5 & 14.5 & 23.5 & 76.5 \\
\hline Mbo, havo, vwo & 30.7 & 13.5 & 16.7 & 20.1 & 79.9 \\
\hline Hbo & 28.6 & 14.5 & 13.4 & 17.1 & 82.9 \\
\hline Wo & 30.4 & 13.9 & 15.5 & 18.8 & 81.3 \\
\hline \multicolumn{6}{|c|}{ Cursussen (zelf betaald) } \\
\hline Niet beëindigd & 26.8 & 12.0 & 14.4 & 22.0 & 78.0 \\
\hline Wel beëindigd & 33.5 & 13.2 & 19.8 & 15.9 & 84.1 \\
\hline \multicolumn{6}{|c|}{ Cursussen (werkgever betaalt) } \\
\hline Niet beëindigd & 26.6 & 11.0 & 15.1 & 22.2 & 77.8 \\
\hline Wel beëindigd & 29.9 & 16.0 & 13.6 & 19.6 & 80.4 \\
\hline
\end{tabular}

Noot: Totale mobiliteit $(\mathrm{N}=10.217$ ) en interne en externe mobiliteit $(\mathrm{N}=10.178)$, berekend per twee jaar, gemiddelden voor panels van 1985-6 tot 2001-2, uitgedrukt in procenten van het aantal werkenden in loondienst. Bron: Bewerking OsA gegevens, Gesthuizen en Dagevos, 2005

liteit verder zal afremmen, zal dit extra reden zijn voor extra ondersteuning, door vertrek van de arbeidsmarkt minder aantrekkelijk te maken en werknemers door middel van scholing, oriëntatie en begeleiding beter op een plaats buiten de organisatie voor te bereiden. Onderwijs en deelname aan cursussen tijdens het werk zijn gunstig voor zowel de interne als externe mobiliteit en voor de vrijwilligheid van de keuze om naar een andere baan of werkgever op zoek te gaan. Er spelen waarschijnlijk ook selectie-effecten, die maken dat mensen die meer gericht zijn op mobiliteit eerder deelnemen aan scholing en er sterker op gericht zijn een begonnen cursus te voltooien.

Interne en externe mobiliteit werken kennelijk niet als communicerende vaten. Zoals we in tabel 2.2 kunnen lezen neemt na een aanvankelijke stijging onder werknemers tussen 24 tot 34 jaar de interne mobiliteit in oudere leeftijdsgroepen af. Dit zou kunnen wijzen op het probleem van een mid-career impasse, die afhankelijk van opleiding en het moment van betreden van de arbeidsmarkt zo 
ongeveer tussen het veertigste en vijftigste leeftijdsjaar optreedt. Op dat moment bereiken velen in hun huidige loopbaan kennelijk een eindpunt (binnen de organisatie) en nemen de kansen op uitdagend en gelijk of beter betaald nieuw werk buiten de organisatie af. Binnen de organisatie staat men stil en krijgt men nieuwe, vaak jongere mensen boven zich. Wanneer de organisatie, de technologie, het werk of commerciële relaties snel veranderen, verliezen lange ervaringsjaren mogelijk hun waarde. Het zou de moeite zijn uit te zoeken hoe dit voor verschillende beroepen, loopbanen en onderwijsprofielen ligt en hoe de transities naar andere werkkringen voorbereid en gefaciliteerd zouden kunnen worden. Ook zou op dit punt aan de verschillen tussen mannen en vrouwen aandacht moeten worden besteed. Aan het slot van ons betoog komen we hierop terug.

\subsubsection{MOBILITEITSREGIMES}

Op dit punt aangekomen is het nodig de eerdergenoemde studie van DiPrete e.a. (1997) over mobiliteitsregimes nog eens van stal te halen. Gebruikmakend van paneldata waarin dezelfde personen over meerdere jaren bevraagd worden, vergeleken zij mobiliteitsgegevens voor de jaren tachtig in vier landen: de Verenigde Staten, Duitsland, Zweden en Nederland. Interne baanmobiliteit is ten dele het gevolg van de wijze waarop men banen definieert. Waar banen nogal nauw omschreven zijn, zoals in de vs, is de interne mobiliteit van baan tot baan het hoogst. De lagere interne mobiliteit in Zweden, Nederland en Duitsland komt overeen met ruimere omschrijvingen van taken en banen in deze landen, wat weer samenhangt met bredere gemiddelde scholing van werknemers en met vakbonden die minder gericht zijn op het scherp afbakenen en bewaken van taken (industrial-political unionism in continentaal Europa versus job control unionism in de vs) (Visser 1990; Streeck 2005). Kort en goed, minder gemeten interne baan mobiliteit hoeft dus niet minder bedrijfsdynamiek te betekenen, hoewel dat ook niet uitgesloten kan worden.

Interessanter aan de internationale vergelijking is de externe baanmobiliteit, van werkgever naar werkgever. Ook die lag volgens de genoemde studie van DiPrete e.a. (1997) hoger in de vs dan in Zweden of Nederland, waar dit weer hoger was dan in Duitsland. De hogere externe mobiliteit en de geringere gemiddelde baanduur bij dezelfde werkgever in de vs worden toegeschreven aan de geringere ontslagbescherming, meer nieuwe bedrijfsvestigingen en faillissementen en de toenemende neiging van Amerikaanse werkgevers om personeel op de externe arbeidsmarkt te werven. Dat laatste duidt op een afname van de betekenis van interne bedrijfsarbeidsmarkten, waarover straks meer. Dat in Duitsland de externe baanmobiliteit in de jaren tachtig lager lag dan in Zweden of Nederland wordt toegeschreven aan de sterkere schotten rond bedrijfsarbeidsmarkten en de rol van bedrijfstakspecifieke scholing en sociale zekerheid in Duitsland. In Zweden zijn onderwijs en scholing sterker gericht op het aanbieden en aanleren van algemene kennis en vaardigheden en is de sociale zekerheid 'universeler' ingericht (Esping-Andersen 1990). 
Tabel 2.3 Enkele kenmerken van de arbeidsmarkt in acht landen 1993-2003.

\begin{tabular}{|c|c|c|c|c|c|c|c|c|c|}
\hline & & NL & DK & $\mathbf{S}$ & D & $\mathbf{F}$ & UK & US & $J$ \\
\hline \multicolumn{10}{|l|}{ WERKLOOSHEID } \\
\hline \multicolumn{10}{|l|}{ Werkloosheid } \\
\hline \multirow[t]{2}{*}{ (als \% beroepsbevolking) } & 2003 & 3,8 & 5,6 & 5,6 & 9,3 & 9,4 & 5,0 & 6,0 & 5,3 \\
\hline & $\Delta 1993-2003$ & $-2,4$ & $-4,0$ & $-3,5$ & 1,6 & $-1,9$ & $-5,0$ & $-0,9$ & 2,8 \\
\hline \multicolumn{10}{|c|}{ Aandeel werkloosheidsduur } \\
\hline \multirow[t]{2}{*}{ boven 1 jaar } & 2003 & 29,2 & 19,9 & 17,8 & 50,0 & 33,8 & 23,0 & 11,8 & 33,5 \\
\hline & $\Delta 1994-2003$ & $-20,2$ & $-12,2$ & 0,5 & 5,7 & $-4,5$ & $-22,4$ & $-0,4$ & 16,4 \\
\hline \multicolumn{10}{|l|}{ BESCHERMING } \\
\hline \multicolumn{10}{|l|}{ Index ontslagbescherming } \\
\hline \multirow[t]{2}{*}{ (regulier en tijdelijk) } & 2003 & 2,1 & 1,4 & 2,2 & 2,2 & 3,0 & 0,7 & 0,2 & 1,8 \\
\hline & $\Delta 1990-2003$ & $-0,6$ & $-0,7$ & $-1,3$ & $-1,0$ & 0,3 & 0,1 & 0,0 & $-0,3$ \\
\hline \multicolumn{10}{|l|}{ De-commodification } \\
\hline \multirow[t]{2}{*}{ index bij werkloosheid } & 2002 & 1,69 & 2,25 & 2,16 & 0,56 & 1,03 & $-1,99$ & $-2,40$ & $-0,50$ \\
\hline & $\Delta 1990-2002$ & $-0,69$ & $-0,23$ & $-1,20$ & $-0,06$ & $-0,88$ & $-0,87$ & $-1,32$ & 0,24 \\
\hline \multicolumn{10}{|l|}{ ARBEIDSMARKTBELEID } \\
\hline \multicolumn{10}{|l|}{ Uitgaven arbeidsmarkt- } \\
\hline beleid - actief (\% BNP) & gem. 1998-2002 & 1,75 & 1,68 & 1,48 & 1,23 & 1,31 & 0,37 & 0,15 & 0,29 \\
\hline \multicolumn{10}{|l|}{ Uitgaven arbeidsmarkt- } \\
\hline beleid - passief (\% BNP) & gem. 1998-2002 & 1,83 & 3,36 & 1,28 & 2,13 & 1,71 & 0,44 & 0,41 & 0,50 \\
\hline \multicolumn{10}{|l|}{ Aandeel uitgaven - actief } \\
\hline als percentage totaal & gem. 1998-2002 & 48,9 & 33,3 & 53,6 & 36,6 & 43,4 & 45,7 & 26,8 & 36,7 \\
\hline
\end{tabular}

Bron: Eigen berekeningen op basis van European Labour Force Survey (Eurostat) en OESO

Ten slotte onderzochten de auteurs het 'push'-effect van krimpende bedrijfstakken en beroepen op de mobiliteit van werknemers naar andere bedrijfstakken en beroepen. Ook die was, zoals verwacht, het hoogst in de Verenigde Staten, gevolgd door Zweden. In dat land zijn het vooral de oudere werknemers die vanuit krimpende bedrijfstakken de overstap naar andere bedrijfstakken maken. Dit gebeurt veel minder in Duitsland of Nederland. In Duitsland blijven werknemers binnen dezelfde bedrijfstak, of ze blijven werkloos tot ze met pensioen mogen. Nader onderzoek van de grootste onder de krimpende beroepen, zoals mijnwerker, slager, politie-inspecteur, dakdekker en tegelzetter, toont een veel geringere mobiliteit in vergelijking met andere beroepen. Dit duidt op de afwezigheid van verbindingslijnen naar andere, nieuwe en uitbreidende beroepen. Krimp leidt dan vaak tot werkloosheid of vertrek van de arbeidsmarkt.

De Nederlandse casus vormt een contrast. Krimp en reorganisatie van bedrijven bleken geen noemenswaardig effect te hebben op de externe baanmobiliteit. Ten opzichte van groeiende bedrijven en bedrijfstakken is de mobiliteit naar andere banen niet groter. Ongeacht groei of krimp is de kans op vervroegde uittreding en vertrek van de arbeidsmarkt even groot. De auteurs schrijven dit toe aan diffusie- 
effecten van de genereuze regelingen die de gevolgen van afslanking, reorganisatie en sluiting in de jaren zeventig en tachtig opvingen via vertrek uit de arbeidsmarkt door middel van vut, WAO en verlengde wW. Zij citeren de studie van Trommel en Van Vroom (1993: 107-108) die in een vergelijkende serie casestudies vaststelden dat zowel bij krimpende als groeiende bedrijven werknemers massaal uittraden en dit toeschreven aan het Loreley-effect van vervroegde uittreding, ofwel de blijvende "aantrekkingskracht van de mogelijkheid van uittreding, ongeacht de sociale, organisatorische of financiële wenselijkheden en mogelijkheden". Deze collectivisering van de vervroegde uittreding vlakt uiteraard de lokale effecten van krimp en groei op de baanmobiliteit van werknemers af. Per saldo betekent het dat werkgevers in groeiende bedrijfstakken en beroepen meer mensen op de externe arbeidsmarkt moeten werven om de effecten van vervroegde uittreding op te vangen.

Tekenend voor een individualistisch mobiliteitsregime als het Amerikaanse is dat individuele kenmerken van werknemers zoals onderwijs en ervaringsjaren bij dezelfde werkgever (tenure of anciënniteit) een belangrijke factor zijn bij vrij-willige externe baanmobiliteit. Vooral in de Nederlandse paneldata bleef, na controle voor de effecten van zelfselectie, weinig van deze invloed over en DiPrete e.a. zien het collectivistische mobiliteitsregime van Nederland in de jaren tachtig dan ook als de tegenpool van de weinig gereguleerde Amerikaanse arbeidsmarkt (zie ook tabel 2.3). Voorzichtigheidshalve voegen we hieraan toe dat er sinds de jaren tachtig wel wat is veranderd en met name de toegang tot WAO, vut en WW aanzienlijk is beperkt. Overigens hebben alle hier onderzochte landen, met uitzondering van Japan en Frankrijk, de ontslagbescherming afgezwakt en geeft de ontwikkeling van de decommodificatie-index (zie EspingAndersen 1990) aan dat het moeilijker is geworden om een bestaan buiten de arbeidsmarkt te financieren met sociale uitkeringen bij werkloosheid, al blijven de saillante verschillen tussen bijvoorbeeld Scandinavië en Nederland aan de ene kant en de meer liberale markteconomieën (vs en vK) bestaan. Tevens zien we dat vooral in Zweden en Nederland actief arbeidsmarktbeleid aan betekenis heeft gewonnen (tabel 2.3).

\subsection{VERANDERENDE INTERNE ARBEIDSMARKTEN EN HET NIEUWE PSYCHOLOGISCH CONTRACT}

\subsubsection{VAN INTERNALISERING NAAR EXTERNALISERING ALS DOMINANTE BEDRIJFSSTRATEGIE}

De twintigste eeuw is er een geweest van toenemende bedrijfsconcentratie. De dominante bedrijfsstrategie was gericht op internalisering, de absorptie van onzekerheid in de omgeving, bijvoorbeeld door middel van verticale integratie (Chandler 1977). Door de grotere omvang van bedrijven en vooral de toename van grote bedrijven ontstond er ruimte voor interne baanmobiliteit en werd het mogelijk en soms ook wenselijk de interne arbeidsmarkt van de externe arbeidsmarkt af te schermen. In de interne arbeidsmarkt gelden veeleer administratieve 
regels, die worden uitonderhandeld en bewaakt door vakbonden en werkgevers (Doeringer and Piore 1971; Jacoby 1985). In de externe arbeidsmarkt gelden eerst en vooral de wetten van vraag en aanbod.

Vanaf de jaren tachtig is er sprake van een trendbreuk en volgen meer en meer bedrijven een strategie van externalisering en stoten ze afdelingen, functies en personeel af, onder meer door afslanking en terugtrekken op de corebusiness, uitbesteding en het werken in allianties. Carroll en Hannan (2000) rapporteren dat de gemiddelde omvang van ondernemingen in de vs is afgenomen van 60 werknemers in 1960 tot 34 in 1990 . Hiermee wijzen ze niet alleen op de afslanking en ontvlechting van grote ondernemingen, maar ook op het groeiend aantal nieuwe en kleine ondernemingsvestigingen. Externalisering betekent ook een verandering in aansturing van bedrijfsactiviteiten en van werknemers. Markttransacties en contracten vervangen geheel of ten dele interne gezagsverhoudingen en organisatorische controles (Scott 2004). Deze ontwikkeling raakt uiteraard ook de mobiliteit van werknemers en hangt samen met de verandering of zelfs beëindiging van het impliciete contract tussen werknemers en werkgevers, gebaseerd op baanzekerheid in ruil voor loyaliteit en gestage inzet. Met name in de vs ervaren werknemers deze omslag (Osterman 1999; Stone 2004; Pfeffer en Baron 1988, voor een vroege studie).

\subsubsection{INTERNE ARBEIDSMARKTEN}

De economische literatuur over de interne arbeidsmarkt dateert uit halverwege de twintigste eeuw. In de arbeidsmarkt van de neoklassieke economische theorie bewegen arbeiders zich vrijelijk van baan naar baan en van bedrijf naar bedrijf, op zoek naar betere mogelijkheden en hogere lonen. Werkgevers, van hun kant, zijn vrij in het aannemen en ontslaan van werknemers. Het productievolume wordt aangepast aan de schommelingen in de vraag naar producten en het aanbod van arbeid en grondstoffen, lonen worden verhoogd of verlaagd in overeenstemming met de spanning of slapte op de markt, en op elk moment krijgen werknemers de waarde van het marginale product betaald. In theorie bestaat er een 'evenwichtsloon' voor elk scholingsniveau en kunnen er geen blijvende verschillen in arbeidsvoorwaarden tussen bedrijven bestaan (Ehrenburg en Smith 1997).

In de jaren veertig en vijftig publiceerden arbeidseconomen als Dunlop, Kerr en Reynolds empirische studies die duidelijk maakten dat arbeidsmarkten niet werken volgens de voorspellingen van de neoklassieke theorie. Werknemers bewegen niet vrijelijk tussen bedrijven en banen, lonen convergeren niet maar verschillen afhankelijk van de omvang en sector van het bedrijf, de meeste werknemers blijven bij hun werknemer, zelfs als ze elders meer kunnen verdienen, en werkgevers verlagen de lonen niet voor oudere en minder productieve werknemers, zelfs niet als de lonen bij de concurrentie lager zijn, oudere werknemers worden in dienst gehouden, enzovoort. Kerr (1954) schrijft over "gebalkaniseerde" arbeidsmarkten, met segmenten waartussen weinig mobiliteit bestaat. Dunlop (1966) munt het begrip “interne arbeidsmarkt”, gekenmerkt door 
"interne baanladders", interne promotiekansen en geringe zijwaartse instroom, nauw omschreven hiërarchische classificaties van taken en banen, bedrijfsspecifieke scholing, impliciete of expliciete regels voor beloning, bevordering en ontslagbescherming naar anciënniteit en secundaire arbeidsvoorwaarden die het vertrek van werknemers moeten ontmoedigen en de loyaliteit aan het bedrijf versterken. Zulke interne arbeidsmarkten komen in de vs vooral voor in de verwerkende industrie en zijn het antwoord op het hoge verloop en de geringe toewijding aan het werk in de naar tayloristisch model georganiseerde massafabricage (Jacoby 1985; Kaufman 1988). Zulke interne arbeidsmarkten verbreiden zich ook naar grote bureaucratische organisaties in andere bedrijfstakken, zoals banken en verzekeringsmaatschappijen, spoorwegen en posterijen, de overheidsinstellingen, et cetera.

In hun baanbrekende studie van interne arbeidsmarkten tonen Doeringer en Piore (1971) aan dat zowel werkgevers als werknemers baat hebben bij deze vorm van organisatie van de arbeidsmarkt. Naast het terugdringen van het verloop van ervaren en net ingewerkte werknemers en de besparing op rekruteringskosten, zijn werkgevers gebaat bij informele on-the-job training van nieuwkomers door ervaren werknemers. Oudere werknemers zullen dat alleen doen als hun baan zeker is en ze niet pardoes door de net ingewerkte goedkopere arbeidskrachten worden vervangen. Vanuit het perspectief van de werknemer biedt de interne arbeidsmarkt de belofte van een hogere beloning, mogelijk promotie na jaren van trouwe dienst en zekerheid tegen het risico van ontslag op oudere leeftijd. Daarbij past doorgaans een leeftijdsafhankelijke looncurve, die in het begin, wanneer de werknemer nog veel moet leren, boven de productiviteit, dan lange tijd onder de productiviteit en ten slotte er weer boven ligt. Dit wordt ook wel gezien als een vorm van uitgestelde beloning of 'gedwongen besparing', waarbij de werknemer meebetaalt aan zijn of haar scholing en zich daarna lange tijd met een lagere betaling tevredenstelt om het risico van een lagere productiviteit aan het einde van de loopbaan te dekken (Frank en Hutchens 1993). Dit loonsysteem is voor bedrijven niet altijd gunstig en zij zullen soms proberen zich alsnog van oudere, want dure en minder productieve werknemers te ontdoen (Lazear 1990). Werknemers zullen pogen zich met de hulp van vakbonden daartegen te verweren met harde afspraken. ${ }^{3}$

Williamson e.a. (1975) verklaren beloning naar anciënniteit als oplossing voor het probleem dat de prestaties van werknemers onvoldoende gecontroleerd kunnen worden. Door loyaliteit te belonen en promotie in het vooruitzicht te stellen worden werknemers gemotiveerd hun plichten niet te verzaken en zich voor het bedrijf in te spannen om zo hun kansen niet te vergooien. Het anciënniteitsbeginsel vergroot de kosten van eventueel ontslag. Hoe ouder, hoe geringer de kans om bij een andere werkgever ooit nog hetzelfde te verdienen. Becker (1964) daarentegen ziet uitgestelde beloning vooral als oplossing voor het probleem van bedrijfsspecifieke scholing en als een strategie om werknemers ertoe aan te zetten nieuwkomers op te leiden. In beide gevallen functioneert het beloningsysteem als rem op (vrijwillige) externe mobiliteit. Andere auteurs wijzen op de rol van 
vakbond en wetgever bij de institutionalisering van interne arbeidsmarkten, waarbij vakbonden hard hebben gevochten om de impliciete regels van baanzekerheid en anciënniteit expliciet in arbeidsvoorwaarden en wettelijke voorschriften vast te leggen (Jacoby 1985; Kaufman1988).

Daarnaast kenden grote bedrijven in de vs nog een keur aan maatregelen in de sfeer van pensioenen en verzekering tegen medische kosten, zaken die in Europese verzorgingsstaten veeleer door de overheid of collectief per bedrijfstak verzekerd zijn. ${ }^{4}$ Als gevolg van dergelijke regels zijn interne arbeidsmarkten niet of slechts gedeeltelijk aan de werking van vraag en aanbod op de arbeidsmarkt blootgesteld. Werknemers die van een plaats in zo'n interne arbeidsmarkt verzekerd zijn, kennen minder onzekerheid ten aanzien van het voortbestaan van hun baan en minder schommelingen in hun inkomen. Vakbonden zijn in principe dol op zulke gereguleerde arbeidsmarkten. Objectieve criteria voor beloning, bevordering en ontslag geven minder macht aan het management en beperken de mogelijkheden van voortrekken en discriminatie. Standaardisatie van taken en beloning via collectieve contracten bieden de mogelijkheid de werk- en inkomenszekerheid van werknemers enigszins los te koppelen van het onzekere wel en wee van de onderneming, beperken de onderlinge concurrentie tussen werknemers en leggen daarmee de basis voor gemeenschappelijke organisatie en solidariteit (Streeck 2005). In de meeste continentaal Europese landen vond deze standaardisatie doorgaans op bedrijfstakniveau plaats, via gezamenlijke afspraken over lonen en arbeidstijden en een gemeenschappelijk functieclassificatiesysteem met afspraken over taakwaardering en beloning. In de Verenigde Staten ontbrak daarvoor de basis en legden werkgevers en werknemers zich toe op verregaande wederzijdse controle op de uitvoering van het werk binnen het bedrijf, althans in die bedrijven waar vakbonden een voet aan de grond wisten te krijgen. Inmiddels is dat een snel slinkende minderheid, nu de vakbondsorganisatiegraad in de marktsector gedaald is tot onder tien procent. In Engeland waren vanouds de (geschoolde) beroepsvakbonden sterk en legden de bonden zich toe op gedetailleerde afspraken over de afbakening van beroepen en wie welk werk mocht doen. Daarvan is door het machtsverlies van de vakbonden sinds de jaren tachtig niet zo heel veel meer over.

Deze verschillen hebben uiteraard grote invloed op zowel de interne als externe mobiliteit. Zo zal het in Engeland makkelijker zijn van bedrijf of zelfs bedrijfstak te veranderen dan van (geschoold) beroep. In Duitsland is een werknemer veeleer aan een bedrijfstak en daarbinnen aan een beroep gebonden; in Zweden ook aan een bedrijfstak maar minder aan een beroep en in de vs aan het bedrijf, al is dat laatste minder geworden. Deze demarcaties bepalen wat in een bepaalde context als open of gesloten arbeidsverhouding geldt, waarbij als operationele definitie van een gesloten (interne) arbeidsverhouding geldt dat de instroom uit en uitstroom naar andere posities aanmerkelijk geringer is dan op grond van kansberekening het geval zou zijn (Sørensen en Tuma 1981). Het eerder aangehaalde voorbeeld van beroepen als mijnwerker, tegelzetter of politie-inspecteur duidt op gesloten arbeidsverhoudingen. Gesloten arbeidsverhoudingen of interne arbeids- 
markten kunnen betrekking hebben op beroepen, bedrijven (geheel of gedeeltelijk) of bedrijfstakken (Althauser en Kalleberg 1981; Osterman 1988). De meest 'open' arbeidsverhoudingen zijn die waarin iedereen onmiddellijk aan de slag kan, omdat scholing en ervaring weinig telt. In een bedrijfstak als de schoonmaak of de bevoorrading van winkelbedrijven zullen werkgevers weinig redenen en werknemers weinig kansen hebben om interne arbeidsmarkten in te richten, al sluit dat selectieve rekruteringspatronen, bijvoorbeeld onder bepaalde 'old boys' netwerken, families, etnische groepen of immigranten niet uit. Sociale uitsluiting van een beroep of functie kan op veel gronden plaatsvinden.

\section{Slimmer werken en flexibel organiseren: het einde van de interne arbeidsmarkt}

In de geschiedenis van de Amerikaanse industrie wordt de opkomst en institutionalisering van interne arbeidsmarkten gezien als antwoord op de tayloristische werkorganisatie en de problemen van hoog verloop, gebrekkige motivatie en onthe-job training. Met de toenemende opleiding van werknemers en veeleisender consumenten kwamen de nadelen van dit systeem steeds duidelijker aan het licht. Het werd moeilijker werknemers te werven en te behouden en er moest steeds meer voor betaald worden. Verder deed zich veel productie-uitval voor, liet de kwaliteit te wensen over en sloot de serviceverlening aan klanten vaak niet bij de wensen van de consument aan. Deze gebreken kwamen vooral aan het licht op het moment dat de Japanse concurrentie toenam. Aoki (1986) en MacDuffie (1995) wijzen er bijvoorbeeld op dat in Amerikaanse bedrijven, in tegenstelling tot Japan, onvolkomenheden niet direct op de werkvloer opgespoord kunnen worden. Daartoe moet meer verantwoordelijkheid aan lagere niveaus in de organisatie worden gegeven en dienen werknemers beter en meer allround getraind te zijn dan in Amerika gebruikelijk is.

In meer recente Amerikaanse literatuur wordt veel aandacht besteed aan de introductie van high performance work organisations, gebaseerd op zelfsturende teams en het delen van informatie en verantwoordelijkheden tussen de werkvloer en het management (Osterman 1999). Kochan en Osterman (1994) spreken van de mutual gains enterprise, Appelbaum en Batt (1994) van de new American workplace, Capelli (1999) heeft het, met een verwijzing naar de doorbraak in sociale wetgeving en arbeidsverhoudingen uit de jaren dertig, over de New Deal at Work, die erop neerkomt dat de "lang gekoesterde verwachting van een duurzame binding tussen werknemer en één onderneming” wordt vervangen door een nieuwe verwachting van flexibiliteit, multi-inzetbaarheid en brede en voortdurende scholing. Bij die twee praktijken en verwachtingen horen verschillende institutionele kaders (wetgeving, arbeidsovereenkomsten, psychologische contracten) waarover straks meer. Kochan, Katz en McKersie (1986) menen dat er vanaf het begin van de jaren tachtig sprake is van een transformatie van de Amerikaanse arbeidsverhoudingen als gevolg van nieuwe strategische keuzen van het management. 
In de post-tayloristische arbeidsorganisaties moeten taken flexibeler ingericht en breder gedefinieerd worden. Er moet weer meer denken in het doen en het zelfoplossend vermogen van productiemedewerkers moet omhoog. Meer autonomie op de werkvloer door zelfsturende teams is aanvankelijk het parool. Dit punt werd al gemaakt in het bekende boek van Piore en Sabel uit 1984 over de Second Industrial Divide, de periode na de massafabricage die aanbreekt met 'flexibele specialisatie' van productieprocessen die dankzij de doorbraak in de informatietechnologie (computergestuurde productie, design en marketing) mogelijk wordt. Bovendien moeten arbeidsorganisaties meer naar buiten gericht worden. Niet alleen kunnen meer fouten worden opgespoord en verholpen door samenwerking van specialisten uit verschillende afdelingen, ook bestaat de gedachte dat het meeste geleerd wordt niet in het hart maar aan de rand van de organisatie, waar contacten met klanten, leveranciers en kenniscentra bestaan. Volgens General Electric baas en managementgoeroe Jack Welch leidt de 'loyaliteit' die hoorde bij het oude psychologische contract en de interne arbeidsmarkt ertoe dat werknemers te veel met hun carrière binnen de organisatie bezig zijn en te weinig gericht op vernieuwingen en contacten buiten de organisatie. Hij ziet alleen al om die reden het intrekken van de belofte van vast werk en het schrappen van beloning of promotie naar anciënniteit als wenselijk (geciteerd in Tichy en Charan 1989). Dit sluit aan bij theorieën over organisatieleren en opvattingen dat vernieuwende ondernemingen meer willen van hun werknemers dan het routinematig uitvoeren van taken. Van kenniswerkers wordt verwacht dat ze vaardigheden ontwikkelen om nieuwe producten en diensten te scheppen (Nonaka en Takeuchi 1995). Zulke kenniswerkers zijn betrokken bij een variëteit aan activiteiten, zoals productontwikkeling, productontwerp en marketingpresentatie. De gedachte is dat de bedrijfsorganisatie minder hiërarchisch moet en samenwerkingsverbanden moet aangaan met andere bedrijven waardoor de grenzen van de onderneming vertroebelen en netwerken van bedrijven een grotere reikwijdte krijgen. Strategische allianties kunnen diverse vormen aannemen. Voorbeelden daarvan zijn gemeenschappelijke productontwikkeling en gemeenschappelijke distributieketens. Dat gebeurt vooral in de nieuwere sectoren van de economie, zoals de ICT, biotechnologie, uitgeverijen en media.

Het nieuwe organisatiepatroon heeft fundamentele gevolgen voor de verhouding tussen interne en externe arbeidsmarkten en voor de mobiliteit van medewerkers. De tendens tot multivaardigheid en horizontale mobiliteit wordt ondersteund door meer medewerkers met een hoger opleidingsniveau aan te trekken. Arbeidsverhoudingen staan dan niet langer in het teken van het belonen van trouw en nauwgezet uitvoeren van taken, maar van de bevordering van ontwikkelingsmogelijkheden van medewerkers, ook buiten de organisatie. Meer en meer werknemers merken aan den lijve dat het impliciete contract tussen werknemers en werkgevers, gebaseerd op baanzekerheid binnen dezelfde organisatie in ruil voor loyaliteit en gestage inzet, niet meer bestaat. Veel Amerikaanse auteurs concluderen dat de interne arbeidsmarkt, zoals beschreven door Doeringer en Piore in de jaren zeventig, niet meer bestaat (Pfeffer en Baron 1988; Osterman 1999; Stone 2004). 
Er zijn inmiddels verschillende representatieve studies over de verbreiding van de nieuwe organisatiepatronen en arbeidsverhoudingen in de Amerikaanse industrie. Het meest bekend zijn de twee surveys uit 1992 en 1997 van Osterman (1994; 1999) waarin hij naging hoe sterk vier vernieuwingen - zelfsturende teams, total quality management (zoals bredere taakomschrijvingen, horizontaal management en competentietraining) kwaliteitskringen en jobrotatie - in het Amerikaanse bedrijfsleven ingang hebben gevonden. In 1992 betrof dat ongeveer eenkwart van alle vestigingen, met als uitschieter zelfsturende teams die in ruim tweevijfde van alle vestigingen voorkwamen. Vijf jaar later kwamen deze praktijken in bijna 60 procent van alle vestigen voor. Alleen het gebruik van zelfsturende teams was licht teruggegaan. Osterman verklaart dat door de afgenomen stabiliteit van banen. De andere drie vormen zijn volledig verenigbaar met de nieuwe arbeidsverhoudingen: meer nadruk op training, competenties, projecten en netwerken, maar minder garanties voor duurzame relaties en banen. Zelfsturende teams daarentegen vergen bindingen van langere duur om goed op elkaar in te spelen en vertrouwen te wekken. Een van Ostermans bevindingen was dat bedrijven die deze nieuwe praktijken hadden ingevoerd, hun werknemers minder stabiele banen boden dan vergelijkbare bedrijven zonder zulke vernieuwingen. In de zogenaamde 'high performance' bedrijven kwamen meer (vrijwillige en onvrijwillige) contractontbindingen voor, terwijl de omvang van het totale personeelsbestand niet afnam. Wel was er een duidelijke afname van het aantal banen in het middenechelon van het management, wat duidt op een plattere organisatie en minder hiërarchie.

Dat wil niet zeggen dat er geen tayloristische werkorganisaties meer bestaan (bijvoorbeeld in de fastfoodsector) of dat in alle bedrijfstakken (bijvoorbeeld bij de overheid of in de dienstensector) beloning naar anciënniteit is vervangen door beloning naar competentie en prestatie (Weinstein en Kochan 1995). Bovendien kunnen we conclusies over de verandering en erosie van interne arbeidsmarkten in de vs niet zonder meer naar Europa of Nederland doortrekken. In veel Europese landen golden en gelden andere principes van bedrijfs- en arbeidsorganisaties, de rol van de vakbeweging was er een andere en de macht van financiële markten vooralsnog beperkter. Het is overigens ook niet zo dat in de vs de doorsnee organisatie met 'zelfsturende teams' werkt en dat de doorsneecarrière 'boundryless' (Arthur 1994) is. Hierover gaan de beide volgende paragrafen.

\section{Internationale variatie in interne arbeidsmarkten en arbeidsverhoudingen}

Naast de genoemde bedrijfs- en arbeidsorganisatorische achtergronden voor het verzwakken van de interne arbeidsmarkt zijn er twee factoren die, zeker in de Amerikaanse context, dit proces versneld hebben. Ten eerste is er de sterkere invloed van financiële markten die op gespannen voet staat met beloftes aan andere stakeholders, zoals werknemers. Dit komt onder meer tot uitdrukking in conflicten over pensioenverplichtingen, vooral waar die gebaseerd zijn op 'defined benefits'. De recente heronderhandelingen over de pensioenen van reeds gepensioneerde ex-werknemers van General Motors en de meeste Amerikaanse luchtvaartmaatschappijen zijn hiervan een voorbeeld. Een 'impliciet contract' om 
als het enigszins kan banen en pensioenen te garanderen past niet in de nieuwe benadering en de meeste beursgenoteerde ondernemingen doen dat dan ook niet. Bedrijfssluitingen en afvloeiingen moeten ook mogelijk zijn wanneer er volop winst gemaakt wordt en hiervan zijn er inmiddels veel voorbeelden, ook in Europa. Shleifer en Summers (1988) wijzen erop dat vijandige overnames vaak leiden tot het openbreken van (op lange termijn gerichte) impliciete arbeidsovereenkomsten. Met name oudere werknemers, maar ook de minder geschoolden, worden de dupe van overnames door ontslag, het schrappen in secundaire arbeidsvoorwaarden en toepassing van een vlakkere looncurve (Gokhale, Groshen en Neumark 1995).

Wat de vs betreft kunnen we er niet omheen de ernstige verzwakking van de vakbeweging in het verhaal te betrekken. Uit tabel 2.4 blijkt dat de Amerikaanse vakbeweging nog maar voor een kleine minderheid van bedrijven en werknemers relevant is. De cao-dekkingsgraad in het bedrijfsleven ligt bij ruim tien procent van alle werknemers, ieder bedrijf staat er alleen voor en wordt doorgaans in de eigen sector of regio geconfronteerd met vele ondernemingen zonder cao. De coördinatie tussen bedrijven of bedrijfstakken op arbeidsvoorwaardelijk gebied is nihil. Pogingen om naar Europees voorbeeld een wettelijk informatie- en consultatierecht voor Amerikaanse werknemers sneuvelden in het Amerikaanse congres en kregen zelfs geen steun van de vakbonden (Rogers en Streeck 1994; Weiler 1990).

Tabel 2.4

Positie van de vakbeweging en collectieve organisatie van de arbeidsmarkt, 1993-2003

\begin{tabular}{|lccccccccc|} 
& & NL & DK & S & D & F & UK & US & J \\
COLLECTIEVE ORGANISATIE & & & & & & & & & \\
ARBEIDSMARKT & & & & & & & & & \\
Vakbondsorganisatiegraad & $2000-2003$ & 23 & 72 & 78 & 24 & 8 & 31 & 12 & 21 \\
$\begin{array}{l}\text { Vakbondsaanwezigheid } \\
\text { bedrijven }\end{array}$ & $2000-2003$ & $>60$ & $>80$ & $>90$ & $>60$ & 39 & 48 & 15 & 21 \\
$\begin{array}{l}\text { Cao-dekkingsgraad } \\
\text { Coördinatie arbeids- }\end{array}$ & $2000-2003$ & 82 & 76 & 92 & 63 & 92 & 35 & 14 & 20 \\
voorwaardenvorming & $2000-2003$ & 4,0 & 4,0 & 3,5 & 4,0 & 2,0 & 1,0 & 1,0 & 4,0 \\
\hline
\end{tabular}

Bron: Eigen berekeningen Visser (2006)

Het politiek isolement en de verzwakking van de Amerikaanse vakbeweging, vooral na 1980 (onder president Reagan) heeft de erosie van de interne arbeidsmarkt, gebaseerd op job control, versneld. Het overgrote deel van de industriële werkgelegenheid in de vs is geconcentreerd in niet-vakbondsbedrijven die lagere lonen, minder secundaire arbeidsvoorwaarden, minder stabiele werkgelegenheid en vooral minder ontslagbescherming bieden (Katz en Darbishire 2000: 34-47). Deze bedrijven bieden hun personeel niet langer een 'impliciet contract' van 
baanbehoud voor trouwe dienst, maar passen de employment-at-will doctrine onverkort toe, met enkele beperkingen in geval van collectief ontslag (vooral in vakbondsbedrijven) en in geval van individueel ontslag relatief strenge toetsing op antidiscriminatiebepalingen. Ook in wat eens het pronkstuk van de mede door vakbonden gegarandeerde interne arbeidsmarkt was, te weten de autoindustrie verenigd in de Big Three (General Motors, Ford en Chrysler) is de ontmanteling al ver voortgeschreden (Katz en Darbishire 1999; Milkman 1997).

Deze beschrijving van bedrijfsorganisatorische veranderingen en de verzwakking van de interne arbeidsmarkt in de Verenigde Staten zijn niet zonder meer geldig voor Europa of Nederland. Toch moet volgens Powell (2001) niet onderschat worden dat ontwikkelingen in het Amerikaanse bedrijfsleven een mondiale uitstraling hebben, doordat financieel kapitaal wereldwijd mobiel is, bedrijven deelnemingen hebben in verschillende landen, internationale standaarden worden gehanteerd en internationale consultancy en adviesorganisaties dezelfde praktijken en ideeën verspreiden. Andere auteurs menen evenwel dat er zelfs in tijden van harde internationale concurrentie (globalisering) ruimte is voor varieties of capitalism (Hall en Soskice 2001; Streeck en Crouch 1997) afhankelijk van instituties als onderwijs- en beroepsscholing, de organisatie van werkgevers, de coördinatie van de arbeidsvoorwaarden, de inrichting van financiële markten en de productieorganisatie. Ook Powell (2001) stelt overigens dat er ruimte blijft voor nationale en regionale specialisatievoordelen, zoals elektronica in Japan, 'hightech engineering' in Duitsland, Italiaanse mode- en ontwerpindustrie, de Engelse uitgeverijwereld en de Amerikaanse software, biotechnologie en film industrie.

Marsden (1999) heeft een elegante micro-economische theorie opgesteld ter verklaring van de macro-institutionele variatie op het niveau van landen. Zijn uitgangspunt is dat werkgevers en werknemers zoeken naar efficiënte waarborgen tegen elkaars opportunistisch gedrag, dat nu eenmaal mogelijk is gegeven het feit dat arbeidsovereenkomsten van tevoren niet alle voorwaarden en gedragingen kunnen dichttimmeren en prestaties tijdens het werk vaak niet goed te controleren zijn. Organisaties kunnen dat oplossen door taken zo te ontwerpen dat ze precies omschreven en afgebakend zijn, door werknemers daarop te selecteren en op nauwgezette uitvoering te belonen. Dat was het tayloristische recept zoals toegepast in de Amerikaanse industrie. Taken en banen kunnen ook ontworpen worden als algemene, breed gedefinieerde competentiegebieden, met een nadruk op waarden en functies in plaats van vooraf omschreven taken. Deze broadbanding, ook wel de trainings- of competentiebenadering genoemd, reïntegreert denken en doen en is in zekere zin een terugkeer naar de ambachtelijke traditie voor het taylorisme. Professionele en beroepsbonden, als in Denemarken en Engeland, hebben deze traditie voortgezet. Op de verticale as staat de wijze waarop toezicht wordt uitgeoefend. Daarbij bestaat volgens Marsden een principiële keuze tussen de controle op taken en uitvoering tijdens het werk, dan wel een functiegerichte controle die steunt op competentieontwikkeling en kwalificaties. Voorbeelden van het laatste zijn vooral in Japan of Duitsland te vinden. 
Figuur 2.2 Organisatie van interne arbeidsmarkten

\begin{tabular}{|c|c|c|}
\hline $\begin{array}{l}\text { Taakverdeling } \\
\text { Toezicht }\end{array}$ & Productie benadering & Competentiebenadering \\
\hline \multirow[t]{2}{*}{ Taakgericht } & $\begin{array}{l}\text { Nauwkeurige afbakening van taken } \\
\text { en hiërarchische ordening, als in een } \\
\text { bureaucratische organisatie. }\end{array}$ & $\begin{array}{l}\text { Baandomeinen in combinatie met } \\
\text { vakmanschap }\end{array}$ \\
\hline & (voorbeeld: vs en Frankrijk) & $\begin{array}{l}\text { (ambachtelijke traditie: voorbeelden in } \\
\text { Denemarken en Engeland, en onder } \\
\text { professionals) }\end{array}$ \\
\hline Functiegericht & $\begin{array}{l}\text { Globale rangorde van banen naar } \\
\text { toenemende competentie }\end{array}$ & $\begin{array}{l}\text { Ordening van banen op grond van } \\
\text { kwalificaties }\end{array}$ \\
\hline & (voorbeeld: Japan) & (voorbeeld: Duitsland) \\
\hline
\end{tabular}

Bron: vrij naar Marsden, 1999

Marsden toont aan dat deze simpele ontwerpregels, afhankelijk van de nationale institutionele context, vertaald worden in oplossingen die relatief duurzaam zijn en min of meer algemene verbreiding in een bepaald land krijgen. Deze institutionalisering is vooral het gevolg van de opleiding en scholing van werknemers. Door onderwijs en scholing worden bepaalde kwalificaties maatschappelijk erkend en de voorwaarden gedefinieerd waaronder arbeidsovereenkomsten ontstaan en nageleefd worden. Naarmate meer organisaties deze regels gebruiken, worden ze robuuster. Andere bedrijven en instellingen leven deze regels vervolgens na, waardoor diffusie optreedt. Bovendien zijn de verschillende typen regels wederzijds uitsluitend en kunnen ze niet tegelijk op één type baan of werkende worden toegepast. Op deze manier kan de micro-economische onderbouwing van de interne arbeidsmarkt worden gerelateerd aan de macroeconomische inrichting van het arbeidsbestel. Als dezelfde bedrijfsspecifieke regel in verschillende bedrijven wordt toegepast, dan vereenvoudigt dat de regelgeving en het toezicht op naleving en ontstaan evidente transactievoordelen.

In het schema van figuur 2.2 past het Amerikaanse type, zoals dat tussen 1920 en 1970 tot bloei kwam, in de linkerbovenhoek. Daarentegen kenmerkt het Japanse 'life-time employment' systeem zich door een grote interne flexibiliteit en worden werknemers gedisciplineerd door een subtiel promotiesysteem dat elementen van anciënniteit en competentieontwikkeling combineert. De interne flexibiliteit van Japanse bedrijven kent zowel een functionele (interne opleidingen en roulatie van functies) als een numerieke (flexibele werktijden, overwerk) component (Passet 2003). Hierdoor is het verloop van personeel aanzienlijk lager en de gemiddelde baanduur veel hoger dan in veel andere OESO-landen (zie tabel 2.1). Bovendien worden bij reorganisaties oudere werknemers dikwijls overgeplaatst naar een van de aangesloten organisaties in het netwerk van bedrijven die onder- 
ling samenwerken (de zogenoemde Keiretsu). Ontslag zonder dwingende reden wordt door Japanse rechters slechts op uitzonderlinge gronden toegestaan en vergt instemming van de per bedrijf georganiseerde vakbonden die zeer nauw met het management samenwerken in het besturen van de interne arbeidsmarkt (Araki 2005). Opvallend genoeg wordt het Japanse stelsel van wettelijke ontslagbescherming door de OESO toch als minder restrictief gezien dan het Nederlandse, Duitse of Zweedse, om van het Franse niet te spreken (zie tabel 2.3). Het is mogelijk dat de OESO indicator 'boven-' of 'buitenwettelijke' normen ten aanzien van de aanvaardbaarheid van ontslag niet goed in beeld brengt. Ook scoort Japan laag op de decommodificatie-index, zeker ten opzichte van landen in continentaal Europa, en is het niet eenvoudig om buiten de arbeidsmarkt op een uitkering te overleven. Aan de onderkant van de Japanse arbeidsmarkt is er overigens recent sprake van een forse flexibilisering (Keizer 2005). Na Nederland heeft Japan het hoogste percentage deeltijdarbeid en ook in flexibele arbeid steekt Japan Nederland naar de kroon. Het hoge aandeel van zelfstandige arbeid is overigens snel aan het afnemen. De wettelijke mogelijkheden voor tijdelijke arbeidsovereenkomsten zijn de laatste jaren verruimd en sinds 2003 kunnen tijdelijke contracten drie jaar duren en hernieuwd worden. Ook uitzendwerk en de onderlinge of collegiale plaatsing van werknemers bij bedrijven zijn geliberaliseerd. Deeltijdarbeid komt in Japan neer op flexibele arbeid, soms is er nauwelijks verschil tussen deeltijd en voltijd werknemers in feitelijk gewerkte uren. Deeltijders in Japan kunnen zich niet beroepen op contractueel gegarandeerde uren en inkomens, hun uurloon is dikwijls lager, in de regel ontbreken secundaire arbeidsvoorwaarden, en er is geen of nauwelijks ontslagbescherming (Houseman en Osawa 1998). Op dit punt bestaat een aanzienlijk verschil met de positie van deeltijdwerkers in Nederland. Onder de Europese richtlijn voor deeltijdwerk uit 1997 en de Europese (en Amerikaanse) regelgeving over gelijke beloning zou de Japanse positie van deeltijdwerkers als discriminatie worden veroordeeld. Vooral vrouwen met zorgtaken en mensen met een afgebroken opleiding of ontbrekende startkwalificatie werken in Japan in deeltijdbanen. Frankrijk wordt net als de Verenigde Staten gezien als een land met scherp afgebakende interne arbeidsmarkten, hiërarchische ordening van taken en functies, interne scholing en loopbanen (Marsden 2004). De Franse arbeidsmarkt wordt vaak voorgesteld als rigide, al staat vanwege de blijvend hoge werkloosheid de deregulering van de arbeidsmarkt al vijftien jaar hoog op de politieke agenda en is er een forse toename van flexibele contracten aan de onderkant van de arbeidsmarkt. In 1998 werkten viermaal zoveel werknemers met een tijdelijk arbeidscontract als tien jaar eerder, terwijl de totale werkgelegenheid in deze periode met slechts negen procent toenam. De Franse overheid zet tijdelijke arbeidscontracten in om de werkloosheid onder met name jongeren te bestrijden. Volgens sommigen is de groei van de publiekelijk gefinancierde jeugdwerkgelegenheid een substituut voor politiek heikele hervormingen die zich keren tegen de zeer krachtige bescherming van de insiders in de Franse arbeidsmarkt (Galtier en Gautié 2003). Deze vorm van flexibilisering voor nieuwkomers werkt in feite als een subsidie aan de werkgevers en dankzij deze externe flexibiliteit kunnen bedrijven zich makkelijker aanpassen aan economische fluctuaties. De combinatie met aantrekkelijke vertrekregelingen voor ouderen kan uiteindelijk zeer kost- 
baar worden, vooral als de doorstroom vanuit het flexibele werk problematisch is en jongeren gezinsvorming uitstellen en weinig zekerheid voor later kunnen opbouwen. Bovenstaande ontwikkelingen versterken het beeld van een duale arbeidsmarkt. De OEso heeft in een harde kritiek op de recente, inmiddels afgeblazen hervormingsplannen van de Franse regering om voor jongeren tot 26 elke vorm van ontslagbescherming op te heffen, op de onhoudbaarheid van deze strategie gewezen.

Het Duitse arbeidsbestel kenmerkt zich vanouds door de hoge eisen die aan beroep en vakmanschap worden gesteld. Veelzijdige kwaliteitsproductie, hét kenmerk van de succesvolle Duitse exportindustrie, vereist brede vakscholing bij het betreden van de arbeidsmarkt, maar ook competentieontwikkeling en voortgezette opleiding tijdens het werk. Streeck (1992) betoogt dat werknemers in een arbeidsbestel zoals het Duitse moeten beschikken over een breed en gevarieerd aanbod van deskundigheden en kwalificaties. Zo'n systeem vraagt, om goed te werken, om een zekere mate van overkwalificatie over de brede linie, om hoge kwaliteitsproductie te garanderen en loondrift tegen te gaan. Zo'n systeem lijkt alleen mogelijk als werkgevers het eens zijn over de inhoud van beroepsopleiding en bereid zijn de kosten te dragen. Tot nu toe kenmerkt het Duitse systeem door hechte brancheorganisaties, maar dat staat voor kleine bedrijven en in het voormalige Oost-Duitse deel van het land onder druk. Het Duitse stelsel is kwetsbaar als bedrijven door internationalisering meer exit-opties krijgen en als branches vervagen of intern diverser worden. Het wordt dan moeilijker om bedrijven op een lijn te krijgen en de vereiste opleidings- en kwalificatie-eisen vast te stellen. Overigens is het interessant te vermelden dat de IT-industrie in Duitsland (net zoals in Nederland) recent een functiekwalificatiesysteem heeft ingevoerd. Ten slotte wordt zo'n systeem van branchegebonden beroepsopleiding en overkwalificatie erg duur als mensen die hun baan verliezen niet snel elders geplaatst kunnen worden, en valt het gemakkelijker te realiseren in groeisectoren dan in krimpsectoren.

Denemarken kent een relatief dynamische arbeidsmarkt (Madsen 2003). De gemiddelde baanduur van werknemers in Denemarken ligt met ongeveer 8,5 jaar enkele jaren lager dan in Europa gebruikelijk is. Gezien de stabiliteit van anciënniteitcijfers over de jaren heen kan deze indicator aangemerkt worden als een structureel kenmerk van het Deense arbeidsbestel. Een ander kenmerk is het lage percentage werknemers met een flexibel arbeidscontract. Er is blijkbaar voldoende flexibiliteit binnen het standaardarbeidscontract. Opvallend is dat bijna 80 procent van de Deens bedrijven minder dan 10 werknemers in dienst heeft. Minder dan eenvijfde van alle werknemers werkt in een bedrijf met meer dan 500 werknemers. Interne mobiliteit en promotieladders moeten daarom wel een geringere rol spelen. Door het systeem van beperkte ontslagbescherming in combinatie met een genereuze werkloosheidsuitkering worden de kosten voor de numerieke flexibiliteit grotendeels door de staat gedragen en uit algemene belastingmiddelen betaald. Denemarken kenmerkt zich door een kostbaar activerend arbeidsmarktbeleid, met veel nadruk op omscholing en begeleiding. Toch 
gaat ook in Denemarken het meeste geld naar passief beleid, zoals uitkeringen aan werklozen, verlofmaatregelen en vroeggepensioneerden (tabel 2.3). De constellatie van geringe ontslagbescherming, uitgebreide sociale zekerheid en activerende arbeidsmarktprogramma's levert een hoge mate van externe mobiliteit (van baan naar baan, werk naar werkloosheid en werkloosheid naar werk) en een hoge arbeidsdeelname, zowel in personen als uren gemeten. De kosten van dit systeem zijn echter niet verwaarloosbaar. Verder valt op dat Zweden het (net als de vs) veel beter doet wat betreft de participatie van ouderen en lager geschoolden (zie tabel 2.5).

Tabel 2.5

Arbeidsdeelname in acht landen 1993-2003

\begin{tabular}{|c|c|c|c|c|c|c|c|c|c|}
\hline ARBEIDSDEELNAME & & NL & DK & $s$ & D & $\mathbf{F}$ & UK & US & J \\
\hline \multicolumn{10}{|l|}{ Netto participatiegraad } \\
\hline \multirow[t]{2}{*}{ (\% bevolking 15-64 jaar) } & 2003 & 73,6 & 75,1 & 72,9 & 65,0 & 63,2 & 71,5 & 71,2 & 68,4 \\
\hline & $\Delta 1993-2003$ & 10,0 & 3,0 & 1,6 & $-0,1$ & 3,9 & 4,1 & $-2,0$ & $-5,8$ \\
\hline \multicolumn{10}{|l|}{ Netto participatiegraad } \\
\hline \multirow[t]{2}{*}{ mannen } & 2003 & 81,1 & 79,6 & 74,2 & 70,9 & 69,4 & 77,7 & 76,9 & 79,8 \\
\hline & $\Delta 1993-2003$ & 6,5 & 3,8 & 1,2 & $-4,0$ & 2,1 & 3,8 & $-1,3$ & $-8,3$ \\
\hline \multicolumn{10}{|l|}{ Netto participatiegraad } \\
\hline \multirow[t]{2}{*}{ vrouwen } & 2003 & 66,0 & 70,5 & 71,5 & 58,9 & 57,2 & 65,3 & 65,7 & 56,8 \\
\hline & $\Delta 1993-2003$ & 13,8 & 2,3 & 1,8 & 3,8 & 5,7 & 4,5 & 0,0 & $-3,4$ \\
\hline \multicolumn{10}{|l|}{ Verschil participatie } \\
\hline mannen-vrouwen & 2003 & 15,1 & 9,1 & 2,7 & 12,0 & 12,2 & 12,4 & 11,2 & 23,0 \\
\hline \multicolumn{10}{|l|}{ Netto participatiegraad } \\
\hline \multirow[t]{2}{*}{ ouderen (55-64 jaar) } & 2003 & 44,3 & 60,2 & 71,9 & 39,0 & 38,8 & 55,4 & 59,9 & 62,1 \\
\hline & $\Delta 1993-2003$ & 15,5 & 8,2 & 6,8 & 2,2 & 6,9 & 7,7 & 5,5 & $-1,8$ \\
\hline \multicolumn{10}{|l|}{ Netto participatiegraad } \\
\hline lager geschoolden & 2003 & 58,7 & 61,0 & 68,2 & 50,9 & 57,8 & 52,9 & 57,0 & 66,6 \\
\hline \multicolumn{10}{|l|}{ Netto participatiegraad } \\
\hline hoger geschoolden & 2003 & 87,1 & 87,2 & 86,5 & 83,6 & 83,3 & 87,8 & 83,2 & 79,7 \\
\hline \multicolumn{10}{|l|}{ Verschil participatie } \\
\hline hoger en lager geschoolden & 2003 & 28,4 & 26,2 & 18,3 & 32,7 & 25,5 & 34,9 & 26,2 & 13,1 \\
\hline
\end{tabular}

Bron: OECD, Employment Outlook 2004, Paris, 2005 (reference tables)

Hoogopgeleide werknemers zijn minder afhankelijk van schommelingen in de vraag naar producten en om die reden minder onderworpen aan onvrijwillige mobiliteit, die inderdaad het meeste voorkomt onder laagopgeleiden (Madsen 2003). Verder hebben lager opgeleiden en ouderen veel meer moeite weer aan het werk te komen als ze werkloos zijn. Dit hangt ook samen met geringere scholingsinvesteringen van werkgevers in deze groep. Eurostat-gegevens, op basis van de European Labour Force Survey, laten duidelijk zien dat over het algemeen minder in ouderen en minder in laagopgeleiden wordt geïnvesteerd (tabel 2.6). Overigens zijn de verschillen tussen landen opmerkelijk groot en investeert 
Zweden over de hele linie veel meer in scholing, ook onder ouderen, werklozen, inactieven en laagopgeleiden. De gepresenteerde cijfers zijn overigens beter binnen dan tussen landen vergelijkbaar, aangezien ze geen rekening houden met de informele scholing in het bedrijf tijdens werktijd (zonder verlof). Dat laatste speelt vooral een rol in Duitsland en in mindere mate ook in Frankrijk. Toch geven de cijfers goed weer hoe ver de werkelijkheid afstaat van het ideaal van 'voortgezette scholing' en algemene competentiebevordering van oudere werknemers (vanaf 35 jaar?) en mensen met een lagere of afgebroken schoolopleiding.

Tabel 2.6 Deelname aan onderwijs en scholing in zes landen, in 2003

\begin{tabular}{|c|c|c|c|c|c|c|c|}
\hline \multicolumn{8}{|c|}{ DEELNAME ONDERWIJS EN SCHOLING ${ }^{a}$} \\
\hline BEROEPSBEVOLKING & NL & DK & SE & DE & FR & UK & $J$ \\
\hline \multicolumn{8}{|l|}{ Beroepsbevolking 15-64 jaar } \\
\hline werkenden & 2003 & 18.4 & 17.9 & 33.3 & 5.4 & 8.2 & 23.0 \\
\hline werklozen & 2003 & 16.1 & 19.3 & 31.0 & 5.8 & 7.6 & 20.6 \\
\hline inactieven & 2003 & 10.5 & 23.5 & 44.6 & 7.0 & 5.0 & 14.1 \\
\hline \multicolumn{8}{|l|}{ Hoogst genoten onderwijs } \\
\hline hoger (hbo, universiteit) & 2003 & $22.6^{* b}$ & 25.5 & 49.5 & 8.4 & 14.1 & 33.9 \\
\hline middelbaar (mbo, vwo) & 2003 & $18.2^{*}$ & 16.9 & 30.9 & 6.1 & 7.2 & 19.4 \\
\hline lager & 2003 & $9.4^{*}$ & 12.8 & 18.3 & 2.2 & 3.2 & 7.3 \\
\hline \multicolumn{8}{|l|}{ Leeftijd } \\
\hline 25-34 jaar & 2003 & 24.8 & 31.5 & 39.7 & 14.2 & 12.1 & 26.4 \\
\hline 35-44 jaar & 2003 & 18.7 & 18.9 & 35.1 & 5.2 & 7.9 & 22.7 \\
\hline $45-54$ jaar & 2003 & 13.4 & 14.9 & 33.1 & 3.3 & 6.2 & 19.9 \\
\hline 55-64 jaar & 2003 & 7.2 & 9.5 & 27.8 & 1.2 & 2.1 & 13.2 \\
\hline
\end{tabular}

a Deelname aan scholing en onderwijs (met verlof, buiten werktijd) volgens eigen opgave werknemers. Dit omvat dus niet de informele scholing tijdens werktijd, wat een deel van de lage percentages voor Duitsland en Frankrijk verklaart.

b $*=2002$.

Bron: Eurostat, European Labour Force Survey, Europese Commissie, structurele indicatoren Europese Werkgelegenheids-strategie, key indicator 21, Compendium 2004-2005

Nederland past waarschijnlijk net als Duitsland en Zweden rechtsonder in figuur 2.2 In het algemene en sectorale beroepsonderwijs worden leerlingen op een brede wijze geschoold (vergelijk Kerckhoff 2001). Daarnaast zijn ze gemiddeld genomen behoorlijk in staat om in bepaalde functies meerdere taken op zich te nemen. De laatste tijd worden veel problemen gesignaleerd met betrekking tot schooluitval, de kwaliteit en aansluiting van het beroepsonderwijs en ontbrekende of gebrekkige startkwalificaties. In de kenniseconomie worden meer generieke probleemoplossende vaardigheden gevraagd, in aanvulling op baanspecifieke kwalificaties, zodat werknemers zich aan kunnen passen aan voortdurende technologische en organisatorische veranderingen. 
Er zijn enkele uitvoerige studies beschikbaar over de werking van interne arbeidsmarkten, zoals de dissertaties over de bedrijven Hoogovens (Van Veen 1997) en Fokker (Dohmen 2003). Van Hoof (1990) heeft in zijn dissertatie geconcludeerd dat er geen empirisch onderzoek bestaat dat het bestaan van horizontaal en verticaal gerangschikte arbeidsmarktsegmenten overtuigend aantoont, ook niet in perioden van omvangrijke werkloosheid als in de eerste helft van de jaren tachtig. Een afgezwakte versie, die ervan uitgaat dat werkgevers goede bedrijfskundige redenen kunnen hebben om werknemers vaste arbeidscontracten aan te bieden, boven de 'marktprijs' te betalen, aan het werk te houden als het tegenzit (labour hoarding) en de 'interne arbeidsmarkt' af te schermen van de dynamiek en onzekerheid van de externe arbeidsmarkt, is gepopulariseerd in het bekende 'insider-outsider'-model van de arbeidsmarkt (Blanchflower en Oswald 1988; Lindbeck en Snower 1988) en dat heeft ook binnen Nederland wel toepassing gevonden. Deze zwakkere variant van de interne arbeidsmarkt legt de nadruk op relatieve verschillen, brengt de betekenis van teamwerk en onderlinge samenwerking van werknemers, ook bij de opleiding van nieuwkomers, nadrukkelijker in beeld, alsmede de macht en de belangen van vakbonden en ondernemingsraden (zie Van der Meer 1998).

In Nederland hebben vooral de arbeidstijdflexibiliteit (deeltijd, jaarmodellen, variabele werktijden, zie Goudswaard e.a. 200o) en de grote toestroom van nieuwkomers (vrouwen met name) bijgedragen aan de flexibiliteit. De soep is er minder heet gegeten dan in de vs of Groot-Brittannië, waar met een stevige politieke aanval op de 'insidersmacht' van vakbonden de arbeidsmarkt voor de bulk van de gevestigde werknemers is geflexibiliseerd. Maar ook minder heet dan in Frankrijk, Italië of Spanje, waar een sterkere tweedeling is opgetreden en de flexibilisering vooral de nieuwkomers en kleine banen aan de onderkant van de arbeidsmarkt betreft. De 'normalisering' van deeltijdwerk (Visser 2002) en de flexicurity-strategie (Wilthagen 2003) ten aanzien van tijdelijk en uitzendwerk heeft bijgedragen aan de sterkere verbreiding van deze 'moderne' vormen van arbeid en contracten (zie tabel 2.7). De grotere aantrekkelijkheid ervan blijkt uit het feit dat in Nederland (en Denemarken) deeltijdwerkers aangeven dat zij deze keuze vrijwillig maken en niet op zoek zijn (geweest) naar voltijdbanen. Nochtans is de uitdaging van de toekomst een nieuw mobiliteitsregime voor gevestigde werknemers met vaste arbeidscontracten te ontwikkelen, waarin een nieuwe afruil van zekerheid en flexibiliteit ontstaat, werknemers minder rechten aan ontslagbescherming en ervaringsjaren kunnen ontlenen en werkgevers en overheden zich meer moeten inzetten voor scholing en begeleiding naar nieuwe banen en carrières in of zelfs voor de tweede van het werkzame leven, binnen maar in toenemende mate buiten het bedrijf of de organisatie waar men werkt. Deze uitdaging vergt aanpassingen in het psychologisch contract tussen werkgever en werknemer en ook een nieuwe benadering van ontslagbescherming en sociale zekerheid. 


\begin{tabular}{|c|c|c|c|c|c|c|c|c|c|}
\hline \multicolumn{2}{|c|}{ MODERNISERINC ARBEIDSMARKT } & NL & DK & $\mathbf{S}$ & D & $\mathbf{F}$ & UK & US & J \\
\hline \multicolumn{10}{|l|}{ Deeltijdbanen } \\
\hline \multirow[t]{2}{*}{ (als \% van alle banen) } & 2003 & 34,5 & 15,8 & 14,1 & 19,6 & 12,9 & 23,3 & 13,2 & 26,0 \\
\hline & $\Delta 1994-2003$ & 8,0 & $-1,3$ & $-1,7$ & 6,1 & 0,6 & 1,1 & $-0,3$ & 3,4 \\
\hline \multicolumn{10}{|l|}{ Tijdelijke contracten } \\
\hline \multirow{2}{*}{ (als \% van alle contracten) } & 2003 & 14,5 & 9,3 & 15,5 & 12,0 & 12,7 & 6,1 & 4,0 & 13,9 \\
\hline & $\Delta 1993-2003$ & 4,0 & $-1,3$ & 3,5 & 1,7 & 1,8 & $-0,2$ & 0,0 & 3,3 \\
\hline \multicolumn{10}{|l|}{ Uitzendwerknemers } \\
\hline \multirow[t]{2}{*}{ (als \% van alle werknemers } & 2004 & 2,5 & 1,2 & 1,0 & 1,0 & 2,1 & 5,0 & 4,5 & .. \\
\hline & $\Delta 1999-2004$ & $-2,0$ & 1,0 & 0,5 & 0,3 & 0,1 & 1,4 & 0,5 & .. \\
\hline \multicolumn{10}{|l|}{ Aandeel zelfstandige } \\
\hline \multirow{2}{*}{ arbeid } & 2003 & 13,9 & 7,1 & 4,9 & 10,2 & 8,8 & 12,7 & 7,6 & 14,9 \\
\hline & $\Delta 1993-2003$ & $-1,7$ & $-2,1$ & $-0,6$ & 0,5 & $-2,8$ & $-0,8$ & $-1,2$ & $-7,4$ \\
\hline
\end{tabular}

Bron: Eigen berekeningen op basis van European Labour Force Survey (Eurostat) en OEso. Uitzendwerk op basis van opgave door de Confédération Internationale des Entreprises de Travail Temporaire (СIETT).

\section{Indicatoren: verdwijnt de interne arbeidsmarkt?}

Welke indicatoren wijzen op de veranderingen en mogelijk het verdwijnen van interne arbeidsmarkten? We willen hier enkele noemen. We beginnen met de externalisering van bedrijfsactiviteiten. Het afstoten van activiteiten en meer in het bijzonder de 'outsourcing' van voorheen interne bedrijfsactiviteiten kan verschillende vormen aannemen en zal in het algemeen tot een verkleining van de gemiddelde bedrijfsomvang leiden. Deze trend is in elk geval voor de vs goed gedocumenteerd (Carroll en Hannan 20oo). Verkoop of splitsing van het bedrijf; oproeparbeid; uitzendwerk; gebruik van inleenbedrijven en onderaanneming zijn vormen van externalisering. Wat de arbeidsverhouding betreft moet een onderscheid gemaakt worden tussen situaties waarin het (inlenende) bedrijf in juridische zin werkgever blijft (wel bij oproeparbeid, niet bij de overige genoemde vormen) en het feitelijk toezicht over de verrichte arbeid blijft uitoefenen (wel bij uitzendarbeid, niet bij inleenarbeid en onderaanneming) (Kalleberg e.a. 2003).

\subsubsection{TIJDELIJKE CONTRACTEN EN UITZENDWERK}

Als eerste indicator voor de erosie en verkleining van interne arbeidsmarkten geldt de opkomst van tijdelijk en uitzendwerk, alsmede het toenemend gebruik van inleenbedrijven en freelance werk. In de vs verdubbelde het uitzendwerk tussen 1980 en 1990 en opnieuw tussen 1990 en 2000 . Momenteel werkt ongeveer 4,5 procent van de Amerikanen via een uitzendcontract, samen met het Verenigd Koninkrijk het hoogste marktaandeel in de westerse wereld (zie tabel 2.7). In Nederland verdubbelde het marktaandeel van uitzendbedrijven in de jaren 
negentig van twee tot vier procent (Dunnewijk 200o). Op uitzendgebied was Nederland tot 1999 koploper, maar sindsdien is het marktaandeel van uitzendwerk drastisch teruggelopen, ten dele om conjuncturele redenen, maar waarschijnlijk ook als gevolg van de strengere eisen aan het werkgeverschap van uitzendorganisaties in de Wet Flexibiliteit en Zekerheid uit 1999.

Uit onderzoek op basis van een representatieve steekproef van Amerikaanse bedrijven uit 1997 bleek dat 20 procent gebruikmaakt van flexibele arbeidscontracten voor het eigen personeel in dienst (hetzij via oproepcontracten of contracten voor bepaalde tijd) ruim 50 procent een beroep doet op uitzendkrachten en bijna 40 procent op inleenbedrijven en onderaannemers (Kalleberg en Marsden 2005). Verder bleek dat bedrijven uitzendarbeid inzetten bij kernactiviteiten waar ze controle over willen behouden, zoals productie, R\&D en klantenadministratie. Daarentegen gebruiken ze inleenbedrijven voor functies die het verst van hun kernactiviteiten afstaan, zoals veiligheid, schoonmaak, catering, reparatie, soms ook IT en personeelsadministratie. Op zich betekent deze ontwikkeling niet dat de interne arbeidsmarkt verdwijnt, wel dat ze kleiner wordt. Het zou ook kunnen betekenen dat het onderscheid intern versus extern, wat de uitvoering van het werk vager, maar wat betreft de rechten en arbeidsvoorwaarden van werknemers juist scherper wordt. Het naast elkaar werken van werknemers, die soms dezelfde activiteiten verrichten of in teams met elkaar samenwerken maar verschillende rechten en vooruitzichten hebben, is op macroniveau een uitdaging aan het arbeidsrecht en de sociale zekerheid (Supiot 2001) en op microniveau, binnen de onderneming, een HRM-probleem en roept veel vragen op met betrekking tot competentiemanagement, scholing en mobiliteit van personeel.

Opmerkelijk is dat in de vs veel geschoolde werknemers via uitzendcontracten werken. Ruim driekwart van alle bedrijven in de verwerkende industrie in de vs gebruikt uitzendkrachten (Houseman 2001). Daarnaast is ook het gebruik van tijdelijke contracten, direct in dienst van de werkgever waar het werk plaatsvindt, toegenomen en werken vooral in de nieuwe sectoren als ICT en media, velen op basis van 'werk'-opdrachten in plaats van 'arbeidscontracten, dat wil zeggen buiten het arbeids- en sociale zekerheidsrecht. Internationale cijfers van onder meer de OESO (zie tabel 2.7) laten echter zien dat de omvang van tijdelijk werk en zelfstandige arbeid in de Verenigde Staten relatief beperkt is. In Nederland, Zweden, Japan, Frankrijk en Duitsland werkt een veel groter deel van de werknemers op tijdelijke basis en is de groei van tijdelijke contracten in de jaren negentig veel groter geweest. Ook is in de vs het aandeel van 'zelfstandigen' tamelijk bescheiden. Dit houdt verband met het verdwijnen van de kleine boer en middenstand, een ontwikkeling die nu Japan in zijn greep heeft en ook in Europa nog steeds voor een teruggang van zelfstandige arbeid zorgt. Overigens moet bij de vergelijking tussen landen wel rekening gehouden worden met institutionele verschillen. Strengere ontslagwetgeving leidt in veel landen tot het gebruikmaken van tijdelijke contracten als noodoplossing. Als werkgevers makkelijk van vast personeel afkomen en wetgeving en vakbonden hen daaraan niet kunnen hinderen, dan is er weinig redenen om een apart kanaal voor 'tijdelijke contrac- 
ten' in te richten. Bovendien kan deeltijdwerk in de vs, net als in Japan, in de meeste gevallen tot marginaal werk, met weinig zekerheid en secundaire arbeidsvoorwaarden, worden gerekend. Uit tabel 2.8 wordt duidelijk dat de flexibilisering van de arbeidsmarkt vooral via het scheppen van meer ruimte en minder regels voor tijdelijke contracten heeft plaatsgevonden, vooral in landen waar een strikter regelgeving bestaat met betrekking tot de ontslagbescherming voor reguliere dienstverbanden. We zien ook dat met betrekking tot reguliere dienstverbanden en collectief ontslag vrijwel niets veranderd is.

Tabel 2.8 Ontslagbescherming regulier en flexibel werk in acht landen 1988-2003

\begin{tabular}{|lccccccccc}
\multicolumn{2}{l}{ INDEX ONTSLAGBESCHERMING } & NL & DK & S & D & F & UK & US & J \\
Reguliere dienstverbanden & 2003 & 3.1 & 1.5 & 2.9 & 2.7 & 2.5 & 1.1 & 0.2 & 2.4 \\
& $\Delta 1988-2003$ & 0.0 & 0.0 & 0.0 & 0.1 & 0.2 & 0.2 & 0.0 & 0.0 \\
Tijdelijke dienstverbanden & 2003 & 1.2 & 1.4 & 1.6 & 1.8 & 3.6 & 0.4 & 0.3 & 1.3 \\
& $\Delta 1988-2003$ & -1.2 & -1.7 & -2.5 & -2.0 & 0.5 & 0.1 & 0.0 & -0.5 \\
Collectief ontslag & 2003 & 3.0 & 3.9 & 4.5 & 3.8 & 2.1 & 2.9 & 2.9 & 1.5 \\
& $\Delta 1998-2003$ & 0.0 & 0.0 & 0.0 & 0.3 & 0.0 & 0.0 & 0.0 & 0.0 \\
& & & & & & & & & \\
\hline
\end{tabular}

Bron: OESO (2005)

Onderzoek naar de doorstroom van werknemers in Nederland met tijdelijke aanstellingen naar vaste banen biedt geen eenduidige conclusies. Dit wordt veroorzaakt door verschillen in onderzoeksmethode en onderzoekspopulaties. Zijl, Van den Berg en Heyma (2004) en Marloes De Graaf-Zijl in haar dissertatie (2006) laten zien dat uitzendwerk in veel gevallen de werkloosheidsduur terugbrengt en dient als een springplank tot een vaste baan. Zijl en Van Leeuwen (2004) concluderen aan de hand van een literatuurstudie dat ongeveer twintig procent van de tijdelijke werknemers en een iets hoger percentage van de uitzendkrachten binnen een jaar doorstroomt naar een permanente baan. Dit blijkt overigens ongelijk verdeeld te zijn over verschillende bevolkingsgroepen. Onder vrouwen is de doorstroom beperkter. Mogelijk wordt dit beïnvloed door het werken in deeltijd (Muffels en Steijn 1998). Voor werknemers uit etnische minderheden en voor laagopgeleiden in het algemeen geldt eveneens een lagere doorstroomkans (Zandvliet et al. 2002).

\subsubsection{PERCEPTIE VAN TOEGENOMEN BAANONZEKERHEID}

Een tweede indicator voor de veranderingen in de aard van de arbeidsverhouding is de toegenomen perceptie van baanonzekerheid. Bij interne arbeidsmarkten past een 'impliciete' of onuitgesproken overeenkomst van baanzekerheid in ruil voor loyale en plichtsgetrouwe inzet. Het bijpassende 'psychologische contract' is gestoeld op de overtuiging dat er een garantie van een blijvend dienstverband bij dezelfde werkgever is gegeven (Robinson en Rousseau 1994; Anderson en Schalk 1998). Veranderingen in de perceptie van baanzekerheid vormen daarom een 
directe aanwijzing dat in de beleving van werknemers interne arbeidsmarkten en de daarbij horende zekerheid bezig zijn te verdwijnen.

In de meeste westerse landen beleven werknemers volgens eigen opgave een toename van de onzekerheid van hun werk (Böckerman 2003; Clark en Postel-Vinay 2005; Sverke et al. 2004). Deze stijging wordt in verband gebracht met de toename van de werkloosheid, de opkomst van tijdelijk werk en bedrijfsreorganisaties. Op individueel niveau, gebruikmakend van data uit het European Community Household Panel (ECHP) hangt de perceptie van baanonzekerheid onder meer samen met (oudere) leeftijd, een laag scholingsniveau en persoonlijke ervaringen met reorganisaties en werkloosheid. Uit deze data en uit een survey van de European Foundation of Living and Working Conditions in Dublin komt tevens naar voren dat baanonzekerheid gepaard gaat met gevoelens van machteloosheid en onvrede over het werk. Nationale verschillen zijn aanzienlijk, met de laagste gemeten baanonzekerheid in Denemarken en de hoogste in Spanje, Griekenland en Italië, juist de landen met de sterkste ontslagbescherming voor reguliere dienstverbanden.

Tabel 2.9

Perceptie van baanonzekerheid, in 1998

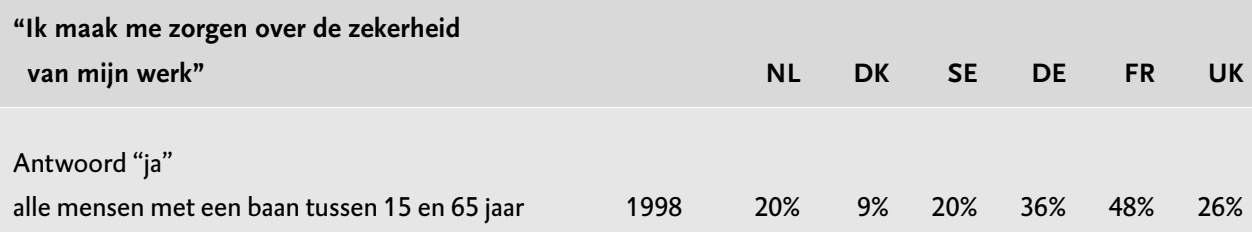

Bron: Böckerman, 2003

In Nederland voelden in 1998, bij een dalende trend in de werkloosheid, naar verhouding twee keer zoveel werknemers zich onzeker over de toekomst van hun werk dan in Denemarken, waar de werkloosheid toen hoger lag en minder snel daalde (tabel 2.9). In Duitsland en vooral in Frankrijk voelen nog meer werknemers zich ongewis over de toekomst van hun werk, maar dat kan ten dele met de blijvend hoge werkloosheid in die landen samenhangen. Gecontroleerd voor de omvang van de werkloosheid voelen werknemers in Frankrijk en Duitsland zich onzekerder over de toekomst van hun baan dan werknemers in Denemarken, Zweden of Nederland (Böckerman 2003). Dat suggereert dat baanonzekerheid uit twee componenten bestaat: de kans op baanverlies en de kosten van baanverlies. Terwijl sterk gereguleerde interne arbeidsmarkten en bescherming van gevestigde werknemers de kans op baanverlies vermindert, verkleint het ook de kans op nieuw werk en dus ook de kosten van baanverlies, vooral als werkloosheid een belangrijke inkomensderving met zich meebrengt. Zoals uit de decommodificatie-index bleek (tabel 2.3) zijn werknemers in Denemarken, Zweden en Nederland wat dat betreft beter af. 


\subsubsection{GEMIDDELDE OF MODALE BAANDUUR VAN WERKNEMERS}

Cijfers over een afnemende gemiddelde of modale baanduur zouden een derde aanwijzing voor de erosie van interne arbeidsmarkten kunnen zijn. Stone (2004: 75-83) analyseert de veranderingen in de modale baanduur tussen 1983 en 2001 in de Verenigde Staten met hulp van de Current Population Survey van het US Bureau of Labor Statistics. Opsplitsing naar geslacht, leeftijd en scholingsniveau laat markante verschillen zien. Uiteraard is de modale baanduur het laagst (voor mannen gemiddeld 3 jaar, voor vrouwen 2,5 jaar) in de jongste leeftijdsgroep (24-34 jaar) en het hoogst (mannen 11 jaar, vrouwen 9,5 jaar) in de oudste groep (55-64 jaar). Maar terwijl er bij mannen in alle leeftijdsgroepen behalve de jongste een zeer duidelijke daling in de modale baanduur is opgetreden (in de oudste leeftijdsgroep van 16 naar 11 jaar) is er onder vrouwen over de hele linie behalve de jongste leeftijdsgroep sprake van een lichte stijging in de modale baanduur. Volgens Stone wijst de daling onder mannen op de erosie van interne arbeidsmarkten en is de stijging onder vrouwen het gevolg van het feit dat meer vrouwen blijven doorwerken na de geboorte van kinderen. $\mathrm{Zij}$ wordt in deze interpretatie gesterkt door het gegeven dat vooral onder mannen met geringe scholing de modale baanduur het meeste afnam (zie ook Farber 1999). Dit was de groep werknemers in de industrie voor wie het impliciete contract op blijvend werk het belangrijkste was. Het is de groep voor wie de erosie van de interne arbeidsmarkt en het wegvallen van de garantie van vast werk en inkomen, met de mogelijkheid van interne promotie, het meest bedreigend is. Daarnaast rapporteert Stone een sterke afname van het aandeel mannelijke werknemers dat langer dan tien jaar bij dezelfde werkgever in dienst is, een daling die in alle leeftijdsgroepen maar vooral in de oudste groep optreedt.

Helaas beschikken we voor Nederland en andere landen niet over zulke gedetailleerde tijdreeksen. Cijfers van het Centraal Bureau voor de Statistiek geven aan dat de gemiddelde baanduur het hoogst is voor mensen met alleen lager onderwijs en lager en gemiddeld beroepsonderwijs, maar dit is ten dele een cohorteffect. Werknemers met een achtergrond in het algemeen onderwijs (universiteit en vwo) kenmerken zich door meer mobiliteit dan werknemers uit het beroepsonderwijs (vbo, mbo en, zij het in mindere mate, hbo). Uit de bewerking van OSA- en CBS-gegevens voor de jaren negentig trekt het SCP de conclusie dat de discrepantie tussen feitelijke en gewenste baankenmerken een tamelijk goede voorspeller is voor zoekgedrag en externe mobiliteit (Gesthuizen en Dagevos 2005). Toch is er ook een groep werkenden die deze discrepantie wel ervaart, maar geen zoekgedrag vertoont en niet (extern) mobiel is. Dit zijn met name ouderen, lager opgeleiden en mensen met (jonge) kinderen. In tegenstelling tot deze groepen zijn jongeren, vrouwen, gescheiden personen, hoogopgeleiden, personen met een afgeronde cursus, werkenden met een tijdelijk contract en werkenden in de kleinschalige handel en dienstverlening juist vaker mobiel. Helaas zijn de gegevens van het СBS (Statline) vanwege definitieveranderingen moeilijk door de tijd te vergelijken. Gegevens voor 1995 en 1999 laten dezelfde verschillen in baanduur tussen mannen en vrouwen, werknemers met verschil- 
lende opleidingsduur en uit verschillende leeftijdsgroepen zien als in de vs, zij het dat in Nederland de baanduur in elke categorie gemiddeld hoger ligt. Ook is er een ontwikkeling naar een kortere gemiddelde baanduur van mannen, vooral in de groep met alleen basisonderwijs, te bespeuren en neemt de gemiddelde baanduur van vrouwen toe. Maar vier jaar zijn te kort om van een echte trend te spreken. Zulke ontwikkelingen worden gemist als we de gemiddelde cijfers, ongeacht geslacht, leeftijd en opleidingsniveau, bezien (zie ook Farber 1999). De in tabel 2.1 gepresenteerde gemiddelden geven daarom wel uitsluitsel over de grote verschillen tussen landen (langste gemiddelde baanduur in Japan en de kortste in de vs, met Nederland daar tussenin) maar niet over de veranderingen. Vooral het tegenstrijdig effect bij mannen en vrouwen is verwarrend. De conclusie van Auer en Cazes (2002) en Auer (2004) dat de gemiddelde baanduur niet daalt maar gelijk blijft, is daarom niet het laatste woord. We kunnen daaraan zeker niet de conclusie ontlenen dat interne arbeidsmarkten intact zijn gebleven en het impliciete contract van een blijvend dienstverband nog bestaat. Bernhardt en Marcotte (2000: 24) merken terecht op dat met name de verdeling van stabiele dienstverbanden aan verandering onderhevig is en dat vooral de laaggekwalificeerde werknemers die ooit konden rekenen op vast werk, on-the-job scholing en beloning naar anciënniteit aan het kortste eind trekken.

\subsubsection{NAAR EEN NIEUW PSYCHOLOGISCH CONTRACT?}

De nieuwe arbeidsverhouding richt zich minder op de sociale en juridische bescherming van een duurzame verbintenis van werknemer en werkgever dan op de ondersteuning van "een portfolio van menselijk kapitaal" (Carnoy, Castells en Brenner 1997) door middel van deelname aan training en netwerken. Dit sluit aan op het beeld van de 'ondernemende werknemer', die zelfstandiger zijn 'human capital' op peil houdt, mobieler is, vooral tussen bedrijven en waar mogelijk zijn of haar heil in zelfstandig ondernemerschap zoekt. Naar de 'ondernemende werknemer' is in Nederland onderzoek gedaan door Bolweg en De Korte (1994) en ook door Gasperz en Ott (1996) met als resultaat dat de 'echte' nieuwe en ondernemende werknemer nog niet is opgestaan, maar net als vroeger hunkert naar zekerheid. Maar dat is wellicht een andere dan de oude zekerheid van routineus werk, uitgestippelde carrièrepaden en een vaste betrekking bij dezelfde werkgever. De vraag is welk psychologisch contract en welke juridische regelgeving bij de nieuwe arbeidsverhouding past.

Organisatiepsychologen gebruiken het begrip 'psychologisch contract' voor de perceptie en verwachtingen die werknemers ten aanzien van hun arbeidsverhouding hebben. Het drukt uit in hoeverre de werknemer gelooft of verwacht dat werknemer en werkgever verplichtingen jegens elkaar hebben die verdergaan dan hun geschreven overeenkomst (Guest 1998; Van den Brande 1999). Robinson en Rousseau (1994: 246) definiëren een psychologisch contract als "iemands overtuiging dat er een soort van belofte is gedaan en de contractuele voorwaarden door beide partijen zijn aanvaard". Zo'n psychologisch contract kan gestoeld zijn op de perceptie, verwachting of overtuiging dat de tegenpartij een vaste baan in 
het vooruitzicht heeft gesteld, voorrang zal geven bij bevordering, een vast inkomen garandeert, scholing zal verzorgen of zal helpen bij het vinden van een nieuwe baan. Deze inhouden kunnen verschillen, sommige onderdelen ervan kunnen geformaliseerd en in afspraken vastgelegd zijn, maar doorgaans is het psychologisch contract "impliciet, onuitgesproken en zelden bediscussieerd" (Anderson en Schalk 1998: 637). Rousseau en anderen maken een onderscheid tussen verwachtingen met betrekking tot de arbeidsverhouding en een psychologisch contract. Een verwachting drukt in hun ogen een aspiratie of hoop uit, een psychologisch contract stoelt op een overtuiging. Als een verwachting niet uitkomt, leidt dit tot teleurstelling; wordt een psychologisch contract niet nagekomen, dan voelt men zich tekortgedaan, bedrogen of zelfs verraden (Robinson en Rousseau 1994; Rousseau en Tijoriwala 1999). Beide hebben consequenties voor de arbeidsverhoudingen, maar in het laatste geval zijn deze veel ernstiger. De gevolgen zijn diepgevoelde frustratie, demotivatie, stress, ernstig productiviteitsverlies en verlies van 'organisatorisch burgerschapsgedrag' (Organ 1988) zoals de bereidwilligheid collega's te helpen of wanneer nodig in te springen en iets extra's te doen (Anderson en Schalk 1998; Turnley en Feldman 1999). Het kan daarom vanuit personeelsbeleid erg belangrijk zijn om bijtijds helder te zijn over de termen van het psychologisch contract, vooral waar organisaties naast plichtbesef en goede taakuitoefening juist ook organisatorisch burgerschap en inventiviteit van hun medewerkers vragen.

Er is een behoorlijk grote consensus onder organisatiekundigen in de Amerikaanse literatuur en praktijk dat het oude psychologische contract, gebaseerd op de belofte van baanzekerheid, interne promotie en een stabiel en groeiend (pensioen)inkomen, niet meer bestaat (Roehling et al. 1998). In figuur 2.3 vatten we de richting van de verandering in de arbeidsverhoudingen samen. Volgens Cavanaugh en Noe (1999: 324) nemen eigen verantwoordelijkheid voor carrièreontwikkeling en sterkere binding aan (de inhoud van) het werk de plaats in van binding aan organisatie en baan. De verwachtingen jegens het werk richten zich op de ontplooiingskansen dat het werk biedt en op de gelegenheden voor netwerken naar een volgende baan. Het nieuwe psychologische contract draait om de impliciete belofte dat de werkgever alles doet om zo'n loopbaanontwikkeling buiten de organisatie mogelijk te maken door bij te dragen aan scholing en gelegenheid te bieden tot deelname aan interessante netwerken. De werkgever moet wel, omdat hij of zij anders nooit het gewenste extra uit zijn medewerkers krijgt. In dit opzicht worden ondernemingen in de kenniseconomie kwetsbaarder, omdat ze sterker op de actieve betrokkenheid van hun werknemers zullen zijn aangewezen. Ontwikkelen, delen en gebruiken van kennis kan immers niet zonder de actieve coöperatie van werknemers en hun bereidheid die ten bate van de onderneming aan te wenden. Het is niet meer voldoende om taken passief, zonder fouten en zonder betrokkenheid te verrichten.

Volgens Stone (2006) wordt het nieuwe psychologische contract en, meer in het algemeen, de (externe, horizontale en verticale) mobiliteit in de kenniseconomie bedreigd door een nieuw conflict over het eigendomsrecht op kennis en mense- 
Figuur 2.3 De nieuwe arbeidsverhouding

\begin{tabular}{|c|c|c|}
\hline $\begin{array}{l}\text { Taakverdeling } \\
\text { Toezicht }\end{array}$ & standaard arbeidsverhouding & nieuwe arbeidsverhouding \\
\hline $\begin{array}{l}\text { Contractuele } \\
\text { voorwaarden }\end{array}$ & $\begin{array}{l}\text { Gespecificeerd, gedetailleerde functie- of } \\
\text { taakbeschrijving, weinig eigen invulling }\end{array}$ & $\begin{array}{l}\text { In sterkere mate onvolledig, meer ruimte } \\
\text { en verwachting van eigen invulling }\end{array}$ \\
\hline $\begin{array}{l}\text { Monitoring en } \\
\text { toezicht }\end{array}$ & $\begin{array}{l}\text { Directe supervisie en/of sterke binding } \\
\text { aan vooropgezette taken }\end{array}$ & $\begin{array}{l}\text { Indirecte controle (jaargesprekken, tar- } \\
\text { gets) en monitoren van output op af- } \\
\text { stand (audits), eventueel zelf-monitoren }\end{array}$ \\
\hline $\begin{array}{l}\text { Psychologisch } \\
\text { contract }\end{array}$ & $\begin{array}{l}\text { Geloof in zekerheid baan, promotie, } \\
\text { inkomen en pensioen }\end{array}$ & $\begin{array}{l}\text { Geloof in ontwikkelingskansen werk, } \\
\text { deelname aan interessante netwerken } \\
\text { en bijdrage werkgever aan verdere } \\
\text { scholing en opleiding }\end{array}$ \\
\hline Scholing en opleiding & Bedrijfs- of beroepsspecifiek & $\begin{array}{l}\text { Algemener en overdraagbaar } \\
\text { (individueel recht) }\end{array}$ \\
\hline Zekerheid & Baanzekerheid & $\begin{array}{l}\text { Werkzekerheid en employability } \\
\text { (recht of training) }\end{array}$ \\
\hline Beloning & $\begin{array}{l}\text { Vast en naar ervaringsjaren of leeftijd } \\
\text { (interne arbeidsmarkt) }\end{array}$ & $\begin{array}{l}\text { Gedeeltelijk variabel, gerelateerd aan } \\
\text { winst en/of prestatie }\end{array}$ \\
\hline Mobiliteit & $\begin{array}{l}\text { Intern (verticaal) en exit van arbeids- } \\
\text { markt }\end{array}$ & $\begin{array}{l}\text { Intern (horizontaal en verticaal) en } \\
\text { extern (netwerken) }\end{array}$ \\
\hline Arbeidsverhouding & $\begin{array}{l}\text { Collectieve bescherming, verdelings- } \\
\text { model }\end{array}$ & $\begin{array}{l}\text { Individuele rechten, procedurele } \\
\text { normen van fair gedrag, partnerschap }\end{array}$ \\
\hline
\end{tabular}

Bron: Vrij naar Collins, 2001 en Stone, 2004

lijk kapitaal die verkregen is door deelname in netwerken en scholing waaraan werkgevers een beslissende bijdrage leveren. Zij citeert een groot aantal recente rechtszaken in de vs, waarin rechters steeds minder terughoudend zijn in het bindend opleggen van afspraken (convenanten) met een concurrentiebeding. In een eerder stadium waren rechters juist heel voorzichtig geweest in de uitleg van zulke afspraken en gaven ze voorrang aan een vrijwel onbeperkt recht op (vrijwillige) mobiliteit als uitdrukking van het Amerikaanse streven naar positieverbetering. Volgens Stone is het feit dat deze kwestie steeds vaker bij de rechter komt een indicatie dat in de afgelopen decennia de arbeidsverhoudingen grondig zijn veranderd, van een situatie waarin kennis van werknemers werd ontmoedigd, althans ondergeschikt gemaakt aan plichtsgetrouwe taakuitoefening, naar een situatie waarin kennis en ontwikkeling van werknemers hogelijk gewaar- 
deerd wordt. Bovendien speelt de verschuiving naar opener organisaties mee, met medewerkers en kenniswerkers die intensief betrokken zijn bij en kennis opdoen in netwerken met andere bedrijven. De kennis die daarin opgedaan en getoetst wordt is waardevol, omdat deze aan de wieg staat van innovaties (in bijvoorbeeld productontwikkeling of klantenbinding) en derhalve belangrijk is voor de concurrentie. Ook 'negatieve kennis' over producten en experimenten die mislukken of processen die onproductief zijn is waardevol en kan in de handen van de concurrentie belangrijke bezuinigingen opleveren. Dit alles maakt bedrijven kwetsbaar voor het vertrek van medewerkers. Daarbij komt dat een deel van deze kennis niet gecodificeerd is of zelfs beschreven kan worden, in de hoofden van mensen zit en derhalve niet makkelijk overgedragen kan worden (Polanyi 1967). Stone trekt de parallel met de ambachtelijke organisatie van voor het taylorisme. Destijds stonden managers voor het probleem dat werknemers hun kennis 'onder de pet hielden' om op die manier hun autonomie te behouden. $\mathrm{Nu}$ is hun probleem hoe voorkomen kan worden dat deze kennis met het vertrek van de werknemer naar de concurrentie verhuist.

Conflicten over van wie de kennis is die opgedaan wordt in netwerken met leveranciers, klanten, andere producenten of kennisinstituten, kunnen een hindernis opwerpen voor de externe mobiliteit in de kenniseconomie en voor het 'nieuwe psychologische contract' dat uitgaat van de medewerking van werkgevers aan de grotere inzetbaarheid (employability) van werknemers die het zonder de zekerheid van een vaste baan moeten doen. Het is interessant om op te merken dat de 'hoge snelheid arbeidsmarkt' van Silicon Valley, waarin de overstap van hooggeschoolde werknemer naar eigen bedrijf of concurrent eerder regel dan uitzondering was en aan de wieg stond van zoveel innovatie en werkgelegenheid, in dit opzicht geen beperkingen kende. Als enige van de 51 staten kent Californië geen effectief concurrentiebeding en wordt de wet op handelsgeheimen niet gehandhaafd. Volgens Hyde (2002: 250) identificeren wetgevers en rechters in deze staat de mobiliteit van werknemers met het publieke belang, "ingegeven door een vage notie dat ingenieurs en managers hun brein meenemen naar het werk, dat de verspreiding van informatie via netwerken van bedrijf cruciaal is voor economische groei en dat openbaar bestuur en beleid gericht is op de bevordering van mobiliteit en spillover van informatie". Inderdaad, werkgevers kunnen niet de taart hebben en opeten. Bescherming van interne kennis en handelsgeheimen kan een redelijke eis zijn in een interne arbeidsmarkt die duurzame arbeidsverbintenissen in het vooruitzicht stelt. In een kenniseconomie waarin dat vooruitzicht niet meer bestaat of zelfs actief wordt ontmoedigd is dat niet langer het geval.

Dat is niet het enige conflict over regulering van de nieuwe arbeidsverhoudingen in de kenniseconomie. Volgens Collins (2001) zijn de bestaande arbeidsverhoudingen en is het bestaande arbeidsrecht ingericht vanuit de gedachte dat vertrouwen goed maar controle beter is. Daarbij horen taakomschrijving, nauw omschreven functie-eisen, vaste schalen en regels voor beloning, nauwgezet toezicht en onvervreemdbare rechten van procedurele en inhoudelijke aard die bepalen hoe lang er gewerkt mag worden, in welke omstandigheden en onder 
welke voorwaarden ontslag mogelijk is, enzovoort. Sommige rechten en maatschappelijke afspraken zijn met opzet buiten de invloedssfeer van (individuele) werkgevers en werknemers geplaatst. Behalve als bescherming van de zwakkere partij in de arbeidsmarkt werd en wordt dit ook gerechtvaardigd vanuit de opvatting dat harde en ononderhandelbare rechten werkgevers en vakbonden dwingen om te zoeken naar productievere methoden van werken en om bedrijven met ondermaatse lonen en arbeidsvoorwaarden van de markt te weren (Deakin en Wilkinson 1994; Streeck 1992). Dat kan een publiek belang zijn en bijdragen aan productiviteit en kwaliteit van arbeid en leven.

Collins meent echter dat dit standpunt in een open kenniseconomie, die blootstaat aan wereldwijde concurrentie, niet gehandhaafd kan worden of althans te absoluut geformuleerd is. Geconfronteerd met harde wettelijke eisen en standaarden kunnen bedrijven de productie verhuizen naar landen met lagere lonen en minder eisen. Of ze bezuinigen op bijvoorbeeld de uitgaven voor scholing. In dat geval is de uitkomst voor de groei en welvaart van een land op zijn minst onvoorspelbaar. Hij stelt een andere benadering voor en wettelijke regels of standaarden te onderwerpen aan een nieuw soort economische test waarom bepaalde handelwijzen wel of niet de steun van harde instituties of regels nodig hebben. Het traditionele arbeidsrecht staat in het teken van de correctie op ongelijke machtsverhoudingen en ongelijke uitkomsten. In plaats daarvan moet het arbeidsrecht in de nieuwe verhoudingen de reden voor regels en instituties laten afhangen van de vraag of het bijdraagt aan vergroting van potentiële output, die vervolgens verdeeld kan worden en bijdraagt aan gelijke kansen van werknemers en burgers om daaraan deel te hebben (Collins 2002). Ten tweede denkt hij dat flexibele arbeidsverhoudingen en 'slimme regels' die partijen een keuze gunnen meer kunnen bewerkstelligen dan harde en onvervreemdbare rechten. De redenering is dat ononderhandelbare rechten tot verzet onder werkgevers hogere kosten en uitval in werkgelegenheid zullen leiden. De beperking van zelfregulering en reflexief recht, waarin meer aan de partijen in onderhandelingen wordt toevertrouwd, ligt besloten in twee condities: de mate waarin alle partijen voldoende geïnformeerd zijn en gedwongen kunnen worden negatieve externe effecten van hun keuzes te internaliseren (Van der Meer, Visser en Wilthagen 2005). We zullen deze gedachtegang toepassen in de hierna te bespreken regels over ontslag en het tijdig switchen naar een nieuwe loopbaan.

\subsection{BELEID TEN AANZIEN VAN MOBILITEIT: ENKELE VOORBEELDEN}

De bespreking van deze literatuur leidt tot twee ten dele tegengestelde voorspellingen over de ontwikkeling van interne arbeidsmarkten. Enerzijds heerst de gedachte dat de per bedrijf of sector georganiseerde 'interne' arbeidsmarkten onder druk staan, kleiner worden en minder zekerheid bieden. Het onderscheid tussen interne en externe arbeidsmarkt, dat al nooit helemaal waterdicht was, vervaagt. Anderzijds menen vele auteurs dat onderwijs en opleiding en andere, niet goed meetbare kwaliteiten als creativiteit, vermogen tot omschakeling en 
sterke karaktereigenschappen, steeds meer van belang zijn voor de kansen op de arbeidsmarkt. En dat daarnaast de loopbaankansen en niet te vergeten de inkomens van mensen met verschillende startkansen en opleidingen nog sterker zullen verschillen dan nu al het geval is. Met andere woorden, de arbeidsmarkten voor deze groepen zullen nog meer geprivilegieerd zijn, zij het minder sterk gebonden aan interne arbeidsmarkten en carrières, maar veeleer georganiseerd in netwerken en projecten. De mobiliteit binnen deze nieuwe half interne arbeidsmarkten zal dan groter zijn, maar tussen deze en andere deelmarkten juist geringer. Administratieve regels en vaste rechten lijken plaats te maken voor kennisconcurrentie gebaseerd op hoge toetredingsdrempels. Of er plaats zal zijn voor medebestuur van vakbonden en andere institutionele 'enablers' (zoals brancheverenigingen en opleidingsinstituten) is op voorhand niet te zeggen. In Denemarken en Zweden is dat duidelijk het geval, in de vs niet.

\subsubsection{JONGEREN: KWETSBAAR ZONDER STARTKWALIFICATIES}

Jongeren op de arbeidsmarkt zijn relatief kwetsbaar op de arbeidsmarkt. Hun lonen zijn de laatste decennia relatief gedaald en in perioden van economische neergang hebben zij beduidend meer problemen om een baan te vinden (Salverda 2004). In de grote steden zijn er veel jonge etnische minderheden met een kwetsbare positie op de arbeidsmarkt (Zandvliet at al. 2002; Klaver et al. 2004). Onder jongeren bestaat een belangrijk verschil tussen laag- en hoger geschoolden. Onder laaggeschoolden is de mobiliteit lager. Zij zijn meer afhankelijk van de aard van hun beginkwalificaties en de vraag wat zij kunnen leren. De Grip en Wolbers (2003) hebben scholing voor jongeren vergeleken voor interne markten en beroepsarbeidsmarkten. In een interne arbeidsmarkt hebben jongeren meer ontplooiingskansen en werkzekerheid, indien ze tevens 'on the job' training ontvangen. Het voordeel is dat werknemers niet gebonden zijn aan nauwe taakafbakening en nieuwe binnenkomers voorbereid kunnen worden op nieuwe en toekomstgerichte functies. In een beroepsarbeidsmarkt is de voorziening van om- en bijscholing minder gemakkelijk te realiseren aangezien individuele bedrijven niet bereid zijn voor de kosten van de opleiding op te draaien. De arbeidsmarktkansen hangen dan af van de bijdragen van sectorgebonden scholingsinstituten (De Grip en Wolbers 2003). In dit licht is het voor jongeren in het algemeen van belang dat zij op school tenminste een startkwalificatie behalen. Daarnaast moeten zij voldoende werkervaring kunnen opdoen om door te kunnen groeien op de arbeidsmarkt. Dat kan in de vorm van werkstages, uitzendwerk en eventueel verplichte tewerkstelling aan publieke dienstverlening.

Als in interne arbeidsmarkten meer flexibiliteit (in functie-uitoefening en tijd) van werknemers wordt gevraagd en werknemers hun inzetbaarheid op peil moeten houden, dan is een 'intermediair' tussen de bedrijfsorganisatie en de werknemer wellicht een geschikte organisatievorm. Kerngedachte is dat werkgevers medeverantwoordelijkheid dragen voor de ontplooiing van werknemers, binnen het 'nieuwe' psychologisch contract dat 'baan'-zekerheid vervangt door 'werk'-zekerheid. Randstad, Vedior en de Algemene Bond van Uitzendonderne- 
mingen hebben zich als 'institutionele enterpreneurs' op deze markt gericht en door hun invloed op cao-vorming en wetswijzigingen (Flexibiliteit en Zekerheid) de verantwoordelijkheid van uitzendondernemingen als werkgevers bekrachtigd. Soms verruimen bedrijven de interne mobiliteit door middel van een intern uitzendbureau. Zo deelden de vele Stork-bedrijven een arbeidspool, kent de Universiteit van Amsterdam een job-centre voor ondersteunend en beginnend onderzoekspersoneel en bestaan er in ziekenhuizen arbeidspools waarbij oproepcontracten met aanstellingen van bijvoorbeeld nul tot twintig uur flexibel inzetbaar zijn. Vanuit de pool kunnen mensen doorstromen naar de meer beschermde 'interne' arbeidsmarkt waarbinnen banen en loopbanen meer vaste contouren krijgen en ontslagbescherming ontstaat. Het fasenmodel van de uitzend-cao vormt een vergelijkbaar model van gradaties van zekerheid die het scherpe onderscheid tussen interne en externe arbeidsmarkt en tussen open en gesloten arbeidsverhoudingen overbruggen.

\subsubsection{MANNEN EN VROUWEN: OPLEIDINGSVERSCHILLEN EN UITEENLOPENDE KEUZEN}

Uit de internationale literatuur kunnen we afleiden dat de arbeidsmarktsegregatie voor vrouwen hoger is in landen met een arbeidsmarkt waar sterke beroepskwalificaties van belang zijn, terwijl in landen met een onderwijssysteem waar generieke vaardigheden worden aangeleerd deze ongelijkheid kleiner is (Estevez Albe 2001; 2005). Zo is in Duitsland, Nederland en Zweden de horizontale en verticale seksesegregatie hoger dan bijvoorbeeld in Engeland of Amerika. Uit de CBS- en OSA-cijfers, die we eerder bespraken, blijkt bovendien dat de anciënniteit van vrouwen geringer is dan die van mannen en dat de interne mobiliteit en vooral de externe mobiliteit van vrouwen hoger is dan die van mannen (Gesthuizen en Dagevos 2005). Welke interpretaties kunnen we daaraan verbinden?

Door de stijgende arbeidsparticipatie van vrouwen is de Nederlandse arbeidsmarkt de afgelopen twee decennia fundamenteel van karakter veranderd. In 1983 werkte nog maar 30 procent van de vrouwen, in 2004 is dit toegenomen tot 54 procent. Hiervan werkt bijna 60 procent in deeltijd. Het percentage werkzame mannen is in dezelfde periode gestegen van 68 naar 74 procent, waardoor het verschil in arbeidsdeelname tussen mannen en vrouwen enigszins terugloopt. Tegelijkertijd is de segregatie gebleven (Tijdens 2006). Het is niet op voorhand duidelijk hoe deeltijd de mobiliteit beïnvloedt. Deeltijdwerknemers hebben minder toegang tot bedrijfsscholing (OECD 2003) en maken minder kans op promotie. Vooral in verband met het 'glazen plafond' is gewezen op de negatieve gevolgen van deeltijdwerk voor de carrières van vrouwen. Aan de andere kant kan deeltijdwerk een positieve invloed hebben op de baanduur. De omschakeling van voltijd naar deeltijd maakt het immers mogelijk door te werken tijdens ouderschap (Vlasblom en Schippers 2005). De mogelijkheid tot omzetting van voltijd- in deeltijdbanen, inmiddels als individueel recht gegarandeerd in de Wet Aanpassing Arbeidsduur van 2000, voorkomt gedwongen externe mobiliteit, vaak gevolgd door vertrek van de arbeidsmarkt (Visser e.a. 2004). 
De horizontale beroepssegregatie vindt zijn oorsprong in de keuzes die jongens en meisjes maken in het secundaire onderwijs. Vrouwen werken beduidend vaker dan mannen in zorggerelateerde en administratieve functies en in de publieke dienstverlening, mannen daarentegen werken vooral in economische en technische functies, met een eigen dynamiek en mobiliteitspatroon. Van alle scholieren met een gemiddeld rapportcijfer zeven voor bètavakken, kiest 32 procent van alle jongens en slechts 9 procent van alle meisjes voor een technisch beroep (De Grip en Willems 2003). De gevolgen van deze verschillen in opleidingsachtergrond zijn aanzienlijk. Uit de gegevens van Borghans en Groot (1999) blijkt dat circa 20 procent van de werkzame beroepsbevolking een andere opleidingachtergrond zou moeten hebben om de horizontale beroepssegregatie op te heffen.

De verticale segregatie vindt plaats binnen de interne arbeidsmarkt van de arbeidsorganisatie, of tenminste het netwerk van samenwerkende bedrijven of instellingen. In 2003 was bijvoorbeeld slechts dertien procent van de managers in hogere en wetenschappelijke functies vrouw. Dit kan voor een deel worden verklaard uit individuele keuzen, vrouwen nemen meer dan mannen de verantwoordelijkheid voor zorgtaken in het huishouden op zich. De geringe verticale doorstroom van vrouwen heeft echter niet alleen met hun persoonlijke ambitie te maken, maar ook met wat het Sociaal en Cultureel Planbureau symbolische en structurele factoren heeft genoemd (SCP 2004). Symbolische factoren verwijzen naar de opvattingen, normen en waarden in een samenleving over seksespecifieke eigenschappen en gedragingen. Deze ideeën werken door in de beeldvorming over de geschiktheid van vrouwen voor bepaalde functies. Structurele factoren betreffen de inrichting en het functioneren van de organisatie zoals een masculiene organisatiecultuur, het niet of beperkt kunnen werken in deeltijd, specifieke selectieprocedures, ongelijke kansen op onderwijstrajecten of de beperktere toegang tot netwerken (zie bijvoorbeeld Van Vianen 1998; Van Doorne-Huiskes en Schalkwijk 2001; Flanders 1994, Van der Meer en Roosblad 2004). De Pater (2005) verklaart de ondervertegenwoordiging van vrouwen in topposities uit het significante verschil in de bereidheid van mannen en vrouwen om uitdagende taken uit te voeren.

\subsubsection{LAAG PRODUCTIEVE WERKNEMERS EN OUDEREN: OVER DE MOGELIJK- HEDEN VAN EEN TIJDIGE LOOPBAANVERANDERING}

Interne arbeidsmarkten veranderen en organisaties stellen grotere eisen aan werknemers. Werknemers worden ook zelf verantwoordelijk gehouden voor het onderhoud van hun kennis en vaardigheden, om eventueel bij andere werkgevers aan de slag te komen. In Europa wordt uitvoerig aandacht gevraagd voor het belang van een 'leven lang leren' en 'blijvende inzetbaarheid'. In de Nederlandse praktijk staat dit onderwerp al sinds het midden van de jaren negentig op de agenda. Toch is de algemene indruk dat dit thema slechts moeizaam van de grond komt ondanks verschillende aanbevelingen van de Stichting van de Arbeid en afspraken in cao's. Dergelijke afspraken blijken vaak een dode letter. 
Uit onderzoek van Maassen van de Brink en Groot (2000) in de metaalindustrie weten we dat om- en bijscholing wel wordt toegepast, maar vooral ten bate van jongeren en niet ten gunste van ouderen. Ook Heckman (200o) wijst er in Amerikaanse studies op dat scholing van ouderen relatief weinig zinvol is en dat het geld beter aan jongeren kan worden besteed. Bij ouderen is de terugverdientijd gering en het aanpassingsvermogen relatief beperkt, terwijl veel jongeren gebaat zouden zijn met een extra startkwalificatie.

Tegelijk herinneren DiPrete et al. (1997) ons eraan dat de "mid carreer change" aandacht verdient bij de analyse van arbeidsmarktmobiliteit. De vraag is relevant of mensen halverwege hun loopbaan in staat zijn - gedwongen of vrijwillig - nog te veranderen van baan en iets nieuws te beginnen. Kunnen mensen die twintig jaar fysiek belastend werk hebben gedaan (zoals bouwvakkers, brandweerlieden) of geestelijk werk (zoals medewerkers in een callcenter, of bijvoorbeeld wetenschappelijk onderzoekers) nog veranderen? Kan dat bij dezelfde werkgever, of kunnen mensen van sector en werk veranderen? En welke instituties zijn daarbij noodzakelijk? Zou het helpen als alle dienstverbanden en bijbehorende bescherming tegen ontslag beperkt worden tot vijf jaar, zoals voorgesteld door Kalshoven in zijn zaterdagse rubriek in de Volkskrant. Zo'n harde regel zou tenminste het voordeel hebben dat het werknemers direct confronteert met zijn of haar inzetbaarheid en employability en werkgevers moeite zullen moeten doen om aantrekkelijker te worden voor de werknemers die ze niet willen verliezen. Maar het is niet direct een voorbeeld van een slimme regel en het is wellicht beter na te denken hoe door maatwerk op bedrijfs- of bedrijfstakniveau afspraken over functioneel leeftijdsontslag, scholing en nieuwe carrièrepaden gemaakt kunnen worden. In een studie naar de werkbelasting van ambulancepersoneel blijkt bijvoorbeeld dat een verhoogd risico op gezondheidsklachten al op 40-jarige leeftijd aanwezig is (Sluiter en Frings-Dresden 2004). Loopbaanbeleid voor oudere werknemers die zich op het eind van hun carrière bevinden, komt voor deze groep eenvoudig te laat. Al halverwege het werkzame leven zijn taak- en functietoetsen noodzakelijk om te bepalen of iemand het werk nog kan uitvoeren. Dergelijke voorbeelden betreffen ook het functioneel leeftijdsontslag van brandweerlieden, het werk van stratenmakers of van piloten. Voor hen is onzeker wat voor soort werk zij zullen verrichten nadat ze twintig jaar hebben gefunctioneerd. Is dat werk beschikbaar en kunnen ze dat ook aan? Vroeger werd de mythe in stand gehouden dat overtollig personeel laagproductieve arbeid kon verrichten. Dat kon alleen als er groei was in de organisatie, als er 'vet zit op de botten' van de organisatie en als er overigens voldoende uitstroom is van medewerkers. Tegenwoordig is dat allerminst vanzelfsprekend. De allocatie van deze mensen kan niet op bedrijfsniveau worden opgelost, dat vraagt om complementaire activiteiten buiten de organisatie. Een aanpak op het niveau van de bedrijfstak, de regio, een winkelstraat of een bedrijventerrein ligt meer voor de hand. In dat kader zou kunnen worden afgesproken dat ziekenhuizen geen portiers en ondersteunend personeel van 20 jaar werven, maar mikken op personen van 40 jaar en ouder uit andere paramedische beroepen die een tweede carrière 
beginnen. Hier kan inspiratie worden ontleend aan het Japanse model, waar ouderen hun status kunnen behouden, maar inhoudelijk minder belastend werk verrichten.

Daarnaast vragen de vergrijzing van de beroepsbevolking en de betaalbaarheid van de verzorgingsstaat om een aantal aanpassingen in het sociaal beleid van bedrijven en instellingen. De laatste jaren is het pensioenstelsel enigszins geflexibiliseerd en is de regelgeving over vervroegd uittreden veranderd. De introductie van het middelloon heeft een aantal perverse aspecten van de impliciete looncontracten (zoals de bevordering van medewerkers aan het eind van de loopbaan) weggenomen. Impliciete looncontracten zijn voor ouderen een bindingsmiddel en daarnaast een vorm van uitgestelde beloning. Het nadeel is dat het voor werkgevers verleidelijker wordt ouderen te ontslaan, wat weer dichtgetimmerd moet worden door harde ontslagwetgeving. Een impliciet looncontract is overigens een riskant mechanisme voor hen die de boot hebben gemist en werkt niet als er veel mobiliteit is. Ouderen die echt productief zijn, zullen niet zo gemakkelijk ontslagen worden, zeker indien in kwalificaties wordt geïnvesteerd die schaars zijn op de arbeidsmarkt. Dit vereist een verstandig management, met aandacht voor persoonlijke ontwikkelingsplannen van werknemers. Bij de herziening van het ouderenbeleid wordt in dit kader recentelijk een pleidooi gehouden alle ouderenregelingen zoals seniorendagen, 'ontlasting', extra vrije tijd voor oudere werknemers, et cetera, af te schaffen en te vervangen door training en opleiding. Het idee is derhalve een overgang te bewerkstelligen van een passief naar actief beleid voor ouderen.

Collins (2001) bepleit vervanging van veel bestaande ontslagbescherming door enkele 'default rules' die gelden als een der partijen in gebreke blijft. Als voorbeeld noemt hij dat ontslag wegens incompetentie onredelijk is indien de werkgever verzuimt om de werknemer in staat te stellen in werktijd aan scholing en opleiding deel te nemen. Andersom, indien de werknemer nalaat gebruik te maken van de mogelijkheden van scholing en vervolgens onvoldoende tegen zijn of haar taken is opgewassen, is er geen verweer tegen ontslag. De verplichting tot scholing en onderhoud van employability wordt op deze manier geloofwaardig doordat er een zware sanctie aan wordt verbonden. Verder geeft het naar beide partijen een signaal dat scholing en kennisontwikkeling tot de basisvoorwaarden van de nieuwe productie en arbeidsverhoudingen behoort en beïnvloedt het aldus de verwachtingen van werkgevers en werknemers. Het draagt dus bij aan institutionalisering van het nieuwe psychologische contract.

\subsection{CONCLUSIES: NAAR EEN NIEUWE ARBEIDSVERHOUDING}

Op basis van de literatuur kunnen we concluderen dat interne arbeidsmarkten veranderen. Bedrijven en instellingen passen in het licht van hun concurrentiepositie en nieuwe technologische mogelijkheden hun arbeidsbestand aan. Sommige bedrijven fuseren en groeien waardoor de interne arbeidsmarkt in omvang toeneemt. Maar afslanking, uitbesteding, inlenen van flexibel personeel 
en vervanging van hiërarchische aansturing door netwerken en markttransacties lijkt het dominante ontwikkelingspatroon. Hierdoor neemt de interne arbeidsmarkt in omvang af en krijgen arbeidsverhoudingen een andere aansturing.

In dit hoofdstuk hebben we geprobeerd de ontwikkelingen van de interne arbeidsmarkt te relateren aan de mobiliteit op de arbeidsmarkt. Mobiliteit kan worden onderscheiden in gedwongen en vrijwillige mobiliteit. Als bedrijven hun poorten sluiten, de inhoud van het werk veranderen, of als werkenden aan het einde van hun loopbaan zijn gekomen, ontstaat er gedwongen mobiliteit. Vrijwillige mobiliteit betreft de keuze van werkenden van baan te veranderen in de eigen organisatie, het veranderen van werkgever of het onderbreken van de loopbaan ten behoeve van bijvoorbeeld zorgactiviteiten of scholing.

Op basis van ons literatuuroverzicht kunnen we concluderen dat er in de Verenigde Staten onmiskenbaar sprake is van erosie van interne arbeidsmarkten, bedrijven werken meer in netwerken en maken gebruik van onregelmatige arbeidscontracten op de beroepsgebonden arbeidsmarkt, waardoor een daling van het relatieve loon resulteert. Daarbij speelt zowel vrijwillige als onvrijwillige mobiliteit een rol.

Ook in Europese landen is de structuur van de interne arbeidsmarkt aan het verschuiven. De dienstensector is sterk in opkomst en in toenemende mate wordt er met atypische of niet-standaardarbeidsovereenkomsten gewerkt. In een aantal Europese landen zijn aan de entreezijde van de arbeidsmarkt velerlei contractvormen mogelijk geworden, terwijl de ontslagbescherming van werknemers met een vaste aanstelling niet of nauwelijks is aangepast. Dat kan leiden tot een verscherping van het insider-outsider-model van de arbeidsmarkt, met een grote groep van vooral jongeren met geringe arbeidsmarktkansen.

De beschikbare arbeidsmarktstatistieken leiden niet tot een conclusie dat er sprake is van het 'einde' van de vaste baan of de standaardarbeidsovereenkomst, maar wel van een geleidelijke overgang naar een nieuwe arbeidsverhouding. In deze nieuwe arbeidsverhouding krijgen de psychologische, economische en juridische bindingen van de relatie tussen werkgever en werknemer een nieuwe betekenis (Marsden 2004). In figuur 2.4 vatten we dit samen.

Deze ontwikkelingen houden in dat werknemers zich moeten realiseren dat in de nieuwe arbeidsovereenkomst het onderhoud van kwalificaties in toenemende mate als hun eigen verantwoordelijkheid wordt gezien. $\mathrm{Zij}$ worden verwacht flexibel inzetbaar te zijn en moeten rekenen op een beloning die voor een deel gebaseerd is op hun prestaties. $\mathrm{Zij}$ zullen bovendien meer worden aangesproken op het inzetten en opbouwen van eigen middelen, zoals (pre)pensioengelden, spaargelden en kredietfaciliteiten, bij verandering van werkomgeving tijdens de loopbaan. Zij worden daarmee ook verantwoordelijk gehouden voor een eventuele inkomensterugval in zorgintensieve perioden. 
Figuur 2.4 Institutionele kenmerken van de nieuwe arbeidsovereenkomst

\begin{tabular}{|lll} 
& Oud & Nieuw \\
Economische binding & Impliciet looncontract & Loon naar prestaties \\
Psychologische binding & Vaste pensioenrechten & Verzekeren van eigen risico's \\
& Loyaliteit en zekerheid & Flexibele inzetbaarheid, scholing en \\
Juridische binding & Collectieve en individuele rechts- & Individuele rechtsbescherming \\
& bescherming & \\
& Ononderhandelbare afspraken & Reflexief recht (slimme regels) \\
& Detail regels & Default regels
\end{tabular}

Bron: vrij naar Collins, 2001 en Stone, 2004

Ook van de werkgevers kan worden verwacht dat zij investeren in het onderhoud van menselijk kapitaal en in brede inzetbaarheid van werknemers. Zoals Collins (2001; 2002) opmerkte, kan de vormgeving van de sociale zekerheid bij ontslag en baanverandering worden afgestemd op de mate waarin werkgevers investeren in de vaardigheden van hun medewerkers. Bedrijven en instellingen zullen in de toekomst ook vaker de arbeidsduur afstemmen op de persoonlijke behoeften en voorkeuren van werknemers, waardoor de zeggenschap over de interne arbeidsmobiliteit voor een deel bij werknemers komt te liggen.

De overheid heeft tenslotte een verantwoordelijkheid een actief arbeidsmarktbeleid te voeren met betrekking tot de integratie van werkzoekenden en met name voor degenen zonder goede startkwalificatie. Zij kan ook haar fiscale beleid richten op het bevorderen van scholing, het ondersteunen van verlof en het mogelijk maken van arbeidsmarkttransities door het faciliteren van kinderopvang en zorg en het wegnemen van fiscale belemmeringen bij baanwisselingen. De overheid heeft bovendien als werkgever een voorbeeldfunctie bij de tewerkstelling en de bevordering van horizontale en verticale mobiliteit van verschillende groepen medewerkers. 


\section{NOTEN}

De auteurs bedanken Roos van Os-Van den Abeelen voor haar competente ondersteuning bij de verzameling van data en literatuur. Hun dank gaat verder uit naar Ton Wilthagen (Universiteit van Tilburg) Jules Theeuwes (WRR) Dirk Scheele (WRR) en naar AIAs-collega's Wiemer Salverda, Kea Tijdens, Herman van de Werfhorst en Paul de Beer voor hun commentaar op een eerdere versie van dit stuk. Uiteraard is niemand dan de auteurs verantwoordelijk voor de inhoud van de tekst. Gegevens ontleend aan Amsterdam in cijfers in 2005 samengesteld door de Dienst Onderzoek en Statistiek van de Gemeente Amsterdam, uitgave november 2005; eigen berekening uit de tabellen op blz. 125 en 155. In Nederland en in andere Europese landen (Ebbinghaus 2006) boden vervroegde uittreding en WAO een met belastinggeld gefinancierde uitweg aan bedrijven om te reorganiseren en zich van deze kostbare verplichting te ontdoen. Het bespaarde vakbonden de noodzaak de naleving van het 'psychologische contract' af te dwingen en de samenleving een reeks van conflicten die zo immers uitgesmeerd konden worden en verschoven naar later, in de hoop op betere tijden. Een bedrijf als General Motors, niet lang geleden het grootste ter wereld, moet voor zijn huidige en ex-werknemers per auto gemiddeld ongeveer \$ 1,00o aan pensioenverplichtingen en $\$ 1,400$ aan gezondheidszorgkosten reserveren (Financial Times, 21 mei 2006). Moeizame onderhandelingen met de vakbonden hebben net een faillissement kunnen afwenden, maar steeds meer Amerikaanse bedrijven uit de 'oude' economie vragen bescherming onder Chapter 11 (uitstel van betaling) aan om met name van torenhoge pensioenverplichtingen af te komen. In het recente verleden werden pensioenbeloften gezien als een goedkope (en van belastingen vrijgestelde) manier om werknemers te rekruteren en te binden voor overigens onaantrekkelijke banen. 


\section{LITERATUUR}

Althauser, R.P. en A.L Kalleberg (1981) 'Firms, Occupations and the Structure of the Labor Market: A Conceptual Analysis', in I. Berg (red.): Sociological Perspectives on Labor markets, New York: Academy Press: 119-149.

Anderson, N. en R. Schalk, R. (1998) 'The psychological contract in retrospect and prospect', Journal of Organizational Behavior, 19: 637-647.

Aoki, M. (1986) 'Horizontal vs. vertical information structure of the firm', American Economic Review, 76: 971-983.

Appelbaum, E. en R. Batt (1994) The New American Workplace: Transforming Work Systems in the United States, Ithaca, New York: Cornwell University/IRL Press.

Araki, T. (2005) 'Corporate Governance Reforms and Employment Relations in Japan: Whither Japan's Practice Dependent Stakeholder Model?’, in H. Gospel en A. Pendleton (red.): Corporate Governance and Labour Management: An International Comparison. Oxford: Oxford University Press.

Arthur, M.B. (1994) 'The Bounderyless Career: A new perspective for organizational inquiry', Journal of Organizational Behavior, 15: 295.

Auer, P. (2004) 'Protected mobility for employment and decent work: employment security in a globalized world', paper presented at the IRRA's 7 th European regional meeting, Lissabon.

Auer, P. en S. Cazes (red.) (2003) Employment stability in an age offlexibility. Evidence from industrialized countries, International Labour Office, Genève.

Becker, G.S. (1964) Human capital: a theoretical and empirical analysis with special reference to education, New York: NBER.

Bernhardt, A., D.E. Marcotte (200o) 'Is “Standard Employment" Still What It Used to Be?’, in F. Carré, M. Ferber, L. Golden en S.A. Herzenberg (red.): Nonstandard Work: The Nature and Challenge of Changing Employment Arrangements. Industrial Relations Research Association (IRRA) Champaign, IL, 21-40.

Blanchflower, D. en A. Oswald (1988) 'Internal and external influences upon pay settlements', British Journal of Industrial Relations, 26: 363-370.

Bolweg, J.F. en A.W de Korte (1994) De nieuwe werknemer?! Assen: Van Gorcum.

Borghans, L. en L. Groot (1999) 'Educational presorting and occupational segregation', Labour Economics, 6: 375-395.

Brande, I. van den (1999) 'Het psychologisch contract - een kritische discussie van het concept en haar operationalisatie', Tijdschrift voor arbeidsvraagstukken, 65-78.

Böckerman, P (2003) 'Perception of job instability in Europe', Social Indicators Research, 67: 283-314.

Capelli, P. (1999) The New Deal at Work. Managing the Market-Driven Workforce, Boston: Harvard Business School Press.

Carnoy, M., M. Castells en C. Benner (1997) 'Labor Markets and Employment Practices in the Age of Flexibility: A Case Study of Silicon Valley', International Labour Review, 136: 27-48.

Carroll, G. R. en M.T. Hannan (2000) The Demography of Corporations and Industries, Princeton: Princeton University Press.

Cavanaugh, M. en R. Noe (1999) 'Antecedents and consequences of relational components 
of the new psychological contract', Journal of Organizational Behavior, 20: 323-340.

Chandler, A.D. Jr. (1977) The Visible Hand: The Managerial Revolution in American Business, Cambridge, Mass.: Belknap of Harvard University Press.

Clark, A. en F. Postel-Vinay (2005) 'Job Security and Job Protection', Bonn, IZ A discussion paper, nr. 1489.

Collins, H. (2001) 'Regulating the Employment Relation for Competitiveness', Industrial Law Journal, 30: 17-47.

Collins, H. (2002) 'Is there a Third Way in Labour Law?' in J. Conaghan, R.M. Fischli en K. Klare (red.): Labour Law in an Era of Globalization: Transformative practices and possibilities. Oxford: Oxford University Press.

Deakin, S. en F. Wilkinson (1994) 'Rights Versus Efficiency? The Economic Case for Transnational Labour Standards', Industrial Law Journal, 23: 289-310.

DiPrete, T.A., P.M. de Graaf, R. Luykx, M. Tahlin, H.P. Blossfeld (1997) 'Collectivist versus individualist mobility regimes? Structural change and job mobility in four countries', American Journal of Sociology, 103: 318-358.

Doeringer, P. en M. Piore (1971) Internal Labor Markets and Manpower Analysis, Lexington Mass.: Heath Lexington Books.

Dohmen, T. J. (2003) Internal Labor Markets: Theory and Evidence at the Firm Level, Maastricht: University Press Maastricht.

Doorne-Huiskes, J. van en S. Schalkwijk (2001) Mannen en vrouwen in hogere en managementposities bij het Ministerie van Verkeer en Waterstaat. Den Haag: ministerie van Verkeer en Waterstaat.

Dunlop, J. (1966) 'Job Vacancy Measures and Economic Analysis', The Measurement and Interpretation of Job Vacancies, A Conference Report, Columbia University Press: New York.

Dunnewijk, T.J.A. (2000) Why is the Dutch market for temporary labour so mature?, in De Grip (red.): De Nederlandse Arbeidsmarktdag, ROA, Maastricht.

Ebbinghaus, B. (2006) Reforming Early Retirement in Europe, Japan and the USA. Oxford: Oxford University Press.

Ehrenburg, R.G. en R. S. Smith (1997) Modern Labor Economics. Theory and practice. New York: Random Hause.

Esping-Andersen, G. (1990) The Three Worlds of Welfare Capitalism. Cambridge: Polity Press.

Estévez-Abe, M., T. Iversen en D. Soskice (2001) 'Social Protection and the Formation of Skills: A Reinterpretation of the Welfare State’ in P.A. Hall en D. Soskice (red.): Varieties of Capitalism: The Institutional Foundations of Comparative Advantage. Oxford: Oxford University Press, 145-183.

Estévez-Abe, M. (2005) 'Gender bias in skills and social policies: The varieties of capitalism perspective on sex segregation', Social Politics, 12: 180-215.

Farber, H.S. (1999) 'Mobility and stability: the dynamics of job change in labor markets', in O. Ashenfelter en D. Card (red.): Handbook of Labor Economics, vol. 3B, 2439-2483.

Flanders, M.L. (1994) Breakthrough: The Career Woman's Guide to Shattering the Glass Ceiling. Londen: Paul Chapman Publishing Ltd.

Frank, R.H. en R.M. Hutchens (1993) ‘Wages, Seniority, and the Demand for Rising 
Consumption Profiles', Journal of Economic Behavior and Organization, 21: 251276.

Galtier B. en J. Gautie (2003) 'Flexibility, Stability and the Interaction between Employment Protection and Labour Market Policies in France', in P. Auer en S. Cazes (red.): Employment stability in an age of flexibility. Evidence from industrialized countries. International Labour Office, Genève, 59-105.

Gaspersz, J. en M. Ott (1996) Management van employability, Assen: Van Gorcum.

Gesthuizen, M. en J. Dagevos (2005) Arbeidsmobiliteit in goede banen: oorzaken van baan- en functiewisselingen en gevolgen voor de kenmerken van het werk. Den Haag: Sociaal en Cultureel Planbureau.

Gokhale, J., E. Groshen en D. Neumark (1995) 'Do Hostile Takeovers Reduce Extramarginal Wage Payments?’, Review of Economic and Statistics, 77, augustus.

Goudswaard, A. (200o) Flexibilisering van arbeid: determinanten en effecten van flexibilisering voor werknemers en werkgevers, mei 2000 , Hoofddorp.

Graaf, M. de-Zijl, (2006) Economic and social consequences of temporary employment, Tinbergen institute research series, nr. 380 , Amsterdam: Tinbergen Instituut.

Grip, A. de en M. Wolbers, (2003) Do Low-Skilled Youngsters get Better Jobs in Countries where Internal Labour Markets Dominate?, Research Memoranda, ROA, Research centrum voor Onderwijs en Arbeidsmarkt.

Grip, A. de en E. Willems (2003) 'Youngsters and technology', Research Policy, 32: 17711781 .

Groot, W. en H. Maassen van den Brink (2000) 'De verborgen kosten van de WAO', Economisch Statistische Berichten, 12: 1052-1054.

Guest, D. (1998) 'Is the psychological contract worth taking seriously?', Journal of Organisational Behaviour, 19: 649-664.

Hall, P. en D. Soskice (red.) (2001) Varieties of Capitalism. The Institutional; Foundations of Comparative Advantage. New York: Oxford University Press.

Heckman, J.J., (200o) 'Policies to foster human capital', in Research in economics, vol. 54 (1) 3-56.

Hoof, J van. (1990) De arbeidsmarkt als arena. Arbeidsmarktproblemen in sociologisch perspectief. Amsterdam: SUA.

Houseman, S. en M. Osawa (1998) 'What is the Nature of Part-time work in the United States and Japan?’ in O’Reilly J. en C. Fagan (red.): Part-time prospects. Londen: Routledge.

Houseman, S. N. (2001) 'Why Employers Use Flexible Staffing Arrangements: Evidence from an Establishment Survey', Industrial and Labor Relations Review, 55:149-170.

Hyde, A. (2002) 'A closer look at the Emerging Employment Law of Silicon Valley's HighVelocity Labour Market', in Conaghan, J. Fischl, E.M. and Klare, K. (red.) Labour Law in an Era of Globalization, Oxford: Oxford University Press.

Jacoby, S.M. (1985) Employing Bureaucracy: Managers, Unions, and the Transformation of Work in American Industry, New York: Columbia University Press.

Kalleberg, A.L. (2003) 'Flexible Firms and Labor Market Segmentation', Work and Occupations, 30: 154-175.

Kalleberg, A.L. en P.V. Marsden (2005) 'Externalizing organizational activities: where and how Us establishments use employment intermediaries', Socio-Economic Review, 3: 389-416. 
Katz, H.C. en O. Darbishire (200o) Converging Divergences: Worldwide Change in Employment Systems, Ithaca, N.Y. en Londen: ILR Press.

Kaufman, B. (1988) 'The Postwar View of Labor Markets and Wage Determinations' in

B. Kaufman (ed.): How Labour Markets Work. Massachusetts: Lexington Books.

Keizer, A.B. (2005) The Changing Logic of Japanese Employment Practices: A Firm-Level Analysis of Four Industries, Rotterdam: Erasmus Research Institute of Management, Erasmus Universiteit.

Kerckhoff, A.C. (2001) Education and social stratification processes in comparative perspective, in: Sociology of education, extra uitgave, 3-18.

Kerr, C. (1954) 'The Balkanization of Labor Markets' in E. Wight Bakke, P. M. Hauser, G. L. Palmer, C.A. Myers, D. Yoder en C. Kerr (red.): Labor Mobility and Economic Opportunity. Cambridge: MIT Press, 92-110.

Klaver, J., J.W.M. Mevissen en A.W.M. Odé (2005) Etnische Minderheden op de arbeidsmarkt. Amsterdam: Regioplan beleidsonderzoek.

Kochan, T. A. en P. Osterman (1994) The Mutual Gains Enterprise: Forging a Winning Partnership among Labor, Management, and Government, Boston: Harvard Business School.

Kochan, T.A., H. Katz en R. McKersie (1986) The Transformation of American Industrial Relations. New York: Basic Books.

Lazear, E.P. (1990) 'Job Security Provisions and Employment', Quarterly Journal of Economics, 105: 699-726.

Lindbeck, A. en D.J. Snower (1988) 'Cooperation, Harassment and Involuntary Unemployment', in American Economic Review, 78: 167-188.

MacDuffie, J. P. (1995) 'Human Resource Bundles and Manufacturing Performance: Organizational Logic and Flexible Production Systems in the World Auto Industry', Industrial and Labor Relations Review, 48: 197-221.

Madsen, P.K. (2003) “"Flexicurity” through labour market policies and institutions in Denmark', in P. Auer en S. Cazes (red.): Employment stability in an age offlexibility. Evidence from industrialized countries, International Labour Office, Genève, p. 59-105.

Marsden, D. (1999) A Theory of Employment Systems: Micro-Foundations of Societal Diversity, New York: Oxford University Press.

Marsden, D. (2004) 'The 'Network Economy' and Models of the Employment Contract: Psychological, Economic, and Legal', British Journal of Industrial Relations, 42: 659-684.

Meer, M. van der, (1998) Vaklieden en werkzekerheid, Amsterdam: Thela Thesis.

Meer, M. van der en J. Roosblad (2004) Overcoming Marginalisation? Gender and Ethnic Segregation in the Dutch Construction, Health, IT and Printing Industries. Amsterdam: AIAS, Universiteit van Amsterdam, WP29.

Meer, M. van der, J. Visser en T. Wilthagen (2005) Adaptive and Reflexive governance The limits of organised decentralisation, European Journal of Industrial Relations, 11, p. $347-365$.

Milkman, R. (1997) Farewell to the Factory: Auto Workers in the Late Twentieth Century. Berkeley: University of California Press.

Muffels, R. J. A. en A.J. Steijn (1998) Flexible and permanent jobs on the Dutch labour market, Utrecht: Netherlands School for Social and Economic Policy Research. 
Nonaka, I. en H. Takeuchi (1995) The Knowledge-Creating Company, New York: Oxford University Press.

OESO (2003) Employment Outlook 2003, Parijs: OESO.

Organ, D.W. (1988) 'Organizational Citizenship Behavior: The good soldier syndrome', Journal of Applied Psychology, 73.

Osterman, P. (1994) 'Internal Labor Markets: Theory and Change' in C. Kerr. en P.D. Staudohar (red.): Labor Economics and Industrial Relations. Markets and Institutions, Cambridge, Mass. en Londen: Harvard University Press, Genève: International Labour Office, 159-217.

Osterman, P. (1988) Employment Futures. New York: Oxford University Press.

Osterman, P. (1999) Securing Prosperity. The American Labor Market: How It Has Changed and What To Do About It, Princeton, New York: Princeton University Press.

Passet, O. (2003) 'Stability and Change: Japan's Employment System under Pressure', in P. Auer en S. Cazes (red.): Employment stability in an age of flexibility. Evidence from industrialized countries, International Labour Office, Genève, 119-217.

Pater, I. de (2005) Doing Things Right or Doing the Right Thing: A New Perspective on the Gender Gap in Career Success, Amsterdam: Kurt Lewin Institute.

Pfeffer, J. en J.N. Baron (1988) 'Taking the Workers Back Out: Recent trends in the structure of employment', in B.M. Staw en L.L. Cummings (red.): Research in Organizational Behavior, vol. 10, Greenwich, CT: JAI: 257-303.

Piore, M. J. en C.E Sabel (1984) The Second Industrial Divide: Possibilities for Prosperity, Londen: Basic Books

Powell, W.W. (2001) 'The Capitalist Firm in the Twenty-First Century: Emerging Patterns in Western Enterprise', in P. Dimaggio (red.): The Twenty-First-Century Firm: Changing Economic Organization in International Perspective, Princeton, NJ: Princeton University Press, 33-68.

Polanyi M. (1967) The Tacit Dimension. New York: Doubleday.

Robinson, S.L. en D.M. Rousseau (1994) 'Violating the psychological contract: not the exception but the norm', Journal of Organisational Behaviour, 15: 245-259.

Roehling, M.V., M.A. Cavanaugh, L.M. Moynihan en W. Boswell (2000) 'The nature of the new employment relationship: A content analysis of the practitioner and academic literatures', Human Resource Management, 39: 305-320.

Rogers, Joel en Wolfgang Streeck (1995) United States: Lessons from abroad and home. In Works Councils: Consultation, representation, co-ordination. Redactie J. Rogers en W. Streeck. Chicago: University of Chicago Press, 375-410 .

Rogers, J. en W. Streeck (1994) 'Workplace Representation Overseas: the works council story', in R.B. Freeman (red.): Working Under Different Rules, New York: Russell Sage.

Rousseau D.M. en S.A, Tijoriwala (1999) 'What's a Good Reason to Change? Motivated Reasoning and Social Accounts in Promoting Organizational Change', Journal of Applied Psychology, 84: 514-528.

Salverda. W. (2004) 'Low Pay and Wage Flexibility in Europe: What Does the Taskforce Offer?’ in E. Hönekopp (red.): Impulses for European Employment Policy Impulses for Germany. The Report of the European Employment Task Force IAB Institute for Employment Research, Nürnberg, Germany. 
Scott, W. R. (2004) 'Reflections on a Half-Century of Organization Sociology', Annual Review of Sociology, 30: p. 1-21.

Shleifer, A. en L. Summers (1988) 'Breach of trust in hostile takeovers', in Auerbach, A. (red.): Corporate Takeovers: Causes and Consequences. Chicago: University of Chicago Press, IL.

Sluiter, J. en M.H.W. Frings-Dresen (2004) Ambulance onderzoek. Gezondheidskundige basis voor collectieve leeftijdsgrenzen bij functioneel leeftijdsontslag van ambulance personeel. Coronel Instituut en AMC Amsterdam.

Sørensen, A.B. en N.B. Tuma (1981) 'Labor Market Structures and Job Mobility', Research in Social Stratification and Mobility, 1: 67-94.

Stone, K. V. W. (2001) 'The New Psychological Contract: Implications of the Changing Workplace for Labor and Employment Law', UCLA Law Review, 48: 519-659.

Stone, K.V.W. (2004) From Widgets to Digits. Employment Regulation for the Changing Workplace. Cambridge: Cambridge University Press.

Stone, K.V.W. (2006) 'Thinking and Doing - The regulation of workers' human capital in the United States', Socio-Economic Review, 4 (1): 1-33.

Streeck, W. (1992) Social institutions and economic performance, Londen: Sage.

Streeck, W. (2005) Labor Markets and Trade Unions. In The Handbook of Economic Sociology. Redactie N.J. Smelser en R. Swedberg. Princeton and Oxford, Princeton University Press, with Russell Sage Foundation, 254-283.

Streeck, W. en C.J. Crouch (red.) (1997) Political Economy of Modern Capitalism, Mapping Convergence and Diversity, Londen: Sage.

Supiot, A. (2001) Beyond Employment. Changes in Work and the Future of Labour Law in Europe, New York: Oxford University Press.

Sverke, M., J. Hellgren, K. Näswall, A. Chirumbolo, H. De Witte en S. Goslinga, (2004) Job insecurity and union membership: European unions in the wake offlexible production. Brussel: P.I.E.-Peter Lang.

Tichy, N. en R. Charan (1989) Speed, Simplicity, and Self Confidence: An Interview with Jack Welch, Harvard Business Review, oktober-november.

Trommel, W. en B. de Vroom (1993) 'The Netherlands: The Loreley-Effect of Early Exit', in F. Naschold en Bert de Vroom (red.) Regulating Employment and Welfare: Company and National Policies of Labour Force Participation at the End of Worklife in Industrial Countries, edited by Berlijn: de Gruyter, 52-115.

Turnley, W. H. en D.C. Feldman (1999) 'The impact of Psychological Contract Violations on exit, voice, loyalty and neglect', Human Relations, 52: 895-922.

Tijdens, K.G, (2006) Een wereld van verschil: arbeidsparticipatie van vrouwen 19452005, oratie, Rotterdam: EUR.

Veen K. van. (1997) Inside an Internal Labor Market. Thesis Publishers: Amsterdam.

Verhoeven, W., P. Gibcus en P. de Jong (2005) Bedrijvendynamiek in Nederland: goed of slecht? Zoetermeer: EIM.

Vianen, A. van (1998) 'Competitie om de schaarse functies: de publicatie-meetlat', in B. van Balen en A. Fischer (red.): De universiteit als modern mannenklooster. Amsterdam: Het Spinhuis.

Visser, J. (1990) In Search of Inclusive Unions. Deventer en Boston: Kluwer Law and Taxation.

Visser, J. (2002) 'The First Part-Time Economy in the World. A model to be followed?', Journal of European Policy, 12: 23-42. 
Visser, J., T. Wilthagen, R. Beltzer en E. van der Putte (2004) 'From Atypicality to a Typicality', in S. Sciarra en M. Freedland (red.): Employment Policy and the Regulation of Part-time Work in the European Union. Cambridge: Cambridge University Press, 190-222.

Vlasblom, J.D. en J.J. Schippers (2005) 'Motherhood and labour market participation: generational dynamics', Universiteit van Utrecht.

Weiler, P. (1990) Governing the Workplace: The Future of Labor and Employment Law. Cambridge, Mass.: Harvard University Press.

Weinstein, M. en T. Kochan (1995) 'The Limits of Diffusion. Recent developments in Industrial Relations and Human resource Practices in the Unted States', in R. Locke, T. Kochan en M. (red.): Employment relations in a changing economy. Cambridge, Mass.: MIT Press.

Williamson, O., J. Harris en M. Wachter (1975) 'Understanding the Employment Relation. The analysis of ideosyncretic exchange', Bell Journal of Economics, 6: 250278.

Wilthagen, A.C.J.M., (2003) 'De overgankelijke arbeidsmarkt en het (on)vergankelijke sociaal recht' (oratie Tilburg) Tijdschrift Sociale wetenschappen, 86-113.

Zandvliet, K., R. Blanken, J. Gravesteijn-Ligthelm en J. de Koning (2002) Doorstroom van etnische minderheden op de werkvloer. Den Haag: Elsevier bedrijfsinformatie.

Zijl, M., G.J van den Berg en A.O.J. Heyma (2004) 'Stepping-stones for the unemployed: the effect of temporary jobs on the duration until regular work', SE O Working Paper 30, Amsterdam: Stichting voor Economisch Onderzoek.

Zijl, M. en M.J. van Leeuwen (2004) Tijdelijk werk: tussenstap of springplank. Amsterdam: Stichting voor Economisch Onderzoek. 


\title{
3 MENSELIJK KAPITAAL EN HET PROCES VAN CREATIEVE DESTRUCTIE
}

\author{
Arie Gelderblom en Jaap de Koning
}

\subsection{INLEIDING}

Dit hoofdstuk gaat over de relatie tussen menselijk kapitaal en het proces van creatieve destructie. Menselijk kapitaal is het geheel aan productieve kennis en vaardigheden dat in mensen is belichaamd. Met het proces van creatieve destructie op de arbeidsmarkt wordt gedoeld op de creatie van nieuwe werkgelegenheid en de destructie van bestaande werkgelegenheid die gepaard gaat met onder meer de internationalisering van de economie en technologische vernieuwing. Omdat de nieuwe werkgelegenheid qua inhoud en niveau verschilt van de werkgelegenheid die verdwijnt, vergt dit proces van creatieve destructie aanpassingen van de betrokken werknemers. Niet alleen moeten zij van baan en vaak ook van werkgever veranderen, maar ook moeten zij hun competenties aanpassen.

Dergelijke aanpassingsprocessen zijn niet nieuw. In de negentiende en ook nog een deel van de twintigste eeuw moesten velen die werkzaam waren in de landbouw, waar door rationalisatie veel werkgelegenheid verloren ging, een baan zoeken in de nieuw opkomende industrie. De jaren zestig en zeventig werden gekenmerkt door verlies van werkgelegenheid in de traditionele industriële sectoren en door de opkomst van de dienstensector. Ook hierbij deden zich aanzienlijke aanpassingsproblemen voor. Onder invloed van de technologische ontwikkeling en de opkomst van de Aziatische landen verdween vooral laagopgeleide, industriële arbeid, terwijl de werkgelegenheidsgroei zich in het bijzonder voordeed in de hoogopgeleide segmenten.

Technische vernieuwing en internationale verschuiving van economische activiteiten spelen ook thans een rol. Opnieuw valt een verschuiving naar lagelonenlanden (India, China, de landen in Oost-Europa) te bespeuren. Verder hebben de ontwikkelingen in de informatie- en communicatietechnologie (ICT) een nieuwe impuls gegeven aan de rationalisatie van de economie. Maar er zijn ook verschillen met het verleden. In de eerste plaats leidt ICT niet alleen in de industrie, maar ook in de dienstensector tot productiviteitsstijging. Daardoor treedt niet alleen verlies van laagopgeleide arbeid op, maar verdwijnen ook banen voor middelbaar en zelfs hoger opgeleiden. Men denke aan de functies die in de bankensector verdwijnen door de toenemende selfservice bij het opnemen van geld en het uitvoeren van transacties. Verder verdwijnt hoogwaardige werkgelegenheid op terreinen als informatica en R\&D naar een land als India. 
In dit hoofdstuk staan de volgende vragen centraal.

Leiden investeringen in menselijk kapitaal ertoe dat individuen beter bestand zijn tegen de gevolgen van het proces van creatieve destructie?

Leidt een beter opgeleide beroepsbevolking tot meer economische groei, innovatie en groei van werkgelegenheid?

Investeringen in menselijk kapitaal om de gevolgen van het proces van creatieve destructie het hoofd te bieden zou men de defensieve benadering van dit proces kunnen noemen; investeringen om meer dynamiek en groei te genereren de offensieve benadering. Beide invalshoeken komen in dit hoofdstuk aan de orde.

Het proces van creatieve destructie in relatie tot investeringen in menselijk kapitaal zal vooral ook in relatie worden gezien met het proces van de veroudering van de bevolking. De theorie van het menselijk kapitaal voorspelt dat investeringen in menselijk kapitaal vooral zullen plaatsvinden op jongere leeftijd, omdat dan de pay-off-periode het langst en dus het rendement het hoogst is (zie bijv. Ben-Porath 1967 voor een formele afleiding). Doordat de economie in vergelijking met vroeger meer aan veranderingen blootstaat, neemt de noodzaak toe ook op latere leeftijd in menselijk kapitaal te investeren. In allerlei beleidsstukken wordt om die reden het 'levenslang leren' bepleit. Maar levert leren op latere leeftijd wel voldoende op? Hierbij speelt niet alleen de korte pay-off-periode een rol, maar ook de vraag of het leervermogen en de motivatie op oudere leeftijd voldoende op peil blijven.

De opzet is als volgt. In paragraaf 3.2 voeren we een beschrijvende analyse uit waarbij we indicatoren over investeringen in menselijk kapitaal, arbeidsmarktprestaties en economische prestaties op een rijtje zetten voor een aantal OECDlanden. Hiermee vormen we ons een beeld van de relatieve positie van Nederland op deze punten. Paragraaf 3.3 gaat over de vraag of investeringen in menselijk kapitaal individuen gemakkelijker inzetbaar maken in het arbeidsproces. Is de participatiegraad en de arbeidsmobiliteit onder hoger opgeleiden hoger en de werkloosheid lager dan onder lager opgeleiden? Voorkomt scholing van werkenden dat zij werkloos worden of de arbeidsmarkt verlaten? Bevordert scholing de herintreding van werklozen? In paragraaf 3.4 is de centrale vraag of investeringen in menselijk kapitaal gunstige macro-economische effecten hebben in de zin van een hogere economische groei, een hogere groei van de arbeidsproductiviteit en een hogere werkgelegenheid. Ook hierbij kijken we naar de afzonderlijke effecten van het initiële onderwijs, scholing van werkenden en scholing van werklozen. Het hoofdstuk wordt besloten met een samenvatting en een conclusie. In deze slotparagraaf gaan we ook in op de beleidsimplicaties. 


\subsection{WERKGELEGENHEID EN MENSELIJK KAPITAAL: EEN BESCHRIJVENDE ANALYSE}

\subsubsection{INLEIDING}

Deze studie betreft de rol van menselijk kapitaal in relatie tot de dynamiek op de arbeidsmarkt die optreedt door veranderingen die zich in de economie voordoen. Voordat we echter de literatuur over relaties hiertussen beschrijven, willen we eerst een positionering geven van Nederland op een aantal kernvariabelen rondom dit thema. Hiertoe hebben we indicatoren verzameld op de volgende terreinen:

- menselijk kapitaal, zoals de deelname aan initieel onderwijs, scholing van werkenden en werklozen;

- technologie-indicatoren, zoals investeringen in ICT en uitgaven aan R\&D;

- prestatie-indicatoren voor de economie als geheel en de arbeidsmarkt, zoals productiegroei, productiviteitsgroei, werkloosheid en arbeidsparticipatie;

- indicatoren voor de dynamiek op de arbeidsmarkt, en dan voornamelijk de mate van baanwisselingen die optreden.

Deze indicatoren worden gebruikt om allereerst te zien hoe Nederland nu scoort ten opzichte van een aantal andere OECD-landen. Is in Nederland bijvoorbeeld sprake van relatief hoge investeringen in menselijk kapitaal, of blijft Nederland juist achter? Een ander doel is om een eerste verkenning uit te voeren of uit de cijfers een direct verband spreekt van de intensiteit van menselijk kapitaal met prestatie-indicatoren en indicatoren voor de dynamiek op de arbeidsmarkt. Voorts zijn een aantal indicatoren specifiek ook voor ouderen berekend, zodat tevens de relatieve positie van ouderen duidelijker wordt (zowel ten opzichte van jongeren, maar ditzelfde dan ook direct in vergelijking met andere landen).

Voor de vergelijking zijn twaalf andere landen opgenomen, waarvan acht EUlanden in Noord- en West-Europa (België, Duitsland, Frankrijk, Ierland, GrootBrittannië, Denemarken, Zweden, Finland) en 4 andere OECD-landen buiten de EU (vs, Canada, Australië, Nieuw-Zeeland).

\subsubsection{INDICATOREN VOOR MENSELIJK KAPITAAL}

Hoe scoort Nederland nu wat betreft investeringen in menselijk kapitaal? In tabel 3.1 is een aantal indicatoren hiertoe opgenomen. Hierbij is Nederland vergeleken met een gemiddelde van een aantal andere OECD-landen. De achterliggende cijfers voor al deze landen zijn opgenomen in bijlage 3.1. De meeste van deze indicatoren zijn opgesteld door de OECD. Uiteraard doen zich in de vergelijkingen tussen landen altijd problemen voor in de vergelijkbaarheid van data. Zo moeten bijvoorbeeld voor het initiële onderwijs verschillende nationale onderwijsstelsels omgewerkt worden naar een standaardindeling, zoals de ISCED. ${ }^{1} \mathrm{De}$ meeste van deze indicatoren bestaan echter al een groot aantal jaren, zodat erva- 
ring hiermee is opgedaan, wat de kwaliteit van de vergelijkbaarheid ten goede is gekomen. Zo is bijvoorbeeld door Eurostat over 1993 een survey onder bedrijven georganiseerd over deelname aan bedrijfsopleidingen (uitgevoerd door nationale statistische bureaus), dat in 1999 is herhaald. In de survey over 1993 deden zich veel problemen voor, welke ervaringen zijn benut voor de uitvoering voor 1999 . Ook zijn bij sommige onderwerpen meerdere indicatoren beschikbaar, zoals bij scholing van werklozen, die wordt gemeten in termen van deelnemers en in uitgaven.

Nederland is op deze indicatoren zeker geen koploper. Dit geldt in ieder geval zowel voor het initiële onderwijs ${ }^{2}$, als voor scholing van werkenden. Binnen Europa scoren op al deze fronten de Scandinavische landen (Denemarken, Zweden en Finland) in ieder geval beter. Ook ten opzichte van de overige EUlanden is Nederland dan nog geen koploper. Op het terrein van initieel onderwijs scoort Nederland veelal ook lager dan de andere OECD-landen buiten de EU. De vergelijking van cijfers over verwachte opleidingsduur tussen 1997 en 2003 laat zien dat Nederland hier niet met een inhaalslag bezig is, al moet daarbij opgemerkt worden dat deze opleidingsduur ook bekort zal zijn door studieduurbekorting zoals die met name in het academisch hoger onderwijs is doorgevoerd tezamen met maatregelen die uitloop van een studie dienen te bekorten (zoals korting op studiefinanciering).

Op het gebied van scholing van werkzoekenden scoort Nederland relatief wel beter, al is er wel verschil in de indicator naar geld (relatief hoog) en naar deelname (relatief lager). Een mogelijke verklaring hiervoor is dat in Nederland relatief langere cursussen worden gegeven. Bij de relatief hoge positie van Nederland moet wel opgemerkt worden dat het hier cijfers van 2002 betreft. Er zijn aanwijzingen dat in recente jaren de uitgaven voor scholing van werklozen gedaald zijn. In paragraaf 3.3 komen we hier nog op terug. Overigens gaat het bij deze OECDcijfers om een fors bedrag (ca. 0,5 procent van het GDP in 2002), wat de vraag oproept hoe deze indicator precies is gedefinieerd en welke uitgaven hier precies zijn meegenomen. Zo zijn bijvoorbeeld ook uitgaven meegenomen voor scholing aan werkenden die een risico lopen om hun baan verliezen. Tevens is uit de Employment Outlook van 2004 af te leiden dat ook de uitkeringen voor degenen die scholing volgen worden meegenomen.

In de tabel 3.1 zijn ook enkele specifieke indicatoren voor ouderen opgenomen. Voor wat betreft het initiële opleidingsniveau geldt dat ouderen minder hoog zijn opgeleid dan jongeren. Dit verschil in opleidingsniveau tussen ouderen en jongeren is in Nederland niet zo hoog als bij de meeste andere landen. Voor scholing van werkenden geldt echter het tegenovergestelde. Op basis van internationaal vergelijkbare IALS-data ${ }^{3}$ uit 1995-1996 scoren ouderen relatief laag, ook in vergelijking met andere landen. In termen van opleidingsduur is deze ondervertegenwoordiging van ouderen nog veel sterker, wat er op wijst dat ouderen relatief korte cursussen volgen. Hierbij dient wel opgemerkt te worden dat ouderen sindsdien in Nederland een inhaalslag hebben gemaakt op dit terrein, zoals zal 
worden geïllustreerd met OSA-data in paragraaf 3.3. Recente, betrouwbare internationaal vergelijkbare data voor wat betreft de deelname van ouderen aan scholing van werkenden zijn er echter niet.

\section{Tabel $3.1 \quad$ Indicatoren voor menselijk kapitaal}

Indicatoren

Nederland

Ongewogen gemiddelde 13 OECD landen ${ }^{\mathrm{a}}$ )

(incl. Nederland)

Verdeling bevolking naar opleidingsniveau (25-64 jarigen), 2002

Aandeel hoger opgeleiden (ISCED 7-8)

Aandeel middelbaar opgeleiden (ISCED 3-6)

Aandeel lager opgeleiden (ISCED 1-2)

Aandeel hoger opgeleiden bij verschillende leeftijdsgroepen, 2002

Aandeel hoger opgeleiden van 55-64 jarigen

Aandeel hoger opgeleiden van 45-54 jarigen

$25 \%$

$29 \%$

Aandeel hoger opgeleiden van 35-44 jarigen

$26 \%$

Aandeel hoger opgeleiden van 25-34 jarigen

Verwacht gemiddelde aantal jaren dat men in initieel onderwijs

(full-time en part-time) zal doorbrengen vanaf 5 de jaar

Verwachte jaren, 2003

Verwachte jaren, 1997

Indicatoren scholing (oudere) werknemers

\% geschoolde werknemers, 1999 (CVTS2 onderzoek Eurostat)

Participatiegraad scholing werkenden van 55-64 jarigen

ten opzichte van 25-34 jarigen, 1995-1996, obv IALS-data

$(100=$ evenredig $)$

Duur scholing werkenden 55-64 jarigen tov 25-34 jarigen,

1995-1996, obv IALS data (100 = evenredig)

\section{Indicatoren scholing werklozen}

$\%$ GDP voor scholing werklozen en met werkloosheid

bedreigden, 2002

\% GDP scholing werklozen en met werkloosheid

bedreigden, 1999

$0,40 \%$

$0,26 \%$

Participatie scholing werklozen en met werkloosheid bedreigden

(\% beroepsbevolking), 2002

Participatie scholing werklozen en met werkloosheid bedreigden

(\% beroepsbevolking), 1999

a) De achterliggende cijfers zijn weergegeven in bijlage 1 .

Bron: Bewerking van gegevens van de OECD 
Bovenstaande cijfers hebben betrekking op diverse volume-indicatoren van menselijk kapitaal. Daarin treden duidelijke verschillen op tussen landen, en Nederland heeft zeker geen koppositie. Ook op andere dimensies dan het volume treden belangrijke verschillen tussen landen op. Een voorbeeld hiervan is de richting van het onderwijs. Tabel 3.2 laat zien dat in het hoger onderwijs de meer exacte en technische richtingen in Nederland relatief ondervertegenwoordigd zijn.

Tabel 3.2 Verdeling afgestudeerden hoger onderwijs (alleen ISCED 8) over richtingen, in procenten, 2002

\begin{tabular}{|c|c|c|}
\hline Richting & Nederland & $\begin{array}{r}\text { Ongewogen gemiddelde } \\
\qquad \begin{array}{r}13 \text { OECD landen }{ }^{\mathrm{a}} \text { ) } \\
\text { (incl. Nederland) }\end{array}\end{array}$ \\
\hline Onderwijs & 17 & 11 \\
\hline "Humaniora" en kunst & 7 & 13 \\
\hline Sociale wetenschappen en recht & 34 & 32 \\
\hline Dienstverlening & 2 & 2 \\
\hline Technisch & 11 & 12 \\
\hline Landbouw & 2 & 2 \\
\hline Gezondheid en welzijn & 21 & 16 \\
\hline Life Sciences & 1 & 3 \\
\hline Natuurwetenschappen & 2 & 3 \\
\hline Wiskunde en statistiek & 0 & 1 \\
\hline Informatica & 2 & 4 \\
\hline Onbekend/overig & - & 1 \\
\hline Totaal & 100 & 100 \\
\hline
\end{tabular}

a) De achterliggende cijfers zijn opgenomen in bijlage 1 .

Bron: OECD

Oosterbeek en Webbink (1996) laten zien dat er in Nederland zeker nog een potentieel is aan leerlingen die gezien hun kenmerken en prestaties op de middelbare school naar verwachting relatief succesvol een technische studie zouden kunnen doen. Toch kiezen deze leerlingen vaak voor een andere studie, zoals rechten of medicijnen. Oosterbeek en Webbink spreken in dit verband van een verborgen technisch potentieel. Een van de verklaringen die ze geven is dat studies als rechten en medicijnen voor 'goede' studenten relatief goede mogelijkheden bieden om hoge salarissen te verdienen. Bij technische studies zijn de inkomensverschillen tussen afstudeerders 'vlakker', wat ongunstig is voor relatief 'goede' studenten. Zij geven de suggestie van collegegelddifferentiatie om aan deze allocatiemechanismen tegenwicht te bieden.

Oosterbeek en Webbink (1996) constateren dat het verborgen technisch potentieel zich zeker sterk bij vrouwen voordoet. Dit is ook in lijn met internationale cijfers over de deelname van vrouwen aan hoger onderwijs. Bij de exacte en tech- 
nische studies studeren in Nederland relatief weinig vrouwen af in vergelijking met andere landen (tabel 3.3).

Tabel 3.3 Aandeel vrouwen in afstudeerders hoger onderwijs (alleen ISCED 8) bij 2 exacte richtingen, 2002

\begin{tabular}{|llllllllllll} 
Studierichting & NL & BE & DU & FR & IR & UK & DK & ZW & FIN & Vs $\begin{array}{c}\text { Ongewogen } \\
\text { gemiddelde } \\
\text { (inclusief Nederland) }\end{array}$ \\
$\begin{array}{l}\text { Wiskunde en } \\
\text { informatica }\end{array}$ & 16 & 21 & 23 & 31 & 37 & 28 & 28 & 40 & 39 & 32 & 22 \\
Technisch & 13 & 21 & 21 & 25 & 22 & 20 & 23 & 28 & 21 & 22 & \\
\hline
\end{tabular}

Bron: OECD

\subsubsection{TECHNOLOGIE-INDICATOREN}

Een van de motors achter het proces van baancreatie en -destructie is de technologische ontwikkeling. In tabel 3.4 is een viertal technologie-indicatoren opgenomen, waarvan er drie betrekking hebben op ICT en de andere indicator op R\&D. Nederland heeft op al deze indicatoren scores die dicht bij het gemiddelde liggen. Finland scoort hoog op alle indicatoren. Alleen bij de R\&D-indicator wordt Finland nog voorafgegaan door Zweden en bij de ICT-investeringen door de vs. Finland en Zweden scoorden ook reeds hoog op de menselijk kapitaal variabelen en bij de vs was dit voor het initiële onderwijs het geval. Dit zou kunnen wijzen op een verband tussen opleidingsniveau en innovatie.

\subsubsection{PRESTATIE-INDICATOREN}

In tabel 3.5 zijn prestatie-indicatoren voor zowel de economie als de arbeidsmarkt opgenomen. Voor wat betreft de groeicijfers van de economie in de periode 19952003 scoort Nederland onder het gemiddelde. Voor de productiviteitsgroei geldt zelfs dat Nederland de laagste score heeft van alle opgenomen landen. Het verschil tussen productiviteits- en productiegroei kan onder meer worden verklaard uit de weergegeven arbeidsmarktindicatoren. Voor Nederland geldt namelijk dat de arbeidsmarktparticipatie in deze periode sterk is gestegen, wat heeft bijgedragen aan de productiegroei. Vooral de participatiegraad en de werkgelegenheidsgraad onder laagproductieve groepen is toegenomen mede door premieverlaging voor laagbetaalde arbeid. ${ }^{4}$ Hierbij dient wel opgemerkt te worden dat veel van deze groei uit deeltijdbanen heeft bestaan. Wanneer de participatiegraad in volumetermen zou worden gemeten, zou Nederland minder hoog scoren. Ook bij de relatief gunstige score voor werkloosheid dient de opmerking gemaakt te worden dat deze in gunstige zin beïnvloed kan zijn door verborgen werkloosheid in de WAO. Dit geldt vooral voor de werkloosheid onder ouderen. 


\begin{tabular}{|c|c|c|c|c|}
\hline & $\begin{array}{r}\text { R\&D intensiteit } \\
\text { als \% GDP, } 2001 \\
\text { (OECD, MSTI } \\
\text { database) }\end{array}$ & $\begin{array}{r}\text { Aandeel (\%) ICT } \\
\text { toegevoegde } \\
\text { waarde in totale } \\
\text { toegevoegde } \\
\text { waarde markt- } \\
\text { sector, } 2000\end{array}$ & $\begin{array}{r}\text { Aandeel (\%) ICT } \\
\text { werkgelegenheid } \\
\text { in marktsector, } \\
2000\end{array}$ & $\begin{array}{r}\text { ICT investeringen } \\
\text { als aandeel (\%) } \\
\text { investeringen in } \\
\text { vaste activa } \\
\text { (excl. Gebouwen), } \\
2000\end{array}$ \\
\hline Nederland & 1,94 & 10,3 & 8,0 & 20,9 \\
\hline België & 1,96 & 10,1 & 7,3 & 12,0 \\
\hline Duitsland & 2,49 & 6,2 & 3,9 & 19,2 \\
\hline Frankrijk & 2,20 & 16,5 & 7,2 & 13,1 \\
\hline lerland & 1,17 & 10,4 & - & 14,6 \\
\hline Groot-Brittanië & 1,90 & 10,4 & 8,1 & 22,0 \\
\hline Denemarken & 2,19 & 8,5 & 6,8 & 19,1 \\
\hline Zweden & 4,27 & 10,8 & 9,0 & 21,6 \\
\hline Finland & 3,40 & 15,6 & 10,9 & 29,4 \\
\hline Verenigde Staten & 2,82 & 11,1 & 6,2 & 31,4 \\
\hline Canada & 1,94 & 8,6 & 8,4 & 21,4 \\
\hline Australië & 1,53 & 8,1 & 5,4 & 22,5 \\
\hline Nieuw-Zeeland & 1,03 & 11,0 & - & - \\
\hline Ongewogen gemiddelde & 2,22 & 10,6 & 7,4 & 20,6 \\
\hline
\end{tabular}

Bron: Website OECD

Dat participatiegroei ook samen kan gaan met productiviteitsgroei blijkt uit de cijfers voor Ierland. Wat betreft de productiegroei en productiviteitsgroei is Ierland een zeer duidelijke koploper voor deze periode. Voorheen zagen we dat Ierland ook maar een modale score heeft op de menselijk kapitaal factoren, wat in ieder geval een indicatie is dat de relatie tussen groei en menselijk kapitaal niet eenduidig ligt. Mogelijk is een verklaring voor Ierland dat voor dit land het niveau van de productiviteit in de uitgangssituatie relatief laag was. Overigens geldt dat Zweden en Finland ook goed op productiviteitsgroei en participatiegraad scoren, terwijl dit landen zijn die er wat betreft menselijk kapitaal ook uitspringen.

In tabel 3.6 zijn de arbeidsmarktindicatoren ook speciaal voor de oudere groep 55-64 weergegeven. Hieruit blijkt dat Nederland relatief laag scoort voor participatie en werkgelegenheidsgraad van deze groep. Alleen een aantal ons direct omliggende landen (België, Duitsland, Frankrijk) scoren hierbij nog lager. Overigens is Nederland een inhaalslag aan het maken, omdat de cijfers laten zien dat de participatiegraad en werkgelegenheidsgraad sinds 1990 aanzienlijk gestegen zijn. Deze zijn ook sneller gestegen dan bij de zojuist genoemde ons direct omliggende landen. De werkloosheid is laag onder ouderen, maar hier moeten we nogmaals op de WAO wijzen, die deels het verschil met andere landen kan verklaren. 
Tabel 3.5

Indicator

Nederland

Ongewogen gemiddelde

13 OECD landen ${ }^{\mathrm{a}}$ )

Gemiddelde jaarlijkse reële productiegroei 1995-2003

$2,5 \%$

$3,1 \%$

Gemiddelde jaarlijkse productiviteitsgroei per gewerkt uur, 1995-2003

$0,9 \%$

Participatiegraad 15-64 jarigen, 2003

$75,9 \%$

$74,0 \%$

Participatiegraad 15-64 jarigen, 2000

$74,9 \%$

$73,7 \%$

Participatiegraad 15-64 jarigen, 1990

$66,2 \%$

$72,2 \%$

Werkgelegenheidsgraad 15-64 jarigen, 2003

$73,6 \%$

$69,2 \%$

Werkgelegenheidsgraad 15-64 jarigen, 2000

$72,9 \%$

$69,2 \%$

Werkgelegenheidsgraad 15-64 jarigen, 1990

$61,1 \%$

$67,3 \%$

Werkloosheidspercentage, Gemiddeld 1995-2003 (OECD)

$4,5 \%$

Aandeel langdurige werkloosheid, gemiddelde 1995-2003

$71,2 \%$

a) De achterliggende cijfers zijn in bijlage 1 opgenomen.

Bron: bewerking gegevens OECD

\subsubsection{INDICATOREN BAANMOBILITEIT}

Een van de belangrijke variabelen waarin dynamiek van de arbeidsmarkt tot uitdrukking komt is de baanmobiliteit. Hoe vaak wisselen werknemers van werkgever? Op dit terrein zijn weinig data beschikbaar waarin vergelijkingen tussen

Tabel 3.6 Leeftijdsopbouw en prestatie-indicatoren arbeidsmarkt voor ouderen

Indicator

Aandeel 55-64 jarigen in groep 25-64 jarigen, 2003

Aandeel 45-54 jarigen in groep 25-64 jarigen, mannen, 2003

Aandeel 25-44 jarigen in groep 25-64 jarigen, 2003

Participatiegraad 55-64 jarigen, 2003

Participatiegraad 55-64 jarigen, 2000

Participatiegraad 55-64 jarigen, 1990

Werkgelegenheidsgraad 55-64 jarigen, 2003

Werkgelegenheidsgraad 55-64 jarigen, 2000

Werkgelegenheidsgraad 55-64 jarigen, 1990

Werkloosheidspercentage, 55-64 jarigen

Gemiddeld 1995-2003 (OECD)

\section{Nederland}

$20,1 \%$

$25,4 \%$

$54,6 \%$

$44,9 \%$

$38,6 \%$

$30,9 \%$

$44,9 \%$

$37,9 \%$

$29,7 \%$

$3,8 \%$
Ongewogen gemiddelde 13 OECD landen ${ }^{2}$ )

$21,1 \%$ $25,5 \%$

$53,7 \%$

$52,4 \%$

$48,9 \%$

$45,4 \%$

$52,0 \%$

$46,4 \%$

$43,2 \%$

$6,2 \%$

a) De achterliggende cijfers zijn in bijlage 1 opgenomen.

Bron: bewerking gegevens OECD 
landen worden gemaakt. De OECD, die op heel veel terreinen internationaal vergelijkende data publiceert, publiceert op dit terrein geen data. Daarom maken we voor dit terrein gebruik van ad-hocstudies waarin internationaal vergelijkende data zijn gepubliceerd.

De eerste studie is Burgess (1999) die verschillende nationale databronnen heeft benut om de gemiddelde baanduur naar leeftijd en geslacht weer te geven. Aan de vergelijkbaarheid tussen landen zitten hierbij de nodige haken en ogen, omdat de precieze vraagstelling waarop deze cijfers zijn gebaseerd verschilt. Bovendien hebben deze cijfers van landen betrekking op verschillende periodes. Juist omdat baanmobiliteit sterk conjunctuurgevoelig is, kunnen deze verschillen in tijdsperiode de vergelijking sterk verstoren. Omdat er echter zeer weinig internationale overzichten van baanduur bestaan, geven we de cijfers met alle mitsen en maren toch weer. Bovendien geldt dat de nadelen in ieder geval in veel mindere mate opgaan bij de vergelijking naar geslacht en leeftijd binnen landen, omdat dan met eenzelfde definitie en tijdsperiode wordt gewerkt.

De verschillen tussen landen in de tabel zijn niet heel groot. Nederland scoort gemiddeld. Frankrijk kent, met uitzondering van jongeren, een relatief lange baanduur, dus een lage mobiliteit, terwijl in de vs de baanduur relatief kort is. Voor alle landen geldt dat de baanduur bij ouderen aanzienlijk hoger ligt voor jongeren, wat natuurlijk haast per definitie zo is. ${ }^{5} \mathrm{Bij}$ mannen is dit leeftijdseffect nog groter dan bij vrouwen.

Tabel 3.7 Gemiddelde baanduur naar geslacht en leeftijd

\begin{tabular}{|c|c|c|c|c|c|c|}
\hline $\begin{array}{l}\text { Gemiddelde } \\
\text { baanduur }\end{array}$ & $\begin{array}{r}\text { Vrouwen } \\
<=25\end{array}$ & $\begin{array}{r}\text { Vrouwen } \\
26-45\end{array}$ & $\begin{array}{r}\text { Vrouwen } \\
46-60\end{array}$ & $\begin{array}{r}\text { Mannen } \\
<=25\end{array}$ & $\begin{array}{r}\text { Mannen } \\
26-45\end{array}$ & $\begin{array}{r}\text { Mannen } \\
46-60\end{array}$ \\
\hline Nederland & 2,29 & 6,21 & 10,55 & 2,18 & 7,59 & 16,37 \\
\hline Duitsland & 2,38 & 7,04 & 11,60 & 2,37 & 7,42 & 17,31 \\
\hline Frankrijk & 1,67 & 8,39 & 17,92 & 1,84 & 9,00 & 19,64 \\
\hline Groot Brittanië & 2,39 & 5,89 & 10,27 & 2,56 & 8,25 & 14,48 \\
\hline Zweden & 1,88 & 8,02 & 14,38 & 2,14 & 7,68 & 17,33 \\
\hline Verenigde Staten & 1,97 & 5,77 & 10,54 & 2,02 & 6,87 & 14,17 \\
\hline Ongewogen gemiddelde & 2,10 & 6,89 & 12,54 & 2,19 & 7,80 & 16,55 \\
\hline
\end{tabular}

Bron: Burgess (1999)

Een andere studie waarin mobiliteit tussen landen wordt vergeleken, is een studie van Sousa-Poza en Henneberger (2002). Deze baseren zich wel op een uniforme vragenlijst, maar deze richt zich op mobiliteitsintenties. De auteurs geven op grond van andere studies aan dat mobiliteitsintenties een sterke samenhang vertonen met feitelijke mobiliteit en daarmee dus tot een bruikbare indicator leiden. De resultaten per land staan in tabel 3.8. Nederland scoort hierop relatief laag, net als Duitsland en Zweden. Hoog scoren de Verenigde Staten en het 
Verenigd Koninkrijk. Opvallend is dat ook Frankrijk hoog scoort, terwijl op grond van baanduur in de vorige tabel, juist het beeld naar voren kwam dat de mobiliteit laag is in Frankrijk. Het toch verschillende patroon tussen landen geeft nog maar eens aan dat de betreffende cijfers met voorzichtigheid gehanteerd moeten worden. Wel geldt dat in geen van beide Nederland hoog scoort voor wat betreft mobiliteit.

Tabel 3.8 Aandeel werknemers dat van plan is om van werkgever te wisselen (1997)

$\begin{array}{lr}\text { Percentage werknemers dat van plan is om van werkgever te gaan wisselen } & \% \\ \text { Nederland } & 7,8 \\ \text { Duitsland } & 7,3 \\ \text { Frankrijk } & 13,9 \\ \text { lerland } & 10,0 \\ \text { Groot-Brittanië } & 14,3 \\ \text { Denemarken } & 11,1 \\ \text { Zweden } & 7,7 \\ \text { Verenigde Staten } & 14,3 \\ \text { Nieuw-Zeeland } & 12,1 \\ \text { Ongewogen gemiddelde } & 10,9\end{array}$

Bron: Sousa-Poza en Henneberger (2002)

\subsubsection{CONCLUSIES}

In deze paragraaf is Nederland vergeleken met diverse andere OECD-landen op het gebied van menselijk kapitaal, technologie, economische groei en arbeidsmarkt. Op geen van deze terreinen bevindt Nederland zich in de frontlinie. Wel is er een aantal arbeidsmarktindicatoren waarop Nederland goed scoort. Zo is de werkloosheid laag en is een achterstand in participatiegraad ingelopen. Ook is een duidelijke verbetering te constateren in enkele indicatoren die met ouderen te maken hebben. De participatiegraad van ouderen, die aanvankelijk aanzienlijk lager lag dan elders, is sterk gestegen, evenals de cursusdeelname van ouderen. Ook de meer recente cijfers geven echter voor ouderen nog altijd een beeld van een kwetsbare groep. Zowel op indicatoren voor menselijk kapitaal, als arbeidsmarktindicatoren (mobiliteit en participatiegraad) scoort deze groep relatief ongunstig. Al met al is het beeld voor Nederland niet erg positief. In vergelijking met de ons omringende landen is het beeld minder negatief.

Wanneer verbindingen gelegd worden tussen deze indicatoren, dan is het beeld toch vrij diffuus. Er lijkt wel enig verband te zijn tussen de indicatoren voor menselijk kapitaal en de technologie-indicatoren. Landen als Finland en Zweden scoren bijvoorbeeld hoog op beide. Ook lijkt er enige samenhang te zijn met bijvoorbeeld participatiegraad en werkgelegenheidsgraad, die eveneens bij de Scandinavische landen hoog is. In zijn algemeenheid geldt echter dat het zeker 


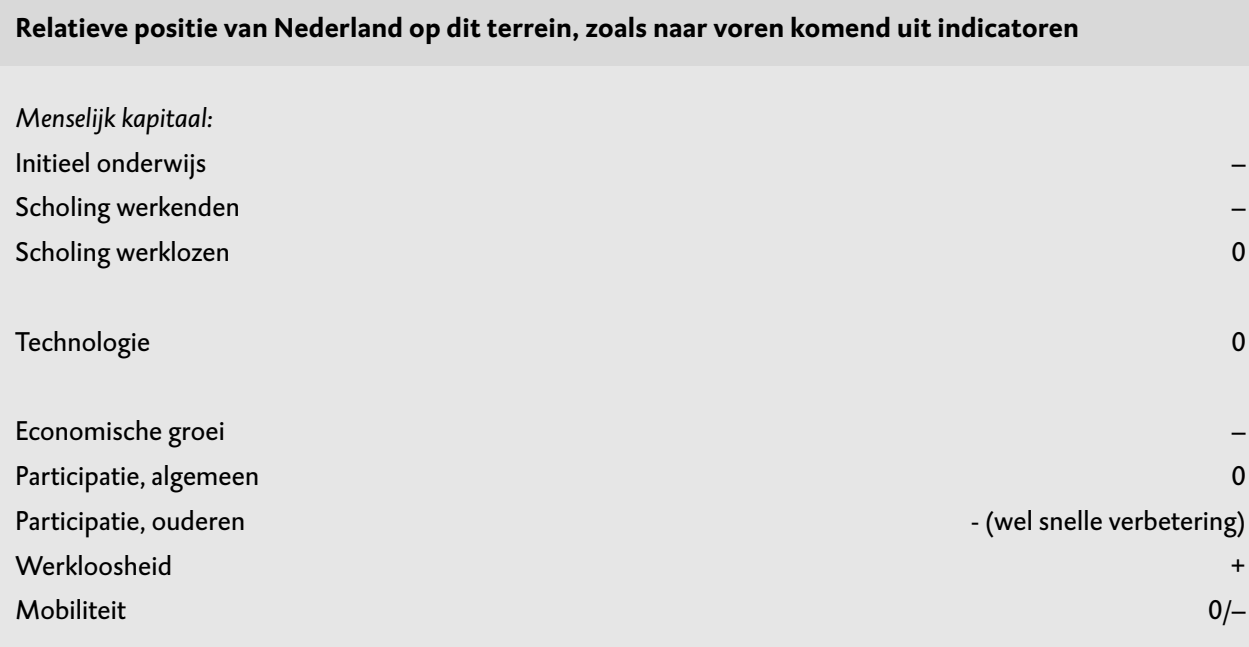

- = relatief ongunstig, $0=$ ongeveer gemiddeld, $+=$ relatief gunstig.

niet om 1-op-1-verbanden gaat. De patronen van rankings geven toch ook wel duidelijke verschillen tussen de indicatoren. Zo is bijvoorbeeld opvallend dat Ierland zeer goed scoort op economische groei, terwijl het zeker niet bovenmatig goed scoort op bijvoorbeeld technologie en menselijk kapitaal. In de volgende paragrafen zullen we via de beschrijving van bestaand meer analytisch onderzoek op dit terrein - ook op microniveau - dieper ingaan op dergelijke relaties.

\subsection{ZIJN BETER OPGELEIDEN MEER OPGEWASSEN TEGEN VERANDERINGEN IN DE ARBEIDSMARKT?}

\subsubsection{INLEIDING}

In deze paragraaf gaan we na welke rol onderwijs en scholing spelen voor de daadwerkelijke participatie van personen op de arbeidsmarkt. Onderwijs en scholing kunnen bijdragen aan het vinden en het behoud van een plaats op de arbeidsmarkt, juist omdat via onderwijs en scholing personen ook worden toegerust voor veranderingen die zich voortdurend op deze arbeidsmarkt afspelen. Dit positieve effect van onderwijs en scholing zou tot uitdrukking kunnen komen, doordat hoger opgeleiden en geschoolden zich eerder aanbieden op de arbeidsmarkt, daar makkelijker een plaats vinden, minder vaak vanuit een baan instromen in werkloosheid en inactiviteit, en als zij dit wel doen, ook weer eerder terugkeren.

Eén van de mechanismen waarlangs deze effecten zich voordoen, zijn veranderingen in functie. Veranderingen op de arbeidsmarkt betekenen dat werknemers zodanig flexibel moeten zijn dat zij een overstap naar ander werk moeten kunnen maken. Met een dergelijke overstap bedoelen we niet alleen de overstap naar een andere werkgever (externe mobiliteit), maar ook de overstap naar een andere 
functie in het bedrijf (interne mobiliteit) en eventueel ook de tijdelijke inzet of het bijspringen in een andere functie. Ook bij dit soort transities kijken we naar de rol van onderwijs en scholing.

Bij de rol van onderwijs en scholing maken we een onderscheid voor de rol van het initiële opleidingsniveau (subparagraaf 3.3.2), scholing van werkenden (3.3.3) en scholing van werklozen (3.3.4). Naast deze meer formele vormen van leren speelt informeel leren uiteraard ook een belangrijke rol bij kennisverwerving. De Grip (200o) wijst op onderzoek waaruit blijkt dat ervaring en zelfstudie zelfs een veel belangrijkere rol spelen bij het verwerven van verschillende competenties dan initieel onderwijs en scholing. Het probleem bij het vaststellen van effecten van informeel leren op bijvoorbeeld mobiliteit en productiviteit is dat de 'deelname' aan informele scholing moeilijk gemeten kan worden. Jaren werkervaring is bijvoorbeeld slechts een ruwe benadering hiervan. Overigens is er wel onderzoek waarin getracht wordt deze deelname nauwkeuriger te meten. Een voorbeeld is Livingstone (200o) die een kwantitatief onderzoek heeft uitgevoerd in Canada, waaruit blijkt dat informeel leren bij ouderen en lager opgeleiden een relatieve grote plaats inneemt. Ook dit onderzoek onderstreept het relatieve belang van informeel leren.

\subsubsection{HET INITIËLE OPLEIDINGSNIVEAU}

Dat vooropleiding een rol speelt om personen voor te bereiden op een dynamische arbeidsmarkt waar zij zich staande kunnen houden, blijkt uit gegevens over de werkgelegenheidsgraad en werkloosheid onder de verschillende opleidingsgroepen. De werkloosheidsgraad van hoger opgeleiden is in recente jaren ongeveer de helft van die van lager opgeleiden (tabel 3.10). Ook de werkgelegenheidsgraad vertoont forse verschillen. Het aandeel werkenden is meer dan 8 o procent bij hoger opgeleiden en minder dan 50 procent bij lager opgeleiden.

Tabel 3.10 Werkloosheid en werkgelegenheidsgraad naar vooropleidingsniveau

\begin{tabular}{|lccc|} 
& 1996 & 1999 & 2002 \\
Werkloosheidspercentage & & & 6,1 \\
Lager onderwijs & 11,0 & 6,6 & 3,3 \\
Middelbaar onderwijs & 6,3 & 3,6 & 3,2 \\
Hoger onderwijs & 5,4 & 2,8 & 47,9 \\
Werkgelegenheidsgraad & & & 72,7 \\
Lager onderwijs & & 46,3 & 81,8 \\
Middelbaar onderwijs & 41,8 & 71,0 & 80,7 \\
Hoger onderwijs & 67,1 & \\
\hline
\end{tabular}

Bron: CBS, Statline 
Deze verschillen komen terug bij alle leeftijdsgroepen. Om dit te illustreren geven we dezelfde cijfers ook alleen voor de groep ouderen (tabel 3.11).

Tabel 3.11 Werkloosheid en werkgelegenheidsgraad naar vooropleidingsniveau voor ouderen (45-64 jaar)

\begin{tabular}{|lccc|} 
& 1996 & 1999 & 2002 \\
Werkloosheidspercentage & & & 3,9 \\
Lager onderwijs & 7,9 & 4,4 & 2,8 \\
Middelbaar onderwijs & 5,2 & 3,2 & 2,7 \\
Hoger onderwijs & 4,5 & 3,1 & 43,0 \\
Werkgelegenheidsgraad & & & 64,3 \\
Lager onderwijs & & 38,6 & 75,5 \\
Middelbaar onderwijs & 34,3 & 61,2 & 72,7 \\
Hoger onderwijs & 56,8 & & \\
\hline
\end{tabular}

Bron: CBS, Statline

Ook wanneer we onderscheid maken tussen autochtonen en allochtonen en mannen en vrouwen, vinden we binnen deze groepen duidelijke verschillen naar opleidingsniveau (tabel 3.12). Wel ligt het algemene niveau van de werkloosheidspercentages bij allochtonen aanzienlijk hoger dan bij autochtonen. Ook bij de hoogst opgeleide allochtonen is het werkloosheidspercentage nog aanzienlijk. Bij vrouwen is het verband met opleiding nog aanzienlijk sterker dan bij mannen. Zowel werkgelegenheidsgraad als werkloosheidspercentage varieert bij vrouwen sterk met het opleidingsniveau.

Vertaald in termen van overgangen op de arbeidsmarkt betekent zo'n gunstige arbeidsmarktpositie voor hoger opgeleiden dat zich een of meer van de volgende verschillen voordoen.

- Hoger opgeleiden maken een betere start (stromen na afronding van de opleiding voor een groter deel door naar een baan).

- De mobiliteit van baan naar baan van hoger opgeleiden is groter (minder vastroesten).

- Hoger opgeleiden worden minder snel werkloos of inactief (of vanuit werkloosheid minder snel inactief).

- De kans is groter dat zij vanuit werkloosheid of inactiviteit een baan vinden.

De eerste mogelijkheid gaat maar zeer ten dele op (tabel 3.13). Weliswaar is bij de hbo'ers en wo'ers een relatief laag percentage werkloos na het schoolverlaten, maar als men werkloos is, is dit wel voor relatief lange tijd.

Is de mobiliteit van baan naar baan bij hoger opgeleiden groter? Hierbij kunnen we een onderscheid maken in externe baanmobiliteit (naar andere werkgever) 
Tabel 3.12 Werkgelegenheidsgraad en werkloosheidspercentage bij opleidings-groepen naar etniciteit en geslacht, 2002

\begin{tabular}{|c|c|c|}
\hline & $\begin{array}{r}\text { Werkgelegenheids- } \\
\text { graad }\end{array}$ & $\begin{array}{r}\text { Werkloosheids- } \\
\text { percentage }\end{array}$ \\
\hline \multicolumn{3}{|l|}{ Autochtonen } \\
\hline Basisonderwijs & $41 \%$ & $6,2 \%$ \\
\hline Vbo/Mavo & $54 \%$ & $4,4 \%$ \\
\hline Middelbaar & $74 \%$ & $2,9 \%$ \\
\hline Hoger & $84 \%$ & $2,6 \%$ \\
\hline \multicolumn{3}{|l|}{ Allochtonen } \\
\hline Basisonderwijs & $33 \%$ & $10,8 \%$ \\
\hline Vbo/Mavo & $49 \%$ & $10,6 \%$ \\
\hline Middelbaar & $68 \%$ & $5,7 \%$ \\
\hline Hoger & $73 \%$ & $6,0 \%$ \\
\hline \multicolumn{3}{|l|}{ Mannen } \\
\hline Lager & $63 \%$ & $5,0 \%$ \\
\hline Middelbaar & $82 \%$ & $2,5 \%$ \\
\hline Hoger & $87 \%$ & $3,0 \%$ \\
\hline \multicolumn{3}{|l|}{ Vrouwen } \\
\hline Lager & $34 \%$ & $8,0 \%$ \\
\hline Middelbaar & $63 \%$ & $4,4 \%$ \\
\hline Hoger & $76 \%$ & $3,4 \%$ \\
\hline
\end{tabular}

Bron: Allochtonen/autochtonen: eigen bewerkingen SEOR met CBS data van EBB 2002; vrouwen/mannen: CBS, Statline

en interne baanmobiliteit (andere functie bij dezelfde werkgever). Uit tabel 3.14 komt naar voren dat lager opgeleiden een lagere baanmobiliteit hebben dan middelbaar en hoger opgeleiden. Tussen deze laatste groepen treden overigens weinig verschillen op. Uit de tabel komt ook naar voren dat leeftijd veel sterker met externe mobiliteit samenhangt. Juist omdat leeftijd ook met onderwijsniveau samenhangt, kan pas in een multivariate analyse meer uitsluitsel over de rol van de vooropleiding gegeven worden. In de Koning e.a. (2003a) worden transitiekansen tussen verschillende arbeidsmarktstatussen verklaard. De vooropleiding blijkt een positieve rol te spelen bij de transitie van de ene werkgever naar de andere. Wel is het effect van opleiding gering in vergelijking met leeftijd. Het patroon naar leeftijd vertoont een monotone daling van mobiliteit van baan naar baan met de leeftijd. Deze studie kijkt echter niet naar interactieeffecten tussen leeftijd en vooropleiding, zodat niet te zeggen is of het effect van vooropleiding zich met name bij bepaalde leeftijdsgroepen voordoet. Dit gebeurt wel in de eerdere studie van Hebbink e.a. (1996), die speciaal ingaat op 


\begin{tabular}{|c|c|c|}
\hline Opleiding & $\begin{array}{r}\text { Aandeel dat werkloos } \\
\text { is direct na } \\
\text { schoolverlaten }\end{array}$ & $\begin{array}{r}\text { Gemiddelde duur van } \\
\text { de intredewerkloosheid, } \\
\text { in maanden }\end{array}$ \\
\hline Mavo & $14 \%$ & 0,7 \\
\hline Havo & $17 \%$ & 0,9 \\
\hline Vwo & $13 \%$ & 1,1 \\
\hline Vbo & $7 \%$ & 0,5 \\
\hline Bol, niveau $1 / 2$ & $16 \%$ & 1,5 \\
\hline Bol, niveau 3/4 & $4 \%$ & 0,6 \\
\hline Bbl, niveau $1 / 2$ & $4 \%$ & 0,7 \\
\hline Bbl, niveau 3/4 & $2 \%$ & 0,3 \\
\hline $\mathrm{HBO}$ & $6 \%$ & 1,1 \\
\hline wo & $5 \%$ & 1,9 \\
\hline
\end{tabular}

Bron: ROA

de mobiliteit van ouderen. Hierbij blijkt dat bij hoger opgeleiden de externe mobiliteit hoger is. Dit effect komt daarentegen minder tot uitdrukking in de internationale studie van Burgess (1999), uit welke studie ook internationale cijfers over baanduur zijn opgenomen in paragraaf 3.2. In een verklarende analyse van baanduren, zijn aparte analyses per leeftijdsgroep uitgevoerd. Hieruit blijkt dat het effect van vooropleiding met name opgaat voor degenen van 26-45 jaar, en niet voor jongeren en ouderen. Alleen bij de 26-45-jarigen geldt dat een hogere vooropleiding tot een kortere baanduur leidt. In zijn algemeenheid concludeert Burgess dat de rol van vooropleiding bij de verklaring van verschillen tussen landen in baanduur beperkt is. Daarbij moeten wel de beperkingen in de gebruikte data in acht worden genomen, evenals het feit dat het om een analyse met onvoltooide baanduren gaat (zie paragraaf 3.2). Overigens kan een kortere baanduur bij een werkgever niet alleen met externe mobiliteit te maken hebben, maar ook met instroom in de werkloosheid of inactiviteit. Het is dus ook met de gegevens van Burgess mogelijk dat de effecten van onderwijs op externe mobiliteit minder tot uitdrukking komen, omdat een hogere vooropleiding ook weer de kans verkleint om een baan te verliezen door werkloosheid of uitstroom naar inactiviteit. Op deze specifieke transitievorm gaan we zo direct nog in.

De beschrijvende cijfers uit tabel 3.14 geven een indicatie dat de rol van vooropleiding bij interne mobiliteit groter is dan bij externe mobiliteit. Niet alleen zijn de verschillen tussen opleidingsgroepen groter, maar de stijging heeft - met uitzondering van 2000-2002 - ook een gelijkmatiger patroon. Leeftijd speelt ook bij interne mobiliteit een rol, maar de verschillen naar leeftijdsgroepen zijn toch minder sterk dan bij externe mobiliteit. 
Maken hoger opgeleiden minder snel kans om werkloos of inactief te worden? Deze transitie is empirisch niet eenvoudig vast te stellen. Voor een dergelijke analyse zijn paneldata het meest geëigend, omdat daarin gedurende de loop van de tijd de arbeidsmarktstatus van personen steeds gevolgd wordt. In dat geval kan de kans op de overgang van werk naar werkloosheid/inactiviteit vergeleken worden voor verschillende groepen wat betreft opleidingsachtergrond. Het probleem bij veel van de bestaande panels is echter dat het aantal respondenten dat in een bepaalde periode daadwerkelijk deze arbeidsmarkttransitie maakt beperkt is. Dit probleem doet zich bijvoorbeeld voor bij analyses in deze richting met het OSA aanbodpanel (Gelderblom e.a. 1998; De Koning e.a. 2003a). De eerste studie vindt geen significante effecten van de vooropleiding. In de tweede studie scoren hoger opgeleide werknemers in ieder geval beter dan lager opgeleiden in de transitie naar deeltijdbanen vanuit werkloosheid of inactiviteit.

Een specifieke situatie waarbij het onderwijs mogelijk een rol speelt bij de kans op instroom in de werkloosheid vanuit werk, is de situatie waarbij gedwongen ontslagen vallen omdat banen verdwijnen. In hoofdstuk 2 van de Employment Outlook van 1994 worden diverse casestudies op een rij gezet van wat er gebeurt met degenen die ontslagen zijn. Slechts bij één van deze casestudies wordt rekening gehouden met de vooropleiding van de betreffende werknemers. In deze

Tabel 3.14 Externe en interne baanmobiliteit naar leeftijd en vooropleidings-niveau, 1996-2002

\begin{tabular}{|c|c|c|c|c|c|c|}
\hline \multicolumn{4}{|c|}{ Externe mobiliteit (\% van werkenden) } & \multicolumn{3}{|c|}{ Interne mobiliteit (\% van werkenden) } \\
\hline & $\begin{array}{r}1996- \\
1998\end{array}$ & $\begin{array}{r}1998- \\
2000\end{array}$ & $\begin{array}{r}2000- \\
2002\end{array}$ & $\begin{array}{r}1996- \\
1998\end{array}$ & $\begin{array}{r}1998- \\
2000\end{array}$ & $\begin{array}{r}2000- \\
2002\end{array}$ \\
\hline \multicolumn{7}{|l|}{ Leeftijd } \\
\hline $16-24$ & 47 & 48 & 46 & 10 & 8 & 6 \\
\hline $25-34$ & 31 & 36 & 31 & 15 & 14 & 10 \\
\hline $35-44$ & 20 & 23 & 22 & 14 & 13 & 12 \\
\hline $45-54$ & 12 & 14 & 13 & 8 & 10 & 8 \\
\hline $55-64$ & 5 & 7 & 8 & 5 & 8 & 4 \\
\hline \multicolumn{7}{|l|}{ Onderwijs } \\
\hline Lager Onderwijs & 13 & 18 & 14 & 6 & 6 & 3 \\
\hline \multicolumn{7}{|l|}{ Lager Beroepsonderwijs/ } \\
\hline \multicolumn{7}{|l|}{ Middelbaar algemeen } \\
\hline voortgezet onderwijs & 18 & 25 & 22 & 8 & 8 & 5 \\
\hline \multicolumn{7}{|l|}{ Middelbaar Beroepsonderwijs/ } \\
\hline \multicolumn{7}{|l|}{ Hoger algemeen voortgezet } \\
\hline onderwijs (Havo/Vwo) & 25 & 28 & 25 & 13 & 13 & 10 \\
\hline Hoger Beroepsonderwijs & 23 & 23 & 20 & 13 & 14 & 12 \\
\hline Wetenschappelijk onderwijs & 23 & 31 & 25 & 19 & 19 & 10 \\
\hline
\end{tabular}


casestudie van massaontslag bij AEG in Duitland bleek dat lager opgeleiden aanzienlijk minder kans hadden om weer een baan te vinden.

Maken hoger opgeleide werklozen of inactieven sneller een kans om weer actief te worden? Hiervoor zijn aanwijzingen gevonden in de analyse van De Koning e.a. (2003a). Hoger opgeleiden hebben een kleinere kans om als werkloze naar inactiviteit door te stromen en een kleinere kans als inactieven om dit te blijven. Voorts speelt in de literatuur van evaluaties van actief arbeidsmarktbeleid de vooropleiding vaak een rol als controlevariabele. Een recent voorbeeld voor Nederland is de studie van Heyma, Zwinkels en Van Seters (2003). In deze studie is de baanzoekduur van ww'ers onderzocht. Daaruit kwam naar voren dat degenen met een HBO- of wO-achtergrond een kortere baanzoekduur kennen.

\section{Conclusies}

Naarmate het opleidingsniveau hoger is, is men minder vaak werkloos en neemt men vaker deel aan het arbeidsproces. Blijkbaar is men met een goede vooropleiding beter geëquipeerd om zich staande te houden op de arbeidsmarkt met alle veranderingen die zich daar ook voordoen. In termen van transities komt deze positieve rol van onderwijs niet zozeer tot uitdrukking in de overgang van school naar werk, omdat het voor hoger opgeleiden soms wat langer duurt voordat men een baan gevonden heeft. Wel zijn er verschillende aanwijzingen dat hoger opgeleide werkenden minder snel werkloos of inactief worden en als zij dit wel worden, dit ook voor kortere tijd is in vergelijking met lager opgeleiden.

Een van de mogelijke manieren waarop werkloosheid voorkomen kan worden, is wisseling van baan. Het blijkt dat hoger opgeleiden zeker binnen bedrijven vaker van functie wisselen. Voor het vinden van een baan bij een andere werkgever zijn er eveneens aanwijzingen dat een dergelijk verband opgaat.

\subsubsection{SCHOLING VAN WERKENDEN}

\section{Algemeen}

In deze paragraaf gaan we in op de rol van scholing van werkenden voor hun arbeidsmarktpositie. Leidt scholing van werkenden ertoe dat de kans op werkloosheid en inactiviteit wordt verkleind? Stimuleert scholing mobiliteit? En leiden scholing en mobiliteit ook op iets langere termijn tot een grotere kans aan het werk te blijven? In eerste instantie beantwoorden we deze vragen in algemene zin. Vervolgens gaan we specifiek in op de rol van scholing voor ouderen (subparagraaf 3.3.2).

Bij de rol van scholing op transitiekansen naar een andere baan bij een andere werkgever is van belang op voorhand op te merken dat scholing twee elementen kan hebben, namelijk de opbouw van specifiek kapitaal die het zowel voor werknemer als werkgever aantrekkelijker kan maken dat de betreffende werknemer langer in het bedrijf blijft en de opbouw van algemeen kapitaal waarmee juist ook de positie voor een overstap sterker wordt. Hoe ligt de relatie per saldo in empi- 
risch onderzoek? Recent onderzoek van De Wolff (De Wolff e.a. 2002) op grond van Nederlandse paneldata van de OSA vindt geen verband tussen scholing en externe mobiliteit. Ook overzichten van internationale studies laten veelal geen verband met externe mobiliteit zien (Employment Outlook 1999 en 2004; Ok en Tergeist 2003). In de meeste van deze studies worden hierbij echter geen kruiseffecten met leeftijd onderzocht, die wel een rol kunnen spelen. Dit gebeurt wel in een uitgebreid onderzoek van de OECD op grond van huishoudpanels in de Employment Outlook van 2004. Daar wordt een positief verband van scholing met externe mobiliteit vastgesteld, maar dit is met name van toepassing voor degenen tussen 25 en 34 jaar en de hoger opgeleiden. Dit leeftijdseffect is dan weer in tegenspraak met eerder Nederlands onderzoek van Groot en Maassen van de Brink (1997) die juist een negatief verband vonden op basis van OSA-paneldata bij degenen die jonger zijn dan 45 jaar. Dit negatieve verband gaat niet bij ouderen op. Zij stellen dit verband tussen scholing en externe mobiliteit echter niet in een multivariate analyse vast, maar op basis van beschrijvende data. Al met al is het op grond van de empirische literatuur niet mogelijk om harde conclusies te trekken over een verband tussen scholing en externe mobiliteit. Veel studies geven aan dat er geen verband is. ${ }^{6}$

Bij interne mobiliteit constateren Groot en Maassen van den Brink wel een positief verband. Uit dit onderzoek blijkt dat degenen die in 1991-1992 een cursus hebben gevolgd, in 1993-1994 vaker intern veranderen van baan. Opvallend is dat dit effect zich met name bij ouderen voordoet. Van de 45-64-jarigen die geen scholing in de twee jaar daarvoor hebben gehad, verandert slechts 6 procent intern van baan. Bij degenen die wel scholing hebben gehad, is dit 16 procent. Multivariate analyses met meer recente OsA-paneldata laten echter geen verband zien tussen deelname aan scholing en interne mobiliteit (De Wolff e.a. 2002). Zij kijken echter niet specifiek naar de situatie van ouderen.

Interne functiemobiliteit zoals die hierboven is geformuleerd, concentreert zich op volledige veranderingen van baan binnen een bedrijf. Een dergelijke flexibiliteit kan echter ook een beperkter karakter hebben, bijvoorbeeld door tijdelijk bij te springen in een andere functie. Ook dergelijke minder vergaande vormen van flexibiliteit zijn uiteraard belangrijk voor de employability van werknemers. Groot en Maassen van den Brink (1997) analyseren de mate van inzetbaarheid in taken in andere functies of andere afdelingen. De relatie met vooropleiding is hier niet geheel eenduidig. Dit geldt wel voor scholing, die een duidelijk positief effect heeft op deze vorm van flexibiliteit.

Leidt scholing tot een beperking van de kans om werkloos of inactief te worden? Reeds in de voorgaande paragraaf is geconstateerd dat op grond van panelanalyses dergelijke verbanden moeilijk zijn te toetsen, omdat de overgang van werk naar werkloosheid of inactiviteit niet zo heel vaak in een panel voorkomt. Dit kan dan ook een reden zijn dat Gelderblom e.a. (1998) geen verband vinden met scholing als tegelijkertijd ook met allerlei andere factoren wordt rekening gehouden die de kans op werkloosheid of inactiviteit beïnvloeden. Bij De Koning e.a. 
(2003a), waar meer golven zijn gepoold, zodat de waarnemingenset groter is, wordt wel een effect van scholing gevonden, namelijk een vermindering van de instroom in inactiviteit. Een andere indicatie dat scholing wel degelijk effect heeft, komt naar voren in Groot en Maassen van den Brink (1997). Een beschrijvende analyse laat zien dat werknemers die in de voorgaande periode een bedrijfsopleiding hebben gevolgd, minder vaak werkloos verwachten te worden of te stoppen met werken.

In een aantal buitenlandse studies - met veelal meer waarnemingen in de paneldata - komt een dergelijk effect van scholing duidelijker naar voren. Een voorbeeld is een studie Schoeman en Becker (2002) met Duitse paneldata, waaruit blijkt dat scholing tijdens het werk de kans op werkloosheid op een later moment verlaagt. In deze studie is het selectieproces van deelname aan scholing apart gemodelleerd en verdisconteerd in de effectmeting, zodat de effectmeting zo min mogelijk vertroebeld wordt door selectie-effecten. Een soortgelijk resultaat komt naar voren in een recente uitgebreide analyse in de Employment Outlook van 2004 op basis van huishoudpanels. Deelname aan scholing door werkenden verkleint de kans op gedwongen ontslag (vooral voor vrouwen en lager opgeleiden) en vergroot de kans dat men op een later moment (nog) daadwerkelijk participeert op de arbeidsmarkt, ook als gecorrigeerd wordt voor selection bias bij degenen die aan scholing deelnemen. Voorts blijkt dat als men eenmaal werkloos is, de kans op werk vinden groter is als men in het verleden als werkende aan scholing heeft deelgenomen. Het effect van de kans op latere participatie op de arbeidsmarkt is ook gesplitst naar groepen. Daarbij blijkt dat dit effect van scholing groter is voor vrouwen en ouderen (45-54 jaar; de oudste groep in de analyse). Voorts is opvallend dat in zijn algemeenheid het participatie-effect van scholing juist in Nederland het kleinste is van alle onderzochte landen. De OECD voert ook een geaggregeerde analyse uit van de correlatie tussen de scholingsdeelname in landen en de participatiegraad en werkgelegenheidsgraad. Ook hier is in ieder geval sprake van een positief verband.

\section{Ouderen}

Hierboven is ingegaan op de effecten van scholing, waaruit reeds een aantal specifieke uitkomsten naar leeftijd naar voren kwamen. Groot en Maassen van den Brink (1997) geven op basis van paneldata aan dat scholing niet zozeer invloed heeft op de externe mobiliteit van oudere werknemers, maar wel op de interne mobiliteit, dat wil zeggen functiewisselingen binnen dezelfde werkgever. Bij ouderen die in een periode van enkele jaren vooraf scholing hebben gevolgd is de interne mobiliteit zelfs 2,5 keer zo hoog dan bij degenen die dit niet hebben gedaan. Ook de OECD-studie vindt bij ouderen (45-54 jaar) geen effect op de externe mobiliteit. Voor zover er een verband met scholing is, ligt dit bij ouderen dus eerder bij interne functiewisselingen dan bij externe baanwisselingen.

Waarom is mobiliteit nu zo belangrijk voor oudere werknemers? Hiervoor hebben we opgemerkt dat de baanmobiliteit van ouderen lager is. Dit betekent dat ouderen zich steeds meer gaan specialiseren op een beperkter terrein. Dit 
betekent in zo'n geval dat men veel weet, maar op een beperkt terrein. Thijssen (1996) duidt dit aan als ervaringsconcentratie. Hij laat ook zien dat juist deze ervaringsconcentratie risico's geeft in een dynamische omgeving. Door technologische veranderingen of het verdwijnen van bepaalde typen arbeid naar andere landen kan de opgebouwde - nauwe - ervaring in één klap minder bruikbaar zijn. Vervolgens heeft men onvoldoende brede ervaring en kennis om in een nieuwe functie aan de slag te kunnen. Thijssen benadrukt dan ook het belang van mobiliteit voor het employable houden van ouderen. Ook in het onderzoek van Gelderblom en De Koning (1992b) blijkt dat problemen in het functioneren van oudere werknemers minder zijn, als men een arbeidsverleden heeft met veel functiewisselingen. Voorts komt uit dit onderzoek naar voren dat het patroon leeftijd - functioneren verschillend is naar verschillende functieaspecten. Ouderen hebben vaker moeite met aspecten als hoge werkdruk en technologische veranderingen, zoals de opkomst van ICT, zie ook Gelderblom, De Koning en Mosheuvel (2001), maar juist minder problemen in de sfeer van sociale vaardigheden. Mobiliteitspatronen zouden zodanig vorm gegeven moeten worden dat juist de relatief sterke punten die gekoppeld zijn aan een bepaalde leeftijdsfase optimaal benut worden. Soms zal dit echter ook een overgang naar een ander bedrijf of zelfs een andere bedrijfstak moeten betekenen, omdat andersoortig meer geschikt werk eenvoudigweg niet voldoende beschikbaar is. In Nederland zijn sommige branches ook bewust beleid aan het ontwikkelen voor dergelijke intersectorale mobiliteit, zie De Koning e.a. (2003b). Een voorbeeld is de schoonmaakbranche die (vaak oudere) werknemers die fysieke problemen krijgen helpt om een overgang te maken naar de beveiligingsbranche (waar sociale vaardigheden een belangrijke rol spelen). Scholing speelt daarbij een rol. Het feit dat het verband van scholing met externe mobiliteit in arbeidsmarktdata nog niet duidelijk is, geeft aan dat dergelijke mobiliteitstrajecten waarbij scholing een rol speelt, eerder nog incidenten zijn dan meer terugkerend structureel beleid.

Scholing speelt niet alleen een rol bij mobiliteit, maar komt ook bij andere arbeidsmarkttransities van ouderen naar voren. De studie van Schoeman en Becker (2002) die in het algemene deel hiervoor is besproken, suggereert zelfs dat scholing bij ouderen nog effectiever is dan bij andere groepen voor wat betreft de vermindering van de kans op werkloosheid op een later moment. Ook de OECDstudie (Employment Outlook 2004) laat zien dat het verminderende effect op gedwongen ontslag bij 45-54-jarigen groter is dan bij 25-34-jarigen (maar wel ongeveer gelijk of zelfs iets minder dan het effect bij 35-44-jarigen). Ook Groot en Maassen van den Brink (1997) constateren dat oudere werklozen minder vaak deelgenomen hebben aan bedrijfsopleidingen in het verleden dan hun leeftijdsgenoten die nog werkzaam zijn. Ditzelfde geldt ook voor instromers in de WAO. Dit alles wijst erop dat scholing (juist) ook voor ouderen preventief werkt op de overgang van werk naar werkloosheid en de WAO.

Ondanks het belang van scholing voor oudere werknemers, investeren zij minder hierin (tabel 3.15). Om dit investeringsgedrag te verklaren komen we weer terug op de human capital-theorie. De theorie van het menselijk kapitaal voorspelt dat 
oudere werknemers minder geneigd zullen zijn hierin te investeren, althans als het gaat om investeringen die primair op het werk zijn gericht.7 De oorzaak hiervan is dat de periode waarin zij deze investeringen te gelde kunnen maken relatief kort is.

Sinds Becker (1964) wordt onderscheid gemaakt tussen algemeen en specifiek menselijk kapitaal, waarbij algemeen menselijk kapitaal kennis betreft die in meerdere bedrijven toepasbaar is, terwijl specifiek menselijk kapitaal alleen in een bepaald bedrijf toegepast kan worden. De theorie stelt dat bij algemeen menselijk kapitaal individuen de investeringen voor hun rekening nemen, en dat bij specifiek menselijk kapitaal het bedrijf en de werknemer de kosten en baten delen. De aanname dat werknemers investeringen in algemene training geheel voor hun rekening nemen spoort echter niet met de werkelijkheid. De hoge kosten van training, gepaard gaande met onzekerheid over het rendement ervan leiden ertoe dat werknemers terughoudend zijn om de training zelf te financieren. Er blijkt dat veelal bedrijven een aanzienlijk deel van algemene training financieren of dit zelfs geheel voor hun rekening nemen, al dan niet gekoppeld aan een verplichting voor de werknemer ten minste een bepaalde tijd bij de werkgever te blijven (of bij eerder vertrek alsnog de training geheel of gedeeltelijk te betalen). ${ }^{8}$

$\mathrm{Nu}$ zou men kunnen stellen dat het argument dat training van oudere werknemers een laag rendement oplevert even goed opgaat als werkgevers de training financieren. Groot en Maassen van den Brink (1997) wijzen echter op een belangrijk verschil, namelijk dat voor het rendement vanuit werkgeversoptiek van belang is hoe lang een werknemer naar verwachting bij de werkgever blijft. Doordat de mobiliteit van oudere werkgevers relatief laag is, is het maar de vraag of de pay-off-periode bij deze groep vanuit werkgeversperspectief lager is dan bij jongeren. Dit ligt uiteraard aan de leeftijd. Als men de pensioenleeftijd dicht nadert, zal de verwachte pay-off-periode uiteraard wel kort worden. Bovendien is de kans groot dat ouderen voortijdig afvloeien via de WAO of prepensioen. Daarom is maar zeer de vraag of het argument van Groot en Maassen van den Brink opgaat voor 50-plussers.

Voor de oudere zelf geldt de kortere pay-off-periode in ieder geval. Daar komt nog bij dat men ook een motivatieprobleem kan hebben om bijvoorbeeld via scholing nog om te schakelen naar ander werk, waarbij men weet dat men nooit meer hetzelfde ervaringsniveau zal bereiken. Voor kortere scholingen die op een kortere termijn zijn gericht en minder samenhangen met ingrijpende wijzingen op het werk, gaan dergelijke beperkingen uiteraard veel minder op. Het is echter de vraag of juist dergelijke kortere, minder ingrijpende cursussen, voldoende productiviteitswinst opleveren, zodat daarmee de positie van ouderen weer wordt versterkt. Als de productiviteitswinst gering is, zal er een zekere spanning blijven met de hoge lonen van ouderen en daarmee een prikkel blijven bestaan om juist ouderen af te laten vloeien. 
Maar er zijn ook andere punten van belang die tot nu toe buiten beschouwing zijn gebleven. Leren ouderen wel even gemakkelijk als jongeren? Als ouderen moeilijker leren, zal dit tot uiting komen in een lager scholingsrendement. Uit de literatuur (zie Gelderblom, De Koning en Kroes 2003 voor een overzicht) komt naar voren dat het leervermogen van mensen tot op vrij hoge leeftijd intact blijft. Wel is het belangrijk dat de aard van de scholing ook aansluit op deze doelgroep. Onderwijskundigen benadrukken bijvoorbeeld dat zeker voor oudere werknemers het belangrijk is dat de leeromgeving 'veilig' is (fouten maken mag bijvoorbeeld) en dat deze aansluit op de ervaring die men reeds heeft. Verder kan de gemiddeld lagere vooropleiding van ouderen een rol spelen. Onderzoek leert namelijk dat naarmate de vooropleiding hoger is, de deelname aan scholing ook hoger ligt. De cijfers uit onderstaande tabel 3.15 illustreren dit ook. Een van de mogelijke verklaringen daarvoor is dat de initiële opleiding ook een basis voor 'leren leren' legt.

Dit verband tussen vooropleiding en scholingsdeelname kan ook hebben bijgedragen aan het feit dat de verschillen in scholingsdeelname tussen leeftijdsgroepen minder geworden zijn (tabel 3.15). De ouderen van nu hebben immers een hogere vooropleiding dan de ouderen van 10 jaar geleden. Toch kan dit zeker niet de gehele verklaring zijn. Uit tabel 3.15 blijkt de vermindering van verschillen in deelname aan scholing namelijk vrij sterk, terwijl de toename van het vooropleidingsniveau van ouderen slechts een geleidelijk proces is. Een andere verklaring is dat specifieke beleidsinstrumenten op dit terrein effect hebben gehad. Zowel binnen branches als op nationaal niveau zijn namelijk instrumenten ontwikkeld die gericht zijn op verhoging van de scholing van oudere werknemers. Op nationaal niveau is dit in ieder geval de scholingsaftrek die in 1998 is geïntroduceerd. De fiscale aftrek voor bedrijven van scholing van oudere werknemers (ouder dan 40) is extra hoog. De cijfers uit tabel 3.15 laten echter geen specifiek effect rond de begintijd van de maatregel zien. Ook evaluaties van SEOR en SCHOLAR geven aan dat het effect van deze maatregel beperkt is (ministerie van Economische Zaken 2001). Ook het beleid levert dus naar verwachting maar een deel van de verklaring. Een andere mogelijke verklaring is dat zowel bedrijven en individuen zich het belang van scholing voor ouderen realiseren, zeker nu traditionele 'vluchtwegen' bij minder functioneren als vut en WAO minder beschikbaar zijn.

\section{Conclusies}

Vanuit empirische studies zijn diverse aanwijzingen dat scholing een rol speelt bij de versteviging van de arbeidsmarktpositie van werkenden. Dit komt onder meer tot uitdrukking in kleinere kansen om in latere fases werkloos of inactief (zoals arbeidsongeschikt) te worden. Een van de mechanismes waarlangs dit zou kunnen werken, is - naast productiviteitsvergroting binnen dezelfde functie ook de mogelijkheid die scholing biedt om makkelijker intern of extern van baan te wisselen. Empirisch onderzoek naar het verband tussen scholing en mobiliteit is echter niet eenduidig. Wel zijn er aanwijzingen dat juist bij ouderen scholing tot een hogere interne mobiliteit leidt. Ook voor de uitstroomkans uit werkloosheid zijn er aanwijzingen dat de effecten van scholing bij ouderen groter zijn. 
Tabel 3.15 Cursusdeelname van werkenden naar leeftijd, opleidingsniveau en sector, 1992-2002, in procenten

\begin{tabular}{|c|c|c|c|c|c|}
\hline & 1992-1994 & 1994-1996 & 1996-1998 & $1998-2000$ & 2000-2002 \\
\hline \multicolumn{6}{|l|}{ Leeftijd } \\
\hline $16-24$ & 29,0 & 30,7 & 29,9 & 33,3 & 33,6 \\
\hline $25-34$ & 34,8 & 41,2 & 43,6 & 41,2 & 44,7 \\
\hline $35-44$ & 26,3 & 33,8 & 41,2 & 38,0 & 43,1 \\
\hline $45-54$ & 18,4 & 28,0 & 35,9 & 33,6 & 38,0 \\
\hline $55-64$ & $5,0 \mathrm{a}$ & 20,7 & 23,7 & 23,8 & 29,1 \\
\hline \multicolumn{6}{|l|}{ Onderwijs } \\
\hline Lager Onderwijs & 13,7 & 20,6 & 29,2 & 22,5 & 30,6 \\
\hline \multicolumn{6}{|l|}{ Lager Beroepsonderwijs / Middelbaar } \\
\hline algemeen voortgezet onderwijs & 21,6 & 29,4 & 31,9 & 29,5 & 31,2 \\
\hline \multicolumn{6}{|l|}{ Middelbaar Beroepsonderwijs / } \\
\hline \multicolumn{6}{|l|}{ Hoger algemeen voortgezet } \\
\hline onderwijs (Havo/Vwo) & 31,7 & 38,8 & 41,7 & 38,5 & 40,0 \\
\hline Hoger Beroepsonderwijs & 33,2 & 40,8 & 46,4 & 43,4 & 48,0 \\
\hline Wetenschappelijk onderwijs & 36,7 & 34,2 & 38,5 & 40,6 & 48,3 \\
\hline \multicolumn{6}{|l|}{ Sector } \\
\hline Landbouw & & & & 30,7 & 28,6 \\
\hline Industrie & & & & 35,6 & 37,4 \\
\hline Bouw & & & & 41,7 & 40,6 \\
\hline Handel & & & & 32,8 & 29,1 \\
\hline Transport & & & & 34,3 & 35,5 \\
\hline Bank/verzekeringswezen & & & & 39,2 & 43,6 \\
\hline Quartaire sector & & & & 39,8 & 42,5 \\
\hline
\end{tabular}

Bron: osA, Trendrapport Aanbod van arbeid, diverse jaargangen.

a Dit lage percentage is terug te vinden in de trendrapporten van de OSA, maar is wel een uitschieter, ook vergeleken met de jaren daarvoor. In de jaren daarvoor is de deelname van ouderen ook aanzienlijk lager dan voor jongeren, maar is deze niet zo extreem laag als in 1992-1994. De wijze van meting in de jaren daarvoor wijkt enigszins af, vandaar dat deze cijfers voor oudere jaren niet zijn opgenomen.

Hoger opgeleide werknemers participeren meer in scholing dan lager opgeleide. Dit verband is zodanig dat het niet alleen lijkt te kunnen worden verklaard uit het feit dat ouderen die relatief laagopgeleid zijn, minder participeren in scholing. Het gevolg is dat scholing van werkenden de voorsprong van hoger opgeleiden bij aanvang van de loopbaan verder versterkt.

\subsubsection{SCHOLING VAN WERKLOZEN}

\section{Het actief arbeidsmarktbeleid en de rol van scholing}

In veel gevallen zullen werknemers die bedreigd worden met werkloosheid in staat zijn een andere baan te vinden voordat zij daadwerkelijk werkloos worden. 
Maar werkloosheid is niet altijd te vermijden. Het activerend arbeidsmarktbeleid (ook wel aangegeven met de term reïntegratiebeleid) is dan bedoeld om mensen te helpen weer aan het werk te komen. Scholing is een van de instrumenten binnen dit beleid. Andere instrumenten zijn incentives voor werklozen (bonussen, sancties, monitoring), bemiddeling, instroomsubsidies voor werkgevers die werklozen aannemen en gesubsidieerde arbeid. Deze instrumenten kunnen ook in combinatie worden toegepast.

De institutionele vormgeving van het arbeidsmarktbeleid is in de afgelopen vijftien jaar sterk veranderd. Voerde vijftien jaar geleden een directeur-generaal van het ministerie van Sociale Zaken en Werkgelegenheid dit beleid uit, thans zijn de gemeenten en het UWV verantwoordelijk voor de uitvoering van een groot deel van dit beleid en besteden deze organisaties de daadwerkelijke uitvoering uit aan particuliere bemiddelings- en scholingsorganisaties (de reïntegratiebedrijven) door middel van tender procedures. De verwachting is dat door concurrentie tussen de bedrijven de effectiviteit en de efficiency van het reïntegratiebeleid toeneemt. ${ }^{9}$ Hoewel er geen harde gegevens beschikbaar zijn, zijn er aanwijzingen dat in de nieuwe structuur het scholingsinstrument veel minder wordt gebruikt dan voorheen (zie De Koning e.a. 2004). De reden hiervoor is dat de inzet van scholing voor reïntegratiebedrijven weinig aantrekkelijk is. Zij bepalen vaak zelf welk instrument zij inzetten en worden betaald op basis van het deel van de hen toegewezen cliënten dat zij aan een reguliere baan weten te helpen. Scholing neemt relatief veel tijd in beslag, waardoor het weinig aannemelijk is dat het leidt tot (een sterke) bekorting van de lopende werkloosheidsperiode. Bovendien is het een relatief duur instrument. Een instrument als bemiddeling is financieel gezien voor reïntegratiebedrijven veel aantrekkelijker. ${ }^{10}$ Hierbij komt dat bij de bepaling wat als resultaat geldt, niet van belang is of cliënten ook op wat langere termijn aan het werk blijven. Enigszins cynisch zou je kunnen stellen dat bedrijven er juist belang bij hebben dat een cliënt niet te lang aan het werk blijft.

\section{Welke effecten zijn van scholing te verwachten?}

Waarom zijn van actief arbeidsmarktbeleid in het algemeen en subsidies voor scholing in het bijzonder gunstige effecten voor de betrokken werklozen en voor de economie als geheel te verwachten? Het antwoord is gelegen in het feit dat werkloosheid ontstaat door marktfalen en door verstoring van de marktwerking door ander overheidsbeleid. Actief arbeidsmarktbeleid kan in beginsel de gevolgen van beide verschijnselen verzachten.

Marktfalen heeft vooral te maken met informatietekorten die sterk samen hangen met de heterogeniteit van individuen en banen. ${ }^{11}$ Daardoor ontstaat frictie tussen vraag en aanbod, waarbij zelfs op relatief homogene deelmarkten openstaande vraag en werkloosheid naast elkaar voorkomen. Onvolledige informatie speelt verder een rol bij het aanname- en scholingsbeleid van werkgevers. De mogelijkheid dat werkloosheid (vooral langdurige werkloosheid) te maken heeft met (moeilijk waar te nemen) eigenschappen van de werklozen zelf, maakt veel werkgevers terughoudend (langdurig) werklozen aan te nemen en te scholen. Werklo- 
zen op hun beurt zullen terughoudend zijn te investeren in scholing door de combinatie van hoge kosten, onzekere baten (vindt men na de scholing een baan en blijft men voldoende lang aan het werk met een voldoende hoog loon om de investeringen eruit te krijgen?) en de beperkte mogelijkheden geld te lenen. Daardoor kan onderinvestering in scholing ontstaan. Deze punten zullen overigens niet voor iedere werkloze even belangrijk zijn, maar vooral voor werklozen met 'ongunstige' kenmerken. Hieronder worden verstaan kenmerken die om uiteenlopende en wellicht niet altijd rationale redenen door werkgevers worden geassocieerd met een relatief lage productiviteit of inzetbaarheid (bijvoorbeeld een lage opleiding, allochtone afkomst of een relatief hoge leeftijd).

Naast marktfalen speelt ook marktverstorend overheidsbeleid een rol. Door sociale protectie in de vorm van sociale uitkeringen en minimumlonen ligt de werkloosheid hoger dan zij van nature zou zijn. Vooral op minimuminkomensniveau ontstaan hierdoor twee problemen: de werkloosheidsval en de productiviteitsval. Van de werkloosheidsval is sprake als werklozen er financieel nauwelijks of niet op vooruitgaan (of door cumulatie met andere subsidies er zelfs op achteruit gaan) als zij een baan accepteren. De productiviteitsval treedt op als werklozen een te lage productiviteit hebben in vergelijking tot het loon dat werkgevers minimaal moeten betalen. Beide 'vallen' lijken dus vooral op te treden bij werklozen die aangewezen zijn op laagbetaalde arbeid.

Voor oudere werknemers die hun baan verliezen speelt een aantal specifieke factoren mee. Vaak specialiseren mensen zich tijdens hun loopbaan en bouwen zij een uitgebreide ervaringsdeskundigheid op een betrekkelijk smal terrein. Door technische ontwikkelingen kan deze ervaringsdeskundigheid plotsklaps overbodig worden. Een voorbeeld vormen drukkerijen waarin door de overgang op digitale technieken veel oud vakmanschap niet meer nodig was. Oude werknemers zullen niet meer dezelfde bedrevenheid in de nieuwe techniek ontwikkelen en daarmee ook niet meer de centrale plaats in het productieproces innemen als voorheen. Ook voor oudere werknemers die de werkdruk van hun oude baan niet meer aan kunnen geldt dat zij om te kunnen blijven werken een stapje terug zouden moeten doen. Als er financieel aantrekkelijke alternatieven voor zowel werkgever als werknemer zijn (arbeidsongeschiktheid of vervroegde uittreding) voor herplaatsing, dan is men vaak geneigd voor die alternatieven te kiezen. Worden oudere werknemers werkloos, dan is de herintredingskans naar werk gering. Productiviteits- en werkloosheidsval zijn voor oudere werklozen beide nadrukkelijk van belang. ${ }^{12}$ De korte pay-off-periode, de onzekerheid over het functioneren (ook na scholing) en de relatief hoge salariseisen zullen het voor werkgevers weinig aantrekkelijk maken oudere werklozen aan te trekken en te scholen. ${ }^{13}$ Onderzoek bevestigt dit beeld (zie De Koning e.a. 2003b voor een literatuuroverzicht en de resultaten van een enquête onder werkgevers).

In beginsel vormen scholingssubsidies een oplossing voor een aantal van de genoemde problemen. Als hierdoor de investeringen in menselijk kapitaal bij werklozen toenemen en daardoor ook hun productiviteit toeneemt, zouden meer 
werklozen employable worden en zou, door het uitzicht op beter betaald werk, betaald werk voor hen ook aantrekkelijker worden. Onderinvestering in menselijk kapitaal leidt er niet alleen toe dat werklozen geen baan krijgen, maar kan ook tot gevolg hebben dat op sommige deelmarkten vacatures langdurig onvervuld blijven waardoor de productie van de bedrijven op deze deelmarkten wordt belemmerd. Scholingssubsidies kunnen er daarom ook toe bijdragen dat de aansluiting tussen vraag en aanbod verbetert, waardoor zowel de openstaande vacatures als de werkloosheid afnemen en de werkgelegenheid toeneemt.

Voor een uiteindelijke beoordeling van reïntegratiebeleid zou een integrale kosten-batenanalyse moeten worden uitgevoerd, waarbij ook de kosten van het beleid en de algemeen-evenwichtseffecten worden betrokken. Verder zou ook rekening moeten worden gehouden met mogelijke niet-markteffecten van reïntegratiebeleid. Onder anderen Haveman en Wolfe (1984, 2001) hebben aannemelijk gemaakt dat bij het initiële onderwijs effecten op gezondheid, crimineel gedrag en dergelijke van even groot belang zijn als de markteffecten. Soortgelijke effecten zouden ook bij reïntegratiebeleid van belang kunnen zijn. Werkloosheid roept wellicht maatschappelijk ongewenst gedrag op waaraan maatschappelijk kosten verbonden zijn. Vermindering van de werkloosheid zou deze kosten dan verminderen. ${ }^{14}$ Op de macro-economische effecten van scholing komen we terug in de volgende paragraaf.

Uit het voorgaande maken we op dat theoretisch gezien subsidies voor de scholing van werklozen zinnig zouden kunnen zijn. Dit geldt dan vooral voor werklozen die te maken hebben met de werkloosheidsval en de productiviteitsval. Oudere werklozen behoren zeker ook tot de groepen waarvoor scholingssubsidies zinvol lijken. Scholing dient dan wel afgewogen te worden tegen andere reïntegratie-instrumenten. Om de werkloosheidsval tegen te gaan kan ook worden gedacht aan incentives voor werklozen (sancties, bonussen en monitoring) en om de productiviteitsval te overbruggen kan ook worden gedacht aan instroomsubsidies voor werkgevers die werklozen aannemen. Verder is bemiddeling een alternatief, omdat het de transactiekosten voor werkgevers vermindert en - afhankelijk van de activiteiten van de bemiddelende instantie - werkgevers informatie biedt over de eigenschappen van de werkzoekende..$^{15}$

Dat scholing en andere reïntegratie-instrumenten in theorie gunstige effecten zouden kunnen hebben, betekent niet dat deze effecten ook in de praktijk gerealiseerd worden. Zo moet rekening worden gehouden met crowding-out-effecten. Zo kan verdringing optreden als de (ex-)deelnemers aan reïntegratie-instrumenten vacatures vervullen die anders door andere werkzoekenden zouden zijn vervuld. Dit wordt ook wel het substitutie-effect genoemd. Voorts zullen overheidssubsidies de commerciële markt voor bemiddeling en scholing verkleinen. Wel valt aan te nemen dat deze laatste effecten bij scholing, en dan vooral langduriger en duurdere vormen van scholing, minder groot zullen zijn. Verder is te verwachten dat deze effecten kleiner zijn bij groepen die minder kansrijk op de arbeidsmarkt zijn. Wel is de vraag of de groepen die bijvoorbeeld scholing het 
hardste nodig hebben, gemotiveerd zijn scholing te volgen en in staat zijn deze met succes af te ronden. Dit zal mede afhangen van de wijze waarop deze groepen worden benaderd en van de mate waarin de scholing op hen is afgestemd. De effectiviteit zal dus waarschijnlijk afhangen van de targeting van de deelnemers, de vormgeving van de instrumenten en meer in het algemeen van de kwaliteit van de uitvoering. Dit brengt ons op een ander punt: organisatie en uitvoering. Is de overheid in staat het actief arbeidsmarktbeleid zo uit te voeren of te laten uitvoeren dat het potentiële rendement ervan wordt gerealiseerd? Want naast marktfalen kan er ook sprake zijn van overheidsfalen.

\section{Wat is er bekend over de effecten van scholing?}

Wat is er nu bekend over de effectiviteit van scholing in relatie tot andere instrumenten. Voor wie is het effectief? Als aanvulling op eerdere overzichtsstudies (Heckman e.a. 1999; Kluve en Schmidt 2002; Calmfors e.a. 2002; Hujer en Caliendo 2002) zijn door SEOR in het kader van een onderzoeksopdracht voor UWV en het ministerie van SzW in totaal 130 studies verzameld met microevaluaties van arbeidsmarktmaatregelen (De Koning e.a. 2005). Al deze studies onderzoeken het effect van deze maatregelen op de herintredingskans. Een deel kijkt ook naar inkomenseffecten. Slechts een beperkt deel geeft inzicht op de effecten op de individuele arbeidsmarktpositie op langere termijn. Omdat een deel van de studies meer dan één instrument analyseert is het aantal beschikbare metingen 161 . Hiervan hebben er 85 betrekking op scholing. Tabel 3.16 geeft een overzicht.

Tabel 3.16 Overzichten uitkomsten internationaal wetenschappelijk onderzoek naar de effecten van reïntegratiebeleid op de herintredingskans

\begin{tabular}{|c|c|c|c|c|}
\hline \multirow[t]{2}{*}{ Instrument } & \multicolumn{3}{|c|}{ Gevonden effect op herintredingskans } & \multirow{2}{*}{$\begin{array}{r}\text { Totaal (aantal } \\
\text { beschikbare } \\
\text { metingen) }\end{array}$} \\
\hline & $\begin{array}{r}\text { Significant } \\
\text { positief }\end{array}$ & $\begin{array}{r}\text { Varieert met } \\
\text { methode, } \\
\text { kenmerken van } \\
\text { deelnemers, e.d. }\end{array}$ & $\begin{array}{r}\text { Insignificant } \\
\text { of significant } \\
\text { negatief }\end{array}$ & \\
\hline Scholing & $42 \%$ & $20 \%$ & $38 \%$ & $100 \%(n=85)$ \\
\hline \multicolumn{5}{|l|}{ Incentives voor } \\
\hline werkzoekenden & $82 \%$ & $6 \%$ & $12 \%$ & $100 \%(n=17)$ \\
\hline Bemiddeling & $64 \%$ & $9 \%$ & $27 \%$ & $100 \%(n=22)$ \\
\hline \multicolumn{5}{|l|}{ Instroomsubsidies } \\
\hline voor werkgevers & $62 \%$ & $23 \%$ & $15 \%$ & $100 \%(n=13)$ \\
\hline Gesubsidieerde arbeid & $33 \%$ & $8 \%$ & $58 \%$ & $100 \%(n=24)$ \\
\hline Totaal & $50 \%$ & $16 \%$ & $35 \%$ & $100 \%(n=161)$ \\
\hline
\end{tabular}

Bron: Inventarisatie uitgevoerd in het kader van een onderzoek voor de UWV en SZW 
Kijken we naar de resultaten van de scholingsstudies, dan vindt 42 procent een positief effect op de baankans en 38 procent een niet-significant of significant averechts effect. Significant averechtse effecten komen niet vaak voor. De overige 20 procent geeft gemengde resultaten te zien, afhankelijk van de scholingsmethode, de kenmerken van de deelnemers, en dergelijke. Het totaalbeeld is onduidelijk, al zou je gemiddeld tot een licht positief effect neigen. Onder de metingen is een achttal experimentele evaluaties, die waarschijnlijk betrouwbaarder zijn dan de studies waarin niet-experimentele methoden worden toegepast. ${ }^{16} \mathrm{De}$ experimentele evaluaties laten een wat gunstiger beeld zien dan de niet-experimentele, maar door hun geringe aantal is moeilijk hieraan een duidelijke conclusie te verbinden.

Uit de tabel komt verder naar voren dat incentives voor werkzoekenden, bemiddeling en instroomsubsidies effectiever zijn dan scholing. Gesubsidieerde arbeid is het minst effectief. Daarbij moet worden aangetekend dat de samenstelling van de deelnemersgroepen kan verschillen. Zo hebben nogal wat scholingsstudies betrekking op jongeren, voor wie scholing minder effectief dan gemiddeld is. Bij instroomsubsidies is niet altijd duidelijk of het effect na afloop van de subsidie is gemeten of slechts het kortetermijneffect, zodat het beeld voor dit instrument mogelijk wat geflatteerd is.

In de internationale wetenschappelijk literatuur is weinig onderzoek gedaan naar de effecten voor specifieke groepen. Het meest gevonden onderscheid is tussen jongeren en volwassenen. Ook zijn er tamelijk veel studies die resultaten presenteren voor vrouwen en mannen apart. Daaruit komt naar voren dat reïntegratieinstrumenten en ook specifiek scholing voor vrouwen effectiever is dan voor mannen. In het overzicht van de literatuur komt ook een zekere tendens naar voren dat reïntegratiebeleid voor kansarmen effectiever is dan voor meer kansrijken, maar er zijn te weinig studies met dit onderscheid om uitspraken te doen voor het scholingsinstrument afzonderlijk.

Van de 85 scholingsstudies onderzoeken er 21 ook de inkomenseffecten. In 12 van de gevallen is het gevonden effect op het uurloon of het inkomen niet-significant of significant negatief en slechts in zes gevallen significant positief; in de overige drie gevallen zijn de resultaten gemengd. Dus wat de inkomenseffecten betreft is het totaalbeeld duidelijk negatiever dan ten aanzien van de effecten op de herintredingskans. Zoals aangegeven komt daaruit naar voren dat scholing voor jongeren minder effectief lijkt dan voor volwassenen. Er zijn echter weinig studies in de internationale literatuur die resultaten geven voor specifiek oudere werklozen. Een dergelijk onderscheid is wel te vinden in een aantal Nederlandse studies. Tabel 3.17 bevat hiervan een overzicht.

Vastgesteld moet worden dat het alleen om niet-experimentele studies gaat en dat afgezien van een enkele studie niet gecorrigeerd is voor selectie-onzuiverheid. In tegenstelling tot het overzicht in tabel 3.16 is in tabel 3.17 ook een studie meegenomen die effectmeting baseert op de percepties van deelnemers. Uit de 
Tabel 3.17 Overzicht van Nederlandse studies waarin het effect van scholing afzonderlijk van oudere werklozen wordt gegeven

\begin{tabular}{|c|c|c|c|}
\hline $\begin{array}{l}\text { Auteurs } \\
\text { (jaar van publicatie) }\end{array}$ & Scholingsinstrument & Methode & Uitkomsten \\
\hline $\begin{array}{l}\text { De Koning en Van Nes } \\
\text { (1989) }\end{array}$ & Kaderregeling Scholing & $\begin{array}{l}\text { Percepties van deel- } \\
\text { nemers }\end{array}$ & $\begin{array}{l}\text { Gemiddeld positief effect } \\
\text { op herintredingskans. } \\
\text { Effect is voor ouderen } \\
\text { (>40 jaar) groter dan } \\
\text { gemiddeld }\end{array}$ \\
\hline $\begin{array}{l}\text { De Koning en Van Nes } \\
\text { (1990) }\end{array}$ & СвB & $\begin{array}{l}\text { Controlegroep via } \\
\text { matching; } \\
\text { OLS op baankans } \\
\text { Geen correctie voor } \\
\text { selectie-onzuiverheid }\end{array}$ & $\begin{array}{l}\text { Gemiddeld positief effect } \\
\text { op herintredingskans. } \\
\text { Effect is voor ouderen } \\
\text { (>40 jaar) groter dan } \\
\text { gemiddeld }\end{array}$ \\
\hline $\begin{array}{l}\text { Zandvliet e.a. } \\
\text { (1995) }\end{array}$ & $\begin{array}{l}\text { CBB } \\
\text { Kaderregeling Scholing }\end{array}$ & $\begin{array}{l}\text { Logit-analyse op baankans } \\
\text { Geen correctie voor } \\
\text { selectie-onzuiverheid }\end{array}$ & $\begin{array}{l}\text { Voor СBВ gemiddeld vrij- } \\
\text { wel geen kansvergroting; } \\
\text { voor KRS duidelijke kans- } \\
\text { vergroting. Effect is voor } \\
\text { ouderen aanzienlijk groter } \\
\text { dan gemiddeld }\end{array}$ \\
\hline $\begin{array}{l}\text { Gravesteijn e.a. } \\
\text { (1995) }\end{array}$ & $\begin{array}{l}\text { Scholingsprojecten } \\
\text { binnen ESF-programma }\end{array}$ & $\begin{array}{l}\text { Controlegroep via } \\
\text { matching } \\
\text { Geen correctie voor } \\
\text { selectie-onzuiverheid }\end{array}$ & $\begin{array}{l}\text { Positief effect op baan- } \\
\text { kans voor groep ouder dan } \\
35 \text { jaar }\end{array}$ \\
\hline $\begin{array}{l}\text { Olieman e.a.(1998) } \\
\text { en } \\
\text { De Koning e.a.(1999) }\end{array}$ & $\begin{array}{l}\text { Scholingsprojecten } \\
\text { binnen ESF-programma }\end{array}$ & $\begin{array}{l}\text { Controlegroep via } \\
\text { matching } \\
\text { OLS } \\
\text { Geen correctie voor } \\
\text { selectie-onzuiverheid }\end{array}$ & $\begin{array}{l}\text { Gemiddeld negatief effect } \\
\text { van scholing op baankans } \\
\text { bij directe vergelijking met } \\
\text { controlegroep. Na correc- } \\
\text { tie voor waargenomen } \\
\text { heterogeniteit klein signi- } \\
\text { ficant positief effect. Voor } \\
\text { ouderen (> } 40 \text { jaar) effect } \\
\text { groter dan gemiddeld. } \\
\text { Effect is na ca. anderhalf } \\
\text { jaar na afronding van de } \\
\text { scholing nog intact }\end{array}$ \\
\hline CPB (2000) & $\begin{array}{l}\text { Geen specifieke } \\
\text { informatie }\end{array}$ & $\begin{array}{l}\text { Timing of events } \\
\text { Correctie voor selectie- } \\
\text { onzuiverheid }\end{array}$ & $\begin{array}{l}\text { Gemiddeld niet significant } \\
\text { op } 5 \% \text { niveau. Voor oude- } \\
\text { ren (> } 45 \text { jaar) wel signifi- } \\
\text { cant positief }\end{array}$ \\
\hline Heyma e.a.(2003) & $\begin{array}{l}\text { Geen specifieke } \\
\text { informatie }\end{array}$ & $\begin{array}{l}\text { Timing of events methode } \\
\text { Geen correctie voor } \\
\text { selectie-onzuiverheid }\end{array}$ & $\begin{array}{l}\text { Gemiddeld significant } \\
\text { positief effect op baankans. } \\
\text { Bij ouderen effect groter } \\
\text { dan gemiddeld }\end{array}$ \\
\hline
\end{tabular}

tabel komt naar voren dat scholing de herintredingskans van ouderen vergroot. Scholing lijkt juist voor ouderen een effectief instrument. 
Het aantal scholingsstudies dat ook ingaat op de langetermijneffecten van scholing op het hebben van werk is betrekkelijk gering. Men zou de redenering kunnen volgen dat kwalificerende scholing die tot niveauverhoging leidt en die relatief veel tijd in beslag neemt, niet zozeer leidt tot bekorting van de uitkeringshoogte, maar tot verminderde kans op werkloosheid in de toekomst. De verzamelde studies geven hiervoor geen aanwijzingen. Wat we bij enkele studies juist zien is dat de kortetermijneffecten wel positief zijn, maar de effecten op langere termijn kleiner worden (De Koning, Koss en Verkaik 1988; Hujer, Maurer en Wellner 1998; Fitzenberger en Prey 200o; Lechner 200o). Slechts bij een enkele studie (Larsson 200o) wordt gevonden dat de effecten op langere termijn beter zijn dan op korte termijn.

Over de invloed van vormgevingsaspecten op de effectiviteit van scholing is weinig bekend. De constatering van Friedlander e.a. (1997) dat in evaluatiestudies het scholingsproces als een blackbox wordt beschouwd, geldt nog steeds. Op grond van een meta-analyse op basis van circa 50 Nederlandse scholingsstudies komt De Koning (2002a) tot de conclusie dat ook na correctie voor verschillen in doelgroep, korte cursussen een relatief hoge bruto-effectiviteit laten zien (verreweg de meeste van deze studies bevatten geen informatie over netto-effectiviteit $\left.{ }^{17}\right)$. Van de langere cursussen gaven die op het gebied van technische vakopleiding relatief gunstige brutoresultaten te zien.

Ook over niet-markteffecten is nauwelijks iets bekend. Het Belgische onderzoeksinstituut HIVA doet momenteel onderzoek hiernaar. Dit onderzoek gaat over de effecten van een non-profitorganisatie in België waarbij langdurig werklozen tijdelijk in dienst komen om werkervaring op te doen en geschoold te worden ten einde hen te plaatsen in een reguliere baan. Bij de evaluatie wordt lange perioden zowel voor als na de deelname in beschouwing genomen. Als methode wordt een controlegroepbenadering toegepast in combinatie met een vergelijking voor en na deelname. De resultaten wijzen niet alleen op vergroting van de kans op een reguliere baan door deelname, maar ook op aanzienlijke positieve effecten op gezondheid, sociale participatie, en dergelijke. De Koning e.a (1999) vinden dat in vergelijking tot de controlegroep, deelnemers aan ESFprojecten beter scoren op punten als sociale participatie, sociale contacten en zelfvertrouwen.

\section{Conclusie en slotopmerkingen}

Op basis van een inventarisatie van de Nederlandse en de internationale literatuur valt te concluderen dat er iets meer studies zijn die een positief effect van scholing op de herintredingskans van werklozen vaststellen dan studies waar dit niet het geval is. De uiteindelijke balans van deze studies valt dus licht uit naar een positief effect, ook als bij deze inventarisatie rekening gehouden wordt met verschillen in kwaliteit van de meetmethoden. Voor specifiek oudere werklozen is het beeld duidelijk positiever; voor jongeren lijkt scholing minder effectief. Een mogelijke verklaring voor de beperkte effectiviteit bij jongeren zou kunnen zijn dat zij nog over recent verworven menselijk kapitaal beschikken en bijscholing slechts een 
beperkte toevoeging betekent, terwijl ouderen over verouderd menselijk kapitaal beschikken en bijscholing een forse toevoeging betekent aan de hoeveelheid kapitaal. Nederlandse studies wijzen over het algemeen op relatief grote effecten van scholing, vooral ook voor oudere werklozen. Maar er zijn vraagtekens te zetten bij de in deze studies gehanteerde meetmethoden. De empirische literatuur wijst niet in de richting van grotere langetermijneffecten op de kans op werkloosheid; de effecten nemen eerder na verloop van tijd af. Over mogelijke niet-markteffecten is weinig bekend. De weinige studies die ingaan op dergelijke effecten geven wel aan dat deze effecten niet a priori verwaarloosd kunnen worden. Evenmin weten we of de geconstateerde effecten op plaatsingskansen groot genoeg zijn om de kosten van de scholing goed te maken.

Het is aannemelijk dat de effectiviteit van scholing afhangt van de kenmerken van degene die geschoold wordt, de aard en duur van de scholing en de vorm en uitvoering van de scholing. Maar juist over deze punten is heel weinig bekend. Er is bijvoorbeeld geen recente informatie over de vertegenwoordiging van de verschillende opleidingsniveaus onder de deelnemers aan scholing. Onderstaande overwegingen zijn daarom enigszins speculatief.

Wij denken dat de effectiviteit van het reïntegratiebeleid kan worden vergroot als een gevalideerd profiling systeem wordt gehanteerd waarmee nieuw ingestroomde werklozen kunnen worden gecategoriseerd op grond van hun risico op langdurige uitkeringsafhankelijkheid. Men categoriseert wel in Nederland, maar dit is niet gebaseerd op een statistische analyse van werkloosheidsduren uit het verleden. Studies uit de Verenigde Staten wijzen uit dat daar de reeds lange tijd toegepaste profiling en de daarop gebaseerde preventieve maatregeltoepassing zich terugverdient door besparing op uitkeringen (Black e.a. 2003). Een goede profiling vermindert waarschijnlijk de mate waarin beleidsinstrumenten worden toegepast op personen die anders ook wel een baan zouden hebben gevonden (ook wel aangeduid als 'deadweight'). De instrumenten worden immers meer selectief toegepast op groepen waarvan op grond van bestaande informatie verwacht mag worden dat de netto-effectiviteit bij hen hoger ligt.

Kort durende scholingstrajecten zijn waarschijnlijk uit een oogpunt van reïntegratie op korte termijn te prefereren boven lang durende. Maar een nadeel van korte cursussen kan zijn dat de investering in menselijk kapitaal te gering is om duurzame arbeidsinpassing te bewerkstelligen. Daarom valt te overwegen om de scholing te laten plaatsvinden binnen het kader van een tijdelijk arbeidscontract bij een werkgever. Op dit moment bestaat zo'n regeling alleen voor scholing van werklozen zonder startkwalificatie, waarbij de subsidie (in de vorm van een afdrachtskorting sociale premies) laag is ( $€$ 1.500,- per geval).

Het rendement van scholing kan wellicht worden verhoogd door kostenbesparing door cursussen via ICT aan te bieden. Op dit gebied lopen momenteel in Nederland enkele experimenten. De eerste resultaten wijzen uit dat scholing voor werklozen via ICT perspectief biedt (zie Gelderblom 2004 voor een evaluatie van een van deze experimenten). 
Een knelpunt bij de reïntegratie van oudere werklozen blijft waarschijnlijk het feit dat een aanzienlijk deel in loon omlaag moet om kans te maken op een nieuwe baan. Dit betreft vooral degenen van wie het menselijk kapitaal verouderd is en die van beroep moeten veranderen. De ervaringsdeskundigheid die in het oude beroep was verworven zal maar zeer ten dele meetellen bij de beloning in een nieuwe functie. Alleen scholing zal in veel gevallen niet voldoende zijn om een vergelijkbare beloning te krijgen als in de oude baan. Scholing en bemiddeling van oudere werklozen zullen dus gecombineerd moeten worden met andere instrumenten om herintreding mogelijk te maken. Daarbij kan zowel aan positieve (bonussen bij werk vinden, een tijdelijke aanvulling op het loon in de nieuwe functie) als aan negatieve prikkels (korting op de uitkering bij inactief zoekgedrag en het stellen van onredelijke eisen aan een baan) worden gedacht. Uit de literatuur blijkt dat beide typen prikkels effectief zijn

\subsection{EFFECTEN VAN MENSELIJK KAPITAAL OP WERKGELEGENHEID EN ECONOMISCHE GROEI}

\subsubsection{INLEIDING}

In deze paragraaf gaan we aan de hand van de bestaande literatuur na welke effecten investeringen in menselijk kapitaal hebben op werkgelegenheid en economische groei. Lag in de vorige paragraaf meer de nadruk op het microniveau, in deze paragraaf kijken we ook nadrukkelijk naar macro-economische effecten.

In de vorige paragraaf zijn we nagegaan wat investeringen in menselijk kapitaal kunnen betekenen om de arbeidsparticipatie te verhogen, uitstroom vanuit een baan naar werkloosheid en inactiviteit te voorkomen en herintreding in een baan vanuit werkloosheid en inactiviteit te bevorderen. Toename van de arbeidsparticipatie onder lager opgeleiden, allochtonen, vrouwen en ouderen kan een zekere compensatie bieden voor de effecten van de vergrijzing waarvan een negatief effect uitgaat op de omvang van de potentiële beroepsbevolking. Tegelijkertijd moeten we vaststellen dat vanuit een internationaal perspectief arbeidsparticipatie en werkgelegenheidsgraad in Nederland al relatief hoog zijn. Verdere verhoging is mogelijk, maar zet op de lange termijn geen zoden aan de dijk uit een oogpunt van bevordering van economische groei.

Investeringen in menselijk kapitaal zijn zeker zo belangrijk - zo niet belangrijker - uit een oogpunt van bevordering van productiviteits- en productiegroei dan om redenen van bevordering van de arbeidsparticipatie en de inzetbaarheid van het arbeidsaanbod. Ook hier vormt de vergrijzing van de potentiële beroepsbevolking reden tot intensivering van de investeringen in menselijk kapitaal. De theorie van het menselijk kapitaal voorspelt dat oudere werknemers minder geneigd zullen zijn hierin te investeren, althans als het gaat om investeringen die primair op het werk zijn gericht. ${ }^{18}$ De oorzaak hiervan is dat de periode waarin zij deze investeringen te gelde kunnen maken relatief kort is. Mensen zullen vooral op jongere leeftijd in onderwijs en scholing investeren. Dit leidt tot een patroon 
waarbij op jonge leeftijd de productiviteit toeneemt met de leeftijd, maar op den duur de stijging afneemt en er zelfs een omslagpunt kan komen waarna de productiviteit in absolute zin gaat dalen. Recent empirisch onderzoek waarin de toegevoegde waarde van individuele bedrijven in verband wordt gebracht met de leeftijdssamenstelling van het personeel (naast andere factoren zoals vast en menselijk kapitaal) vinden een dergelijk verband tussen beide (Gelderblom, De Koning en Kroes 2003; Crépon, Deniau en Pérez-Duarte 2002). Naarmate het aandeel van de 'middengroepen' hoger is, is de gemiddelde productiviteit van bedrijven hoger. Bij een hoog aandeel jongeren (jonger dan 30 in het onderzoek van Gelderblom e.a. 2003) en een hoog aandeel ouderen (ouder dan 55) is de gemiddelde productiviteit lager. Maar ook micro-economische metingen gebaseerd op de gepercipieerde productiviteit door chefs of de werknemers zelf wijst op zo'n verband. ${ }^{19}$ De vergrijzing zou dan een negatief effect op de macroproductiviteit hebben, waarvoor hogere investeringen in menselijk kapitaal compensatie zouden kunnen bieden. ${ }^{20}$

Maar intensivering van menselijk kapitaal om de gevolgen van het vergrijzingsproces te compenseren veronderstelt dat menselijk kapitaal van groot belang is voor het niveau en de groei van de productiviteit. Maar is dit wel zo? In deze paragraaf gaan we dit na aan de hand van de bestaande literatuur, waarbij we weer onderscheid maken tussen initieel onderwijs, scholing van werkenden en scholing van werklozen.

\subsubsection{INITIEEL ONDERWIJS}

\section{Individueel rendement van onderwijs}

Er is heel veel onderzoek gedaan naar het individuele rendement van het initiële onderwijs ${ }^{21}$ Hieruit is de algemene conclusie dat voor individuen de kosten van het initiële onderwijs (de directe onderwijskosten en het gederfde inkomen) ruimschoots worden goed gemaakt door een hogere kans op werk en een hoger inkomen tijdens het arbeidsleven. Een traditioneel meetprobleem bij de berekening van onderwijsrendementen is dat verschillen in inkomens tussen opleidingsgroepen niet alleen aan het onderwijs zelf kunnen worden toegeschreven, maar dat ook factoren als motivatie, intelligentie en de sociale achtergrond meespelen. Zeer wel denkbaar is dat degenen die een hogere opleiding volgen, intelligenter zijn, een meer gemotiveerde levensinstelling hebben en via hun achtergrond veel sociaal kapitaal hebben meegekregen. As hier geen rekening mee wordt gehouden, wordt de bijdrage van onderwijs op inkomens overschat. Uit diverse studies blijkt echter dat het rendement niet veel lager en soms zelfs hoger uitpakt als met dergelijke selectie-effecten wordt rekening gehouden (zie Oosterbeek 2001 voor een overzicht).

Ook als alle onderwijskosten worden meegenomen, dat wil zeggen ook de kosten die niet door het individu maar door de maatschappij worden gedragen, en uitgegaan wordt van bruto-inkomen is het rendement (men spreekt dan van maatschappelijk rendement) meestal positief. Voor zover lonen de (marginale) 
productiviteit weergeven, kan dit ook zo worden geïnterpreteerd dat onderwijs de productiviteit verhoogt.

Het is echter de vraag of lonen altijd de marginale productiviteit weerspiegelen. Gemiddeld is dit waarschijnlijk wel zo, maar waar het gaat om verschillen in beloning tussen leeftijdsgroepen - die een belangrijke input vormen bij rendementsberekeningen - is er reden dit te betwijfelen. Zoals we eerder hebben gezien, zijn er aanwijzingen voor een dalende productiviteit op latere leeftijd. De lonen hebben echter niet de neiging op latere leeftijd te dalen, in elk geval lang niet in dezelfde mate als de productiviteit. Een verklaring hiervoor wordt gegeven door de contracttheorie of uitgestelde beloningstheorie (Lazear en Moore 1984), die stelt dat werkgevers jonge medewerkers minder betalen dan hun productiviteit, maar hen tevens een perspectief van stijgende lonen in het vooruitzicht stellen om hen zo te binden en gemotiveerd te houden. Volgens deze theorie zou dan op latere leeftijd de beloning hoger zijn dan de productiviteit. Het beloningsoverschot op oudere leeftijd is dan te zien als een uitgestelde betaling voor het beloningstekort op jongere leeftijd. In empirisch onderzoek zijn daarvoor ook aanwijzingen gevonden (Gelderblom en De Koning 1992a; Gelderblom, De Koning en Kroes 2003; Medoff en Abraham 1980; Mendes de Oliviera, Cohn en Kiker 1989; Crépon, Deniau en Pérez-Duarte 2002).

\section{Macro-economische effectstudies}

Een andere manier om de economische effecten van het initiële onderwijs te bepalen is het type analyse waarbij door pooling van geaggregeerde tijdreeksgegevens over landen, de economische prestaties van landen worden verklaard uit onder andere het opleidingsniveau van de (potentiële) beroepsbevolking. Inmiddels is een vrij groot aantal van dergelijke studies uitgevoerd. Overzichten van dergelijke studies zijn gegeven in Stevens en Weale (2003) en Canton (2002).

Deze studies zijn sterk geïnspireerd door de nieuwe groeitheorie. Hierin worden drie dimensies van menselijk kapitaal onderscheiden:

- het opleidingsniveau van de beroepsbevolking;

- kennisvernieuwing, waardoor de productiviteit van iemand met een bepaald opleidingsniveau nu hoger is dan in het verleden. Hier ligt een analogie met de gedachte van 'vintages' kapitaal die in de jaren tachtig wel toegepast werd op 'vast' kapitaal in productiefuncties;

- kennisdiffusie. Doordat kennis van de ene naar de andere werknemer wordt overgegeven ontstaan in feite schaalvoordelen in het productieproces.

Het effect van een toenemend aandeel hoger opgeleiden op de productiviteit is begrensd. Afhankelijk van de aard van de substitutiemogelijkheden kan het zelfs economisch optimaal zijn dat slechts een deel van de werkenden hoger opgeleid is. Dit geldt als de substitutiemogelijkheden tussen soorten arbeid eindig zijn en hoger opgeleiden niet productiever zijn dan lager opgeleiden in soorten arbeid die ook door laatstgenoemden kunnen worden verricht. Een basisvariant van dergelijke benaderingen van de productiefunctie is de 'growth-accounting- 
methode'. Hierbij wordt de economische groei verklaard door de volumestijging van de inzet van kapitaal en arbeid. Het onderwijsniveau krijgt hierin een plaats doordat deze een gewicht geeft aan arbeid. Deze methode is ontwikkeld door Solow, en door Denison (1967) op de vs toegepast. De conclusie was dat slechts een gering deel van de groei direct kon worden toegeschreven aan de kwaliteitsverhoging van human capital. Stevens en Weale (2003) laten ook studies voor andere landen zien waarbij slechts een beperkt deel van de groei (veelal minder dan $20 \%$ ) door de kwaliteitsverhoging wordt verklaard.

Een andere specificatie is als onderwijs tot uitdrukking komt in verschillende soorten arbeid in een productiefunctie. Toepassing van een dergelijke methode met twee soorten arbeid in een internationale vergelijking waarin ook ontwikkelingslanden zijn opgenomen levert een hoog effect op (Mankiw e.a. 1992). Een verdubbeling van de onderwijsinspanningen levert op langere termijn een inkomensstijging op van 66 procent. Deze resultaten kunnen echter niet direct vertaald worden naar de situatie van een ontwikkeld land als Nederland. Specifiek voor Nederland zijn ook productiefuncties geschat op basis van doorsnedeanalyses van sectordata (Gelderblom e.a. 1996). Dit bevestigde een duidelijke rangorde in productiviteit van soorten arbeid naar opleidingsniveau. Wel liep deze rangorde niet in alle gevallen geheel conform de mate van gevolgd onderwijs. Met name de mavo-groep scoorde relatief goed. Een meer verfijnde indeling in soorten arbeid op grond van onderwijsniveaus leidde duidelijk tot een betere verklaringsgraad. Dit geeft aan dat de wijze waarop onderwijs wordt in gebracht in de productiefunctie invloed zal hebben op de resultaten.

Bij kennisvernieuwing is er in beginsel geen begrenzing. Door continu een deel van de beschikbare resources in te zetten voor kennisvernieuwing kan een permanente groei van de arbeidsproductiviteit worden verkregen. Naarmate de diffusie van nieuwe kennis sneller verloopt en een groter bereik heeft, zal het groei bevorderende effect groter zijn. De hypothese zou kunnen zijn dat een hoger opgeleide beroepsbevolking een positief effect heeft op de productie en diffusie van nieuwe kennis en daarmee op de groei van de productiviteit. Omdat nieuwe kennis deels ook een publiek goed is, waarvan ook anderen profiteren, leidt onderwijs via deze weg tot positieve externe effecten, waarbij mensen bijdragen aan de productiviteit zonder dat dit in hun eigen beloning tot uitdrukking komt.

De empirische invulling geschiedt vaak door in een regressievergelijking direct de invloed van een aantal onderwijsindicatoren op de economische groei op te nemen. Het effect van de kennisvernieuwing en -diffusie komt dan tot uitdrukking door niet alleen de groei van het human capital op te nemen, maar ook het niveau ervan op te nemen. In diverse overzichtsartikelen van deze zogenaamde eerste endogene groeitheorieën, wordt aangegeven dat deze op empirische gronden moet worden verworpen (zie bijv. Jacobs en Webbink 2004). De gevonden effecten van onderwijs op economische groei bleken niet robuust. Dit bleek bijvoorbeeld reeds uit secundaire analyses van Englander en Gurney (1994), maar 
ook uit een latere kritische evaluatie van Krueger en Lindahl (2001).

Een variant van deze endogene groeitheorie is die waarin met name de nadruk wordt gelegd op de rol van onderwijs voor diffusie van nieuwe kennis via het 'catch-up-effect'. Hiermee wordt tot uitdrukking gebracht dat via een hoger onderwijsniveau het makkelijker is om de meest geschikte en meest vooraanstaande technologie van elders over te nemen. Ook de resultaten van deze variant wordt door Krueger en Lindahl (2001) op econometrische gronden bekritiseerd. $\mathrm{Zij}$ constateren dat de meeste winst kan worden geboekt bij landen met een laag onderwijsniveau, omdat hun achterstand nog groot is. Voor landen als Nederland kan verwacht worden dat de rol van catching up nog maar van zeer beperkt belang is (Jacobs en Webbink 2004). Het is daarom niet verwonderlijk dat er weinig robuuste resultaten worden gevonden voor de OECD (Sianesi en Van Reenen 2002). Alle empirische studies overziende, zijn de resultaten van de endogene groeitheorie dus weinig robuust en kan er bijvoorbeeld nog geen definitief uitsluitsel worden gegeven of het effect van onderwijs op de groei nu vooral via de veranderingen of het niveau verloopt (Stevens en Weale 2003).

Een meer recente variant van dit type literatuur is benut door Kneller en Stevens (2002). Zij gebruiken een technologische frontier-functie. Onderwijs heeft zowel invloed op de frontier-functie, maar ook op een efficiencyterm die uitdrukt hoe ver men van de frontier verwijderd is. Naast onderwijs hebben ook andere factoren invloed op deze inefficiëntie. Bij empirische toetsing blijkt onderwijs van belang, maar gaat het positieve effect hiervan alleen op voor open economieën, een factor die eveneens van invloed is op de mate van efficiëntie.

In de zogenaamde tweede generatie endogene groeitheorieën wordt sterk de nadruk gelegd op de rol van onderwijs voor de efficiency en effectiviteit van het R\&D-proces. Uit het overzichtsartikel van Jacobs en Webbink (2004) blijkt dat er overtuigend empirisch bewijs is voor de rol van R\&D voor de productiviteits(groei) en dat R\&D externe effecten heeft. Of meer onderwijs echter leidt tot meer R\&D en daarmee tot een hogere productiviteits(groei) is empirisch minder duidelijk. Een mogelijke verklaring die Jacobs en Webbink geven is dat slechts een fractie van de hoger opgeleiden daadwerkelijk in de R\&D-sfeer terechtkomt. Het aanbod van R\&D-werkers en het gemiddelde opleidingspeil hoeven dus op macroniveau geen sterke correlatie te vertonen. Het feit dat veel personen die in de R\&D-sfeer werken hoogopgeleid zijn, geeft aan dat we het belang van onderwijs voor R\&D en innovatie niet terzijde kunnen schuiven. Alleen op macroniveau is het moeilijk om dit ook via correlaties zichtbaar te maken. Wanneer dit soort verbanden op macroniveau worden getoetst, wordt veelal met de effecten van onderwijs in kwantitatieve zin gerekend. Naar verwachting is echter niet in de eerste plaats meer (hoger) onderwijs van belang voor R\&D, maar meer kwalitatieve factoren, zoals het aanbod van bepaalde specifieke studierichtingen, de kwaliteit van het onderwijs zelf en de samenwerking met het bedrijfsleven.

Methodisch zitten aan al deze macrobenaderingen sowieso veel haken en ogen. Ten eerste dient human capital gekwantificeerd te worden. Hierboven is reeds 
opgemerkt dat soorten onderwijs ook een verschillend effect kunnen hebben, waardoor het effect zeker niet altijd lineair verloopt met het aantal gevolgde studiejaren, zoals vaak wordt verondersteld. Voorts wordt veelal geen rekening gehouden met post-initieel onderwijs en training, evenmin als met de kwaliteit van het onderwijs. Ten tweede bestaat bij een macrobenadering de set van waarnemingen uit of een tijdreeks van een zelfde land en/of een doorsnedeanalyse van verschillende landen. De beperking van een vergelijking in de tijd is dat in de tijd ook allerlei andere factoren veranderen die invloed op de groei hebben. Een beperking van een vergelijking tussen landen is dat verschillende onderwijssystemen op een noemer dienen te worden gebracht, ondanks mogelijke (grote) verschillen in kwaliteit. Ten derde geldt bij al dit soort analyses het causaliteitsprobleem. Economische groei geeft immers de ruimte om middelen voor onderwijs vrij te maken. Ten slotte kan worden opgemerkt dat in dit type literatuur een grote diversiteit aan modellen wordt gehanteerd en daarmee ook in gehanteerde veronderstellingen. In het licht van al deze punten is het dan ook niet verwonderlijk dat de omvang van de effecten van onderwijs sterk varieert tussen de diverse studies. Al met al kan echter wel uit deze literatuur worden geconcludeerd dat onderwijs een rol speelt voor de productiviteit op macroniveau, alleen is de precieuze omvang van deze effecten nog met de nodige onzekerheid omgeven.

\subsubsection{SCHOLING VAN WERKENDEN}

In onderstaande tabel zijn een aantal studies opgenomen waarin onderzoek is gedaan naar de productiviteitseffecten van scholing. De weergegeven resultaten zijn deels overgenomen uit overzichtsstudies over de effecten van scholing van werkenden (OECD Employment Outlook 1999 en Ok en Tergeist 2003). De gehanteerde aanpak in de opgenomen studies verschilt sterk. Ten eerste verschilt het analyseniveau van de studies. Sommige van de studies hebben bijvoorbeeld betrekking op het niveau van de werknemer, terwijl andere op bedrijfsniveau zijn uitgevoerd. Ten tweede is - deels samenhangend met het eerste punt - de maatstaf voor productiviteit sterk verschillend. Als productiviteitsmaatstaf op individueel niveau wordt bijvoorbeeld een beoordeling door de directe chef gebruikt, maar ook meer directe productiviteitsindicatoren als de behaalde omzet per werknemer. Op bedrijfsniveau wordt vaak de omzet of de toegevoegde waarde op bedrijfsniveau als indicator gebruikt. Ten derde hebben sommige van de studies betrekking op doorsnedeanalyses, terwijl andere gebaseerd zijn op paneldata. In het laatste geval is scholing veelal in verband gebracht met de verandering in de productiviteitsmaatstaf. Er wordt dan bijvoorbeeld gekeken naar het effect van scholing op de groei van de toegevoegde waarde in bedrijven in de periode waarbinnen de scholing heeft plaatsgevonden. Het voordeel van een dergelijke analyse is dat het causaliteitsprobleem minder verstorend werkt. Bedrijfsprestaties en individuele prestaties kunnen immers ook de mate van scholing beïnvloeden. Om dit causaliteitsprobleem nog verder te ondervangen kunnen zowel prestaties als scholingsdeelname apart gemodelleerd worden (correctie voor endogeniteit). Een andere correctie die soms is uitgevoerd, is voor niet waargenomen selectiviteit in de cursusdeelnemers of scholende bedrijven. Het kan bijvoorbeeld zo 
zijn dat niet waargenomen variabelen zowel prestaties als scholing beïnvloeden waardoor er automatisch een verband ontstaat. Denk bijvoorbeeld aan motivatie die zowel invloed kan hebben op scholingsdeelname als prestaties. In sommige studies is ook voor deze vorm van selectiviteit (niet waargenomen heterogeniteit) gecorrigeerd.

Tabel 3.18 Overzicht van studies waarin de productiviteitseffecten van scholing van werkenden zijn onderzocht

$\begin{array}{ll}\text { Land en auteur(s) } & \text { Belangrijkste bevindingen } \\ \begin{array}{l}\text { Nederland: De Kok } \\ (2000)\end{array} & \begin{array}{l}\text { Het volume van scholing hangt positief samen } \\ \text { met de toegevoegde waarde in bedrijven }\end{array}\end{array}$

Nederland: Groot (1999)

Nederland: Boon

(1998)

Nederland: Gelderblom en Koning (1992a)

Duitsland: Zwick (2002)

Frankrijk en Zweden: Ballot, Fakhfakh en Taymaz (2002)

lerland: Barret en

O'Connell (1998)

Italië: Conti

(2004)

Spanje: Alba-Ramirez (1994)

Verenigde Staten: Black en Lynch (1996)

Verenigde Staten: Bartel (1995)

Zweden: Regner (1995 en 1997)

Op basis van een analyse van veranderingen in tiviteitsgroei

Investeringen in training hebben een positief op de toegevoegde waarde van bedrijven

Op basis van paneldata, na correctie voor (niet waargenomen) selectiviteit, blijkt dat scholing de productiviteit van bedrijven vergroot

Op basis van paneldata en na controle voor op de productiviteit van bedrijven aanbieden is hoger dan in andere bedrijven een positief effect heeft op productiviteit van bedrijven

Het aandeel werknemers dat aan scholing deelneemt, is gecorreleerd met omzet en toegevoegde waarde per werknemer

Het aandeel geschoolde werknemers is (zwak) gecorreleerd met omzet per werknemer

Significante en positieve effecten van scholing op individuele prestaties na controle voor endogeniteit
Speciale effecten voor groepen of soorten scholing

Het effect van scholing hangt af van de tijd die bedrijven besteden aan voorbereiden, uitvoeren en evalueren van scholing beoordelingen door chefs, blijkt dat de duur van scholing een positief effect heeft op de produceffect op de toegevoegde waarde van bedrijven

Het effect van externe cursussen is groter dan van interne cursusen endogeniteit, heeft scholing een positief effect

De productiviteitsgroei in bedrijven die scholing

Op basis van gelinkte panels van werknemers en bedrijven, en na controle voor niet waargenomen heterogeniteit en endogeniteit, blijkt dat scholing

Het rendement op scholing is hoog en significant
Het effect van scholing is groter in combinatie met R\&D inspanningen (positief effect kruisterm)

Algemene scholing is effectiever dan specifieke scholing voor wat betreft productiviteitsvergroting

De correlatie is sterker bij oudere werknemers

Scholing buiten werktijd heeft een positief significante correlatie met omzet per werknemer 
Opvallend is dat ondanks al deze verschillen al de studies uit de tabel een positief effect van scholing vinden. Blijkbaar is het positieve effect van scholing een vrij robuust gegeven. In sommige van deze studies is ook een schatting van het effect op de lonen gemaakt en wordt geconstateerd dat het effect op de productiviteit aanzienlijk hoger is dan op de beloning. Scholing kan daarmee dus bijdragen aan een verbetering van de verhouding tussen productiviteit en beloning, wat zeker voor de oudere werknemers van belang is. Overigens geven maar weinige van deze studies aparte analyse-uitkomsten voor ouderen, Alleen Alba-Ramirez (1994) geeft een aparte uitkomst, waarbij blijkt dat het positieve effect voor ouderen nog groter is. Ook in Gelderblom en De Koning (1992a) is het effect voor ouderen getoetst. Dit bleek echter niet specifiek van het gemiddelde effect af te wijken, wat wel betekent dat het positieve effect ook voor ouderen opgaat.

In sommige van de studies is wel onderscheid gemaakt naar typen scholing. Scholing is immers een heterogeen verschijnsel. Sommige cursussen zijn lang en andere zijn kort. Ook de richting en gehanteerde methodieken verschillen. Gelderblom en De Koning (1992a) constateren grotere effecten van externe scholing, dat wil zeggen opleidingen of cursussen die ontworpen en/of georganiseerd zijn door een andere organisatie dan het eigen bedrijf. Dit resultaat loopt grotendeels parallel aan het door Barret en O'Connell (1998) gevonden gegeven dat algemene scholing in de zin van Becker grotere effecten heeft dan specifieke training. Long (2004) geeft een overzicht van studies voor de effecten van scholing op lonen en constateert dat er aanwijzingen zijn dat langere cursussen ook een groter effect sorteren. Naar verwachting zal bij productiviteit ook een dergelijk verband opgaan. Bij Groot (1999) en De Kok (200o) blijkt dit ook zo te zijn. Long geeft ook aan dat er aanwijzingen zijn dat het effect van scholing zich ook over een langere termijn uitstrekt, naarmate de scholing langer is. Over het precieze tijdspatroon van de effecten is echter weinig bekend, en dat geldt zeker voor de productiviteitseffecten. Hoe lang deze voortduren, ofwel hoe snel het opgebouwde menselijk kapitaal weer afgeschreven dient te worden, daar is nog weinig over te zeggen.

Wat betreft de methodiek geldt dat uit recent onderzoek blijkt dat er geen significante verschillen optreden in de productiviteitseffecten van scholing als traditionele vormen van scholing vergeleken worden met scholing die via ICT plaatsvindt (E-learning) (Gelderblom en De Koning 2004). Dit spoort ook met een brede overzichtsstudie van de effecten van ICT als scholingsmedium (Russell 2001). Met name door de tijdswinst (en dus kostenbesparing) die via E-learning optreedt en ook de grotere flexibiliteit kan het rendement van scholing verhoogd worden. Voorwaarde is dat de ontwikkelingskosten van dergelijke scholingsvormen - die vaak nog hoog zijn - dan wel verder dalen. Uit het onderzoek blijkt eveneens dat dergelijke scholingsvormen weinig problemen hoeven op te leveren voor lager opgeleide en oudere werknemers. Ook deze groepen kunnen hier goed mee overweg. 
De bedrijfscontext zal ook een rol spelen bij de omvang van het effect van scholing. De Kok (200o) laat zien dat het productiviteitseffect afhangt van de tijd die bedrijven besteden aan de voorbereiding, uitvoering en evaluatie van de scholingen. Dit geeft aan dat cursussen die plaatsvinden binnen het kader van een breder scholingsbeleid meer effect sorteren. Onderwijskundigen zoals Gielen (1995) benadrukken het belang van een dergelijke bedrijfscontext, inclusief de betrokkenheid van de directe chef.

Een van de mogelijke mechanismen waarlangs de effecten van scholing optreden is de relatie met innovaties. Brouwer en Kleinknecht (1994) en Sonia (1997) laten zien dat bedrijven die hoog scoren op innovaties ook veel aan scholing doen. Gelderblom, De Koning en Van der Weijde (1996) laten zien dat een dergelijk verband ook op sectorniveau bestaat. Ballot, Fakhfakh en Taymaz (1997 en 2002) hebben in hun studies naast scholing ook rekening gehouden met R\&D als factor die de productiviteits(groei) van bedrijven beïnvloedt. Een opvallend gegeven is dat er tussen scholing en R\&D een positief interactie-effect bestaat, dat wil zeggen dat scholing nog eens extra effectief is als bedrijven veel aan R\&D doen. Dit benadrukt nog eens de rol van scholing voor R\&D.

\subsubsection{SCHOLING VAN WERKLOZEN}

In paragraaf 3.3.4 bleek dat de internationale literatuur over de inkomenseffecten van scholing een duidelijk minder positief beeld geeft dan ten aanzien van de effecten op de herintredingskans. Voor zover het inkomen of het loon een indicator is voor de kwaliteit van de baan of de productiviteit, zijn er dus geen duidelijke aanwijzingen voor productiviteits- of kwaliteitsbevorderende effecten van scholing van werklozen.

$\mathrm{Nu}$ gaat de in paragraaf 3.3.4 behandelde literatuur alleen in op de effecten van scholing op de arbeidsmarktpositie en het inkomen of het loon van de deelnemers aan de scholingsprogramma's. De macro-economische effecten kunnen echter afwijken van de individuele effecten. Hierbij kunnen de volgende mogelijke effecten worden genoemd:

- verdringingseffecten. Als scholing tot een hogere baankans van de geschoolden leidt, kan dit tot verdringing van andere werklozen leiden. Daardoor kunnen de effecten op de macrowerkgelegenheid in elk geval op de korte termijn beperkt zijn;

- effecten op de aansluiting tussen vraag en aanbod. Als scholing leidt tot een betere aansluiting, neemt, alle andere factoren gelijkblijvend, de macrowerkloosheid en de openstaande vraag beide af en de werkgelegenheid toe;

- effecten op de omvang van het arbeidsaanbod. Met het oplopen van de werkloosheidsduur, nemen de baankansen van werklozen af door stigmatisering door werkgevers, verlies aan menselijk kapitaal en verlies aan motivatie. Daardoor ontstaat een groep die weliswaar een werkloosheidsuitkering heeft, maar feitelijk niet meer actief is op de arbeidsmarkt. Van degenen die niet (meer) in aanmerking komen voor een uitkering, zal een deel zich terugtrekken van de 
arbeidsmarkt. Scholing en andere reïntegratie-instrumenten kunnen voorkomen dat werklozen in zo'n situatie terechtkomen en bevorderen dat degenen die in zo'n situatie terechtkomen weer 'employable' worden. Hierdoor kan het aantal personen dat actief op de arbeidsmarkt is als werkende of werkloze werkzoekende toenemen. Te verwachten is dat hiervan een positief effect op de werkgelegenheid zou uitgaan;

- effecten op de loonvorming. Of reïntegratiebeleid per saldo tot verruiming of verkrapping van de arbeidsmarkt leidt is a priori niet te zeggen. Derhalve kan ook over het effect op de loonvorming geen uitspraak worden gedaan.

Verdringingseffecten zijn vooral onderzocht voor instroomsubsidies en gesubsidieerde arbeid. Over het algemeen zijn de gevonden verdringingseffecten aanzienlijk (zie onder meer De Koning 2002b; Allaart 2002; Skedinger 1995; Forslund \& Krueger 1995). Bij scholing zouden deze effecten geringer kunnen zijn voor zover de geschoolden vacatures vervullen op deelmarkten waarop zich vraagknelpunten voordoen. Maar hiernaar is weinig onderzoek gedaan en voor zover er onderzoek is, levert dit geen hard bewijs dat scholing van werklozen de aansluiting tussen vraag en aanbod verbetert (zie De Koning 2001 voor een overzicht).

Om de uiteindelijke effecten op de macro-economische productie, productiviteit en werkgelegenheid te bepalen zou gebruik moeten worden gemaakt van een algemeen-evenwichtsmodel, waarin dan ook bijvoorbeeld de financiering van het beleid en de gevolgen van de uitgaven aan uitkeringen meegenomen zouden moeten worden. Het enige voorbeeld dat we kennen van een dergelijke benadering is een studie van Jongen, Van Gameren en Graafland (2000), waaruit slechts geringe effecten van scholing en andere activerende maatregelen op de macroeconomische uitkomsten naar voren komen. Om alle relevante economische mechanismen te kwantificeren dienen echter vele veronderstellingen te worden gemaakt die maar zeer ten dele empirisch onderbouwd kunnen worden.

Een alternatieve benadering waarbij kwantificering van de mechanismen in de economie en de arbeidsmarkt vermeden kan worden, is een cross-sectieanalyse over landen. Als mag worden aangenomen dat spill-over-effecten klein zijn, kunnen uit een eventuele samenhang tussen macro-economische grootheden en scholingsinspanningen ten aanzien van werklozen, conclusies worden getrokken over de effecten van scholing van werklozen op de macro-economische ontwikkeling. Er zijn ook geaggregeerde effectstudies waarbij gebruik wordt gemaakt van gepoolde tijdreeksgegevens van regio's binnen een land.

De Koning (2001) geeft een overzicht van geaggregeerde effectstudies naar het actief arbeidsmarktbeleid. Aangevuld met enkele recentere studies (De Koning en Van Nes 2002; ministerie van SZW 2003) is dit een totaal van 26 studies met vooral studies uit Duitsland, Nederland en Zweden, alsmede studies op basis van gegevens over de OECD-landen. De resultaten zijn wisselend. Er zijn zes studies die significant gunstige effecten laten zien op geaggregeerde grootheden als werk- 
loosheid en werkgelegenheid, en acht studies waaruit geen significante effecten naar voren komen. Bij 12 studies worden voor sommige van de onderzochte instrumenten significante resultaten gevonden en voor andere niet of worden op sommige doelvariabelen significante effecten gevonden en op andere niet. In de meeste studies worden de effecten van het actief arbeidsmarktbeleid als geheel onderzocht en wordt geen onderscheid gemaakt naar instrument. De weinige geaggregeerde studies waarin het scholingsinstrument wordt onderscheiden geven een even wisselend beeld te zien als het totaal van de geaggregeerde studies.

Onze conclusie is dat op basis van de beschikbare Nederlandse en internationale literatuur er geen aanleiding is om aan te nemen dat de macro-economische effecten van het actief arbeidsmarktbeleid en daarbinnen van scholing groter zijn dan naar voren komt uit de micro-economische literatuur. Verder valt op grond van kwalitatieve informatie over de aard van de scholing niet aan te nemen dat scholing van werklozen een impuls geeft aan innovatie en daarmee indirect aan de economische groei. In de jaren negentig waren er projecten als bijvoorbeeld het PION-project in het kader waarvan werkloze hoger opgeleiden omgeschoold werden tot informaticus, een beroep waarin destijds tekorten voorkwamen. Dergelijke projecten zouden nog wel een zeker effect op de economische groei kunnen hebben. Maar voor zover ons bekend komen in de huidige situatie dergelijke gecoördineerde scholingsinspanningen voor werklozen gericht op vermindering van specifieke vraagknelpunten in de private sector niet meer voor. Een belangrijke oorzaak hiervoor is dat de uitkeringsinstellingen die hiervoor de coördinerende rol zouden moeten vervullen zich primair richten op de uitkeringsgerechtigden en op schadelastbeperking. $\mathrm{Zij}$ hebben nauwelijks zicht op de vraagzijde van de arbeidsmarkt.

\subsubsection{CONCLUSIES}

Uit het vele micro-onderzoek dat hiernaar is gedaan valt af te leiden dat onderwijs een positief inkomensrendement heeft. Het is aannemelijk dat hiermee in samenhang een positief verband tussen onderwijs en productiviteit bestaat. Macro-economisch onderzoek bevestigt dit. Als de voorraad menselijk kapitaal toeneemt, nemen dus ook productiviteit en productieomvang toe. Minder duidelijk uit het onderzoek is of een grotere voorraad menselijk kapitaal ook leidt tot een hogere groei van de productiviteit en het productievolume. Er is wel afdoende bewijs dat $R \& D$ leidt tot hogere groei. Het is aannemelijk dat onderwijs invloed heeft op R\&D, en dus indirect ook op de economische groei, maar niet in de zin dat een groter percentage hoger opgeleiden in de beroepsbevolking automatisch tot meer R\&D leidt. Hierbij zal vooral het percentage hoger opgeleiden met bepaalde studierichtingen spelen. Verder lijken voor doorbraken in de wetenschap en de techniek de kwaliteit van wetenschappelijk onderzoek en onderwijs, alsmede de samenwerking met het bedrijfsleven van belang. Kwaliteit is dus waarschijnlijk belangrijker dan kwantiteit. 
Scholing van werkenden heeft positieve effecten op de productiviteit. Dit effect wordt in vrijwel alle studies gevonden, onafhankelijk van deze wijze waarop productiviteit wordt gemeten (op individueel niveau via percepties van werknemers of hun chefs of via het loonniveau; op bedrijfsniveau via de toegevoegde waarde per werknemer). Zoals te verwachten is, is het effect van scholing groter naarmate de (tijds)investering groter is. Ook het bedrijfsbeleid lijkt een rol te spelen: naarmate bedrijfsopleidingen beter gestructureerd plaatsvinden binnen een breder scholingsbeleid zijn de effecten groter. Verder zijn er aanwijzingen dat scholing van werkenden positief samenhangt met innovaties, waarbij overigens de causale richting van de samenhang onduidelijk is.

Scholing via ICT (bijv. E-learning) is even effectief als scholing in klassieke vorm. Bij toenemende toepassing van scholing via ICT zullen de kosten van scholing mogelijk lager kunnen worden. ICT maakt scholing minder afhankelijk van tijd en plaats, deze kan plaatsvinden op momenten waarop het minder druk is (daling van de gederfde productie). Verder kan ICT tot een grotere efficiency van het scholingsproces leiden. Wellicht biedt dat dan compensatie voor de daling in het rendement die zou kunnen optreden als door snellere veranderingen in de economie en de techniek mensen vaker van werk moeten veranderen en zich vaker moeten om- of bijscholen. Overigens is de efficiëntieverbetering bij scholing door ICT voor een belangrijk deel nog toekomstmuziek.

Wat betreft scholing van werklozen voegen geaggregeerde effectstudies en macro-economische doorrekeningen weinig toe aan de micro-economische literatuur. Er zijn nauwelijks aanwijzingen dat scholing van werklozen bijdraagt aan het niveau en de groei van de productiviteit. Deze scholing moet vooral worden gezien als middel tot verhoging van de werkgelegenheidsgraad voor groepen als ouderen, vrouwen en andere groepen die vanuit de werkloosheid relatief weinig kansen op herintreding hebben.

\section{$3 \cdot 5$ SAMENVATTING EN CONCLUSIES}

\subsubsection{SAMENVATTING}

\section{Achtergrond en vraagstelling}

Dit hoofdstuk gaat aan de hand van de bestaande literatuur na hoe de relatie is tussen menselijk kapitaal en het proces van creatieve destructie. Onder menselijk kapitaal verstaan we het geheel aan productieve kennis dat in mensen is belichaamd. Mensen doen deze kennis op door middel van scholing en onderwijs, maar ook langs informele weg door bijvoorbeeld learning by doing. We richten ons op de meer formele wegen om kennis op te doen.

Met het proces van creatieve destructie wordt gedoeld op simultaan verlies aan banen en ontstaan van nieuwe werkgelegenheid ten gevolge van onder meer de internationalisering en de vernieuwingen van producten en productieprocessen. Procesvernieuwing gaat gepaard met rationalisatie en verlies van werkgelegen- 
heid. Dit kan voor een deel worden gecompenseerd doordat de productiviteitsstijging leidt tot hogere lonen en daardoor tot toename van de afzet voor de bedrijven waarin de rationalisatie plaatsvindt. Maar vaak is deze compensatie slechts gedeeltelijk en profiteren vooral bedrijven in andere sectoren met nieuwe producten van de grotere bestedingsmogelijkheden. In die laatste sectoren treedt dan groei van werkgelegenheid op.

Voor de lange termijn is niet te verwachten dat dit proces van creatieve destructie een negatieve invloed heeft op de totale omvang van de werkgelegenheid. Uitgaande van een voldoende flexibel werkende arbeidsmarkt bepaalt de omvang van het aanbod van arbeid de werkgelegenheid. Hoogstens zou technische vernieuwing tot verandering van de werkgelegenheid leiden doordat - via productiviteitsstijging - het uurloon erdoor toeneemt, wat van invloed kan zijn op het aantal uren dat mensen willen werken. Verder zou een effect kunnen optreden als de huishoudelijke technologie verandert, waardoor mensen minder tijd aan het huishouden hoeven te besteden en dus meer gelegenheid krijgen om arbeid aan te bieden. Maar afgezien daarvan lijkt de invloed van technische vernieuwing op de omvang van de werkgelegenheid op de lange termijn beperkt.

De problemen die het proces van creatieve destructie meebrengt liggen veeleer op het vlak van de aansluiting tussen vraag en aanbod. De nieuwe banen zullen veelal in andere bedrijven en sectoren ontstaan dan waar banen verdwijnen. Verder vraagt de nieuwe werkgelegenheid meestal andere competenties. Het proces van creatieve destructie brengt derhalve niet alleen mee dat werknemers van baan en werkgever moeten veranderen. $\mathrm{Zij}$ moeten zich ook bij- of omscholen. Maar voor velen is een dergelijke omschakeling niet eenvoudig. Zo hebben we in het verleden gezien dat vooral werkgelegenheid voor laaggeschoolden verdwijnt. Deze groep heeft weinig affiniteit met onderwijs. Het proces van creatieve destructie kan daarom gepaard gaan met aanzienlijke aanpassingsproblemen.

Deze aanpassingsprocessen kunnen van twee kanten worden bekeken. In de eerste plaats kun je je afvragen hoe werknemers reageren op veranderingen in de structuur van de werkgelegenheid. Kunnen zij zich hieraan makkelijk aanpassen? Welke rol spelen investeringen in menselijk kapitaal hierbij? Maar je kunt het ook van de andere kant bekijken: in hoeverre leidt een goed opgeleide beroepsbevolking tot productiviteits- en inkomensgroei? Beide kanten komen aan de orde. Verder komen demografische effecten aan de orde. De gevolgen van de vergrijzing krijgen hierbij de meeste aandacht in verband met de verwachte gevolgen hiervan voor de arbeidsparticipatie en de productiviteit.

\section{Investeringen in menselijk kapitaal en arbeidsmarktprestaties internationaal vergeleken}

Hoe staat Nederland er voor wat betreft investeringen in menselijk kapitaal? Een vergelijking met de economisch meest ontwikkelde OECD-landen laat zien dat op de meeste indicatoren de scores voor Nederland lager liggen dan gemiddeld voor 
de andere landen. In Nederland zijn de uitgaven aan initieel onderwijs en scholing van werkenden relatief laag. Tot voor enige jaren gaf Nederland naar verhouding wel veel uit aan scholing van werklozen, maar sinds enige tijd wordt in het actief arbeidsmarktbeleid minder prioriteit aan het scholingsinstrument gegeven.

De deelname aan het initiële onderwijs en de participatie van werkenden in scholing laten een vergelijkbaar beeld zien en dit komt ook naar voren in het relatief lage opleidingsniveau van de beroepsbevolking. Bij lager opgeleiden ligt het deelnamepercentage aan scholing van werkenden ongeveer op de helft van dat van hoger opgeleiden. Dit betekent dat de na het initiële onderwijs opgelopen achterstand in menselijk kapitaal tijdens het arbeidsleven alleen maar groter wordt. Ook onder ouderen is de deelname aan bedrijfsopleidingen relatief laag, al is het verschil met de andere leeftijdsgroepen in de afgelopen periode wel kleiner geworden.

Op punten als werkloosheidspercentage, participatiegraad en werkgelegenheidsgraad scoort Nederland internationaal gezien goed. Wel moet worden aangetekend dat deeltijdarbeid in Nederland aanzienlijk meer voorkomt dan in de andere landen. Als we de werkgelegenheidsgraad in fulltime-equivalenten meten is het beeld nog steeds vrij goed, maar minder uitgesproken. De participatie van vrouwen is dan in vergelijking met andere landen minder gunstig. Verder neemt Nederland een middenpositie in als het gaat om de participatiegraad van oudere werknemers. De arbeidsmarktpositie van allochtonen is uitgesproken slecht met een lage participatiegraad en een hoge werkloosheid.

\section{De invloed van menselijk kapitaal op participatie en inzetbaarheid}

De hoogte van de initiële opleiding is sterk bepalend voor het succes op de arbeidsmarkt. Naarmate de vooropleiding hoger is, is de kans op inactiviteit en werkloosheid kleiner. Hoewel ook bij hoger opgeleiden de participatiegraad boven het vijftigste leeftijdsjaar afneemt, is de afname duidelijk minder dan bij lager opgeleiden. De hogere participatie en de lagere werkloosheid onder hoger opgeleiden gaan gepaard met hogere mobiliteit van baan naar baan. Dit suggereert dat het probleem dat met het toenemen van de leeftijd concentratie van ervaringsdeskundigheid optreedt, waardoor werknemers kwetsbaar worden voor veranderingen, voor hoger opgeleiden minder opgaat.

De verschillen in participatiegraad en werkloosheidspercentage tussen de verschillende opleidingsniveaus zijn bij vrouwen aanzienlijk groter dan bij mannen (waar de verschillen overigens ook duidelijk aanwezig zijn). In veel huishoudens is betaalde arbeid voor de vrouw een nevenactiviteit naast het huishouden. Juist bij laagopgeleiden weegt het loon vaak niet op tegen de kosten (denk aan kinderopvang) die moeten worden gemaakt om betaald werk te kunnen verrichten.

De verschillen in arbeidsparticipatie tussen allochtonen en autochtonen zijn onder alle opleidingsniveaus ongeveer even groot. De verschillen in werkloos- 
heidspercentage zijn echter bij lager opgeleiden minder groot dan bij hoger opgeleiden. Ook bij allochtonen gaat een hoger opleidingsniveau gepaard met een lager werkloosheidspercentage, maar de daling is relatief kleiner dan bij autochtonen.

Hoewel minder uitgesproken, wijst onderzoek eveneens uit dat scholing van werkenden de kans op een stabiel arbeidsleven vergroot. Scholing tijdens de baan vermindert de kans op werkloosheid. Verder blijkt dat oudere werknemers die tijdens hun loopbaan scholing hebben gekregen en van baan zijn gewisseld beter functioneren en langer 'meegaan'. Aan scholing zijn kosten verbonden, zowel directe opleidingskosten als gederfde productie. Als door snellere veranderingen in techniek en economie werknemers tijdens hun arbeidsleven vaker scholing moeten volgen, betekent dit dat de kosten van scholing zullen toenemen. Maar mogelijk bieden de ontwikkelingen op ICT-gebied die verantwoordelijk zijn voor een deel van de aanpassingsproblemen hiervoor ook een oplossing doordat toepassing van ICT scholing goedkoper maakt (denk aan E-learning). ICT kan ook meer informele manieren van scholing vergemakkelijken. Over informeel leren is minder bekend, maar voor zover hiernaar onderzoek is verricht, blijkt dat informele vormen van leren een grote rol spelen voor het opdoen van kennis en ervaring. Er zijn ook aanwijzingen dat informeel leren een relatief grotere rol speelt voor groepen werknemers en bedrijven die ondervertegenwoordigd zijn bij formele scholing, zoals ouderen, en daarmee dus een soort 'tegenwicht' geeft.

Bij voorkeur zouden werknemers bij herstructurering tijdig moeten overstappen naar een andere baan, zonder werkloos te worden. Maar werkloosheid is niet helemaal te voorkomen. Werkloosheid kan overigens ook in verborgen vorm optreden als arbeidsongeschiktheid. Scholing kan bijdragen tot herintreding van werklozen en arbeidsgehandicapten in het arbeidsproces. Marktfalen maakt juist bij reïntegratie interventie van de overheid noodzakelijk.

Gedurende de afgelopen decennia heeft de overheid aanzienlijke bedragen aan reïntegratie van werklozen en arbeidsgehandicapten uitgegeven. Scholing heeft hierin een belangrijke plaats, al bestaat thans de tendens in het reïntegratiebeleid prioriteit aan andere instrumenten te geven. Het internationale evaluatieonderzoek geeft voor dit laatste ook wel enige rechtvaardiging. Hieruit komt namelijk naar voren dat instrumenten als incentives voor werkzoekenden, bemiddeling en instroomsubsidies voor werkgevers zowel effectiever als goedkoper zijn dan scholing. Maar dit is een gemiddeld beeld. Voor bepaalde groepen kan dit anders liggen. Uit Nederlandse evaluatiestudies (in de internationale literatuur worden de effecten veelal niet apart gemeten voor subgroepen) blijkt bijvoorbeeld dat scholing voor oudere werklozen duidelijk beter werkt dan voor jongeren. Het negatieve beeld van scholing van werklozen is waarschijnlijk voor een belangrijk deel gebaseerd op toepassing op jongeren, waarmee de ervaringen inderdaad tamelijk negatief zijn. Maar ook hierbij kun je je voorstellen dat voor sommige groepen jongeren en voor sommige scholingsvormen scholing wel effectief kan zijn. 
De invloed van menselijk kapitaal op productiviteits- en inkomensgroei Zowel de micro- als de macro-economische literatuur wijst uit dat initieel onderwijs een positief rendement oplevert. En dit geldt zowel vanuit individueel als vanuit maatschappelijk perspectief. Het hogere opleidingsniveau van de beroepsbevolking leidt dus tot een hogere productiviteit en een hoger inkomen. Maar de effecten van substitutie van lager opgeleiden door hoger opgeleiden op de productiviteit zijn in beginsel begrensd. De nieuwe groeitheorie is optimistischer over de productiviteitseffecten van onderwijs, onder meer doordat deze theorie ervan uitgaat dat hoger opgeleiden hun kennis doorgeven aan anderen, waardoor schaaleffecten optreden. Maar hiervoor is empirisch minder bewijs.

Innovatie kan wel dergelijke schaaleffecten opleveren. Sommige vindingen hebben dusdanige uitstralingseffecten (ook in de tijd) dat de macro-economische baten ervan veel en veel omvangrijker zijn dan de investeringskosten. Investeringen in menselijk kapitaal zijn van belang voor het innovatieproces, omdat menselijk kapitaal de belangrijkste inputfactor hierin is. Maar hierbij is niet alleen of misschien wel niet zozeer van belang hoeveel er in totaal in menselijk kapitaal wordt geïnvesteerd. Van meer belang lijken de aard en de kwaliteit van het menselijk kapitaal. Het gaat vooral om wetenschappelijk opgeleiden met de vereiste studierichtingen en met een meer dan gemiddelde begaafdheid. De kwaliteit van universiteiten en van het wetenschappelijk onderzoek is hierbij van meer belang dan het aantal opgeleiden. Ook samenwerking tussen universiteiten en bedrijfsleven is hierbij van belang. In Nederland bestaan op beide punten problemen. Er worden onvoldoende mensen met de vereiste studierichtingen opgeleid en het fundamenteel wetenschappelijk onderzoek is losser komen te staan van de $R \& D$-activiteiten van bedrijven.

Er zijn verder aanwijzingen dat scholing van werkenden niet alleen hun inzetbaarheid in het arbeidsproces vergroot (waardoor de kans vermindert om werkloos te worden), maar ook hun productiviteit. Evenals het initiële onderwijs lijkt ook scholing tijdens de loopbaan een positief rendement op te leveren. Hoe het causale verband precies loopt is minder duidelijk. Scholing kan innovaties stimuleren, maar innovaties kunnen ook weer scholingsactiviteiten oproepen.

De macro-economische effecten van scholing van werklozen lijken echter beperkt. De productiviteitseffecten daarvan zijn gering. Ook de effecten op de aansluiting tussen vraag en aanbod op de arbeidsmarkt zijn niet groot.

\subsubsection{GEVOLGEN VOOR HET BELEID}

\section{Het initiële onderwijs}

Nederland scoort internationaal gezien matig op de uitgaven aan onderwijs en de hoogte van het opleidingsniveau van de bevolking. Uit het bestaande onderzoek komt echter duidelijk naar voren dat onderwijs een belangrijke succesfactor is. De aanwijzingen zijn het sterkst op het individuele niveau. Hoger opgeleiden zijn tijdens hun arbeidsleven veel minder vaak werkloos, hebben een hogere partici- 
patiegraad en hebben ook een langer arbeidsleven. Zij zijn mobieler en beter bestand tegen veranderingen.

Onderwijs heeft ook een positief inkomensrendement. Dit wordt door economen ook gezien als een indicatie voor een hogere productiviteit. Macrostudies bevestigen dit, al zijn er geen sterke aanwijzingen voor positieve schaaleffecten zoals worden voorspeld door de nieuwe groeitheorie. Wel speelt opleiding ook een belangrijke rol bij het innovatieproces, al gaat het dan wel meer om de kwaliteit dan om de kwantiteit van de onderwijsinspanningen.

Waarschijnlijk geven de effecten van onderwijs op arbeidsparticipatie en productiviteit ten dele eigenschappen weer die mensen al van nature of via hun opvoeding hebben meegekregen. Maar voor zover daarover informatie beschikbaar is, is aannemelijk dat ook onderwijs een belangrijke rol speelt.

Het vergeleken met andere westerse landen lage opleidingsniveau van de bevolking is dus een probleem. Wat kan hieraan worden gedaan? In de eerste plaats zullen de uitgaven aan onderwijs moeten toenemen. Hoewel dit geen garantie voor verbetering is, is het daarvoor wel een voorwaarde. Meer en vooral betere docenten zullen tot hogere uitgaven leiden. Er zullen knopen moeten worden doorgehakt om de onderwijsachterstand van allochtone kinderen te verminderen, bijvoorbeeld door te bevorderen dat zij vaker in gemengde klassen lessen volgen. Verder zullen leerlingen en studenten moeten worden gestimuleerd (mede door financiële voordelen tijdens de studie) om studierichtingen te kiezen met een hoog maatschappelijk rendement.

Het aandeel jongeren dat zonder startkwalificatie van school komt moet omlaag. Tegelijkertijd moet erkend worden dat een dergelijke startkwalificatie als resultaat van het initiële onderwijs voor een deel van de jongeren niet haalbaar is. Voor die jongeren moeten praktijkgerichte opleidingen komen die aansluiten bij de behoefte van het bedrijfsleven. Daarbij gaat het niet alleen om hervorming van het vmbo. Het is ook van belang dat jongeren met een lts-achtige opleiding de mogelijkheid hebben zich na intrede in de arbeidsmarkt verder te ontwikkelen. Het is de vraag of de huidige mogelijkheden hiervoor via de Roc's wel voldoen. Misschien moeten ook elementen uit het oude leerlingwezensysteem weer in ere worden hersteld.

Leeftijd en etniciteit zijn niet de enige demografische factoren die een rol spelen; ook geslacht is een belangrijke factor. Zorgpunt is dat veel vrouwen kleine deeltijdbanen vervullen en daarbij vaak beneden hun opleidingsniveau werkzaam zijn. Een dergelijk loopbaanperspectief prikkelt niet tot investeringen in menselijk kapitaal. Maar ook als vrouwen in staat en bereid zijn in voltijd te werken, zijn hun loopbaanverwachtingen minder gunstig dan voor mannen. Ook vrouwen met een goede opleiding werken veelal in deeltijd en onder hun opleidingsniveau. Hier is sprake van een fors onbenut arbeidspotentieel. Meer en goedkopere kinderopvangmogelijkheden zijn noodzakelijk om dit onbenutte potentieel 
in te zetten. Verder is te verwachten dat juist bij vrouwen verhoging van het opleidingsniveau (vermindering van het percentage zonder startkwalificatieniveau) gunstige arbeidsmarkteffecten heeft.

\section{Scholing van werkenden}

Op de hele lange termijn leidt niveauverhoging in het initiële onderwijs ook tot betere inzetbaarheid van oudere werknemers, doordat hoger opgeleiden tijdens hun arbeidsleven meer in menselijk kapitaal investeren en mobieler zijn. Daardoor kunnen zij langer actief blijven. Maar voor de komende decennia staan we voor het probleem te zorgen dat de mensen die het initiële onderwijs reeds verlaten hebben, in grotere getale aan het arbeidsproces gaan deelnemen en ook langer in het arbeidsproces blijven. Hierbij moet het dus komen van scholing van werkenden en van werklozen. Op scholing van werklozen komen we hieronder terug.

Preventief beleid om te voorkomen dat werknemers die nu nog relatief jong zijn later problemen krijgen, verdient de meeste prioriteit. Bevordering van mobiliteit van baan naar baan is daarvoor misschien van nog meer belang dan scholing. Overheidssubsidies alleen zijn niet voldoende om scholing van werkenden te stimuleren, althans dat concluderen we uit het bestaande evaluatieonderzoek naar scholing van werkenden. Daarnaast kan vooral worden gedacht aan financiële prikkels in de sociale zekerheid. Experience rating, waarbij de premie die werkgevers betalen afhankelijk is van het aantal werknemers dat zij in het verleden hebben laten afvloeien, is een instrument om werkgevers aan te zetten tot een beter personeelsbeleid. Bij werknemers zou men de uitkeringshoogte bij werkloosheid kunnen laten afhangen van de in de voorgaande periode gepleegde investeringen in menselijk kapitaal. Behaalde erkende diploma's zouden hierbij als criterium kunnen dienen. Tegelijkertijd lijkt het verstandig zowel voor werkgevers als voor individuen subsidiemaatregelen voor scholing in stand te houden of nieuw te ontwikkelen. Daarbij dient dan wel gezocht te worden naar vormen van subsidies die ook daadwerkelijk een stimulerend effect op de scholingsinspanningen hebben. In de afgelopen tijd is de algemene fiscale aftrekmogelijkheid voor bedrijven die hun werknemers scholen afgeschaft, omdat de deadweight van deze maatregel zeer hoog bleek te zijn. Wel bestaat er nog een fiscaal voordeel voor bedrijven die jongeren een combinatie van werken en leren in een beroeps begeleidende leerweg aanbieden. Ook zijn er experimenten uitgevoerd met de financiële ondersteuning van individuele leerrekeningen. ESF-middelen koppelen extra middelen aan gerichte scholingsplannen van bedrijven, maar bijvoorbeeld ook sectororganisaties. Op brancheniveau worden via O\&O-fondsen ook door veel sectoren zelf middelen vrijgemaakt voor scholing. Een interessante ontwikkeling daarbij is dat in sommige sectoren de mogelijkheden verruimd zijn dat ook individuele werknemers zelfstandig een beroep kunnen doen op deze middelen om hun employability op peil te houden. Soms zijn deze faciliteiten specifiek gericht op ouderen.

Preventief beleid komt te laat voor de oudere werknemer van nu of werknemers die de komende vijf jaar tot deze categorie gaan behoren. Bij degenen die nog een 
baan hebben, maar gezien de aard van hun baan (sector, beroep) een verhoogd risico hebben deze te verliezen, kan transitie naar ander soort werk een oplossing bieden. Daartoe dient het voor werkgevers aantrekkelijk te worden gemaakt oudere werknemers aan te nemen. Bij eventuele invoering van experience rating zou compensatie moeten worden gegeven aan werkgevers die oudere werknemers met een verhoogd ontslagrisico aantrekken. Thans is het zo dat werkgevers die oudere werknemers ontslaan vaak een ontslagvergoeding betalen. Je zou je kunnen voorstellen dat in de toekomst werkgevers meebetalen aan de transitie van oudere werknemers (inclusief de daarvoor benodigde scholing) naar ander werk in andere sectoren.

Scholingssubsidies zijn zeker geen garantie voor voldoende deelname aan scholing. Zij dienen gecombineerd te worden met andere maatregelen. Maar subsidies zijn wel nodig. Het huidige klimaat voor scholing is schraal.

\section{Scholing van werklozen}

In het actief arbeidsmarktbeleid dient scholing selectief te worden toegepast. Voor veel werklozen zijn incentives (bonussen, sancties en monitoring), bemiddeling en instroomsubsidies voor reguliere banen effectiever dan scholing. Maar in het huidige reïntegratiebeleid dreigt scholing te veel onder te sneeuwen. Juist voor oudere werklozen kan scholing reïntegratie bevorderen.

Scholing blijkt over het algemeen minder effectief te zijn voor jongere werklozen. Toch zouden vooral laagopgeleide jongeren zonder diploma van het voortgezet onderwijs er baat bij kunnen hebben. Maar hen bij wijze van spreken terugsturen naar de school die zij niet hebben afgerond lijkt weinig zinvol. In het verleden vervulden de Centra Vakopleiding een functie voor dergelijke jongeren (maar overigens ook voor oudere werklozen). Deze centra verzorgden praktijkopleidingen vanuit een op de arbeidsmarkt gerichte visie (op het individu afgestemde cursusinhoud, flexibele instroommogelijkheid, praktijkgerichtheid met theorie voor zover nodig, zo kort mogelijke cursusduur, e.d.). Qua cultuur hadden deze centra meer het karakter van een bedrijf dan van een school, waardoor zij ook voor mensen met een aversie voor de school aantrekkelijk waren. Met het verdwijnen van Arbeidsvoorziening, waarvan de centra deel uitmaakten, is er van deze centra weinig overgebleven.

Het huidige reïntegratiebeleid concentreert zich op korte trajecten die gericht zijn op zo snel mogelijke herintreding van werklozen. Maar juist voor lager opgeleiden is de kans op herhaalde werkloosheid dan groot. Scholing via de werkgever zou dit risico kunnen verminderen. De stimulansen voor werkgevers zijn echter beperkt. Er bestaan fiscale aftrekmogelijkheden voor scholen en leren in het kader van de beroepsbegeleidende leerweg. Ook is er een fiscale aftrekmogelijkheid voor bedrijven die werklozen aannemen en vervolgens de mogelijkheid bieden een startkwalificatie te halen. Maar het gebruik van vooral laatstgenoemde regeling is gering. De hoogte van de aftrek (maximaal 1500 euro) kan hiervan een oorzaak zijn. Mogelijk heeft het geringe gebruik ook te maken met de hoge werk- 
loosheid, waardoor werkgevers relatief gemakkelijk werknemers kunnen aantrekken die al de vereiste kwalificaties bezitten. Ook in het verleden bleek het aantal praktijkplaatsen voor beroepsbegeleidend onderwijs conjunctuurgevoelig te zijn. De eerdergenoemde centra kunnen juist in zo'n situatie werklozen in staat stellen toch praktijkervaring op te doen.

Een ander probleem bij de toepassing van scholing als reïntegratie-instrument is dat de vraagkant van de arbeidsmarkt hierbij nauwelijks in beeld is. Doordat de uitvoering van het beleid sterk gefragmenteerd is, kunnen bijvoorbeeld sectoren die knelpunten ondervinden geen afspraken maken over het scholen en aannemen van werklozen. Samenwerking tussen UWV en CWI zou een gecoördineerde inzet van het scholingsinstrument mogelijk kunnen maken.

\section{Slotopmerkingen}

Er is veel voor te zeggen dat werknemers zelf zoveel mogelijk het heft in handen proberen te nemen tijdens hun loopbaan. Als zij in staat zijn de tekenen des tijds te verstaan en zien aankomen welke veranderingen zich (gaan) voordoen in de gevraagde competenties, kunnen zij tijdig maatregelen treffen, bijvoorbeeld door te investeren in menselijk kapitaal en over te stappen naar ander type werk in een andere sector. Maar het is de vraag of dit wel helemaal realistisch is. In de eerste plaats zal het waarschijnlijk zo blijven dat mensen voor langere tijd bij dezelfde werkgevers werken, waardoor het voor de hand ligt scholing in samenspraak met de werkgever te regelen, waarbij de laatste ook financieel bijdraagt.

Verder is het verstaan van de tekenen des tijds niet eenvoudig. Men kan niet verwachten dat individuele werknemers en werkgevers dit geheel zelfstandig kunnen. De overheid kan hieraan bijdragen door onderzoek naar en advies op dit gebied te steunen, de daaruit resulterende informatie en inzichten te verspreiden en op basis hiervan adviezen te geven. In dit verband zou je je bijvoorbeeld kunnen voorstellen dat een organisatie als het CWI zich meer gaat richten op informatie en advies aan werkenden om werkloosheid te voorkomen.

Werkloosheid zal echter nooit volledig voorkomen kunnen worden. Wel blijven passief en actief arbeidsmarktbeleid beide nodig houden met alle dilemma's die daarbij horen. 


\section{NOTEN}

ISCED staat voor International Standard Classification of Education en is opgesteld door Unesco.

Hierbij dient wel opgemerkt te worden dat de positie van Nederland in de deelname cijfers over deelname aan hoger onderwijs sterk afhankelijk is van of men voor hoger onderwijs alleen ISCED-niveau 8 of $7+8$ neemt. In de tabel is niveau $7+8$ genomen, wat voor Nederland ongunstig is. Bij een 'strenger' criterium (alleen niveau 8), is de positie van Nederland aanzienlijk gunstiger, en ligt deze zelfs boven het gemiddelde. Veel landen hebben relatief veel opleidingen op niveau 7, terwijl Nederland hier zeer laag scoort.

3 IALS staat voor International Adult Literacy Survey. Een nadere beschrijving van deze en ook andere bronnen op het terrein van scholing van werkenden is terug te vinden in de OECD Employment Outlook van 1999, hoofdstuk 3.

4 Deze premieverlaging betreft de SPAK (SPecifieke AfdrachtsKorting), waarvan de werkgelegenheidseffecten zijn onderzocht door Van Polanen Petel e.a. (1999). Het directe werkgelegenheidseffect werd op minstens 50.000 geschat. Ook het СРВ heeft destijds een schatting gemaakt van de werkgelegenheidseffecten van dit type maatregel, die ongeveer 25.0oo personen bedroegen (Graafland en De Mooij 1998).

5 Het gaat om onvoltooide baanduren. Dit betekent dat bij jongeren de baanduren kort zijn, omdat zij nog niet zo lang geleden ingetreden zijn op de arbeidsmarkt en geen rekening gehouden wordt met het feit dat zij alsnog lang bij hun werkgever kunnen blijven.

6 Veelal wordt gedacht dat er externe effecten bestaan bij scholing van werkenden. Werkgevers investeren minder dan optimaal in de scholing van hun werknemers, omdat ze vrezen dat geschoolde werknemers worden weggekocht door andere werkgevers: de poaching externaliteit. Het ontbreken van een duidelijk empirisch verband tussen scholing van werkenden en externe mobiliteit kan gezien worden als op zijn minst een aanwijzing dat de poaching externaliteit zeker niet overdreven mag worden.

Werknemers kunnen ook investeren in kennis in ICT met het oog op hun privéleven. Dit zal echter veel minder het geval zijn bij geavanceerdere toepassingen die sterk aan beroepsmatige activiteiten zijn gerelateerd.

8 Het probleem dat het ene bedrijf investeert in scholing en het andere bedrijf de geschoolde werknemer 'wegkoopt' kan ook worden opgelost door scholingsarrangementen op brancheniveau.

Of deze gunstige effecten ook daadwerkelijk optreden is nog maar de vraag. Voor kritische beschouwingen van de werking van het Nederlandse systeem zie Grubb (2003) en De Koning (2003). Australië, dat al eerder is overgestapt op uitbesteding aan de particuliere sector, heeft waarschijnlijk een beter systeem ontwikkeld. In dat land vinden in tegenstelling tot Nederland serieuze evaluaties plaats die benut worden om het systeem te verbeteren. Maar Grubb (2003) en Struyven e.a. (2002) concluderen dat er geen aanwijzingen zijn dat het nieuwe systeem tot effectievere dienstverlening leidt. Wel is er een besparing opgetreden doordat 
minder gebruik wordt gemaakt van scholing wat een relatief duur instrument is. Maar in beginsel had ook in een publiek systeem besloten kunnen worden tot geringere inzet van dit instrument. De reden achter de geringere inzet van scholing is dezelfde als in Nederland: scholing neemt veel tijd in beslag, is relatief duur en leidt niet tot een snellere herintreding in de lopende werkloosheidsperiode. Omdat reïntegratiebedrijven afgerekend worden op kortetermijnplaatsingsresultaten, is de inzet van scholing voor hen niet aantrekkelijk. Ook de opdrachtgevers, de uitkeringsinstanties, kijken er zo tegen aan. Ook neerwaartse rigiditeit van lonen en effecten van externe schokken. Zoals eerder aangegeven zijn er sterke aanwijzingen voor een aanzienlijke discrepantie tussen productiviteit en beloning bij oudere werknemers, die niet alleen leidt tot verlies van banen, maar ook de herintreding bemoeilijkt. Wat betreft de pay-off-periode stellen Groot en Maassen van den Brink (1997) dat deze vanuit werkgeversoptiek niet korter hoeft te zijn dan voor jongere werknemers, omdat de mobiliteit bij oudere werknemers lager is. Zij doelen hierbij echter op de mobiliteit van baan naar baan. Voor werknemers ouder dan 50 jaar is de kans op uitstroom naar inactiviteit echter hoog.

4 Onderzoek hiernaar is overigens complex door de ingewikkelde causale verbanden. Als zou blijken dat werklozen een slechtere gezondheid hebben dan werkenden, dan kan hieruit niet worden afgeleid dat de arbeidsmarktstatus de gezondheid beïnvloedt. In de eerste plaats kan het causale verband (ook) andersom liggen. En verder kunnen er andere factoren in het spel zijn die zowel van invloed zijn op de gezondheid als op de arbeidsmarktstatus.

15 Gesubsidieerde arbeid, dat wil zeggen het scheppen van kunstmatige banen, is niet direct een alternatief. Dit instrument lijkt meer geschikt voor mensen die niet plaatsbaar zijn in de particuliere sector en evenmin schoolbaar. Ook kan dit instrument worden ingezet tijdens diepe recessies om te voorkomen dat mensen die in normale omstandigheden relatief eenvoudig een baan zouden vinden, langdurig werkloos worden.

Bij niet-experimentele methoden is het probleem dat niet-waargenomen kenmerken tot vertekening van de resultaten kunnen leiden. Stel dat motivatie niet waargenomen wordt, meer gemotiveerde werklozen voor scholing kiezen en gemotiveerde werklozen eerder een baan vinden dan minder gemotiveerde werklozen. Dan zou het kunnen zijn dat het lijkt of werklozen die scholing gevolgd hebben een grotere baankans hebben, terwijl dit laatste veroorzaakt wordt door een grotere motivatie. Hoewel er econometrische methoden zijn ontwikkeld om voor deze selectie-onzuiverheid te corrigeren, zijn deze niet betrouwbaar te achten. Zelfs de nieuwste ontwikkelingen binnen de zogenoemde timings of events-methode (zie Abbring en Van den Berg 2003) hebben nog ernstige beperkingen.

17 Onder netto-effectiviteit verstaan we de kansvergroting op het vinden van een baan onder invloed van de scholingsmaatregel. De maatregel heeft pas een nettoeffect als het percentage deelnemers dat een baan vindt groter is dan wanneer zij niet aan scholing zouden hebben deelgenomen. Een manier om deze netto-effectiviteit te berekenen is de vergelijking van de mate van baanvinden van de deelnemers met een - zoveel mogelijk vergelijkbare - groep van werkzoekenden die niet 
aan de scholingsmaatregel heeft deelgenomen. Nog steeds wordt in Nederland het actief arbeidsmarktbeleid echter voornamelijk beoordeeld op zogenaamde bruto-effecten. Men kijkt dan naar het percentage deelnemers dat een baan vindt (plaatsingspercentages).

18 Werknemers kunnen ook investeren in kennis in ICT met het oog op hun privéleven. Dit zal echter veel minder het geval zijn bij geavanceerdere toepassingen die sterk aan beroepsmatige activiteiten zijn gerelateerd.

19 Voor een overzicht van de literatuur over de relatie leeftijd-productiviteit verwijzen we naar Gelderblom, De Koning en Kroes (2003).

20 Wel moet hierbij worden aangetekend dat de vergrijzing ook tot gevolg heeft dat er minder jongeren komen. Ook jongeren hebben een relatief lage productiviteit, waardoor een lager aandeel van deze categorie in de werkgelegenheid een positief effect heeft op de productiviteit. Aan de andere kant is nieuwe kennis weer vaak belichaamd in jongeren, waardoor een negatief effect zou kunnen optreden op de productiviteitsgroei.

Voorbeelden van metingen voor het onderwijsrendement in Nederland zijn: Leuven en Oosterbeek (200o), Hartog, Odink, Oosterbeek en Smits (1999), Gelderblom, De Koning en Odink (1997) en Hartog, Oosterbeek en Teulings (1993). Een recent internationaal overzicht wordt gegeven in bijvoorbeeld Psacharopoulos en Patrinos (2004). 


\section{LITERATUUR}

Alba-Ramirez, A. (1994) 'Formal training, temporary contracts, productivity and wages in Spain', blz. 151-170 in Oxford Bulletin of Economics and Statistics, 56: 2.

Abbring, J. en G. van den Berg (2003) 'The non-parametric identification of treatment effects in duration models' in Econometrica, 71.

Allaart, P., J. de Koning en J. Theeuwes (2002) Gesubsidieerde arbeid in Nederland, Tilburg: OsA.

Ballot, G., F. Fakhfakh en E. Taymaz (2002) Who benefits from training and $R \& D$ : The firm of the workers? A study on panels of French and Swedish firms, ERC Working Papers in Economics, 02/o1.

Ballot, G., F. Fakhfakh, E. Taymaz (1997) Firms' human capital, R\&D and Performance: an international comparative study, paper for the LVIIth Conference of the Applied Econometrics Association, Maastricht.

Barret, A. and P.J. O'Connell (1998) Does training generally work? The returns to incompany training, CEPR-discussion paper 1879, London.

Bartel, A.P. (1995) 'Training, wage growth and job performance: evidence from a company database' in Journal of Labor Economics 3: 401-425.

Becker, G. S. (1964) Human Capital: A Theoretical and Empirical Analysis, New York and London: Columbia University Press.

Benhabib, J. en M. Spiegel (1994) 'The Role of Human Capital in Economic Development: Evidence form Aggregate Cross-country Data' in: Journal of Monetary Economics 43: 143-174.

Black, D.A., M. Plesca, J.A. Smith en S. Shannon (2003) Profiling U I Claimants to Allocate Reemployment Services: Evidence and Recommendations for States, Us Department of Labour, Employment and Training Administration.

Black, S.E. and L.M. Lynch (1996) 'Human-Capital Investments and Productivity', AEA Papers and Proceedings 86, 2: 263-267.

Boon, M. (1998) Employee training in the Dutch Manufacturing: determinants and productivity effects, Statistics Netherlands, Mimeo.

Brouwer, N.M. and A.H. Kleinknecht (1994) Technologie, werkgelegenheid en lonen in Nederlandse bedrijven, studie OSA-W114, Den Haag: OsA (Organisatie voor Strategisch Arbeidsmarktbeleid).

Burgess, S. (1999) Reallocation of labour: an international comparison using job tenure data, paper, Centre for Economic Performance.

Calmfors, L., A. Forslund en M. Hemström (2002) Does active labour market policy work? Lessons from the Swedish experiences, Institute for International Economic Studies, Stockholm University, Seminar Paper 700.

Canton, E. (2002) Onderwijs R\& D en economische groei, СРВ Memorandum 24.

Centraal Planbureau (200o) Arbeidsbemiddeling en rë̈ntegratie van werklozen. Welke rol heeft de overheid te spelen?, Werkdocument 118, Den Haag: СРВ.

Conti, G. (2004) Training, productivity and wages, paper.

Crépon, B., N. Deniau en S. Pérez-Duarte (2002) Wages, productivity and worker characteristics: A French Perspective, paper.

Denison, E. (1967) Why growth rates differ: post-war experiences in nine Western coun- 
tries, Washington DC: Brooking Institution.

Englander, S. en A. Gurney (1994) Productivity growth: Medium-term trends, OECD, Economic Studies 22.

Fitzenberger, B. en H. Prey (200o) 'Evaluating public sector sponsored training in East Germany', Oxford Economic Papers 52: 497-520.

Friedlander, D., D.H. Greenberg en Ph.K. Robins (1997) 'Evaluating government training programs for the economically disadvantaged' in: Journal of Economic Literature 35(4) 1809-1855.

Gelderblom, A. (2004) Evaluatie experimenten digitale vakschool. Rapportage fase 3, Rotterdam: Stichting Arbeidsmarktbeleid.

Gelderblom, A. en J. de Koning (2004) ICT: The electronic highway to lifelong learning? Paper for the Conference Transitional Labour Market, Amsterdam.

Gelderblom, A., J. de Koning en H. Kroes (2003) Leeftijdssamenstelling en bedrijfsprestaties, OSA-publicatie A201, Den Haag: OSA (Organisatie voor Strategisch Arbeidsmarktonderzoek).

Gelderblom A. en J. de Koning (2002) New opportunities for higher education institutions to train employees? Paper for the International Conference on the New Educational Benefits of ICT in Higher Education, Rotterdam.

Gelderblom, A., J. de Koning en M.B. Mosheuvel (2001) ICT en de oudere werknemer: geen rimpelloze relatie, Rotterdam: Stichting Arbeidsmarktbeleid.

Gelderblom, A., R. Blanken en M. Zwanenburg (2001) Gebruik en effecten van de scholingsaftrek, opgenomen in Scholing van Werkenden, Den Haag: ministerie van Buitenlandse Zaken.

Gelderblom A., en P. van Winden i.s.m. R. Kunnen, W. Praat en Mw. A.M. de VoogdHamelink (OSA) (1998) Scholing en de overgang van werk naar werkloosheid, OSA-publicatie D9, Tilburg: OSA.

Gelderblom, A., J. de Koning en J. Odink (1997) ‘Loont studeren?’, ESB: 500-504.

Gelderblom, A., J. de Koning en I. van der Weijde (1996) Onderwijs, arbeidsproductiviteit en innovatie, Rotterdam: NEI (Nederlands Economisch Instituut).

Gelderblom, A. and J. de Koning (1996) 'Evaluating effects of training within a company: methods, problems and one application', Labour 10, 2: 319-337.

Gelderblom A. en J. de Koning (1992a) Meer-jarig, minder-waardig? Een onderzoek naar de invloed van leeftijd op productiviteit en beloning, OsA-voorstudie v39, Den Haag: OsA.

Gelderblom, A. en J. de Koning (1992b) Leeftijd en functioneren. Een aanzet voor een beleid bij de rijksoverheid, Den Haag: Ministerie van Binnenlandse Zaken.

Gielen, E.W.M. (1995) Transfer of training in a corporate setting (dissertation), Enschedé: Universiteit van Twente.

Graafland, J.J. en R.A. de Mooij (1998) Analyzing fiscal policy in the Netherlands; simulations with a revised $M I M I C, C P B$.

Gravesteijn-Ligthelm, J., J. de Koning, R. Olieman en I. van der Weijde (1995) Ex-post evaluatie van het ESF hulpprogramma's voor doelstelling 3 en 4 in Nederland, Rotterdam: NEI.

Grip, A. de (200o) Van Tweedekansonderwijs naar een leven lang leren. De veranderende betekenis van post-initiele scholing, oratie, Maastricht.

Groot, W. en H. Maassen van de Brink (1997) Bedrijfsgerelateerde scholing en arbeids- 
marktflexibiliteit van oudere werknemers, Serie Wetenschappelijke Publicaties, Den Haag: Welboom Uitgeverij.

Groot, W. (1999) 'Productivity effects of enterprise-related training', Applied Economics Letters 6: 369-371.

Grubb, D. (2003) 'Points of comparison between Australia's Job Network and the Dutch Market for Reintegration Services' in Australian Journal of Labour Economics 6, 2: 357-370.

Hartog, J., J. Odink en J. Smits (1999) 'Rendement op scholing stabiliseert' in ES B, 13 augustus 1999, 582-583.

Hartog, J., H. Oosterbeek en C.N.Teulings (1993) 'Age, wages and education in the Netherlands' in P. Johnson en K.F. Zimmermann, Labour Market in an ageing Europe, Cambridge: Cambridge University Press.

Haveman, R.H., B.L. Wolfe (2001) 'Accounting for the social and non-market benefits of education' in HRDC and OECD, The contribution of human and social capital to sustained economic growth and well-being, Hull (QC).

Haveman, R.H., B.L. Wolfe (1984) 'Schooling and economic well-being: the role of nonmarket effects' in Journal of Human Resources: 19: 379-407.

Hebbink, G., M. Kerkhofs, J. Theeuwes en I. Woittiez (1996) Mobiliteit van oudere werknemers, OSA-werkdocument W151, Den Haag: OSA.

Heckman, J., R. Lalonde en J. Smith (1999) 'The economics and econometrics of active labor market programs' in Handbook of Labor Economics 3, A. Ashenfelter en D. Card (red.) Amsterdam: Elsevier Science.

Heyma, A., W.Zwinkel en J.van Seters (2003) Doelgroepindeling aanbesteding re-integratie: derelatietussen persoonskenmerken, kosten en effectiviteitvan reïntegratietrajecten, TNO Arbeid in opdracht van de Raad voor Werk en Inkomen (RWI), Den Haag.

Hujer, R., K. Maurer en M. Wellner (1998) 'Kurz- und langfristige Effekte von Weiterbildungsmassnahmen auf die Arbeitslosigkeitsdauer in Westdeutschland' in Qualifikation, Weiterbildung und Arbeitsmarkterfolg, ZEW-Wirtschaftanalyses Band 31, F. Pfeiffer en W. Pohlmeier (red.), Nomos-Verlag, 197-221.

Jacobs, B. en D. Webbink (2004) 'Onderwijs, innovatie en productiviteit' in B. Jacobs en J.J.M. Theeuwes Innovatie in Nederland. De markt draalt en de overheid faalt. Preadviezen voor de Koninklijke Vereniging van Staathuishoudkunde.

Jongen, E.W.L., E. van Gameren en J.J. Graafland (2000) The impact of active labour market policy, Den Haag: CPB.

Kluve, J., en C.M. Schmidt (2002) 'Can training and employment subsidies combat European unemployment?' in Economic Policy 17, issue 35.

Kneller, R. en P. Stevens (2002) 'The Role of Efficiency as an Explanation of International Income Differences', National Institute Discussion Paper, 206.

Kok, J. de (200o) 'The impact of firm-provided training on production: testing for firmsize effects', Tinbergen Institute Discussion Papers, TI 2000/073/3.

Koning, J. de, A. Gelderblom, K. Zandvliet en L. van den Boom (2005) Effectiviteit van reintegratie. De stand van zaken. Literatuuronderzoek, Rotterdam: SEOR.

Koning, J. de, A. Gelderblom, K. Zandvliet en R. Blanken (2004) Werkt scholing voor werklozen?, uitgave RWI.

Koning, J. de, (2003) Wat niet weet, wat niet deert; over de decentralisatie en uitbesteding van het arbeidsmarktbeleid, oratie, Rotterdam: SEOR. 
Koning, J. de, G. Bijwaard, A. Gelderblom en H. Kroes (2003a) Arbeidsmarkttransities en aanboddiscrepanties, OSA-Publicatie A191, Den Haag: OSA (Organisatie voor Strategisch Arbeidsmarktonderzoek).

Koning, J. de, A. Gelderblom, J. Gravesteijn-Ligthelm en L. van den Boom (2003b) Meer vrouwen en ouderen aan het werk: wat zijn de randvoorwaarden voor werkgevers?, Doetinchem: Reed Business Information BV.

Koning, J. de (2002a) 'Training the unemployed in the Netherlands: what do we know after more than 50 evaluation studies?' in K. Schömann and Ph.J. O'Connel, Education, Training and Employment Dynamics, Cheltenham: Edward Elgar.

Koning, J. de (2002b) 'De evaluatie van gesubsidieerde arbeid: een overzicht' in Piet Allaart, Jaap de Koning en Jules Theeuwes, Gesubsidieerde arbeid in Nederland, Tilburg: OsA.

Koning, J. de en P. van Nes, met ondersteuning van J. van Acht, E. Abdelgalil en A. Gelderblom (2002) Employment effects of the structural funds: an assessment based on theoretical considerations and empirical evidence, Rotterdam: SEOR.

Koning, J. de (2001) 'Aggregate impact analysis of active labour-market policy: a literature review' in International Journal of Manpower 22, 7, 707-735.

Koning, J. de, J.H. Gravesteijn-Ligthelm, K.C. Jonker, R. Olieman en C. van der Veen (1999) Tweede monitoring en interim evaluatie van het ESF programma voor doelstelling 3, Rotterdam: NEI.

Koning, J. de and A. Gelderblom (1992) Age, productivity and wages, paper for the $4^{\text {th }}$ EALE-Conference, Warwick.

Koning, J. de en P.J. van Nes (1990) Evaluatie van het Св B: bereik en plaatsingseffecten, NEI, uitgave Centraal Bureau Arbeidsvoorziening, OAV-rapport 9o-11, Rijswijk: CPB.

Koning, J. de en P.J. van Nes (1989) Landelijke evaluatie kaderregeling scholing, Rotterdam: NEI.

Koning, J. de, M. Koss en A. Verkaik (1988) De arbeidsmarkteffecten van het centrum voor (administratieve) vakopleiding van volwassenen, tweede deelrapport, Den Haag: Ministerie van Sociale Zaken en Werkgelegenheid.

Krueger, A. en M. Lindahl (2001) 'Education for Growth: Why and for Whom?' in Journal of Economic Literature 39: 1101-1136.

Larsson, L. (2000) 'Evaluation of the Swedish youth labour market programmes', IFAU Working Paper 2000: 1, Uppsala.

Lazear, E.P., R.L. Moore (1984) 'Incentives, productivity and labor contracts' in Quarterly Journal of Economics 275-296.

Lechner, M. (2000) 'An evaluation of public sector sponsored continuous vocational training programs in East Germany' in Journal of Human Resources 35, 2: 347-375.

Leuven, E. en H. Oosterbeek (2000) 'Rendement van onderwijs stijgt' in ESB, 23 juni 2000, 523-524.

Livingstone, O.W. (2000) Exploring the icebergs of adult learning. Findings of the first Canadian Survey of Informal Learning Practices, paper.

Lynch, L.M. (1998) 'A need Analysis of Training Data: What Do We Want, What Do We Have, Can We Ever Get It?’ in J. Haltiwanger, M.E. Manser, R. Topel, Labor Statistics Measurement Issues, Chicago/London: University of Chicago Press, $405-426$. 
Long, M. (2004) Training and economic returns to workers, found on the Internet: http://www.ncver.edu.au.research/proj/nrioo2.

Mankiw, G., D. Romer en D. Weil (1992) 'A contribution to the Empirics of Economic Growth', blz. 407-437 in: Quarterly Journal of Economics, 107.

Medoff, J.J. en K.G. Abraham (1980) 'Experience, performance and earnings' in Quarterly Journal of Economics, 703-736.

Mendes de Oliviera, M., E. Cohn en B.F. Kiker (1989) 'Tenure, earnings and productivity' in Oxford Bulletin of Economics and Statistics, 1-14.

Ministerie van Economische Zaken (2001) Scholing van werkenden, serie Knelpunten op de arbeidsmarkt, bestaat uit combinatie van twee studies: A. Gelderblom, R. Blanken en M. Zwanenburg, Gebruik en effecten van de scholingsaftrek, en E. Leuven en H. Oosterbeek, Determinanten van deelname aan scholing, Den Haag: Ministerie van Economische Zaken.

Ministerie van Sociale Zaken en Werkgelegenheid (2003) De effecten van beleid en conjunctuur op het Abw volume. Een analyse op basis van gemeentedata, Den Haag: Ministerie van Sociale Zaken en Werkgelegenheid.

OECD (1994) Displacement and job loss: the workers concerned, chapter 2, Employment Outlook, Paris.

OECD (1999) Employment Outlook, Paris.

OECD (2003) Employment Outlook, Paris.

Ok, W. and P. Tergeist (2003) 'Improvising workers skills: an analytical evidence and the role of the social partners', OECD Social, Employment and Migration, Working Papers 2003-10.

Olieman, R., J.H. Gravesteijn-Ligthelm, K.C. Jonker, J. de Koning en M. Arents (1998) Interim evaluatie ESF Doelstelling 3, eindrapport, Rotterdam: NEI.

Oosterbeek, H. (2001) Voortschrijdend inzicht, oratie, Universiteit van Amsterdam.

Oosterbeek, H. en D. Webbink (1996) Is there a hidden technical potential? paper.

Pischke, J.S. (1996) 'Continuous training in Germany, National Bureau of Economic Research', Working Paper 5829.

Porath Yoram, B. (1967) 'The production of human capital and the life-cycle of earnings' in Journal of Political Economy 75: 352-365.

Polanen Petel, V.C.A. van, T.W. Hu, J. de Koning en C. van der Veen (1999), Werkgelegenheidseffecten van de SPAK en de VLW, Rotterdam: NEI.

Psacharopoulos, G. en H.A. Patrinos (2004) 'Returns to Investment in Education: A Further Update' in Education Economics 12, 2: 111-134.

Regner, H. (1997) Training at the job and training for a new job, Doctoral Dissertation, Stockholm: Swedish Institute for Social Research.

Regner, H. (1995) 'The impact of on-the-job training on tenure-wage profile and job mobility. Does the distinction between general and firm specific human capital really matter?' Working paper 2, Stockholm: Swedish Institute for Social Research.

Russell, T.L. (2001) The no significant difference phenomenon. A comparative Research, Annotated Bibliography on Technology for Distance Education, IDECC.

Schoemann, K. en R. Becker (2002) 'A long term perspective on the effects of training in Germany' in K. Schoemann en Ph.J. O’Connell (red.) Education, training and employment dynamics. Transitional Labour Markets in the European Union, Cheltenham: Edward Elgar. 
Sianesi, B. en J. van Reenen (2002) 'The returns to Education: Macroeconomics' in Journal of Economic Surveys 17, 2: 1-114.

Skedinger, P. (1995) 'Employment policies and the displacement in the youth labour market', Swedish Economic Policy Review 2, 1.

Sonia, H. (1997) General training and innovation, paper for the LVIIth Conference of the Applied Econometrics Association, Maastricht.

Sousa-Poza, A. en F. Henneberger (2002) 'Analysing job mobility with job turnover intensions: an international cooperative study', paper voor de $7 \mathrm{de}$ jaarlijkse SOLEconferentie, Baltimore.

Stevens, Ph., M. Weale (2003) 'Education and Economic Growth, London, August 2003'. Dit artikel is later opgenomen in het International Handbook on the Economics of Education, geredigeerd door G. Johnes en J. Johnes, uitgegeven door Edward Elgar.

Struyven, L., G. Steurs, A. Peeters en V. Minne (2002) Van aanbieden naar aanbesteden. Marktwerking bij arbeidsbemiddeling en -rë̈ntegratie in Australië, Nederland, Verenigd Koninkrijk en Zweden, Leuven: Uitgeverij Acco.

Thijssen, J.G.L. (1996) Leren, leeftijd en loopbaanperspectief: opleidingsdeelname door oudere personeelsleden als component van Human Resource Development, Tilburg: Katholieke Universiteit Brabant.

Wolff, Ch. de, R. Luijkx en M. Kerkhofs (2002) Bedrijfsscholing en arbeidsmobiliteit, OsAPublicatie A-186, Den Haag: OsA.

Zandvliet, K., E.F. van Bokhoven en E. van Dongen (1995) Kosten en baten van CB B, KRS en Sollicitatieclub in RBA Zuid-Limburg, Rotterdam: NEI.

Zwick, T. (2002) Training and firm productivity. Panel evidence for Germany, research paper 23, Germany: SKOPE. 
BIJLAGE 3.1:

VOLLEDIGE TABELLEN VAN HOOFDSTUK 3 MET ALLE LANDEN

Tabel 3.1 Indicatoren voor menselijk kapitaal

Indicatoren

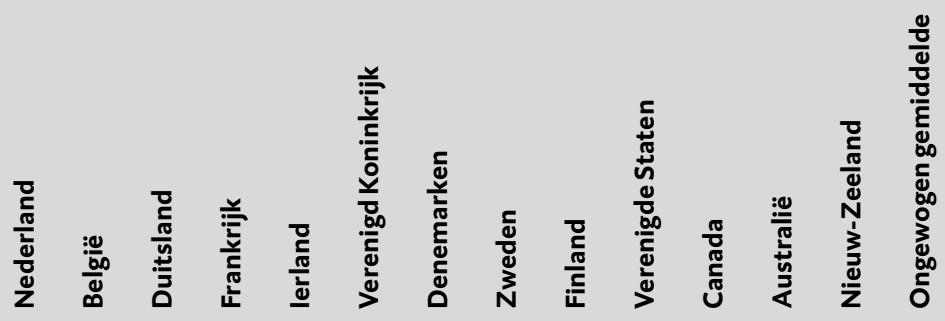

Verdeling bevolking naar opleidingsniveau (25-64 jarigen)

Aandeel hoger opge-

leiden van iedereen tussen 25-64 jaar, 2002

(ISCED 7-8) (\%)

$\begin{array}{lllll}25 & 28 & 23 & 24 & 26\end{array}$

$27 \quad 28$

Aandeel middelbaar

opgeleiden van ieder-

een tussen 25-64 jaar,

2002 (ISCED 3-6) (\%) $\quad \begin{array}{lllllllllllllll}42 & 33 & 60 & 40 & 35 & 56 & 52 & 49 & 42 & 49 & 40 & 30 & 47 & 44\end{array}$

Aandeel lager opge-

leiden van iedereen

tussen 25-64 jaar,

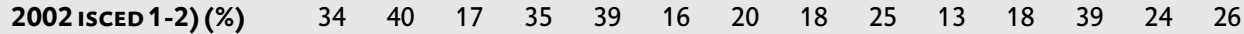

Aandeel hoger opgeleiden bij leeftijdsgroepen

Aandeel hoger

opgeleiden van 55-64

$\begin{array}{lllllllllllllll}\text { jarigen, } 2002(\%) & 19 & 18 & 21 & 15 & 14 & 20 & 22 & 26 & 23 & 33 & 32 & 23 & 26 & 22\end{array}$

Aandeel hoger

opgeleiden van 45-54

$\begin{array}{lllllllllllllll}\text { jarigen, 2002 (\%) } & 25 & 26 & 26 & 20 & 22 & 26 & 29 & 30 & 33 & 29 & 41 & 32 & 33 & 29\end{array}$

Aandeel hoger

opgeleiden van

35-44 jaar (\%)

$\begin{array}{llllllllllllll}26 & 29 & 26 & 23 & 25 & 27 & 30 & 34 & 38 & 39 & 43 & 32 & 31 & 31\end{array}$

Aandeel hoger

opgeleiden van

25-34 jaar (\%)

$\begin{array}{llllllllllllll}27 & 38 & 21 & 36 & 37 & 31 & 29 & 39 & 40 & 40 & 51 & 36 & 30 & 35\end{array}$

Verwacht gemiddelde aantal jaren dat men in initieel onderwijs (full-en part-time) zal doorbrengen vanaf 5 de jaar Verwachte jaren in ini-

tieel onderwijs, $2003 \quad 17,1 \quad 18,5 \quad 17,2 \quad 16,5 \quad 16,0 \quad 18,9 \quad 17,7 \quad 20,3 \quad 18,3 \quad 17,2 \quad 16,5 \quad 19,9 \quad 17,2 \quad 17,8$

Verwachte jaren in ini-

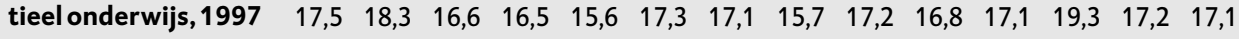


Tabel 3.1 Vervolg - Indicatoren voor menselijk kapitaal

Indicatoren

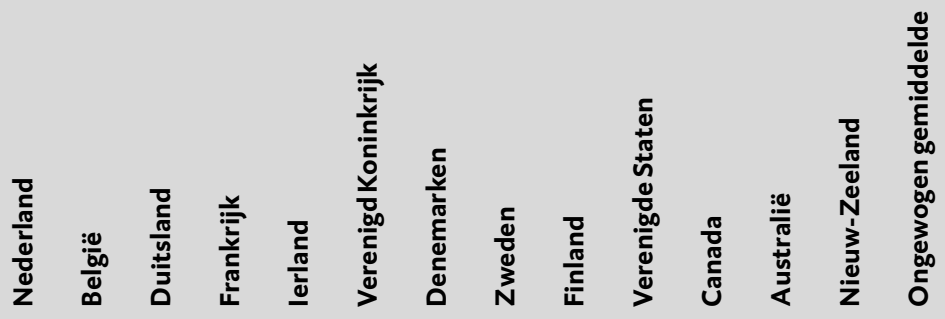

Indicatoren scholing (oudere) werknemers

$\%$ geschoolde werk-

nemers, 1999 (cVTS2

onderzoek Eurostat)

$\begin{array}{lllll}41 \quad 41 & 32 & 46 \quad 41\end{array}$

$41 \quad 49 \quad 56$

$61 \quad 50$

46

Participatiegraad

scholing werkenden

van 55-64 jarigen ten

opzichte van 25-34

jarigen, 1995-1996,

obv IALS-data

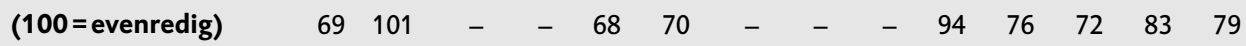

Duur scholing werken-

den 55-64 jarigen tov

25-34 jarigen,

1995-1996, obv IALS

data $\left(100=\right.$ evenredig) $29100 \quad-\quad-\quad \begin{array}{llllllllll}52 & 37 \quad-\quad & - & - & 40 & 51 & 42 & 44 & 49\end{array}$

Indicatoren scholing werklozen

\%GDP voor scholing

werklozen, 2002

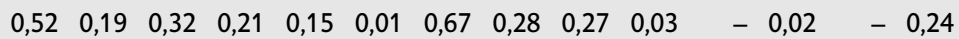

\%GDP scholing

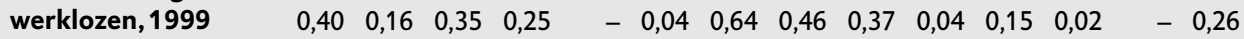

Participatie scholing

werklozen (\% beroeps-

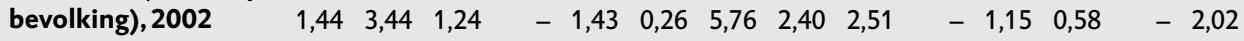

Participatie scholing

werklozen (\% beroeps-

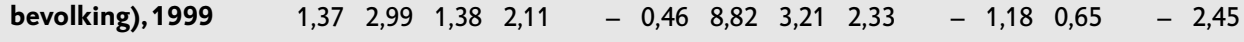

Bron: Bewerking gegevens OECD, tenzij anders aangegeven 
Tabel 3.2 Verdeling afgestudeerden hoger onderwijs (alleen ISCED 8) over richtingen, in procenten, 2002

\begin{tabular}{|c|c|c|c|c|c|c|c|c|c|c|c|c|c|}
\hline Richting & 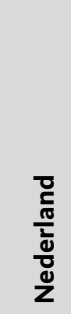 & $\begin{array}{l}\frac{: 0}{00} \\
\frac{0}{0} \\
\infty\end{array}$ & $\begin{array}{l}\text { D } \\
\frac{\pi}{5} \\
\frac{\pi}{5} \\
\overline{0}\end{array}$ & 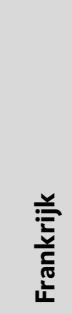 & 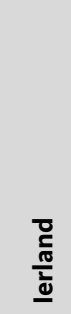 & 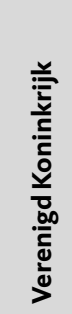 & 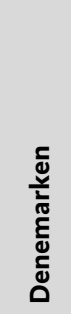 & \begin{tabular}{l}
$\frac{c}{d}$ \\
$\frac{d}{d}$ \\
\multirow{N}{N}{}
\end{tabular} & $\begin{array}{l}\text { D } \\
\text { 竞 } \\
\text { i亡 }\end{array}$ & 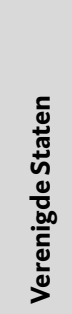 & 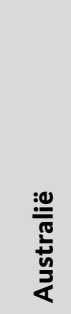 & 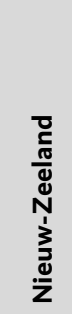 & 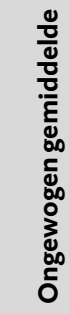 \\
\hline Onderwijs & 17,3 & 6,8 & 8,0 & 9,4 & 9,3 & 11,4 & 12,3 & 17,7 & 6,8 & 13,2 & 11,5 & 13,3 & 11,4 \\
\hline “Humaniora" en kunst & 6,9 & 14,1 & 14,7 & 17,0 & 14,7 & 16,4 & 14,4 & 5,5 & 11,4 & 14,4 & 11,2 & 12,1 & 12,7 \\
\hline \multicolumn{14}{|l|}{ Sociale wetenschappen } \\
\hline en recht & 34,3 & 35,7 & 27,4 & 38,6 & 30,8 & 29,5 & 23,5 & 21,1 & 24,0 & 41,4 & 37,8 & 36,1 & 31,7 \\
\hline Dienstverlening & 2,4 & 3,3 & 1,8 & 3,1 & 1,0 & 1,1 & 1,9 & 0,9 & 4,1 & 3,5 & 2,7 & 1,9 & 2,3 \\
\hline Technisch & 10,7 & 12,1 & 17,6 & 12,5 & 7,7 & 10,1 & 8,9 & 21,7 & 21,6 & 6,3 & 7,7 & 5,7 & 11,9 \\
\hline Landbouw & 2,4 & 2,9 & 1,9 & 0,3 & 1,2 & 1,1 & 1,5 & 0,9 & 2,2 & 2,3 & 1,0 & 1,7 & 1,6 \\
\hline Gezondheid en welzijn & 20,8 & 14,1 & 15,2 & 2,7 & 11,2 & 12,4 & 30,7 & 22,8 & 22,4 & 9,6 & 14,2 & 14,6 & 15,9 \\
\hline Life Sciences & 1,0 & 4,2 & 3,4 & 5,8 & 5,8 & 6,2 & 3,0 & 2,7 & 1,4 & 3,7 & 3,3 & 2,6 & 3,6 \\
\hline Natuurwetenschappen & 2,2 & 3,0 & 5,0 & 4,9 & 2,8 & 4,8 & 2,3 & 2,3 & 2,0 & 1,4 & 2,3 & 4,2 & 3,1 \\
\hline Wiskunde en statistiek & 0,3 & 1,0 & 1,7 & 2,5 & 0,9 & 1,4 & 0,6 & 0,5 & 0,6 & 0,9 & 0,5 & 1,0 & 1,0 \\
\hline Informatica & 1,8 & 2,9 & 3,3 & 3,0 & 8,7 & 5,7 & 1,1 & 3,8 & 3,4 & 3,4 & 7,9 & 6,4 & 4,3 \\
\hline Onbekend/overig & - & - & - & 0,3 & 5,8 & - & - & - & - & - & - & 0,6 & 0,6 \\
\hline Totaal & 100 & 100 & 100 & 100 & 100 & 100 & 100 & 100 & 100 & 100 & 100 & 100 & 100 \\
\hline
\end{tabular}

Bron: Bewerking gegevens OECD. Voor Canada waren de betreffende gegevens niet bekend. 
Tabel 3.3 Prestatie-indicatoren economie en arbeidsmarkt

Indicator

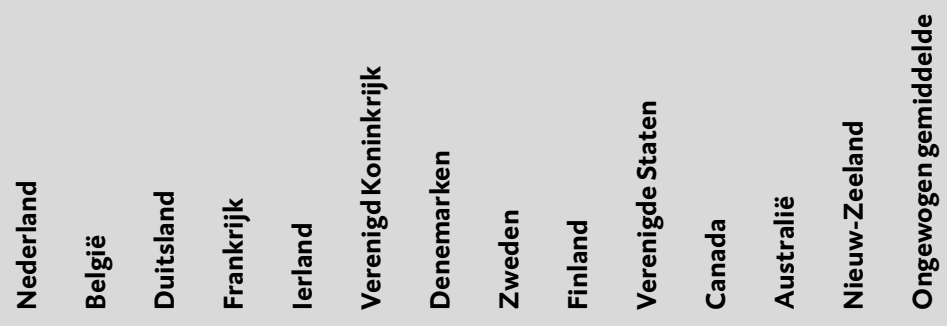

Gemiddelde jaarlijkse reële productiegroei 1995-2003 (\%)

$\begin{array}{llllllllllllll}2,5 & 2,0 & 1,2 & 2,1 & 8,1 & 2,7 & 2,1 & 2,6 & 3,6 & 3,3 & 3,5 & 3,7 & 3,0 & 3,1\end{array}$

Gemiddelde jaarlijkse productiviteitsgroei per gewerkt uur, 1995-2003 (\%)

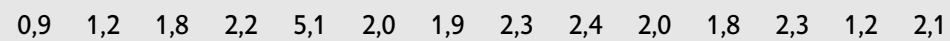

Participatiegraad 15-

64 jarigen, $2003(\%) \quad 75,9 \quad 64,3 \quad 71,3 \quad 69,5 \quad 68,0 \quad 76,6 \quad 79,4 \quad 78,9 \quad 74,1 \quad 75,8 \quad 78,1 \quad 73,6 \quad 76,1 \quad 74,0$ Participatiegraad 15-

64 jarigen, $2000(\%) \quad 74,9 \quad 65,2 \quad 71,1 \quad 68,0 \quad 67,4 \quad 76,6 \quad 80,0 \quad 78,9 \quad 74,3 \quad 77,2 \quad 76,3 \quad 73,6 \quad 75,2 \quad 73,7$

Participatiegraad 15-

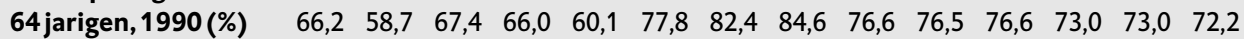

Werkgelegenheidsgraad 15-64 jarigen, $2003(\%)$

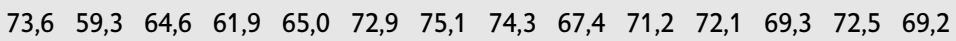

Werkgelegenheidsgraad 15-64 jarigen, $2000(\%)$

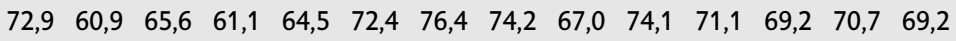

Werkgelegenheidsgraad 15-64 jarigen, $1990(\%)$

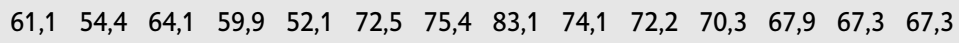

Werkloosheidsper-

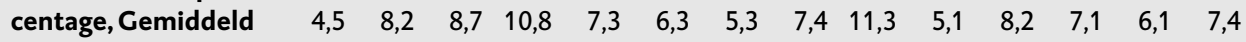
1995-2003 (OECD)

Aandeel langdurige werkloosheid, gemid-

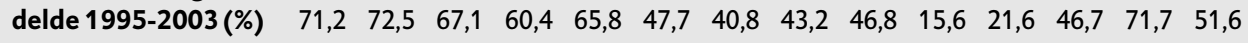

Bron: Bewerking gegevens OECD 
Tabel 3.4 Leeftijdsopbouw en prestatie-indicatoren arbeidsmarkt voor ouderen

Indicatoren

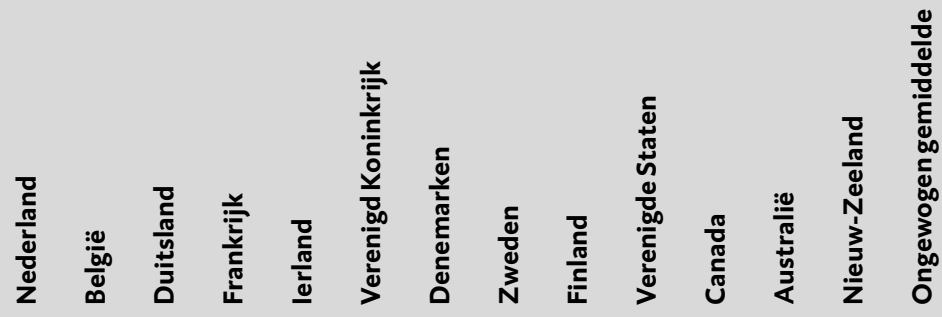

Aandeel 55-64 jarigen in groep 25-64

jarigen, $2003(\%)$

$20,1 \quad 22,3 \quad 21,9 \quad 19,2 \quad 17,7 \quad 19,7 \quad 22,7 \quad 23,6 \quad 22,3$

$-\quad 21,1$

Aandeel 45-54 jarigen in groep 25-64

jarigen, mannen, $2003(\%)$

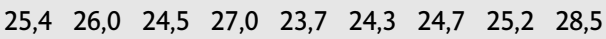

$-\quad 25,5$

Aandeel 45-54 jarigen in groep 25-64 jarigen, $2003(\%)$

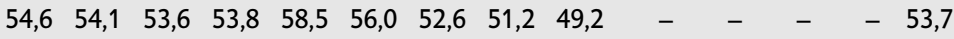

Participatiegraad 55-

64 jarigen, $2003(\%) \quad 44,9 \quad 28,5 \quad 43,1 \quad 39,5 \quad 50,5 \quad 47,3 \quad 63,1 \quad 72,5 \quad 54,1 \quad 62,4 \quad 56,6 \quad 52,2 \quad 66,8 \quad 52,4$

Participatiegraad 55-

64 jarigen, $2000(\%) \quad 38,6 \quad 25,9 \quad 42,9 \quad 37,3 \quad 46,3 \quad 52,8 \quad 56,9 \quad 69,4 \quad 46,6 \quad 59,2 \quad 51,2 \quad 48,8 \quad 60,0 \quad 48,9$ Participatiegraad 55-

64 jarigen, 1990 (\%) $\quad 30,9 \quad 22,2 \quad 39,8 \quad 38,1 \quad 42,1 \quad 53,0 \quad 57,1 \quad 70,5 \quad 43,8 \quad 55,9 \quad 49,3 \quad 44,1 \quad 43,8 \quad 45,4$

Werkgelegenheidsgraad 55-64 jarigen, $2003(\%)$

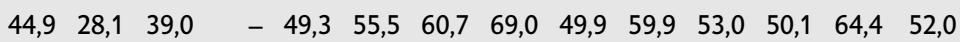

Werkgelegenheids-

graad 55-64 jarigen, $2000(\%)$

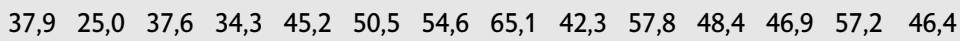

Werkgelegenheidsgraad 55-64 jarigen, $1990(\%)$

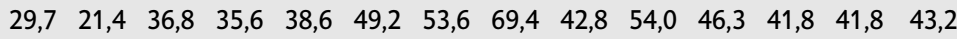

Werkloosheidsper-

centage, 55-64 jarigen Gemiddeld 1995 2003 (OECD)

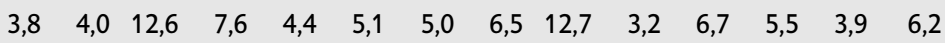

Bron: Bewerking gegevens OECD 


\title{
4 FLEXIBILITEIT EN ONTSLAGRECHT
}

\author{
Alexandra Baris en Evert Verhulp
}

\section{DEEL I}

\section{SCHOLING EN ONTSLAG}

Begin 2005 heeft de SER op verzoek van het kabinet geadviseerd ${ }^{1}$ over de (nieuwe) inrichting van de WW waarbij ook vragen met betrekking tot de vormgeving en de functie van het ontslagrecht een rol spelen. Uit de adviesaanvraag blijkt dat de overheid streeft naar het treffen van maatregelen die kunnen bijdragen aan de beperking van werkloosheid. Het gaat dan om het bevorderen van de uitstroom van werknemers uit de ww, maar ook wordt nagedacht over de maatregelen die worden getroffen ter preventie van werkloosheid van werkenden. De noodzaak tot beperking van de werkloosheid staat buiten kijf. De sociaal-economische gevolgen van werkloosheid, op alle niveaus, zijn daarvoor ernstig genoeg. Betaalde arbeid vormt de primaire bron van zelfstandig inkomen. Het is daarnaast voor veel mensen de basis van (zelf)respect. Voorkoming van werkloosheid is aldus bezien een maatschappelijk maar ook een individueel belang.

De laatste jaren is een duidelijke tendens te herkennen naar grotere verantwoordelijkheid van de partijen bij de arbeidsovereenkomst. Zeker in het geval de werknemer arbeidsongeschikt wordt is deze tendens onmiskenbaar. Bij dreigende werkloosheid is die trend minder duidelijk, maar zeker ook zichtbaar. In het Verenigd Koninkrijk is die tendens zichtbaar geworden toen Blair vanaf 1998 The Third Way introduceerde, waarbij als kern geldt "no rights without responsibilities". Dat leidt ertoe, in de woorden van Fredman, dat "benefits can be withdrawn if people do not take up opportunities” (Fredman 2004).

Deze maatschappelijke wederkerigheid wordt al snel teruggeleid tot de partijen bij de arbeidsovereenkomst, ook in Nederland. In het preadvies voor de Nederlandse juristenvereniging schrijven Van der Heijden en Noordam: "Van een werkgever mag worden verwacht dat hij zijn werknemer in staat stelt zijn 'arbeidsmarktwaarde' op peil te houden, van een werknemer mag op zijn beurt worden verwacht dat hij hieraan medewerking verleent.” (2001: 123) Indien beide partijen zich volledig van hun verantwoordelijkheid hebben gekweten, menen deze auteurs dat het de vraag is of de werknemer zonder meer een vergoeding bij ontslag dient toe te komen. Het wetenschappelijk bureau van het CDA beantwoordt deze vraag ontkennend in het rapport Zekerheid op maat (2004).

Mensen zijn zelf als eerste verantwoordelijk voor hun toekomst (PvdA 2005). Als dus een werknemer de mogelijkheid wordt geboden zich te scholen en zodoende zich te onttrekken aan werkloosheid of de kans werkloos te worden kan beperken, lijkt de huidige maatschappelijke opvatting steeds meer te zijn dat die werk- 
nemer ook verplicht is die mogelijkheid te benutten. Dat betekent niet dat de werknemer met lege handen mag komen te staan als hij die mogelijkheden benut, maar dat niet leidt tot preventie van werkloosheid. Algemeen wordt gemeend dat zeker voor die gevallen een collectieve regeling van inkomensvoorziening voorhanden dient te zijn (CDA 2004; PvdA 2005). Bij de discussies over de uitvoering van het streven werkloosheid te voorkomen wordt het ontslagrecht in toenemende mate betrokken. De rol van het ontslagrecht speelt op twee vlakken. Enerzijds speelt de gedachte dat een soepeler ontslagrecht leidt tot een flexibelere arbeidsmarkt en daarmee de werkloosheid kan verminderen. De gedachte is dat indien het makkelijker wordt om werknemers te ontslaan, werkgevers sneller geneigd zullen zijn werknemers in dienst te nemen. Overigens is dit geen uitsluitend nationale gedachte. De voorstellen van de Franse regering om een proeftijd van twee jaar in te voeren ${ }^{2}$ bewijzen dat, net als het verkiezingsprogramma van de CDU in Duitsland. Anderzijds wordt steeds meer benadrukt dat het ontslagrecht een rol kan spelen bij het voorkomen van werkloosheid. Het ontslagrecht zou zich in deze gedachte niet alleen moeten richten op het beschermen van de werknemer tegen een onrechtvaardig ontslag, maar tegelijkertijd beide partijen bij de arbeidsovereenkomst moeten stimuleren om te voorkomen dat de werknemer na het ontslag werkloos wordt of blijft.

De Ww is in belangrijke mate al gericht op het voorkomen van (verwijtbare ${ }^{3}$ ) werkloosheid en het bevorderen van uitstroom naar ander passend werk. Eigenlijk is het opmerkelijk dat het ontslagrecht daarop nauwelijks is gericht. Het ontslagrecht is er vooral op gericht geweest de werknemer voldoende bescherming te bieden tegen een onrechtvaardig ontslag. Ook is bij de inrichting van het ontslagrecht aandacht geweest voor het behoud van voldoende flexibiliteit om de werkgever in staat te stellen tijdig de arbeidsorganisatie aan te passen aan de veranderende vraag. Bij de mogelijke vormgeving van een activerend ontslagrecht mag deze balans tussen bescherming van de werknemer en voldoende flexibiliteit niet uit het oog worden verloren.

Een van de meest in het oog springende middelen om werkloosheid van werkenden te voorkomen en om bestaande werkloosheid te verminderen is scholing. Het gaat dan om het niveau van scholing van starters op de arbeidsmarkt, scholing van werknemers die reeds deelnemen aan het arbeidsproces, om werknemers die werkloos dreigen te worden en om het door middel van scholing reïntegreren van werklozen. In het (recente) verleden is geëxperimenteerd met scholingsfaciliteiten. Een aantal van deze experimenten heeft geleid tot voorstellen tot wetgeving. ${ }^{4}$ De regering hanteert als uitgangspunt dat scholing een belangrijke rol kan spelen ter preventie en beperking van werkloosheid. ${ }^{5} \mathrm{Bij}$ dit uitgangspunt sluit aan dat de overheid streeft de Nederlandse economie te ontwikkelen tot een hoogwaardige kenniseconomie. Een van de belangrijkste doelstellingen daarbij is het (hoger) kwalificeren van de Nederlandse beroepsbevolking. In Europees verband heeft de Nederlandse overheid de verplichting op zich genomen maatregelen te treffen die ertoe bijdragen dat de Nederlandse beroepsbevolking zich ontwikkelt tot een bepaald niveau. ${ }^{6}$ Scholing speelt hierbij een belangrijke rol. 
Een hoger opgeleide beroepsbevolking, een hoogwaardige kenniseconomie en activering en flexibilisering van de arbeidsmarkt zijn kernwoorden in de huidige politieke doelstellingen en het arbeidsmarktbeleid.

Bij het beschouwen van het ontslagrecht (mede) als stimulans ter voorkoming van werkloosheid moeten ook de sociale partners worden betrokken. Zij treffen in sociaal plannen of cao's nadere regelingen voor met ontslag bedreigde werknemers. De inhoud van cao's verschilt aanzienlijk, maar vaak zijn er bepalingen opgenomen die voorzien in scholing van werknemers om zodoende werkloosheid te voorkomen. In sociaal plannen komen veelal bepalingen voor die voorzien in een aanvulling op de uitkering die de werknemer krachtens de ww verkrijgt, maar niet in een aanvulling op een elders te verdienen lager loon.7 In bijna alle cao's zijn echter bepalingen opgenomen ter bevordering en stimulering van scholing. In cao's gaat het dan om afspraken met betrekking tot de employability van werknemers, veelal gericht op het behoud van voldoende specifieke vaardigheden binnen de sector, maar soms ook gericht op algemenere vaardigheden. Veelal wordt de financiering via een algemeen verbindend verklaard opleidingsfonds door de sector gedragen. Deze bij cao tot stand gebrachte opleidingsfondsen staan momenteel ter discussie, nu blijkt dat deze fondsen vaak over zeer grote budgetten beschikken die niet volledig voor opleidingen worden aangewend. In sociaal plannen gaat het eerder om scholingsfaciliteiten van specifiek met ontslag bedreigde werknemers in dienst van een werkgever (Tros et al. 2005: 12). In dit onderzoek zullen wij ons echter met name richten op scholing van werknemers die (nog) niet met ontslag worden bedreigd in samenhang met de ww en het ontslagrecht. Het door middel van scholing of op andere wijze voorkomen van werkloosheid van werknemers die (nog) niet met ontslag worden bedreigd wordt ook wel primaire preventie van werkloosheid genoemd. Scholingsafspraken voor werkenden zijn veelal te vinden in cao's en kunnen vaak worden gefinancierd uit de hierboven genoemde opleidingsfondsen. Over scholing van werkenden en primaire preventie van werkloosheid zegt de CDA-fractie, ondersteund door de PvdA-fractie, het volgende, zo blijkt uit een brief van minister De Geus van 1 juli $2005^{8}$ :

“(...) dat werkloosheid effectiever kan worden bestreden door meer gericht en anticiperend te investeren in scholing. Een hogere bijdrage aan bijvoorbeeld de O\&O-fondsen, mits voorzien van de juiste randvoorwaarden ten aanzien van effectiviteit en transparantie, wordt volgens diezelfde CDA-fractie terugverdiend in lagere premies voor de sociale zekerheid. Ook zou het geld dat is gemoeid met sociale plannen die worden opgesteld als er een ontslagvergunning wordt aangevraagd, als het ware naar voren moeten worden gehaald. Dat geld zou voor en niet na het ontslag moeten worden ingezet voor extra scholing. Werknemers die adequaat zijn geschoold, hebben geen gouden of zilveren handdruk nodig als zij zo kunnen overstappen op een andere baan."

Hierover gaat dit onderzoek. De aandacht gaat vooral uit naar de werknemer die actief is op de arbeidsmarkt. Minder aandacht wordt besteed aan starters op de arbeidsmarkt en werklozen. In dit onderzoek komt in het bijzonder de vraag aan 
de orde hoe het ontslagrecht, scholing en de vormgeving van de ww kan worden benut ter voorkoming van werkloosheid en kan bijdragen aan activering en flexibilisering van de arbeidsmarkt. Hierbij wordt aandacht besteed aan de vraag hoe de combinatie van deze verschillende aspecten kan bijdragen aan het ontwikkelen van de Nederlandse economie tot een hoogwaardige kenniseconomie, zonder daarbij de (normatieve) beginselen van het arbeidsrecht en de arbeidsrechtelijke bescherming uit het oog te verliezen.

\subsection{KABINETSSTANDPUNT EN ARBEIDSMARKTBELEID}

\subsubsection{INLEIDING}

In april 2005 heeft de SER een tweetal adviezen gegeven, een over de toekomstbestendigheid van de Werkloosheidswet (Ww) ${ }^{9}$, de ander over de Ww en de ontslagpraktijk. ${ }^{10}$ In het laatste adviseert de SER over de vraag of het wenselijk is de ontslagvergoeding voortaan te verrekenen met de WW-uitkering. De SER beantwoordt die vraag ontkennend. De verrekening die het kabinet voorstelt, heeft naar de mening van de SER een aantal negatieve effecten. Onder meer zullen ontslagprocedures moeizamer verlopen. Dat leidt tot een minder flexibel ontslagrecht en daarmee tot verminderde flexibiliteit van de arbeidsmarkt. Verder bepleit de raad, juist ter verbetering van de arbeidsmarktdynamiek, een verregaande beperking van de toets op verwijtbaarheid van de werkloosheid. Hierdoor zijn niet langer pro-formaprocedures nodig om de ww-uitkering veilig te stellen. Dit betekent een belangrijke versoepeling van het ontslagrecht. ${ }^{11}$ De regering heeft dit advies inmiddels in belangrijke mate overgenomen. ${ }^{12}$

In het eerste advies, over de toekomstbestendigheid van de ww, formuleert de raad een integraal pakket van voorstellen om de ww te hervormen. De belangrijkste doelstelling daarvan is de ww meer toekomstbestendig te maken in het perspectief van huidige en toekomstige sociaal-economische ontwikkelingen. Zo kan de ww beter worden toegesneden op een transitionele en flexibele arbeidsmarkt en op de veroudering van de beroepsbevolking. In samenhang met zijn voorstellen voor hervorming van de ww doet de raad voorstellen gericht op preventie van dreigende werkloosheid en op reïntegratie van werkloze uitkeringsgerechtigden. ${ }^{13}$

Naar aanleiding van deze adviezen heeft de regering op 29 april 2005 een standpunt ingenomen. ${ }^{14}$ In dit standpunt staan centraal de preventie van werkloosheid, een activerende werking van de ww, versoepeling van het ontslagrecht en de ontwikkeling van Nederland tot een hoogwaardige kenniseconomie. Bij deze uitgangspunten tracht de regering voldoende inkomensbescherming en ontslagbescherming voor de werknemers te behouden. Daarbij geeft de regering scholing een prominente rol.

In dit hoofdstuk volgt een overzicht van de huidige doelen en uitgangspunten van het kabinet met betrekking tot scholing, ontslag en werkloosheid. De inte- 
grale samenhang tussen deze onderwerpen brengt mee dat de bespreking van één onderwerp er veelal toe noodzaakt ook de andere aspecten daarbij (zijdelings) te betrekken. Dit hoofdstuk beoogt een beknopt overzicht te geven van het kabinetsstandpunt en het huidige arbeidsmarktbeleid. De bespreking en analyse hiervan volgt in deel II (hoofdstuk 3 e.v.) van het onderzoek.

\subsubsection{WW EN ONTSLAGRECHT}

Op 15 februari 2005 heeft de minister van Economische Zaken de SER verzocht te adviseren over het sociaal-economisch beleid op de middellange termijn. In de adviesaanvrage wordt een aantal trends gesignaleerd waarop naar het oordeel van deze regering een volgend kabinet zijn standpunt zou kunnen bepalen. Uit deze aanvraag komt het volgende citaat.

"De genoemde trends vragen op termijn ook om een andere verantwoordelijkheidsverdeling tussen de overheid, sociale partners en individuele werkgevers en burgers met betrekking tot het terrein van werk en inkomen. De maatschappelijke trends stellen ons voor de uitdaging om binnen het sociale stelsel een verschuiving te bewerkstelligen van 'baanzekerheid' naar 'werkzekerheid'. Een toekomstbestendige inrichting van de sociale zekerheid die hierbij past ondersteunt het activeren van onbenut arbeidspotentieel en accommodeert het investeren in kennis en vaardigheden. Een meer dynamische arbeidsmarkt zorgt hierbij voor een omgeving waarin kennis en vaardigheden optimaal kunnen worden benut en waarin mensen die (tijdelijk) buiten het arbeidsproces staan meer kans op werk hebben. Het Kabinet vraagt de Raad om een reactie op de contouren die in de notitie Nieuwe accenten op het terrein van werk en inkomen geschetst worden. Het Kabinet verzoekt de Raad daarbij in elk geval in te gaan op de mogelijkheid en wenselijkheid om een verschuiving te bewerkstelligen van baanzekerheid naar werkzekerheid en daarbij ook de circulatiefunctie van de sociale zekerheid, de flexibiliteit van de arbeidsmarkt en een leven lang leren te betrekken. Verder verzoekt het Kabinet de Raad in het bijzonder in te gaan op de wenselijkheid om binnen het socialezekerheidsstelsel collectieve arrangementen gedeeltelijk te vervangen door spaar- en/of verzekeringselementen, nader in te gaan op de afweging tussen individuele spaaren/of verzekeringselementen en spaar- en/of verzekeringselementen die georganiseerd worden door werknemers en werkgevers op cao-niveau, en aandacht te geven aan de mogelijkheden van een integratie van dergelijke arrangementen met de levensloopregeling."

Na de ontvangst van het advies over de toekomstbestendigheid van de ww heeft de regering te kennen gegeven zich pas nader te beraden over het ontslagstelsel en de ontslagvergoedingen in combinatie met employability en de ww na ommekomst van het advies van de SER over het sociaal-economisch beleid op de middellange termijn, dat naar verwachting in het najaar van 2006 zal verschijnen.

Desalniettemin is een aantal conclusies te trekken uit de adviesaanvrage en de standpuntbepaling na de adviezen van de SER van 15 april 2005. Uit het kabinetsstandpunt blijkt dat de regering meent dat de ww activerend moet werken, maar tevens inkomensbescherming moet bieden. Verder moet het ontslagrecht worden versoepeld, maar de werknemer tegelijkertijd wel beschermd tegen onrecht- 
vaardig ontslag. Dit bij elkaar moet een efficiënte en flexibele allocatie van vraag en aanbod op de arbeidsmarkt bevorderen en tegelijkertijd een zekere mate van bescherming bieden aan werknemers. ${ }^{15}$ In aanvulling op een soepeler ontslagrecht moet de uitstroom uit de WW worden bevorderd door activerende maatregelen. De groep werknemers die langdurig werkloos is of bij herhaling gebruikmaakt van de ww betreft met name lager opgeleiden, allochtonen en ouderen. Vooral voor deze groepen zal dus voor activerende maatregelen moeten worden gezorgd. ${ }^{16}$

Het Ww-stelsel en aanverwante instituties, zoals het ontslagrecht, moeten prikkelen tot een proactieve houding van alle betrokken actoren. Met actoren doelt de regering op zowel werkgevers, werknemers als uitvoerders. Deze proactieve houding moet ertoe bijdragen werknemers zoveel en zolang mogelijk verbonden te houden met de arbeidsmarkt. Zowel de regering als de raad meent dat het scholings- en onderwijsbeleid, maar ook het op peil houden van kennis en vaardigheden kan bijdragen aan de preventie van werkloosheid. Daarvoor acht het kabinet ook van belang dat wordt gestreefd naar vergroting of verbetering van de combineerbaarheid van arbeid- en zorgtaken, bijvoorbeeld via kinderopvang. ${ }^{17}$ Tijdige scholing, investeren in employability van werknemers, of een overstap naar werk dat minder belastend is, moet door het stelsel worden aangemoedigd. Het stelsel moet zo preventief werken. Preventieve werking van de wW vormt een van de (belangrijkste) doelstellingen van het kabinet.

Het hanteren van een strikt stelsel van rechten en plichten in de sociale zekerheid gaat samen met het bieden van kansen voor ontplooiing van individuen door middel van scholing, en dus ook kansen op werkhervatting. Een dwingend reïntegratiebeleid is, met andere woorden, gebaat bij voldoende arbeidsmarktdynamiek en meer flexibiliteit. Het stelsel moet daarom een evenwichtige balans bieden tussen prikkels voor werkgevers en werknemers. Alleen op deze wijze kan de ww bijdragen aan de arbeidsmarktdynamiek, zo meent het kabinet. ${ }^{18}$ Een flexibele arbeidsmarkt biedt meer mogelijkheden om mensen zonder werk te reïntegreren. Van belang in dit kader is een soepel ontslagrecht. Dit bevordert de uitstroom uit de werkloosheid en helpt daarmee het risico van langdurige werkloosheid terug te dringen. ${ }^{19}$

Het kabinet en de raad menen dat de verantwoordelijkheid voor preventie van werkloosheid primair ligt bij de werkgevers en werknemers op ondernemingsniveau en bij de sociale partners op sectorniveau. Er moet een balans zijn tussen publieke en private inspanningen. Daarbij kan zowel private als publieke financiering een rol spelen bij preventie van werkloosheid. Huidige vormen van financiering zullen in hoofdstuk 2 uitgebreider worden besproken. Het kabinet geeft overigens aan geen voorstander te zijn van de inzet van WW-middelen ter voorkoming van ontslag als zodanig. ${ }^{21}$ 


\subsubsection{ONTSLAGBESCHERMING}

Het Nederlandse ontslagstelsel geldt internationaal bezien als gematigd rigide. Het effect van de mate van ontslagbescherming op het niveau van de totale werkgelegenheid en werkloosheid is echter niet eenduidig vast te stellen. ${ }^{22}$ Toch meent het kabinet dat een versoepeling van het Nederlandse ontslagrecht gewenst is. Een dergelijke versoepeling zou de uitstroom uit de werkloosheid kunnen bevorderen en zo helpen het risico van langdurige werkloosheid terug te dringen. ${ }^{23}$

Het kabinet signaleert dat in de maatschappelijke discussie wordt gewezen ${ }^{24}$ op onderdelen van het ontslagrecht die leiden tot belemmering van de flexibiliteit en de dynamiek op de arbeidsmarkt. Een van die onderdelen is het duale karakter van het ontslagrecht, hetgeen leidt tot weinig inzichtelijkheid en verschillen in rechtsgevolgen afhankelijk van de gekozen procedure. ${ }^{25}$ Een ander ontslagrechtelijk aspect dat leidt tot belemmering van de flexibiliteit en de dynamiek op de arbeidsmarkt is de hoogte van de (leeftijdsgerelateerde) ontslagvergoedingen. De hoge ontslagvergoedingen leiden tot een belemmering voor een soepel werkende arbeidsmarkt, zo meent het kabinet. Hoge ontslagvergoedingen leiden immers tot hoge ontslagkosten en dragen daarmee niet bij aan een dynamische werking van de arbeidsmarkt. Het kabinet wil daarom stimuleren dat vooral bij sociaal plannen en individuele afvloeiingsregelingen de nadruk meer komt te liggen op preventie van werkloosheid en werkhervatting. Om deze doelen te bereiken heeft het kabinet voorgesteld de ontslagvergoeding te verrekenen met de wwuitkering. Na het negatief advies van de SER hierover is het kabinet op dit voorstel teruggekomen.

Een andere belemmering vormt de onnodige pro-formaprocedure, die leidt tot ontbinding van de arbeidsovereenkomst uitsluitend met het oog op de verwijtbaarheidstoets van de ww. Het kabinet werkt daarom, in navolging van het advies van de SER, aan een wetsvoorstel waarin de verwijtbaarheidstoets aanzienlijk wordt beperkt, zodanig dat slechts ontslag als gevolg van voorzienbaar verwijtbaar gedrag jegens de werkgever leidt tot een weigering van de ww. Deze wet zal naar verwachting op 1 oktober 2006 worden ingevoerd. ${ }^{26}$ Deze toetsing lijkt op hetgeen in Denemarken geschiedt. Daar wordt een model gehanteerd dat meer gericht is op activering en minder op instroombeperking. Invoering van het voornemen zal volgens het kabinet leiden tot substantieel minder pro-formaprocedures. $^{27}$

Het kabinet wijst erop dat bij de toetsing door het CWI van de bedrijfseconomische noodzaak van ontslag sprake is van doublures en dat soms sprake is van onnodige procedures als gevolg van onbekendheid met regelgeving. ${ }^{28} \mathrm{Om}$ dit te voorkomen is per 1 maart 2006 het Ontslagbesluit aangepast. ${ }^{29}$ Het CWI zal de bedrijfseconomische noodzaak van ontslag niet langer beoordelen als daarover overeenstemming bestaat tussen de werkgever en de betrokken vakbonden. Verder heeft het kabinet voorgesteld dat, indien cao-partijen alternatieve ontslag- 
criteria hebben vastgesteld, in het geheel geen toetsing meer zal plaatsvinden van de individuele ontslagen wegens bedrijfseconomische omstandigheden door het CWI, maar dat partijen daarin zelf dienen te voorzien. ${ }^{30}$ Dit wetsvoorstel is inmiddels ingetrokken. ${ }^{31}$ Ook wijst het kabinet in het kader van de herziening van het ontslagrecht op de heroverweging van het lifo-beginsel. ${ }^{22}$

\subsubsection{EMPLOYABILITY EN ONTSLAG}

Het kabinet stelt zich de vraag of bij het formuleren van beleid met betrekking tot ontslag (en dus ook ontslagvergoedingen) rekening dient te worden gehouden met de employability-inspanningen van de werkgever en/of de werknemer. Hieraan zitten de nodige haken en ogen. De beginselen van goed werkgeverschap en goed werknemerschap bieden aanknopingpunten voor de verplichting voor de werkgever zich in te spannen voor de inzetbaarheid van de werknemer en voor de verplichting voor de werknemer om hieraan mee te werken, dan wel hiervoor initiatieven te ontplooien. De vraag is hoe ver die verplichtingen dan moeten strekken. Moet de werkgever ook scholingsfaciliteiten bieden waardoor de werknemer ook buiten de eigen onderneming inzetbaar is? Kan van de werknemer worden verlangd dat hij zelf initiatieven onderneemt om breder inzetbaar te zijn binnen of buiten de eigen onderneming? Het kabinet meent dat het stellen van regels moeilijk zal zijn en minder voor de hand ligt en dat de primaire verantwoordelijkheid voor het vergroten van de inzetbaarheid van werknemers gelegd moet worden bij de werkgevers en de werknemers. Die verantwoordelijkheid moet dan wel nader worden ingevuld door een andere inrichting van het ontslagrecht en de ww.

Een vergelijkbare gedachte komt aan de orde in het wetenschappelijk rapport van het CDA van 2004. ${ }^{33}$ Hierin wordt de gedachte geopperd dat de gezamenlijke verantwoordelijkheid van werkgevers en werknemers voor employability vertaald kan worden naar de ontslagprocedure. Werkgevers die gedurende het dienstverband voldoende geïnvesteerd hebben in de employability van hun werknemers, zouden (gedeeltelijk) vrijgesteld kunnen worden van het betalen van een ontslagvergoeding. Deze werkgevers hebben er immers aan bijgedragen dat hun werknemers minder kwetsbaar zijn op de arbeidsmarkt en meer kans hebben om een nieuwe baan te vinden. Werkgevers die deze inspanningen hebben nagelaten, zouden hiervan sterker de gevolgen kunnen dragen. Ook aan werknemerszijde kan een dergelijke ontslagrechtrechtelijke prikkel worden ingebouwd. Indien de werknemer weinig in zijn eigen employability heeft geïnvesteerd, verkrijgt hij niet 'automatisch' recht op een ontslagvergoeding. Een dergelijke regeling is vergelijkbaar met de regeling die geldt voor de werkgever en werknemer bij arbeidsongeschiktheid van de werknemer. Werkgevers die niet of onvoldoende bijdragen aan de reïntegratie van de arbeidsongeschikte werknemer, wordt een verlenging van de loondoorbetalingsperiode opgelegd. Daartegenover staat de verplichting van de werknemers mee te werken aan reïntegratie. Doet een werknemer dat onvoldoende, dan kan hem een uitkering krachtens de WAO of WIA worden geweigerd of vervalt zijn beroep op het opzegverbod. De toetsing 
van de inspanningen van de werkgever en de werknemer om te komen tot reïntegratie en de beoordeling van de vraag of een sanctie aan werkgever of werknemer moet worden opgelegd, vindt plaats door het uwv, die daarmee de rol van poortwachter vervult. Naar analogie van deze regeling zou bij de wW ook een poortwachter kunnen komen, die kijkt of door de werkgever voldoende geïnvesteerd is in de employability van de werknemer. Uiteraard geldt dit ook voor de werknemer. Het lijkt erop dat het kabinet deze gedachte uit het rapport heeft omarmd. ${ }^{34}$ Het kabinet meent dat de overheid voorwaarden kan scheppen die het maken van afspraken over scholing en employability en het investeren daarin door werkgevers en werknemers stimuleren. Ook het ingetrokken voorstel bij cao af te wijken van het Ontslagbesluit en de preventieve toets beoogde hieraan bij te dragen. Verder wijst het kabinet op (fiscale) faciliteiten ter stimulering van scholing. Deze faciliteiten worden nader uitgewerkt in hoofdstuk 2.35

\subsubsection{SCHOLING}

Uit de voorgaande paragrafen blijkt dat employability in combinatie met scholing een belangrijke rol speelt in de huidige parlementaire en maatschappelijke discussie, omdat employability en scholing, naar de huidige opvattingen, kunnen bijdragen aan preventie van werkloosheid. Aan scholing wordt in het kabinetsstandpunt, maar ook in eerdere en latere beleidsnotities ${ }^{36}$, veel aandacht besteed. In het kabinetsstandpunt wordt gewezen op de toenemende vraag naar hoger opgeleiden in verhouding tot de vraag naar lager opgeleiden. ${ }^{37}$ De toenemende vraag naar hoger opgeleiden en de afnemende vraag naar lager gekwalificeerde werknemers zal de komende jaren naar verwachting alleen maar toenemen.

Door kwalificatieveroudering kunnen lager opgeleide werknemers overbodig worden of terechtkomen in functies waar zij in eerste instantie niet voor zijn opgeleid. Voor deze werknemers is het meer dan ooit zaak om hun kennis en vaardigheden op peil te brengen en te houden. Circa 30 procent van de beroepsbevolking heeft maximaal een diploma op vmbo-niveau en kan daarmee tot de onderkant van de arbeidsmarkt worden gerekend. Dit onderstreept volgens het kabinet de urgentie van scholing voor brede groepen werknemers..$^{8}$ Investeringen in scholing en employability verhogen het kwalificatieniveau van de beroepsbevolking en hebben daardoor macro-economisch gezien een gunstig effect op het effectief arbeidsaanbod (bemiddelbaarheid en grotere in- en externe inzetbaarheid van werknemers) en op de Nederlandse concurrentiepositie (kenniseconomie), zo meent het kabinet. De werkgever kan gebruikmaken van een aantal faciliteiten om scholing te bevorderen. Een ander relevant aspect op het gebied van scholing is de verplichting die de Nederlandse overheid in Europees verband op zich heeft genomen. In het kader van de zogenoemde Lissabondoelstellingen (2005) wil Nederland zich samen met de rest van Europa ontwikkelen tot een hoogwaardige kenniseconomie. Concreet komt het erop neer dat de Nederlandse overheid ernaar streeft 80 procent van de Nederlandse beroepsbevolking op te leiden tot minimaal mbo 2-niveau. Dit alles moet gebeuren voor het jaar 2010. Wil Nederland aan deze Europese doelstelling voldoen, dan betekent 
dit dat jaarlijks zo'n 50.000 werknemers tot een hoger niveau moeten worden geschoold. Financiering vindt onder andere plaats uit het ESF en door middel van fiscale faciliteiten.

Het kabinet besteedt ook aandacht aan migranten. Meer dan driekwart van de immigranten bestond in 2002 uit volg- en asielmigranten, die veelal laag zijn opgeleid. Aan de onderkant van de arbeidsmarkt kan dit leiden tot een cumulatie van problemen. Migratie is dan ook geen antwoord op de arbeidsmarktknelpunten, zo meent het kabinet. ${ }^{39}$ Scholing en onderwijs van de reeds aanwezige beroepsbevolking staat voorop. De uitdaging is om de aanwas van immigranten op de arbeidsmarkt te accommoderen. Door de toenemende vraag naar hoger opgeleiden zijn er echter in de toekomst naar verwachting niet alleen minder banen beschikbaar voor lager opgeleiden, maar tegelijkertijd juist meer banen voor hoogopgeleiden. Voor de hogere regionen in de arbeidsmarkt is er dus de uitdaging om via het gericht toelaten van goed opgeleide immigranten een bijdrage te leveren aan het wegwerken van hardnekkige knelpunten op de arbeidsmarkt..$^{\circ}$

\subsubsection{CONCLUSIE}

Ww, ontslagrecht en scholing staan hoog op de politieke agenda, niet alleen in Nederland maar ook in de ons omringende landen. Het ontslagrecht moet soepeler worden, de uitstroom uit de wW moet worden bevorderd en van de ww moet een preventieve werking uitgaan. Daarnaast moet scholing van de beroepsbevolking worden bevorderd. Dit laatste niet alleen ter voorkoming van werkloosheid, maar ook ter bevordering van de ontwikkeling van Nederland tot een hoogwaardige kenniseconomie. Het geheel van arbeidsmarktinstituties, sociale zekerheid en scholingsarrangementen zal te allen tijde in zijn onderlinge samenhang moeten worden bezien.${ }^{41}$ Hierbij vormen de effecten die deze communicerende vaten op elkaar (kunnen) hebben een belangrijk aandachtspunt.

\subsection{SCHOLING}

\subsubsection{INLEIDING}

Scholing kan bijdragen aan economische groei. Niet alleen de regering meent dat scholing kan bijdragen aan het ontwikkelen van Nederland tot een hoogwaardige kenniseconomie. Ook vanuit andere hoeken wordt gewezen op het belang van scholing ter bevordering van economische groei. Het CBS heeft erop gewezen dat scholing een bron vormt voor de groei van de economie. Ook het innovatieplatform wijst erop dat kennis veel kost, maar meer geeft (Het Financieele Dagblad 2005). Vanuit de internationale literatuur wordt er wel op gewezen dat training, of scholing het meest effectieve middel is om werkloosheid te voorkomen (Boone en Van Ours 2004). Minister Zalm van Financiën geeft recent in een interview aan dat het verhogen van de productiviteit op de arbeidsmarkt door middel van meer scholing en het stimuleren van innovatie mogelijk moet zijn..$^{42}$ Kennis 
wordt in toenemende mate gezien als de motor van economische groei en als een concurrentiefactor (Ministerie van Economische Zaken 2003; Ministerie van Economische Zaken 2004; Bekker et al. 2005). Hiermee kan echter niet worden gezegd dat scholing van werknemers een wondermiddel is (Van Lieshout et al. 2005: 169). Uiteraard spelen arbeidsmarktaspecten een rol in die zin dat waar geen werk is, ook het niveau of de mate van scholing of opleiding geen uitkomst zal bieden bij de preventie van werkloosheid (Koning 2005: 16).

Toch is scholing voor werkenden in het algemeen en laagopgeleiden in het bijzonder van groot belang. ${ }^{43}$ Hierbij gaat het zowel om het verhogen van het kennisniveau als het op peil houden van de kennis en vaardigheden. Internationalisering in combinatie met technologische ontwikkelingen zorgen dat producten en productieprocessen sneller veranderen. Dit heeft tot gevolg dat de kwalificaties van werknemers sneller verouderen. Deze ontwikkeling vergt van bedrijven en werknemers een steeds groter aanpassingsvermogen. Met name laagopgeleiden lopen het risico hun baan te verliezen door verouderde of te specifieke kennis en te weinig vaardigheden. De scholingsdeelname van laagopgeleide werknemers blijft echter achter bij die van hoger opgeleiden. De oorzaak ligt niet alleen bij werkgevers. Onderzoek (Ministerie van Economische Zaken 2001; Bekker et al. 2005: 115) wijst uit dat laagopgeleiden vaak niet aan scholing deelnemen vanwege persoonlijke motieven (scholingskosten, gebrek aan tijd, gezinssituatie), onvoldoende informatie over de betekenis van educatieve activiteiten en het verwachte geringe nut van investeringen in scholing. Vanuit preventief oogpunt is het belangrijk dat meer laagopgeleide werknemers aan scholing deelnemen.

De overheid wil scholing van de Nederlandse beroepsbevolking bevorderen. Een groot deel van de middelen die momenteel door de overheid ter beschikking worden gesteld, betreft middelen die kunnen worden ingezet op het moment dat een werknemer reeds werkloos is. ${ }^{44}$ Zo is per 1 juli 2005 voor werkzoekenden het zogenaamde 'scholingprotocol' van kracht geworden, ${ }^{45}$ waarbij wordt onderzocht of en zo ja in hoeverre een reeds werkloze werknemer in aanmerking komt voor scholing ter bevordering van reïntegratie. Het op deze wijze inzetten van scholing wordt ook wel tertiaire preventie van werkloosheid genoemd (Evers et al. 2004). De overheid biedt ook faciliteiten ter bevordering en stimulering van scholing van werkenden. Hier wordt wel gesproken van primaire en secundaire preventie van werkloosheid. Van primaire preventie wordt gesproken indien de maatregelen zijn gericht op het voorkomen van (mogelijke) werkloosheid van werknemers welke (nog) niet met ontslag worden bedreigd. Secundaire preventie betreft het voorkomen van werkloosheid van (reeds) met ontslag bedreigde werknemers. De door de overheid geboden scholingsfaciliteiten richten zich vaak zowel op werkenden als werkzoekenden. Een scheidslijn is hierbij niet altijd gemakkelijk te trekken. In dit hoofdstuk zal de nadruk worden gelegd op de inzet van de betreffende middelen ter bevordering en stimulering van scholing van werkenden, en dan vooral waar het betreft de primaire preventie van werkloosheid. 
Niet alleen door de overheid worden maatregelen getroffen ter bevordering van scholing. Ook de sociale partners en in mindere mate individuele werkgevers en werknemers zijn zich bewust van het belang van scholing van werknemers. Zo bevat een groot deel van de cao's afspraken over scholing. Ook wordt voor de financiering van scholing steeds meer gebruikgemaakt van O\&O-fondsen. De uitgaven aan scholing door individuele werkgevers zijn gestegen en werknemers zijn de afgelopen jaren steeds meer gebruik gaan maken van scholingmogelijkheden (Van Lieshout et al. 2005: 42-46). Ook de sociale partners en de individuele werkgevers en werknemers maken een onderscheid tussen scholing van werkenden en scholing van werkzoekenden. Hierbij tekent zich echter een omgekeerd beeld af ten opzichte van de overheid. Het overgrote deel van de scholingsuitgaven en maatregelen in de private sector is gericht op scholing van werkenden.

\subsubsection{OVERHEID}

\section{Verantwoordelijkheid}

De overheid meent dat scholing van werknemers primair de verantwoordelijkheid is van de werkgevers, de werknemers en de sociale partners. Zij richt zich dan ook vooral op het stimuleren van sociale partners en individuele werkgevers en werknemers om tot scholingsafspraken en scholingsinspanningen te komen. De overheid ziet het wel als een belangrijke opdracht om knelpunten voor leren weg te nemen en het leren voor individuen aantrekkelijker te maken. De centrale vraag hierbij is hoe mensen tot leren kunnen worden geprikkeld en hoe ze ervoor kan zorgen dat de werknemer leren als vanzelfsprekend onderdeel van zijn levensloopbaan gaat beschouwen. ${ }^{46}$

De verantwoordelijkheid voor scholing van werkzoekenden ligt primair bij de overheid. Desondanks biedt de overheid ook verschillende mogelijkheden ter bevordering van en stimulering van scholing van werkenden. Wat betreft scholing van werkenden richt de overheid zich hoofdzakelijk op scholing tot een startkwalificatie. ${ }^{47}$ Reden hiervoor is dat de overheid in Europees verband ernaar streeft ervoor te zorgen dat in 201080 procent van de beroepsbevolking van 25-64 jaar een startkwalificatie heeft. Deze scholing wordt wel opscholing genoemd. Opscholing van werkenden tot een hoger niveau dan de startkwalificatie en omscholing van de werknemer blijven primair de verantwoordelijkheid van werkgevers en werknemers. ${ }^{4}$ Op dit moment wordt in Nederland ten opzichte van de oude EU-15-landen overigens relatief veel aandacht en geld besteed aan leven lang leren. Met het formeren van een gezamenlijke projectiedirectie Leren \& Werken van OCW en SZw onderstreept het kabinet het belang dat het hecht aan scholing tijdens het werk. Deze projectdirectie gaat het 'Actieplan Leven Lang Leren' verder uitvoeren. ${ }^{49}$ De totale overheidsuitgaven om werkenden te scholen zijn in 2004 circa $€ 400$ miljoen. . $^{\circ}$ Een aantal van de tot nu toe gebruikte instrumenten loopt de komende jaren door. Of deze instrumenten worden voortgezet en of andere instrumenten worden ingebed, beslist het kabinet na evaluatie. Wanneer dit zal gebeuren is ons op het moment van dit onderzoek niet bekend. 


\section{Faciliteiten}

Het is erg moeilijk een onderscheid aan te brengen in de verschillende scholingsmaatregelen en scholingsfaciliteiten die door de overheid ter beschikking worden gesteld. De overheid biedt verschillende faciliteiten ter stimulering van scholing. Deze betreffen zowel directe als indirecte financiering van scholing, waarbij gedacht kan worden aan fiscale faciliteiten en het Europees Sociaal Fonds (ESF). Ook wordt veel gedaan aan maatregelen ter stimulering van scholing die niet gebaseerd zijn op een financiële prikkel. Hierbij kan zowel gedacht worden aan informatievoorziening als ook aan employability-advisering. ${ }^{51}$ Ook bevordert de overheid de individuele ontwikkeling in de vorm van Erkenning van (elders en eerder) Verworven Competenties (EVC) en de stimulering en bijdrage aan het gebruik van Individuele Leer Rekeningen (ILR's). Samengevat richten deze instrumenten zich op zowel financiële stimulering en op bewustwording en transparantie van scholingsaanbod.

Veel fiscale faciliteiten op het gebied van scholing van werkenden zijn afgeschaft. Zo bestonden er fiscale mogelijkheden als de afdrachtvermindering onderwijs en de zogenaamde scholingsaftrek. Deze laatste regeling hield in dat een onderneming een deel van alle gemaakte scholingskosten kon aftrekken van de fiscale winst. Momenteel geldt als fiscale maatregel van overheidswege de Wet Vermindering Afdracht Onderwijs (WVA-onderwijs). De wVA-onderwijs betreft een afdrachtvermindering in de loonbelasting van maximaal 2500 euro per fulltimewerknemer per kalenderjaar. Op basis van de WvA-onderwijs kan de werkgever een tegemoetkoming krijgen in de kosten van het opleiden van een werknemer via een duale leerweg. Hierbij kan het gaan om scholing in het kader van leerwerktrajecten in het derde of vierde jaar van het middelbaar beroepsonderwijs en het kan gaan om scholing voor assistent-onderzoekers in opleiding, voor promotieonderzoek, voor duale leerwegen in het hoger beroepsonderwijs en voor werkloze werknemers die door scholing op startkwalificatieniveau worden gebracht.

Voorts is geld voor scholing beschikbaar vanuit het ESF. Over de periode 200o2006 is vanuit dit fonds 600 miljoen euro beschikbaar. Deze gelden zijn bestemd voor scholing tot startkwalificatieniveau, maar ook voor opscholing tot mboniveau 4 en sectoroverstijgende scholing. De overheid meent dat de benutting van de ESF (en Equal-) middelen verder kan worden bevorderd. Zo is het O\&Ofondsen inmiddels toegestaan om zogenoemde algemeen verbindend verklaarde middelen als cofinanciering voor ESF-projecten in te zetten..$^{2}$ De fiscale maatregelen (waarvan de afdrachtvermindering onderwijs en de aftrek scholingsuitgaven in de inkomstenbelasting nog van kracht zijn), evenals de inzet van middelen uit het ESF hebben tot doel door middel van een financiële prikkel de scholingsinspanningen door werkgevers en werknemers te stimuleren.

Ondanks het feit dat de aandacht van de overheid vooral is gericht op het brengen van werkenden op startkwalificatieniveau gold tot eind 2005 nog een subsidieregeling Scholingsimpuls van het ministerie van Economische Zaken. De regeling ondersteunde brancheorganisaties om in samenwerking met opleidingsaanbie- 
ders innovatieve scholingstrajecten te ontwikkelen voor werkenden vanaf het startkwalificatieniveau. ${ }^{53}$

Naast de fiscale faciliteiten en de gelden die beschikbaar worden gesteld vanuit het ESF werkt de overheid mee en draagt bij aan verschillende andere maatregelen ter stimulering van scholing van werkenden. Een van deze maatregelen is het erkenning van (elders en eerder) verworven competenties (EVC). Bij EVC gaat het om het volgende.

"Competentieontwikkeling gebeurt niet alleen door scholing, maar ook in betaald werk, vrijwilligerswerk of door betrokkenheid bij maatschappelijke organisaties. Door die veelal verborgen talenten van mensen zichtbaar te maken en te erkennen is op weg naar beroepskwalificatie, veel winst te halen. Zo' $n$ systeem voor het erkennen van eerder verworven competenties, heet EVC. Het resulteert in het toekennen van vrijstellingen, certificaten of diploma's. Als onderdelen van een kwalificatie erkend worden, is een volledige opleiding niet meer nodig. Als standaard voor erkenning fungeert vaak de kwalificatiestructuur van het beroepsonderwijs of een andere landelijke opleidingenstandaard; branches en bedrijven kunnen echter ook kiezen voor een eigen standaard. EVC biedt werk-gevers de mogelijkheid het human capital in het bedrijf optimaal te waarderen en benutten. Werknemers kunnen dankzij Evc hun waarde verzilveren op de arbeidsmarkt. Intermediaire organisaties belast met (her) plaatsing van kandidaten op de arbeidsmarkt kunnen het EVC-instrumentarium inzetten voor het maken van een goede match. En voor opleiders biedt EVC de mogelijkheid maatwerktrajecten te bieden en mensen efficiënt op te leiden." 54

De overheid beschouwt de ontwikkeling van EVC als een belangrijke voorwaarde voor het bereiken van haar doelstellingen. Het aantal uitgevoerde EVC-procedures moet groeien tot 50.000 in 2010 , waarbij de helft moet uitmonden in een wettelijk diploma of een door de branche erkend certificaat. Uitgangspunt voor het kabinet is dat sociale partners na 2004 een steeds grotere verantwoordelijkheid op zich moeten nemen, ook in financiële zin, om EVC breed te implementeren. Er wordt ingezet op een brede implementatie van EVC. 55 Recent heeft minister De Geus aangegeven dat door de projectdirectie Werken \& Leren aan de slag zal worden gegaan met het realiseren van 20.000 EVC-procedures voor $2007.5^{6}$ Ook wordt een start gemaakt met het realiseren van 15.000 leerwerktrajecten. ${ }^{57} \mathrm{Bij}$ dit laatste gaat het niet alleen om het aan het werk krijgen van (jonge) werklozen, maar ook om scholing van werkenden. Bij het realiseren van duale trajecten zal ook EVC een rol spelen. In het kader van EVC is voorts het Kenniscentrum EVC opgericht. Het Kenniscentrum heeft de opdracht de toepassing van de EVC-systematiek bij branches en sectoren te bevorderen en trends en ontwikkelingen te signaleren. Het Kenniscentrum EVC onderzoekt, verzamelt en verspreidt informatie en heeft een netwerkfunctie..$^{8}$ Door een Kenniscentrum EVC en een Empowerment Center 59 in te stellen heeft het kabinet de ontwikkeling en implementatie van het EVC-instrumentarium willen versnellen.

Een andere stimuleringsmaatregel vormt het instellen en gebruikmaken van zogenaamde ILR's. Met het experiment ILR heeft de overheid de potentie van 
persoonsgerichte scholingsfinanciering onderzocht. Een ILR is een persoonsgebonden spaarrekening waarmee een individuele werknemer scholing kan inkopen. Deze spaarrekening is niet werkgever-gebonden (dit in tegenstelling tot bijvoorbeeld het hieronder te bespreken Persoonlijk Opleidingsbuget (РОв)) en kan dus onafhankelijk van de werkgever worden ingezet. De overheid heeft in 2001 voor 1100 werknemers een ILR geopend van 454 euro per rekening. In een tweede fase werden nog eens 1400 rekeningen geopend (Van Lieshout et al. 2005: 106). Een werknemer of werkzoekende kan hiervan gebruikmaken om een werkgerelateerde opleiding of cursus te bekostigen. Doel van de ILR is werknemers meer bewust te maken van hun scholingsmogelijkheden en hiermee ook individuele verantwoordelijkheid en zeggenschap te geven en daarmee de scholingsvraag te stimuleren zonder dat de werkgever hierover beslist (Van Lieshout et al. 2005: 111).

De bevordering van employability-beleid wordt door de overheid ondersteund door gebruikmaking van zogenaamde employability-adviseurs en adviesorganisaties. Een voorbeeld daarvan biedt de door Economische Zaken ingestelde adviesorganisatie Syntens. Deze organisatie biedt landelijk employabilityadvisering aan verschillende $\mathrm{MKB}$-bedrijven. Ook heeft de overheid in een aantal specifieke branches initiatieven ondersteund op het gebied van employabilityadvisering (Van Lieshout et al. 2005: 94). Deze projecten richten zich op het stimuleren van werkgevers in hun employabilitybeleid, maar beogen ook de individuele werknemer te bereiken. De projecten op dit gebied zijn succesvol gebleken. De inzet van employabilityadviseurs is vooral gericht op bewustwording van мКвondernemers (Van Lieshout et al. 2005: 113). De overheid wijst erop dat haar rol en verantwoordelijkheid op dit gebied eindig is en (vooral) ligt in het scheppen van de juiste randvoorwaarden, zoals het wegnemen van belemmeringen op het gebied van regelgeving. ${ }^{60}$

\section{Effectiviteit en wenselijkheid}

Van de bestaande scholingsfaciliteiten wordt, hoewel het gebruik ervan stijgt, in de praktijk nog steeds relatief weinig gebruikgemaakt. Uit onderzoek blijkt dat werkgevers en werknemers veelal pas bereid zijn scholingsinspanningen te verrichten op het moment dat sprake is van een (wettelijke) verplichting. Ook blijken veel werkgevers en werknemers onbekend te zijn met de hen ter beschikking staande scholingsfaciliteiten (Van Lieshout et al. 2005: 88-89). De overheid zou meer (dwingend rechtelijke) bepalingen omtrent scholing kunnen opnemen zonder dat daarbij andere of bestaande bescherming in het geding komt. Voordeel als de overheid scholing regelt door middel van wetgeving is dat er minder sprake zal zijn van concurrerende belangen. Het gaat dan immers om een van bovenaf opgelegde regel waarbij, in tegenstelling tot onderhandelingen tussen de sociale partners geen sprake hoeft te zijn van een uitruil van belangen. Deze macht van de overheid is overigens beperkt. Ook indien een verplichting tot scholing een wettelijke grondslag wil krijgen zal hiervoor wel maatschappelijk draagvlak nodig zijn. Dit neemt niet weg dat wetgeving hoogstwaarschijnlijk de makkelijkste weg is werkgevers en werknemers te bewegen tot scholingsinspanningen. 
Hoewel het door de overheid verplicht stellen van scholing op het eerste gezicht met het oog op effectiviteit een aantrekkelijke optie lijkt, zijn hieraan ook de nodige nadelen verbonden. Zo zal een wettelijke verplichting waarschijnlijk een algemene scholingsverplichting inhouden, waarbij het moeilijk zal zijn rekening te houden met specifieke (behoeften binnen) bedrijfstakken, laat staan met de concrete invulling van die verplichtingen respectievelijk rechten voor individuele werkgevers en werknemers. Ook de uitvoering en toetsing van een wettelijke verplichting kan problemen met zich meebrengen. Een wettelijke verplichting tot scholing zal hoogstwaarschijnlijk leiden tot een grotere belasting van overheidsinstanties, daar zij de uitvoering zullen moeten gaan toetsen. Daarentegen hoeft een toename in de kosten van uitvoering geen problemen op te leveren als de uitvoering kan worden bekostigd door besparingen in de ww.

De overheid zelf is geen voorstander van wettelijke scholingsverplichtingen. Scholing van werkenden is, zo bleek ook eerder al, primair de verantwoordelijkheid van de sociale partners en de individuele werkgevers en werknemers. Meer algemeen bestaat de tendens tot minder overheidsbemoeienis en meer individualisering. De vraag is of een wettelijke verplichting tot scholing niet in strijd komt met deze uitgangspunten. Recent wordt er over gedacht maatregelen te treffen waarmee de overheid indirect een rol kan spelen in de vormgeving van scholingsafspraken. Deze maatregelen richten zich vooral op de sociale partners. Zo is voorgesteld cao-partijen de mogelijkheid te bieden af te wijken van de preventieve ontslagtoets en alternatieve ontslagcriteria overeen te komen. In een dergelijke constructie worden de randvoorwaarden geschapen door de overheid en wordt de concrete invulling en uitvoering daarvan overgelaten aan de wens van de sociale partners. Naar aanleiding van een Kamerdebat van 13 september 2005 is door de leden Weekers en Huizinga-Heringa een motie ingediend waarin wordt verzocht hiervan af te zien. ${ }^{61}$ Begin 2006 is besloten dit voorstel in te trekken. ${ }^{62}$

\subsubsection{SOCIALE PARTNERS}

\section{Verantwoordelijkheid}

Zoals hierboven al bleek meent de overheid dat scholing voor werkenden en primaire preventie van werkloosheid ${ }^{6}{ }^{3}$ vooral de verantwoordelijkheid is van de sociale partners, maar ook van de individuele werkgevers en werknemers. Het prikkelen tot het door de individuele werknemer volgen van scholing en het door de werkgever aanbieden van scholing staat hierbij voorop. Veel maatregelen ter voorkoming van werkloosheid van werkenden vloeien dan ook voort uit initiatieven van de sociale partners en individuele werkgevers, waarbij zij worden bijgestaan door financiële en/of andere hiervoor besproken initiatieven vanuit de overheid.

Van werknemerszijde lijkt men zich bewust van het belang van scholing van werknemers. Dit blijkt alleen al uit het feit dat steeds meer cao's scholingsafspraken bevatten (zie \$ 4.3.2). Van de kant van de werkgevers lijkt veel minder de behoefte te bestaan (meer) verantwoordelijkheden bij werkgevers te leggen en werknemers te scholen. Een belangrijk bezwaar voor werkgevers is dat zij er in 
het algemeen weinig voor voelen hun eigen verlies op te leiden, in die zin dat zij hun geschoolde werknemers verliezen aan de concurrent (Van Lieshout et al. 2005: 101). Anderzijds zal een werknemer die elders wel de mogelijkheid tot scholing heeft wellicht sneller geneigd zijn te vertrekken naar een andere werkgever indien zijn huidige werkgever die mogelijkheid niet biedt. Daarnaast zal, indien alle werkgevers (binnen een bedrijfstak) hun werknemers scholen, een werkgever ook kunnen profiteren van werknemers die door een andere werkgever zijn geschoold.

Een ander bezwaar van werkgeverszijde tegen een (algemene) scholingsverplichting voor werkgevers is gelegen in de uitvoering. Indien scholing een verplichting is zullen de scholingsinspanningen moeten worden bijgehouden, omdat ook zal moeten kunnen worden getoetst of aan die verplichting is voldaan. Overigens brengt het bieden van scholing überhaupt extra administratief en logistiek werk en dus ook kosten mee. Er zal een afdeling moeten komen die de scholing van werknemers regelt en er zal voor vervangend personeel moeten worden gezorgd op het moment dat de werknemer zich laat scholen. Dit bezwaar leeft vooral bij het MKB (Het Financieele Dagblad 2005). Vooral kleinere werkgevers zitten niet te wachten op een toename aan administratieve en logistieke lasten. VNO-NCW onderkent overigens wel dat investering in scholing van werkenden een reguliere verantwoordelijkheid is van het bedrijfsleven (VNO-NCW 2003). Bovengenoemde bezwaren worden des te groter indien eventuele scholingsinspanningen zouden worden uitgeruild tegen de mogelijkheid werknemers makkelijker te ontslaan. Werkgevers vrezen dat zij in een dergelijke situatie zullen moeten gaan bewijzen voldoende scholingsinspanningen te hebben verricht ten aanzien van de werknemer die zij willen ontslaan. De vraag is of in dat geval ontslag daadwerkelijk soepeler kan verlopen, zelfs als dit gepaard zou gaan met bijvoorbeeld de mogelijkheid bij cao af te wijken van de preventieve ontslagtoets.

Hoewel van werknemerszijde het belang van scholing wordt onderkend, bestaat ook aan werknemerszijde geen overeenstemming over de eventuele uitruil van ontslagbescherming tegen meer scholingsinspanningen. Het FNV hecht veel waarde aan scholing, maar meent tevens dat het bieden van scholing niet ten koste mag gaan van de bestaande bescherming van werknemers. Van een flexibeler ontslagrecht wil het niets weten (Het Financieele Dagblad 2005). Het CNV daarentegen lijkt meer bereid te praten over een versoepeling van het ontslagrecht in ruil voor meer employability-inspanningen door werkgevers. ${ }^{64}$ De vraag hoe een eventuele versoepeling van het ontslagrecht er concreet uit zou kunnen zien komt hieronder in hoofdstuk 5 uitgebreid aan bod.

\section{Faciliteiten in cao's en o\&o-fondsen}

Door de sociale partners worden veel maatregelen getroffen ter bevordering en stimulering van scholing van werkenden. Zo zijn inmiddels in vele cao's afspraken over scholing opgenomen. In cao's worden algemene afspraken gemaakt over scholing en scholingsverlof, maar ook worden op de individuele werknemer gerichte afspraken gemaakt over onder andere EVC. Ook bestaan veel afspraken 
over persoonlijke opleidingsplannen (pop's) waarin met werknemers individuele afspraken worden gemaakt over hun loopbaanontwikkeling en voorzien veel cao's in het ter beschikking stellen van zogenaamde persoonlijke opleidingsbudgetten (pob's). Hiermee wordt per werknemer een bepaald bedrag ter beschikking gesteld als tegemoetkoming in scholingskosten.

De afgelopen jaren is het aantal scholingsafspraken in cao's aanzienlijk toegenomen. Uit onderzoek van de arbeidsinspectie blijkt dat in 2004 in 121 van de 122 onderzochte cao's afspraken over scholing voorkomen. Dit betreft 99 procent van de werknemers die onder een cao vallen. De scholingsafspraken in cao's hebben vaak een niet-verplichtend karakter. Dat neemt niet weg dat in 45 cao's een verplichting tot aanbieden en/of een recht op het volgen van scholing bestaat. In 33 cao's (37 procent van de werknemers) gaat het om een verplichting tot scholing en in 23 cao's ( 34 procent van de werknemers) om een recht op scholing. Dit tegenover een percentage van 31 procent respectievelijk 26 procent in 2003. Een combinatie van beide vormen is in 2004 gevonden in 11 cao's (Arbeidsinspectie 2005; Arbeidsinspectie 2004).

Hierbij dient te worden opgemerkt dat afspraken over scholing in cao's vaak in een specifieke context worden geplaatst. Zo gelden afspraken om de inzetbaarheid van werknemers zowel in als buiten de onderneming te vergroten voor 32 procent van de werknemers, en bestaan voor 39 procent van de werknemers afspraken over scholing in verband met technologische ontwikkelingen die gevolgen kunnen hebben voor het functioneren van werknemers. Het meest voorkomend zijn afspraken die te maken hebben met loopbaanontwikkeling. Hier betreft het 59 cao's die betrekking hebben op 35 procent van de werknemers.

Uit de bovenstaande cijfers en percentages blijkt dat in cao's veel afspraken worden gemaakt over scholing. Hierboven worden slechts enkele specifieke aspecten van scholing genoemd waaraan in cao's aandacht wordt besteed. Echter, in alle onderzochte cao's in 2004 komen één of meer employability-bepalingen voor. De sociale partners laten zich op het gebied van scholing dus niet onbetuigd. Ook over pop's en pob's zijn in veel cao's afspraken opgenomen. In 74 procent van de cao's, betrekking hebbend op 77 procent van de werknemers, staan afspraken over ontwikkelingsplannen en studiefaciliteitenregelingen. In 68 cao's, betrekking hebbend op 67 procent van de werknemers, betreft het afspraken over een pop of pob. De overheid meent dat vooral het op deze wijze individueel stimuleren van werknemers een belangrijke bijdrage kan leveren aan scholing en de employability van werknemers (Arbeidsinspectie 2005). 10 procent van de cao's bevat (reeds) afspraken over EVC.

De O\&O-fondsen beogen het gebruik van de beschikbare middelen te bevorderen. ${ }^{65}$ De O\&O-fondsen hebben veel geld beschikbaar ter bevordering van scholing van werkenden. ${ }^{66}$ In de meeste gevallen wordt vereist dat de scholing functie- of branchegericht is, maar er zijn ook fondsen die algemene scholing vergoeden. Daarnaast geeft 8 o procent van de fondsen aan dat bepaalde vormen 
van bovensectorale scholing voor subsidie in aanmerking komen. Hoewel het gebruik van O\&O-fondsen de afgelopen jaren is gestegen, vooral kleinere bedrijven hebben een inhaalslag gemaakt, beschikken de meest fondsen nog steeds over grote reserves en zou het gebruik daarvan verder kunnen worden bevorderd (Waterreus 2002).

\section{Effectiviteit en wenselijkheid}

Cao-afspraken vormen de uitkomst van onderhandelingen. Dit onderhandelingsproces brengt mee dat sprake is van het afwegen van belangen, en uitruil van bescherming. Als gevolg van onderhandelingen tussen de sociale partners zijn in het verleden de o\&O-fondsen tot stand gekomen. In ruil voor loonmatiging werden de O\&O-fondsen ingericht, waaraan door werkgevers een deel van de loonsom werd afgedragen. Ook op het gebied van scholing zouden de sociale partners door de uitruil van belangen tot afspraken kunnen komen. In dat geval is sprake van een onderhandelingsresultaat waar partijen mee akkoord gaan, dit in tegenstelling tot een situatie waar een verplichting tot scholing van bovenaf door de overheid wordt opgelegd. Door de vormgeving van scholing en scholingsinspanningen over te laten aan de sociale partners kan wellicht beter worden aangesloten bij de maatschappelijke behoeften en de wensen van de betrokken partijen. De sociale partners vertegenwoordigen immers (ook) de belangen en behoeften van de (individuele) werkgevers en werknemers. Hiermee wordt voorkomen dat een verplichting dwingend (rechtelijk) van bovenaf wordt opgelegd en wordt duidelijk zichtbaar welke belangen voor de betrokken partijen het zwaarst wegen.

Nadeel van het regelen van scholing in cao's is dat ondanks het feit dat in veel cao's scholingsafspraken zijn opgenomen, daar in de praktijk vrij weinig gebruik van wordt gemaakt. Dit hangt enerzijds samen met het feit dat deze afspraken veelal een recht en geen verplichting tot scholing inhouden. Anderzijds zijn zowel werkgevers als werknemers vaak niet van de gemaakte afspraken op de hoogte, zelfs niet als de afspraken wel een verplichtend karakter hebben. Een oplossing voor dit probleem zou kunnen zijn dat meer verplichtingen tot scholing worden opgenomen en werkgevers en werknemers daarover beter worden geïnformeerd.

Wil men van werknemerszijde echter bereiken dat in cao-afspraken meer dwingende scholingsafspraken worden opgenomen, dan zal hier ongetwijfeld voor werkgevers iets tegenover moeten staan. De vraag hierbij is hoeveel onderhandelingsruimte er bestaat. Bij het vergroten van die onderhandelingsruimte zou de overheid een rol van betekenis kunnen spelen. Daarnaast zal ook het economisch klimaat ten tijde van de onderhandelingen een invloedrijke factor vormen. Daar het gaat om onderhandelingen, is vooral van belang dat hierbij zal moeten worden nagedacht over hoeveel men wil opgeven aan de ene kant, bijvoorbeeld ontslagbescherming of looneisen, om aan de andere kant, op het gebied van scholing, meer te bereiken. Nadeel, maar misschien tegelijkertijd een voordeel, is dat het ene belang voor het andere zal moeten wijken en dat een evenwicht zal moeten worden gevonden in de afweging van belangen. De vraag is of het algemeen belang van scholing in deze onderhandelingen voldoende tot uitdrukking 
kan worden gebracht. Ook hier ligt wellicht een rol voor de overheid in het scheppen van randvoorwaarden. Een rol die de overheid overigens onderkent.

\subsubsection{WERKGEVERS}

\section{Verantwoordelijkheid}

Uit onderzoek onder Nederlandse arbeidsorganisaties blijkt dat 56 procent van deze organisaties opleidingskosten mede door fiscale maatregelen financiert. Veel bedrijven zijn niet bekend met de bestaande scholingsfaciliteiten en gaan daarvan pas gebruikmaken op het moment dat zij om andere redenen hebben besloten hun werknemers te scholen (Van Lieshout et al. 2005: 88). Veelal is die andere reden om te gaan scholen gelegen in een (wettelijke) verplichting daartoe. Daarbij kan gedacht worden aan veiligheidscursussen en Енво-cursussen (Van Lieshout et al. 2005: 89-9o). Het lijkt erop dat werkgevers vaak niet voldoende oog hebben voor de langetermijnontwikkeling van het bedrijf en van de werknemers en daardoor relatief weinig aan scholing doen. Scholing van werknemers kan immers inspelen en aansluiten op toekomstige technologische en maatschappelijke ontwikkelingen.

Ook andere aspecten spelen een rol. Soms kunnen werkgevers de te scholen werknemers slecht missen in het productieproces, of is de werkgever bang werknemers sneller kwijt te raken op het moment dat zij beter geschoold zijn. Ook leeft de angst dat een beter geschoolde werknemer eerder een verhoging van het salaris zal vragen (Van Lieshout et al. 2005: 101). Tegenargument is dat een goede werknemer toch wel een salarisverhoging kan vragen op andere gronden of zal vertrekken naar een concurrent die wel scholing aanbiedt. Verder zou het aanbieden van scholing voor de werkgever zelfs een argument kunnen zijn het salaris (nog even) niet te verhogen, omdat hij ook kosten heeft door het aanbieden van scholing.

Scholingsfondsen blijken vooral door kleinere bedrijven weinig te worden aangewend. Ook dit kan samenhangen met de gedachte dat (juist) deze werkgevers hun werknemers slecht kunnen missen en opzien tegen de kosten die scholingsinspanningen met zich meebrengen (Van Lieshout et al. 2005: 91). Ook scholingsafspraken in cao's lijken weinig invloed te hebben op het scholingbeleid van werkgevers. Van de bedrijven die onder een cao vallen en een scholingsbeleid op papier hebben staan, doet 69 procent daar ook daadwerkelijk iets aan. Dit is niet aantoonbaar meer dan de werkgevers die niet onder een cao vallen (Van Lieshout et al. 2005: 93; Wolff 2001).

\section{Effectiviteit en wenselijkheid}

Grote(re) werkgevers blijken relatief veel te doen aan scholing van hun werknemers en blijken bewuster maatregelen te treffen ter preventie van werkloosheid. De afgelopen jaren is door een aantal grote(re) werkgevers geëxperimenteerd met het aanbieden van scholing aan werknemers. De resultaten van dergelijke scholingsmaatregelen zijn bemoedigend. Uit onderzoek blijkt dat deze inspanningen leiden tot een zeer positief resultaat waar het betreft de preventie van werkloos- 
heid, maar ook het voorkomen van ontslag als zodanig. Het grootste gedeelte van werknemers werkzaam bij deze ondernemingen die zonder scholing waarschijnlijk werkloos zouden worden, blijkt als gevolg van aangeboden scholingstrajecten voortijdig een nieuwe baan te vinden in of buiten de eigen onderneming (Evers et al. 2004: 87). De aangeboden scholingsmogelijkheden richten zich veelal zowel op primaire als secundaire preventie van werkloosheid. Uit het onderzoek blijkt overigens dat de beste wW-preventie is het voorkomen van ontslag als zodanig (Evers et al. 2004: 65).

Door het aanbieden van scholingstrajecten kunnen werkgevers besparen op ontslagkosten. Waar werknemers anders zouden worden ontslagen onder toekenning van een vergoeding, eventueel op basis van een sociaal plan, stromen de af te vloeien werknemers nu door naar een nieuwe functie, binnen of buiten de eigen organisatie. Een deel van de kosten die anders tot uitdrukking zouden komen in ontslagkosten (en ontslagvergoedingen) op het moment van ontslag of afvloeiing worden naar een eerder moment verplaatst met als positief gevolg minder werkloosheid.

Omdat scholingsinspanningen door werkgevers effect blijken te hebben op (primaire en secundaire) preventie van werkloosheid, kunnen deze inspanningen ook (indirect) een collectieve lastenverlichting meebrengen. De afname van de instroom in de ww zou immers op termijn kunnen leiden tot een lastenverlichting wat betreft de af te dragen ww-premies en minder overheidsuitgaven. Minder werkloosheid leidt op termijn tot minder (collectieve) lasten. Hierin zou wellicht een belangrijke prikkel voor werkgevers kunnen worden gevonden werknemers scholingstrajecten aan te bieden.

Tegen deze achtergrond is de vraag van belang hoe men kan bereiken dat bij individuele werkgevers een hoger niveau van bewustwording kan worden bereikt, waar het gaat om het (collectief) belang van scholing. Enkele grote werkgevers plukken reeds de vruchten van hun scholingsbeleid waar het betreft de preventie van werkloosheid en dus het voorkomen van ontslag en (hoge) ontslagkosten. Veel andere werkgevers zijn zich wellicht nog te weinig bewust van de voordelen die het aanbieden van scholing aan werknemers kan bieden. Helaas bestaat, hoewel begrijpelijk, vooral bij kleinere werkgevers weinig behoefte werknemers scholingsmogelijkheden te bieden. $\mathrm{Zij}$ vrezen veelal dat het aanbieden van scholing zal leiden tot extra kosten en veel extra moeite. ${ }^{67}$ Ook de eerdergenoemde angst goede werknemers te verliezen aan de concurrent speelt hierbij een rol.

\subsubsection{WERKNEMERS}

\section{Eigen verantwoordelijkheid}

Veel scholingsmaatregelen richten zich primair op de werkgever. Veelal wordt het aan de werkgever overgelaten zijn werknemers wel of geen scholing aan te bieden. Ook de beslissing welke specifieke werknemer scholing mag gaan volgen is vaak aan de werkgever voorbehouden. Werknemers zelf hebben daar meestal weinig invloed op. 
Vooral onder lager opgeleide werknemers lijkt de behoefte aan scholing vrij klein, althans minder te worden benut (zie ook \$ 4.2.1). Uit experimenten met pop's blijkt de (latente) scholingsbehoefte onder werknemers, ook lager opgeleide werknemers, echter toch aanzienlijk (Van Lieshout et al. 2005: 113). Uit (sociologisch) onderzoek blijkt dat werknemers eerder gebruikmaken van de hen ter beschikking staande scholingsmogelijkheden indien zij in staat worden gesteld daarover ook daadwerkelijk zelf te beschikken. Deze trend sluit overigens goed aan bij de individualiseringsgedachte (Van de Heijden en Noordam 2001: 7). Indien werknemers de mogelijkheid wordt geboden zelf te beslissen over hun scholingsmogelijkheden maken zij daar ook meer gebruik van. Experimenten met ILR's en pob's hebben geleid tot positieve resultaten. Daarentegen lijken scholingsmogelijkheden waarbij de beslissing te scholen aan de werkgever wordt overgelaten vrij weinig te worden benut. ${ }^{68}$ Hierbij hangt het immers af van de voorkeur of de wens van de werkgever een bepaalde werknemer scholing aan te bieden. Zoals hierboven al bleek, lijkt die wens bij werkgevers niet of slechts in geringe mate te bestaan. De verdere stimulering van scholingsbehoeften van individuele werknemers wordt vanuit de overheid nagestreefd in experimenten met ILR's en pob's.

\section{Effectiviteit en wenselijkheid}

Hoe belangrijk het ook is werkgevers te stimuleren hun werknemers scholingstrajecten aan te bieden, voor werknemers geldt dat zij meer gestimuleerd kunnen worden van deze mogelijkheden gebruik te maken. Werknemers lijken zich vooralsnog weinig bewust van het belang van scholing voor hun individuele levensloop. Werknemers zijn zich veelal niet bewust van de hen ter beschikking staande mogelijkheden op het gebied van scholing. Vooral de groep lager opgeleide en oudere werknemers, voor wie scholing bij uitstek gewenst is, lijkt weinig stil te staan bij haar toekomst en de bijdrage die scholing daaraan kan leveren. Het is dus de vraag hoe (vooral deze) individuele werknemers kunnen worden gestimuleerd gebruik te maken van de mogelijkheden die hen worden geboden.

Het zou stimulerend kunnen werken scholingsrechten van de werknemers te individualiseren en werknemers daar zelf de beschikking over te geven en werknemers hierover ook te informeren. Het zou dan moeten gaan om een recht waarvan de werknemer gebruik kan maken onafhankelijk van de wens van zijn werkgever. De werknemer draagt dan zelf de verantwoordelijkheid over zijn scholingsloopbaan. In het verlengde hiervan wordt wel gepleit voor zogenaamde transferable ('mee te nemen', of: 'aan de werknemer verbonden') scholingsgelden (Van Velzen 2004: 181). Hierbij gaat het om scholingsmogelijkheden of gelden die door de individuele werknemers kunnen worden benut onafhankelijk van de wens van hun huidige werkgever en onafhankelijk van een eventueel veranderen van baan en werkgever. Indien werknemers de mogelijkheid hebben zelf te beschikken over de geboden scholingsfaciliteiten lijken zij eerder geneigd deze mogelijkheden ook daadwerkelijk te benutten (Van Lieshout et al. 2005: 106). 
Individualisering lijkt het antwoord op de vraag hoe men werknemers bewust maakt en vervolgens ook daadwerkelijk weet aan te zetten tot scholing. Een aspect dat hierbij niet over het hoofd mag worden gezien is dat de individuele keuzemogelijkheid van werknemers beperkt zal moeten worden tot de keus tussen werken of scholen. Indien men werknemers de keus zou geven scholing te volgen of, in plaats van de dagen die door de werkgever beschikbaar worden gesteld voor scholing, vrije tijd te genieten, zullen waarschijnlijk veel werknemers kiezen voor het laatste. Er zal dus voor de werknemer een voldoende positieve prikkel moeten bestaan gebruik te maken van de scholingsmogelijkheden die hem geboden worden, waarbij het benadrukken van de eigen verantwoordelijkheid voor de levensloop en employability niet uit het oog mag worden verloren.

Naast het individualiseren en transferable maken van scholingsmogelijkheden zouden individuele werknemers ook gestimuleerd kunnen worden tot scholing door middel van een negatieve prikkel. Hierbij kan vooral gedacht worden aan prikkels op het gebied van ontslagbescherming of de toetreding tot de Ww. Zo zou een werknemer die geen gebruikmaakt van de hem geboden scholingsmogelijkheden minder beschermd kunnen worden tegen ontslag dan zijn collega die wel door middel van scholing heeft geïnvesteerd in zijn employability (en dus in de preventie van zijn (mogelijke) werkloosheid). Ook zou bij het toekennen van ontslagvergoedingen rekening kunnen worden gehouden met de investeringen die een werknemer heeft gedaan in zijn eigen employability. Met het creëren van deze eigen verantwoordelijkheid voor en invloed op de eigen ontslagbescherming en eventueel de hoogte van de ww-uitkering, kunnen werknemers directer worden geprikkeld tot scholing. Hierbij moet uiteraard een balans worden gevonden met de (eventueel verplichte) inspanningen van werkgevers.

\subsubsection{KNELPUNTEN EN CONCLUSIE}

Van veel maatregelen ter bevordering en stimulering van scholing wordt in de praktijk relatief weinig gebruikgemaakt. De investeringen in scholing van werknemers zijn de afgelopen jaren weliswaar gestegen, maar uit onderzoek blijkt dat de mogelijkheden beter kunnen (en ook dienen te) worden benut. Veel van de aangeboden scholingsfaciliteiten worden onderbenut vanwege onbekendheid met de regelgeving of onzekerheid of ontevredenheid over de uitvoering.

Een ander belangrijk aspect is dat veel werkgevers vrezen dat op het moment dat zij eraan bijdragen dat hun werknemers hoger gekwalificeerd raken, deze werknemers op zoek zullen gaan naar een (beter betaalde) baan elders. Ook dit element weerhoudt waarschijnlijk veel werkgevers ervan werknemers employability bevorderende scholingsmogelijkheden aan te bieden. Veel werkgevers lijken onvoldoende te beseffen dat scholing zinvol is. ${ }^{69}$ Vaak gaat het dan niet om employability bevorderde scholing, zoals veiligheidscursussen of ЕНвО-cursussen. 
Ook individuele werknemers weten vaak zelf niet precies wat ze willen en laten zich vaak leiden door de wens van de werkgever als het op scholing aankomt. Dat vormt een probleem voor het daadwerkelijk gebruikmaken van scholingsfaciliteiten. Waar werknemers individueel de mogelijkheid wordt geboden zich door middel van scholing te ontplooien, wordt vaak wel een scholingsbehoefte geconstateerd. Bij werknemers is vaak een (latente) behoefte aan scholing wel degelijk aanwezig. Met andere woorden: individualisering van het scholingsaanbod leidt ertoe dat ook de vraag naar scholing wordt opgeroepen (Van Lieshout et al. 2005: 11). Deze vorm van stimulering van scholingsmaatregelen verdient daarom nadere uitwerking.

Bij de uitwerking van beleidsinstrumenten moet goed voor ogen worden gehouden welke mensen of groepen van mensen met welke instrumenten kunnen worden geprikkeld. Generieke maatregelen blijken immers vaak niet voor de gehele bevolking te werken. Het is beter om de wensen en mogelijkheden van bepaalde groepen te identificeren en daarvoor maatregelen op maat te bieden. Waar dit nog niet of onvoldoende gebeurt, zal het kabinet concrete acties ondernemen om scholing van specifieke groepen uit de beroepsbevolking te stimuleren. Daarbij wordt verbinding gezocht tussen beleidsdossiers van de diverse departementen..$^{\circ}$ De stimulering van het individu bij scholingsarrangementen staat voorop.

Vanuit de private sector worden veel scholingsfaciliteiten geboden. Deze faciliteiten zullen door de sociale partners verder worden bevorderd. De uitgaven aan scholing zijn de afgelopen jaren gestegen en zullen naar verwachting toenemen. Ook hier speelt de vraag hoe het daadwerkelijk benutten van deze arrangementen kan worden bevorderd. Individuele stimulering tot scholing van zowel werkgevers als werknemers zal hierbij een belangrijke rol spelen. 


\title{
DEEL II
}

\section{SCHOLING EN ONTSLAGRECHT}

\subsection{HET ONTSLAGRECHT ALS STIMULANS VOOR SCHOLING}

\begin{abstract}
"We moeten zorgen voor een arbeidsmarkt die het mogelijk maakt dat mensen gemakkelijk van aan veranderen zonder werkloos te worden. Dat kan als mensen gewapend zijn met een goede opleiding, met kennis die ze tijdens hun loopbaan hebben aangevuld en vernieuwd. Dan hebben we een arbeidsmarkt waar werkzekerheid voorop staat. Want werkzekerheid moet de plaats innemen van de baanzekerheid waarop veel mensen nu nog vertrouwen. Bij zo'n arbeidsmarkt past een minder rigide ontslagbescherming. Een minder rigide ontslagbescherming biedt meer kansen voor mensen die aan de kant staan. Ouderen, vrouwen, gedeeltelijk arbeidsgeschikten. Want een minder rigide ontslagbescherming neemt de angst van werkgevers weg om mensen in dienst te nemen. We moeten de nadruk leggen op het voorkomen van werkloosheid. We moeten als doel hebben: méér mensen aan het werk. Dan hervinden we een nieuw evenwicht.” (Minister De Geus, Insol-jaarcongres, oktober 2005)
\end{abstract}

\subsubsection{ONTWIKKELINGEN IN HET ONTSLAGRECHT DE AFGELOPEN 25 JAAR}

In 1975 wordt het wetsvoorstel tot herziening van het ontslagrecht ingediend. $7^{2}$ In het voorstel zijn veel nu nog bekende thema's vervat: de toestemming krachtens het BBA zal in het BW worden opgenomen, de terminologie van art. 7:681 BW wordt aangepast en hoger beroep en cassatie tegen de ontbindingsbeschikking wordt mogelijk gemaakt. Dit wetsvoorstel strandt na het voorlopig verslag (Heerma van Voss en Van der Heijden 1990: 141) maar wordt pas in 1990 ingetrokken. In 1981 wordt in een apart wetsvoorstel,73 om technische redenen, appèl en cassatie van de ontbindingsbeschikking opgenomen. Dit wetsvoorstel haalt zonder de bepaling over hoger beroep en cassatie het Staatsblad.74 Door het advies van de in 1982 ingestelde commissie-Van der Grinten, die meent dat als de preventieve toets gehandhaafd blijft, appèl en cassatie van de ontbindingsbeschikking uitgesloten dient te blijven, is dat deel van het wetsvoorstel achterhaald. Het rapport van de commissie-Van der Grinten verschijnt in $1984 . .^{75} \mathrm{De}$ regering werkt dit rapport verder uit, hetgeen leidt tot voorstellen die de regering in 1985 voorlegt aan de SER. De SER komt in 1988 met een unaniem advies dat in belangrijke mate is losgemaakt van de adviesaanvraag. ${ }^{6}$ De SER adviseert onder meer een aanpassing van de opzegtermijnen en een samenvoeging van opzegverboden, op een wijze die overeenkomt met de latere wijzigingen door de Wet flexibiliteit en zekerheid. Verder stelt de SER voor een proeftijd slechts toe te staan voor arbeidsovereenkomsten voor onbepaalde tijd, en pleit de SER voor een partieel appèl van ontbindingsbeschikkingen. Partieel, omdat slechts tegen de vergoeding dient te kunnen worden geappelleerd. De SER adviseert de preventieve toets te handhaven. Op dit advies volgt wetsvoorstel $21479^{77}$, waarin de 
regering in belangrijke mate de hiervoor genoemde voorstellen van de SER overneemt. In de Tweede Kamer wordt dit voorstel kritisch benaderd, waarna de minister een evaluatie van de ontslagtoets toezegt. Deze verschijnt in 1992, waarop de regering voorstelt de preventieve ontslagtoets te handhaven uitsluitend voor gedeeltelijk arbeidsongeschikte werknemers. De SER is verdeeld, maar desalniettemin wordt een wetsvoorstel opgesteld waarin de kernbepaling is dat de werkgever de arbeidsovereenkomst slechts mag opzeggen indien daarvoor een redelijke grond bestaat, na het volgen van een hoorprocedure, de mogelijkheid voor de werknemer om herstel van de arbeidsovereenkomst te vorderen in voorlopige voorziening en normering van de ontslagvergoeding. Dit voorstel wordt ingetrokken voordat de Raad van State daarover heeft geadviseerd. $7^{8}$ De regering acht het wel geboden om enkele knelpunten in de ontslagprocedure weg te nemen. Dat gebeurt, zonder structurele veranderingen te brengen in het ontslagrecht, met de Wet flexibiliteit en zekerheid.79 Tijdens de parlementaire behandeling van deze wet zegt de regering onder meer toe een onafhankelijke commissie van deskundigen te vragen een toekomstverkenning uit te voeren naar de inrichting van het (duaal) stelsel. ${ }^{80}$ Deze commissie, de Adviescommissie Duaal Ontslagstelsel, adviseert de minister op 15 november 2000 te kiezen voor een repressief ontslagstelsel. ${ }^{81}$ Op 16 november 2000 wordt de Stichting van de Arbeid het advies toegezonden met het verzoek om een reactie voor 1 april 2001. Op 15 juli 2003 reageert de Stichting met een pleidooi om "alles overwegende, het huidige wettelijke duale systeem intact te laten" ${ }^{82}$ In de hierboven beschreven voorstellen is weinig of geen rekening gehouden met employability en scholing.

\subsubsection{ONTSLAGRECHT EN SCHOLING}

De gedachte dat scholing en opleiding invloed kunnen hebben op het vinden respectievelijk het behouden van werk is echter niet nieuw. Al in 1986 publiceert de STAR een rapport waarin uitgebreid wordt stilgestaan bij het begrip employability. Heerma van Voss heeft verscheidene keren gewezen op de wens bij ontslag rekening te houden met scholingsinspanningen. Hij ziet hierbij een taak voor het georganiseerd overleg en wijst erop dat de overheid hiervoor de voorwaarden dient te scheppen (1993: 361). In 1993 betoogt Heerma van Voss dat het opeisen van een recht op scholing in de toekomst van even groot gewicht kan worden als de eis van een toetsing van rechtvaardigheid bij het ontslag dat voorheen was (1993: 211). Verder zegt hij: "Ook kan de rechtspositie van de werknemers die voor scholing in aanmerking komen worden geregeld, waarbij het recht op scholing zich kan ontwikkelen tot een sociaal recht." (1993:361; Frenkel 1986). In 1999 herhaalt hij zijn betoog:

"In deze tijd van verandering van het arbeidsproces lijkt het recht op scholing steeds belangrijker te worden. In de afgelopen jaren heeft de term 'employability' ingang gevonden, waarmee wordt benadrukt dat werknemers inzetbaar moeten blijven door scholing en vorming tijdens hun arbeidsleven. Het ontbreken van scholingsmogelijkheden benadeelt de werknemer in het kader van reorganisaties en ontslag. Ondanks de nodige beleidsnota's ontbreekt het in ons land nog steeds aan een wettelijke regeling terzake, afgezien van incidentele bepalingen..." 83 
Momenteel staat de relatie tussen employability en ontslag volop in de (politieke) belangstelling. De Kamerleden Verburg en Bussemaker hebben de regering verzocht om in het ontslagrecht ook de factor investering in en scholing van werknemer mee te nemen:

"overwegende, dat werkgever en werknemer door middel van het preventief bij- en omscholen een gezamenlijke verantwoordelijkheid hebben voor een duurzame positie van de werknemer op de arbeidsmarkt; overwegende, dat de investering in de positie op de arbeidsmarkt dient mee te wegen in het ontslag en de ontslagvergoeding" ${ }^{84}$

Naar aanleiding van deze motie heeft minister De Geus bij brief van 29 april 2005 de SER verzocht in zijn middellange termijnadvies in te gaan op de relatie tussen scholing en ontslag. De SER zal hierover naar verwachting in het najaar van 2006 adviseren (zie ook hoofdstuk 1).

Het ontslagrecht is een (samenhangend) geheel van regels met betrekking tot het eindigen van de arbeidsovereenkomst. Ontslagbescherming is gericht op het bieden van ongelijkheidscompensatie en daarmee het bieden van zekerheid aan de werknemer. De positie van de werknemer ten opzichte van de machtspositie van de werkgever wordt hiermee (enigszins) versterkt. ${ }^{85}$ Bij nadere beschouwing blijkt de zekerheid van de werknemer te onderscheiden in verschillende vormen. Deze vormen zijn: baanzekerheid, werkzekerheid, inkomenszekerheid en combinatiezekerheid. ${ }^{86}$ Het ontslagrecht is tamelijk eenzijdig gericht op slechts een van deze zekerheden, de baanzekerheid, dus het behoud van de (overeengekomen) arbeid. Maar baanzekerheid is, voor zover deze ooit heeft bestaan, tegenwoordig geen gegeven. ${ }^{87}$ Steeds minder bestaat de baan voor het leven. Een werknemer dient voorbereid te zijn op het moeten verrichten van andere werkzaamheden of op het moeten verwerven van een andere functie, misschien bij een andere werkgever. De ontslagbescherming kan tenslotte niet zo ver gaan dat de werknemer onbeperkt recht houdt op voortzetting van de arbeidsovereenkomst. De werkgever heeft belang bij continuering van de arbeidsorganisatie, en dat vergt de mogelijkheid om de omvang van de arbeidsorganisatie aan te passen aan het werkaanbod. Er is onmiskenbaar een spanningsveld (in de belangenafweging) tussen deze behoefte aan flexibiliteit van de werkgever en de behoefte aan bescherming (zekerheid) van de werknemer.

Het ontslagrecht richt zich nauwelijks op andere zekerheden dan baanzekerheid, met name niet op werkzekerheid, dus op het behoud van (andere passende) arbeid in het algemeen. Dit terwijl andere dan de thans geldende arrangementen tussen flexibiliteit en zekerheid denkbaar zijn. Het gelijknamige akkoord van de Stichting van de Arbeid uit $1996^{88}$ had betrekking op een vergroting van de zekerheid voor één groep werknemers, te weten de werknemers met een tijdelijke arbeidsovereenkomst of een uitzendovereenkomst, en de vergroting van de flexibiliteit door een versoepeling van de opzegtermijnen voor werknemers met een arbeidsovereenkomst voor onbepaalde tijd. Het bevorderen van zekerheid voor 
werknemers zou mogelijk zijn door het begrip 'zekerheid' niet alleen te verbinden aan het behoud van de eigen arbeidsplaats, maar meer te verbinden aan de kans op het behoud van werk, al dan niet bij de eigen werkgever. Een toename van werkzekerheid zou het verlies aan baanzekerheid kunnen compenseren, of zelfs meer dan dat. Een meer op werkzekerheid betrokken ontslagstelsel zal de werkgever en de werknemer moeten stimuleren om de werkzekerheid van de werknemer te vergroten, met name door de werknemer employable te houden. Scholing is voor het bereiken van deze zekerheid van groot belang. Hierbij zal een balans moeten worden gevonden in de verdeling van verantwoordelijkheden (zie verder $\$ 4 \cdot 3 \cdot 2$ ).

Indien de arbeidsovereenkomst van rechtswege eindigt, hetgeen zonder meer het geval is bij tijdelijke contracten, stimuleert het ontslagrecht de bevordering van de employability geenszins. Daarbij komt dan nog dat uit onderzoek is gebleken dat in een aanzienlijk aantal cao's een uitbreiding van de ketenregeling is overeengekomen, zodat, langer dan wettelijk is voorzien, tijdelijke arbeidsovereenkomsten van rechtswege kunnen eindigen. ${ }^{89}$ De mate waarin de aanbeveling van de Stichting van de Arbeid om tijdelijke werknemers toegang te bieden tot functiegerelateerde en employability verhogende opleidingsmogelijkheden in cao's is gevolgd, dient nog nader te worden onderzocht. $9^{\circ}$ Op grond van de bevindingen in hoofdstuk 2 denken wij dat, als daaromtrent al nadere regelingen in de cao's blijken te zijn opgenomen, moet worden gevreesd dat het gebruik van deze scholingsmogelijkheden niet indrukwekkend zal zijn. Voor de werknemer met een arbeidsovereenkomst voor onbepaalde tijd zal de inrichting van het ontslagrecht voor het stimuleren van employability van groter belang kunnen zijn. Voor deze werknemer die tijdens de arbeidsovereenkomst onvoldoende de mogelijkheid heeft gekregen zijn employability of anders gezegd zijn inzetbaarheid te vergroten door middel van scholing, zou een grotere ontslagbescherming kunnen gelden. Anderzijds zou een werkgever door het ontslagrecht kunnen worden beschermd tegen de 'gelukzoekende' werknemer die zich op kosten van zijn werkgever laat scholen en vervolgens deze verworven vaardigheden en kennis gebruikt om tegen een hoger salaris werkzaamheden te gaan verrichten bij een andere werkgever. Daarenboven kan het ontslagrecht een belangrijke rol spelen als sanctionerend instrument. De werkgever die niet aan zijn (scholings)verplichtingen voldoet of de werknemer die de mogelijkheden niet benut op het moment dat de arbeidsrelatie bestaat, zou daarop bij het eindigen van de arbeidsovereenkomst kunnen worden afgerekend. In hoofdstuk 5 wordt voor verschillende specifieke delen van het ontslagrecht onderzocht hoe deze zo kunnen worden ingericht dat scholing en employability van werknemers wordt bevorderd, zonder daarbij de wens van flexibiliteit (voor werkgevers) uit het oog te verliezen.

\subsubsection{VERANTWOORDELIJKHEID}

Bij een dergelijk onderzoek past voorzichtigheid. Er zijn immers wel degelijk grenzen aan de verantwoordelijkheid van de werknemer voor het streven naar bevordering van zijn eigen werkzekerheid en employability. Grenzen die worden 
gesteld door de arbeidsmarkt (zoals een zeer beperkt aanbod van arbeidsplaatsen) en door de intellectuele mogelijkheden van de werknemer zelf kunnen naar onze mening niet onder verwijzing naar de eigen verantwoordelijkheid van de werknemer worden gepasseerd. Aan de andere kant moet er aandacht zijn voor de vraag hoe ver de (individuele) verantwoordelijkheid van werkgevers voor werkzekerheid van werknemers dient te strekken. Een nadere invulling van de eigen verantwoordelijkheid kan ons inziens niet zover strekken dat er geen sprake meer is van solidariteit met diegenen die niet in staat zijn hun mogelijkheden volledig te benutten, of met hen die dat wel doen, maar zonder succes.

Het ontslagrecht kent maar (zeer) beperkt postcontractuele verplichtingen en verantwoordelijkheden. De ontslagbescherming is hoofdzakelijk gericht op het bestaan en het behoud van de huidige arbeidsovereenkomst, en richt zich niet op het verkrijgen van arbeid na het eindigen van de arbeidsovereenkomst. De verantwoordelijkheid van de werkgever voor de werknemer houdt op na het eindigen van de arbeidsovereenkomst. Voor zover er in de juridische literatuur (Loonstra 2000: 309-326; Loonstra 2001: 32-40; Grapperhaus 2003: 422; Barendrecht 1994: 230-235) wordt gesproken van een postcontractuele verplichting, wordt deze verplichting veelal in verband gebracht met de (hoogte van) de ontslagvergoeding. Naar onze mening geldt er geen voortdurende verplichting nadat de arbeidsovereenkomst is beëindigd. De verantwoordelijkheden en de daarmee samenhangende verplichtingen van werkgevers en werknemers worden vertaald naar de arbeidsovereenkomst en worden, voor zover daaraan niet is voldaan, verrekend in de vorm en de hoogte van de ontslagvergoeding op het moment dat de contractuele relatie een einde neemt. Een uitzondering hierop vormen omstandigheden in verband met het (ontbreken van een) concurrentiebeding. In het verleden is in de rechtspraak de postcontractuele goede trouw, bij ontbreken van een concurrentiebeding, aangevoerd als argument een werknemer te verbieden te gaan werken voor een andere werkgever..$^{91}$ Deze uitzondering is in die zin begrijpelijk dat het concurrentiebeding primair is gericht op handelen van partijen, vooral de werknemer, nadat de arbeidsovereenkomst is beëindigd.

Een vergelijking met de regelgeving omtrent arbeidsongeschiktheid dringt zich op. De verantwoordelijkheid van de werkgever in het geval de werknemer ziek wordt doet denken aan een postcontractuele zorgplicht. Bij ziekte van de werknemer is het de werkgever gedurende twee jaar verboden de arbeidsovereenkomst op te zeggen en gedurende die periode rust op de werkgever niet alleen de verplichting (een belangrijk deel van) het loon door te betalen, maar ook de verplichting de werknemer te reïntegreren in eigen, of ander passend werk. Het niet nakomen van die verplichtingen wordt tot uitdrukking gebracht in de ontslagbescherming respectievelijk de ontslagvergoeding. ${ }^{92}$ Hoewel niet kan worden gesproken van een postcontractuele zorgplicht, hebben de verplichtingen bij arbeidsongeschiktheid min of meer een vergelijkbaar karakter, zij het dat in dit geval mogelijkheid het contract - de arbeidsovereenkomst - te beëindigen wordt uitgesteld met de gedachte dat de verantwoordelijkheden nog niet zijn geëindigd. 
Deze verantwoordelijkheden gelden ook indien de werkgever op het ontstaan of bestaan van de arbeidsongeschiktheid geen enkele invloed heeft kunnen uitoefenen. De werkgever die niet aan zijn reïntegratie-inspanningen voldoet, wordt geconfronteerd met een verlenging van de loondoorbetalingsperiode en een langere periode van het verbod tot opzegging tijdens ziekte (zie art. 7:670 lid 10 BW). Door de prikkel tot reïntegratie ten laste van de individuele werkgever te brengen wordt hij rechtstreeks gestimuleerd in reïntegratie te investeren. Voor de werknemer geldt een vergelijkbare prikkel. De werknemer die niet actief meewerkt aan zijn reïntegratie kan makkelijker worden ontslagen (zie art. 7:67ob lid $3 \mathrm{BW}$ ) en riskeert een korting op of weigering van eventuele arbeidsongeschiktheidsuitkeringen. Het risico van arbeidsongeschiktheid wordt hiermee geïndividualiseerd (Van der Heijden en Noordam 2001: 7).

De regels met betrekking tot de arbeidsongeschiktheid van de werknemer hebben niet tot doel de risico's en verantwoordelijkheden rechtvaardig te verdelen, maar hebben slechts een pragmatisch doel, te weten het bevorderen van de snelle reïntegratie van de arbeidsongeschikte werknemer (Roozendaal 2005: 23-37), maar ook het beperken van de collectieve en publieke lasten voor arbeidsongeschiktheid. Los van deze doelstellingen lijkt het individueel verantwoordelijk stellen voor de lasten van arbeidsongeschiktheid de reïntegratie te bevorderen. De invoering van de Wet Verbetering Poortwachter die in 2002 de werkgever en werknemer tot een verdergaande en geïndividualiseerde reïntegratie-inspanning verplichten, heeft geleid tot een afname van het beroep op de arbeidsongeschiktheidswetten. De Wet Verbetering Poortwachter is zodoende een succesvol voorbeeld van het stimuleren van gewenst gedrag door prikkels zowel in het ontslagrecht als in het sociale verzekeringsrecht.

Volgens Roozendaal moet de reden van de toenemende verantwoordelijkheid van de werkgever worden gevonden in een afname van het vertrouwen in de overheidsregelingen en in de wens het risico van afwenteling van privérisico's op het collectief te verminderen (Roozendaal 2005: 29-31). Niet duidelijk is waarom een vergelijkbare toedeling van verantwoordelijkheden voor mogelijke werkloosheid door de wetgever niet meer wordt nagestreefd. De werkgever heeft direct invloed op het ontstaan van werkloosheid van een werknemer als hij hem ontslaat, terwijl het ontstaan van arbeidsongeschiktheid veelal (ook) verband houdt met andere factoren. In die lijn zou het passen het uitgangspunt te hanteren dat de werkgever dient te voorkomen dat de werknemer werkloos wordt, en indien de werknemer toch werkloos wordt, de werkgever de verantwoordelijkheid heeft te voorkomen dat de werknemer werkloos blijft. In de arbeidsrechtelijke literatuur is daarvoor wel eerder gepleit (Verhulp 2004: 22), zeker waar het gaat om de periode kort na het ontslag.

"Werkgevers en werknemers primair verantwoordelijk maken voor de kortdurende werkloosheid en de gemeenschap voor de langdurige past bij de subsidiaire taak van de publieke sociale zekerheid." (Noordam 20oo: 341) Een mogelijke verklaring voor het uitblijven van een doeltreffende oplossing met betrekking tot 
het voorkomen van werkloosheid kan zijn dat het ontslagrecht een (zeer) complex geheel van samenhangende regels is, waarbij het verantwoordelijk stellen voor een aspect invloed kan hebben op de verantwoordelijkheidverdeling binnen het geheel. Het wijzigen van deze regels is, om welke reden dan ook, in het verleden zeer moeilijk gebleken. Het maatschappelijk belang, de betrokkenheid van sociale partners en de complexiteit van de materie zijn daar zeker debet aan. Bij iedere wijziging is de coherentie van het ontslagrecht een belangrijk aandachtspunt, net als de samenhang van het ontslagrecht en de sociale zekerheid. Bovendien is het ontstaan en de duur van werkloosheid (ook) conjunctuurgevoelig, en kan het om die reden lastig zijn werkgever (primair) verantwoordelijk te stellen voor het voorkomen daarvan. Dat laat onverlet dat het mogelijk moet zijn het ontslagrecht anders in te richten en een beter middel ter preventie van werkloosheid van werknemers te laten zijn dan thans het geval is. Het incorporeren van scholingsverplichtingen in het ontslagrecht kan hieraan een belangrijke bijdrage leveren.

Een veelgehoorde klacht van werkgevers is dat zij (te) veel worden belast met niet specifiek aan de arbeidsovereenkomst verbonden verplichtingen. Werkgevers dienen zich op verschillende gebieden rekenschap te geven van de privéomstandigheden van de werknemer. Zij dienen rekening te houden met verlof en werktijdvermindering, dienen administratieve handelingen te verrichten die eerder meer in het publieke domein lagen, zoals de inhouding van premies en belasting. Verder bestaat de verplichting tot loondoorbetaling bij arbeidsongeschiktheid en het opstellen van reïntegratieverslagen. Ook worden werkgevers vaak gehouden (mede) te zorgen voor de pensioenvoorziening van werknemers. Het employable maken van het ontslagrecht brengt enerzijds (nog) meer verantwoordelijkheden voor de werkgever met zich, zoals een verplichting tot scholing, terwijl anderzijds, te weten bij het ontslag, een vermindering van 'regeldruk' of verantwoordelijkheid ontstaat. Daarmee zou het employable maken van het ontslagrecht wat betreft de verantwoordelijkheidsverdeling neutraal kunnen zijn. De arbeidsovereenkomst is een contractuele band die het mogelijk maakt om zaken, die raakvlakken hebben met de arbeidsovereenkomst neutraal te regelen. Voor scholing van werknemers geldt dat ook.

In de rechtspraak wordt bij ontslag soms rekening gehouden met de inspanningen van zowel werkgevers als werknemers de inzetbaarheid en employability te vergroten door middel van scholing. Een algemene verplichting van de werkgever tot scholing van de werknemer kan hieruit echter niet worden afgeleid, alhoewel die in een enkel geval, indirect wel lijkt te worden aangenomen. ${ }^{93} \mathrm{Als}$ de verantwoordelijkheid voor (het uitblijven van) scholingsinspanningen al ter sprake komt, gebeurt dat toch vaak pas bij of na het ontslag van de werknemer. Het is dan niet zozeer de vraag of de werknemer alsnog een recht op die scholing kan doen gelden, maar slechts of het uitblijven van scholing aan het ontslag in de weg kan staan, of het ontbreken van de scholing van invloed moet zijn op de hoogte van de toe te kennen vergoeding bij ontbinding van de arbeidsovereenkomst dan wel of de opzegging (mede) door het ontbreken van de scholing kennelijk onredelijk is. 94 
Het gaat in de hierboven genoemde jurisprudentie steeds om bijzondere omstandigheden, zeker in het geval van ontbinding van de arbeidsovereenkomst. Daarenboven betreft het slechts een heel klein deel van de jurisprudentie op dit gebied. Dat maakt het moeilijk om algemene lijnen uit de rechtspraak te destilleren. Deze kanttekening in aanmerking genomen kan uit de jurisprundentie worden afgeleid dat de rechter niet geheel afwijzend staat tegenover het aannemen van een zorgplicht van de werkgever en de werknemer om zich in te spannen ter bevordering van inzetbaarheid en employability. Het betreft dan vooral een zorgplicht in het kader van secundaire preventie van werkloosheid. De wijze waarop de zorgplicht wordt verwoord - namelijk in de hoogte van de ontslagvergoeding - biedt de werknemer echter geen uitzicht op ander werk en dus geen werkzekerheid. Een ontslagvergoeding zal de kans op werkloosheid immers niet verkleinen, maar hooguit de financiële gevolgen van het ontslag en werkloosheid of de inkomensachteruitgang bij een nieuwe baan tijdelijk of gedeeltelijk verzachten. Dit sluit echter niet uit dat een duidelijke lijn in de jurisprudentie werkgever en werknemers zou kunnen prikkelen meer scholingsactiviteiten te ontplooien.

Het investeren van werkgevers en werknemers in elkaar kan bijdragen aan de inzetbaarheid van werknemers op de arbeidsmarkt - de employability. Het breder inzetbaar maken en houden van werknemers, door middel van scholing, kan bijdragen aan het voorkomen van werkloosheid (zie ook \$ 4.5.7). Dit rechtvaardigt dat bij ontslag, dus op het moment dat het werkloosheidsrisico zich voordoet, rekening wordt gehouden met employability bevorderende en dus werkloosheidskansen verkleinende scholingsinspanningen. Hierbij dient rekening te worden gehouden met de verdeling van verantwoordelijkheden. Als een werkgever verwacht dat een werknemer investeert en zich specialiseert in een onderneming, kan van diezelfde werkgever worden verwacht dat hij zich als tegenprestatie inzet voor het behoud van inzetbaarheid van die werknemer elders op de arbeidsmarkt. Deze inspanning wordt in beginsel niet uitgedrukt in (de hoogte van) het loon. ${ }^{95}$ Loon is betaling voor verrichte werkzaamheden en houdt weinig verband met het creëren van zekerheden voor de toekomst. Voor de werknemer staat daar tegenover dat ook hij verplicht is gebruik te maken van de hem geboden mogelijkheden zijn inzetbaarheid te vergroten of te behouden. Als de werkgever de verantwoordelijkheid neemt, is het aan de werknemer daarvan vervolgens ook gebruik te maken. Aan de bezwaren van de werkgevers tegen toename van de verantwoordelijkheden kan worden tegemoetgekomen door werkgevers die aan de scholingsverantwoordelijkheid invulling hebben gegeven een verlichting van de ontslagrechtelijke regels te bieden.

\subsection{SCHOLING EN ONTSLAGRECHTELIJKE BEDINGEN}

Kantonrechter te Zaandam 1 november 2001, JAR 2001/249: “Als een werkgever flexibiliteit wil tegenover een werknemer, waar hij zo nodig van af wil als die binnen vier jaar niet bevalt, moet hij ook de werknemer de ruimte geven om zich binnen die tijd elders verder te ontplooien." 


\subsubsection{INLEIDING}

De regering meent dat scholing van werknemers een verantwoordelijkheid is van werknemers en werkgevers samen (zie hoofdstuk 1 en 2). Tegelijkertijd blijkt dat de bereidheid van werkgevers om werknemers te scholen stuit op bezwaren (zie hoofdstuk 2). Bij het zoeken naar een oplossing van de hiervoor gesignaleerde problemen richten we ons op het ontslagrecht. In dit onderzoek vormt een nadere beschouwing van die regels het zwaartepunt. Ook is een aantal met het ontslagrecht samenhangende arbeidsrechtelijke bedingen van belang bij het bevorderen van scholing en de ontwikkeling van baanzekerheid naar werkzekerheid, die daarom hier niet onbesproken mogen blijven.

\subsubsection{STUDIEKOSTENBEDING}

Het achterblijven van het gebruik van scholingsregelingen kan deels worden verklaard door de angst van werkgevers dat de investering in de opleiding van de werknemer zich niet terugbetaalt, omdat de werknemer eerder uit dienst treedt. In hoofdstuk 2 is dit reeds nader toegelicht. Deze angst bij werkgevers kan worden verminderd door met de werknemer overeen te komen dat bij vroegtijdige uitdiensttreding de kosten van de scholing en vooral de kosten van het doorbetaalde loon geheel of gedeeltelijk worden terugbetaald. Dergelijke regelingen duiden we verder aan als studiekostenbedingen. Bij het ontbreken van een wettelijke bepaling terzake is lang onzeker of een dergelijk beding geldig is. In het arrest Opzeeland van $1983^{96}$ heeft de Hoge Raad een beding waarbij de werknemer werd gehouden tot terugbetaling van het loon over de periode van scholing, geldig geacht, maar onderworpen aan voorwaarden, te weten:

"Anders dan de rechtbank in de zesde rechtsoverweging heeft aangenomen, verzet het systeem van de wet zich niet zonder meer tegen financiële regeling tussen werkgever en werknemer, die met voormelde bijzondere aspecten aldus rekening houdt dat zij:

a. de tijdspanne vaststelt gedurende de werkgever geacht wordt baat te hebben van de door de werknemer tijdens diens studiewerkzaamheden verworven kennis en vaardigheden,

b. bepaalt dat de werknemer, indien de dienstbetrekking tijdens of onmiddellijk na afloop van de studieperiode eindigt, het loon over de periode aan de werkgever zou moeten terugbetalen en

c. deze terugbetalingsverplichting vermindert naar evenredigheid van het voortduren van de dienstbetrekking gedurende de onder a. bedoelde tijdspanne."

Deze voorwaarden worden door de lagere rechtspraak meestal ook verbonden aan het beding dat de werknemer verplicht de kosten van de opleiding terug te betalen: in het algemeen worden dergelijke bedingen die aan deze voorwaarden voldoen, geldig geacht. ${ }^{77}$ Daarbij gelden enige nuanceringen. Zo wordt in het geval een tijdelijke arbeidsovereenkomst met een studiekostenbeding is gesloten de glijdende schaal als bedoeld onder c. niet gehanteerd. $9^{8}$

Uit de gepubliceerde rechtspraak blijkt soms dat de werkgever zelf een belangrijke invloed wil uitoefenen op de inhoud van de scholing en soms met de werk- 
nemer bedingen sluit waarvan de nakoming naar maatstaven van redelijkheid en billijkheid onaanvaardbaar is, of anders gezegd: dat het beding wordt gebruikt om de werknemer te binden. Over het algemeen acht de rechter de werknemer niet aan dergelijke bedingen gebonden, zeker niet als tegenover de kosten geen erkende opleiding staat of de kosten niet duidelijk voor rekening van de werkgever zijn gekomen. ${ }^{99}$ Een andere vorm van een studiekostenregeling als verkapt concurrentiebeding is te vinden in perioden waarbinnen studiekosten, al dan niet volledig, moeten worden terugbetaald. Voorbeelden hiervan zijn het beding dat de werknemer verplicht alle scholingskosten terug te betalen die in de periode van twee jaar voor vrijwillig ontslag zijn gemaakt, ${ }^{100}$ en het beding tot terugbetaling van studiekosten over een periode van vijf jaar voor een leerling-torenkraanmachinist. ${ }^{101}$ Voor een belastingassistente is een terugbetalingsperiode van drie of vier jaar weer toelaatbaar. ${ }^{102}$ Terzijde merken we op dat naar het oordeel van het hof's-Hertogenbosch een terugbetalingsbeding is toegestaan ingeval een opleiding nodig is om te reïntegreren na arbeidsongeschiktheid, zij het dat als het reïntegratietraject niet tot gevolg heeft dat de werknemer het oorspronkelijke werk kan hervatten en nadien elders werk vindt, de werkgever op het beding geen beroep toekomt. ${ }^{103}$ De kantonrechter te Zaandam overweegt met betrekking tot een terugbetalingsbeding dat met een werkneemster in tijdelijke dienst overeengekomen is: "Als een werkgever flexibiliteit wil tegenover een werknemer, waar hij zo nodig van af wil als die binnen vier jaar niet bevalt, moet hij ook de werknemer de ruimte geven om zich binnen die tijd elders verder te ontplooien", waarop de werkgever een beroep op het beding wordt ontzegd. ${ }^{104}$ Op grond van de jurisprudentie kan de conclusie worden getrokken dat terugbetalingsbedingen over het algemeen door de rechter met enig wantrouwen worden bezien, maar als ze voldoen aan de door de Hoge Raad gestelde criteria, vaak geldig worden geacht.

De verplichting van de werknemer om de kosten van de opleiding terug te betalen aan de werkgever bij vroegtijdige uitdiensttreding wordt soms ook bij cao geregeld. Uit een onderzoek van het ministerie van Sociale Zaken en Werkgelegenheid uit 2001 en 2002 blijkt dat in 56 van de onderzochte 122 cao's een studieregeling voorkomt (Arbeidsinspectie 2003). Dit onderzoek strekt zich niet uit tot de vraag of een terugbetalingsbeding geldt. Eigen onderzoek, dat geen beroep kan doen op volledigheid, geeft aanleiding tot de gedachte dat terugbetalingsbedingen of regelingen daaromtrent in cao's niet al te veel voorkomen en voor zover ze voorkomen, zeer divers zijn. Zo kent de ABU-cao 2005-2007 de bepaling dat de uitzendkracht in fase B een persoonlijk opleidingsbudget opbouwt (van 1,1 procent van de loonsom) en dat eventuele opleidingskosten die niet kunnen worden vergoed uit dat budget bij voortijdig einde van de arbeidsovereenkomst door de werknemer dienen te worden terugbetaald, waartoe de werkgever en de werknemer een 'redelijke regeling' dienen te treffen. In art. 30 van de cao voor de suikerwerk- en chocoladeverwerkende industrie 2004 is bepaald dat een terugbetalingsbeding bij functiegerichte scholing niet geldig is, en overigens is geregeld dat een terugbetalingsbeding in een bepaalde vorm overeengekomen kan worden. Art. 14 lid 10 van de cao horeca en aanverwante bedrijven 2003-2004 
bepaalt met betrekking tot het terugbetalingsbeding dat het terug te betalen bedrag maandelijks met minimaal 1/12 deel dient te verminderen. De cao voor de tuincentra heeft een vergelijkbare bepaling waarbij de evenredige vermindering minstens 50 procent na een jaar dient te bedragen. Een enkele keer bevat de cao zelf het terugbetalingsbeding, zoals art. 8B van de cao bitumineuze en kunststof dakbedekkingsbedrijven 2004-2008 met betrekking tot de opleiding ondernemers- en kaderopleiding dakbedekkingsbranche, of zoals blijkt uit oudere rechtspraak, de cao Transavia. ${ }^{105}$ De Stichting van de Arbeid besteedt in 'de agenda 2002' van 9 december 1997 ruime aandacht aan employability, maar zegt over dergelijke bedingen niets. Wel heeft de stichting geadviseerd dat de werkgever primair verantwoordelijk is voor de vormgeving en financiering van de persoonlijke ontwikkelingsplannen. Over het algemeen sluiten de cao's niet uit dat door werkgever en werknemer aanvullende afspraken worden gemaakt.

Opvallend weinig cao's bevatten dus een regeling met betrekking tot terugbetalingsbedingen en als een cao een bepaling terzake bevat, beperkt die over het algemeen slechts de periode waarover het beding geldig is. Het terugbetalingsbeding is dus in belangrijke mate vrijgelaten, hetgeen over het algemeen niet strekt ten voordele van de werknemer en diens employability, omdat de neiging lijkt te bestaan een ruime terugbetalingsverplichting op te nemen. Toch beoordelen wij het terugbetalingsbeding niet uitsluitend negatief. De mogelijkheid de kosten van de opleiding van de werknemer terug te vorderen kan de werkgever stimuleren de werknemer te scholen. Indien de werknemer elders in dienst treedt en daarmee een deel van de kosten van scholing zal moeten terugbetalen, kan de werknemer daarvoor eventueel bij de nieuwe werkgever compensatie vragen. Dat is te rechtvaardigen omdat de nieuwe werkgever voordeel van die scholing heeft en op deze wijze het nadeel voor de werknemer te overzien is. Belangrijk voordeel is ook dat een dergelijk beding de angst bij werkgevers voor poaching (het wegkopen van capabel personeel door andere werkgevers) kan wegnemen ${ }^{106}$ en zodoende de bereidheid om te investeren in scholing van werknemers kan stimuleren.

\subsubsection{CONCURRENTIEBEDING}

Het concurrentiebeding is geregeld in art. 7:653 BW, en door de rechtspraak nader ingevuld. Het wetsvoorstel tot wijziging van art. 7:653 BW is door de Tweede Kamer aangenomen, na voortgezet overleg in de Eerste Kamer gezonden aan de SER met het verzoek nader te adviseren en vervolgens door de Eerste Kamer op 13 juni 2006 verworpen. ${ }^{107}$ In het kader van dit onderzoek is het concurrentiebeding vooral van belang als mogelijkheid om de werknemer aan de werkgever te binden. Indien de werkgever kan bewerkstelligen dat de werknemer de genoten scholing slechts in de bestaande arbeidsovereenkomst kan aanwenden, zou dat de bereidheid tot het aanbieden van scholing kunnen vergroten. Daarom is de mogelijkheid van het sluiten van een concurrentiebeding vanuit het perspectief van het verhogen van het opleidingsniveau positief te beoordelen. Een sluitende regeling van het concurrentiebeding is van belang voor het bereiken van de hoogwaardige kenniseconomie. Het lijkt erop dat (de huidige) regeling van het concurrentiebe- 
ding met name oog heeft voor de bescherming van belangen van werknemers. Over de voorgestelde en inmiddels door de Eerste Kamer verworpen regeling schrijft Verburg (2005: 23) het volgende.

"Het hilarische resultaat zal zijn dat de werknemer ondanks het concurrentiebeding toch bij de concurrent opduikt, en dat zelfs nog met een billijke vergoeding, betaald door de ex-werkgever die probeerde dit tegen te houden! Ik adviseer dus bedrijven met research \& development-afdelingen/laboratoria in Nederland om hun investeringen op know-how gebied naar het buitenland te verleggen. (...) Zo ziet men dus dat met de linkerhand door het kabinet wordt gepoogd via kennisplatformen en dergelijke Nederland als kenniseconomie op de kaart te zetten, terwijl de rechterhand welhaast oproept om kennis elders in de wereld onder te brengen."

Daar staat tegenover dat de individuele werknemer, maar ook de arbeidsmarkt niet (direct) worden geholpen met het concurrentiebeding. De werknemer wordt immers door het beding belemmerd zijn (specifieke) kennis en vaardigheden aan te wenden ten behoeve van andere werkgevers, en wordt dus beperkt in zijn employability. ${ }^{108}$ Die belemmering zal de bereidheid van de werknemer om zich te scholen wellicht verminderen. Het concurrentiebeding is dus vanuit het perspectief van vergroting van de employability niet zonder meer zinvol.

In slechts 1 procent van de cao's is een concurrentiebeding voor werknemers ouder dan 18 jaar opgenomen, zo blijkt uit onderzoek van het ministerie van Sociale Zaken en Werkgelegenheid. ${ }^{109}$ Eigen onderzoek leert dat een enkele keer het sluiten van een concurrentiebeding bij cao wordt verboden, zoals in de cao voor de particuliere beveiligingsorganisaties 2004/2005, art. 12 lid 2. Dit lijkt een uitzondering: als een cao al iets over een concurrentiebeding bepaalt, is dat meestal dat het beding schriftelijk moet worden overeengekomen, hetgeen ook wettelijk is vereist, zie art. 7:653 lid 1 BW. Verreweg de meeste, te weten 16 procent, van de werknemers zijn bij individuele arbeidsovereenkomst gebonden aan een concurrentiebeding, van wie een overgrote meerderheid ook verwacht dat de werkgever hen daaraan zal houden. ${ }^{110}$ Uit de rechtspraak blijkt dat het concurrentiebeding soms wordt gebruikt om te voorkomen dat een werknemer de door de werkgever aangeboden en/of betaalde scholing aanwendt voor een andere werkgever. ${ }^{111}$ Overigens is het niet mogelijk de werknemer te binden aan een concurrentiebeding op grond van alleen de cao, zo blijkt uit de parlementaire geschiedenis. ${ }^{12}$ Tijdens de parlementaire behandeling van het nieuwe wetsvoorstel is over de vraag of in de cao een concurrentiebeding kan worden opgenomen, niet gesproken.

De regeling van het concurrentiebeding stelt geen nadere voorwaarden aan de geldigheid van het beding. Wel kan de werkgever worden verplicht om aan de werknemer voor de duur van de werking van het beding een vergoeding te betalen. De rechter stelt deze vergoeding naar billijkheid vast. In de voorgestelde regeling van het concurrentiebeding is een dergelijke vergoeding zelfs een vereiste voor de geldigheid van het concurrentiebeding. Daarmee wordt de werk- 
nemer in de gelegenheid gesteld om de periode van verplichte non-activiteit te overbruggen.

Zowel de huidige regeling als de eerder voorgestelde regeling bevat nauwelijks employability-stimulerende effecten. Opvallend is dat in de uitvoerige parlementaire behandeling van het wetsvoorstel niet over dergelijke effecten is gesproken. Vanuit het oogpunt van employability zou kunnen worden betoogd dat een concurrentiebeding slechts geldig kan worden geacht indien de werknemer door de werkgever in voldoende mate in staat wordt gesteld om andere passende arbeid te verwerven. Daarbij kunnen werkgever en werknemer de nadruk leggen op die 'andere' arbeid, zodat de werknemer in staat zal zijn om werkzaamheden te verrichten die niet in strijd komen met het concurrentiebeding. In dat geval kan worden betoogd dat in het wetsvoorstel wordt opgenomen, dat aan de werknemer toekomende vergoeding dient te worden benut om de werknemer employable te maken.

Dit betoog heeft slechts beperkte realiteitszin: mocht het wetsvoorstel wel zijn aangenomen, ook dan zou de werknemer veelal niet in staat zijn geweest gedurende de vaak korte periode waarin het beding werkt (meestal een jaar) zich om te scholen, zelf met gebruik van de hem ter beschikking staande vergoeding. Wij concluderen dan ook dat het huidige en de voorgestelde regeling van het concurrentiebeding zich zeer slecht verhoudt met het employability-beleid en zien weinig mogelijkheden daarin verandering te brengen. Een beperking van het gebruik van het concurrentiebeding tot die werkzaamheden die werkelijk concurrentiegevoelig zijn, ligt voor de hand, maar dan dient het concurrentiebeding ook deugdelijk afdwingbaar te zijn. Waar de werkgever nu 'gratis' een concurrentiebeding kan afspreken met de werknemer had de voorgestelde verplichte vergoeding de potentie bij te dragen aan de beperking van het gebruik van het beding tot de gevallen waarin de werkgever het werkelijk noodzakelijk vindt.

\subsubsection{MINIMUMVERBLIJFTIJD}

Een enkele keer wordt gewezen op het bestaan van een maatschappelijke norm die daaruit zou bestaan dat de werknemer gehouden is een zekere tijd bij de werkgever in dienst te blijven. Het Centraal Planbureau wijst in de macro-economische verkenningen 1999 op een dergelijke norm ${ }^{113}$.

“Ook een maatschappelijke norm die een werknemer na het volgen van een opleiding een zekere minimum verblijftijd bij zijn werkgever oplegt, beschermt tegen poaching. Een werknemer die zich snel laat wegkopen, ontwikkelt een reputatie die toekomstige werkgevers zal afschrikken in hem te investeren. Een dergelijke norm is, als die al bestaat, erg zwak en niet afdwingbaar.”

In de praktijk komt een juridisch afdwingbare 'verblijftijd' wel voor. De tijdelijke arbeidsovereenkomst is tussentijds niet opzegbaar, tenzij een periode van vijf jaar 
wordt overschreden. Zie voor dit laatste art. 7:684 BW. Dit betekent dat een werkgever de werknemer gedurende in ieder geval vijf jaar aan zich kan binden. Deze mogelijkheid wordt - een belangrijke uitzondering daargelaten - in de praktijk nauwelijks benut. Een van de redenen zal zijn dat het vaak weinig zinvol is een werknemer te binden die niet meer bereid is zich in te zetten voor het verrichten van zijn werkzaamheden. Een uitzondering betreft de sector betaald voetbal. Daar is gekozen voor een constructie met arbeidsovereenkomsten voor bepaalde tijd. Krachtens art. 7:667 lid 3 BW zijn deze arbeidsovereenkomsten niet tussentijds opzegbaar, tenzij partijen anders overeenkomen. Door de ketenregeling van art. 7:668a BW wordt de (laatste) tijdelijke arbeidsovereenkomst na zesendertig maanden of na drie verlengingen een arbeidsovereenkomst voor onbepaalde tijd. Een arbeidsovereenkomst voor onbepaalde tijd is altijd te beëindigen door opzegging. Dat is uiteraard niet de bedoeling. Om het ontstaan van een arbeidsovereenkomst voor onbepaalde tijd, en dus het recht van opzegging, te voorkomen is in de cao voor contractspelers betaald voetbal Nederland voorzien in een afwijking van art. 7:668a BW. Op grond van de cao worden tijdelijke arbeidsovereenkomsten geen arbeidsovereenkomst voor onbepaalde tijd. De werknemer kan slechts bij het einde van de tijdelijke arbeidsovereenkomst de werkgever verlaten. Het recht om ontbinding te vragen kan niet worden uitgesloten, maar het scheidsgerecht KNVB, die in plaats van de kantonrechter bevoegd is over dergelijke verzoeken te oordelen, weigert over het algemeen gevraagde ontbinding. ${ }^{114}$ Dit systeem is opgezet om te bewerkstelligen dat bij tussentijdse beëindiging van de arbeidsovereenkomst met wederzijds goedvinden de werkgever van de werknemer, of van de hem overnemende voetbalclub, een vergoeding kan bedingen, hetgeen in de praktijk met regelmaat gebeurt. Het is wel zaak om met de werknemer/voetballer tijdig in overleg te treden over de verlenging van de tijdelijke arbeidsovereenkomst. ${ }^{115}$ Indien daarover geen overeenstemming wordt bereikt, heeft de club het dreigmiddel de voetballer niet langer in de A-selectie op te stellen, waardoor de 'waarde' van de speler snel en aanzienlijk zal dalen en hij over het algemeen alsnog met zijn werkgever in onderhandeling treedt. In andere sectoren dan de sport zien we voor deze constructie weinig kansen.

Een ander tot op heden uitsluitend in de sector voetbal voorkomend verschijnsel is het verlengingsoptiebeding. Kort samengevat komt een dergelijk beding erop neer dat de werknemer bij tijdelijke indiensttreding reeds het eenzijdige aanbod doet om de tijdelijke arbeidsovereenkomst te verlengen. Na afloop van de arbeidsovereenkomst kan de werkgever gebruikmaken van het aanbod, maar hoeft dat niet te doen. De werknemer kan niet meer terugkomen op zijn aanbod, zo volgt uit art. 6:219 lid 3 BW. Hoewel het scheidsgerecht van de KNVB het optiebeding geldig heeft geacht, is de juridische toelaatbaarheid discutabel (Bungener en Verhulp 2004; Nieuwland 2004). Naar onze mening leent een dergelijk beding zich niet voor algemeen gebruik. 


\subsubsection{CONCLUSIE}

Het terugbetalings- of studiekostenbeding beoordelen wij niet uitsluitend negatief. Het kan werkgevers stimuleren om te investeren in de scholing van werknemers. Indien een dergelijk beding met inachtneming van de door de Hoge Raad ontwikkelde normen is overeengekomen, is het niet onevenredig belastend voor de werknemer. Het beding kan bijdragen aan het voorkomen van poachen en kan leiden tot een eerlijke verdeling van kosten in het geval een werknemer kort na de scholing die is betaald door de oude werkgever, in dienst treedt van een andere werkgever. Sociale partners kunnen de mogelijkheid om een regeling terzake te treffen in cao's, beter dan thans geschiedt, benutten en daarbij wellicht meer aandacht besteden aan (de gewenste) flexibiliteit.

Het concurrentiebeding is er juist op gericht om de werknemer zijn eigen werk niet meer te laten verrichten gedurende een zekere periode na het einde van de arbeidsovereenkomst. Daarmee is het beding moeilijk te verenigen met de gedachte van behoud of bevorderen van inzetbaarheid, tenzij die inzetbaarheid zich zal richten op het verwerven van andere werkzaamheden. Dat laatste zal veelal moeilijk op korte termijn te realiseren zijn vanwege de vaak specialistische kennis van de werknemer. De huidige (en ook de eerder voorgestelde) regeling van het concurrentiebeding zijn zeker niet waterdicht, hetgeen voor de inzetbaarheid van de werknemer niet binnen de eigen arbeid slecht is, maar wel voor de ontwikkeling van een hoogwaardige kenniseconomie en ook niet voor de employability in het algemeen, omdat de werkgever niet bereid zal zijn te investeren in werknemers die daaraan bijdragen. Hier geldt dat de wetgever duidelijke keuzes zal moeten maken. Hiertoe heeft de wetgever de kans gehad in het licht van de voorgestelde wijziging van de regeling van het concurrentiebeding.

De rol van sociale partners bij de vormgeving van arbeidsrechtelijke bedingen en de bevordering van employability zal beperkt zijn: een concurrentiebeding in de cao is niet geldig. Het overeenkomen van een minimumverblijftijd is dankzij de regeling van de tijdelijke arbeidsovereenkomst wel mogelijk, maar lijkt in de praktijk niet veel voor te komen. Dat geldt ook voor het verlengingsoptiebeding. Beide mogelijkheden lijken ons ook niet geschikt employability-inspanningen te stimuleren.

\subsection{SCHOLING IN HET ONTSLAGRECHT}

“Ten onrechte heeft hij (werknemer) zijn kaarten gezet op een absolute baangarantie. De garantie kan een werkgever niet geven.” (Ktr. 's-Hertogenbosch, 7 april 2005, JAR 2005/104)

\subsubsection{INLEIDING}

De invloed die het ontslagrecht en scholing kunnen hebben op werkzekerheid en dus op het werkloosheidsrisico is hierboven uitgebreid aan bod gekomen. Het 
ontslagrecht biedt verschillende mogelijkheden rekening te houden met het bevorderen en ontwikkelen van werkzekerheid voor werknemers. In deze paragraaf wordt onderzocht hoe veel ruimte het huidige ontslagrecht en eerder voorgestelde wijzigingen in het ontslagrecht ${ }^{116}$ bieden (boden) rekening houdend met scholing ter bevordering van werkzekerheid en preventie van werkloosheid. Hierbij zal worden stilgestaan bij de meest relevante regels die een rol spelen bij beëindiging van de arbeidsovereenkomst en zal worden bezien welke mogelijkheden er zijn om te voorzien in het bevorderen van de inzetbaarheid van werknemers door middel van scholing.

\subsubsection{PREVENTIEVE TOETS}

\section{Ruimte voor scholing}

Bij de toetsing van een ontslagaanvraag kan het CWI op basis van de algemene toetsingsmaatstaf, zie art. 3:1 Ontslagbesluit, rekening houden met scholingsinspanningen van werkgevers en werknemers. Het CWI neemt immers in aanmerking de mogelijkheden en belangen van de betrokken werkgever en werknemer. Ook bij ontslag wegens bedrijfseconomische redenen bestaat de mogelijkheid rekening te houden met scholingsinspanningen en employability van werknemers. De CWI kan op grond van art. 4:2 lid 6 Ontslagbesluit in afwijking van de anciënniteitsregels toestemming weigeren in verband met de zwakke arbeidsmarktpositie van een werknemer. De arbeidsmarktpositie van een werknemer is afhankelijk van de mate waarin een werknemer inzetbaar is op de arbeidsmarkt en dus employable is. De inzetbaarheid en employability worden verhoogd door scholing, dus op deze wijze kan indirect rekening worden gehouden met scholingsinspanningen.

Per 1 maart 2006 is het 'last in, first out'-beginsel (verder lifobeginsel) vervangen door het afspiegelingsbeginsel als hoofdregel bij bedrijfseconomisch ontslag. De mogelijkheid van de hoofdregel af te wijken op grond van de onmisbaarheid (of de zwakke arbeidsmarktpositie, zie art. 4:2 lid 5 resp. 4:2 lid 6 (oud) Ontslagbesluit) van een werknemer is daarbij onverminderd van toepassing. Het afspiegelingsbeginsel komt kort gezegd neer op het toepassen van het lifobeginsel op verschillende leeftijdsgroepen. Doel van de invoering van het afspiegelingsbeginsel is jongere werknemers, met veelal een korter dienstverband, meer kansen te bieden en daarbij (veelal oudere) werknemers met een langer dienstverband te stimuleren tot activiteiten gericht op verbetering van inzetbaarheid. ${ }^{117}$ Voorgesteld is bij de toepassing van het voorgenomen afspiegelingsbeginsel ook rekening te houden met het zogenaamde onmisbaarheidscriterium. Het onmisbaarheidscriterium komt erop neer dat een werkgever, in afwijking van het afspiegelingsbeginsel bij bedrijfseconomisch ontslag rekening mag houden met de onmisbaarheid van een werknemer binnen de onderneming. Deze mogelijkheid was voor 1 maart 2006 geregeld in art. 4:2 lid 5 Ontslagbesluit en na 1 maart 2006 in art. 4:2 lid 4 Ontslagbesluit. ${ }^{118}$ De Kamerleden Verburg en Noorman-Den Uyl hebben in een motie verzocht in dit verband ook rekening te houden met scholingsinspanningen door zowel werkgevers als werknemers. In reactie daarop 
heeft minister De Geus te kennen gegeven dat het niet voor de hand ligt dat de overheid in het Ontslagbesluit (nadere) criteria formuleert voor scholingsinspanningen van een werkgever. ${ }^{119}$ De minister wijst ter onderbouwing van zijn bezwaar tegen een algemene regeling op de maatvoering en de diversiteit van gevallen die zich in de praktijk kunnen voordoen. Dit neemt echter niet weg dat ook nu al de mogelijkheid bestaat, zij het indirect, rekening te houden met scholingsinspanningen.

Bij ontbinding van de arbeidsovereenkomst wordt soms rekening gehouden met de onmisbaarheid van een werknemer ter rechtvaardiging van een afwijking van het anciënniteitsbeginsel. ${ }^{120}$ Toepassing van het onmisbaarheidscriterium kan het gevaar meebrengen dat een werkgever (bewust) onvoldoende investeert in een bepaalde werknemer om hem daarmee minder onmisbaar te maken voor de onderneming. De werknemer heeft hier zelf ook een taak: hij kan de werkgever expliciet om scholing vragen. Denkbaar is dat bij onverkorte toepassing van het onmisbaarheidscriterium deze werknemer makkelijker ontslagen kan worden dan zijn collega's die door de werkgever beter geschoold zijn. Hierover wordt in het Ontslagbesluit niets geregeld, maar het CWI zal met het aanbieden of weigeren van scholing rekening houden bij de algemene toetsing van het ontslag. Door het onmisbaarheidscriterium in dergelijke gevallen te koppelen aan door de werkgevers verrichte scholingsinspanningen zou bovengenoemd gevaar wellicht (nog) beter kunnen worden ondervangen.

\section{Versoepeling preventieve toets?}

Het vergroten van het kennisniveau en employability van de werknemer maakt hem minder afhankelijk van zijn werkgever en leidt daarmee tot een gedeeltelijk herstel van het machtsevenwicht en dus tot ongelijkheidscompensatie. In de lijn van deze gedachte kan scholing een versoepeling van het ontslagrecht in de vorm van minder ontslagbescherming rechtvaardigen. De werkgever is immers zelf steeds meer afhankelijk van de (kennis van) de werknemer, zodat ongelijkheidscompensatie door middel van het vergroten van employability van werknemers in die gedachte een preventieve werking heeft. Deze gedachte is door Pim Fortuyn uitgedragen, onder meer in zijn betoog over ondernemers van de eigen arbeid, die door hun goede opleiding geen risico op de arbeidsmarkt lopen omdat er altijd emplooi voor ze is (Fortuyn 2002). De bestaande machtsongelijkheid tussen werkgever en werknemer kan ons inziens echter nooit volledig worden gecompenseerd door kennis en opleiding, laat staan dat goed opgeleide werknemers geen enkel risico lopen op de arbeidsmarkt, zoals Fortuyn stelt. Deze gedachte doet geen recht aan het feit dat verschillende aspecten bijdragen aan de machtsongelijkheid tussen werkgever en werknemer. In deze lijn heeft Rood erop gewezen dat ondanks het feit dat kennis en opleiding van de werknemer zijn toegenomen, het verschil in economische macht tussen werkgever en werknemer groot is gebleven (Rood 1998).

Hoewel kennis en opleiding het machtsevenwicht niet volledig kunnen herstellen, wint de gedachte dat kennis en opleiding daar wel invloed op hebben steeds 
meer terrein. Van verschillende kanten wordt gepleit voor een versoepeling van het - op ongelijkheidscompensatie gebaseerde - ontslagrecht in ruil voor het verhogen van het kennisniveau en daarmee de employability van werknemers door middel van scholing. ${ }^{121}$ Uiteraard dient deze gedachte gerelativeerd te worden in die zin dat ook andere aspecten ontslagbescherming rechtvaardigen.

De wens de preventieve toets te versoepelen of zelfs af te schaffen heeft zowel in de politiek als in de wetenschap draagvlak. Ook bij de sociale partners lijkt steeds meer bereidheid te bestaan tot versoepeling of afschaffing van de preventieve toets. Hoewel van werknemerszijde nog enige terughoudendheid bestaat op dit gebied, wint de gedachte het ontslagrecht te versoepelen in ruil voor andere vormen van bescherming ook daar terrein. ${ }^{122}$ Denkbaar is dat de positie van de werknemer wordt versterkt als de bescherming van de preventieve toets (voor een deel) wordt uitgeruild tegen meer employability-inspanningen van werkgevers. Met de minister menen wij dat concrete invulling door de sociale partners in specifieke bedrijfstakken voor de hand ligt, en tot betere resultaten kan leiden dan wetgeving. Cao-partijen kunnen rekening houden met de arbeidseconomische conjunctuur en andere factoren die van invloed zijn op het ontslagbeleid van werkgevers en meer of minder ontslagbescherming noodzakelijk maken. Van belang hierbij is dat over de mate van afwijking of versoepeling per cao-periode opnieuw kan worden onderhandeld. Op deze wijze kan een versoepeling van de preventieve toets leiden tot meer flexibiliteit tegen een door sociale partners te bepalen uitruil en kan de bescherming van de werknemer daar waar dat nodig is worden gewaarborgd. Een bescherming die niet uit het oog mag worden verloren en dan op maat kan worden geboden.

De regering heeft voorgesteld de sociale partners de mogelijkheid te bieden bij cao bij ontslag wegens bedrijfseconomische redenen af te wijken van de geldende ontslagcriteria. ${ }^{123}$ Deze mogelijkheid wordt in het wetsvoorstel Wet wijziging WW-stelsel en ontslagrecht als volgt uitgewerkt,

"Bij toepassing van door cao-partijen vastgestelde ontslagcriteria ligt het niet op de weg van de CWI om tussen private partijen afgesproken ontslagcriteria toe te passen. Dat is aan partijen zelf en in laatste instantie aan de rechter. Daarnaast is toetsing door de CWI ook niet wenselijk vanwege de hierbij te verwachten uitvoeringstechnische problemen, zoals toename van de complexiteit van de beoordeling van ontslagverzoeken en de als gevolg daarvan verwachte langere doorlooptijden voor het verlenen van vergunningen. Dit betekent dat indien cao-partijen ervoor kiezen om voor ontslag wegens bedrijfseconomische redenen afwijkende ontslagcriteria vast te stellen, bij ontslag geen ontslagvergunning van de CWI meer zal zijn vereist. Ter bescherming van de werknemer en om belasting van de rechterlijke macht te voorkomen zal erin worden voorzien, dat caopartijen in dat geval verplicht zullen zijn bezwaren van individuele werknemers tegen een voorgenomen ontslag zelf te toetsen, door middel van een op ondernemings- dan wel bedrijfstakniveau verplicht in te stellen bezwarenprocedure. Hiertoe zullen het Burgerlijk Wetboek, de Wet melding collectief ontslag en het 
Buitengewoon Besluit Arbeidsverhoudingen 1945 (BBA 1945) worden aangepast." 124

De mogelijkheid voor sociale partners af te wijken van de preventieve toets zou een belangrijke bijdrage kunnen leveren aan de invulling van scholing en employability bij ontslag. Deze gedachte wordt door de SER en de STAR ondersteund, zo blijkt uit de memorie van toelichting bij het ingetrokken voorstel:

"Voorts wijst de regering erop dat deze mogelijkheid (de mogelijkheid tot alternatieve ontslagcriteria en afwijken van de preventieve toets $\mathrm{AB}, \mathrm{EV}$ ) van belang kan zijn in het kader van door ondernemingen gevoerd beleid gericht op scholing en het vergroten van inzetbaarheid en vaardigheden van werknemers. Uit het SER-advies over de toekomstbestendigheid van de wW en de aanbeveling van de Stichting van 15 april 2005 blijkt dat beide organisaties unaniem voorstander zijn van dergelijke afspraken. Bij reorganisaties kunnen hierop aansluitende ontslagcriteria worden geformuleerd aan de hand waarvan in voorkomende gevallen de ontslagkeuze kan worden bepaald."

De mogelijkheid bij cao af te wijken van de geldende ontslagcriteria biedt de sociale partners de ruimte de bij cao gemaakte scholingsafspraken te voorzien van een (positieve) sanctie. In bestaande cao's worden scholingsafspraken maar weinig voorzien van een sanctie, hetgeen samenhangt met het feit dat deze afspraken veelal als een recht en niet als een verplichting worden geformuleerd. Als gevolg daarvan vermindert de afdwingbaarheid en dus de naleving van deze afspraken (zie hierover hoofdstuk 2). Indien de werkgever, onder de voorgestelde wijzigingen, heeft voldaan aan de scholingsafspraken, zou de werkgever kunnen worden toegestaan zijn werknemer makkelijker te ontslaan. Heeft hij echter geen scholing aangeboden en dus niet aan zijn bij cao overeengekomen verplichtingen voldaan, dan zou hij hierop kunnen worden afgerekend in de vorm van het niet toepassen van de bij diezelfde cao overeengekomen afwijkende ontslagcriteria. Vervolgens dient ons inziens het gangbare ontslagregime te herleven.

Hierboven bleek dat de regering heeft voorgesteld de sociale partners zelf te laten voorzien in een bezwaarprocedure indien afwijkende criteria worden gehanteerd en de preventieve toets komt te vervallen. ${ }^{125}$ Hoewel het voorzien in een bezwaarprocedure tegemoet kan komen aan de door de regering aangegeven bezwaren van het CWI, dient deze bezwaarprocedure ons inziens slechts te worden ingericht met een marginale toets. Dit heeft niet alleen te maken met de organisatorische en financiële consequenties voor de sociale partners indien zij in een dergelijke bezwaarprocedure moeten gaan voorzien. De meest voor de hand liggende invulling van een door de sociale partners op te leggen sanctie, indien in de bezwaarprocedure blijkt dat niet is voldaan aan de afgesproken ontslagcriteria, is dat de werkgever alsnog toestemming zal moeten vragen bij het CWI (of de kantonrechter zal moeten verzoeken de arbeidsovereenkomst te ontbinden) en dat niet de sociale partners zelf overgaan tot een (verdere) inhoudelijke beoordeling van het ontslag. In de bezwaarprocedure zal slechts getoetst dienen te 
worden of in afdoende mate is voldaan aan de afwijkende ontslagcriteria, om een afwijking van het gangbare ontslagrecht te rechtvaardigen. Mocht in de toekomst alsnog tot een dergelijke maatregel worden besloten, dan zal de wijze van toetsing met voldoende waarborgen dienen te worden omkleed.

De hierboven voorgestelde marginale toetsing is ons inziens de meest wenselijke weg, omdat in geval van een sterk inhoudelijk ingerichte bezwaarprocedure door de sociale partners, de complexiteit van het ontslagrecht niet wordt verminderd, en ook de flexibiliteit niet wordt bevorderd. In dat geval wordt een nieuwe ontslagrechtelijke toets in het leven geroepen, hetgeen ons inziens niet wenselijk is en de rechtszekerheid en de transparantie niet bevordert. Het hierboven genoemde bezwaar van het CWI de door cao-partijen afgesproken ontslagcriteria te toetsen komt te vervallen, simpelweg omdat aan de alternatieve ontslagcriteria niet is voldaan. De toets in de bezwaarprocedure zou dan ook uitsluitend de toets tot het wel of niet herleven van het gangbare ontslagregime moeten inhouden. De bezwaarprocedure kan op deze wijze voorzien in het 'herleven' van de preventieve toets indien uit de marginale toets blijkt dat aan de voorwaarden voor de versoepeling daarvan niet is voldaan. In dat laatste geval zal dus een volle toetsing van het ontslag moeten plaatsvinden door het CWI. Heeft de werkgever daarentegen wel voldaan aan de gemaakte afspraken, dan vervalt het toestemmingsvereiste. Deze afwijkingsmogelijkheid zal uiteraard met voldoende waarborgen moeten worden omkleed. Over de verdere (concrete) invulling van de bezwaarprocedure zal daarom nog moeten worden nagedacht. Hoewel een afwijkingsmogelijkheid bij cao ons inziens wenselijk is, zal eventueel in de toekomst bij een nieuw voorstel op dit gebied goed moeten worden nagedacht over de nadere uitwerking en invulling van deze mogelijkheid (Zondag 2005: 427).

De Kamerleden Weekers en Huizinga-Heringa hebben een motie ingediend waarin wordt verzocht af te zien van de afwijkingsmogelijkheid bij cao, omdat daarmee de regels eerder complexer dan eenvoudiger zouden worden. ${ }^{126}$ Hoewel de wens voor een eenvoudiger en minder complex ontslagrecht een breed draagvlak heeft en zeker aandacht verdient, hoeft de afwijkingsmogelijkheid het ontslagrecht niet per definitie complexer te maken. Het hierboven beschreven voorstel kan dit bezwaar ondervangen. Ook nu wordt in de rechtspraak en door het CWI rekening gehouden met in cao's gemaakte afspraken. Bij het invoeren van een afwijkingsmogelijkheid, zoals hierboven voorgesteld, wordt de ruimte voor de sociale partners slechts vergroot en geregeld. ${ }^{127}$ De afwijkingmogelijkheid kan tegemoetkomen aan de behoefte tot maatvoering. ${ }^{128}$ Op deze wijze kan rekening worden gehouden met de aard van de met de arbeidsovereenkomst samenhangende complexiteit van het ontslagrecht zonder daarbij de bescherming van de werknemer uit het oog te verliezen. De sociale partners kunnen hierin voorzien. Ook in de juridische literatuur wordt erop gewezen dat het van driekwart dwingend recht maken van de preventieve toets waarschijnlijk zal leiden tot meer maatwerk, deregulering en flexibilisering. ${ }^{129}$ De regering heeft het voorstel overigens ingetrokken met het argument dat zij geen mogelijkheid ziet te komen tot een evenwichtig pakket van maatregelen dat én de dynamiek van de arbeids- 
markt versterkt én voorkomt dat ouderen meer dan evenredig de ww instromen. ${ }^{130}$ De gedachte hierbij is dat sociale partners de ww zullen gebruiken als vangnet voor oudere werknemers. Deze gedachte houdt onvoldoende rekening met het feit dat alternatieve ontslagcriteria ook gericht kunnen zijn op employability.

De preventieve toets vormt een belangrijk fundament in de bestaande ontslagbescherming. Een drastische doorbreking van deze vorm van bescherming van de werknemer lijkt vooralsnog onvoldoende draagvlak te hebben. ${ }^{13}$ Daarom is, ons inziens, bij de doorbreking van de preventieve toets en de incorporatie van scholingsinspanningen bij de toetsing van ontslag een belangrijke rol weggelegd voor de sociale partners. Door afwijking bij cao mogelijk te maken kan worden onderzocht hoe groot het maatschappelijk draagvlak is voor een versoepeling van de preventieve toets tegen uitruil van andere en nieuwe mogelijkheden van bescherming, zoals bijvoorbeeld scholing, employability en activering. Door afwijking van de preventieve toets mogelijk te maken wordt immers een van de belangrijkste beschermingsconstructies in het huidige ontslagrecht onderhandelbaar en uitruilbaar gemaakt. Vervolgens zal moeten blijken waar en in hoeverre de behoefte bestaat de preventieve toets, eventueel wettelijk, verder te versoepelen in ruil voor deze nieuwe en andere vormen van bescherming (Heerma van Voss 2005: 128).

\subsubsection{OPZEGTERMIJNEN}

\section{Ruimte voor scholing}

Bij de invoering van de opzegtermijn, in de Wet op de arbeidsovereenkomst van 1907 is overwogen dat het voor beide partijen van belang is enige tijd vooraf te weten dat de bestaande dienstbetrekking zal eindigen. ${ }^{132}$ In de MvT wordt dat als volgt weergegeven: "èn in beginsel, omdat daardoor de band tusschen partijen wordt versterkt, het besef wordt verlevendigd, dat er eene geordende rechtsverhouding bestaat; èn uit een practisch oogpunt, omdat het zowel voor werkgever als voor den arbeider van belang is, eenigen tijd vooraf te weten, dat de bestaande dienstbetrekking zal eindigen." ${ }^{133}$ Later is door de wetgever geen andere verklaring voor de opzegtermijn gegeven (Verhulp 2005). Het praktisch belang voor de werknemer was (dus) dat hij op zoek kon gaan naar ander werk en dat zijn ontslag inging op een dag waarop nieuwe dienstbetrekkingen pleegden aan te vangen.

De werkgever was zelfs verplicht de werknemer in de gelegenheid te stellen ander werk te zoeken en gedurende die tijd het loon door te betalen (Canes 1908).

In 1953 en 1968 is de opzegtermijn voor oudere werknemers verlengd (Kuip 1993: 219). Bij de herziening van de regeling van de opzegtermijn in het kader van de Wet flexibiliteit en zekerheid, die leidde tot een verkorting van de opzegtermijnen, heeft de minister van Sociale Zaken en Werkgelegenheid laten weten: "Met minimaal een maand opzegtermijn resteert in alle gevallen een redelijke termijn om naar ander werk om te zien." ${ }^{134}$ De redelijke termijn om ander werk te zoeken varieert kennelijk afhankelijk van het tijdsgewricht waarin naar dat andere werk moet worden gezocht. 
Voor de werkgever is het voordeel van de opzegtermijn dat hij de tijd heeft op zoek te gaan naar een nieuwe werknemer. ${ }^{135}$ Een verklaring voor het bestaan van de opzegtermijn is dus ook het handhaven van stabiliteit op de arbeidsmarkt en het inbouwen van een zekere rust. De opzegtermijn kan daarom mede worden gezien als een periode waarin jegens elkaar bestaande verplichtingen kunnen worden afgewikkeld. Bestaande inspanningen van beide kanten moeten de tijd krijgen te worden afgerond. Dit hangt samen met het karakter van een duurovereenkomst, waarvan de arbeidsovereenkomst een speciale is. De aard van de duurovereenkomst en inspanningen gedurende die overeenkomst brengen immers mee dat de inspanningen en verplichtingen veelal nog enige tijd doorwerken en tijd nodig hebben om te worden afgerond. Ook scholingsinspanningen of verplichtingen die niet (volledig) zijn vervuld kunnen worden afgewikkeld. Hiertoe biedt de opzegtermijn een - zij het zeer beperkte - mogelijkheid. Het doel van de opzegtermijn lijkt dus tweeledig: enerzijds het afronden van de bestaande relatie, anderzijds het voorkomen van frictiewerkloosheid.

\section{Praktijk}

De opzegtermijn is echter in beginsel niet ingericht op het voorkomen van werkloosheid, ook niet door middel van scholing. De wettelijke duur van de opzegtermijn is daarvoor in ieder geval te kort, nu deze krachtens art. 7:672 lid $2 \mathrm{BW}$ voor de werkgever maximaal vier maanden bedraagt, terwijl die termijn op grond van het vierde lid vaak met een maand zal worden verkort. Soms wordt bij cao een afwijking van deze wettelijke termijn overeengekomen, maar een opzegtermijn van langer dan zes maanden komt naar onze inschatting nauwelijks voor. Naar huidig recht gaat de opzegtermijn pas in nadat de arbeidsovereenkomst is opgezegd. Anders gezegd: na de opzegging, gedurende de opzegtermijn, staat vast dat de arbeidsovereenkomst zal gaan eindigen. Partijen worden niet gestimuleerd gedurende deze periode pogingen te ondernemen de werknemer bij de eigen werkgever te plaatsen in andere passende werkzaamheden of om te investeren in scholing. Als daartoe wel mogelijkheden zijn, al dan niet na scholing, is er sprake van een herplaatsingsmogelijkheid die in het algemeen een opzegging in de weg zal staan, alleen al omdat de vergunning door het CWI wordt geweigerd.

\section{Kan de opzegtermijn anders worden ingezet?}

De duur van de opzegtermijn zou afhankelijk kunnen worden gesteld van de door partijen ondernomen scholingsinspanningen. Indien de werkgever zich geen inspanning heeft getroost de werknemer employable te houden, zal dat kunnen leiden tot verlenging van de opzegtermijn. Wellicht is het mogelijk om de werkgever te verplichten gedurende de verlengde opzegtermijn alsnog die inspanningen te verrichten, die hij had moeten verrichten tijdens de arbeidsovereenkomst. Indien de werkgever en werknemer zich voldoende inspanningen hebben getroost of indien de werknemer geen pogingen heeft ondernomen om zijn employability op peil te houden, ondanks inspanning of aanbiedingen van zijn werkgever daartoe, zou de opzegtermijn kunnen worden verkort. 
Een dergelijke constructie betekent een individualisering van de opzegtermijn, afhankelijk van eigen inspanningen van partijen. De wet biedt voldoende mogelijkheden om bij cao een dergelijke afspraak te maken. Lastig is dat het noodzakelijk is te beoordelen wat het vereiste niveau van inspanning van partijen is. $\mathrm{Nu}$ de employability zeer persoonlijk is, zal dat moeilijk in algemene termen te verwoorden zijn en dus moeilijk in algemene regelgeving te vatten zijn. Daarbij geldt dat, indien de opzegtermijn wordt verlengd, deze verlening tot doel moet hebben de werkgever alsnog in de gelegenheid te stellen aan inspanningen te voldoen. Dat kan veel tijd vergen, terwijl de werknemer er belang bij kan hebben zich niet in te spannen om zijn resterende arbeidsduur volledig 'uit te winnen'. De tegengestelde belangen laten zich slecht in een regeling vatten. Daarmee is het goed verklaarbaar dat de cao's terzake geen regeling treffen. We denken dat de gedachte de opzegtermijn afhankelijk te stellen van de scholingsinspanning van partijen geen werkelijke stimulans voor het bevorderen van de scholingsinspanning van werkgevers en werknemers kan zijn.

Wanneer de werkgever de arbeidsovereenkomst wegens het vervallen van de functie van de werknemer wenst op te zeggen, ligt het voor de hand van de werkgever te verlangen dat hij mogelijkheden onderzoekt de werknemer te herplaatsen. Zoals gezegd past dit in het voortraject: indien zich een mogelijkheid voordoet zal het CWI geen toestemming voor opzegging verlenen. Denkbaar is dat de werknemer niet direct geschikt is voor het verrichten van andere passende arbeid, maar daartoe na scholing wel geschikt zal zijn. De vraag is of van de werkgever kan worden verlangd de werknemer die scholing aan te bieden. Deze vraag ligt voor in de preventieve toets als het scholing betreft voor arbeid die de eigen werkgever kan aanbieden. Gaat het om scholing voor werkzaamheden die elders moeten worden verricht, dan kan tijdens de opzegtermijn de vraag opkomen of dergelijke scholing moet worden aangeboden. Dat zal evenwel zeldzaam zijn nu de opzegtermijn veelal te kort is om tot serieuze scholing te komen die de kans op herplaatsing vergroot. Wel is in veel sociale plannen een verplichting voor de werkgever tot het verrichten van onderzoek naar ander passend werk opgenomen, en daarvoor wordt een bepaalde periode die vaak beduidend langer is dan de opzegtermijn, als 'zoekperiode' aangewezen. Bij deze 'zoekverplichting' is zelden een scholingsverplichting opgenomen (Rayer et al. 2005: 529).

Indien vaststaat dat de werkgever voldoende argumenten heeft om de arbeidsovereenkomst met de werknemer op te zeggen, zou de werknemer in een herplaatsingsperiode 'geplaatst' kunnen worden. Tijdens deze periode heeft de werkgever de verplichting om voor de werknemer andere passende arbeid te zoeken en hem daartoe zonodig te scholen. In het ambtenarenrecht is in een dergelijke regeling voorzien. Die houdt in dat het bevoegd gezag gedurende een periode van 18 maanden een verplichting heeft de ambtenaar te herplaatsen, en hem in die periode minstens één maal een passende functie moet worden aangeboden. Ontslag is slechts toegestaan indien het bevoegd gezag op overtuigende wijze kan aantonen dat herplaatsing niet mogelijk is. Daarbij geldt dat het 
bevoegd gezag niet alleen binnen de eigen dienst, maar ook binnen de overheid en zelfs daarbuiten invulling kan geven aan de herplaatsingsplichten en dat scholing aangewezen kan zijn om die invulling gestalte te geven. ${ }^{136}$

Wij vrezen dat een dergelijke benadering in het arbeidsrecht minder vruchtbaar zal blijken te zijn. Allereerst geldt dat in de preventieve toets de beoordeling van de vraag of er andere (na scholing) passende arbeid voorhanden is reeds plaatsvindt. Ten tweede is van belang dat het ambtenarenrecht voor de ambtenaar andere regelingen kent na het einde van de aanstelling, dan die voor de werknemer na het einde van de arbeidsovereenkomst gelden. De ambtenaar kan aanspraak maken op WW en een aanvullingsregeling, de werknemer in het algemeen op een (eenmalige) ontslaguitkering. Dat leidt tot de conclusie dat de overheidswerkgever belang houdt bij employability van de voormalige ambtenaar: als hij na ontslag ander werk vindt voor de ontslagen ambtenaar, vervalt de aanvullingsverplichting.

De gewone werkgever heeft onder de huidige vormgeving van het ontslagrecht geen (direct financieel) belang meer bij de positie van de werknemer op de arbeidsmarkt na ontslagi37: de (eventuele) ontslagvergoeding heeft hij betaald en hij heeft geen verdere verplichtingen. In het arbeidsrecht zal een regeling waarbij verplichtingen worden geformuleerd na het eindigen van de arbeidsovereenkomst naar onze mening alleen goede invulling kunnen krijgen indien de ontslagvergoeding bij een dergelijke regeling wordt betrokken. Hoewel daarvoor wel is gepleit (Noordam 2000: 341), heeft de wetgever zich niet in deze richting uitgelaten, en valt niet te verwachten dat daarin op korte termijn verandering zal komen.

\subsubsection{KENNELIJK ONREDELIJK ONTSLAG}

\section{Ruimte voor scholing}

Er zijn verschillende gronden waarop een ontslag kennelijk onredelijk kan zijn. De belangrijkste grond is gelegen in het zogenaamde 'gevolgencriterium'. Dit criterium is geformuleerd in art. 7:681 lid 2 sub b BW en houdt in dat sprake kan zijn van kennelijk onredelijkheid indien de gevolgen van opzegging voor de werknemer te ernstig zijn in vergelijking met het belang van de werkgever bij de opzegging. Hierbij wordt expliciet verwezen naar de voor de werknemer getroffen voorzieningen en de voor hem bestaande mogelijkheden ander passend werk te vinden. Scholingsinspanningen kunnen invloed hebben op de (te verwachten) gevolgen bij ontslag en op de mogelijkheid voor een werknemer ander passend werk te vinden. Voorzien in scholingsfaciliteiten zou zo beschouwd onder omstandigheden gekwalificeerd kunnen worden als een getroffen voorziening. De formulering van het gevolgencriterium bij kennelijk onredelijk ontslag biedt ruimte rekening te houden met door werkgevers verrichte scholingsinspanningen of aangeboden scholing en dus de mate van employability van werknemers. 


\section{Praktijk}

In de praktijk wordt door rechters bij kennelijk onredelijk ontslag soms rekening gehouden met aspecten die, zij het indirect, verband houden met scholingsinspanningen of de inzetbaarheid van werknemers. Zo oordeelt de kantonrechter te Almelo in 2000 dat de werkgever zich tot het uiterste had moeten inspannen de werknemer elders binnen het concern in te passen, zo nodig met om- of bijscholing. Nu de werkgever aan deze verplichting niet heeft voldaan acht de kantonrechter het ontslag van de werknemer kennelijk onredelijk. ${ }^{13^{8}}$ De verplichting van de werkgever en de kennelijk onredelijkheid van het ontslag worden door de kantonrechter gebaseerd op goed werkgeverschap ex art. 7:611 BW. Opgemerkt dient te worden dat de kantonrechter de leeftijd van de werknemer, 53 jaar, en de lange duur van het dienstverband, 35 dienstjaren, in zijn beslissing mee weegt. De kantonrechter kent de werknemer in afwijking van het sociaal plan een vergoeding van 100.000 gulden toe.

In 2003 acht het hof's-Hertogenbosch het ontslag van een werknemer kennelijk onredelijk wegens het eenzijdig gerichte carrièreverloop van de werknemer. ${ }^{139}$ In het kader van een reorganisatie is aan werknemer conform het sociaal plan een vergoeding toegekend, in de vorm van een zogenaamd persoonlijk budget. Doelstelling van het sociaal plan is zoveel mogelijk werknemers aan een nieuwe functie te helpen door middel van een outplacementtraject. Werknemer is een van drie van de totaal 26 af te vloeien werknemers met een hogere functie, met een daarbij behorend salaris. Een andere van de drie werknemers is herplaatst binnen de onderneming en met de derde werknemer is een aparte financiële regeling getroffen. Werknemer vindt op grond van eigen inspanningen een andere baan tegen aanzienlijk slechtere voorwaarden. Het hof acht het ontslag kennelijk onredelijk wegens het eenzijdige carrièreverloop van de werknemer. Hij beschikt over zeer specifieke kennis op het gebied van de papierindustrie. Dit in combinatie met zijn leeftijd, de duur van het dienstverband (27 jaar) en de mogelijkheden elders een nieuwe baan te vinden maken het ontslag kennelijk onredelijk. Het hof laat hierbij meewegen dat in het sociaal plan geen enkele rekening is gehouden met de hoogte van het salaris.

Hoewel uit de hierboven weergegeven jurisprudentie niet direct een scholingsplicht kan worden afgeleid, is niet ondenkbaar dat het aanbieden van scholing of het verrichten van employability-inspanningen door de werkgever tot een ander oordeel zou hebben geleid. Ons valt op, op basis van een globale beschouwing van de relevante rechtspraak, dat daarin weinig aandacht is voor de scholingsinspanning van werkgever of werknemer, terwijl daar in het kader van de kennelijk onredelijk ontslagprocedure voldoende aanleiding toe is.

\section{$4 \cdot 5 \cdot 5$ ONTBINDING}

\section{Ruimte voor scholing}

De aard van de ontbindingsprocedure leent zich in beginsel niet voor de inhoudelijke beoordeling van de vraag of een werkgever heeft voldaan aan bepaalde 
verplichtingen gedurende de arbeidsovereenkomst. De ontbindingsprocedure is erop gericht snel en zeker tot beëindiging van de arbeidsovereenkomst te komen en leent zich niet bij voorbaat voor de inhoudelijke beoordeling van de vraag wat zich heeft afgespeeld ten tijde van de arbeidsovereenkomst. Bij het toekennen van een ontbindingsvergoeding wordt rekening gehouden met de (wijze van) beëindiging van de arbeidsovereenkomst of de gevolgen daarvan..$^{140}$ Verrichte scholingsinspanningen kunnen een (belangrijke) rol spelen bij de beantwoording van de vraag wat de mogelijke gevolgen van die beëindiging zijn. Als gevolg van de beëindiging van de arbeidsovereenkomst wordt de werknemer blootgesteld aan een werkloosheidsrisico. Het werkloosheidsrisico is groter naarmate er minder scholingsinspanningen zijn verricht. Omdat de gevolgen van scholingsinspanningen pas manifest worden op het moment dat de arbeidsovereenkomst wordt beëindigd, bestaat voldoende aanleiding hiermee rekening te houden in de ontbindingsprocedure en bij de toekenning van de ontbindingsvergoeding. Ook kan zich de situatie voordoen dat een werknemer die wegens gebrek aan scholing geen betere functie heeft kunnen vervullen binnen de eigen organisatie gedurende de arbeidsovereenkomst als gevolg daarvan ook beperkt wordt in zijn kansen een nieuwe baan te vinden op het moment dat de arbeidsovereenkomst wordt beëindigd. Een toekomstige werkgever zal een werknemer die beter geschoold is en dankzij die scholing een hogere of beter functie heeft vervuld waarschijnlijk eerder aannemen dan een werknemer voor wie dat niet het geval is. De kans op werkloosheid of een nieuwe baan wordt zo beschouwd beïnvloed door de mogelijkheden gedurende de arbeidsovereenkomst. De Baijingsleer ${ }^{141}$ biedt (voldoende) ruimte rekening te houden met deze glijdende schaal in feiten.

\section{Praktijk}

Hoe maken rechter, werkgever en werknemers gebruik van de mogelijkheid om scholingsinspanningen te (laten) beoordelen in de ontbindingsprocedure? Van werknemerszijde wordt soms gewezen op gebrekkige opleiding en in het verlengde daarvan de mogelijkheden voor een werknemer ander werk te vinden. ${ }^{142}$ Soms kent de kantonrechter betekenis toe aan gebrekkige opleiding en eenzijdige werkervaring ${ }^{143}$ en overweegt hij dat de werkgever zo nodig door aanvullende opleiding een andere passende functie voor een werknemer had moeten vinden. ${ }^{144}$ Gebrekkige opleiding van werknemers wordt daarentegen door kantonrechters ook gebruikt als argument de arbeidsovereenkomst te ontbinden ${ }^{145}$, soms zelfs in afwijking van het anciënniteitsbeginsel. ${ }^{146}$

Een verplichting voor de werknemer mee te werken aan zijn eigen inzetbaarheid is recent aangenomen. ${ }^{147}$ De kantonrechter te Utrecht heeft de arbeidsovereenkomst ontbonden en in afwijking van het sociaal plan een lagere vergoeding toegekend. Reden hiervoor is dat de werknemer onvoldoende zou hebben meegewerkt aan outplacementbegeleiding. De kantonrechter heeft als volgt beschikt: “A. heeft evenwel, om hem moverende redenen, niet deelgenomen aan het outplacementtraject. Dat is verwijtbaar, omdat hij aldus de kans met behulp van zijn werkgever extern herplaatst te worden onmogelijk heeft gemaakt. Dat klemt te meer, nu hij Campina verwijt hem geen opleidingstraject te hebben aangebo- 
den. Zijn wens tot om- of herscholing is nu juist een van de aspecten die tijdens een outplacementtraject aan de orde kunnen komen. Eveneens is verwijtbaar dat A. het aanbod heeft afgewezen om tijdelijk, tot de sluiting in 2006, in Hilversum geplaatst te worden, naast het volgen van een outplacementtraject. Ten onrechte heeft hij zijn kaarten gezet op een absolute baangarantie. Die garantie kan een werkgever niet geven."

De hierboven genoemde jurisprudentie geeft een wisselend beeld over de mate waarin en de wijze waarop in de ontbindingsprocedure rekening wordt gehouden met scholing en dus de mate van employability of inzetbaarheid van de werknemer. Het betreft hier overigens slechts een heel klein deel van het totaal aantal ontbindingen en de rechtspraak op dit gebied is zeer casuïstisch.

\subsubsection{SCHOLING EN ONTSLAGVERGOEDINGEN, MOTIE VERBURG EN BUSSEMAKER}

Voorgesteld is (expliciet) rekening te houden met scholingsinspanningen bij het toekennen van een ontslagvergoeding. De leden Verburg en Bussemaker hebben de regering verzocht om in het ontslagrecht ook de factor investering in en scholing van werknemer mee te nemen: "overwegende, dat werkgever en werknemer door middel van het preventief bij- en omscholen een gezamenlijke verantwoordelijkheid hebben voor een duurzame positie van de werknemer op de arbeidsmarkt; overwegende, dat de investering in de positie op de arbeidsmarkt dient mee te wegen in het ontslag en de ontslagvergoeding." 148 Deze motie wordt zo geïnterpreteerd dat werknemers die adequaat zijn geschoold geen gouden of zilveren handdruk nodig hebben als zij zo kunnen overstappen naar een nieuwe baan. ${ }^{149}$

De ontslagvergoeding is hierboven meermalen aan bod gekomen. Eerder constateerden we dat in de gepubliceerde rechtspraak opmerkelijk weinig aandacht wordt besteed aan verrichte scholingsinspanningen door werkgever en werknemer. Een enkele keer wegen rechters de scholingsinspanningen, vaak indirect, mee bij het toekennen van een ontslagvergoeding, zo bleek eerder. ${ }^{150}$ Zowel bij kennelijk onredelijk ontslag als bij ontbinding van de arbeidsovereenkomst bestaat de ruimte bij het bepalen van de hoogte van de ontslagvergoeding rekening te houden met scholingsinspanningen. Afhankelijk van de verrichte scholingsinspanningen door zowel werkgevers als werknemers kan een hogere of lagere vergoeding worden toegekend. De motie bevat in die zin niet veel nieuws. Toch verdient het ons inziens aanbeveling partijen bij de overeenkomst bewust te maken van deze bestaande mogelijkheden. De werkgever, die uit hoofde van goed werkgeverschap investeert in de employability van zijn werknemers, kan bij het toekennen van de ontslagvergoeding worden beloond. De rechter zou bij het vaststellen van de hoogte van de aan de werknemer toekomende vergoeding rekening kunnen houden met de door de werkgever betaalde scholingskosten en met de arbeidsmarktpositie van de werknemer. 
Hoewel er in beginsel niets op tegen is bij het toekennen van een ontslagvergoeding rekening te houden met scholing, kunnen wij ons niet vinden in de in de motie geopperde gedachte dat in het geheel geen ontslagvergoeding hoeft te worden toegekend aan werknemers die adequaat zijn geschoold en (mede daardoor) kunnen overstappen naar een nieuwe baan. In deze gedachte wordt ervan uitgegaan dat de ontslagvergoeding in het geheel niet nodig is indien een werknemer voldoende scholing is aangeboden. Los van aangeboden scholing kunnen er echter ook andere omstandigheden het toekennen van een ontslagvergoeding rechtvaardigen (Baris 2004: 329-330; Grapperhaus 2003: 4-5; Rood 1998: 529). Zonder hier al te diep in te gaan op de (mogelijke) grondslagen van de ontslagvergoeding (Baris 2004: 339-345; Loonstra en Zondag 2000: 1267; Loonstra 2001: 32-40; Loonstra 2000: 309-326; Grapperhaus 2003: 416-423) kan bijvoorbeeld de verwijtbaarheid een rol spelen bij de toe te kennen vergoeding. Het voorstel de ontslagvergoeding af te schaffen of in ieder geval aanzienlijk te beperken indien voldoende scholingsmogelijkheden zijn geboden ter bevordering van employability en werkzekerheid, houdt hiermee ons inziens onvoldoende rekening. Scholing mag onder de huidige omstandigheden en vormgeving van het ontslagrecht geen argument vormen de ontslagvergoeding geheel af te schaffen.

De SER is inmiddels verzocht in zijn middellangetermijnadvies over het sociaal en economisch beleid rekening te houden met scholing en ontslagvergoedingen en zal hierover naar verwachting in het najaar van 2006 adviseren. Pas na het uitbrengen van dit advies zal de regering zich hierover verder beraden.

\subsubsection{ONTSLAGRECHT EN WW}

In dit onderzoek is de aandacht gericht op het bevorderen van employability en inzetbaarheid van werkende werknemers door middel van scholing en op de bevordering van de flexibiliteit en de activering van de arbeidsmarkt. Weinig is stilgestaan bij reïntegratieprikkels vanuit de ww, simpelweg omdat in de door ons besproken problematiek van werkloosheid (nog) geen sprake is. Dit neemt echter niet weg dat de vormgeving van de ww invloed kan hebben op het ontslagbeleid van werkgevers en invloed kan hebben op het benutten van de ruimte die bestaat in het ontslagrecht rekening te houden met scholing en employability. Zo kunnen employability-bevorderende maatregelen in het ontslagrecht worden tegengewerkt door regels in de wW en vice versa. Een voorbeeld moge dit verduidelijken. In het wetsvoorstel tot wijziging van het ww-stelsel en het ontslagrecht is voorgesteld de zogenaamde 'preventieprikkel' in de ww in te voeren. ${ }^{151}$ Deze prikkel komt er kort gezegd op neer dat de UWV (een deel van) de WW-uitkering aan werknemers van 55 jaar of ouder verhaalt op de werkgever. Deze regeling komt neer op een, eerder voorgestelde (Scholtens 2001: 1071-1072; Damsteegt 2003: 476), malus in de ww. Doel van de regeling is werkgevers te stimuleren te investeren in employability en werkloosheidspreventie van oudere werknemers. Werkgevers moeten zo een sterker belang krijgen om te investeren in inzetbaarheid van oudere werknemers en om te voorzien in outplacementbe- 
geleiding waarmee werkloosheid kan worden voorkomen. ${ }^{152}$ De gedachte is dat deze regeling leidt tot extra ontslagbescherming van oudere werknemers. Hoewel deze bescherming wellicht ten koste gaat van jongere werknemers, vinden jongere werknemers gemiddeld sneller een nieuwe baan en kan hiermee (op korte termijn) een gunstig effect op de werkloosheid optreden, aldus de regering. ${ }^{153}$

Op de voorgestelde regeling is veel kritiek mogelijk, welke in het kader van dit onderzoek te ver strekt deze te behandelen (Scholtens 2001: 1071-1072; Damsteegt 2003: 476). In het kader van dit onderzoek is van belang dat een dergelijke regeling employabilitybevorderende maatregelen in het ontslagrecht kan beïnvloeden. Zo is in verband met hetzelfde wetsvoorstel besloten het lifobeginsel te wijzingen in die zin dat het afspiegelingsbeginsel hoofdregel is geworden. ${ }^{154}$ De vraag is welke wisselwerking deze regelingen op elkaar hebben. Enerzijds maakt de invoering van het afspiegelingsbeginsel als hoofdregel het makkelijker oudere werknemers, die veelal langer in dienst zijn, te ontslaan. Anderzijds beoogd de preventieprikkel het voor de werkgever moeilijker - althans financieel onaantrekkelijk - te maken oudere werknemers te ontslaan. De vraag is echter of de preventieprikkel inderdaad een tegenwicht biedt aan het makkelijker kunnen ontslaan van oudere werknemers. Onze gedachte is dat de oudere werknemer bij de toepassing - en toepasselijkheid, het moet hierbij immers gaan om bedrijfseconomisch ontslag van oudere werknemers - van deze twee regelingen op beide vlakken misgrijpt. De oudere werknemer kan enerzijds makkelijker worden ontslagen en anderzijds worden werkgevers gestimuleerd daarvan ook nog eens extra gebruik te maken voordat een werknemer de leeftijd van 55 jaar heeft bereikt.

Ook met betrekking tot de preventieve toets zal de preventieprikkel weinig employabilitybevorderend effect sorteren. Als de preventieve toets wordt versoepeld in die zin dat werknemers makkelijker ontslagen kunnen worden indien de werkgever heeft voldaan aan bij cao overeengekomen scholingsverplichtingen, is de voorgestelde preventieprikkel niet op zijn plaats. Deze prikkel zou als gevolg hebben dat een werkgever die heeft voldaan aan zijn scholingsverplichtingen los daarvan gestraft wordt op het moment dat hij na het voldoen aan die verplichtingen een oudere werknemer ontslaat. In dat geval is er weinig reden voor de werkgever te kiezen voor een soepeler ontslagregime en daarvoor employabilitybevorderende maatregelen te treffen. Hij kan dan net zo goed besluiten zijn oudere werknemers zonder die extra inspanningen te ontslaan via het reguliere regime, bij bedrijfseconomisch ontslag met toepassingen van het afspiegelingsbeginsel, voordat een werknemer de leeftijd van 55 jaar heeft bereikt. Het mag duidelijk zijn dat een dergelijk resultaat niet wenselijk is. (Zie over het ontslagbeleid met betrekking tot oudere werknemers de Bijlage bij dit onderzoek.)

Hoewel de hierboven besproken regeling (slechts) betrekking heeft op oudere werknemers, biedt het een goed voorbeeld van de invloed die het ontslagrecht en de ww op elkaar kunnen hebben. Wil het ontslagrecht de inzetbaarheid en 
employability van de werkende werknemer vergroten, dan zal hiermee rekening moeten worden gehouden in de vormgeving van de Ww. Negatieve prikkels vanuit de Ww ter bevordering van employability tegenover positieve prikkels in het ontslagrecht zullen eerder leiden tot benadeling van kwetsbare groepen en niet tot het bevorderen van werkzekerheid en preventie van werkloosheid voor de groepen waarvoor dat bij uitstek wenselijk is.

\subsubsection{NAAR EEN ACTIVEREND ONTSLAGRECHT?}

Uit het vorenstaande blijkt dat het huidige ontslagrecht aanzienlijk beter kan worden benut om employability te bevorderen dan thans geschiedt. We pleiten ervoor te bewerkstelligen dat sociale partners die mogelijkheden beter benutten dan thans het geval lijkt.

Tot (bijna) slot nog een paar overwegingen in het kader van de herziening van het ontslagrecht. Laten we vooropstellen dat een herziening van het ontslagrecht naar onze mening nodig is. Het ontslagrecht is verworden tot zeer complexe regelgeving, met veel systeemfouten en onduidelijkheden, die niet zonder meer leidt tot een billijke uitkomst. Daarbij is het ontslagrecht nu meer gericht op het afrekenen met het verleden dan het toerusten van de werknemer op de arbeidsmarkt. Zonder het belang van een billijke afwikkeling te onderschatten, menen we dat het ontslagrecht meer oog dan thans kan hebben voor de toekomst van de werknemer. Art. 7:611 BW bepaalt dat de werkgever zich heeft te gedragen als een goed werkgever betaamt. Tot dat goede werkgeverschap behoort naar onze mening ook dat de werkgever rekening houdt met de mogelijkheid dat de werknemer werkloos wordt. De werkgever is over het algemeen (behoudens ontslag op staande voet of eigen keuzes van de werknemer die leiden tot beëindiging van de arbeidsovereenkomst) voor die werkloosheid verantwoordelijk: hij is immers overgegaan tot het beëindigen van de arbeidsovereenkomst. De gedachte dat de werkgever dan ook een verantwoordelijkheid heeft om bij te dragen aan het voorkomen van (verdere) werkloosheid, lijkt ons een voor de hand liggende conclusie. Naar onze mening kan bij een herziening van het ontslagrecht de huidige ontslagvergoedingspraktijk niet ongewijzigd blijven.

Ervaringen met de preventie van structurele uitval wegens arbeidsongeschiktheid hebben geleerd dat positieve en negatieve prikkels echt werken. Na de invoering van de Wet Verbetering Poortwachter is de uitstroom in de arbeidsongeschiktheidsverzekeringen opmerkelijk afgenomen. Een dergelijk systeem kan wellicht ook goed werken bij het voorkomen van (langdurige) werkloosheid, en daarbij kan de ontslagvergoeding een belangrijke rol spelen. Indien de thans gebruikelijke ontslagvergoeding moet worden aangewend ter bestrijding van de kosten van werkloosheid en van de kosten gemoeid met het vinden van andere arbeid, zal daarin een zeer grote prikkel voor de werknemer gevonden kunnen worden om snel andere passende arbeid te aanvaarden. Indien de werkgever een deel van de vergoeding kan verrekenen met de door hem tijdens het dienstverband gemaakte kosten om de werknemer employable te houden, en in dat geval 
wellicht meer van de vergoeding kan inhouden dan zijn daadwerkelijke kosten, kan dat een belangrijke stimulans zijn te investeren in de employability van de werknemer. Zeker kort na het ontslag ligt hier eerder een taak voor de werkgever en werknemer dan voor de gemeenschap: de gemeenschap heeft pas een taak bij langdurige werkloosheid. Deze risicoverdeling past bij de subsidiaire taak van de publieke sociale zekerheid (Noordam 2003: 341).

Er zijn meerdere systemen denkbaar om een dergelijke verantwoordelijkheidsverdeling vorm te geven. Het voert te ver die hier te bespreken, maar wij hopen dat bij de herziening van het ontslagrecht deze verantwoordelijkheidsverdeling onderdeel van de overwegingen is.

\subsection{CONCLUSIES}

Het belang van scholing en employability vindt steeds bredere erkenning. Scholing kan bijdragen aan preventie van werkloosheid en aan werkzekerheid, en kan een belangrijke bijdrage leveren aan de gewenste ontwikkeling van een hoogwaardige kenniseconomie. Scholing en employability van werknemers vormen speerpunten in de huidige politieke en maatschappelijke discussie. Hoewel in Nederland al veel scholingsfaciliteiten bestaan, kan het gebruik daarvan worden bevorderd. Ook scholingsafspraken in cao's zouden beter kunnen worden benut. Meer bekendheid met de bestaande faciliteiten en afspraken kan daaraan bijdragen.

In deze bijdrage staat voorop de mogelijkheid het ontslagrecht in te zetten als stimulans voor werkgever en werknemer om werkloosheid te voorkomen. Dit kan worden verbonden aan de al lang bestaande wens het ontslagrecht te herzien. Sommige voorstellen tot herziening bevatten een mogelijkheid het ontslagrecht meer activerend te maken. De voorgestelde mogelijkheid af te wijken van de preventieve toets had een opening geboden meer rekening te houden met scholing bij ontslag. Daarnaast had dit de mogelijkheid geboden scholingsafspraken in cao's (beter) afdwingbaar te maken. Invoering van het voorstel had ruimte geboden te onderzoeken hoe groot het maatschappelijke draagvlak is bestaande zekerheden te handhaven of uit te ruilen tegen andere nieuwe vormen van bescherming. Ook andere voorgestelde herzieningen worden in deze bijdrage besproken. De conclusie is dat de herzieningsvoorstellen over het algemeen niet gericht zijn op activering van partijen met als doel de werkloosheid van de werknemer te voorkomen, maar eerder op een zorgvuldige en rechtvaardige afwikkeling van de arbeidsovereenkomst. Hoewel we het belang daarvan onderkennen, achten we dat een wat beperkte visie op het doel van het ontslagrecht: dat doel is in onze ogen niet alleen gericht op het verleden (afwikkeling), maar vooral op de toekomst van de werknemer. De werknemer moet door de werkgever goed toegerust op de arbeidsmarkt worden 'teruggezet', waardoor hij een reële kans heeft op het vinden van andere passende arbeid.

Maar ook zonder de invoering van ingrijpende wijzigingen in het ontslagrecht kan dat recht meer activerend worden ingezet. Werkgevers, werknemers en hun 
vertegenwoordigers zouden zich meer bewust kunnen zijn van de verschuiving van baanzekerheid naar werkzekerheid en niet alleen in cao's en andere afspraken maar ook bij het ontslag vaker kunnen wijzen op het belang van scholingsinspanningen. Het ontslagrecht is in belangrijke mate niet (geheel, maar driekwart) dwingend recht, zodat afwijkingen bij cao zijn toegestaan. Zo is denkbaar dat in cao's of sociale plannen de ontslagbescherming, zoals opzegtermijnen of ontslagvergoedingen, geheel of gedeeltelijk wordt ingeruild tegen employabilitybevorderende maatregelen. Uit onderzoek blijkt tot op heden niet dat sociale partners deze mogelijkheden optimaal benutten. Toch zouden zij op deze manier vorm kunnen geven aan activering van werknemers en werkgevers, gericht op het vinden van andere passende werkzaamheden voor de met ontslag bedreigde werknemer. Een dergelijke bewustwording en uitvoering zijn nog niet volledig aanwezig. Dit neemt echter niet weg dat meer nadruk op scholingsinspanningen in het ontslagrecht waarschijnlijk zal leiden tot een wenselijke ontwikkeling; de overgang van baanzekerheid naar werkzekerheid kan hiermee worden bevorderd.

In deze bijdrage onderzoeken we een paar mogelijkheden om de verschuiving van baanzekerheid naar werkzekerheid binnen het huidige ontslagrecht vorm te geven. Sociale partners kunnen besluiten scholingsafspraken in cao's te koppelen aan de opzegtermijn. Indien de werkgever zijn scholingsverplichting heeft verzuimd, zou de opzegtermijn kunnen worden verlengd. Hoewel een verlenging van de opzegtermijn de werknemer onvoldoende tijd biedt echt employable te worden, zou hij in ieder geval met behoud van loon een begin kunnen maken met een inhaalslag en kan dit wellicht toch een positief effect hebben op de instroom in en de duur van de ww. In ieder geval krijgen scholingsafspraken op deze wijze een meer verplichtend karakter, waardoor het gebruik kan worden bevorderd. Daarvoor zal wel een verlenging van de bestaande termijnen nodig zijn. Hoewel niet onmogelijk, zien we verschillende problemen bij de invoering van een dergelijke regeling. De belangrijkste zijn de noodzakelijke controle op de tijdens de arbeidsovereenkomst verrichte employability-inspanningen en de tegenzin om te investeren in een werknemer van wie vaststaat dat hij uit dienst zal treden.

Rechters lijken bij kennelijk onredelijk ontslag (iets) meer rekening te houden met scholingsinspanningen dan bij ontbinding van de arbeidsovereenkomst. Heeft een werkgever voldoende scholingsinspanningen verricht, dan kan dat tot uiting komen in een lagere aan de werknemer toe te kennen vergoeding; is daarvan onvoldoende sprake, dan kan dat tot uiting komen in een hogere ontslagvergoeding. Naar onze mening ligt het voor de hand bij de toekenning van een ontbindingsvergoeding niet alleen rekening te houden met de vraag óf de werknemer een andere arbeidsovereenkomst heeft gesloten of daar concreet zicht op heeft, maar ook met de kans dat de werknemer andere passende arbeid zal vinden. Dit geldt temeer indien de werkgever aan die kans voor de werknemer heeft bijgedragen. 
Ingrijpen van de wetgever om te bereiken dat scholingsinspanningen in de ontbindingsprocedure worden meegewogen, lijkt ons gelet op de aard van de ontbindingsprocedure en de discretionaire bevoegdheid van kantonrechters niet wenselijk. Ook een verplichting tot het overleggen van een scholingsverslag lijkt ons niet wenselijk. Ervaringen met het verplichte reïntegratieverslag bieden weinig hoop dat een verplichting bij ontbinding een scholingsverslag te overleggen zal leiden tot het gewenste resultaat. Tot wetgeving op het gebied van het overleggen van scholingsverslagen bij ontbindingsverzoeken zal het daarom niet komen. Wel kunnen sociale partners met het maken van scholingsafspraken in cao's en sociaal plannen de toetsing daarvan in de ontbindingsprocedure bevorderen. Indien sociale partners scholingsinspanningen vastleggen in een sociaal plan en de kosten daarvan in mindering brengen op de aan de werknemer bij ontslag toe te kennen vergoeding, zal de rechter die keuze (employabilityinspanningen in plaats van ontslagvergoeding) in beginsel volgen. Kantonrechters houden immers rekening met in sociale plannen gemaakte afspraken. ${ }^{155}$ Ook zouden kantonrechters zelf het initiatief kunnen nemen in het benadrukken van scholingsinspanningen in de ontbindingsprocedure. Gedacht kan worden aan het opnemen van een aanbeveling hieromtrent in de aanbevelingen van de kring van kantonrechters. Hierbij kan tevens worden stilgestaan bij het meewegen van scholingsinspanningen in (de hoogte van) de ontbindingsvergoeding.

Daarenboven speelt ook de samenhang tussen het ontslagrecht en de wW een belangrijke rol. Bij een employability-bevorderend ontslagrecht hoort een wW die deze uitgangspunten aanvult en versterkt. Hoewel het ontslagrecht een belangrijke rol kan vervullen in de vormgeving van een employabilitybevorderend en inzetbaarheidstimulerend beleid, zal hierop moeten worden ingespeeld in de ww. Deze onderlinge samenhang mag niet worden verwaarloosd wil men komen tot een flexibele arbeidsmarkt waarin de noodzakelijke bescherming van de werknemer niet uit het oog wordt verloren. 


\section{DEEL II I}

\section{ONTSLAGRECHT EN OUDERE WERKNEMERS}

In deze bijlage wordt nagegaan op welke wijze in het ontslagrecht rekening wordt gehouden met de leeftijd van werknemers. Aandacht wordt besteed aan de aard van de arbeidsovereenkomst met oudere werknemers en de wijzen waarop arbeidsovereenkomsten met oudere werknemers kunnen eindigen. Hierbij wordt ook ingegaan op de invloed die het bereiken van de 65-jarige, of pensioengerechtigde, leeftijd heeft op het (voort) bestaan van de arbeidsovereenkomst.

\section{Einde van rechtswege ${ }^{156}$; de 'pensioenregel'}

In de literatuur is de vraag aan de orde gekomen of een arbeidsovereenkomst met een werknemer die de leeftijd van 65 jaar bereikt moet worden aangemerkt als een arbeidsovereenkomst die van rechtswege eindigt zonder dat daarover in de arbeidsovereenkomst afspraken zijn gemaakt. Voor het aannemen van een dergelijke 'pensioenregel' is in het verleden gepleit. ${ }^{157}$ De gedachte dat de arbeidsovereenkomst van rechtswege eindigt op het moment dat de werknemer de leeftijd van 65 jaar heeft bereikt is echter geen vanzelfsprekendheid (meer). Zo wijzen Verhulp en Keulaerds en Vas Nunes er op dat er onvoldoende aanleiding bestaat voor het aannemen van de pensioenregel. ${ }^{158}$

Ter onderbouwing van het aannemen van de pensioenregel wordt verwezen naar het in 1995 gewezen arrest Codfried/ISS. ${ }^{159}$ De Hoge Raad overweegt in dit arrest dat “(...) niet kan worden gezegd dat de regel dat een dienstbetrekking in het algemeen van rechtswege eindigt bij het bereiken van de 65-jarige leeftijd, niet langer in overeenstemming is met de rechtsopvatting van brede lagen van de bevolking." De Hoge Raad zegt in deze overweging echter niets over de wijze waarop de arbeidsovereenkomst van rechtswege kan eindigen, maar zegt slechts dat het eindigen op zich in overeenstemming is met de rechtsopvatting binnen brede lagen van de bevolking.

Ook het in 2002 gewezen arrest Op 't Land/Employment Service ${ }^{160}$ geeft geen aanleiding tot het uitgangspunt dat de arbeidsovereenkomst bij het bereiken van de leeftijd van 65 jaar zonder meer van rechtswege eindigt. In dit arrest overweegt de Hoge Raad: “De regering heeft voorts (in het kader van de parlementaire behandeling van de WGBL, AB) benadrukt dat voor de gehanteerde leeftijdsgrens een groot maatschappelijk draagvlak bestaat en dat deze aansluit bij de sociale zekerheidswetgeving. Bij deze stand van zaken is er ook thans geen aanleiding tot een minder terughoudende beoordeling dan is aanvaard in het vermelde arrest van de Hoge Raad van 13 januari 1995 en evenmin grond voor het oordeel dat een objectieve en redelijke rechtvaardiging voor het onvrijwillig beëindigen van de dienstbetrekking bij het bereiken van de 65-jarige leeftijd niet langer bestaat." In casu was de toestemming voor ontslag verleend en stelde werkneemster vervolgens een vordering in wegens kennelijk onredelijk ontslag (zie hier- 
over verder § 5). Het bestaan van de pensioenregel kan hieruit niet worden afgeleid. In een in 2004 door de Hoge Raad gewezen arrest ${ }^{161}$ betrekking hebbend op leeftijdsontslag van vliegers, lagen cao-afspraken ten grondslag aan het (verplichte) leeftijdsontslag. Ook dit arrest kan hiermee geen aanleiding vormen voor het aannemen van een pensioenregel.

In een recente beschikking wijst de Kantonrechter Utrecht de pensioenregel expliciet van de hand. ${ }^{162}$ De kantonrechter stelt dat uit het arrest Codfried/IsS niet kan worden afgeleid hoe de arbeidsovereenkomst dient te eindigen. Dat de opvatting dat het op 65-jarige leeftijd tijd wordt te stoppen met werken ongetwijfeld door velen wordt gedeeld, brengt aldus de kantonrechter niet zonder meer met zich mee dat een arbeidsovereenkomst terzake waarvan partijen niet zijn overeengekomen dat deze eindigt bij het bereiken van 65-jarige leeftijd, niettemin van rechtswege eindigt.

Concluderend kan worden aangenomen dat het bestaan van een pensioenregel niet algemeen is aanvaard. Naar de huidige opvattingen kan een arbeidsovereenkomst bij het bereiken van 65-jarige leeftijd slechts (van rechtswege) eindigen indien daarover of afspraken op individueel dan wel collectief niveau zijn gemaakt, ofwel het CWI toestemming heeft verleend voor ontslag, dan wel de kantonrechter de arbeidsovereenkomst op verzoek van één der partijen ontbindt.

\section{Toestemming cwI}

Bij het verlenen van toestemming voor ontslag kan het CWI op verschillende wijzen rekening houden met de leeftijd van werknemers. Hierbij kan onderscheid worden gemaakt tussen de situatie dat de toestemming wordt verleend expliciet op grond van leeftijd, en de situatie waarin de toestemming wordt verleend op grond van andere (selectie)criteria, waarbij leeftijd indirect een rol kan spelen. In deze paragraaf wordt aandacht besteed aan de vraag in hoeverre het mogelijk is bij het verlenen van toestemming voor ontslag, direct of indirect, rekening te houden met de leeftijd van werknemers.

\section{Toestemming op grond van leeftijd}

Wat de eerste situatie betreft, het verlenen van toestemming op grond van leeftijd, geldt dat het CWI verzoeken tot verlening van een ontslagvergunning op het moment dat de werknemer de 65-jarige leeftijd heeft bereikt in beginsel inwilligt. Hierbij baseert het CWI zich op zowel nationale als internationale jurisprudentie en wetgeving op dit gebied. ${ }^{163}$

Ter onderbouwing van de beleidsregel het bereiken van de 65 -jarige leeftijd te hanteren als algemene rechtvaardigingsgrond voor het verlenen van toestemming voor ontslag verwijst het CWI onder andere naar de hiervoor besproken arresten Codfried/Iss en Op 't Land/Employment Service, waarin is meegewogen dat er een groot maatschappelijk draagvlak is voor deze leeftijdsgrens. 
Voorts wijst het CWI erop dat uit de Wet Gelijke Behandeling op grond van Leeftijd bij de arbeid (verder: WGBL) ${ }^{164}$ blijkt dat het discriminatieverbod niet geldt indien het onderscheid betrekking heeft op het beëindigen van een arbeidsverhouding in verband met het bereiken van de pensioengerechtigde leeftijd.

Het CWI wijst verder in het bijzonder op het belang van participatie van jongeren op de arbeidsmarkt, waarop ook de Hoge Raad wijst in Codfried/Iss: "In de tweede plaats leidt het stelsel van ontslag bij het bereiken van de 65 -jarige leeftijd ertoe dat het vrijkomen van arbeidsplaatsen voor jongere werknemers een regelmatiger en vlotter verloop heeft dan wanneer dat zou afhangen van de bereidheid van oudere werknemers om de door hen ingenomen arbeidsplaatsen prijs te geven." Verder wordt van belang geacht dat met het hanteren van de leeftijdsgrens ontslag kan worden verleend zonder aanzien des persoons, en dus niet per persoon hoeft te worden vastgesteld of hij of zij nog wel voldoet.

Wat betreft het verlenen van toestemming voor ontslag op grond van een leeftijd jonger dan 65 jaar geldt de algemene toetsingsmaatstaf van art. 3:1 Ontslagbesluit. Indien in deze situatie toestemming voor ontslag wordt gevraagd dient het CWI de belangen van werkgever en werknemer en eventuele andere belangen af te wegen. Als andere belang kan bijvoorbeeld worden aangemerkt het arbeidsmarktbelang, waarbij ook weer de behoefte aan doorstroming een rol kan spelen.

Voor werknemers die de leeftijd van 65 jaar reeds zijn gepasseerd hanteert het CWI andere beleidsregels. Indien een werkgever de arbeidsovereenkomst met een werknemer na het bereiken van de 65 jarige leeftijd heeft voortgezet, wordt er vanuit gegaan dat “(...) ingeval de werkgever deze leeftijdgrens laat passeren, hij geacht wordt zijn recht op een beroep op de genoemde (algemene, AB) rechtvaardigingsgrond te hebben verwerkt." ${ }^{165}$ Ter ondersteuning van dit uitgangspunt is in de literatuur aangevoerd dat het in strijd zou komen met het gelijkheidsbeginsel indien de werkgever in het recente verleden werknemers heeft laten doorwerken na het bereiken van de pensioengerechtigde leeftijd. Ook in dit geval zal het CWI de ontslagaanvraag dienen te beoordelen aan de hand van de algemene redelijkheidstoets van art. 3:1 Ontslagbesluit.

Bij ontslag op grond van leeftijd jonger of ouder dan 65 jaar zal het CWI aansluiting kunnen zoeken bij de in de jurisprudentie en in de WGBL gehanteerde criteria ter rechtvaardiging van ontslag op grond van een andere leeftijd dan de pensioengerechtigde leeftijd. Deze criteria komen kort gezegd erop neer dat een objectieve rechtvaardiging moet worden gevonden, waarbij moet zijn voldaan aan de eisen van legitimiteit, doelmatigheid en proportionaliteit. Deze criteria zullen hieronder nog nader worden uitgewerkt. Het CWI zal echter niet treden in de uitleg van overeenkomsten. Voor zover sprake is van afspraken in de cao of individuele arbeidsovereenkomst, is de beoordeling van die afspraken voorbehouden aan de civiele rechter. Dit sluit overigens niet uit dat het CWI toestemming voor zover vereist verleent. 


\section{Toestemming op andere gronden; bedrijfseconomische redenen en het afspiegelingsbeginsel}

De tweede manier waarop rekening wordt gehouden met leeftijd is indirect. Het gaat hierbij vooral om de toepassing van anciënniteitsregels bij bedrijfseconomische ontslagen. De wijze waarop het CWI rekening houdt met de anciënniteitregels is geregeld in het Ontslagbesluit.

Per 1 maart 2006 is het Ontslagbesluit aangepast, in die zin dat niet langer het last in, first out-beginsel maar het afspiegelingsbeginsel als hoofdregel geldt bij bedrijfseconomische ontslagen. ${ }^{166}$ Artikel 4:2 Ontslagbesluit luidt sinds 1 maart 2006 als volgt:

"Voor zover het bij de te vervallen arbeidsplaatsen om uitwisselbare functies gaat, worden per leeftijdsgroep binnen een categorie uitwisselbare functies van de bedrijfsvestiging de werknemers met het kortste dienstverband het eerst voor ontslag in aanmerking gebracht, waarbij het aantal werknemers dat per leeftijdsgroep voor ontslag in aanmerking wordt gebracht voor zover mogelijk overeenkomt met de onderlinge verhouding van het aantal werknemers in elk van de leeftijdsgroepen binnen de betreffende categorie uitwisselbare functies ${ }^{167}$. De in de eerste volzin bedoelde leeftijdsgroepen zijn de groepen van 15 tot 25 jaar, van 25 tot 35 jaar, van 35 tot 45 jaar, van 45 tot 55 jaar en van 55 jaar en ouder."

De wijziging van het last in, first out-beginsel in het afspiegelingsbeginsel heeft invloed op de positie van de oudere werknemer. Het gevolg van de invoering van het afspiegelingsbeginsel als hoofdregel is dat per leeftijdsgroep werknemers in uitwisselbare functies die het kortst in dienst zijn als eerste voor ontslag in aanmerking komen. Dit betekent dat oudere werknemers met veelal een langer dienstverband, eerder met ontslag bedreigd zullen worden dan onder de toepassing van het last in, first out-beginsel het geval was. Onder de toepassing van het last in, first out-beginsel zouden zij, daar zij veelal langer in dienst zijn dan hun jongere collega's, minder snel in aanmerking komen voor ontslag. Met de opsplitsing in leeftijdsgroepen krijgen jongeren meer kans te blijven en zullen ouderen met een korter dienstverband eerder afvloeien.

\section{Contractuele afspraken}

De arbeidsovereenkomst kan van rechtswege eindigen indien afspraken zijn gemaakt welke voorzien in het eindigen van de arbeidsovereenkomst op het moment dat de werknemer de leeftijd van 65 jaar (maar soms ook een andere leeftijd) heeft bereikt. Dergelijke afspraken komen regelmatig voor en zijn veelal geregeld bij cao.

Een nadeel van contractuele afspraken is dat deze afspraken in beginsel niet voldoen aan de voorwaarden zoals gesteld in art. 7: 667 lid 4 BW om opvolgend een arbeidsovereenkomst voor bepaalde tijd aan te kunnen gaan, waarvoor geen voorafgaande opzegging is vereist. Voorgenoemd artikel bepaalt immers met zoveel woorden: "Indien een voor onbepaalde tijd aangegane arbeidsovereenkomst, die anders dan door opzegging of door ontbinding door de rechter is 
geëindigd, eenmaal of meermalen is voortgezet door een arbeidsovereenkomst voor bepaalde tijd (...), is voor de beëindiging van die laatste arbeidsovereenkomst voorafgaande opzegging nodig." 68

De gedachte achter deze regel is dat een werknemer bij een opvolgende arbeidsovereenkomst (voor bepaalde tijd) niet de ontslagbescherming mag missen die hij op basis van een eerdere arbeidsovereenkomst (voor onbepaalde tijd) genoot indien hij de bescherming die hem toekwam op basis van die eerdere arbeidsovereenkomst niet heeft genoten. Verhulp meent dat de met deze regel bedoelde bescherming onvoldoende nauwkeurig is vastgelegd. Een arbeidsovereenkomst voor onbepaalde tijd kan naar zijn mening eindigen op andere wijze dan rechtsgeldige opzegging of ontbinding, zonder dat kan worden volgehouden dat daarbij onvoldoende bescherming is geboden aan de werknemer. Deze gedachte is, aldus Verhulp, in lijn met de parlementaire geschiedenis en de bedoeling achter deze regeling. ${ }^{169}$

In lijn met het voorgaande heeft het Hof Amsterdam in 2005 een in een cao opgenomen bepaling gelijkgesteld met rechtsgeldige opzegging of ontbinding. ${ }^{170}$ In casu betrof het een cao-afspraak waarin was opgenomen dat de arbeidsovereenkomst zou eindigen ingeval de werknemer zou besluiten gebruik te maken van een overbruggingsregeling ingevolge de pensioenregeling van het PGGM. Het hof overweegt dat onder deze omstandigheden - er is een overeenkomst gesloten tussen cao-partijen en werkneemster heeft besloten daarvan gebruik te maken de wijze waarop de arbeidsovereenkomst voor onbepaalde tijd tot een einde is gekomen niet kan worden geacht onvoldoende bescherming te hebben geboden in die zin dat dit een toepassing van art. 7:667 lid 4 BW noodzakelijk maakt.

Het voordeel van contractuele afspraken is dat per bedrijfstak afspraken kunnen worden gemaakt over de gewenste doorstroming en flexibiliteit op de arbeidsmarkt of binnen de bedrijfstak. Daar waar arbeidsparticipatie van oudere werknemers minder gewenst is en het vervangingsniveau van jongere werknemers dusdanig hoog is en zowel werkgevers als werknemers daar behoefte aan hebben, kunnen daarover afspraken worden gemaakt die vervolgens, conform de eerder besproken uitspraak van het Hof Amsterdam ook de gewenste gevolgen kunnen hebben, namelijk het kunnen aangaan van een nieuwe arbeidsovereenkomst voor bepaalde tijd waarvoor geen opzegging is vereist. Hiermee wordt aangesloten bij de wensen binnen een bepaalde bedrijfstak en worden de belangen van oudere werknemers door de vakbeweging aan een belangenafweging onderworpen en zo nodig gewaarborgd. ${ }^{171}$

In het hierboven besproken arrest van het hof betrof het een werkneemster die de leeftijd van 65 jaar nog niet had bereikt. Hieruit kan worden afgeleid dat contractuele afspraken ook indien het betreft 'leeftijdsontslag' van werknemers die nog niet de pensioengerechtigde leeftijd hebben bereikt, kunnen rechtvaardigen dat een arbeidsovereenkomst eindigt. Deze gedachte is in lijn met eerdere jurisprudentie op het gebied van leeftijdsontslag, waarnaar ook al is verwezen bij de 
bespreking van de beleidsregels van de CWI. In 2004 overweegt de Hoge Raad in het arrest Van Pelt c.s./Martinair en VNV dat leeftijdsdiscriminatie is toegestaan indien daarbij wordt voldaan aan de eisen van legitimiteit, doelmatigheid en proportionaliteit. ${ }^{172}$ In casu ging het om cao-afspraken omtrent verplichte pensionering van vliegers op 56 -jarige leeftijd om daarmee de doorstroming te bevorderen.

De vraag is of deze uitkomst in strijd is met de toen nog niet ingevoerde WGBL. ${ }^{173}$ In de parlementaire behandeling wordt de casus van de verkeersvliegers genoemd als een voorbeeld van een objectieve rechtvaardiging van de uitzondering op het verbod van onderscheid. Deze uitzondering is opgenomen in art. 7 lid I sub c van de WGBL, waarin is bepaald dat het verbod van onderscheid niet geldt indien het onderscheid objectief gerechtvaardigd is door een legitiem doel en de middelen voor het bereiken van dat doel passend en noodzakelijk zijn.

Een voorbeeld dat bij de WGBL wordt genoemd als een niet objectief gerechtvaardigd onderscheid is een in 2000 gewezen arrest van het Hof Amsterdam. ${ }^{174}$ De KNVB hanteerde een leeftijdsgrens voor scheidsrechters, omdat zij boven de gehanteerde leeftijdsgrenzen, 47 respectievelijk 49 jaar, minder goed inzetbaar zouden zijn. Het hof oordeelt echter dat het relatief eenvoudig is de inzetbaarheid te testen door scheidsrechters periodiek te laten deelnemen aan cooper- of shuttletests en acht het onderscheid om die reden niet objectief gerechtvaardigd.

Met betrekking tot contractuele afspraken over het eindigen van de arbeidsovereenkomst bij 65 jaar bestaat in de jurisprudentie vrij weinig onduidelijkheid. ${ }^{175}$ Algemeen wordt aangenomen dat dergelijke afspraken geldig zijn en dat de arbeidsovereenkomst bij dergelijke afspraken van rechtswege eindigt. Dit is in overeenstemming met de heersende opvattingen omtrent het eindigen van arbeidsovereenkomsten bij het bereiken van 65-jarige leeftijd, de beleidsregels van het CWI hieromtrent en de WGBL waarin in art. 7 lid 1 sub b is bepaald dat het verbod op onderscheid niet geldt bij beëindigen van de arbeidsovereenkomst wegens het bereiken van de pensioengerechtigde leeftijd. ${ }^{176} \mathrm{Wil} \mathrm{men} \mathrm{echter} \mathrm{bereiken} \mathrm{dat}$ vervolgens een arbeidsovereenkomst voor bepaalde tijd kan worden aangegaan waarvoor geen opzegging nodig is, dan is daarvoor een afspraak in de individuele arbeidsovereenkomst niet voldoende, zo bleek eerder, maar zal men het CWI om toestemming moeten vragen of de kantonrechter moeten verzoeken de arbeidsovereenkomst te ontbinden. ${ }^{177}$ De geldigheid van contractuele afspraken over het eindigen van de arbeidsovereenkomst na het bereiken van de leeftijd van 65 jaar, zal moeten worden beoordeeld aan de hand van art. 7 lid 1 sub c WGBL. Het ligt voor de hand dat de rechter hierbij aansluiting zoekt bij de beleidsregels van het CWI.

Opzegtermijnen

De opzegtermijnen zijn geregeld in art. 7:672 BW. Bij de duur van de opzegtermijnen wordt niet expliciet rekening gehouden met de leeftijd van een werknemer. De duur van de opzegtermijn is afhankelijk gesteld van de duur van de arbeidsovereenkomst. Dit kan als gevolg hebben dat werkgevers voor oudere werknemers, met veelal maar niet noodzakelijk, een langer dienstverband, een langere 
opzegtermijn in acht hebben te nemen dan voor jongere werknemers met een korter dienstverband. Hierbij verdient opmerking dat de opzegtermijn in het algemeen niet wordt ervaren als een regeling die invloed heeft op het ontslagbeleid met betrekking tot oudere werknemers of leidt tot een beperking van de flexibiliteit op de arbeidsmarkt.

\section{Kennelijk onredelijk ontslag}

Bij de beoordeling van de vraag of een ontslag kennelijk onredelijk is houdt de rechter rekening met zowel de belangen van de werkgever als de werknemer. Bij het meewegen van de factor leeftijd kan aansluiting worden gezocht bij de hiervoor besproken aspecten die een rol spelen bij de vraag of een ontslag wel of niet gerechtvaardigd is. In het kader van een kennelijk onredelijk ontslagprocedure zal de rechter deze omstandigheden alsmede alle andere relevante omstandigheden meewegen in de beoordeling van de vraag of hij het ontslag kennelijk onredelijk acht en de op grond daarvan toe te kennen vergoeding. Bij het toekennen van een kennelijk onredelijke ontslagvergoeding wordt veelal aansluiting gezocht bij de kantonrechterformule. ${ }^{178}$

\section{Ontbinding en ontbindingsvergoeding}

De rechtspraak op het gebied van ontbinding van de arbeidsovereenkomst is casuïstisch en uitvoerig. Dit maakt het niet eenvoudig een duidelijke lijn te ontdekken in de wijze waarop en de mate waarin kantonrechters in ontbindingsbeschikkingen rekening houden met de leeftijd van werknemers. Ook bij het toekennen van een ontbindingsvergoeding en de hoogte daarvan zijn kantonrechters verdeeld over de wijze waarop en de mate waarin rekening dient te worden gehouden met de leeftijd van werknemers. ${ }^{179}$

\section{Ontbinding}

Recent heeft een aantal kantonrechters een ontbindingsverzoek afgewezen op grond van anciënniteit in combinatie met leeftijd. ${ }^{180}$ Hierbij wordt soms rekening gehouden met, of reflexwerking toegekend aan de regels die daaromtrent zijn opgenomen in het Ontslagbesluit. ${ }^{181}$ Veelal wordt hierbij van belang geacht dat de werknemer een zwakke arbeidsmarktpositie heeft (mede) als gevolg van zijn leeftijd.

In 2003 heeft de Kantonrechter Deventer een arbeidsovereenkomst met een 68-jarige werkneemster ontbonden met als (belangrijkste) argument dat het arbeidzame leven in het algemeen eindigt op 65-jarige leeftijd en dit onderscheid een objectieve rechtvaardiging oplevert. ${ }^{182}$ Daar de werkneemster deze leeftijd ruimschoots was gepasseerd achtte de kantonrechter ook in dit geval ontbinding onvrijwillige beëindiging wegens hogere leeftijd gerechtvaardigd. Deze beschikking is niet in lijn met de beleidsregels van het CWI, waar de kantonrechter overigens niet aan gehouden is, maar kantonrechters hebben over het algemeen wel de neiging het Ontslagbesluit te volgen. Verder is deze beschikking in strijd met de na het wijzen van beschikking ingevoerde WGBL. Het is dus zeer wel mogelijk, en valt ook te verwachten, dat de beschikking vandaag de dag anders zou uitvallen. 


\section{Ontbindingsvergoeding}

In de ontbindingsvergoeding speelt de leeftijd van de werknemer een belangrijke rol. De leeftijd van een werknemer komt tot uitdrukking in de kantonrechtersformule die wordt gehanteerd bij de vaststelling van (de hoogte van) de ontbindingsvergoeding. In de kantonrechtersformule komt de leeftijd tot uitdrukking in de A-factor. Het aantal dienstjaren wordt vanaf 40-jarige leeftijd 1,5 keer meegeteld en vanaf 50 jaar 2 keer. ${ }^{183}$ Dit heeft als gevolg dat een oudere werknemer gemiddeld een hogere ontslagvergoeding ontvangt dan een jongere werknemer.

Hoewel het wegen van de dienstjaren enerzijds extra bescherming biedt aan de oudere werknemer, die veelal moeilijker een nieuwe baan zal vinden dan zijn jongere collega, leidt deze regel anderzijds ertoe dat werkgevers wellicht minder snel geneigd zullen zijn oudere werknemers aan te nemen. Een aantal kantonrechters ${ }^{184}$ meent dat de werknemer die op latere leeftijd in dienst treedt van een werkgever bij de berekening van de ontbindingsvergoeding geen recht heeft op de gewogen dienstjaren als is voorzien in de kantonrechtersformule. ${ }^{185}$ Deze beschikkingen steunen op de gedachte dat moet worden voorkomen dat de werkgever wordt gestraft voor het feit dat zij een oudere werknemer in dienst heeft genomen. Deze problematiek behoeft enige nuancering, daar de hoogte van de ontslagvergoeding is gemaximeerd tot het inkomensverlies tot 65-jarig leeftijd. Een duidelijke lijn valt in de (zeer casuïstische) jurisprudentie op dit gebied niet te ontdekken, daar er ook kantonrechters zijn die menen dat ook bij indiensttreding op latere leeftijd het aantal dienstjaren gewogen dient te worden. ${ }^{186}$

Naast het mogelijk belemmerend effect op het aannemen of in dienst houden van oudere werknemers is de weging van dienstjaren aan de hand van de leeftijd van de werknemer mogelijk in strijd met de WGBL. Nu aanbeveling 3.2 van de kantonrechtersformule noopt tot het maken van een dergelijk onderscheid, zou dit deel van de aanbeveling weleens niet in overeenstemming met deze wet kunnen zijn. Deze gedachtegang biedt de kantonrechters die van mening zijn dat de werkgever die een werknemer op latere leeftijd in dienst neemt, wordt gestraft door dit deel van de aanbeveling, een behoorlijke steun. Anderzijds is het onderscheid niet in strijd met de WGBL indien bij het wegen van de dienstjaren wordt voldaan aan de uitzondering genoemd in art. 7 lid 1 sub c van de wet, zoals ook hierboven al is besproken. Afhankelijk van de omstandigheden kan het wegen van dienstjaren bij het toekennen van de ontbindingsvergoeding objectief gerechtvaardigd zijn. ${ }^{187}$

\section{Conclusie}

Vooralsnog wordt er in politiek, rechtspraak en wetenschap van uitgegaan dat er een groot maatschappelijk draagvlak is voor het hanteren van de 65-jaarsgrens bij ontslag. In de literatuur wordt er echter wel op gewezen dat het "rommelt rond de vanzelfsprekendheden die aan deze leeftijd zijn opgehangen" (Westerveld 2005). 
De vraag is of het uitgangspunt dat een arbeidsovereenkomst met een werknemer die de leeftijd van 65 jaar heeft bereikt in beginsel niet zonder meer van rechtswege eindigt, invloed heeft op de flexibiliteit op de arbeidsmarkt. Waarschijnlijk is de invloed van dit uitgangspunt vrij gering, zolang het CWI als regel hanteert dat in beginsel een toestemming wordt verleend indien een werkgever een werknemer die de pensioengerechtigde leeftijd heeft bereikt wenst te ontslaan. Daarnaast bestaat de mogelijkheid contractuele afspraken te maken over het al dan niet eindigen van de arbeidsovereenkomst waarmee en waardoor de doorstroming en de flexibiliteit op de arbeidsmarkt, daar waar dat gewenst is kan worden bevorderd.

Dat bij het bereiken van de leeftijd van 65 jaar in beginsel sprake is van een arbeidsovereenkomst (voor onbepaalde tijd), waarvoor voorafgaande opzegging, ontbinding of een afspraak omtrent beëindiging nodig is, hoeft geen belemmering te vormen voor de arbeidsparticipatie van oudere werknemers. Wil men de arbeidsovereenkomst in plaats van voor onbepaalde tijd voor bepaalde tijd voortzetten zonder de verplichtingen welke de toepassing van art. 7:667 lid $4 \mathrm{BW}$ meebrengen, dan is daarin te voorzien door het CWI toestemming te vragen of de kantonrechter te verzoeken de arbeidsovereenkomst te ontbinden. ${ }^{188}$ In dat geval kan conform de regels van art. 7: 667 BW een arbeidsovereenkomst voor bepaalde tijd worden overeengekomen welke vervolgens van rechtswege zal eindigen. Hetzelfde geldt indien afspraken zijn gemaakt bij cao.

Bij het ontslagbeleid met betrekking tot oudere werknemers zal rekening moeten worden gehouden met de effecten die daarop gerichte maatregelen zullen hebben op andere groepen werknemers. Met het hanteren van de in de WGBL neergelegde regels kan enerzijds tegemoet worden gekomen aan de belangen van jongere werknemers, bijvoorbeeld omdat de behoefte aan doorstroming kan leiden tot een objectieve rechtvaardiging voor het maken van leeftijdsonderscheid. Anderzijds wordt met het verbod op leeftijdsonderscheid de bescherming van de oudere werknemer, waar noodzakelijk, gewaarborgd. Hiermee wordt tegemoetgekomen aan de gewenste flexibiliteit en doorstroming op de arbeidsmarkt. 


\section{NOTEN}

SER-advies 05/05, 15 april 2005 en SER-advies 05/o6, 15 april 2005.

Zie onder meer NRC, 3 augustus 2005, en www.premier-ministre.gouv.fr/information/les_dossiers_actualites_19/plan_urgance.

Per 1 oktober 2006 is de verwijtbaarheidstoets in de wW komen vervallen. Zie hierover verder Kamerstukken II, 2005-2006, 30370

Zie o.a. Kamerstukken II, 2004-2005, 30 016, Wijziging van de Werkloosheidswet in verband met het preventief inzetten van reïntegratie-instrumenten, het opdragen van de reïntegratietaak aan overheidswerkgevers, het ondersteunen van WAO-herbeoordeelden bij scholing, het subsidiëren van scholing in het kader van de WAJONG en enkele andere wijzigingen in wetten die de reïntegratieinstrumenten betreffen.

Zie o.a. Kamerstukken II, 2004-2005, 30 109, nr. 1, p. 16. Zie kabinetsnotitie duale trajecten, I maart 2005, Kamerstukken II, 2004-2005, 30 o12, nr. 3. Lissabondoelstellingen: Commissie van de Europese Gemeenschappen, mededeling aan de Europese Voorjaarsraad; Samen werken aan werkgelegenheid en groei; Een nieuwe start voor de Lissabon-strategie, Brussel: 02-02-2005 en Kamerstukken II, 2003-2004, 27 406, nr. 7, p. 5. Een startkwalificatie is volgens de overheid het minimale onderwijsniveau dat nodig is om kans te maken op duurzaam werk. Een startkwalificatie is een havo of vwo-diploma of een mbodiploma vanaf niveau 2. Een vmbo-diploma wordt dus niet gezien als een startkwalificatie. Tot dit niveau dient de Nederlandse beroepsbevolking zich te ontwikkelen.

Zie bijvoorbeeld Ktr. Heerlen, 8 juni 2005, JAR 2005/16o en Ktr. Heerlen, JAR $2005 / 87$.

Kamerstukken II, 2004-2005, 29 804, nr. 17, p. 1-2. SER-advies 05/05, 15 april 2005. SER-advies 06/05, 15 april 2005. Bijna letterlijk van www.ser.nl. Zie ook Kamerstukken II, 2005-2006, 30370. Kamerstukken II, 2004-2005, 30 109, nr. 1 en Persbericht SZW van 16 september 2005, nr. 05/o29, 'Ww wordt brug tussen twee banen'.

Ook: www.ser.nl.

Kamerstukken II, 2004-2005, 30 109, nr. 1.

Kamerstukken II, 2004-2005, 30 109, nr. 1, p. 11.

Zoals reeds eerder aangegeven richt dit onderzoek zich vooral op maatregelen voor werknemers die nog niet werkloos zijn. De groep werknemers die reeds werkloos is zal wel worden genoemd

Kamerstukken II, 2004-2005, 30 109, nr. 1, p. 16.

Kamerstukken II, 2004-2005, 30 109, nr. 1, p. 14/15.

Kamerstukken II, 2004-2005, 29 804, nr. 1, p. 17. Het kabinet verwijst hierbij naar het rapport van de Employment Taksforce Kok, Jobs, Jobs, Jobs. Creating more employment in Europe, November 2003. 
Kamerstukken II, 2004-2005, 30 109, nr.1, p. 37. Het kabinet verwijst ter onderbouwing van deze stellingen naar: 'Afscheid van het duale ontslagrecht', rapport van de commissie ADO, sZW Den Haag 2000 en OESO Employment Outlook 2004. Zie noot 7: Kamerstukken II, 2004-2005, 29 804, nr. 1, p. 17. Het kabinet verwijst hierbij naar het rapport van de Employment Taksforce Kok, Jobs, Jobs, Jobs. Creating more employment in Europe, november 2003.

Kamerstukken II, 2004-2005, 30 109, nr. 1, p. 40.

Kamerstukken II, 2004-2005, 30 109, nr. 1, p. 40.

Zie hierover o.a. Kamerstukken II, 2005-2006, 30370.

Kamerstukken II, 2004-2005, 30 109, nr. 1, p. 46-48 en Persbericht SZW van 16 september 2005, nr. 05/O29, 'WW wordt brug tussen twee banen' en Kamerstukken II, 2005-2006, 30370

Kamerstukken II, 2004-2005, 30 109, nr. 1, p. 40-41.

Staatscourant, 13 december 2005, nr. 242.

Kamerstukken II, 2004-2005, 30 109, nr. 1, p. 48.

Kamerstukken II, 2005-2006, 30 370, nr. 8, p. 3-4.

Met de wijziging van het Ontslagbesluit per 1 maart 2006 is het lifo-beginsel komen te vervallen en is het afspiegelingsbeginsel hoofdregel geworden. 'Zekerheid op maat, van nazorg naar voorzorg in de sociale zekerheid', Wetenschappelijk instituut van het CDA, maart 2004.

Zie Kamerstukken II, 2004-2005, 29 804, nr. 17, p. 2. Kamerstukken II, 2004-2005, 30 109, nr. 1, p. 50-51.

Zie o.a. Kamerstukken II, 2003-2004, 27 406, nr. 7 (De kenniseconomie in zicht), Kamerstukken II, 2003-2004, 27 406, nr. 32 (Actieplan Leven Lang Leren) en Kamerstukken II, 2005-2006, 30370.

Kamerstukken II, 2004-2005, 30 109, nr. 1, p. 14. Het kabinet verwijst ter onderbouwing van deze stelling naar: R. de Mooij en P. Tang, Four Futures of Europe, Den Haag 2003.

38 Kamerstukken II, 2004-2005, 29 804, nr. 1, p. 9.

39 Uit recente cijfers van het CBS blijkt overigens dat het opleidingsniveau onder vooral Turkse en Marokkaanse allochtonen het sterkst is gestegen (NRC, 27/05/05)

40 Kamerstukken II, 2004-2005, 29 804, nr. 1, p. 15-16.

41 Kamerstukken II, 2004-2005, 29 804, nr. 1, p 23.

42 Interview Zalm, FD, 21 september 2005.

43 Scholing lijkt zelfs invloed te hebben op de gezondheid van werknemers. Zie in dit verband minder recent onderzoek waaruit blijkt dat ook het ontslag en de nasleep ervan vaak een langdurige en desastreuze invloed hebben op de geestesgesteldheid van de (vooral oudere) ontslagenen en hun naasten, M. van Klaveren, 'Verslag van Collectief Ontslag', Wetenschappelijk instituut van het NVv, Amsterdam 1970, p. 7. Hierin wordt verwezen naar een artikel van drs. Nijhof over de psychische gevolgen van ontslag in het Maandblad Geestelijke Volksgezondheid, 1967-4. Maar ook recenter: Onderwijsraad, Werk maken van een leven lang leren, Den Haag 2003, en S. Bekker, P. Ester, en A.C.J.M Wilthagen, Jong en oud op de arbeidsmarkt, generaties, transities en levensloop, Reed Business Information, Den Haag 2005, p. 114 
44 Voor het gemak verwijzen wij in het kader van dit onderzoek slechts naar werkloosheid. Veel van deze middelen kunnen tevens worden ingezet in het kader van de WAO of WAJONG

45 Zie o.a. Kamerstukken II, 2004-2005, 28 719, nr. 22 en www.uwv.nl.

46 Kamerstukken II, 2003-2004, 27 406, nr. 32, p. 5.

47 Lissabondoelstellingen en kabinetsreactie Kamerstukken II, 2003-2004, 27 406, nr. 7, p. 5. Een startkwalificatie is volgens de overheid het minimale onderwijsniveau dat nodig is om kans te maken op duurzaam werk. Een startkwalificatie is een havo- of vwo-diploma of een mbo-diploma vanaf niveau 2. Een vmbodiploma wordt dus niet gezien als een startkwalificatie.

$48 \quad$ Kamerstukken II, 2003-2004, 27 406, nr. 7, p. 6.

49 Kamerstukken II, 2004-2005, 29 544, nr. 33, p. 5. De ambities van de projectdirectie zijn overigens nauw verbonden met de Lissabondoelstellingen op het terrein van onderwijs en arbeid in 2010. H. van Lieshout e.a., 'Postinitiële scholing, van patstelling naar pact', OSA, Tilburg 2005, p. 84

Afdrachtvermindering onderwijs $€ 217$ miljoen, aftrek Inkomstenbelasting voor scholingsuitgaven $€ 110$ miljoen, ESF $€ 64$ miljoen (2002). Zie: Kamerstukken II, 2003-2004, 27 406, nr. 32, p. 19-20. Ter vergelijking: voor scholing van werkzoekenden geeft de overheid op jaarbasis een bedrag uit van ongeveer $€ 1.9$ miljard (2002).

Een voorbeeld van een dergelijke adviesorganisatie biedt de door EZ ingestelde adviesorgansisatie Syntens. Zie ook www.syntens.nl Kamerstukken II, 2004-2005, 26 642, nr. 70, p. 1. Zie ook 'Kabinetsnotitie duale trajecten' van 1 maart 2005, Kamerstukken II, 2004-2005, 30012, nr. 3 en 'Leren en werken verstreken', plan van aanpak 20052007 van de projectdirectie Werken \& Leren, te downloaden via www.szw.nl Zie www.kenniscentrumevc.nl. Kamerstukken II, 2004-2005, 30 109, nr. 1, p. 19. Kamerstukken II, 2004-2005, 29 804, nr. 17, p. 3. Zie over duale trajecten ook de kabinetsnotitie duale trajecten, Kamerstukken II, 2004-2005, 30 012, nr. 3 en 'Leren en werken verstreken', plan van aanpak 20052007 van de projectdirectie Werken \& Leren, te downloaden via http://www.szw.nl/.

58 Zie: http://www.kenniscentrumevc.nl/.

59 De doelgroep van het Empowerment Centre bestaat uit werkzoekenden, migranten, vluchtelingen, gehandicapten en gedeeltelijk arbeidsongeschikten. Zie hierover onder andere: http://agentschap.szw.nl/index.cfm?fuseaction=dsp_document\&link_id $=69083$

6o Kamerstukken II, 2003-2004, 27 406, nr. 32, p. 11.

$61 \quad$ Kamerstuken II, 2004-2005, 30 109, nr. 11.

62 Kamerstukken II, 2005-2006, 30 370, nr. 8, p.3-4.

63 Zie voor deze definitie: Best practices in wW-preventie, Wilthagen etc., p. 16

64 Zie interview met Paas, FD, 15 augustus 2005, hij geeft hierbij overigens aan gecharmeerd te zijn van het voorstel van Kamerlid Verburg scholingsinspanningen te verrekenen in de ontslagvergoeding.

65 Zie ook H. van Lieshout e.a., 'Postinitiële scholing, van patstelling naar pact', 
OSA, Tilburg 2005, p. 55 e.v. en p. 90 e.v.

66 De totale reserve in 2002 wordt geschat op 1 miljard euro, Waterreus 2002, p. 30.

De reserve van de algemeen verbindend verklaarde fondsen bedraagt in 2005619 miljoen euro, Persberichten SZW, 1 juni 2005, nr. 05/100.

67 De vraag is of dit ook juist is. Momenteel loopt er een onderzoek naar het (individuele) rendement voor werkgevers van investeringen in opleiding van werknemers. Zie www.eim.nl. Aanleiding voor het onderzoek is dat werkgevers in het algemeen weinig gevoelig zijn voor de marcro-effecten van scholing, zoals minder werkloosheid.

68 Zie onderzoek H. van Lieshout e.a., 'Postinitiële scholing, van patstelling naar pact', OSA, Tilburg 2005, p. 87-102. Dit geldt voor verschillende scholingsinstrumenten waarbij de keus te scholen wordt overgelaten aan de werkgever.

69 H. van Lieshout e.a., 'Postinitiële scholing, van patstelling naar pact', osA, Tilburg 2005, p. 89-9o. In Frankrijk geldt een wettelijke verplichting tot scholing. H. van Lieshout e.a., 'Postinitiële scholing, van patstelling naar pact', OSA, Tilburg 2005, p. 58.

$70 \quad$ Kamerstukken II, 2004-2005, 27 406, nr. 32, p. 13.

71 Deze paragraaf vormt een bewerking van E. Verhulp, 'Ontslagrecht in beweging?' in: Ontslagrecht in beweging, Sdu, Den Haag 2004, p. 11-12.

Kamerstukken II, 1975-1976, 13 656, nrs. 1-3.

Kamerstukken II, 1980-1981, 16 682, nrs. 1-2.

$74 \quad$ Stb. 1984, 97.

Het DIA-rapport (Deregulering, inkomensvorming en arbeidsmarkt), Kamerstukken II, 1983-1984, 17 931, nr. 24. SER-advies 88/12, 16 september 1988 . Kamerstukken II, 1989-1990, 21 479, nrs. 1-3.

78 Dit wetsvoorstel is nooit gepubliceerd, een versie met een stempel 'strikt vertrouwelijk' is bekend. Zie over de gang van zaken: ADO 2000, p. 31 e.v. Stb. 1998, 300 en Stb 1998, 741.

8o Kamerstukken I, 1997-1998, 25 263, nr. 132g (brief van 12 mei 1998).

81 ADO, Afscheid van het duale ontslagstelsel, 15 november 2000.

$82 \quad$ STAR 15 juli 2003, kenmerk S.A. 03.05978/Ha.

83 G.J.J. Heerma van Voss, Goed werkgeverschap als bron van vernieuwing van het arbeidsrecht, Reeks VVA 29.

84 Zie Kamerstukken II, 29 804 (Nieuwe accenten op het terrein van werk en inkomen), nr. 5, nr. 14 en nr. 17, p. 1-2.

85 Zie M.G. Rood, 'Naar een nieuwe sociaalrechtelijk denkraam' in: F.M. Noordam (red.), Sociaalrechtelijke oraties 1977-1997, Kluwer Deventer 1998, p. 539, waar hij zegt dat kennis en opleiding van de werknemer zijn toegenomen, maar ondanks het feit dat het verschil in economische macht tussen werkgever en werknemer groot is gebleven.

86 Zie onder meer A.C.J.M. Wilthagen, F. Tros en H. van Lieshout: Toward Flexicurity? Balancing flexibility and flexicurity in EU member states: paper presented for the $13^{\text {th }}$ World Congress of the IIRA, Berlin September 2003. Zie ook: http://tilburguniversity.nl/faculties/frw/research/schoordijk/flexicurity/pub lications/papers. 
87 Zie o.a. Ktr. ’s-Hertogenbosch, 7 april 2005, JAR 2005/104 en verder § 5.2.

88 STAR, 'Flexibiliteit en zekerheid', 2/96, 3 april 1996.

89 Zie Kamerstukken II, 2004-2005, 30108 (Evaluatie Wet Flexibiliteit en Zekerheid), nr. 1, p. 3-5. In het periodieke cao-onderzoek 'Contracten voor bepaalde en onbepaalde tijd', te doen in 2006, zie Kamerstukken II, 2004-2005, 30 108, nr. 1, p. 8.

91 Zie Hof's-Gravenhage, 21 maart 2003, JAR 2003/140.

92 Zie o.a. Hof's Gravenhage, 8 april 2005, JAR 2005/169, HR 3 maart 2002, JAR 2002/67 (Guerand/PTT) en Ktr. Zutphen, 25 februari 2003, JAR 2003/100.

93 Zie bijv. Pres. Rb. Haarlem, 13 juli 2001, JAR 2001/171, r.o. 5.8.

94 Zie bijvoorbeeld Ktr. Almelo, 15 juni 2000, JAR 2000/165 (kennelijk onredelijk ontslag), Ktr. 's-Hertogenbosch, 7 april 2005, JAR 2005/104 (ontbinding met lagere vergoeding dan geldt volgens sociaal plan omdat de werknemer aangeboden scholing weigerde).

95 Dit sluit echter niet uit dat (het gebrek aan) scholingsinspanningen ter bevordering van employability (wordt) kan worden verdisconteerd in het loon (dit kan vooral van belang zijn bij contracten voor bepaalde tijd waarbij het ontslagrecht een minder belangrijke rol speelt). Zie voor een voorbeeld met betrekking tot ontslagvergoedingen en preventie van werkloosheid E. Verhulp, 'Ontslagrecht in beweging?’ in: Ontslagrecht in beweging, Sdu, Den Haag 2004, p. 22-23.

$96 \quad$ HR 10 juni 1983, NJ 1983, 796.

97 Zie onder meer Ktr. Delft, 21 december 2000, JAR 2001/30 en Ktr. Amsterdam, 22 november 2002, JAR 2003/2.

98 Ktr. Tilburg, 2 februari 2005, JAR 2005/59.

99 Hof Amsterdam, 26 februari 2004. JAR 2004/202, Ktr. Utrecht, 24 oktober 2001, JAR 2002/30.

100 Ktr. Amsterdam, 5 juni 2002, JAR 2002/158, Ktr. Rotterdam, 4 mei 2002, JAR 2002/142, Ktr. Hoorn, 18 maart 2002, JAR 2002/83.

101 Ktr. Amsterdam, 7 januari 2003, JAR 2003/45.

102 Ktr. Rotterdam, 1 oktober 2004, JAR 2004/269.

103 Hof's Hertogenbosch, 11 mei 2004, JAR 2004/165.

104 Ktr. Zaandam, 1 november 2001, JAR 2001/249.

105 Rb. Amsterdam, 15 juni 1994, JAR 1994/148.

106 Zie over poaching: СРВ Macro-Economische Verkenning 1999, bijzondere onderwerpen p. 117, zie http://www.cpb.nl/nl/cepmev/mev/1999/speciale_onderwerpen/employability.pdf.

107 Bij brief van 4 november 2005 en http:/www.eerstekamer.nl/.

108 Lees: inzetbaarheid op de arbeidsmarkt in het algemeen.

109 Bijlage bij Kamerstuk 28 170, nr. 40 (14 september 2005): onderscheid naar leeftijd in cao's.

110 Kamerstukken I, 2005-2006, 28 167, E (nadere memorie van toelichting), p. 1-2.

111 Ktr. Alphen aan den Rijn, 7 juli 1998, JAR 1998/204.

112 Kamerstukken II, 1993-94, 23 438, nr. 3.

113 CPB MEV 1999, p. 122, zie

http://www.cpb.nl/nl/cepmev/mev/1999/speciale_onderwerpen/employability.pdf. 
114 Zie bijv. Arbitragecommissie KNVB, 30 juni 1998, JAR 1998/171 (De Boer/Ajax).

115 Zie uitvoerig over het opleidingssysteem van de FIFA: S.F.H. Jellinghaus, 'Het opleidings- en solidariteitssysteem van de FIFA: de stand van zaken', ArA 2005/2, p. 4-45.

116 Zie Kamerstukken II, 2004-2005, 30 109, in het bijzonder nr. 3 en voor de intrekking van de voorstellen Kamerstukken II, 2005-2006, 30 370, nr, 8, p. 3-4. Zie voor de wijziging van het Ontslagbesluit, Staatscourant, 13 december 2005, nr. 242

117 Kamerstukken II, 2004-2005, 30 109, nr. 1, p. 44. Zie ook de notitie 'Heroverweging Last in, first out-beginsel', Kamerstukken II, 2003-2004, 29200 XV, nr. 87.

118 Het onmisbaarheidscriterium werd voor 1 maart 2006 geregeld in art. 4:2 lid 5 Ontslagbesluit en is nu geregeld in art. 4:2 lid 4 Ontslagbesluit. Zie over de wijzing ook: Kamerstukken II, 2004-2005, 30 109, nr. 11 (motie Weekers en Heringa-Huizinga) en Kamerstukken II, 2004-2005, 30 109, nr. 12 (motie Verburg en Noorman-Den Uyl). Ook vanuit de CWI gaan stemmen op bij bedrijfseconomisch ontslag rekening te houden met de onmisbaarheid van werknemers, zie Het Financieele Dagblad, 6 oktober 2005.

119 Kamerstukken II, 2004-2005, 30 109, nr. 13, p. 13.

120 Zie o.a. recent Ktr. Haarlem, 5 november 2004, JAR 2005/56 en Ktr. SittardGeleen, 17 mei 2005, JAR 2005/143.

121 Zie bijv. Halsema in een debat met Jongerius, De Volkskrant, 26 november 2005.

122 Zie interview met Paas, Het Financieele Dagblad, 15 augustus 2005, hij geeft hierbij overigens aan gecharmeerd te zijn van het voorstel van Kamerlid Verburg scholingsinspanningen te verrekenen in de ontslagvergoeding.

123 Kamerstukken II, 2004-2005, 30 109, nr. 1, p. 46.

124 Kamerstukken II, 2005-2006, 30 370, nr. 3, p. 23-24. Zoals reeds eerder vermeld is dit voorstel ingetrokken, zie Kamerstukken II, 30370 , p. 8, p. 3-4.

125 Kamerstukken II, 2004-2005, 30 109, nr. 1, p. 46 en Kamerstukken II, 2005-2006, 30370, nr. 2 (voorstel van wet), p. 21 en nr. 3 (MvT), p. 24.

126 Kamerstukken II, 2004-2005, 30 109, nr. 11, p. 1.

127 Minister De Geus zegt hierover: '.. dat de cao geen instrument is om juist meer regels te maken, maar juist om vrijheid te creëren. De cao is juist een instrument om af te wijken van die regels.' Handelingen TK, 13 september 2005, 105, p. 6340. 128 Kamerstukken II, 2004-2005, 30 109, nr. 13, p. 13.

129 Zie in gelijke zin: G.J.J Heerma van Voss, 'Driekwart dwingend recht', in: R.A.A. Duk e.a., CAO-recht in beweging, Den Haag: Sdu 2005, p. 128 en W.A. Zondag, 'De rol van het anciënniteitsbeginsel als selectiecriterium bij ontslag wegens bedrijfseconomische redene', SMA 2005, nr. 10, p. 473.

130 Kamerstukken II, 30370 , p. 8, p. 3-4.

131 STAR: Advies inzake het rapport van de Adviescommissie Duaal Ontslagstelsel, 15 juli 2003, publicatienummer 07/03.

132 MVT, ontwerp Drucker, A.E. Bles, Wet op de arbeidsovereenkomst 19o9, deel IV, p. 13 .

133 MvT, ontwerp Drucker, A.E. Bles, Wet op de arbeidsovereenkomst 19o9, deel IV, p. 13.

134 Brief van 7 oktober 1997, kenmerk AV /RV/97/1553, van het Ministerie van SzW. 
135 Zie echter S.G. Canes, Critische systematische commentaar op de wet op het arbeidscontract, Noordhoff, Groningen 1908, p. 272, waar hij erop wijst dat blijkens de praktijk veel werkgevers maar ook werknemers niet van opzegging waren gediend.

136 Zie bijvoorbeeld CRVB, 4 november 1999, TAR 1999, 100, en E. Verhulp (red.) 'Inleiding Nederlands Ambtenarenrecht', BJU 2003, p. 59.

137 Hierbij gaan wij niet in op de eventuele mogelijkheid tot premiedifferentiatie respectievelijk preventieprikkel voor oudere werknemers vanuit de WW

138 Ktr. Almelo, 15 juni 2000, JAR 2000/165.

139 Hof's-Hertogenbosch, 9 december 2003, JAR 2004/32

140 Zie HR, 1 maart 2002, JAR 2002/66 en 67 (TNO/Termeulen en Guèrand/PTT). Zie uitgebreider over welke aanspraken wel en welke niet kunnen worden meegewogen in de ontbindingprocedure o.a. recent T.E.E. Tjong Tjin Tai en Th. Veling, in: Voor De Laat: de Hoge Raad, blz. 155-183, Reeks Vereniging voor Arbeidsrecht nr. 34, Kluwer, Deventer 2005, C.J. Loonstra en L.G. Verburg. 'Hoe exclusief is exclusief? Over de juridische status van de 685-procedure en de contractuele vergoeding', ArA 2005/1, p. 48-752.

141 Zie vorige noot.

142 Ktr. Amsterdam, 30 augustus 2004, JAR 2004/224, Ktr. Sittard, 21 december 2001, JAR 2002/28 (verweer werknemers).

143 Ktr. Sittard-Geleen, 16 oktober 2003, JAR 2003/271.

144 Ktr. Utrecht, 21 januari 2003, JAR 2003/51.

145 Krt. Amsterdam, 17 februari 2004, JAR 2004/56 (geen afwijking anciënniteitsbeginsel, ontbinding wegens gebrekkige opleiding).

146 Ktr. Rotterdam, 23 juni 1999, JAR 1999/141 (afwijking anciënniteitsbeginsel na weigering werknemer tot overleg over ander functie. Werkgever voert aan dat oudere werknemer scholing minder snel met goed gevolg zal afronden), Ktr. Haarlem, 5 november 2004, JAR 2005/56, (afwijking anciënniteitsbeginsel, werknemer beschikt over specialisme en is niet anders inzetbaar), Ktr. SittardGeleen, 17 mei 2005, JAR 2005/143, Ktr. Nijmegen, 3 mei 2005, JAR 2005/163 (afwijking anciënniteitsbeginsel, na aanbieden scholing).

147 Ktr. 's-Hertogenbosch, 7 april 2005, JAR 2005/104. Een en ander blijkt uit de beschikking van de kantonrechter's-Hertogenbosch waarin wordt verwezen naar een beschikking van de kantonrechter Utrecht. In verband met de Baijingsleer kon de kantonrechter's-Hertogenbosch hierover niet opnieuw oordelen 148 Zie Kamerstukken II, 2004-2005, 29804 (Nieuwe accenten op het terrein van werk en inkomen), nr. 5, nr. 14 en nr. 17, p. 1-2.

149 Kamerstukken II, 2004-2005, 29804 (Nieuwe accenten op het terrein van werk en inkomen), nr. 17, p. 2

150 Zie voor kennelijk onredelijk ontslag: Ktr. Almelo, 15 juni 2000, JAR 2000/165 en hof 's-Hertogenbosch, 9 december 2003, JAR 2004/32 en voor ontbinding o.a. Krt. Sittard-Geleen, 16 oktober 2003, JAR 2003/271, Ktr. Utrecht, 21 januari 2003, JAR 2003/51 en Ktr. 's-Hertogenbosch, 7 april 2005, JAR 2005/104.

151 Ook dit voorstel is ingtrokken in combinatie met het voorstel de sociale partners de mogelijkheid te bieden af te wijken van de preventieve toets. Kamerstukken II, 2005-2006, 30 370, nr. 8, p. 4 . 
152 Kamerstukken II, 2005-2006, 30 370, nr. 3, p. 19.

153 Kamerstukken II, 2005-2006, 30 370, nr. 3, p. 42.

154 Zie persbericht SWZ, 7 december 2005, nr. 05/209 "Last in, first out niet langer hoofdregel bij ontslag' en Staatscourant, 13 december 2005, nr. 242.

155 Zie de aanbevelingen van de kring van kantonrechters, aanbevelingen 3.6. en HR, 14 juni 2002 en JAR 2002/165 (Bulut/Troost).

156 In de literatuur is discussie geweest over de vraag of een arbeidsovereenkomst voor onbepaalde tijd van rechtswege kan eindigen en over de vraag of een arbeidsovereenkomst met een werknemer die de leeftijd van 65 jaar bereikt moet worden aangemerkt als een arbeidsovereenkomst voor bepaalde tijd of voor onbepaalde tijd. Het strekt in het kader van dit onderzoek te ver deze discussie nader uit te werken. Zie voor een overzicht van deze discussie M.J.M.T. Keulaerds en P.C. Vas Nunes, 'Pensioenontbinding', in: Ontbinding van de arbeidsovereenkomst in tienvoud, reeks Vereniging voor arbeidsrecht, nr. 35, Deventer, Kluwer 2005, p.111-133.

157 Zie o.a. E. Lutjes, Pensioenvoorzieningen voor werknemers (diss. vu), Zwolle Tjeenk Willink 1989, p. 696-698 en recent: M. Heemskerk, 'Ontslagrecht voor 65-plusser is onduidelijk', SMA, maart 2005, nr. 3, p. 131. Hierbij laat ik verder buiten beschouwing of in dat geval de arbeidsovereenkomst moet worden gekwalificeerd als arbeidsovereenkomst voor bepaalde tijd of voor onbepaalde tijd. Zie hierover meer uitgebreid, W.F.C. van Meegen, 'Einde van een arbeidsovereenkomst voor onbepaalde tijd met een maximumduur?', Arbeidsrecht 1998, 63 en M.J.M.T. Keulaerds en P.C. Vas Nunes, 'Pensioenontbinding', in: Ontbinding van de arbeidsovereenkomst in tienvoud, reeks Vereniging voor arbeidsrecht, nr. 35, Deventer, Kluwer 2005, p. 124

158 E.Verhulp, in JAR-Verklaard van 2 juli 2005, Sdu 2005, p. 9 en M.J.M.T. Keulaerds en P.C. Vas Nunes, a.w.

159 HR, 13 januari 1995, JAR $1995 / 35$ (Codfried/ISS).

160 HR, 1 november 2002, JAR 2002/279.

161 HR, 8 oktober 2004, JAR 2004/258 (Van Pelt c.s/Martinair en VNV).

162 Zie Ktr. Utrecht, 22 februari 2005, JAR 2005/77.

163 Zie voor een overzicht Beleidsregels ontslagtaak CWI, Beleidsregels voor de uitvoering van artikel 6 ВВА en het ontslagbesluit, hoofdstuk 35 .

164 Wet van 17 december 2003, Stb. 30 ter uitvoering van de richtlijn 2000/78/EG tot instelling van een algemeen kader voor gelijke behandeling in arbeid en beroep ( $\mathrm{PbEG}$, 2000, L3O3).

165 Beleidsregels ontslagtaak CWI, Beleidsregels voor de uitvoering van artikel 6 BBA en het ontslagbesluit, hoofdstuk 35, p. 35-36.

166 Zie over de wijziging van het Ontslagbesluit en heroverweging van het last in, first out-beginsel ook hoofdstuk 2.

167 Zie voor een uitwerking van wat onder uitwisselbare functies moet worden verstaan uitgebreid W.A. Zondag, 'De rol van het anciënniteitsbeginsel als selectiecriterium bij ontslag wegens bedrijfseconomische redenen', SMA 2005, nr. 10, p. 459 e.v.

168 Deze regel vormt de codificatie van de zogenaamde Ragetlieregel, zie HR, 4 april 1986, NJ 1987, 678 (Ragetlie). 
169 E.Verhulp, in JAR-Verklaard van 2 juli 2005, Sdu 2005, p. 8.

170 Hof Amsterdam, 25 april 2005, JAR 2005/132.

171 Zie over recente voorstellen sociale partners meer ruimte te geven binnen het ontslagrecht hoofdstuk 2.

172 Hoge Raad, 8 oktober 2004, JAR 2004/258.

173 Zie Kamerstukken II, 2001-2002, 28 170, nr. 3 (MvT).

174 Hof Amsterdam, 13 januari 2000, JAR 2000/42.

175 Zie voor een overzicht de in paragraaf 1 van dit hoofdstuk besproken jurisprudentie.

176 Hier wordt verder buiten beschouwing gelaten het mogelijke verschil tussen 65jarige leeftijd en de pensioengerechtigde leeftijd.

177 Zie voor een voorbeeld, Ktr. Utrecht, 30 september 2005, JAR 2005/261.

178 Over de reflexwerking van de kantonrechtersformule op de kennelijk onredelijk ontslagvergoeding zijn de meningen, ook onder rechters, verdeeld. Zie hierover o.a. C.G. Scholtens, 'Kennelijk-onredelijk-ontslagvergoedingen 1992-2001, verschil moet er zijn', ArbeidsRecht 2002, nr. 11, p. 3-14.

179 Deze onduidelijkheid hangt wellicht (deels) samen met het appèlverbod, zoals neergelegd in art.7:685 lid $11 \mathrm{BW}$

180 Zie Ktr. Utrecht, 2 juli 2004, JAR 2004/201 en Ktr. Deventer, 30 november 2005, JAR 2006/23

181 Ktr. Deventer, 30 november 2005, JAR 2006/23.

182 Ktr. Deventer, 28 mei 2003, JAR 2003/186.

183 Zie aanbeveling 3.2 van de aanbevelingen voor de procedures ex. art. 7:685 BW van de kring van kantonrechters.

184 Zie o.a Ktr. Zwolle, 14 maart 2005, JAR 2005/94 en Ktr. Almelo, 22 juni 2005 JAR 2005/176.

185 Zie hierover ook E.Verhulp in JAR-Verklaard april 2003-juni 2003 en E.Verhulp in JAR-Verklaard 2 juli 2005, p. 9-10.

186 Zie bijvoorbeeld Ktr. Alphen aan den Rijn, 1 juli 2003, JAR 2003/183.

187 Hierbij verdient opmerking dat de gedachte dat trouwe dienst, van veelal oudere werknemers, moet worden beloond en de gedachte dat oudere werknemers veelal een slechtere positie op de arbeidsmarkt hebben zeer wel kan leiden tot de conclusie dat er een objectieve rechtvaardiging is voor het wegen van de dienstjaren. Zie over het anciënniteitsbeginsel recent en zeer uitgebreid W.A. Zondag, 'De rol van het anciënniteitsbeginsel als selectiecriterium bij ontslag wegens bedrijfseconomische redenen', SMA 2005, nr. 10, p. 458-473. Met de invoering van de WGBL staat echter wel het automatisme het wegen van dienstjaren (op zijn minst) ter discussie. Zie voor een dergelijk verzoek Ktr. Utrecht, 30 september 2005, JAR 2005/261. 


\section{LITERATUUR}

Arbeidsinspectie (2003) Levensloopbestendige afspraken, Den Haag: Ministerie van Sociale Zaken en werkgelegenheid.

Arbeidsinspectie (2005) Voorjaarsrapportage cao-afspraken 2005, Den Haag: Ministerie van Sociale Zaken en werkgelegenheid.

Arbeidsinspectie (2004) Voorjaarsrapportage cao-afspraken 2004, Den Haag: Ministerie van Sociale Zaken en werkgelegenheid.

Baris, A. (2004) 'Kiezen voor groei', Sociaal Recht 10: 329-330.

Baris, A. (2004) 'Vergoeding bij ontslag zonder grondslag?', SMA 339-345.

Barendrecht, J.M. (1994) ‘Civielrechtelijke ontslagbescherming?’, TVVS 9: 230-235.

Bekker, S., P. Ester en A.C.J.M. Wilthagen (2005) Jong en oud op de arbeidsmarkt generaties, transities en levensloop, Den Haag: Reed Business Information.

Boone, J. en J.C. van Ours (2004) 'Effective active labor market policies', Discussion paper, Tilburg: Tilburg University.

Bungener, A.F. en E. Verhulp (2004) 'De eenzijdige verlengingsoptie in de arbeidsovereenkomst', Arbeidsrecht, 64.

Canes, S.G. (1908) Critische systematische commentaar op de wet op het arbeidscontract, Groningen: Noordhoff.

Commissie van de Europese Gemeenschappen (2005) Mededeling aan de Europese Voorjaarsraad; Samen werken aan werkgelegenheid en groei. Een nieuwe start voor de Lissabon-strategie, Brussel.

CPB MEV (1999)

http://www.cpb.nl/nl/cepmev/mev/1999/speciale_onderwerpen/employability.pdf

Damsteegt, A.C. (2003) De aansluiting van het werkloosheidsrecht op het ontslagrecht, Den Haag: RUL.

Employment Taskforce Kok (2003) Jobs, Jobs, Jobs. Creating more employment in Europe.

Evers, G.H.M., A.J.C.M. Wilthagen en I. Borghouts-van der Pas et al. (2004) Best practices in Ww-preventie, Tilburg: OsA.

Het Financieele Dagblad (2005) ‘Hoge werkloosheid houdt jongeren in de schoolbanken', 30 augustus.

Het Financieele Dagblad (2005) 'Kennis kost veel, maar geeft meer', 6 oktober.

Fortuyn, P. (2002) De puinhopen van acht jaar paars, Uithoorn: Karakter.

Fredman, S. (2004) 'The Ideology of new Labour Law', in C. Barnard et al. The Future of Labour Law, Liber Amicorum Sir Bob Hepple, Oxford.

Frenkel, B.S. (1986) Scholing en vakopleiding als sociaal recht, Tilburg.

Grapperhaus, F.B.J. (2003) 'De positie van de bestuurder van de Nederlandse beursvennootschap' Ondernemingsrecht, 11:422.

Grapperhaus, F.B.J. (2003) 'Het recht van de werknemer op een beëindigingsvergoeding staat los van zijn recht op (werkloosheids)uitkering', Sociaal Recht 1: 4-5

Heemskerk, M. (2005) 'Ontslagrecht voor 65-plusser is onduidelijk', SMA 3: 131

Heerma van Voss, G.J.J. en P.F. van der Heijden (1990) Herziening van het ontslagrecht volgens wetsvoorstel 21 479, SR 1990-5.

Heerma van Voss, G.J.J. (1993) Ontslagrecht in Nederland en Japan, Deventer: Kluwer. 
Heerma van Voss, G.J.J. (2005) 'Driekwart dwingend recht' in R.A.A. Duk et al. Cao-recht in beweging, Den Haag Sdu.

Heijden van der, P.F. en F.M. Noordam (2001) 'De waarde(n) van het sociaal recht, over beginselen van sociale rechtsvorming en hun werking' in Tjeenk Willink Preadvies NVJ, Deventer: Kluwer.

Keulaerds, M.J.M.T. en P.C. Vas Nunes (2005) 'Pensioenontbinding' in 'Ontbinding van de arbeidsovereenkomst in tienvoud', Reeks Vereniging voor Arbeidsrecht, 35 , Deventer: Kluwer.

Koning, J. (2005) 'Effectief arbeidsmarktbeleid: effectiever dan vaak wordt aangenomen', Tijdschrift voor Arbeidsvraagstukken, 1: 16.

Kuip, S.W. (1993) Ontslagrecht met bijzondere aandacht voor de dringende reden, Deventer: Kluwer.

Leuven, L. en H. Oosterbeek (2001) Scholing van werkenden. Deel II: Determinanten van deelname aan scholing, Den Haag: Ministerie van Economische Zaken.

Lieshout, H. van, P. Kamphuis, F. Jellema en T. Wilthagen (2005) Postinitiële scholing, van patstelling naar pact, Tilburg: OSA.

Loonstra, C.J. (200o) 'Het systeem van het ontslagvergoedingsrecht', in De onderneming en het arbeidsrecht in de $21^{e}$ eeuw; Liber Amicorum voor Prof. Mr. F. Koning, Den Haag: BJU.

Loonstra, C.J. (2001) 'De rechtsgrond(en) van ontslagvergoedingen', in Arbeidsrecht, 8/9: $32-40$.

Loonstra, C.J. en W.A. Zondag (200o) 'Ontslagvergoedingsrecht: stand van zaken en perspectief', NJB 1267.

Loonstra, C.J. en L.G. Verburg (2005) 'Hoe exclusief is exclusief? Over de juridische status van de 685-procedure en de contractuele vergoeding', ArA 1: 48-752.

Lutjes, E. (1989) Pensioenvoorzieningen voor werknemers, Zwolle: Tjeenk Willink.

Meesgen, W.F.C. van (1998) 'Einde van een arbeidsovereenkomst voor onbepaalde tijd met een maximumduur?', Arbeidsrecht 63 .

Ministerie van Economische Zaken (2003) Innovatiebrief; deel I. In actie voor innovatie, Den Haag.

Ministerie van Economische Zaken (2004) Trendrapport. Vraag naar arbeid, Den Haag.

Ministerie van Sociale Zaken en Werkgelegenheid (2005) Plan van aanpak 2005-2007 Werken $\&$ Leren, Den Haag.

Ministerie van Sociale Zaken en Werkgelegenheid (2005) Empowerment Centre http://agentschap.szw.nl/index.cfm?fuseaction=dsp_document\&link_id=69o8 3

Nieuwland, D.S. (2004) 'De eenzijdige optie nader beschouwd' Rechtshulp, 6/7: 37-42.

Noordam, F.M. (200o) 'Einde werk, einde verhaal? Vijf modellen', blz. 341 in C.J. Loonstra, De onderneming en het arbeidsrecht in de $21^{\text {ste }}$ eeuw, Den Haag: BJU.

Partij van de Arbeid (2005) Beginselen, Amsterdam: PvdA.

Rayer, C.W.G., F.H. Tros en E. Verhulp (2005) 'Flexibiliteit en zekerheid in sociale plannen. Naar meer activering?’ SMA, 12: 529.

Rood, M.G. (1998) ‘Naar een nieuw sociaalrechtelijk denkraam’ in F.M. Noordam (red.) Sociaalrechtelijke oraties 1977-1997, Deventer: Kluwer.

Roozendaal, W.L. (2005) 'De zorgende werkgever. Over de grondslagen van de verantwoordelijkheid van de ziekte van de werknemer' ArbeidIntegraal, 3: 23-37. 
Scholtens C.G. (2001) 'Malus in de WW, een nieuw monstrum', NJB 1071-1072 .

Scholtens C.G. (2002) 'Kennelijk-onredelijk-ontslagvergoedingen 1992-2001, verschil moet er zijn', ArbeidsRecht 11: 3-14.

T.E.E. Tjong Tjin Tai en Th. Veling (2005) 'Voor De Laat: de Hoge Raad', Reeks Vereniging voor Arbeidsrecht 34: 155, Deventer: Kluwer.

Velzen, M. van (2004) Learning on the fly. Worker training in the age of employment flexibility, Amsterdam.

Verburg, L.G. (2005) 'De bestuurder beschermd: effecten van dualiteit op de positie van statutair directeur' Arbeidsrecht, 43:23.

Verhulp, E.(2003) (red.) Inleiding Nederlands Ambtenarenrecht, Den Haag: BJU.

Verhulp, E. (2004) 'Ontslagrecht in beweging?’ in E. Verhulp Ontslagrecht in beweging, Den Haag: sdu.

Verhulp, E. (2005) 'De opzegtermijnen nader beschouwd' in Arbeidsrecht, 1.

VNO-NCW (2003) Nederland moet slimmer. Onderwijsbeleid voor de kenniseconomie 2010, Amsterdam: VNO-NCW.

Waterreus, J.M. (2002) O\&O-fondsen op herhaling, Amsterdam: Max Goote Kenniscentrum.

Westerveld, M. (2005) 'Weg met de 65-jaargrens! Of niet?' SMA 7/8: 346-354.

Wetenschappelijk Instituut voor het CDA (2004) Zekerheid op maat, van nazorg naar voorzorg in sociale zekerheid, Den Haag: WI CDA.

Wilthagen, A.C.J.M., P. Ester, H.E. Meihuizen, H. van den Berg, I. Borghouts- Van de Pas, W.A. Zondag en G. Evers (2004) Best practices in WW-preventie, Tilburg: OSA

Wilthagen, A.C.J.M., F. Tros en H. van Lieshout (2003) 'Toward Flexicurity? Balancing flexibility and security' in EU member states: paper presented for the $13^{\text {th }}$ World Congress of the IRRA, Berlin.

Zondag, W.A. (2005) 'De rol van het anciënniteitsbeginsel als selectiecriterium bij ontslag wegens bedrijfseconomische redenen’, SMA, 10: 472 . 


\title{
5 ONTSLAGREGELS: EEN RECHTSECONOMISCHE ANALYSE
}

\author{
Ann-Sophie Vandenberghe
}

\subsection{INLEIDING}

Wanneer een werkgever en een werknemer een arbeidsovereenkomst sluiten, weten zij dat de toekomst onzeker is. Deze onzekerheid is het gevolg van een gebrek aan informatie over de economische omstandigheden in de toekomst. Aangezien het voor de arbeidspartijen onmogelijk is om bij het aangaan van de arbeidsovereenkomst voorzieningen te treffen voor gebeurtenissen waarover zij nog geen informatie hebben, dienen zij aanpassingsmechanismen af te spreken. Deze aanpassingsmechanismen maken het mogelijk dat de arbeidsovereenkomst - in hun wederzijds belang - wordt aangepast aan gewijzigde omstandigheden. De aanpassing kan inhouden dat de inhoud van de arbeidsovereenkomst, zoals de werkzaamheden, de arbeidsplaats, de arbeidsduur of het loon, wordt gewijzigd of dat de arbeidsovereenkomst in haar geheel wordt beëindigd. Een drietal aanpassingsmechanismen kan worden onderscheiden: aanpassing door wederzijds akkoord, de eenzijdige aanpassing en aanpassing door een derde partij.

Het arbeidsovereenkomstenrecht bevat een aantal dwingende regels voor de aanpassing van de arbeid. De wijziging en de beëindiging van de arbeidsovereenkomst zijn belangrijke leerstukken uit het arbeidsrecht. Aan de aanpassing door wederzijds akkoord worden in principe geen andere eisen gesteld dan die welke gelden ten aanzien van het sluiten van overeenkomsten in het algemeen. Ten aanzien van de eenzijdige aanpassing door de werkgever gelden wel specifieke regels die er veelal op neerkomen dat een derde partij - de rechter of de administratieve overheid - oordeelt over de wenselijkheid van de aanpassing, die daardoor eigenlijk niet langer als een eenzijdige aanpassing kan worden beschouwd, maar als een aanpassing door een derde partij. ${ }^{1}$ De bescherming van de werknemer staat hierbij voorop. Dit is onder meer het geval voor de eenzijdige beëindiging van de arbeidsrelatie door middel van opzegging door de werkgever. Waar in het begin van de twintigste eeuw slechts de vereiste gold om bij het opzeggen een wettelijke opzegtermijn in acht te nemen, heeft daarna een verschuiving plaatsgevonden van ontslagvrijheid (van de werkgever) naar ontslagbescherming (van de werknemer), ter bescherming van het sociaal en economisch belang dat het behoud van de baan voor de werknemer vertegenwoordigt (Bakels 1997: 94). De ontslagvrijheid van de werknemer wordt in Nederland beperkt doordat voor de eenzijdige opzegging van de arbeidsrelatie van onbepaalde duur een vergunning van de Centrale organisatie voor werk en inkomen (CWI) is vereist. De CWI toetst of het voorgenomen ontslag redelijk is. Daartoe zal de werkgever moeten aantonen dat hij een gegronde reden heeft voor het ontslag. ${ }^{2}$ Door deze vorm van ontslagbescherming die betrekking heeft op de gronden voor het ontslag, krijgt de werknemer meer baanzekerheid. ${ }^{3}$ 
Meer baanzekerheid voor de ene partij, de werknemer, betekent dat een andere partij, de werkgever, meer risico's moet dragen. Sedert de jaren tachtig van de vorige eeuw zijn wetsontwerpen ingediend en sommige ingevoerd om het ontslagrecht te versoepelen, maar tot een fundamentele wijziging van het ontslagrecht heeft dit niet geleid (Bakels 1997: 94). De pogingen tot versoepeling van het ontslagrecht rusten deels op de overweging dat de bestaande ontslagbescherming werkgevers zou ontmoedigen om nieuw personeel aan te trekken (Jacobs en Plesen 1992: 83). Regels die de baanzekerheid verhogen zouden het aantal beschikbare banen en daarmee de werkzekerheid verlagen. Echter, in termen van werkloosheid en werkgelegenheid presteert de Nederlandse arbeidsmarkt niet slechter dan de meer flexibele arbeidsmarkten. ${ }^{4}$ Maar ontslagbescherming kan ook gevolgen hebben voor de manier waarop de arbeid wordt georganiseerd en op de productieve waarde van bestaande arbeidsrelaties.

Ontslagbescherming kan ertoe leiden dat werkgevers besluiten om de arbeid anders te organiseren, bijvoorbeeld op basis van tijdelijke contracten, uitzendarbeid of opdrachtovereenkomsten. Deze overeenkomsten hebben gemeen dat ze zonder tussenkomst van een derde partij kunnen worden beëindigd. Bedrijven met een grote onzekerheid over de gepaste grootte en samenstelling van hun personeelsbestand in de toekomst, kiezen in een aantal gevallen voor deze flexibelere vormen van arbeidsrelaties. Op die manier kunnen bedrijven het risico vermijden dat ze in de toekomst gebonden zijn aan een arbeidsrelatie die zij niet willen voortzetten ten gevolge van een wijziging in de economische omstandigheden. De Nederlandse arbeidsmarkt is verdeeld tussen een groep werknemers met een los of tijdelijk dienstverband die vaak van baan wisselen en een groep werknemers met een vast dienstverband die lang bij eenzelfde bedrijf werkzaam zijn. Daarnaast beïnvloedt ontslagbescherming de gezamenlijke waarde voor de werkgever en werknemer in bestaande arbeidsrelaties. Door productieve investeringen in de arbeidsrelatie, door risico's te transfereren naar diegene die het best geplaatst is om het risico te dragen en door transactiekosten te verlagen kunnen de arbeidspartijen de gezamenlijk waarde van hun samenwerking verhogen. ${ }^{5}$ Minstens even belangrijk als de vraag naar de effecten van ontslagbescherming op werkloosheid is de vraag naar de effecten van ontslagbescherming op de gezamenlijke waarde van arbeidsrelaties. Deze vraag staat centraal in dit onderzoek.

\section{Onderzoeksvraag}

De centrale onderzoeksvraag luidt: kunnen de Nederlandse ontslagregels beschouwd worden als efficiëntieverhogend? Ter beantwoording van die vraag wordt aan de hand van de rechtseconomische methode een prikkel-, risico- en transactiekostenanalyse van de ontslagregels gemaakt. Regels zijn efficiënt wanneer zij beantwoorden aan hetgeen rationele partijen contractueel afspreken bij afwezigheid van transactiekosten en marktimperfecties. Uitgangspunt van de rechtseconomische analyse is dat rationele partijen - wanneer zij vrijwillig een arbeidsovereenkomst aangaan in een perfecte markt - bedingen overeenkomen die de gezamenlijke waarde van tewerkstelling maximaliseren. Een beding is efficiënt wanneer de voordelen ervan opwegen tegen de kosten die ermee gepaard 
gaan. De kosten van ontslagbescherming zijn arbeidskosten die de lonen die een werkgever wil betalen verlagen. Niettemin zullen rationele partijen regels met betrekking tot ontslagbescherming afspreken wanneer de voordelen ervan hoger zijn dan de kosten. Echter, transactiekosten en marktimperfecties kunnen de totstandkoming van efficiënte bedingen verhinderen. Het ontslagrecht kan dan een welvaartsvermeerderende rol vervullen door de arbeidsovereenkomst in overeenstemming te brengen met wat rationele partijen afgesproken zouden hebben bij afwezigheid van transactiekosten en marktimperfecties.

Het onderzoek is in de eerste plaats positief verklarend van aard. Er wordt gekeken of de huidige ontslagregels efficiënt zijn. Daarnaast zullen een aantal normatieve conclusies van conditionele aard worden gemaakt. Indien efficiëntie als doelstelling van het ontslagrecht wordt aanvaard, hoe zouden de huidige regels aangepast kunnen worden om ze meer in overeenstemming te brengen met hetgeen vanuit rechtseconomisch oogpunt als optimaal kan worden beschouwd?

\section{Opbouw van het onderzoek}

In dit onderzoek wordt een onderscheid gemaakt tussen twee aspecten van het ontslagrecht: (I) de regels met betrekking tot de gronden voor ontslag en (II) de regels met betrekking tot de ontslagvergoeding. ${ }^{6}$ Voor wat betreft de gronden voor ontslag geldt in Nederland dat de werkgever tegenover een derde partij (CWI of de kantonrechter) moet kunnen aantonen dat er gegronde of gewichtige redenen bestaan om de arbeidsrelatie met een onbepaalde duur eenzijdig te beëindigen. Dit systeem staat tegenover een systeem waarbij de werkgever de arbeidsovereenkomst voor onbepaalde duur naar eigen goeddunken kan beëindigen. Eerst wordt gekeken wat een regime waarbij een gegronde reden voor ontslag moet worden aangetoond betekent voor het gebruik van de externe arbeidsmarkt voor de reallocatie van werknemers en de kosten die ermee gepaard gaan. Daarna wordt onderzocht of de Nederlandse regels met betrekking tot de gronden voor ontslag economische voordelen met zich meebrengen die opwegen tegen de kosten. Deze voordelen kunnen gelegen zijn in de bescherming van de individuele belangen, het algemene belang of het socialezekerheidsbelang.

Het tweede deel van het onderzoek betreft de regels omtrent de ontslagvergoeding. In de huidige ontslagpraktijk dient de werkgever veelal een ontslagvergoeding te betalen aan de werknemer om de nadelige gevolgen van het ontslag te verzachten. Dit is niet alleen zo wanneer de arbeidsovereenkomst wordt ontbonden door de kantonrechter, maar ook in andere gevallen van onvrijwillige beëindiging (bijvoorbeeld bij collectieve ontslagen). Kan het recht op een ontslagvergoeding en de wijze waarop de vergoeding wordt berekend verklaard worden op economische gronden? Werknemers die naar aanleiding van economische veranderingen worden ontslagen kunnen verliezen lijden. Nadat aangetoond wordt om welke verliezen het precies gaat, wordt nagegaan of de ontslagvergoeding het geschikte middel is om de verliezen te compenseren. 


\subsection{RECHTSECONOMISCHE BENADERING}

\subsubsection{DE RECHTSECONOMISCHE BENADERING}

In dit onderzoek worden de ontslagregels vanuit een rechtseconomisch perspectief benaderd. De rechtseconomische analyse onderzoekt het effect van rechtsregels op de efficiënte allocatie van middelen. Door een efficiënte allocatie van middelen kan waarde of welvaart worden gecreëerd in de maatschappij. Tal van rechtsregels, zoals het aansprakelijkheidsrecht en het contractenrecht, kunnen als efficiënt worden verklaard, omdat ze partijen ertoe aanzetten om een optimale hoeveelheid middelen aan zorg te besteden om schade aan andere partijen te voorkomen, bewerkstelligen dat risico's worden gedragen door de partij die het risico tegen de laagste kosten kan dragen, transacties waarvan de opbrengsten hoger zijn dan de kosten bevorderen en omgekeerd, transacties waarbij dat niet het geval is, verhinderen. Transactiekosten speelt hierbij een belangrijke rol. Immers, zoals werd aangetoond door Ronald Coase (1960) in zijn artikel 'The Problem of Social Cost', zullen partijen bij afwezigheid van transactiekosten, zelf optimale, waardemaximaliserende arrangementen afspreken. Het recht speelt in dat geval geen rol voor wat betreft de efficiënte allocatie van middelen. Het recht speelt wel een efficiëntieverhogende en dus welvaartsvermeerderende rol wanneer transactiekosten de vrijwillige totstandkoming van welvaartsvermeerderende transacties verhinderen.

Voor de rechtseconomische analyse van de regels van het arbeidsovereenkomstenrecht, waaronder het ontslagrecht, wordt gebruikgemaakt van de inzichten uit de rechtseconomische analyse van het contractenrecht. De arbeidsovereenkomst is immers ook een contract. Voor een overzicht van de rechtseconomische analyse van het contractenrecht kan verwezen worden naar het boek van Gerrit de Geest (1994) Economische analyse van het contracten- en quasi-contractenrecht. De Geest bespreekt daarin eerst hoe contractuele samenwerking baten kan creëren. Dat is het geval wanneer (I) goederen door contractuele samenwerking in handen komen van een persoon voor wie het een hoger nut heeft of (II) taken worden verricht door diegene die dat het goedkoopst kan uitvoeren (cheapest cost producer) of (III) risico's worden gealloceerd naar degene die het best geplaatst is om het risico te dragen (cheapest cost insurer). Daarna bespreekt hij welke transactiekosten, bestaande uit informatiekosten, prikkelkosten en kosten van additionele risicocreatie, gepaard gaan met het onderhandelen (precontractuele fase), uitvoeren (contractuele fase) en handhaven (postcontractuele fase) van overeenkomsten. Al deze kosten verlagen de baten van contractuele samenwerkwerking en bepalen daarom (I) of een transactie tot stand komt en (II) welke vorm een transactie zal aannemen. In de rechtseconomische analyse wordt met deze kosten rekening gehouden om (III) te bepalen welke rechtsregels optimaal zijn. Een complete rechtseconomische analyse van regels bekijkt de invloed ervan op (1) de efficiënte aanwending van middelen (2) de efficiënte allocatie van risico's en (3) de transactiekosten. 


\subsubsection{TYPISCHE KENMERKEN VAN DE ARBEIDSRELATIE}

Voor de rechtseconomische analyse van ontslagregels zijn een aantal typische kenmerken van de arbeidsovereenkomst van belang.

\section{INFORMATIEKOSTEN}

\section{Niet-verifieerbare informatie}

Het is voor de arbeidspartijen vaak moeilijk om aan te tonen voor een derde partij (de rechter) dat de andere partij de verbintenissen uit de arbeidsovereenkomst niet heeft nageleefd. Partijen bij een commerciële overeenkomst daarentegen kunnen makkelijker voor de rechter aantonen dat de andere partij niet heeft betaald of geleverd conform de afspraak. Dit is moeilijker bij arbeidsovereenkomsten, omdat vele afspraken stilzwijgend zijn en omdat uitvoering van de overeenkomst vaak afhangt van factoren zoals inzet en motivatie die voor de werkgever observeerbaar zijn, maar niet verifieerbaar zijn door de derde partij (de rechter). In dat geval kunnen rechters vergissingen begaan; ze begaan dan een 'juridische fout' (legal error). De kern van het probleem zit in de informatieasymmetrie: de partijen of een van de partijen weten het best wat de werkelijke feiten zijn. De rechter moet afgaan op het naar voren gebrachte bewijsmateriaal. Bewijskosten leiden tot lagere kosten van legal error. De vergissingen door rechters bestaan vooral in het slecht beoordelen van de feitenkwesties en leiden tot additionele prikkel- en onzekerheidskosten. Wanneer sommige gedragingen systematisch moeilijk te bewijzen zijn, dan kunnen prikkelproblemen ontstaan; de arbeidspartijen hebben geen prikkel om de arbeidsovereenkomst optimaal uit te voeren. Daarnaast leidt onzekerheid over hoe de rechter zal oordelen tot een welvaartsverlies bij risico-averse personen.

\section{Niet-observeerbare informatie}

Er bestaan verificatieproblemen voor rechters, maar ook voor de werkgever is het vaak moeilijk om na te gaan of de werknemer zich optimaal inspant bij de uitvoering van de arbeidsovereenkomst. Tijdens de uitvoeringsfase ontstaat een prikkelprobleem, het 'principaal-agent' probleem. Dit probleem doet zich voor telkens wanneer iemand werkt voor iemand anders en zelf niet de nadelen ondervindt van slechte prestaties. Door meer controlekosten (agency costs) te maken, een vorm van informatiekosten in de uitvoeringsfase, kunnen principaal-agent kosten worden beperkt. De werkgever kan vaak niet perfect controleren hoe hard de werknemer werkt. De werknemer heeft daarom een zekere mate van vrijheid om het werk in te richten en te bepalen hoe hard hij zich inspant.

\section{Kosten opportunistisch gedrag}

Veel arbeidsovereenkomsten zijn 'relationele contracten'. Het eerste kenmerk van relationele contracten is dat ten minste een van de partijen relatiespecifieke investeringen maakt. Deze investeringen gaan verloren wanneer de arbeidsrelatie wordt beëindigd. Arbeidseconomen maken een onderscheid tussen twee vormen van menselijk kapitaal (gedefinieerd als het vermogen om inkomen te verwer- 
ven, earnings capacity): algemeen menselijk kapitaal en specifiek menselijk kapitaal. Waar algemeen menselijk kapitaal waarde heeft bij vele alternatieve werkgevers, is dat niet het geval voor menselijk kapitaal dat specifiek is aan een bepaalde werkgever. Wanneer de werknemer investeringen doet die specifiek zijn voor een bepaalde arbeidsrelatie, dan wordt hij kwetsbaar, met name wanneer de werkgever hem te allen tijde willekeurig zou kunnen ontslaan. Het risico bestaat dan dat de werkgever de werknemer opportunistisch ontslaat of de arbeidsvoorwaarden opportunistisch wijzigt in het nadeel van de werknemer. De werknemer wordt als het ware gedwongen om in te stemmen met de voor hem nadelige aanpassing van de arbeidsvoorwaarden, omdat hij anders zou worden ontslagen waarbij hij eerder gedane relatiespecifieke investeringen verliest. In commerciële contracten wordt de partij die eerst presteert (bijvoorbeeld degene die de goederen eerst levert) beschermd tegen het opportunistisch gedrag van de andere partij door een juridisch afdwingbaar contract (bijvoorbeeld de juridisch afdwingbare verbintenis om het afgesproken bedrag na levering te betalen). Ook voor arbeidsrelaties geldt dat de kosten van opportunistisch gedrag worden verlaagd door juridisch afdwingbare arbeidsvoorwaarden af te spreken in de arbeidsovereenkomst. Echter, bij arbeidsovereenkomst is het vaak niet mogelijk om al vanaf het begin af te spreken welke arbeidsvoorwaarden voor de hele duur van de samenwerking zullen gelden. Het tweede kenmerk van relationele contracten is dat het bij het aangaan van het dienstverband - door een gebrek aan informatie over toekomstige omstandigheden - niet mogelijk om de inhoud van de arbeidsovereenkomst in detail vast te leggen. Bij het aangaan van de arbeidsovereenkomst moeten contractontwerpkosten gemaakt worden. Dit zijn de kosten voor het uitwerken van gedetailleerde regelingen. Zonder deze transactiekosten zou het ideaal zijn dat alle contracten compleet waren. Maar indien men bij het aangaan van het contract nog geen informatie heeft over de toekomst, dan kan men op dat moment nog geen gedetailleerde regelingen afspreken. Over het contract zal dus in de toekomst wanneer er meer informatie beschikbaar is - opnieuw onderhandeld moeten worden. Bij heronderhandelingen zijn er ex post contractontwerpkosten. Maar wanneer een of beide partijen relatiespecifieke investeringen heeft verricht, dan ontstaat er ex post een (bilateraal) monopoly. Een ex post (bilateraal) monopoly leidt tot prikkelkosten - kosten van strategisch gedrag bij heronderhandelingen. Onderhandelingskosten zijn een netto verliespost: de tijd die de partijen besteden aan de discussie hoe ze de winst van de samenwerking onder elkaar zullen verdelen is op zichzelf niet productief.

\section{Risico van wijziging in externe economische omstandigheden}

Een wijziging in externe omstandigheden kan met zich meebrengen dat het voor een van de arbeidspartijen niet langer voordelig is om de arbeidsrelatie voort te zetten. Wat indien de onderneming naar aanleiding van een reductie in de vraag naar de producten of diensten die worden geproduceerd, het personeelsbestand wil inkrimpen? Wat indien de werknemer ergens anders een betere baan kan krijgen? Bij commerciële contracten wordt dit risico normaal gealloceerd naar de partij die de overeenkomst wenst te beëindigen. Deze partij is wellicht het best in staat om te voorkomen dat hij later spijt krijgt van hetgeen in het contract is over- 
eengekomen. Juridisch krijgt dit vorm door de partij die de overeenkomst niet wenst uit te voeren aansprakelijk te stellen voor de schade die de andere partij lijdt ten gevolge van contractbreuk. Hoe wordt dit risico gealloceerd in de arbeidsovereenkomst? Wanneer de partijen een bepaalde duur hebben afgesproken, is duidelijk dat de voortijdige beëindiging een vorm van contractbreuk inhoudt, waarvoor degene die het initiatief tot beëindigen neemt aansprakelijk is. Maar het is moeilijker vast te stellen hoe partijen dit risico hebben willen alloceren voor arbeidsovereenkomsten van onbepaalde duur. Hebben de partijen geen duur afgesproken, dan kan daaruit niet afgeleid worden dat partijen zich verbonden hebben om de arbeidsrelatie voort te zetten tot aan de pensioengerechtigde leeftijd. Maar betekent dat dan dat iedere partij de arbeidsrelatie kan beëindigen wanneer hij dat wenst?

Zowel de werkgever als de werknemer kan bij het sluiten van de arbeidsovereenkomst waarde hechten aan het recht om de arbeidsrelatie eenzijdig te kunnen beëindigen wanneer voortzetting van de arbeidsrelatie niet langer aantrekkelijk is als gevolg van een wijziging van omstandigheden. Geen van de partijen loopt dan het risico dat de relatie moet worden voortgezet tegen zijn wil. Maar eenzijdige opzegging door de ene partij kan specifieke verliezen met zich meebrengen voor de andere partij. Dat is bijvoorbeeld het geval wanneer de werknemer van wie de arbeidsovereenkomst eenzijdig door de werkgever wordt opgezegd, relatiespecifieke investeringen heeft gedaan die door de opzegging verloren gaan. Opdat rekening gehouden wordt met de specifieke verliezen bij opzegging, kunnen de arbeidspartijen dan afspreken dat de werkgever bepaalde voorwaarden in acht neemt wanneer hij zijn recht op eenzijdige opzegging van de arbeidsrelatie uitoefent, zoals de opzegtermijn of de ontslagvergoeding.

\subsubsection{ONTSLAGREGIMES}

Onder ontslagregime wordt begrepen de regels die gelden wanneer de werkgever de arbeidsovereenkomst eenzijdig wil beëindigen. ${ }^{7}$ Afhankelijk van het geldende ontslagregime geniet de werknemer meer of minder juridische ontslagbescherming. Elke van de hierna opgesomde regimes heeft voor- en nadelen in het licht van de hierboven genoemde typische kenmerken van de arbeidsrelatie.

\section{Ontslag naar eigen goeddunken}

Onder een regime van puur 'ontslag naar eigen goeddunken' (termination at will) kan de werkgever de arbeidsrelatie te allen tijde eenzijdig beëindigen zonder dat hij zijn ontslagbeslissing moet verantwoorden. De werknemer heeft geen wettelijk of contractuele bescherming tegen ontslag. ${ }^{8}$ De werknemer heeft geen rechtsgrond om de ontslagbeslissing aan te vechten. Omdat de werkgever te allen tijde een einde kan maken aan de arbeidsovereenkomst, betekent dit ook dat hij de inhoud van de arbeidsrelatie te allen tijde kan aanpassen, ook op opportunistische wijze wanneer de werknemer relatiespecifieke investeringen heeft gedaan. Daar staat tegenover dat de werkgever de arbeidsrelatie van werknemers die niet goed presteren gemakkelijk kan beëindigen. Onder dit flexibele regime loopt de 
werkgever niet het risico dat de relatie moet worden voortgezet wanneer hij of zij dat niet wenst als gevolg van een wijziging van omstandigheden.

\section{Opzegtermijnen}

De opzegtermijn is een lichte vorm van ontslagbescherming. Het basisprincipe is dat de werkgever naar eigen goeddunken kan ontslaan zoals onder subparagraaf 5.2.3, maar dat hij hierbij een opzegtermijn in acht moet nemen. Gedurende de opzegtermijn wordt het loon van de werknemer volledig doorbetaald. Wat is de functie van opzegtermijnen? Zij bieden inkomensbescherming gedurende de periode waarin de werknemer zoekt naar een nieuwe baan. Dit betekent dat een langere opzegtermijn gerechtvaardigd is wanneer de werknemer gemiddeld een langere termijn nodig heeft om een gelijkwaardige functie te vinden. Bijvoorbeeld, een jurist die zich specialiseert in ondernemingsrecht zal bij ontslag gemiddeld minder tijd nodig hebben om een andere baan te vinden dan een jurist die zich specialiseert in maritiem recht. De markt voor juristen die gespecialiseerd zijn in maritiem recht is immers kleiner. In België bijvoorbeeld zijn de wettelijk geregelde opzegtermijnen voor bedienden langer dan die voor arbeiders. De regeling stamt nog uit de tijd dat arbeiders na ontslag sneller een nieuwe baan vonden dan bedienden. De Belgische regeling in verband met opzegtermijnen biedt ook een langere opzegtermijn voor 'hogere' bedienden dan voor 'lagere' bedienden. Dit reflecteert het feit dat er aan de top minder posities beschikbaar zijn. In Nederland verschillen opzegtermijnen enkel met het aantal dienstjaren op het ogenblik van het ontslag.

\section{Opzegtermijnen plus bescherming tegen een kennelijk onredelijke opzegging}

De werknemer heeft iets meer ontslagbescherming wanneer hij naast de opzegtermijn ook beschermd wordt tegen een 'kennelijk onredelijke' opzegging. Onder dit regime kan de werkgever de arbeidsrelatie eenzijdig opzeggen mits met eerbiediging van de opzegtermijn, maar wordt hij gesanctioneerd wanneer de werknemer kan aantonen dat er sprake is van kennelijk onredelijk ontslag. De bewijslast van de onredelijkheid van het ontslag ligt bij de werknemer. De mate van ontslagbescherming hangt af van hoe rechters het begrip 'kennelijk onredelijk ontslag' interpreteren. Het adjectief 'kennelijk' wijst erop dat de rechters de ontslagbeslissing slechts marginaal toetsen. Bij een marginale toetsing beoordelen de rechters niet de wenselijkheid, opportuniteit of redelijkheid van het ontslag, maar gaan zij alleen na of de ontslagbeslissing zo onredelijk is dat geen enkele redelijke werkgever daartoe had kunnen besluiten.

\section{De vereiste van een gegronde reden voor ontslag}

Onder het regime waarbij een gegronde reden voor het ontslag is vereist (just cause termination) dient een derde partij (administratieve overheid of rechter) toestemming te verlenen voor het ontslag. De werkgever draagt de bewijslast; hij moet aantonen dat er gegronde economische of andere redenen zijn om de arbeidsovereenkomst te beëindigen. Onder dit regime zal het voorkomen dat de werkgever de arbeidsrelatie wil beëindigen als gevolg van een wijziging in 
externe omstandigheden, maar dat daar naar het oordeel van de derde partij geen gegronde reden voor is. Deze beperking in de flexibiliteit is mogelijk nodig om de werknemer te bewegen tot het doen van relatiespecifieke investeringen, hoewel later in dit onderzoek aangetoond zal worden dat dit ook kan door het betalen van een ontslagvergoeding. Het regime veronderstelt ook dat de derde partij in staat is om de kwaliteit van de uitvoering van de arbeidsovereenkomst te verifiëren. Is dat niet het geval, dan bestaat het risico dat de werkgever een werknemer die niet goed presteert moet blijven tewerkstellen.

Het Nederlandse ontslagregime voor arbeidsovereenkomst voor onbepaalde duur bestaat uit de vereiste van een gegronde reden voor ontslag en de vereiste om een opzegtermijn in acht te nemen met bescherming tegen een kennelijk onredelijke opzegging.

\section{De vaste aanstelling}

Bij een vaste aanstelling (tenure) kan de werknemer alleen ontslagen worden wanneer er sprake is van een grove tekortkoming in de uitvoering van de arbeidsovereenkomst; de werknemer kan niet ontslagen worden omwille van gewijzigde economische omstandigheden. Deze vorm van tewerkstelling komt voornamelijk voor bij de overheid. Blijkbaar zijn werknemers enkel bereid om bepaalde overheidsfuncties uit te oefenen wanneer dat gepaard gaat met een grote ontslagbescherming. Dit zou het geval kunnen zijn wanneer het einde van de arbeidsrelatie ook het einde van een carrière betekent, omdat er buiten de overheid geen markt voor die beroepen bestaat. Voor rechters en militairen bijvoorbeeld kan dat het geval zijn.

\subsection{DE RECHTSECONOMISCHE ANALYSE VAN DE REGELS MET BETREKKING TOT DE GRONDEN VOOR ONTSLAG}

In dit onderdeel wordt een economische analyse gemaakt van Nederlandse regels met betrekking tot de gronden van het ontslag. Met de term 'ontslagbescherming' wordt in dit onderdeel van het onderzoek bedoeld de regels die de ontslagvrijheid van de werkgever beperken, doordat hij voor de eenzijdige opzegging toestemming nodig heeft van een derde partij en daartoe tegenover die derde partij moet aantonen dat hij een gegronde reden heeft voor het ontslag. Andere regels die de werknemer beschermen bij ontslag maar die niet de gronden zelf van het ontslag reguleren, zoals de opzegtermijn en de ontslagvergoeding, komen aan bod in paragraaf 5.4. In subparagraaf 5.3.1 wordt gekeken naar de effecten van ontslagbescherming op de reallocatie van werknemers via de externe arbeidsmarkt en de kosten die daarmee gepaard gaan. Daarna wordt onderzocht of ontslagbescherming in de vorm van de regulering van ontslaggronden economische voordelen met zich meebrengt die opwegen tegen de kosten ervan. Achtereenvolgens worden de bescherming van de individuele belangen (\$ 5.3.2), en de bescherming van het algemeen en sociale zekerheidsbelang ( $\$ 5.3 .3$ ) behandeld. 


\subsubsection{ONTSLAGBESCHERMING EN DE REALLOCATIE VAN ARBEID VIA DE EXTERNE ARBEIDSMARKT}

Externe mobiliteit houdt in dat de werknemer via de externe arbeidsmarkt naar een andere baan wordt gealloceerd. Het gebruik van de externe arbeidsmarkt voor de reallocatie van arbeid is efficiënt of waardeverhogend wanneer de werknemer terechtkomt in een baan waar hij zijn arbeid productiever kan aanwenden dan in de vorige baan.

\section{Flexibele loonaanpassingen versus arbeidsovereenkomsten met een vast Ioon}

In een flexibele arbeidsmarkt met losse dienstverbanden en flexibele loonaanpassingen zorgt het loonmechanisme voor de efficiënte allocatie van werknemers naar banen. Met flexibele loonaanpassingen wordt bedoeld dat zodra nieuwe informatie beschikbaar komt over de marginale productiviteit van de werknemer in de onderneming, de lonen daaraan aangepast worden. De werknemer vergelijkt dan het loon dat de huidige werkgever biedt met het loon dat alternatieve werknemers bieden en kiest voor tewerkstelling bij die werkgever die het hoogste loon biedt. Dat is efficiënt wanneer aangenomen wordt dat de andere werkgever enkel een hoger loon zal bieden wanneer de werknemer er productiever tewerkgesteld kan worden. De aldus ontstane mobiliteit gebeurt vrijwillig. De transactiekosten voor de allocatie via de externe arbeidsmarkt zijn de kosten voor de werknemer om uit te vinden welke ondernemingen arbeid vragen en welke lonen ze aanbieden.

De situatie is anders wanneer de arbeidspartijen een arbeidsovereenkomst sluiten waarin het loon bij indiensttreding wordt vastgelegd. Waarom sluiten de arbeidspartijen een arbeidsovereenkomst met een vast loon dat later niet flexibel wordt aangepast aan de werkelijke productiviteit van de werknemer in de onderneming? Bij het in dienst treden bestaat er onzekerheid over de toekomstige productiviteit van de werknemer in het bedrijf. De partijen zouden de bepaling van het loon kunnen uitstellen tot op het moment dat er meer informatie beschikbaar is. Maar dat is riskant wanneer partijen na indiensttreding relatiespecifieke investeringen maken. Deze investeringen hebben tot gevolg dat een bilateraal monopolie ${ }^{9}$ ontstaat op het moment dat over de lonen later onderhandeld wordt. Immers, door de investeringen creëren de partijen een surplus, en beide zullen proberen om een zo groot mogelijk deel van het surplus op te eisen. Deze pogingen betekenen een verspilling van middelen en kunnen ertoe leiden dat het niveau van relatiespecifieke investeringen te laag is. Wie wil immers nog investeren als er onzekerheid bestaat of de opbrengsten ervan kunnen worden verkregen? De oplossing voor dit probleem bestaat eruit dat de partijen vooraf (i.e. voordat de relatiespecifieke investeringen worden gemaakt) in een arbeidsovereenkomst de voorwaarden, inclusief het loon, specificeren waaronder arbeid zal worden verricht. ${ }^{10}$ Het vooraf bepaalde loon kan echter hoger of lager zijn dan de achteraf gerealiseerde marginale productiviteit, maar de lonen worden daaraan niet aangepast aangezien de partijen een vast loon hebben afgesproken. 
De situatie waarbij de arbeidspartijen een arbeidsovereenkomst sluiten met een vast loon is verschillend van die waarin sprake is van een los dienstverband waarin de werkgever het loon flexibel aanpast aan de marginale productiviteit van het moment, de werknemer dat loonoffer telkens vergelijkt met andere loonoffers en vrijwillig van baan verandert wanneer elders een hoger loon wordt geboden. Wanneer een arbeidsovereenkomst is gesloten moet vooraleer gebruikgemaakt wordt van de externe markt voor de reallocatie van arbeid, eerst de huidige arbeidsovereenkomst worden beëindigd. Beëindiging van een arbeidsovereenkomst kan dus worden beschreven als de rechtshandeling die leidt tot het gebruik van de externe arbeidsmarkt voor werknemersreallocatie. Dat gebruik kan vanuit het perspectief van de werknemer vrijwillig of onvrijwillig zijn afhankelijk of de werknemer of de werkgever het initiatief neemt tot beëindiging van de arbeidsovereenkomst.

Het gebruik van de externe arbeidsmarkt voor reallocaties van arbeid is onlosmakelijk verbonden met de regels die gelden ten aanzien van de beëindiging van arbeidsovereenkomsten. Die regels verschillen naar gelang het type arbeidsovereenkomst en het ontslagregime. Er zijn twee types arbeidsovereenkomsten: de arbeidsovereenkomst voor bepaalde tijd en de arbeidsovereenkomst voor onbepaalde tijd. De arbeidsovereenkomst voor bepaalde tijd is een overeenkomst waarvan het einde niet afhankelijk is van de wil van de werkgever of de werknemer. Het gaat om een bepaalde tijdsduur of om een bepaald project (Loonstra 2005: 81). De arbeidsovereenkomst voor onbepaalde tijd wordt gedefinieerd als een overeenkomst waarvan het einde afhankelijk is van de wil van de werkgever of werknemer. Neemt geen van beiden het initiatief tot opzegging, dan blijft de arbeidsovereenkomst van kracht (Loonstra 2005: 81). Opdat een efficiënte reallocatie via de externe arbeidsmarkt kan plaatsvinden, is het dus nodig dat een van de arbeidspartijen eerst het initiatief neemt om de huidige arbeidsovereenkomst te beëindigen. Zonder deze rechtshandeling blijft de huidige arbeidsovereenkomst van kracht. Voor de eenzijdige beëindiging van de arbeidsovereenkomst voor onbepaalde duur kunnen bijzondere regels gelden. Zo moet in Nederland de werkgever een gegronde reden kunnen aantonen. Het regime waarin een gegronde reden is vereist voor de eenzijdige beëindiging staat tegenover een regime waarin de loutere wil van de werkgever voldoende is. Dit regime zal worden aangeduid met ontslag naar eigen goeddunken.

Ontslag is juridisch gezien de eenzijdige rechtshandeling die leidt tot het einde van de arbeidsovereenkomst, maar is economisch gezien een handeling die leidt tot het gebruik van de externe arbeidsmarkt. Het ontslag is bijgevolg efficiënt wanneer als gevolg ervan de werknemer via de externe arbeidsmarkt wordt gealloceerd naar een productievere baan. Dat is het geval wanneer op het ogenblik van het ontslag de productiviteit van de werknemer in de huidige baan lager is dan de productiviteit van de werknemer in de beste alternatieve baan. Hierna wordt voor beide ontslagregimes onderzocht of en op welke wijze de efficiënte reallocatie van werknemers via de externe arbeidsmarkt tot stand komt en welke transactiekosten daarmee gepaard gaan. 


\section{Ontslag naar eigen goeddunken}

Onder ontslag naar eigen goeddunken is de beëindiging afhankelijk is van de loutere wil van een van de partijen. De gevolgen voor het aantal efficiënte beëindigingen van een ontslagregime dat elke partij toelaat om de arbeidsrelatie naar eigen goeddunken op te zeggen, werden beschreven door Hall en Lazear (1984).

\section{Figuur 5.1 Interne en externe mobiliteit in Nederland 1987-2002}

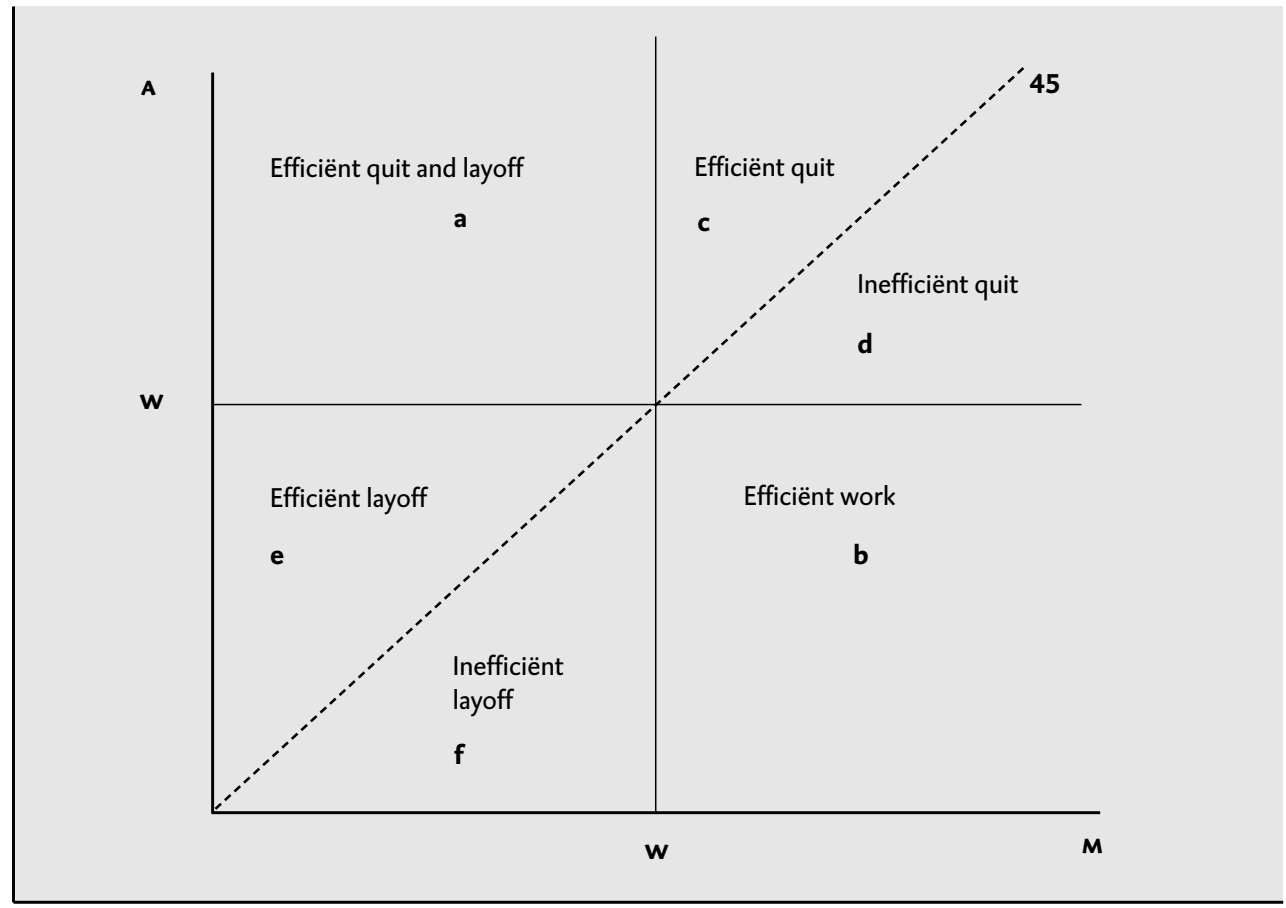

Bron: Hall en Lazear (1984)

W staat voor het overeengekomen loon in de huidige baan. A, op de verticale as, staat voor de marginale productiviteit van de werknemer in een alternatieve tewerkstelling en $\mathrm{M}$, op de horizontale as, staat voor de marginale productiviteit van de werknemer in zijn huidige tewerkstelling. De werkgever zal de arbeidsrelatie beëindigen wanneer de marginale productiviteit van de werknemer (M) lager is dan het loon (w) (in de gebieden a, e en $\mathrm{f}$ ). Ook voor de werknemer is beëindiging gewenst wanneer de waarde van alternatieve tewerkstelling (A) hoger is dan het overeengekomen loon (w) (gebied a). In het gebied linksonder wil de werknemer de relatie beëindigen, maar aangezien de waarde in alternatieve tewerkstelling lager is dan het overeengekomen loon, zal de werknemer erop achteruitgaan in loon. Niettemin zijn ontslagen in het gebied linksonder efficiënt wanneer de waarde bij alternatieve tewerkstelling hoger is dan de productieve waarde in de huidige tewerkstelling (gebied e). Alleen wanneer de waarde in de huidige tewerkstelling hoger is dan in de alternatieve tewerkstelling is het ontslag inefficiënt (gebied f). Deze inefficiënte ontslagen zouden in principe kunnen worden vermeden wanneer het loon naar beneden toe wordt aangepast. ${ }^{11}$ Maar het is juist 
deze loonaanpassing die door het vaste looncontract is uitgesloten. De auteurs concluderen dat het nadeel van het vaste looncontract een occasioneel inefficiënt ontslag is. Dat zal het geval zijn wanneer de situatie slecht is in de onderneming ( $\mathrm{M}$ is laag), maar nog slechter in de hele economie ( $\mathrm{A}$ is nog lager).

Het gebruik van de externe arbeidsmarkt kan ook gebeuren op initiatief van de werknemer wanneer de werknemer de arbeidsrelatie eenzijdig beëindigt (gebieden c en d). Op deze wijze van beëindigen ga ik in deze studie niet nader in.

De kosten voor de werkgever voor het beëindigen van de arbeidsrelatie onder het regime van ontslag naar eigen goeddunken zijn laag. De werkgever moet alleen kosten maken om het besluit te nemen en zijn ontslagbesluit naar de werknemer toe te communiceren. ${ }^{12}$

\section{Gegronde reden als vereiste voor ontslag}

De arbeidsovereenkomst voor onbepaalde tijd wordt gedefinieerd als de overeenkomst waarvan het einde afhankelijk is van de wil van de werkgever of werknemer. De loutere, subjectieve wil is onder het huidige Nederlandse ontslagrecht niet voldoende voor het beëindigen van de arbeidsrelatie. Artikel 6 lid 1 van het Buitengewoon Besluit Arbeidsverhoudingen 1945 stelt immers dat de werkgever, voordat hij tot opzegging van de arbeidsovereenkomst overgaat, voorafgaande toestemming nodig heeft van de Centrale Organisatie voor Werk en Inkomen (CWI). Wanneer de werkgever opzegt zonder voorafgaande toestemming, dan is, zo stelt artikel 9 lid 1 BBA, de opzegging vernietigbaar; de werknemer heeft recht op voortzetting van de arbeidsrelatie. Op grond van artikel 3 Ontslagbesluit toetst de CWI of het voorgenomen ontslag redelijk is. Voor ieder ontslag moet dus een objectief geldige of gegronde reden aanwezig zijn, een justa causa dimissionis. ${ }^{13} \mathrm{De}$ werkgever moet aannemelijk maken dat uit bedrijfseconomisch oogpunt arbeidsplaatsen moeten vervallen. Wat betekent dit regime voor het aantal efficiënte beëindigingen van arbeidsovereenkomsten? In deze analyse wordt alleen gekeken naar de gevallen waarbij een vergunning wordt gevraagd om bedrijfseconomische redenen. Er wordt niet gekeken naar die gevallen waarin verwijtbaar handelen of nalaten als grond voor de beëindiging wordt aangevoerd. ${ }^{14}$

De toestemming van de CWI is slechts vereist wanneer de arbeidsverhouding door opzegging van de werknemer eenzijdig wordt beëindigd. Beëindiging met wederzijds goedvinden is te allen tijde mogelijk. ${ }^{15}$ In dat geval moet geen gegronde reden worden aangetoond. Wanneer de marginale productiviteit van de werknemer in zijn huidige baan lager is dan het afgesproken loon en tegelijkertijd de marginale productiviteit van de werknemer in een alternatieve tewerkstelling hoger is dan het loon (zie gebied a in figuur 5.1), kan door middel van de beëindiging met wederzijds goedvinden de efficiënte reallocatie plaatsvinden.

Ook wanneer de marginale productiviteit in een andere baan hoger is dan in de huidige baan, maar tegelijkertijd het loon in de andere baan lager is dan het afgesproken loon in de huidige baan (gebied e in figuur 5.1), is de reallocatie naar de andere baan efficiënt. Echter, in dat geval zal de werknemer de beëindiging niet 
'goed vinden', omdat hij er in loon op achteruit gaat. Voor de werkgever zijn er dan twee mogelijkheden: ofwel hij zegt de arbeidsovereenkomst eenzijdig op, maar daarvoor is wel een ontslagvergunning nodig, ofwel hij kan zonder ontslagvergunning toch de werknemer overtuigen om akkoord te gaan met een beëindigingovereenkomst in ruil voor een vergoeding.

\section{De ontslagvergunningsprocedure}

Wil de werkgever de arbeidsovereenkomst eenzijdig beëindigen, dan heeft hij daarvoor een vergunning van de CWI nodig. Daarvoor moet de werkgever de CWI overtuigen dat er een gegronde reden is voor het ontslag. Dat is niet eenvoudig wanneer het bestaan van die gegronde reden moeilijk te bewijzen is. Met het bewijzen gaan bewijskosten voor de werkgever en bewijsverificatiekosten voor de CWI gepaard. Voor de CWI is het niet voldoende dat de werkgever stelt dat er gegronde redenen zijn, maar de werkgever moet dit kunnen aantonen aan de hand van bewijsstukken. De checklist van de CWI vermeldt onder meer geconsolideerde balansen en verlies- en winstrekeningen met in toelichting ingegaan op onder andere verhouding vreemd/eigen vermogen, kostenontwikkeling, rentabiliteit, solvabiliteit, liquiditeit, nettoresultatenontwikkelingen, weergave van toekomstige ontwikkelingen (ca. zes maanden), prognose financiële positie in de nabije toekomst (minimaal zes maanden), het oude en toekomstige organisatieplaatje bij reorganisatie, vergelijkbare omzet/productiegegevens over de laatste twee jaar. Aan de hand van de door de werkgever geleverde gegevens toetst de CWI of het gestelde ontslagmotief voldoende aannemelijk is gemaakt. Maar de CWI gaat nog een stapje verder. Naast het aangeven van de economische of organisatorische noodzaak die het verval van arbeidsplaatsen met zich meebrengt (verminderde vraag, noodzakelijke organisatorische aanpassingen, mogelijk ingegeven door een andere wijze van produceren of verlenen van diensten of door technologische veranderingen), moet de werknemer inzicht geven in de maatregelen die hij heeft genomen en kan nemen om de ontslagen te voorkomen, de afvloeiingsregelingen, en de wijze waarop de keuze is gemaakt voor wie voor ontslag in aanmerking komt. In het kader van de redelijkheidstoets zal de CWI de bijzondere positie van de werknemer mede in ogenschouw moeten nemen, zoals diens leeftijd, de duur van de arbeidsovereenkomst en de arbeidsmarktpositie van de werknemer. De redelijkheidstoets brengt met zich mee dat ontslag voor de werkgever in het algemeen het uiterste middel dient te zijn om uit de problemen te komen. De ontslagvergunning wordt niet verleend indien de werknemer redelijkerwijze in dienst kan blijven door overplaatsing, omscholing of doordat andere medewerkers op natuurlijke wijze afvloeien. De CWI velt niet alleen een oordeel over het bestaan van het ontslagmotief, maar ook over de opportuniteit of wenselijkheid van het inroepen ervan. Met andere woorden, de werkgever kan van oordeel zijn dat de economische omstandigheden het ontslag rechtvaardigen, maar de CWI kan oordelen op grond van redelijkheid dat het ontslag in de gegeven omstandigheden niet gewenst is. 
De procedure voor de CWI is op tegenspraak, in die zin dat de werknemer verweer kan voeren tegen het door de werkgever voorgenomen ontslag. Een tweede of zelfs derde ronde van hoor en wederhoor is mogelijk. Deze ronden dienen als aanvulling op datgene wat de werkgever reeds naar voren heeft gebracht, terwijl de werknemer hiertegen verweer kan voeren binnen 1o dagen. Een ronde van hoor en wederhoor duurt ongeveer 5 à 6 weken. De duur van de procedure kan aanzienlijk worden beperkt tot ongeveer twee weken wanneer er door de werknemer geen inhoudelijk verweer wordt gevoerd maar slechts een 'formeel verweer' (pro-formazaken). Dat is een verweer waarbij de werknemer stelt dat hij het niet eens is met het verzoek om een ontslagvergunning, hoewel hij hiertegen geen inhoudelijk verweer kan of wil voeren. In vergelijking met het inhoudelijke verweer verlaagt het pro-formaverweer van de werknemer de procedurekosten voor de werkgever. De werkgever kan de werknemer prikkelen om aan het ontslag mee te werken door af te spreken dat de werknemer een vergoeding krijgt wanneer hij enkel een pro-formaverweer voert.

\section{De beëindigingsovereenkomst}

Verwacht de werkgever dat de bewijskosten om een gegronde reden aan te tonen te hoog zullen zijn of verwacht hij dat op grond van de door de CWI gehanteerde standaarden geen ontslagvergunning verleend zal worden, dan kan de werkgever de werknemer trachten te overtuigen om akkoord te gaan met de beëindiging in ruil voor een vergoeding. In de beëindigingsovereenkomst werkt de werknemer als het ware mee aan de door de werkgever gewenste beëindiging in ruil voor een financiële vergoeding. ${ }^{6}$ De beëindigingsvergoeding die deel uitmaakt van de overeenkomst is de prijs die de werkgever daarvoor betaalt. Of een beëindigingsovereenkomst wordt gesloten, hangt af van de transactiekosten die met het sluiten ervan gepaard gaan. De werknemer zal alleen akkoord gaan met de beëindiging wanneer hij daarvoor een vergoeding krijgt die compenseert voor de lagere beloning in de alternatieve baan. Asymmetrische informatie omtrent de waarde van de alternatieve tewerkstelling en de verwachte inkomensachteruitgang bemoeilijken de onderhandelingen. Partijen kunnen zich ook strategisch gedragen bij de onderhandelingen; de werknemer heeft er alle belang bij om de verliezen zo hoog mogelijk voor te stellen, en de werkgever heeft er alle belang bij om de situatie in de onderneming zo slecht mogelijk voor te stellen. Dit laatste doet de kans dat de CWI een ontslagvergunning zal toekennen (zonder vergoeding voor de werknemer) toenemen, waardoor de werknemer eerder akkoord gaat met een lagere vergoeding in de beëindigingsovereenkomst. Wanneer beide partijen zich hard opstellen tijdens de onderhandelingen, dan vergroot dat de kans dat de onderhandelingen afbreken. Tot voor kort liep de werknemer ook het risico om uitgesloten te worden van de werkloosheidsverzekering wanneer hij akkoord ging met de beëindigingsovereenkomst. ${ }^{17}$

Concluderend kan gesteld worden dat ook onder een regime waarbij een gegronde reden is vereist voor ontslag, arbeidsovereenkomsten zullen beëindigd worden wanneer dat efficiënt is, maar niet altijd. In ieder geval gaat de reallocatie via de externe markt naar een productievere baan gepaard met hogere kosten. 
Deze kosten bestaan uit de bewijskosten om de CWI te overtuigen van de bedrijfseconomische noodzaak van het ontslag en/of de kosten voor het onderhandelen van een beëindigingsovereenkomst. Anders dan de vergoedingen in de beëindigingsovereenkomst - die een pure transfer van de werkgever naar de werknemer zijn - verlagen de bewijs- en onderhandelingskosten het surplus van de tewerkstelling. Wanneer het gebruik van de externe arbeidsmarkt via ontslag duur is, kan dat ertoe leiden dat de reallocatie van de arbeid op een andere manier georganiseerd wordt.

\section{Alternatieve organisatie van de reallocatie van arbeid}

Omdat het gebruik van de externe arbeidsmarkt voor de reallocatie van werknemers duur is onder een regime waarbij een gegronde reden nodig is voor ontslag, kan de onderneming besluiten de reallocatie van de werknemers eventueel anders te organiseren. Voor de reallocatie van de werknemers kan gebruikgemaakt worden van de interne arbeidsmarkt of van outplacement. Reallocatie via de interne arbeidsmarkt houdt in dat de werknemer elders binnen het bedrijf productiever wordt tewerkgesteld en bij outplacement maakt de werkgever gebruik van zijn netwerk om de werknemer te realloceren naar een andere baan.

Een andere mogelijkheid is dat de werkgever kiest voor een ander type overeenkomst, zoals uitzendarbeid, de arbeidsovereenkomst voor bepaalde duur of de overeenkomst van opdracht, waarvoor geldt dat het gebruik van de externe arbeidsmarkt gepaard gaat met lagere transactiekosten. Deze overeenkomsten komen tot een einde zonder dat daarvoor toestemming van een derde partij is vereist.

\subsubsection{ONTSLAGBESCHERMING EN HET GEZAMENLIJKE BELANG VAN DE INDIVIDUELE ARBEIDSPARTIJEN}

De regel dat de arbeidsovereenkomst enkel eenzijdig door de werkgever kan worden opgezegd wanneer daar een gegronde reden voor bestaat is een sterke vorm van ontslagbescherming. Onder dit ontslagregime heeft de werknemer veel baanzekerheid; de werknemer wordt enkel voor ontslag geselecteerd wanneer dat - naar het oordeel van de CWI - het laatste redmiddel is voor de onderneming om uit de problemen te komen. Voor de werkgever betekent deze regel dat hij niet flexibel kan reageren op economische veranderingen door werknemers te ontslaan. ${ }^{18}$ Niettemin zouden rationele arbeidspartijen deze regel vrijwillig overeenkomen wanneer er economische voordelen mee worden bereikt die opwegen tegen de beperking van de flexibiliteit. Mocht de vereiste van een gegronde reden voor ontslag voordelen met zich meebrengen die opwegen tegen de kosten ervan, dan verhoogt deze vorm van ontslagbescherming de gezamenlijke waarde van de tewerkstelling. Beantwoordt de ontslagbescherming in haar huidige vorm aan hetgeen rationele arbeidspartijen vrijwillig zouden overeenkomen? Leidt ontslagbescherming ertoe dat de partijen geprikkeld worden om productieve handelingen te verrichten die de waarde van hun samenwerking doen toenemen en die bij afwezigheid van ontslagbescherming niet tot stand zouden komen? 
Biedt ontslagbescherming een optimale verzekering tegen baanverlies? Verhoogt de ontslagbescherming de waarde van de arbeidsrelatie door een verlaging van kosten?

\section{Investeringen in specifiek menselijk kapitaal}

Een van de economische argumenten in het voordeel van ontslagbescherming is dat het de prikkels van de werknemer om te investeren in waardeverhogende specifieke kennis en vaardigheden verhoogt. Zonder juridisch afdwingbare ontslagbescherming zou de werknemer niet bereid zijn om deze investeringen te doen, omdat hij geen zekerheid heeft dat de investeringen daadwerkelijk zullen worden terugverdiend. Op grond van deze argumentatie is ontslagbescherming in het gezamenlijke belang van de arbeidspartijen, omdat ze welvaartsvermeerderende transacties met betrekking tot ondernemingsspecifieke investeringen bevordert.

Ontslagbescherming in de vorm van de vereiste van een gegronde reden voor ontslag biedt meer baanzekerheid waardoor eerder gemaakte relatiespecifieke investeringen worden beschermd. Echter, het feit dat de werknemer een hoge mate van juridische baanzekerheid heeft, waarborgt niet dat de werknemer daadwerkelijk investeert in relatiespecifieke kennis en vaardigheden. Om het optimale resultaat te bereiken is nodig dat naast ontslagbescherming op grond van de arbeidsovereenkomst wordt bepaald hoeveel en welke relatiespecifieke investeringen gemaakt moeten worden. Dit verhoogt de contractontwerpkosten en de controlekosten van de arbeidsovereenkomst.

De partijen kunnen het gewenste resultaat op een goedkopere manier bereiken door beide te investeren in ondernemingsspecifieke kennis en vaardigheden. In dat geval ontstaat tussen partijen een bilateraal monopoly: elk van de partijen verliest investeringen wanneer de arbeidsrelatie wordt beëindigd. Ontslag zou inhouden dat ook de werkgever eerder gedane investeringen niet meer kan terugverdienen, waardoor de werkgever de werknemer niet snel zal ontslaan. Op die manier verkrijgt de werknemer meer de facto baanzekerheid. Ook zonder juridisch afdwingbare ontslagbescherming heeft de werknemer baanzekerheid. Hij heeft echter geen absolute zekerheid. Wanneer de werkgever het bedrijf wil sluiten, dan zal zijn belang om relatiespecifieke investeringen terug te verdienen, niet verhinderen dat de werknemer toch wordt ontslagen. Maar in dat geval zou ook juridische ontslagbescherming niet verhinderen dat de werknemer wordt ontslagen, aangezien een bedrijfssluiting als gegronde reden wordt beschouwd om de arbeidsovereenkomst op te zeggen.

Juridische afdwingbare baanzekerheid is dus strikt genomen niet nodig om relatiespecifieke investeringen te beschermen wanneer de werknemer al de facto baanzekerheid heeft, omdat beide partijen hebben geïnvesteerd in specifiek menselijk kapitaal. Betekent dat het voor de arbeidspartijen niet uitmaakt of er juridische dan wel de facto baanzekerheid is? Juridische baanzekerheid brengt extra kosten met zich mee omdat de werkgever - in het geval dat ontslag toch 
noodzakelijk wordt - kosten moet maken om de derde partij te overtuigen van de noodzaak van het ontslag. Deze kosten zijn arbeidskosten die het loon dat de werkgever wil betalen verlaagt. De vraag is of werknemers deze premie willen betalen om juridische baanzekerheid te hebben bovenop de de facto baanzekerheid die ze al hebben wanneer beide partijen hebben geïnvesteerd in specifiek menselijk kapitaal.

De waarde die een werknemer hecht aan juridische baanzekerheid via ontslagbescherming neemt toe met de leeftijd. Leeftijd verlaagt de productiviteit voor een aantal werknemers en verkort de periode waarover relatiespecifieke investeringen door de werkgever kunnen worden terugverdiend. De oudere werknemer heeft dan minder de facto baanzekerheid; hij kan er minder op vertrouwen dat het verlies aan opbrengsten uit relatiespecifieke investeringen, de werkgever ervan zal weerhouden de werknemer te ontslaan.

\section{Herinvesteringen in specifiek menselijk kapitaal}

Menselijke kapitaal is, zoals fysiek kapitaal (machines en gebouwen), onderhevig aan veroudering. Om de opbrengsten van investeringen op peil te houden is het nodig dat nieuwe investeringen worden gedaan en dat de werknemer zich nieuwe kennis en vaardigheden eigen maakt. Een efficiënte aanwending van menselijk kapitaal kan met zich meebrengen dat een werknemer na een zekere tijd andere werkzaamheden moet verrichten. Hebben werknemers optimale prikkels om te herinvesteren in menselijk kapitaal? In eerste instantie zou gedacht kunnen worden dat juridisch afdwingbare baanzekerheid de prikkels om te herinvesteren vergroot, omdat de werknemer meer zekerheid verkrijgt dat de gedane investeringen daadwerkelijk worden terugverdiend. Maar juridische ontslagbescherming kan het omgekeerde effect hebben. Een werknemer die zich verzekerd weet van zijn baan kan minder prikkels hebben om mee te werken aan een meer efficiënte aanwending van zijn menselijk kapitaal. Zonder ontslagbescherming daarentegen weet de werknemer dat hij zijn macht in de onderneming kan vergroten door te herinvesteren en dat hij daardoor de facto baanzekerheid krijgt. ${ }^{19}$ In dit geval is de werknemer eerder bereid om vrijwillig mee te werken aan een meer efficiënte aanwending van zijn menselijk kapitaal.

Hiermee is natuurlijk niet gezegd dat een werknemer die juridisch afdwingbare baanzekerheid geniet nooit zal willen investeren in nieuwe vaardigheden; de werkgever kan op basis van zijn gezagsbevoegdheid nadere instructies geven over de invulling van de taken en de vaardigheden die een werknemer moet verwerven. ${ }^{20}$ Een weigering van de werknemer om de instructies op te volgen kan ook een gegronde reden zijn voor ontslag. Maar juridisch afdwingbare ontslagbescherming betekent wel dat bij een eventueel conflict de rechter of de administratieve overheid de vraag zal stellen of er sprake is van een verwijtbare tekortkoming van de werknemer (gegronde reden voor ontslag) of dat de werkgever de inhoud van de arbeidsovereenkomst wijzigt, terwijl daar geen zwaarwegend belang voor is (geen gegronde reden voor ontslag). Uit de uitspraken van het CWI en de kantonrechter kan worden afgeleid dat een werknemer op minder begrip 
zal kunnen rekenen (dus minder ontslagbescherming geniet) wanneer hij weigert in te stemmen met een reallocatie binnen het bedrijf indien het bedrijf in economische moeilijkheden verkeert en aanpassingen noodzakelijk worden. Maar dan komen de aanpassingen om de productiviteit op peil te houden eigenlijk al te laat. Reallocaties binnen het bedrijf zijn nodig om financiële moeilijkheden in de eerste plaats te voorkomen, dus wanneer er nog geen sprake is van een zwaarwegend belang om de inhoud van de arbeidsovereenkomst te wijzigen, zoals dat juridisch wordt gedefinieerd. Juridische baanzekerheid via ontslagbescherming kan ertoe leiden dat efficiënte herallocaties binnen het bedrijf niet plaatsvinden en/of dat de kosten ervan hoger worden.

\section{Verzekering tegen baanverlies}

Aangezien de vraag naar arbeid een afgeleide is van de vraag naar de producten en diensten die door het bedrijf geproduceerd worden, hebben wijzigingen in de vraag op producten- en dienstenmarkt een invloed op de vraag naar arbeid. Ontslagbescherming met als doel baanzekerheid voor de werknemers, houdt in dat de werkgever tot op zekere hoogte het risico van een daling in de vraag naar arbeid moet dragen, zodat de werknemers verzekerd zijn van hun baan.

Stel dat een werkgever 4 werknemers tewerkstelt. Maandelijks is er een vraag naar 100 goederen en elk van de werknemers produceert 25 stuks. Hiervoor krijgen ze elk 2000 euro. Op een gegeven moment daalt de vraag naar de producten van 100 naar 75 en daarmee de vraag naar arbeid van 4 naar 3 werknemers. De werkgever wil een werknemer ontslaan. Stel dat de CWI niet dezelfde economische afweging maakt als de werkgever en geen ontslagvergunning aflevert voor het ontslag van een werknemer omwille van het ontbreken van een gegronde reden. Ontslagbescherming met als doel baanzekerheid voor de werknemer houdt in dat de werkgever de arbeidsrelatie met alle 4 de werknemers dient voor te zetten. De werkgever draagt het risico dat de vraag naar arbeid daalt. De werknemers zijn verzekerd van hun baan. Maar tot op welke hoogte? Stel dat op een gegeven moment de vraag naar de producten tot o wordt gereduceerd en het bedrijf de deuren moet sluiten. In dat geval zijn de werknemers niet langer verzekerd van hun baan; de CWI zal een vergunning verlenen voor het ontslag van de 4 werknemers.

Zouden rationele partijen bij het aangaan van het dienstverband vrijwillig een dergelijk verzekeringsarrangement afspreken? Voor het verzekeren van de baan van de werknemer, wanneer het risico dat de vraag naar arbeid daalt zich voordoet, zal de werkgever een risicopremie vragen. De lonen zullen met deze risicopremie worden verlaagd. De hoogte van deze premie zal afhangen van hoe duur het is voor het individuele bedrijf om de werknemers tegen baanverlies te verzekeren. Dit hangt weer af van de mate waarin de werkgever het risico kan spreiden in de tijd en over de verschillende bedrijfsonderdelen. Wensen werknemers zich op die manier te verzekeren tegen het verlies van hun baan? Voor een aantal werknemers is het goedkoper om zich te verzekeren tegen het verlies van hun baan door na ontslag elders aan te slag te gaan. Werknemers die zichzelf niet 
goedkoop kunnen verzekeren tegen het verlies van hun baan, omdat ze niet gemakkelijk een alternatieve gelijkwaardige baan kunnen vinden, zullen wel belang hechten aan een verzekeringsarrangement met hun werkgever. Maar welk verzekeringsarrangement is optimaal? Voor de beantwoording van die vraag proberen rechtseconomen uit te vinden welke overeenkomst partijen zelf vrijwillig gesloten zouden hebben, mochten zij hierover onderhandeld hebben in een perfect functionerende markt zonder transactiekosten.

Welke vorm zou een vrijwillig onderhandeld verzekeringsarrangement aannemen? Onder de huidige ontslagbescherming wordt de werknemer tot op zekere hoogte verzekerd in de vorm van baanbehoud; de werknemer is 'verzekerd van zijn baan'. Dat is - om het in verzekeringstermen uit te drukken - een zeer ruime dekking van het risico. Slechts onder bepaalde voorwaarden zouden partijen dit zeer ruime verzekeringsarrangement vrijwillig afspreken, bijvoorbeeld wanneer een bedrijf dit risico goedkoop kan verzekeren, omdat het de risico's gemakkelijk kan spreiden (bijv. een zeer groot bedrijf) of omdat het bedrijf weinig onderhevig is aan economische veranderingen (bijv. de overheid) en de werknemer tegelijkertijd veel waarde hecht aan baanzekerheid, omdat hij buiten dat bedrijf geen alternatieve tewerkstellingsmogelijkheden heeft.

De partijen kunnen een minder ruime verzekering afspreken. Zij kunnen overeenkomen dat wanneer de vraag naar arbeid daalt, de werkgever de werknemer zal verzekeren van de baan voor de duur die de gemiddelde werknemer nodig heeft om een alternatieve baan te vinden. Dit is wat gebeurt wanneer de partijen een opzegtermijn afspreken. Of de partijen zouden kunnen afspreken dat de werkgever de werknemer bij ontslag verzekerd voor een bedrag ter dekking van de specifieke verliezen die de werknemer naar aanleiding van het verlies van zijn baan lijdt. Dit gebeurt wanneer partijen een ontslagvergoeding overeenkomen. ${ }^{21}$ De opzegtermijn en de ontslagvergoeding zijn verzekeringsarrangementen bij baanverlies terwijl baanzekerheid een verzekering is tegen baanverlies.

\section{Opportunistisch ontslag}

Wanneer de vrijheid van de werkgever om te werknemer de ontslaan op geen enkele wijze zou worden beperkt, dan bestaat het risico dat de werkgever zijn recht te kwader trouw of op opportunistische wijze uitoefent. Dat zou bijvoorbeeld het geval zijn wanneer hij de werknemer ontslaat met geen ander belang dan het belang om de werknemer schade toe te brengen, of als represaille tegen de werknemer omdat hij zijn wettelijke rechten uitoefent. Er bestaat geen twijfel dat partijen deze mogelijkheid bij het aangaan van het dienstverband hebben willen uitsluiten. Door een regel die stelt dat de werkgever wordt gesanctioneerd wanneer hij de werknemer op kennelijk onredelijke wijze ontslaat worden opportunistische ontslagen voorkomen.

Een belangrijke vraag is welke toets rechters gebruiken bij de beoordeling of het ontslag kennelijk onredelijk is. Puur opportunistische ontslagen kunnen worden voorkomen door de werkgever te sanctioneren wanneer de getroffen werknemer 
aannemelijk kan maken dat de werkgever hem heeft ontslaan met geen ander belang dan het belang om de werknemer schade toe te brengen, waarvoor de werkgever het tegenbewijs niet kan leveren. Om puur opportunistische ontslagen te voorkomen is dus niet nodig dat de werkgever voor iedere opzegging moet aantonen dat hij daarvoor een gegronde reden heeft. De vereiste dat de werkgever voor het ontslag een gegronde reden kan aantonen beperkt de ontslagvrijheid van de werkgever meer dan de vereiste dat de werkgever de werknemer niet mag ontslaan met geen ander belang dan het belang om de werknemer schade toe te brengen.

In het merendeel van de ontslaggevallen gaat het niet om puur opportunistische ontslagen, maar zegt de werkgever de arbeidsrelatie op om bedrijfseconomische of organisatorische redenen of omdat de werknemer niet goed functioneert. Omdat de gevallen van puur opportunistisch ontslag beperkt zijn, is het niet nodig om voorafgaand aan elke opzegging te toetsen of het voorgenomen ontslag kennelijk onredelijk is.

De conclusie is dat een zekere beperking van de ontslagvrijheid van de werkgever noodzakelijk is om puur opportunistische ontslagen te voorkomen. Maar de huidige ontslagregels met betrekking tot de gronden van ontslag beperken de ontslagvrijheid meer dan strikt noodzakelijk is om puur opportunistische ontslagen te voorkomen.

\subsubsection{ONTSLAGBESCHERMING EN HET ALGEMENE EN SOCIALE ZEKERHEIDS- BELANG}

Kenmerkend voor het Nederlandse ontslagstelsel is dat de werkgever op grond van artikel 6 lid 1 Buitengewoon Besluit Arbeidsverhoudingen (BBA, 1945) voordat hij tot opzegging van de arbeidsovereenkomst overgaat, voorafgaande toestemming nodig heeft van de Centrale Organisatie voor Werk en Inkomen (CWI). Krachtens het BBA is het verrichten van de rechtshandeling, namelijk eenzijdige opzegging van de arbeidsovereenkomst, vernietigbaar behoudens toestemming/vergunning van het bevoegde overheidsorgaan. De vergunning is een administratiefrechtelijk instrument. Is administratiefrechtelijke handhaving een efficiënter instrument voor de handhaving van ontslagbescherming dan civielrechtelijke handhaving? Is de administratiefrechtelijke regulering en handhaving van ontslagbescherming nodig ter bescherming van het algemene of het sociale zekerheidsbelang?

\section{Administratiefrechtelijke regulering versus civielrechtelijke aansprakelijkheid}

Wat zegt de rechtseconomie over de keuze tussen administratiefrechtelijke en civielrechtelijke handhaving als juridische instrumenten? Volgens Shavell (1984) heeft zowel de administratiefrechtelijke regulering als de civielrechtelijke aansprakelijkheid voor- en nadelen als juridische instrumenten. In het artikel 'Liability for Harm Versus Regulation of Safety' toont Shavell (1984) aan dat, afhankelijk van de situatie, soms het ene, soms het andere efficiënter is en dat het soms 
efficiënt is dat beide instrumenten tegelijkertijd worden gebruikt. De rechter in een civielrechtelijk geschil komt pas tussenbeide nadat schade werd geleden. De administratieve overheid heeft de mogelijkheid om in te grijpen vooraleer een ongeval/schade zich voordoet. Dat kan noodzakelijk zijn wanneer de eventuele schade zeer groot is en het gevaar bestaat dat de dader niet over voldoende financiële middelen beschikt om de schade te vergoeden. Administratiefrechtelijke regulering van gedrag is ook nodig wanneer de benadeelden geen prikkels hebben om de schade te verhalen via de rechter, bijvoorbeeld omdat ze geen informatie hebben over wie de schade heeft veroorzaakt of wanneer de schade die per individu wordt geleden te klein is om een rechtszaak te starten. Daarom is administratiefrechtelijke regulering van het gedrag van partijen die met elkaar in een contractuele relatie staan zeer ongebruikelijk. De partijen kennen elkaar, weten wanneer de andere contractpartij zijn contractuele verbintenissen niet nakomt, en hebben een prikkel om een rechtszaak te starten omdat ze zo voor de geleden schade worden vergoed.

\section{Het algemeen belang}

De oorsprong van het ontslagverbod van het BBA dat op 5 oktober 1945 tot stand kwam, is de Duitse Verordnung über die Beschränkung des Arbeitsplatzwechels (de Arbeitsplatzwechselverordnung) van i september 1939 (Naber 1983: 74). Ingevolge het eerste artikel van deze verordening mochten werkgevers en werknemers pas opzeggen, wanneer het arbeidsbureau toestemming had verleend voor de ontbinding van de arbeidsverhouding. De sanctie voor het overtreden van deze bepaling bestond uit een gevangenisstraf of een boete. Tijdens de bezettingstijd in Nederland trad op 13 juni 1940 het Eerste Uitvoeringsbesluit van de secretaris-generaal van het departement van Sociale Zaken in werking ingevolge verordening No. 8/1940 van de rijkscommissaris betreffende het beperken van werk. ${ }^{22}$ De ontslagverordening bepaalde onder meer dat het de werkgever verboden was werknemers te ontslaan. De directeur-generaal van de Arbeid of de door hem hiertoe gemachtigde organen kunnen uitzonderingen op de regel vaststellen; de toestemming hiertoe kan afhankelijk gemaakt worden van het nakomen van bijzondere voorwaarden. Het BBA van 1945 nam het ontslagverbod over. Verbodswetgeving heeft ten doel het verrichten van rechtshandelingen door de burger te verhinderen, behoudens vergunning van het bevoegde overheidsorgaan. Verbodswetgeving dient het algemeen belang. Dat algemeen belang bestond na de oorlog uit de wederopbouw van het land. Het BBA 1945 had primair op het oog het herstel van het land (Naber 1983: 51). Om dat doel te bereiken diende de productie na op gang te zijn gebracht ongestoord voortgang te kunnen vinden. Te veel beweging op de arbeidsmarkt zou een spoedig herstel van het land kunnen schaden. Om dat te voorkomen werd een ontslagverbod noodzakelijk geacht. Werkgevers en werknemers mochten hun arbeidsverhouding in het algemeen niet beëindigen zonder toestemming. Overtreding van het verbod werd strafrechtelijk gesanctioneerd met een gevangenisstraf van ten hoogste twee maanden of een geldboete van ten hoogste duizend gulden. Tevens werd gesteld dat het ontslag gegeven in strijd met het ontslagverbod nietig was. Nietigheid is een civielrechtelijke sanctie. Bij wet van 14 december 1979, (Stb. 693) is de strafbaar- 
heid van overtreding van artikel 6 BBA komen te vervallen. Alleen de civielrechtelijke sanctie van nietigheid/vernietigbaarheid is gebleven. In het begin van de jaren vijftig kon de wederopbouw van het land als voltooid worden beschouwd, waardoor toetsing aan het algemeen belang niet langer het primaire doel van artikel 6 BвA was. Met de tijd is de toetsing dan ook verschoven van het algemeen belang naar de private belangen van de werknemer en werkgever.

Is de administratieve vergunning wel het gepaste instrument voor de afweging van private belangen van partijen? Waarom bedient de overheid zich in het algemeen van verbodswetgeving, op grond waarvan het verrichten van bepaalde rechtshandelingen is verboden behoudens toestemming c.q. vergunning van de overheid? Deze vraag wordt gesteld en als volgt beantwoord door Naber (1983: 57).

"Toch niet uit het oogpunt van private belangenbehartiging. Neen, verbodswetgeving heeft ten doel aantasting van algemene belangen door individuele rechtsuitoefening tegen te gaan. Bij het individu ligt de bewijslast om aan te tonen dat zijn rechtsuitoefening geen schade berokkent aan de algemene belangen."

$\mathrm{Nu}$ bij de regulering van de opzegging de bescherming van de private belangen vooropstaat, kan het algemeen belang niet meer ingeroepen worden als rechtvaardiging voor de vergunningsprocedure. Voor de afweging van individuele belangen ingevolge een contractuele relatie is de civielrechtelijk procedure beter geschikt.

Wanneer als regel geldt dat elk ontslag redelijk moet zijn, dan heeft de vergunningsprocedure wel als voordeel dat over de redelijkheid van het ontslag vooraf wordt geoordeeld, dat wil zeggen vooraleer de werkgever overgaat tot de opzegging van de arbeidsrelatie. Bij een civielrechtelijke procedure vindt de beoordeling van de redelijkheid nadien plaats, dat wil zeggen nadat de arbeidsovereenkomst reeds effectief is beëindigd. Dit stelstel heeft als nadeel dat partijen tot aan de uitspraak in onzekerheid verkeren over hetgeen zij bij de opzegging in acht hebben te nemen. Dit is het gevolg van het gebruik van de open norm 'redelijkheid' voor de beoordeling van de opzegging..23 De hierdoor ontstane juridische onzekerheid kan worden verlaagd door een preventieve toetsing (anticipatory adjudication), waarbij de werkgever om een rechterlijke uitspraak vraagt vooraleer hij tot opzegging overgaat. Hiermee wordt voorkomen dat de werkgever een schadevergoeding moet betalen wanneer de rechter achteraf zou oordelen dat het ontslag onredelijk is. Dus zelfs indien de administratiefrechtelijke redelijkheidstoets vervangen zou worden door een civielrechtelijke redelijkheidstoets, zouden partijen er belang bij hebben dat de preventieve toets blijft bestaan ter verlaging van de kosten die gepaard gaan met onzekerheid. Een substantiëlere hervorming van het ontslagrecht behelst niet de vraag of de administratiefrechtelijke redelijkheidstoets vervangen moet worden door een civielrechtelijke controle omtrent de redelijkheid van de opzegging, maar de vraag of de redelijkheidstoets zelf moet worden gehandhaafd. 


\section{Het socialeverzekeringsbelang}

Het bestaan van een collectieve werkloosheidsverzekering kan ertoe leiden dat arbeidsovereenkomsten vaker worden opgezegd dan economisch gezien optimaal is. Door de Werkloosheidswet en andere programma's ter ondersteuning van werkloze werknemers worden de kosten van werkloosheid (na ontslag) door de gemeenschap van werkgevers en werknemers (of alle belastingsbetalers) gedragen, waardoor de prikkels voor de individuele werkgever en werknemer om ontslag te voorkomen afnemen. Met name bestaat de mogelijkheid dat de werknemer akkoord gaat met ontslag in ruil voor een suppletie op de werkloosheidsuitkering. De afvloeiing wordt op die manier gefinancierd ten koste van de algemene middelen. De beperking van de bevoegdheid tot ontslag door regulering door de administratieve overheid zou dan begrepen kunnen worden als een manier om het aantal beëindigingen terug te brengen tot het niveau dat zou bestaan indien de kosten van ontslag niet geëxternaliseerd zouden kunnen worden. Regulering van de ontslagbeslissing dient dan om de inefficiënties op te lossen die het gevolg zijn van een systeem van collectieve werkloosheidsverzekering. Echter, het gevaar hiervan is dat het inroepen van een bepaalde vorm van regulering (collectieve werkloosheidsverzekering) om een andere vorm van regulering te rechtvaardigen (administratiefrechtelijk controle op ontslagbeslissingen) aanleiding kan zijn tot een cumulatie van reguleringen. ${ }^{24}$ Administratiefrechtelijke regulering van de beëindiging van arbeidsovereenkomsten is mijns inziens niet het meest geschikte juridische instrument om oneigenlijk gebruik van de sociale zekerheid te voorkomen.

Het beroep op werkloosheidsuitkeringen kan immers op twee manieren worden teruggedrongen. Ten eerste kan men de toegang tot de werkloosheidsuitkering beperken. Tot deze categorie maatregelen behoren de regels die het recht tot opzegging van de arbeidsovereenkomst beperken. Ten tweede kan men de uitstroom uit de werkloosheid bevorderen. Hiertoe kan men werklozen monitoren, stimuleren en begeleiden bij het vinden van een nieuwe baan. Oneigenlijk gebruik van de werkloosheidswet kan beter worden tegengaan door aanpassing van de Werkloosheidswet zelf dan door regulering van de ontslagbeslissing. Het is immers voor de administratieve overheid bijzonder moeilijk om te verifiëren of het ontslag een onverwachte gebeurtenis is ten gevolge van een wijziging van economische omstandigheden dan wel of met het ontslag een onterecht gebruik van de Werkloosheidswet wordt beoogd.

\subsubsection{VERSOEPELING ONTSLAGRECHT}

Op grond van de analyses in de vorige paragrafen kan geconcludeerd worden dat de Nederlandse regel op grond waarvan de werkgever een gegronde reden moet kunnen aantonen alvorens hij toestemming kan krijgen van een derde partij om op te zeggen, de gezamenlijke waarde van tewerkstelling niet verhoogt in vergelijking met een systeem waarbij de ontslaggronden niet gereguleerd zijn. Het Nederlandse systeem brengt geen economische voordelen met zich mee die zouden opwegen tegen de extra transactiekosten van het systeem voor de real- 
locatie van werknemers via de externe arbeidsmarkt. Dat de werkgever voor de eenzijdige opzegging een gegronde reden moet aantonen leidt niet vanzelfsprekend tot meer relatiespecifieke investeringen en kan de prikkels voor de werknemer om te herinvesteren in relatiespecifieke kennis doen afnemen. Voor zover de derde partij de kwaliteit van de prestaties van de werknemer niet goed kan verifiëren, kunnen de prikkels van werknemers om zich optimaal in te spannen afnemen. Bovendien houdt het systeem in dat de werkgever de werknemer - tot op zekere hoogte - dient te verzekeren van zijn baan wanneer de vraag naar arbeid in de onderneming daalt, een verzekeringsarrangement dat slechts onder bepaalde voorwaarden als optimaal kan worden beschouwd. In andere gevallen is het in het gezamenlijke belang ${ }^{25}$ van de arbeidspartijen dat de werknemer zich verzekert door elders aan de slag te gaan of dat de werkgever de werknemer slechts tijdelijk verzekert van de baan voor de duur van de opzegtermijn of dat de werkgever een bedrag uitbetaalt ter compensatie van de specifieke verliezen na ontslag. Aangezien de Nederlandse regel met betrekking tot de ontslaggronden de gezamenlijke waarde van tewerkstelling niet verhoogt, maar wel extra transactiekosten met zich meebrengt, is op grond van deze economische overwegingen een versoepeling van het ontslagrecht waar het de gronden van het ontslag betreft, gerechtvaardigd.

Een versoepeling van het Nederlandse ontslagrecht hoeft niet te betekenen dat men overgaat naar een regime van puur 'ontslag naar eigen goeddunken', zoals het Amerikaanse termination at will, waarbij de werknemer geen enkele contractuele of wettelijke vorm van ontslagbescherming heeft. Een versoepeling kan inhouden dat voor de eenzijdige opzegging door de werkgever niet langer een vergunning is vereist, maar dat de werknemer wel nog wordt beschermd tegen kennelijk onredelijk ontslag, en dat de werkgever bij de opzegging een opzegtermijn in acht moet nemen en/of een ontslagvergoeding moet betalen. Meer ontslagvrijheid ten aanzien van de gronden voor ontslag, laat andere vormen van ontslagbescherming onverlet. Het Nederlandse ontslagrecht met betrekking tot de gronden voor ontslag wordt versoepeld wanneer werkgevers niet meer voor elke opzegging de CWI of de rechter moeten overtuigen van de noodzaak ervan, zoals nu het geval is. Het schrappen van de vereiste van de voorafgaande toestemming van de CWI, geeft de werkgever de vrijheid om zelf te oordelen over de wenselijkheid van de opzegging waardoor de kosten om de CWI te overtuigen worden vermeden. Mocht in Nederland gekozen worden voor een versoepeling van de ontslaggronden, dan moet er wel op gelet worden dat de versoepeling niet ongedaan gemaakt wordt via de route van de kennelijk onredelijke opzegging (art. 7: 681 BW). ${ }^{26}$ Indien rechters de vereiste dat de opzegging niet kennelijk onredelijk mag zijn zouden interpreteren als een vereiste voor de werkgever om aan te tonen dat het ontslag redelijk is, dan is er in praktijk geen verschil met het huidige regime waarbij de werkgever voor elke opzegging een gegronde reden moet aantonen voor de CWI.

Werknemers met een dienstverband voor onbepaalde duur hebben onder de huidige ontslagregels veel juridische baanzekerheid; de CWI geeft maar toestem- 
ming voor ontslag als daar naar haar oordeel een gegronde reden voor is. Zou het schrappen van de vereiste van de voorafgaande toestemming van de CWI betekenen dat werknemers te weinig baanzekerheid zullen hebben?

Ook zonder de regel dat de werkgever alleen kan opzeggen wanneer daarvoor een gegronde rede is, heeft de werknemer tot op zekere hoogte baanzekerheid. De werkgever heeft er immers geen belang bij om de arbeidsrelatie met een werknemer die goed presteert en investeert in de relatie te beëindigen. $\mathrm{Na}$ ontslag moet de werkgever immers kosten maken voor het aanwerven en opleiden van een nieuwe werknemer en hij weet op voorhand niet of de nieuwe werknemer ook goed zal presteren. Omdat de werkgever deze kosten wil vermijden, zal hij de huidige werknemers niet zomaar, willekeurig ontslaan. Hierdoor verkrijgt de werknemer de facto baanzekerheid. Bovendien zou een werkgever die zijn werknemers systematisch zonder reden ontslaat, een slechte reputatie krijgen. Normaal gezien willen werkgevers een slechte reputatie vermijden. ${ }^{27}$

Wel zal de werkgever van zijn vrijheid om de arbeidsovereenkomst op te zeggen gebruikmaken wanneer hij - als gevolg van een wijziging in economische omstandigheden - voortzetting van de arbeidsrelatie niet meer wenselijk acht. Voor die gevallen zal de werknemer minder baanzekerheid hebben dan onder de huidige regels van ontslagbescherming. Een werkgever zal - mocht hij de vrijheid daartoe hebben - een arbeidsrelatie in het algemeen niet willen voortzetten wanneer de geldelijke waarde van de marginale productiviteit die hij met de werknemer produceert lager wordt dan de arbeidskosten voor het tewerkstellen van de werknemer. Welke juridische of morele grondslag rechtvaardigt dat de werkgever in die gevallen de werknemer zou moeten verzekeren van zijn baan? De baanzekerheid kan een contractuele grondslag hebben. Dat is het geval wanneer uit de tekst van de overeenkomst duidelijk blijkt dat het de bedoeling van de werkgever was om zich ertoe te verbinden om de werknemer tot aan zijn pensioengerechtigde leeftijd tewerk te stellen. Maar is er bij afwezigheid van een contractuele grondslag een andere norm die baanbehoud rechtvaardigt? Hiertoe zou aanleiding zijn wanneer uit de manier waarop de arbeidspartijen de arbeidsrelatie hebben ingericht volgt dat de werknemer volledig economisch afhankelijk is geworden van het voortduren van de arbeidsrelatie. Een werknemer is volledig economisch afhankelijk van het voortduren van de arbeidsrelatie wanneer tewerkstelling in die bepaalde baan ertoe heeft geleid dat hij daarbuiten niet meer productief aan de slag kan. Dat is geen realistische weergave van de meeste moderne arbeidsrelaties. Een groot deel van de werknemers heeft na ontslag nog mogelijkheden om elders een baan te krijgen. ${ }^{28}$ Toch is er ook een groep werknemers voor wie de alternatieve tewerkstellingsmogelijkheden bij ontslag gering zijn. Ik denk bijvoorbeeld aan werknemers die fysieke arbeid verrichten waarbij de capaciteit om die arbeid te verrichten afneemt met de leeftijd. Maar voor deze risico's lijken alternatieve verzekeringsarrangementen, zoals vroegpensioen, of herscholing beter geschikt dan de verzekering in de vorm van baanbehoud. 


\subsection{DE RECHTSECONOMISCHE ANALYSE VAN ONTSLAG- VERGOEDINGEN}

\subsubsection{DE HUIDIGE NEDERLANDSE REGELS MET BETREKKING TOT DE ONTSLAGVERGOEDING}

Wanneer wordt geoordeeld (door CWI of kantonrechter) dat er voldoende gronden zijn om de arbeidsovereenkomst te beëindigen, dan rijst de vraag of naar aanleiding van het ontslag een ontslagvergoeding door de werkgever aan de werknemer moet worden betaald. De kantonrechter kan in geval van ontbinding wegens veranderingen in de omstandigheden aan een der partijen een vergoeding toekennen, zo hem dat met het oog op de omstandigheden van het geval billijk voorkomt (art. 7:685 lid 6 BW). Voor het vaststellen van de vergoeding is het aantal gewogen dienstjaren (A) en het bruto maandsalaris (B) van belang. Bij een zogeheten 'kleurloze' of 'neutrale' ontbinding lijkt de werknemer zonder meer recht te hebben op een vergoeding gelijk aan A x B. De kantonrechter is echter bevoegd een correctiefactor (C) te hanteren en een ander bedrag vast te stellen indien hij dat op grond van de bijzondere omstandigheden van het geval gerechtvaardigd acht. De correctiefactor wordt bij een neutrale ontbinding (geen van de partijen heeft in het bijzonder schuld aan het feit dat de arbeidsovereenkomst ten einde komt) op 1 gesteld; deze c-factor kan al naar gelang de schuld van de werknemer mogelijk tot o worden gereduceerd, terwijl schuld aan de kant van de werkgever tot $\mathrm{c}=2, \mathrm{c}=3$ of desnoods nog hoger kan leiden (Loonstra 2006: 116). In de kantonrechtersformule is nog als slotbepaling opgenomen dat een vergoeding, behoudens immateriële schade, niet hoger zal zijn dan de verwachte inkomensderving tot aan de pensioengerechtigde leeftijd. Dit om bijvoorbeeld te voorkomen dat een 63-jarige werknemer een vergoeding zou ontvangen die hoger ligt dan zijn redelijkerwijs te verwachten inkomensderving (Bakels 1997: 140).

Het recht op een vergoeding ontstaat zonder dat een fout van de werkgever moet worden aangetoond. In de zogenaamde neutrale gevallen wordt de betaling van de ontslagvergoeding door de kantonrechter gerechtvaardigd, doordat wordt gesteld dat het ontslag het gevolg is van een risico dat voor rekening van de werkgever komt. Reorganisaties of inkrimping van de onderneming worden gezien als risico's die voor rekening van de werkgever komen. De werknemer krijgt geen vergoeding wanneer de ontbinding het gevolg is van zijn verwijtbaar slecht functioneren of wanneer de werknemer vrijwillig vertrekt, omdat wordt aangenomen dat het ontslag dan het gevolg is van een risico dat voor rekening van de werknemer komt.

Ontslagvergoedingen worden niet alleen toegekend naar aanleiding van ontbinding van de arbeidsovereenkomst door de kantonrechter, maar worden ook collectief onderhandeld in het kader van een collectief ontslag. De afvloeiingsregelingen die naar aanleiding van een collectief ontslag worden onderhandeld zijn zeer divers, maar vaak wordt ook de kantonrechtersformule gebruik voor de berekening van de ontslagvergoeding. 


\subsubsection{ECONOMISCHE VERANDERINGEN EN DE KOSTEN VAN ONTSLAG}

Verschillende arbeidsrechtelijke schrijvers hebben zich gebogen over de vraag welke aanknopingspunten het rechtsgevoel biedt voor het toekennen van deze vergoeding, maar de vraag werd volgens Buijs (2004:45-46) nog niet overtuigend beantwoord. Voor Scholtens (2004: 91) gaat het in essentie om de vraag wie de financiële gevolgen van een ontslag moet dragen: de werkgever, de werknemer of de gemeenschap. Om te verklaren waarom de werkgever (een deel van) de kosten van ontslag moet dragen in de vorm van een ontslagvergoeding moet aangetoond worden welke kosten een werknemer lijdt ten gevolge van het ontslag en op grond van welke theorie het gerechtvaardigd is dat de werkgever die kosten draagt.

Een verandering in externe omstandigheden kan ertoe leiden dat de werkgever de werknemer ontslaat om bedrijfseconomische of organisatorische gronden. De veranderingen leidend tot het ontslag kunnen bestaan uit technologische veranderingen, al dan niet seizoensgebonden vraagverschuivingen, demografische of geografische verschuivingen enzovoort. Aanpassingen aan economische veranderingen bewerkstelligen economische groei. De maatschappij als geheel (ondernemingen, werknemers en consumenten) profiteert van de voordelen van economische groei. Maar er zijn ook kosten verbonden aan aanpassingen aan economische veranderingen, waaronder de kosten voor de werknemer die als gevolg van de economische verandering wordt ontslagen. Welke kosten lijden werknemers door ontslag? 29

Voor een aantal werknemers zullen de kosten van ontslag gering zijn. De werknemer verliest door ontslag wel zijn baan, maar niet zijn menselijk kapitaal, of vermogen om inkomen te verwerven. De werknemer kan zich verzekeren tegen het verlies door elders aan de slag te gaan. Maar in andere gevallen zijn de kosten substantieel en kan de werknemer zich niet verzekeren, bijvoorbeeld de kosten ten gevolge van de werkloosheid, en de kosten die het gevolg zijn van het verlies aan specifiek menselijk kapitaal en uitgestelde beloning. Hierna wordt voor elk type kosten nagegaan of het vanuit het oogpunt van de efficiënte allocatie van arbeid en risico's optimaal is dat de werkgever de kosten draagt in de vorm van de betaling van een ontslagvergoeding. ${ }^{30}$

Naar gelang de kosten die met de ontslagvergoeding worden vergoed kan de ontslagvergoeding de functie hebben van een substituut voor werkloosheidsverzekeringen (5.4.3.), een vergoeding voor relatiespecifieke investeringen (5.4.4), of een vergoeding voor uitgestelde beloning (5.4.5). Daarnaast is het mogelijk dat ontslagvergoedingen inhouden dat de werknemer tijdens tewerkstelling zelf een beëindigingsvergoeding bijeen spaart (5.4.6). In subparagraaf 5.4.7 wordt onderzocht of de Nederlandse regels met betrekking tot de toekenning en de hoogte van de ontslagvergoeding economisch verklaard kunnen worden. 


\subsubsection{ONTSLAGVERGOEDINGEN ALS SUBSTITUUT VOOR DE COLLECTIEVE WERKLOOSHEIDSVERZEKERING}

Een van de kosten van ontslag zijn de kosten van werkloosheid. Bij afwezigheid van een verzekering bij werkloosheid zullen lonen compenseren voor de verwachte werkloosheid wanneer werknemers bij het aangaan van het dienstverband perfecte informatie hebben over de toekomstige economische veranderingen die leiden tot ontslag. Wanneer werkgevers en werknemers perfecte informatie hebben over toekomstige economische veranderingen, dan zorgen vrijwillig gesloten arbeidsovereenkomsten voor een efficiënte allocatie van werknemers naar sectoren en bedrijven. Seizoensarbeid is een voorbeeld van tewerkstelling waarbij werknemers goede informatie hebben over de toekomstige economische veranderingen en verwachte werkloosheid. Werknemers zullen er een compensatie in de vorm van een hoger loon bedingen om te compenseren voor de tijdelijke seizoenswerkloosheid. Neem bijvoorbeeld een werknemer die de keuze heeft tussen permanente tewerkstelling in een kantine van een universiteit of tijdelijke seizoensgebonden tewerkstelling bij een restaurant. Hoewel andere baankenmerken een rol kunnen spelen bij de hoogte van het loon, zal het hogere loon bij seizoensgebonden tewerkstelling compenseren voor de periodes van werkloosheid. Op die manier is het verwachte jaarinkomen voor de werknemer in beide banen hetzelfde.

Vaak bezitten de arbeidspartijen geen perfecte informatie over de toekomstige economische veranderingen. Dat is het geval wanneer er onzekerheid bestaat over toekomstige economische veranderingen. De werknemer kan het ontslagrisico in de verschillende sectoren en bedrijven niet inschatten en hiervoor geen geschikte vergoeding vragen in de vorm van een hoger loon. Het marktloon voor de werknemer is dan in de verschillende sectoren en bedrijven gelijk (afgezien van beloningsverschillen die compenseren voor andere baankenmerken). Achteraf zal pas blijken dat de baan stabiliteit per sector/bedrijf verschilt. Achteraf gezien hebben de stabiele bedrijven dus een te hoog loon betaalt en de instabiele bedrijven een te laag loon. Solidariteit en gelijkheid tussen werknemers kan dan bewerkstelligd worden door de verplichte collectieve werkloosheidsverzekering. De ontslagen werknemers ontvangen een werkloosheidsuitkering waarvoor alle werkgevers en werknemers premies betalen. Niettemin is het vanuit het oogpunt van efficiëntie wenselijk dat sectoren/bedrijven met een groter werkloosheidsrisico een hogere werkloosheidspremie betalen door premiedifferentiatie (experience rating) in te voeren.

Op dit ogenblik wordt in Nederland het werkloosheidsrisico collectief verzekerd op grond van de Werkloosheidswet. Is het wenselijk om dit systeem te veranderen in de zin dat de werkgever verplicht wordt om een ontslagvergoeding te betalen voor het werkloosheidsrisico wanneer hij werknemers ontslaat als gevolg van economische veranderingen? Hiervoor werd gesteld dat de lonen niet compenseren voor het werkloosheidsrisico wanneer de werknemers geen perfecte informatie hebben over toekomstige economische veranderingen. Een verplichting voor 
werkgevers om het werkloosheidsrisico te dragen zou een manier kunnen zijn om de kosten van ontslag te internaliseren. Bijvoorbeeld bij het nemen van de beslissing om een nieuwe technologie in te voeren waarbij arbeidsplaatsen verdwijnen, zal de werkgever dan rekening houden met de mogelijke werkloosheid van de ontslagen werknemers. Echter, de wijziging in economische omstandigheden is vaak het gevolg van nationale en internationale factoren waarop de individuele onderneming niet veel invloed heeft. ${ }^{31}$ Is de individuele onderneming het best geplaatst om het werkloosheidsrisico te dragen?

De kosten van risico's kunnen verlaagd worden door de verzekering ervan. De onderneming zou zich voor zijn verplichting om het werkloosheidsrisico te dragen kunnen herverzekeren bij een particuliere verzekeraar op de markt. ${ }^{32}$ Private verzekeringsmaatschappijen kunnen de kosten van risico's verlagen doordat zij de risico's van vele bedrijven (uit verschillende sectoren en landen) kunnen poolen. Er zijn op dit ogenblik in Nederland geen private verzekeraars die verzekeringen verkopen tegen werkloosheid. Dat kan enerzijds te wijten zijn aan het feit dat private verzekeraars geen verzekering tegen het risico op werkloosheid willen aanbieden ${ }^{33}$, maar anderzijds is er ook geen vraag naar, omdat het werkloosheidsrisico wordt verzekerd door de collectieve werkloosheidsverzekering die door de overheid wordt geregeld op grond van de Werkloosheidswet. Het voordeel van een collectieve verzekering is de betrokkenheid van de overheid als partij. Bij een grote recessie kunnen algemene middelen aangewend worden voor het betalen van de uitkeringen voor zover die niet met de gestorte premies kunnen worden betaald. Op die manier worden ook aan de overheid prikkels gegeven om goed beleid te voeren om recessies te vermijden of te beperken.

Er zijn landen die geen collectieve werkloosheidsverzekering kennen en waar op de werkgever de verplichting rust om bij ontslag een ontslagvergoeding ter compensatie van het werkloosheidsrisico te betalen. Verplichte ontslagvergoedingen voor dit doel zijn een substituut voor collectieve werkloosheidsverzekeringen in landen met weinig administratieve capaciteit. ${ }^{34}$ Voor een dergelijk systeem is minder administratieve capaciteit vereist, omdat de werknemers niet opgenomen moeten worden in de administratie van de sociale zekerheid, de werkgever geen maandelijkse premies moet betalen, de administratieve diensten geen uitkeringen moeten doen en niet moeten controleren of iemand wel effectief werkloos is. De enige administratieve kosten zijn de kosten van handhaving van het recht op een ontslagvergoeding te betalen door de werkgever bij ontslag. De verplichte ontslagvergoeding verstoort de prikkels van werknemers niet, omdat het recht niet toekomt aan werknemers die ontslagen worden omwille van hun eigen verwijtbaar gedrag en het bedrag van de vergoeding onafhankelijk is van de duur dat de werknemer effectief werkloos is. De verplichte ontslagvergoeding creëert geen prikkel voor de werknemer om werkloos te blijven.

Voor Nederland bestaat er geen reden om de collectieve werkloosheidsverzekering te vervangen door een systeem van verplichte ontslagvergoedingen ter dekking van het werkloosheidsrisico. Zoals gezegd, is dat systeem enkel een goed 
alternatief voor landen met een lage administratieve capaciteit. ${ }^{35}$ Een collectieve werkloosheidsverzekering verlaagt de kosten van het werkloosheidsrisico door een ruime spreiding van dit risico en prikkelt de overheid om het werkloosheidsrisico te beperken. Deze voordelen gaan verloren wanneer elk bedrijf zelf het werkloosheidsrisico moet vergoeden. Toerekening van het werkloosheidsrisico naar individuele bedrijven of sectoren kan gebeuren door meer premiedifferentiatie in de collectieve werkloosheidsverzekering in te voeren zonder de collectieve werkloosheidsverzekering zelf op te heffen.

\subsubsection{DE ONTSLAGVERGOEDING ALS VERGOEDING VOOR HET VERLIES AAN RELATIESPECIFIEKE INVESTERINGEN}

Naast de kosten van werkloosheid kan ontslag ook kosten veroorzaken in de vorm van een verlies aan relatiespecifieke investeringen waartegen de werknemer zich niet kan verzekeren. Het verloren laten gaan van een andere carrièremogelijkheid en investeringen in specifiek menselijk kapitaal zijn twee vormen van relatiespecifieke investeringen tijdens tewerkstelling.

\section{Het verloren laten gaan van een andere carrièremogelijkheid}

In een aantal gevallen laat de werknemer door de keuze voor tewerkstelling in een bepaalde baan de mogelijkheid voor tewerkstelling in een andere baan voorbij gaan. Het voorbij laten gaan van kansen voor andere contracten is een vorm van relatiespecifieke investering. Door tewerkstelling in een bepaalde baan draagt de werknemer de opportuniteitskosten van de verloren gegane mogelijkheid van een alternatieve carrière. Bij een ontslag kan zich dat vertalen in een reductie van de verdiencapaciteit in vergelijking met de verdiencapaciteit die de werknemer zou hebben gehad indien hij de alternatieve carrière niet had laten voorbijgaan.

Stel dat een afgestudeerde jurist effectief twee aanbiedingen krijgt: starten in een advocatenkantoor als stagiair of een promotieonderzoek doen aan de universiteit. De jurist kiest om promotieonderzoek te doen bij de universiteit. Door die keuze laat hij de mogelijkheid om een carrière als advocaat uit te bouwen voorbijgaan. Stel dat de jurist ondertussen het doctoraat behaalt, les geeft en zich verder specialiseert in een bepaalde tak van de wetenschap. Maar na tien jaar tewerkstelling bij de universiteit moeten er banen verdwijnen en wordt de universitair docent ontslagen. Kiest de jurist na ontslag om bij een advocatenkantoor te gaan werken, dan heeft hij een achterstand van tien jaar in vergelijking met de situatie waarin hij onmiddellijk na afstuderen als advocaat was gaan werken. De ontslagen werknemer kan er ook voor kiezen om de academische carrière voort te zetten. Hier bestaat het probleem dat hij niet onmiddellijk eenzelfde baan kan vinden bij een andere universiteit omdat, de arbeidsmarkt voor academici, gespecialiseerd in die bepaalde tak van de wetenschap, klein is. De universiteit zou dan bij ontslag het loon kunnen doorbetalen gedurende de periode die de werknemer nodig heeft om een gelijkaardige functie te vinden bij een andere universiteit. Dit is wat gebeurt wanneer de werkgever een opzegtermijn in acht moet nemen. Op grond van artikel 7: 672 BW moet de werkgever de werknemer tijdig op de hoogte stellen 
van zijn voornemen om de arbeidsrelatie te beëindigen door het in acht nemen van een opzegperiode van 1 tot 4 maanden afhankelijk van de duur van het dienstverband. Gedurende de opzegtermijn heeft de werknemer het recht op volledige loondoorbetaling. Stel dat de regels voor ontslag niet zouden bepalen dat er een opzegtermijn in acht moet worden genomen. Wellicht heeft de werknemer dan gedurende de periode waarin hij zoekt naar een gelijkaardige functie recht op een uitkering op grond van de collectieve werkloosheidsverzekering. De Ww is echter een partiële verzekering. De sociale verzekering dekt de inkomensverliezen tijdens werkloosheid slechts voor 70 procent van het minimumloon of van het laatstverdiende loon (dat aan een maximum van 30.500 euro bruto per jaar is verbonden). In die zin is de werknemer onderverzekerd. Maar deze beperking van de $\mathrm{WW}$-verzekering is nodig om moreel risico te voorkomen. Wie immers voor honderd procent verzekerd is, heeft geen prikkel om inspanningen te leveren om een nieuwe baan te vinden. Maar niet elke periode van werkloosheid is te wijten aan te weinig inspanningen om een nieuwe baan te vinden. Dit is met name het geval voor de periode die de werknemer nodig heeft om een gelijkaardige functie te vinden in een kleine arbeidsmarkt. In dat geval is de werknemer onderverzekerd (slechts voor $70 \%$ van het laatstverdiende loon). Opzegtermijnen lossen het probleem van onderverzekering op, omdat voor de duur van de opzegtermijn het loon voor honderd procent wordt doorbetaald. Door de verplichting om een opzegtermijn in acht te nemen bij ontslag verzekert de werkgever de werknemer tegen 'zoekwerkloosheid', werkloosheid tijdens de periode die de werknemer nodig heeft om een gelijkwaardige functie te vinden na ontslag.

\section{Investeringen in specifiek menselijk kapitaal}

In vele banen wordt van de werknemer verwacht dat hij investeert in het verwerven van vaardigheden en kennis over procedures die specifiek zijn voor het bedrijf. Wanneer de werknemer in het verwerven van deze relatiespecifieke kennis en vaardigheden heeft geïnvesteerd, zal hij een hoger loon ontvangen, omdat de werkgever niet wil dat deze werknemer vertrekt en omdat de werknemer een hogere productieve waarde heeft in het bedrijf. Maar wanneer de arbeidsrelatie definitief wordt beëindigd, dan zal het feit dat de werknemer over kennis en vaardigheden beschikt die specifiek zijn aan zijn vorige werkgever de tewerkstellingskansen bij een andere werkgever niet vergroten. En wanneer hij wordt aangenomen in een nieuwe baan, dan zal het bezit van specifiek menselijk kapitaal uit een vorige baan geen invloed hebben op de inschaling. Studies hebben uitgewezen dat de achteruitgang in inkomen in een alternatieve baan voornamelijk te wijten is aan het verlies aan specifiek menselijk kapitaal. De werknemer kan het specifiek menselijk kapitaal uit een vorige baan niet uitspelen als relevante werkervaring bij het zoeken naar een nieuwe baan. ${ }^{6}$ Wordt de werknemer ontslagen, dan verliest hij de investeringen in specifieke vaardigheden en kennis en daarmee een deel van zijn vermogen om in de toekomst inkomen te verwerven. Dit leidt ertoe dat werknemers minder bereid zijn om te investeren in specifiek menselijk kapitaal; zij zullen eerder investeren in het verwerven van algemene vaardigheden en kennis die hun onderhandelingsposi- 
tie tegenover toekomstige werkgevers wel vergroten. In een 'multi-tasking' baan bijvoorbeeld zullen werknemers meer investeren in het uitvoeren van taken waarmee ze kennis en vaardigheden verwerven die ook naar toekomstige werkgevers toe waardevol zijn dan in het uitvoeren van taken waarbij investeringen in specifieke kennis en vaardigheden nodig zijn waarmee zij weliswaar hun productieve waarde (en bijpassend loon) bij de huidige werknemer verhogen, maar niet bij toekomstige werkgevers.

Hoe kan de werkgever zijn werknemers prikkelen om toch optimaal te investeren in specifiek menselijk kapitaal? Door bij het in dienst treden af te spreken dat aan de werknemer bij eventueel ontslag een vergoeding zal worden toegekend die afhangt van de hoeveelheid relatiespecifieke investeringen die op het ogenblik van het ontslag werden gedaan. Bij commerciële contracten kan de benadeelde partij bij contractbreuk gemakkelijk het verlies aan specifieke investeringen bewijzen aan de hand van betalingsbewijzen. Voor arbeidsrelaties is het heel moeilijk om te meten hoeveel relatiespecifieke investeringen de werknemer op het ogenblik van het ontslag heeft gedaan. Er zullen dus methoden en technieken ontwikkeld moeten worden om de gedane relatiespecifieke investeringen bij benadering te meten. Het aantal dienstjaren en het loon lijken geschikte maatstaven te zijn voor het berekenen van een vergoeding van dien aard. De investeringen in specifiek menselijk kapitaal nemen toe naarmate de werknemer langer werkzaam is bij een bepaalde onderneming. Het loon dat de werknemer verdient op het ogenblik van het ontslag is gerelateerd aan de productiviteit van de verworven specifieke kennis en vaardigheden.

\subsubsection{DE ONTSLAGVERGOEDING ALS VERGOEDING VOOR HET VERLIES AAN UITGESTELDE BELONING}

De kosten van het ontslag kunnen bestaan uit het verlies van (een deel van) de uitgestelde beloning.

\section{Anciënniteitsbeginsel als selectiecriterium bij ontslag}

Werknemers hebben vaak geen perfecte informatie over het ontslagrisico, maar gewoonlijk weten zij wel welk selectiecriterium de werkgever zal hanteren bij ontslagen om economische redenen. Tot 1 maart 2006 gold in Nederland het anciënniteitsbeginsel (last in, first out) als selectiecriterium bij collectief ontslag om bedrijfseconomische redenen. Welke invloed heeft deze senioriteitsregel op de efficiënte allocatie van werknemers naar bedrijven en sectoren? Indien deze regel alleen betrekking zou hebben op de selectie bij ontslag, maar niet op de lonen van werknemers met verschillende dienstjaren, dan zouden de lonen omgekeerd evenredig zijn met het aantal dienstjaren; het loon zou bepaald worden aan de hand van het ontslagrisico dat afhankelijk is van de opgebouwde anciënniteit. Werknemers die zoveel dienstjaren hebben dat ze niet meer voor ontslag in aanmerking komen, zouden hetzelfde loon krijgen als werknemers die tewerkgesteld worden in bedrijven waar tewerkstelling permanent is. In realiteit zijn de lonen op zijn minst onafhankelijk van senioriteit en vaak stijgen ze met 
het aantal dienstjaren. Onder deze voorwaarden is het loon dat wordt geboden om nieuwe werknemers aan te trekken te laag, tenzij de nieuwe werknemers genoegen nemen met dat loon omdat ze van plan zijn hun hele arbeidsleven werkzaam te zijn in het bedrijf. Hoewel de werknemer in het begin onderbetaald is, treedt hij toe tot een systeem waarin een deel van de beloning is uitgesteld tot later in zijn loopbaan. Wanneer de arbeidsrelatie met de werknemer definitief wordt beëindigd, dan zou hij een ontslagvergoeding moeten ontvangen die gelijk is aan de nettocontante waarde van de uitgestelde beloning die hij heeft opgebouwd maar nog niet heeft terugverdiend op het moment van het ontslag.

\section{Uitgestelde beloningsstructuur}

Ook zonder anciënniteitsbeginsel als selectiecriterium voor ontslag kan het voorkomen dat de werknemer tewerkgesteld wordt onder een uitgestelde beloningsstructuur: de werknemer wordt in het begin van zijn carrière onderbetaald (loon lager dan zijn productiviteit) en aan het eind van zijn carrière overbetaald (loon hoger dan zijn productiviteit). Er kunnen verschillende redenen zijn waarom de arbeidspartijen een dergelijke beloningsstructuur overeenkomen. Edward Lazear (1979) stelt dat een uitgestelde beloningsstructuur principaal-agent problemen oplost; een werknemer die niet goed presteert wordt ontslagen en verliest daarmee (een deel van) de uitgestelde beloning. Het uitzicht op de uitgestelde beloning prikkelt de werknemers om goed te presteren.

De uitgestelde beloning kan ook een manier zijn om het inkomen te herverdelen over de levensloop van de werknemer. De productiviteit van werknemers die fysieke arbeid verrichten neemt af met de leeftijd. In realiteit stijgen de lonen vaak - weliswaar in afnemende mate - met de leeftijd. Omdat dit ook het geval is voor ongeschoolde arbeid, kan de toename in loon niet verklaard worden als opbrengsten uit eerder gedane investeringen in kennis en vaardigheden. De discrepantie tussen loon en marginale productiviteit voor oudere werknemers kan verklaard worden als een herverdeling van het loon wanneer de werknemer jong is naar later wanneer hij ouder is.

Wanneer er sprake is van een uitgestelde beloningsstructuur, dan zou de werknemer wanneer hij ontslagen wordt om bedrijfseconomische redenen een ontslagvergoeding moeten krijgen die gelijk is aan de nettocontante waarde van de uitgestelde beloning die hij heeft opgebouwd op het moment van het ontslag.

\subsubsection{DE ONTSLAGVERGOEDING ALS SPAARSYSTEEM}

In een aantal landen zoals Oostenrijk $\mathrm{k}^{37}$ en Columbia ${ }^{38}$ hebben werknemers het recht op een beëindigingsvergoeding. Onder een dergelijk systeem hebben werknemers recht op een vergoeding bij het einde van de arbeidsrelatie, ongeacht of ze worden ontslagen, zelf vertrekken naar een nieuwe baan of met pensioen gaan. Vaak heeft dit systeem de vorm severance-payments savings accounts waarbij de werkgever periodiek een deel van het loon moet storten op een private spaarrekening van de werknemer. Omdat de verplichting om een deel van het loon te stor- 
ten op de spaarrekening van de werknemer niet afhangt van gebeurtenissen anders dan tewerkstelling zelf, kan de beëindigingsvergoeding beschouwd worden als een vorm van uitgestelde beloning. In subparagraaf 5.4.5 werd de ontslagvergoeding beschouwd als een vergoeding voor het gemiste deel van de uitgestelde beloning bij ontslag, maar onder een spaarsysteem is de beëindigingsvergoeding op zichzelf een vorm van uitgestelde beloning. Het systeem is vergelijkbaar met bijvoorbeeld pensioensparen of levensloopsparen.

Onder het gedwongen spaarsysteem voor beëindigingsvergoedingen in Oostenrijk storten werkgevers maandelijks een percentage (1,5377 procent) van het brutoloon op een private spaarrekening van de werknemer. Het spaarbedrag kan aangewend worden bij ontslag of bij vrijwillig vertrek of wordt uitbetaald samen met het pensioen. In feite legt de wetgever de werknemers op om een deel van hun loon te sparen en regelt daar bovenop nog eens het tijdstip waarop de werknemer over dit spaarbedrag kan beschikken. Voorafgaand aan de introductie van dit spaarsysteem kende Oostenrijk een systeem dat vergelijkbaar was met het huidige Nederlandse systeem van ontslagvergoedingen, zij het dat de vergoedingen minder hoog waren en alleen werknemers die op het ogenblik van ontslag ten minste drie jaar bij de werkgever werkzaam waren recht hadden op een vergoeding.

Met het systeem heeft men in Oostenrijk getracht om tot een rechtvaardiger toekenning van beëindigingsvergoedingen te komen. Onder het oude systeem hadden werknemers met een dienstverband van korter dan drie jaar geen recht op een ontslagvergoeding door de werknemer. Onder het nieuwe systeem sparen alle werknemers elke maand een deel van hun loon, dus ook de werknemer die ontslagen wordt minder dan drie jaar na indiensttreding kan beschikken over een spaarbedrag.

Een andere doelstelling van de introductie van het Oostenrijkse spaarsysteem is om de vrijwillige mobiliteit van werknemers te bevorderen. De gespaarde bedragen komen immers definitief aan de werknemer toe, ook wanneer hij vrijwillig van baan verandert. Onder het oude systeem werd de ontslagvergoeding slechts toegekend wanneer de werknemer onvrijwillig werd ontslagen. Daarom liep de werknemer een risico wanneer hij vrijwillig van baan veranderde. Bij vrijwillig vertrek ontving de werknemer geen ontslagvergoeding. Een werknemer zal in principe alleen vrijwillig vertrekken wanneer hij in een andere baan beter af is. Er kan echter onzekerheid bestaan over de baanzekerheid in de nieuwe baan. Kwam er snel een einde aan de nieuwe baan, dan was de ontslagvergoeding niet hoog. De dienstjaren uit de vorige baan telden immers niet mee voor de berekening van de ontslagvergoeding onder het oude systeem. Onder een spaarsysteem voor beëindigingsvergoedingen lopen werknemers die vrijwillig van baan veranderen minder risico. Stel dat een werknemer 15 jaar bij een bepaalde onderneming werkt. Gedurende die 15 jaar wordt elke maand 1,5377 procent van zijn brutoloon op zijn individuele spaarrekening gestort. $\mathrm{Na} 15$ jaar bij dezelfde onderneming slaat de verveling toe en wisselt de werknemer vrijwillig van baan. Hij vertrekt naar een jong bedrijf dat een uitdagende baan aanbiedt maar waarvan de continu- 
ïteit in de toekomst onzeker is. Na vier jaar moet dit jonge bedrijf de deuren sluiten en wordt de werknemer onvrijwillig ontslagen. Op dat ogenblik kan de werknemer aanspraak maken op een bedrag dat hij gedurende 19 jaren heeft bijeen gespaard. Onder het oude systeem van ontslagvergoedingen zou de werknemer geen vergoeding hebben gekregen bij vrijwillig vertrek uit de eerste baan en een vergoeding gebaseerd op slechts 4 dienstjaren bij onvrijwillig ontslag uit de tweede baan.

Is het wenselijk dat in Nederland een gedwongen spaarsysteem in de vorm van beëindigingsvergoedingen wordt geïntroduceerd? Dé beleidsvraag die voor een aanpassing in die zin moet worden beantwoord is of het wenselijk en nodig is dat alle werknemers in de vorm van een loonsverlaging bij tewerkstelling een deel van hun loon sparen om later aan te wenden bij ontslag, vertrek of pensionering. Het ingrijpen van de overheid om de burgers te dwingen te sparen is gerechtvaardigd wanneer werknemers bijvoorbeeld door beperkte rationaliteit te veel consumeren en te weinig sparen en daardoor in de problemen komen wanneer bepaalde risico's zich voordoen. Het Oostenrijkse severance payments savings systeem kan gezien worden als een van de pijlers van het Oostenrijkse pensioensysteem en als aanvulling op de werkloosheidsuitkeringen. Voor zover het pensioensysteem en de werkloosheidsverzekering reeds adequaat zijn geregeld in Nederland, lijkt er geen aanleiding te zijn om hier een systeem van beëindigingsvergoedingen in te voeren met de functie van een gedwongen spaarsysteem.

\subsubsection{BEOORDELING VAN DE NEDERLANDSE REGELS MET BETREKKING TOT DE ONTSLAGVERGOEDING}

In deze paragraaf wordt nagegaan of de Nederlandse regels voor de toekenning en de hoogte van de ontslagvergoeding economisch verklaard kunnen worden en of er op grond van de economische overwegingen ontwikkeld in de vorige paragrafen aanleiding is om de regels aan te passen. 39

\section{De berekeningswijze van de ontslagvergoeding: de kantonrechtersformule}

De kantonrechtersformule wordt als volgt weergegeven: a x b x c. Waarbij:

$\mathrm{a}=$ Het gewogen aantal dienstjaren (het aantal jaren dat de werknemer in de onderneming heeft gewerkt, waarbij vanaf de leeftijd van 40 jaar ieder jaar voor 1,5 jaren geldt en vanaf de leeftijd van 50 jaar ieder jaar voor 2 jaren;

$\mathrm{b}=$ het brutomaandsalaris, waarbij alleen wordt uitgegaan van de vaste salariscomponenten;

$c=$ de correctiefactor, die bij een neutrale ontbinding (geen van de partijen heeft in het bijzonder schuld aan het feit dat de arbeidsovereenkomst ten einde komt) op 1 wordt gesteld. Deze cfactor kan al naar gelang de schuld van de werknemer zo mogelijk tot o worden gereduceerd, terwijl schuld aan de kant van de werkgever tot $\mathrm{c}=2, \mathrm{c}=3$ of desnoods nog hoger kan leiden. Tot slot geldt dat de vergoeding niet hoger zal zijn - behoudens eventuele immateriële schadedan de verwachte inkomensderving tot aan de pensioengerechtigde leeftijd. 


\section{Leeftijd, dienstjaren en loon ( $a \times b)$}

In de paragrafen 5.4.4 en 5.4.5 werd gesteld dat de economisch optimale ontslagvergoeding afhangt van het bestaan en de hoogte van de relatiespecifieke investeringen en de uitgestelde beloning. Wanneer de ontslagvergoeding compenseert voor het verlies aan specifiek menselijk kapitaal, dan neemt zij toe met het aantal dienstjaren en loon. Compenseert de ontslagvergoeding voor het verlies aan uitgestelde beloning, dan zou de vergoeding moeten toenemen met het aantal dienstjaren tot aan een zekere leeftijd; vanaf een zekere leeftijd zou de ontslagvergoeding afnemen totdat zij tot o wordt gereduceerd bij pensionering. Vanaf een zekere leeftijd krijgt de werknemer immers bij tewerkstelling een deel van zijn uitgestelde beloning in de vorm van een hoger loon uitbetaald en de nettocontante waarde van de uitgestelde beloning neemt af totdat bij pensionering de volledige uitgestelde beloning is verkregen.

Onder de kantonrechtersformule wordt de vergoeding hoger naarmate de werknemer langer bij de werkgever in dienst is geweest en een hoger loon heeft. Bovendien is de vergoeding niet hoger dan het gederfde inkomen tot aan de pensioengerechtigde leeftijd, zodat de vergoeding afneemt wanneer de ontslagen werknemer dichter bij de pensioenleeftijd komt. Het lijkt er dus op dat de kantonrechtersformule qua structuur aansluit bij de economisch rationele berekening voor het verlies aan specifiek menselijk kapitaal en uitgestelde beloning. Toch is meer onderzoek nodig om na te gaan of de kantonrechtersformule de verliezen wel precies meet. Wat is de werkelijke grootte van het verlies aan specifiek menselijk kapitaal en uitgestelde beloning. Is dat een maandloon per dienstjaar? Of is het een weekloon of een half maandloon per gewerkt dienstjaar? Een preciezere berekening van de nettocontante waarde van de uitgestelde beloning en de gedane specifieke investeringen op het moment van ontslag is wellicht mogelijk. Bovendien zou de leeftijd waarop de ontslagvergoeding dient af te nemen preciezer vastgesteld kunnen worden. Nu leidt de vereiste dat de vergoeding niet hoger kan zijn dan het gederfde inkomen in praktijk tot een afname van de vergoeding tot aan de pensioenleeftijd; wellicht kan preciezer vastgesteld worden vanaf welke leeftijd de uitgestelde beloning aan de werknemer wordt betaald, zodat bepaald kan worden hoeveel uitgestelde beloning de werknemer al heeft verkregen op het moment van het ontslag. ${ }^{40}$

Het is moeilijker om een economische verklaring te vinden voor het feit dat de dienstjaren worden gewogen aan de hand van leeftijd, tenzij aangetoond zou kunnen worden dat oudere werknemers per gewerkt dienstjaar meer uitgestelde beloning opbouwen of meer investeren in specifiek menselijk kapitaal dan jongere werknemers. Dat is niet het geval. De rechter laat de dienstjaren voor oudere werknemers zwaarder meetellen, omdat dat met het oog op de omstandigheden van het geval billijk voorkomt; oudere werknemers hebben immers minder kans om een nieuwe baan te vinden. Er zijn voldoende economische studies die aantonen dat de kans op een nieuwe baan afneemt met de leeftijd. Voor de ontslagen oudere werknemer is het billijk dat hij een hogere ontslagvergoeding ontvangt, maar tegelijkertijd kan het gebruik van gewogen dienstjaren in 
de kantonrechtersformule de kans dat de oudere werknemer een nieuwe baan vindt nog laten afnemen.

Voorbeeld: twee werknemers worden op hetzelfde moment in dienst genomen, maar werknemer $\mathrm{X}$ is 20 jaar en werknemer $\mathrm{Y}$ is 45 jaar bij het aangaan van het dienstverband. Zij doen hetzelfde werk en verdienen op het ogenblik van ontslag hetzelfde maandloon van 2000 euro. Na een dienstverband van 10 jaar worden beiden vanwege een bedrijfssluiting ontslagen.

$\mathrm{x}$ heeft recht op een ontslagvergoeding van: $10 \times 2.000=20.000$ euro. $\mathrm{Y}$ heeft recht op een ontslagvergoeding van: $[(5 \times 1,5)+(5 \times 2)] \times 2.000=35.000$ euro.

$\mathrm{Na}$ ontslag zal een potentiële nieuwe werkgever B de volgende afweging maken. Mocht hij na een aantal jaren de werknemer moeten ontslaan, dan zou elk dienstjaar van $\mathrm{Y}$ dubbel tellen en van $\mathrm{X}$ enkel voor de berekening van de ontslagvergoeding. De verwachte arbeidskosten voor het aannemen van $\mathrm{Y}$ zijn hoger dan voor het aannemen van $\mathrm{x}$ (wanneer wordt aangenomen dat aan beiden eenzelfde loon wordt betaald). $\mathrm{x}$ heeft dus meer kans dat hij wordt aangenomen na ontslag dan Y. Voor de kleinere kans dat Y een nieuwe baan vindt, krijgt hij een hogere ontslagvergoeding van A. Dit leidt tot de merkwaardige conclusie dat de kantonrechtersformule vergoedt voor een situatie die door de formule zelf wordt veroorzaakt. Deze stelling moet echter genuanceerd worden, omdat B nog om andere redenen dan de kantonrechtersformule een jongere werknemer kan prefereren, bijvoorbeeld omdat de werkzaamheden bij в ondernemingsspecifieke investeringen vereisen waarvoor de terugverdienperiode voor jongere werknemers langer is dan voor oudere werknemers. Niettemin is het nuttig om de wenselijkheid van de huidige leeftijdsgrenzen en wegingsfactoren die gehanteerd worden in de kantonrechtersformule verder te onderzoeken. Met name rijst de vraag of de gevolgen van leeftijd op de tewerkstellingskansen een aspect is waarvoor de individuele arbeidsovereenkomst een oplossing moet bieden of dat het een aspect is waarvoor maatregelen getroffen moeten worden op het niveau van de hele maatschappij.

\section{Schuld (c-factor)}

De correctiefactor $\mathrm{C}$ in de kantonrechtersformule houdt in dat toekenning van de ontslagvergoeding gebeurt naar rato van de mate van verwijtbaarheid van de partijen aan de ontbinding van de arbeidsovereenkomst. Wordt geoordeeld dat de totstandkoming van het conflict in hoge mate is te wijten aan de schuld van de werkgever, dan wordt de c-factor verhoogd (c >1) en wanneer geoordeeld wordt dat het conflict in hoge mate is te wijten aan de schuld van de werknemer, dan wordt de c-factor verlaagd $(\mathrm{c}<1)$.

Is het efficiënt dat de ontslagvergoeding wordt verlaagd wanneer de werkgever kan aantonen dat de ontbinding te wijten is aan de schuld van de werknemer? Wanneer de ontslagvergoeding ( $\mathrm{a} \mathrm{x} \mathrm{b}$ ) zou worden toegekend onafhankelijk van de vraag of de werknemer schuld heeft aan de ontbinding, dan zouden prikkel- 
problemen ontstaan. Toekenning van een ontslagvergoeding kan ertoe leiden dat de werknemer onverschillig wordt tussen de continuering of de beëindiging van de arbeidsrelatie. Hij zou zich daarom minder kunnen inzetten voor het behoud van zijn baan. Vandaar dat de werknemer zonder meer recht heeft op de neutrale vergoeding wanneer het heel waarschijnlijk is dat de werknemer geen aandeel heeft in de beëindiging ervan, zoals in het geval van reorganisatie of inkrimping, maar dat de vergoeding wordt verlaagd wanneer door de werkgever aangetoond kan worden dat de werknemer wel schuld heeft aan de beëindiging. Een verhoging van de ontslagvergoeding zou gerechtvaardigd kunnen worden wanneer de ontslagvergoeding de werknemer ondercompenseert voor de geleden verliezen en de werkgever zich minder dan optimaal inspant voor het behoud van de arbeidsrelatie.

Niettemin brengt toerekening naar rato van relatieve schuld extra kosten met zich mee, omdat er sprake is van asymmetrische informatie van de rechter omtrent de feiten die aan de ontbinding ten grondslag liggen en de partijen kosten moeten maken om op een verifieerbare wijze de rechter over de feiten te informeren. Daardoor zullen rechters soms vergissingen begaan: soms krijgt een werknemer onterecht een verhoogde vergoeding en soms krijgt hij onterecht een verlaagde vergoeding. Het risico dat er vergissingen worden begaan brengt kosten van onzekerheid voor de partijen met zich mee. Bovendien kan dit leiden tot prikkelproblemen. Voor de financiële positie van de partijen maakt de schuldtoerekening veel uit. Hierop anticiperend kunnen de partijen middelen verspillen om de rechter te overtuigen dat de ontbinding te wijten is aan de schuld van de andere partij. Is de arbeidsverhouding duurzaam verstoord door onenigheid, dan is het in het belang van de partijen dat de relatie wordt ontbonden. Maar de werkgever zal in dat geval nog allerlei onproductieve maatregelen nemen om te voorkomen dat de c-factor wordt verhoogd en de werknemer zal ongemotiveerd aan de maatregelen meewerken om te voorkomen dat de c-factor wordt verlaagd. Bovendien moeten partijen hun pogingen tot herstel van de verstoorde arbeidsverhouding goed documenteren als bewijsmateriaal in een procedure. Inzet en motivatie zijn de belangrijkste factoren voor het al dan niet slagen van pogingen om het conflict op te lossen, maar net deze factoren zijn het moeilijkst te bewijzen in een procedure.

\section{Habe nichts, habe wenig-exceptie}

Een werkgever met weinig financiële middelen of draagkracht kan een beroep doen op 'habe nichts, habe wenig'-exceptie om een lagere of geen ontslagvergoeding te betalen. Draagkracht van de werkgever op het moment van het ontslag speelt dus een rol bij de toekenning van de ontslagvergoeding. Dit kan ertoe leiden dat de werknemer het uitgestelde deel van zijn beloning definitief verliest of geen vergoeding krijgt voor eerder gedane relatiespecifieke investeringen. Wanneer de werkgever niet over de financiële middelen beschikt om de ontslagvergoeding ineens bij ontslag te betalen, kan in eerste instantie nagegaan worden of periodieke betaling ervan mogelijk is. Mocht het probleem van habe nichts, habe wenig groter worden ${ }^{41}$, dan zou gedacht kunnen worden aan een verzeke- 
ring voor het geval dat een werkgever door insolventie de ontslagvergoeding niet kan betalen. Omdat het onwaarschijnlijk is dat een dergelijke verzekering door private verzekeraars zal worden aangeboden, zou daarvoor een vorm van verplichte collectieve verzekering moeten worden ingevoerd. Andere landen die een systeem van verplichte vergoedingen bij ontslag om bedrijfseconomische redenen kennen, zoals Groot-Brittannië ${ }^{42}$ en België ${ }^{43}$, kennen een regeling waarbij de vergoedingen betaald worden uit een fonds wanneer de onderneming insolvent is. Dit fonds wordt gefinancierd door premies die alle werkgevers betalen.

\section{Geen ontslagvergoeding bij vrijwillig vertrek van de werknemer}

Onder de huidige ontslagregels krijgt de werknemer geen vergoeding wanneer de ontbinding het gevolg is van verwijtbaar slecht functioneren van de werknemer of wanneer hij zelf vertrekt, omdat wordt aangenomen dat de ontbinding dan het gevolg is van een risico dat voor rekening van de werknemer komt. Is het wenselijk om het recht uit te breiden naar werknemers die vrijwillig vertrekken naar een andere baan wanneer wordt aangenomen dat de ontslagvergoeding een vergoeding is voor het verlies aan relatiespecifieke investeringen en uitgestelde beloning? In ondernemingen die een uitgestelde beloningsstructuur hanteren of waar de werknemers investeren in specifieke kennis en vaardigheden neemt de vrijwillige mobiliteit van werknemers naar andere banen af, ongeacht hun anciënniteit. Voor bedrijven is dat voordelig, omdat daadoor kosten voor het aanwerven en opleiden van nieuwe werknemers worden uitgespaard. Wanneer het wenselijk zou zijn voor de economie als geheel om vrijwillige mobiliteit te stimuleren om aanpassingen aan economische veranderingen te versnellen, dan kan dit bewerkstelligd worden door ook aan werknemers die vrijwillig vertrekken een vertrekvergoeding toe te kennen die gelijk is aan de nettocontante waarde van de uitgestelde beloning en het verlies aan specifiek menselijk kapitaal. Uitbreiding van het recht op een ontslagvergoeding naar werknemers die vrijwillig naar een andere baan vertrekken leidt wel tot problemen wanneer ook de werkgever heeft geïnvesteerd in de specifieke kennis van de werknemers, zoals meestal het geval is. Met het vertrek van de werknemer verliest de werkgever de verwachte opbrengsten uit eerder gedane investeringen in specifiek menselijk kapitaal. Bovendien zullen de kosten voor werving en opleiding voor nieuwe werknemers die de vertrokken werknemers moeten vervangen stijgen.

\section{Ook een ontslagvergoeding wanneer er geen sprake is van specifieke verliezen}

Onder de huidige ontslagregels heeft de werknemer recht op een ontslagvergoeding bij ontbinding wanneer het ontslag het gevolg is van een risico dat voor rekening van de werkgever komt, zoals een inkrimping of een reorganisatie. In deze gevallen, de 'neutrale' ontbinding, heeft de werknemer zonder meer recht op een vergoeding gelijk aan het aantal gewogen dienstjaren (a) vermenigvuldigd met het brutoloon (b). Hierboven werd aangetoond dat het efficiënt is om een ontslagvergoeding te betalen voor het verlies aan specifiek menselijk kapitaal en uitgestelde beloning. In het vervolg zal ik deze verliezen aanduiden als specifieke verliezen. Echter, wanneer er geen sprake is van relatiespecifieke investeringen of 
uitgestelde beloning, is er vanuit economisch perspectief geen reden om een ontslagvergoeding toe te kennen. De werknemer lijdt dan immers geen specifieke verliezen, dat wil zeggen verliezen anders dan die ten gevolge van werkloosheid. Het verlies aan inkomen bij werkloosheid wordt door de collectieve werkloosheidsverzekering vergoed. Niettemin wordt in Nederland bij ontslag om bedrijfseconomische redenen zonder meer een ontslagvergoeding toegekend. Wat zijn de gevolgen van het recht op een ontslagvergoeding wanneer dat niet begrepen kan worden als een vergoeding voor specifieke verliezen?

Werkgevers reageren op de verplichting om bij onvrijwillig ontslag een vergoeding te betalen door de lonen van werknemers evenredig te verlagen met de verwachte ontslagvergoeding. Een deel van het loon wordt dan als het ware uitgesteld en later uitbetaald als ontslagvergoeding. In vergelijking met de situatie waarin de ontslagvergoeding een vergoeding is voor het vroegtijdig beëindigen van een door de arbeidspartijen afgesproken uitgestelde beloningsstructuur of voor eerder gedane relatiespecifieke investeringen, is de verplichting om een ontslagvergoeding te betalen wanneer de arbeidspartijen zelf geen uitgestelde beloning hebben afgesproken, op zichzelf een vorm van uitgestelde beloning.

Voorbeeld. Twee werknemers X en Y worden tewerkgesteld bij werkgever A in een functie zonder relatiespecifieke investeringen. Het gaat bijvoorbeeld om ongeschoolde arbeid of functies waarvoor enkel algemene kennis en vaardigheden zijn vereist. Bij een eventueel ontslag worden geen specifieke verliezen geleden, omdat de werknemer snel een gelijkwaardige baan kan vinden voor hetzelfde loon. ${ }^{44}$ Niettemin moet de werkgever bij ontslag een ontslagvergoeding betalen, omdat dit recht voor werknemers bestaat ongeacht de aard van de afgesproken beloningsstructuur. De werkgever zal dan het loon van beide werknemers verlagen met het bedrag van de verwachte ontslagvergoeding. Stel dat werknemer $\mathrm{X}$ wordt ontslagen. Hij krijgt bij ontslag een vergoeding die gelijk is aan de loonsverlaging. Hier wordt duidelijk dat tijdens tewerkstelling een deel van het loon van $\mathrm{X}$ werd uitgesteld en later uitbetaald als ontslagvergoeding.

Wanneer slechts werknemers die onvrijwillig ontslagen worden het recht hebben op de uitgestelde beloning in de vorm van een ontslagvergoeding, dan leidt dat tot onrechtvaardige situaties tussen werknemers. Stel dat Y niet wordt ontslagen. Ook het loon van Y wordt verlaagd met de verwachte ontslagvergoeding wanneer de werkgevers en werknemers vooraf niet weten wie van de werknemers voor ontslag geselecteerd zal worden. Omdat er op grond van Nederlandse regels slechts een recht op een ontslagvergoeding bestaat wanneer de werknemer onvrijwillig wordt ontslagen, werkt $\mathrm{Y}$ wel voor een lager loon, maar krijgt hij daar later geen bedrag voor terug wanneer hij niet onvrijwillig wordt ontslagen. Wanneer het recht op een ontslagvergoeding leidt tot een evenredige verlaging van het loon voor alle werknemers, bestaan er rechtvaardigheidsargumenten voor een aanpassing van de regeling in de zin dat alle werknemers het uitgestelde loon terugkrijgen in de vorm van een beëindigingsvergoeding bij onvrijwillig ontslag, vrijwillig vertrek of bij pensionering. 
Het recht op een ontslagvergoeding bij onvrijwillig ontslag dat niet begrepen kan worden als een vergoeding voor specifieke verliezen, leidt tot een beperking van de vrijwillige mobiliteit van werknemers naar andere banen. Een werknemer die vrijwillig vertrekt loopt het risico dat hij slechts een lage vergoeding krijgt wanneer hij onverwacht snel wordt ontslagen uit zijn nieuwe baan. De dienstjaren uit de oude baan tellen immers niet mee voor de berekening van de vergoeding wanneer de werknemer wordt ontslagen uit de nieuwe baan. Hiervoor zijn er twee mogelijke oplossingen.

(1) De werknemer heeft geen recht op een ontslagvergoeding wanneer er geen sprake is van specifieke verliezen.

(2) Wanneer er geen sprake is specifieke verliezen heeft de werknemer het recht op een beëindigingsvergoeding in alle gevallen waarin de arbeidsrelatie ten einde komt: bij onvrijwillig ontslag, vrijwillig vertrek of bij het pensioen.

Onder de eerste oplossing zullen werkgevers de lonen niet meer verlagen met het bedrag van de verwachte ontslagvergoeding en wordt de vrijwillige mobiliteit niet beperkt. Wel is nodig dat de kantonrechter afziet van het toekennen van een ontslagvergoeding wanneer er geen sprake is van specifieke verliezen. Onder de tweede oplossing zullen werkgevers wel de lonen van werknemers verlagen met het bedrag van de beëindigingsvergoeding, maar elke werknemer zal vroeg of laat dat bedrag uitbetaald krijgen. De beëindigingsvergoeding verkrijgt dan het karakter van een gedwongen spaarsysteem. Aangezien in Nederland al voldoende voorzorg is ingebouwd via de pensioenregeling en de collectieve werkloosheidsverzekering, is een dergelijk systeem niet nodig.

Omdat het toekennen van een ontslagvergoeding bij onvrijwillig ontslag van werknemers die geen specifieke verliezen leiden leidt tot onrechtvaardige situaties tussen de werknemer die wel en niet wordt ontslagen en tot een beperking van de vrijwillige mobiliteit van de werknemers, is het niet wenselijk dat kantonrechters een vergoeding toekennen bij de ontbinding van arbeidsrelaties waarbij geen sprake is van relatiespecifieke investeringen of van een uitgestelde beloningsstructuur.

\section{Private beëindigingsovereenkomsten versus wettelijke normering van ontslagvergoedingen}

De hoogte van ontslagvergoedingen is in Nederland niet wettelijk genormeerd. In de meeste gevallen komen partijen onderling een bedrag overeen. De beëindigingsovereenkomst waarin ontslagvergoedingen worden afgesproken nemen een belangrijke plaats in in het Nederlandse arbeidsovereenkomstenrecht, als belangrijkste bouwsteen voor de vele geregelde ontbindingen en opzeggingen. Volgens Grapperhaus (2004: 284) leidt het systeem van beëindigingsovereenkomsten en de daaropvolgende geregelde ontbindingen en ontslagvergunningen uiteindelijk tot een geolied ontslagstelsel. Het voordeel van private beëindigingsovereenkomsten (onderhandeld op het moment van het ontslag of bij het sluiten van de arbeidsovereenkomst) is dat de private arbeidspartijen rekening kunnen houden met de unieke kenmerken van de arbeidsrelatie die ze beogen en uiteindelijk 
realiseren. Rigide wettelijke normen voor ontslagvergoedingen kunnen deze functie niet vervullen. Maar ook private beëindigingsovereenkomsten komen niet tot stand in een vacuüm; elke overeenkomst komt tot stand in de context van de rechten die door overheid worden erkend en gehandhaafd. Het onderhandelen van beëindigingsovereenkomsten vindt plaats in the shadow of the law. De grenzen van individueel of collectief onderhandelde beëindigingsovereenkomsten worden bepaald door de regels die van toepassing zullen zijn bij afwezigheid van een privaat onderhandelde overeenkomst. Het is de taak van de wetgever en de rechters om duidelijke regels van aanvullend recht, dat wil zeggen de regels die gelden bij afwezigheid van een private beëindigingsovereenkomst, vast te stellen.

\section{$5 \cdot 5$ CONCLUSIES EN AANBEVELINGEN}

Zijn de Nederlandse ontslagregels efficiënt? Om deze vraag te beantwoorden werd met de rechtseconomische methode een prikkel -, risico- en transactiekostenanalyse van de Nederlandse ontslagregels gemaakt. De regels werden onderverdeeld in de regels met betrekking tot de gronden van het ontslag en de regels in verband met de financiële vergoeding bij ontslag (de ontslagvergoeding).

\subsubsection{CONCLUSIES}

\section{Ontslaggronden}

Een onderdeel van de Nederlandse ontslagbescherming betreft de regulering van de gronden voor ontslag. Die bestaat eruit dat de werkgever voor de eenzijdige beëindiging van de arbeidsrelatie toestemming nodig heeft van de CWI en die toestemming enkel krijgt wanneer daar naar het oordeel van de CWI een gegronde reden toe is. Deze toets van de ontslaggronden is een verregaande beperking van de ontslagvrijheid van de werkgever en biedt de werknemer veel baanzekerheid. Voor deze vorm van ontslagbescherming kom ik op basis van dit onderzoek tot de volgende conclusies.

- De vereiste dat de werkgever voor de eenzijdige opzegging van de arbeidsrelatie ten aanzien van de CWI moet aantonen dat hij hiervoor een gegronde reden heeft, leidt tot hogere transactiekosten bij het gebruik van de externe arbeidsmarkt voor de efficiënte reallocatie van werknemers. De kosten bestaan uit de bewijskosten om de CWI te overtuigen van de bedrijfseconomische noodzaak van het ontslag of de informatiekosten en kosten van strategisch gedrag bij het onderhandelen van een beëindigingsovereenkomst. Deze kosten verlagen het surplus van de arbeidsrelatie.

- Door de vereiste dat de werkgever de arbeidsrelatie enkel eenzijdig kan beëindigen wanneer hij daarvoor een - naar het oordeel van de CWI - gegronde reden heeft, verkrijgt de werknemer veel juridische baanzekerheid. Door baanzekerheid neemt de prikkel van de werknemer om te investeren in relatiespecifieke kennis toe waardoor het productieve surplus van de arbeidsrelatie stijgt. Echter, wanneer de werknemer al de facto baanzekerheid heeft omdat beide partijen hebben geïnvesteerd in relatiespecifieke kennis, veroorzaakt juridische baanzekerheid onnodige kosten. 
- Juridische baanzekerheid kan de prikkel van de werknemers om te herinvesteren in menselijk kapitaal, wanneer de productieve waarde ervan met de tijd daalt, doen afnemen. Waarom zouden werknemers kosten maken om te herinvesteren indien zij toch verzekerd zijn van hun baan?

- Slechts onder bepaalde voorwaarden zouden de arbeidspartijen bij het aangaan van het dienstverband vrijwillig akkoord gaan met een verzekeringsarrangement waardoor de werkgever de werknemer 'verzekert van zijn baan' voor het geval dat de vraag naar arbeid daalt naar aanleiding van een wijziging in economische omstandigheden.

- Omdat, in tegenstelling tot het naoorlogse Nederland, ontslagregels niet dienen ter bescherming van het algemene belang, is privaatrechtelijke handhaving op initiatief van de arbeidspartijen te verkiezen boven administratiefrechtelijke handhaving door de CWI. De private arbeidspartijen hebben meer informatie dan de administratieve overheid over de vraag of de handeling van het ontslag in strijd is met de individuele belangen.

- Omdat het voor derde partijen zeer moeilijk is om te verifiëren wat de werkelijke reden is voor het ontslag, kan oneigenlijk gebruik van de sociale zekerheid beter voorkomen worden door maatregelen in de socialezekerheidsregeling zelf dan door regels die de ontslagvrijheid beperken.

\section{Ontslagvergoedingen}

Voor de Nederlandse regels met betrekking tot de ontslagvergoeding kom ik op basis van dit onderzoek tot de volgende conclusies.

- In Nederland worden de inkomensverliezen ten gevolge van werkloosheid gedekt door de collectieve werkloosheidsverzekering. Het gebruik van ontslagvergoedingen voor de verzekering van het werkloosheidsrisico - zoals in een aantal landen het geval is - is niet wenselijk. De voordelen van een collectieve werkloosheidsverzekering zijn dat de kosten van het risico op conjuncturele en structurele werkloosheid worden verlaagd door een ruime spreiding over bedrijven en sectoren en dat de overheid als betrokken partij geprikkeld wordt om maatregelen te nemen om het werkloosheidsrisico te beperken.

- Tijdens de opzegtermijn verzekert de werkgever de werknemer voor honderd procent van het inkomensverlies dat te wijten is aan zoekwerkloosheid. Door de duur van de opzegtermijn te laten afhangen van de tijd die een werknemer met een bepaalde functie gemiddeld nodig heeft om een nieuwe geschikte functie te vinden, worden relatiespecifieke investeringen die bestaan uit het verloren laten gaan van alternatieve mogelijkheden van tewerkstelling beschermd. Onder de huidige wettelijke regeling van opzegtermijnen variëren opzegtermijnen enkel met het aantal dienstjaren en niet met de aard van de functie die de werknemer heeft vervuld.

- Een optimale allocatie van arbeid en risico's brengt met zich mee dat de werkgever - wanneer hij reageert op economische veranderingen door werknemers te ontslaan - een ontslagvergoeding betaalt als vergoeding voor het verlies aan investeringen in specifiek menselijk kapitaal en het verlies aan uitgestelde beloning. Verder onderzoek is nodig om na te gaan of de huidige methode 
voor de berekening van de ontslagvergoeding, de kantonrechtersformule, het verlies aan specifiek menselijk kapitaal en uitgestelde beloning voldoende precies meet.

- Onder de huidige regels wordt bij ontbinding van de arbeidsrelatie zonder meer een neutrale ontslagvergoeding (A x B) toegekend wanneer de ontbinding het gevolg is van een risico dat voor rekening van de werkgever komt, zoals inkrimping of reorganisatie. Het komt dus ook voor dat de werkgever een ontslagvergoeding betaalt wanneer geen sprake is van verlies aan specifiek menselijk kapitaal en verlies aan uitgestelde beloning. In die gevallen leidt het recht op een ontslagvergoeding ertoe dat tijdens de tewerkstelling een deel van het loon wordt ingehouden en later in de vorm van een ontslagvergoeding als uitgestelde beloning wordt uitbetaald, maar alleen bij onvrijwillig ontslag. Hierdoor wordt de vrijwillige mobiliteit van werknemers onnodig beperkt. Deze beperking zou opgeheven kunnen worden door een ontslagvergoeding te betalen in alle gevallen dat de arbeidsrelatie wordt beëindigd, bij onvrijwillig ontslag, vrijwillig vertrek of pensionering, maar dat zou betekenen dat via de ontslagvergoedingen een gedwongen spaarsysteem wordt ingevoerd, zoals in Oostenrijk. Omdat in Nederland de voorzorg voor pensioenen en werkloosheid al adequaat is geregeld, is daar geen behoefte aan.

\subsubsection{AANBEVELINGEN}

Op basis van de conclusies uit het onderzoek kan het volgende ontslagregime worden aanbevolen. 45

- Voor arbeidsovereenkomsten voor onbepaalde duur geldt als regel dat beide partijen de vrijheid hebben om de arbeidsrelatie eenzijdig op te zeggen. Deze vrijheid houdt in dat voor de opzegging geen vergunning is vereist en dat voor de eenzijdige opzegging niet vereist is dat tegenover een derde partij, de CWI of de rechter, moet worden aangetoond dat er een gegronde reden voor de opzegging bestaat.

- De regel dat elk der arbeidspartijen de vrijheid heeft om de arbeidsovereenkomst eenzijdig op te zeggen, is een regel van aanvullend recht, dat wil zeggen een regel die geldt voor zover de partijen geen afwijkende regeling hebben afgesproken. De ontslagvrijheid kan door de partijen contractueel worden beperkt.

- De werknemer heeft het recht op schadevergoeding wanneer de opzegging als kennelijk onredelijk kan worden beschouwd. De toets of een ontslag kennelijk onredelijk is, is een marginale toetsing. De rechter beoordeelt de wenselijkheid van het ontslag niet, maar sanctioneert de werkgever enkel wanneer de werknemer aannemelijk kan maken dat het ontslag is gegeven met geen ander belang, dan het belang om de werknemer te schaden, en de werkgever hiervoor geen tegenbewijs kan leveren.

- Bij het sluiten van de arbeidsovereenkomst of op het ogenblik van ontslag onderhandelen de partijen over een individuele of collectieve beëindigingsovereenkomst waarin zij afspraken maken met betrekking tot de opzegtermijn en/of de ontslagvergoeding. 
- Bij afwezigheid van een private beëindigingsovereenkomst gelden de 'achtergrond'-regels of regels van aanvullend recht. Deze regels bepalen dat de werknemer recht heeft op een opzegtermijn die gelijk is aan de termijn die de werknemer gemiddeld nodig heeft om een gelijkaardige baan te vinden. Deze regels bepalen ook dat de werknemer recht heeft op een ontslagvergoeding wanneer aangetoond wordt dat het onvrijwillige ontslag gepaard gaat met een verlies aan investeringen in specifiek menselijk kapitaal of aan uitgestelde beloning. Voor de berekening van deze verliezen worden methoden en technieken gebruikt waarmee de verliezen zo precies mogelijk worden gemeten. 


\section{NOTEN}

Wanneer een derde partij oordeelt over de wenselijkheid van de aanpassing wordt in de Engelstalige literatuur gesproken van third party governance. Daarnaast kan de kantonrechter de arbeidsovereenkomst ontbinden wanneer de werkgever aantoont dat daarvoor een gewichtige reden bestaat.

3 Buechtemann (1993) maakt een onderscheid tussen 'job security' (functiezekerheid), 'macro-economic employment security' (werkzekerheid) en 'microeconomic employment security' (baanzekerheid). Hij definieert de begrippen als volgt: "Job security refers to a worker's probability of keeping a particular job, including the specific work tasks, skill requirements, compensation, and nonwage attributes (e.g., competences) associated with that job. (...) Macroeconomic employment security refers to the availability of employment opportunities in the economy as a whole and can be defined as a worker's probability of staying in employment or finding new employment when first entering or reentering the labor market. (...) The degree of macroeconomic employment security is influenced primarily by macroeconomic policies and only very indirectly by labor legislation. (...) Micro-economic employment security refers to the worker's probability of not being unjustly or arbitrarily fired from his or her job and thereby relates to ongoing employment with a particular firm rather than to a particular job within that firm" (Buechtemann 1993:5-6). De vereiste van een gegronde of gewichtige reden voor de opzegging of ontbinding bevordert de baanzekerheid (micro-economic employment security).

$4 \quad$ Vergelijkende studies naar de effecten van ontslagbescherming op werkloosheid en werkgelegenheid tonen wel aan dat het aandeel langdurige werkloosheid in de totale werkloosheid hoger is dan in landen met minder ontslagbescherming.

Het surplus dat de partijen door samenwerking genereren kunnen zij onder elkaar verdelen; voor werknemers betekent dat een hoger loon.

Een dergelijk onderscheid komt bijvoorbeeld ook voor in het echtscheidingsrecht, waar enerzijds regels bestaan m.b.t. de gronden voor echtscheiding en anderzijds regels m.b.t. de financiële regeling en alimentatie bij echtscheiding. Het arbeidsrecht bevat ook regels voor de werknemer die de arbeidsovereenkomst opzegt, maar in dit onderzoek wordt alleen gekeken naar de regels die voor de werkgever gelden.

8 Het feit dat er geen contractuele of wettelijke vorm van ontslagbescherming is, betekent niet dat de werknemer geen baanzekerheid heeft. De werknemer kan een hoge mate van de facto baanzekerheid genieten.

Een bilateraal monopolie is een marktvorm die gekenmerkt wordt door een vrager en een aanbieder. De situatie waarin een werkgever en werknemer verkeren nadat relatiespecifieke investeringen zijn gemaakt, is vergelijkbaar met een bilateraal monopoly, omdat de opbrengsten van de investeringen alleen verwezenlijkt kunnen worden binnen de bestaande arbeidsrelatie en niet in een alternatieve relatie.

In de cao wordt gewoonlijk een beloningsstructuur afgesproken waarbij de lonen per dienstjaar stijgen, de zogenaamde periodieken. Ook deze beloningsstructuur 
is vooraf afgesproken, dit wil zeggen, is bij de werknemer bekend bij het aangaan van de arbeidsrelatie. Niettemin worden lonen, meer bepaald de stijgingspercentages, tijdens de looptijd van de arbeidsovereenkomst door collectieve onderhandelingen heronderhandeld. Aanpassingen van de lonen aan de gerealiseerde productiviteit is dus in zekere mate mogelijk. De nominale lonen worden echter niet neerwaarts aangepast, hoogstens wordt geen of een laag stijgingspercentage afgesproken bij slechte economische omstandigheden of om de internationale concurrentiepositie te behouden.

Bij een aanpassing van het loon zodat $\mathrm{W}<\mathrm{M}$, zal de werkgever niet het initiatief nemen om de arbeidsrelatie te beëindigen.

De wetgever kan wel formele eisen stellen aan de wijze waarop de opzegging naar de werknemer toe wordt gecommuniceerd, bijv. door middel van een aangetekende brief. De kosten van de formele vereisten staan tegenover de toegenomen zekerheid omtrent de juridische positie. De kosten verbonden aan de formele vereisten verlagen de kosten om de juridische positie te bewijzen.

De werkgever kan ook de kantonrechter verzoeken om de arbeidsrelatie te ontbinden. Art. 7:685 BW bepaalt dat de kantonrechter de arbeidsovereenkomst wegens een gewichtige reden kan ontbinden. Als gewichtige reden wordt onder meer beschouwd, veranderingen in de omstandigheden welke van dien aard zijn dat de arbeidsovereenkomst billijkheidshalve dadelijk of na korte tijd behoort te eindigen. Beëindiging om redenen die met het gedrag van de werknemer te maken hebben kan efficiënt zijn als manier om principaal-agent problemen te verminderen. Iedere overeenkomst komt tot een einde als de contractpartijen in kwestie daarmee akkoord gaan. Deze regel is eveneens van toepassing op de arbeidsovereenkomst. De ontslagbepalingen zijn in dat geval niet van toepassing. In de beëindigingsovereenkomst 'koopt' de werkgever als het ware het recht van de werknemer om de nietigheid van de opzegging te vorderen wegens gebrek aan een ontslagvergunning.

17 Sinds 1 oktober 2006 hoeven werknemers niet meer te protesteren tegen hun ontslag om voor een ww-uitkering in aanmerking te komen. Wel kan een uitkering geweigerd worden bij dringende reden, bijv. diefstal en de werknemer mag ook niet zomaar zelf het initiatief nemen om zijn baan op te zeggen. Wanneer de partijen een beëindigingsovereenkomst sluiten, dan is het voor het veiligstellen van de werkloosheidsuitkering van belang dat op papier wordt gezet dat het initiatief uitgaat van de werkgever. De regel houdt ook in dat de werkgever de arbeidsrelatie met een niet goed functionerende werknemer zal moeten voortzetten wanneer de cwi de kwaliteit van de prestaties niet goed kan verifiëren.

Ook hier geldt weer dat de de facto baanzekerheid van oudere werknemers minder groot kan zijn. Voor een aantal werknemers neemt het vermogen om nieuwe kennis en vaardigheden aan te leren af met de leeftijd alsook de periode waarover de investeringen kunnen worden terugverdiend. Het gevolg is dat de herinvesteringen in menselijk kapitaal afnemen met de leeftijd.

20 Promoties en de daarbij behorende loonsverhoging kunnen ook gebruikt worden als instrument om de werknemer te prikkelen om nieuwe vaardigheden aan te leren. 
Ontslagvergoedingen worden besproken in paragraaf 5.4 .

Op 1 maart 1943 werd een verordening van de rijkscommissaris van kracht waarbij het ontslagverbod tweezijdig werd gemaakt. De tweezijdigheid van het ontslagverbod ging over in het BBA dat op 5 oktober 1945 tot stand kwam. De vrees was dat de werknemers de ingevoerde loonstop zouden kunnen frustreren door van baan te veranderen. Het vertrekverbod voor werknemers is ondertussen opgeheven.

23 Open normen staan tegenover specifieke regels. Het recht kan bijvoorbeeld bepalen dat er een snelheidsbeperking van $120 \mathrm{~km}$ per u geldt (specifieke regel) of dat automobilisten hun snelheid in redelijkheid moeten aanpassen (open norm). Een norm heeft als voordeel dat rekening kan worden gehouden met specifieke omstandigheden van het geval, maar heeft als nadeel dat er bij de partijen meer onzekerheid bestaat over wat zij geacht worden te doen.

24 Posner (1992: 335-336) schrijft in dit verband: "A series of incremental steps each of which makes economic sense in the light of the previous steps may, looked as a whole, make no economic sense at all."

25 Een minder ruime verzekering dan baanbehoud is ook in het belang van de werknemer wanneer de werknemer voor de baanzekerheid een verzekeringspremie in de vorm van een lager loon moet betalen. Wanneer de te betalen verzekeringspremie hoger is dan het voordeel van baanzekerheid voor de werknemer, dan is baanzekerheid als verzekeringsarrangement niet welvaartsverhogend.

Art. 7: 681 BW bepaalt dat indien een van de partijen de arbeidsovereenkomst kennelijk onredelijk opzegt de rechter een schadevergoeding kan toekennen aan de wederpartij.

7 Een slechte reputatie brengt kosten met zich mee. Goede werknemers verlaten het bedrijf met een slechte reputatie en een bedrijf met een slechte reputatie zal hogere lonen moeten betalen om nieuwe werknemers aan te trekken.

8 Dat betekent niet dat rationele arbeidspartijen geen enkele vorm van verzekeringsarrangement zouden afspreken. Ze kunnen bijvoorbeeld afspreken dat de werkgever de werknemer verzekert voor de duur die hij gemiddeld nodig heeft om een gelijkwaardige functie te vinden (i.e. de opzegtermijn) of voor een bedrag ter compensatie van de specifieke verliezen bij ontslag (i.e. de ontslagvergoeding).

In dit onderzoek wordt enkel gekeken naar de materiële schade bij ontslag. De werknemer kan door het verlies van zijn baan echter ook immateriële of emotionele schade lijden. Wanneer de werkgever deze schade moet vergoeden, dan zal hij daarvoor een premie vragen in de vorm van een loonsverlaging tijdens tewerkstelling. De wenselijkheid van een verplichting voor de werkgever om immateriële schade te vergoeden hangt dus af van de vraag of de werknemers bereid zijn om te betalen om verzekerd te zijn tegen emotionele schade bij ontslag. Individuen kopen gewoonlijk geen verzekering tegen emotionele verliezen.

30 De werkgever draagt de kosten niet noodzakelijk in de vorm van de uitbetaling van een ontslagvergoeding, maar kan deze kosten ook dragen in de vorm van de uitbetaling van hogere lonen tijdens tewerkstelling. Werkloosheid kan bijvoorbeeld het gevolg zijn van te lage bestedingen (conjuncturele werkloosheid). 
Dit doen werknemers nu bijvoorbeeld al naar aanleiding van de wettelijke verplichting om het loon van een zieke werknemer gedurende twee jaren door te betalen.

Private verzekeraars verzekeren geen interdependente risico's, risico's die ze niet goed kunnen inschatten of risico's waar het averechtse selectie en moreel risico probleem te groot zijn. In Denemarken komt gedeeltelijke private verzekering van het werkloosheidsrisico wel voor.

34 Een dergelijk systeem komt bijvoorbeeld voor in Peru.

35 Evenwel zijn de administratieve kosten die gepaard gaan met de werkloosheidsverzekering relatief hoog in vergelijking met de uitgekeerde bedragen, maar reorganisaties van de uitkeringsinstanties (UWV) zouden moeten leiden tot lagere administratieve kosten.

36 Daar staat wel tegenover dat investeringen in ondernemingsspecifieke kennis de kans dat de werknemer wordt ontslagen verlagen. Immers, werkgevers investeren mee in deze kennis en vaardigheden en lijden evenzeer verlies door het vertrek van deze werknemers. Ondernemingsspecifieke investeringen bieden op die manier meer baanzekerheid.

37 De Wet betreffende het fonds voor pensioenen en beëindigingsvergoedingen voor werknemers (Mitarbeitersvorsorgegesetz, MVG, 2002) verplicht werkgevers om bij te dragen aan het MVK-fonds (Mitarbeitervorsorgekasse) voor alle arbeidsovereenkomsten die na 1 januari 2003 werden afgesloten. Voor 2002 moest de werkgever een beëindigingsvergoeding betalen aan werknemers die ten minste drie jaar bij de werkgever hadden gewerkt. Werknemers met drie jaar senioriteit kregen 1 maandloon; de vergoeding steeg naar rato van de anciënniteit tot een maximum van 1 jaarloon na 25 jaar. Beëindigingsvergoedingen dienden in de boekhouding te worden opgenomen als een reguliere loonsverhoging. De werkgevers moeten een voorziening maken in hun boekhouding voor ten minste de helft van de waarde van de beëindigingsvergoedingen die mogelijk betaald dienden te worden. Onder de nieuwe regeling dient de werkgever een bedrag gelijk aan 1.5377 procent van het brutoloon af te dragen aan het fonds vanaf de eerste dag dat de werknemer in dienst is. Wanneer de werknemer wordt ontslagen heeft hij de keuze tussen ofwel onmiddellijke uitbetaling van de vergoeding (belast tegen 6 procent) ofwel uitbetaling ervan gelijktijdig met het pensioen (uitkering wordt niet belast). Werknemers die ontslagen worden minder dan drie jaar na de indiensttreding en werknemers die zelf ontslag nemen of die om dringende redenen worden ontslagen, hebben niet de mogelijkheid tot onmiddellijke uitbetaling. $\mathrm{Zij}$ behouden evenwel het recht tot uitbetaling gelijktijdig met de pensioenuitkering. De regeling beoogt een rechtvaardiger verdeling van het recht op een beëindigingsvergoeding, doordat ook werknemers met een dienstverband dat korter is dan drie jaar het recht toe te kennen. Ook beoogt de regeling de mobiliteit van werknemers te verhogen mede ook door het behoud van rechten wanneer de werknemer zelf vertrekt. De regeling komt erop neer dat werknemers met een dienstverband van 37 jaar een uitkering krijgen gelijk aan 1 jaarloon. Hierbij gaat men ervan uit dat de fondsen een rendement van 6 procent genereren op het belegde kapitaal (40 procent van het kapitaal mag belegd worden in aandelen). 
$38 \quad$ Het systeem van ontslagvergoedingen werd in 1990 in Columbia gewijzigd. Voor alle nieuwe arbeidsovereenkomsten getekend vanaf 1 januari 1991 geldt een spaarregeling, een systeem genoemd 'severance payments savings accounts'. Elke maand moeten werkgevers 8,3 procent van het salaris storten op een individuele spaarrekening van de werknemer. Het systeem wordt gecontroleerd door een administratieve overheid. Werknemers kunnen het spaarbedrag opnemen voor investeringen in huisvesting, scholing, bij werkloosheid en bij pensioen.

39 De normatieve aanbevelingen om de regels aan te passen aan hetgeen economisch optimaal is gelden alleen voor zover dat economische efficiëntie als doelstelling van het ontslagbeleid wordt aanvaard.

$40 \quad$ Een preciezere meting van de werkelijke verliezen is enkel wenselijk voor zover de voordelen van een preciezere berekening opwegen tegen de kosten ervan.

41 In praktijk wordt nu niet vaak beroep gedaan op deze exceptie.

42 In Groot-Brittannië hebben boventallig geworden werknemers op grond van section 162 van de Employment Rights Act (1996) recht op een ontslagvergoeding verschuldigd door de werkgever, of, wanneer die insolvent is, door het National Insurance Fund.

43 Op grond van de Wet 28 juni 1966 betreffende de schadeloosstelling van de werknemers die ontslagen worden bij sluiting van ondernemingen, is een sluitingsvergoeding verschuldigd door de werkgever of, bij gebrek aan betaling door deze laatste binnen de gestelde termijnen, door het Sluitingsfonds.

44 Eventueel kan de werknemer werkloos worden, maar de inkomensverliezen ten gevolge van de werkloosheid worden door de collectieve werkloosheidverzekering vergoed.

45 Deze aanbevelingen gelden enkel voor zover efficiëntie als doelstelling van het ontslagrecht wordt aanvaard. 


\section{LITERATUUR}

Bakels, H.L. (1997) Schets van het Nederlands arbeidsrecht, Deventer: Kluwer.

Buechtemann, Chr. F. (1993) 'Introduction: Employment Security and Labor Markets', 3-66 in Chr. F. Buechtemann (ed.) Employment Security and Labor Market Behavior, Ithaca: ILR Press.

Buijs, D.J. (2004) 'Beëindingsvergoedingen in het kader van de arbeidsovereenkomst', 27-46 in F.B.J. Grapperhaus et al. (red.) Afuloeiingsregelingen: Arbeidsrecht, sociale verzekering en belasting, Deventer: Kluwer.

Coase, R.H. (1960) 'The Problem of Social Cost', 3 Journal of Law and Economics 1, 44.

Geest, G. de (1994) Economische analyse van het contracten- en quasi-contractenrecht, Antwerpen: Maklu.

Grapperhaus, F.B.J (2004) 'Individuele beëindigingsovereenkomst en afvloeiingsregeling', 217-286 in F.B.J. Grapperhaus et al. (red.) Afuloeiingsregelingen: Arbeidsrecht, sociale verzekering en belasting, Deventer: Kluwer.

Hall R. en E. Lazear (1984) 'The Excess Sensitivity of Layoffs and Quits to Demand', Journal of Labour Economics vol. 2, 239.

Jacobs, A.T.M. en W. Plesen (1992) 'Deregulering van het arbeidsrecht', SEW 2: p. 83.

Naber, H. (1983) Ontslagrecht in Nederland, Deventer: Kluwer.

Lazear, E. (1979) 'Why is there Mandatory Retirement?', Journal of Political Economy 87: 1261-1284.

Loonstra, C.J. (2006) Hoofdstukken sociaal recht, Groningen: Wolters-Noordhoff.

Posner, R.A. (1992) Economic Analysis of Law, Boston: Little, Brown.

Scholtens, C.G. (2004) 'Formules en Statistieken', 47-215 in F.B.J. Grapperhaus et al. (red.) Afuloeiingsregelingen: Arbeidsrecht, sociale verzekering en belasting, Deventer: Kluwer.

Shavell, St. (1984) 'Liability for Harm Versus Regulation of Safety', legal Studies 13: 357374 . 


\title{
6 ARBEIDSMARKTINSTITUTIES EN ARBEIDSMARKT- DYNAMIEK
}

\author{
Michèle Belot en Jan van Ours
}

\subsection{INLEIDING}

Arbeidsmarkten zijn voortdurend in beweging. Mensen verliezen hun baan en worden werkloos, werklozen vinden een baan, mensen treden tot de arbeidsmarkt toe, werkgevers gaan failliet waardoor arbeidsplaatsen verdwijnen, bedrijven expanderen en creëren nieuwe banen, enzovoorts. De dynamiek van de arbeidsmarkt is belangrijk, omdat economische veranderingsprocessen gebaat zijn bij flexibiliteit van personen en arbeidsplaatsen.

De dynamiek in de Nederlandse arbeidsmarkt speelt een belangrijke rol in het WRR-project Arbeidsmarktdynamiek, flexibiliteit en zekerheid. De centrale probleemstelling van het project is als volgt geformuleerd: "Hoe zijn de institutionele condities te creëren om, gegeven de veranderende omgeving nu en in de toekomst, voor verschillende groepen op de arbeidsmarkt werkzekerheid te scheppen en tegelijkertijd tegemoet te komen aan de behoefte aan flexibilisering met het oog op een zo groot mogelijke arbeidsparticipatie en een voortgaande groei van de arbeidsproductiviteit?” Volgens de WRR zijn de relevante instituties in dit verband het stelsel van werkloosheidsuitkeringen, de ontslagbescherming, het minimumloon en het actieve arbeidsmarktbeleid. Wat de WRR in het bijzonder interesseert, is de bijdrage die deze arbeidsmarktinstituties leveren aan het omgaan met creatieve destructie op de arbeidsmarkt. Met andere woorden: het gaat om de vraag of deze regels helpen met het wegstrijken van de scherpe kanten van creatie en destructie en het daarmee vergroten van de acceptatie van de veranderingsprocessen, of dat ze een soepele verwerking van de veranderingsprocessen in de weg staan. Daarnaast is het volgens de WRR de vraag of de vergrijzing van de beroepsbevolking (d.w.z. de aanwezigheid van een groot percentage oudere werknemers van wie bekend is dat ze minder mobiel zijn en langere werkloosheidsduren kennen dan jongere werknemers) nog tot bijzondere afwegingen leidt in de analyse van de effecten van de arbeidsreguleringen.

De rol van arbeidsmarktinstituties is complex. Zo is het voor een goede inschatting van de relaties tussen instituties en dynamiek nodig niet alleen naar de mogelijke invloed van afzonderlijke instituties te kijken, maar ook naar de invloed van verschillende combinaties van instituties (zie hierover ook Belot en Van Ours 2001 en 2004). Een combinatie van veel ontslagbescherming en lage werkloosheidsuitkeringen is bijvoorbeeld vanuit het gezichtspunt van inkomensbescherming vergelijkbaar met een combinatie van weinig ontslagbescherming en hoge werkloosheidsuitkeringen. In het eerste geval is er sprake van inkomensbescherming doordat een werknemer niet zo snel ontslagen zal worden. In het tweede geval doordat de inkomensconsequenties van ontslag niet zo groot zijn. 
Ten aanzien van de dynamiek op de arbeidsmarkt hebben de twee combinaties van instituties een heel verschillende uitwerking. Terwijl de eerste combinatie met veel ontslagbescherming leidt tot weinig doorstroming op de arbeidsmarkt, leidt de tweede combinatie juist tot veel doorstroming.

In dit preadvies worden de relaties tussen arbeidsmarktinstituties en arbeidsmarktdynamiek tegen het licht gehouden. Eerst wordt Nederland op een kwantitatieve manier in internationaal perspectief geplaatst door een vergelijking van arbeidsmarktinstituties en arbeidsmarktprestaties. Daarna worden inzichten vanuit de arbeidseconomische literatuur besproken. Ten slotte wordt op basis hiervan een perspectief gegeven op de relatie tussen arbeidsmarktinstituties en arbeidsmarktdynamiek.

\subsection{GLOBALE EMPIRIE}

Om de betekenis van de Nederlandse arbeidsmarktinstituties in internationaal perspectief te plaatsen worden allereerst de vier arbeidsmarktinstituties die in dit preadvies centraal staan - werkloosheidsuitkeringen, ontslagbescherming, minimumloon, en actief arbeidsmarktbeleid - vergeleken met die in België, Denemarken, Duitsland, Ierland, het Verenigd Koninkrijk, de Verenigde Staten en Zweden. Vervolgens worden de arbeidsmarktprestaties in deze landen vergeleken met die van Nederland. Ten slotte wordt de empirische samenhang tussen instituties onderling en tussen instituties en arbeidsmarktprestaties bediscussieerd.

\subsubsection{ARBEIDSMARKTINSTITUTIES}

\section{Werkloosheidsuitkeringen}

Ten aanzien van de invloed van werkloosheidsuitkeringen op het functioneren van de arbeidsmarkt gaat het vooral om de hoogte en de duur. Het is wat dit betreft geen eenvoudige zaak landen met elkaar te vergelijken, ook al omdat binnen een land nogal wat verschillen kunnen bestaan. Vaak hangen hoogte en duur van de uitkering af van het arbeidsverleden en soms ook van de gezinssituatie. Dus kunnen er binnen landen behoorlijke verschillen bestaan tussen categorieën werklozen. Tabel 6.1 geeft een overzicht van hoe de uitkeringshoogte verloopt over de duur van de werkloosheid voor verschillende categorieën werklozen. Denemarken is het enige land waarin de uitkeringshoogte onafhankelijk is van werkloosheidsduur en gezinssituatie. In Zweden wordt geen onderscheid gemaakt naar gezinssituatie maar wel naar uitkeringsduur.

In het eerste jaar van de werkloosheid zijn er al vrij grote verschillen tussen landen. Nederland behoort met Denemarken en Zweden tot de landen waar de (bruto-)uitkering het hoogst is, $65-75$ procent van het (bruto) laatstverdiende loon. In het Verenigd Koninkrijk, de Verenigde Staten en Ierland is de uitkering het laagst in het eerste jaar. In vrijwel alle landen daalt de uitkeringshoogte met de uitkeringsduur. Het sterkst is deze daling in Zweden. In het eerste jaar bedraagt de uitkering nog 74 procent van het laatstverdiende loon, in het tweede 
en derde jaar is dat nog slechts 3 procent. De daling in Nederland, die wordt veroorzaakt doordat voor sommige categorieën werklozen de uitkeringsduur beperkt is, is ook redelijk groot voor alleenstaanden en tweeverdieners, maar niet voor een eenverdiener.

Tabel 6.1 Uitkeringshoogte in relatie tot duur werkloosheid en gezinssituatie ${ }^{\text {a) }}$

\begin{tabular}{|c|c|c|c|c|c|c|c|c|c|c|}
\hline \multirow[b]{2}{*}{ Categorie } & \multicolumn{3}{|c|}{ Eerste jaar } & \multicolumn{3}{|c|}{ Tweede en derde jaar } & \multicolumn{4}{|c|}{ Vierde en vijfde jaar } \\
\hline & $\mathbf{I}$ & II & III & I & II & III & I & II & III & Totaal \\
\hline België & 47 & 47 & 43 & 33 & 47 & 28 & 33 & 47 & 28 & 39 \\
\hline Denemarken & 66 & 66 & 66 & 66 & 66 & 66 & 66 & 66 & 66 & 66 \\
\hline Duitsland & 37 & 37 & 37 & 33 & 33 & 17 & 33 & 33 & 17 & 30 \\
\hline lerland & 29 & 47 & 29 & 30 & 47 & 4 & 30 & 47 & 0 & 29 \\
\hline Nederland & 70 & 71 & 70 & 56 & 65 & 56 & 21 & 30 & 21 & 51 \\
\hline Verenigd Koninkrijk & 19 & 24 & 9 & 19 & 30 & 0 & 19 & 30 & 0 & 17 \\
\hline Verenigde Staten & 29 & 33 & 25 & 7 & 12 & 0 & 7 & 12 & 0 & 14 \\
\hline Zweden & 74 & 74 & 74 & 3 & 3 & 3 & 0 & 0 & 0 & 26 \\
\hline
\end{tabular}

a) Bruto uitkering als percentage van het laatstverdiende brutoloon (gemiddelde van $2 / 3$ en $100 \%$ van loon van een volwassen voltijdwerknemer in de industrie); situatie in 1999

Categorieën: I. Alleenstaande

II. Eenverdieners huishouden

III. Tweeverdieners huishouden

Bron: OECD (2002)

Door de OECD is een poging ondernomen om landen vergelijkbaar te maken door een aantal standaarduitkeringssituaties te combineren en te integreren tot een indicator voor de hoogte van de werkloosheidsuitkering. Deze staat weergegeven in de laatste kolom van tabel 6.1. Tabel 6.2 geeft voor de onderscheiden landen een overzicht van de ontwikkelingen in deze indicator over de periode 1990-1999.

Uit deze tabel komt naar voren dat er in de meeste landen in de jaren negentig niet veel verandering is geweest in de hoogte van de werkloosheidsuitkering. Een uitzondering is Denemarken waar de gemiddelde uitkering fors is toegenomen van ongeveer 50 procent naar 65 procent van het laatstverdiende loon. Ten opzichte van de andere landen is de brutowerkloosheidsuitkering in Nederland - wederom met uitzondering van Denemarken - met ongeveer 50 procent van het laatstverdiende brutoloon relatief hoog. De gemiddelde uitkeringshoogte in het Verenigd Koninkrijk over de eerste vijf jaar van de werkloosheid bedraagt slechts 17 procent van het laatstverdiende loon, terwijl dat in Duitsland, Zweden en Ierland 25-30 procent is, en in België 4o procent. Tabel 6.2 laat ook zien dat de verhouding netto-uitkering - nettoloon veel groter is. ${ }^{1}$

De invloed van werkloosheidsuitkeringen op het functioneren van de arbeidsmarkt hangt niet alleen af van de hoogte maar ook van de duur. Met betrekking 


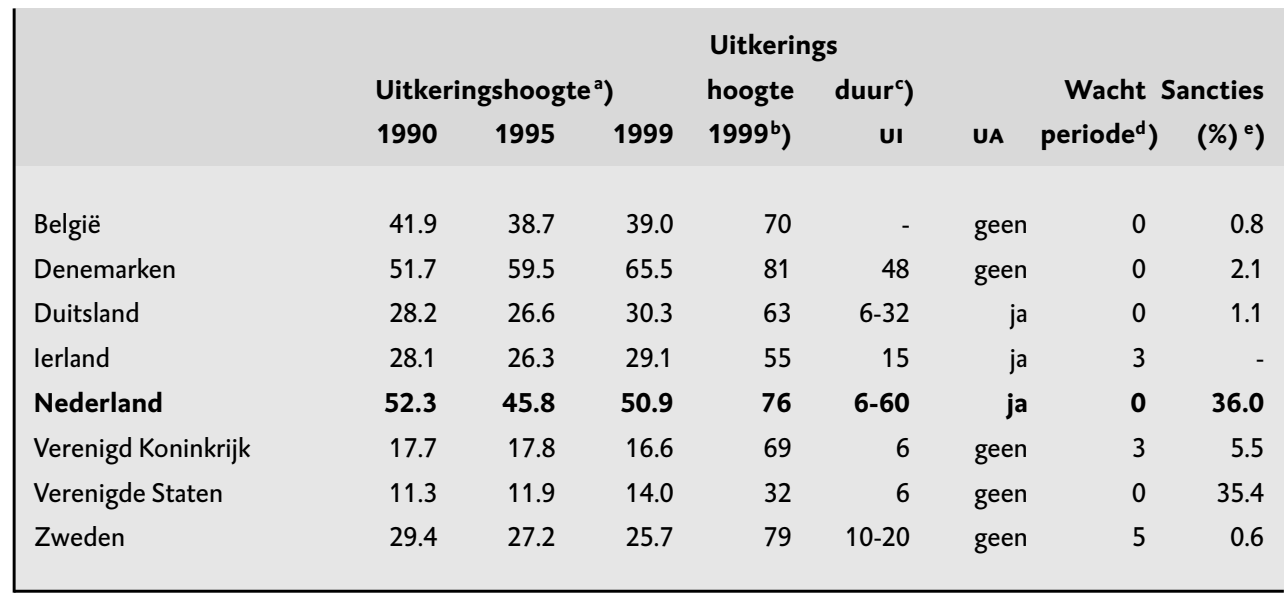

a) Verhouding tussen bruto uitkering en bruto laatstverdiende loon; samenvattende maatstaf

b) Verhouding tussen netto uitkering en netto laatstverdiende loon; samenvattende maatstaf

c) Uitkeringsduur in maanden; $\mathrm{UI}=$ werkloosheidsverzekering, $\mathrm{UA}=$ bijstandsuitkering

d) Wachtperiode in dagen

e) Gedragsgerelateerde sancties gedurende de uitkeringsperiode als percentage van het aantal uitkeringsontvangers; 1997-98

Bron: OECD, EU Commissie, DGo5, Grubb (2000), Boone en Van Ours (2000)

tot de uitkeringsduur bestaan er grote verschillen tussen landen. In België is de uitkering in principe van onbeperkte duur, terwijl deze in het Verenigd Koninkrijk slechts een half jaar bedraagt. In Nederland - evenals in Duitsland, zij het dat het daar iets minder sterk is - is er nogal wat variatie in de uitkeringsduur. Voor sommige categorieën werklozen is de uitkeringsduur internationaal gezien vrij lang. Nederland kent in tegenstelling tot Ierland, het Verenigd Koninkrijk en Zweden geen wachtperiode ten aanzien van de werkloosheidsuitkeringen. Tabel 6.2 geeft ook nog een overzicht van het gebruik van sancties in de werkloosheidsuitkeringen. Indien werklozen zich niet gedragen volgens de regels waaronder de uitkering wordt verstrekt kan de uitkering worden gekort. Zoals weergegeven zijn in Nederland en de Verenigde Staten veel meer sancties toegekend dan in andere landen. Tabel 6.3 geeft tot slot nog een aantal specifieke kenmerken van de werkloosheidsuitkeringen in de verschillende landen weer. Er is nogal wat variatie in de referte-eisen, maar Nederland wijkt niet sterk af van de andere landen. De weergegeven hoogte van de uitkering heeft betrekking op de uitkeringsregels. In Ierland en het Verenigd Koninkrijk bestaat de uitkering uit een vast bedrag, in de andere landen is de hoogte van de uitkering gerelateerd aan het laatstverdiende loon. De relatie tussen uitkeringsduur en leeftijd verschilt nogal. In België duurt de uitkering in principe tot iemand 65 jaar wordt, terwijl in het Verenigd Koninkrijk, de Verenigde Staten en Zweden de uitkeringsduur onafhankelijk is van de leeftijd. In Nederland is er in tegenstelling tot de andere landen - met uitzondering van België - een sterke afhankelijkheid tussen leeftijd en uitkeringsduur. 


\begin{tabular}{|c|c|c|c|c|c|}
\hline & \multirow[b]{2}{*}{ Referte eisen } & \multirow{2}{*}{$\begin{array}{l}\text { Hoogte } \\
\text { uitkering }(\%)^{\text {a) }}\end{array}$} & \multicolumn{3}{|c|}{$\begin{array}{l}\text { Max.uitkeringsduur (mnd) } \\
\text { naar leeftijd }\end{array}$} \\
\hline & & & $25 \mathrm{jr}$ & $50 \mathrm{jr}$ & $60 \mathrm{jr}$ \\
\hline België & 312 dagen in 18 maanden & 60 & 480 & 180 & 60 \\
\hline Denemarken & 52 weken in 3 jaar & 90 & 48 & 48 & 60 \\
\hline Duitsland & 12 maanden in 3 jaar & 60 & 12 & 22 & $\left.32^{b}\right)$ \\
\hline lerland & 39 weken in 1 jaar & vast bedrag & - & - & - \\
\hline Nederland & 26 weken in 39 weken & 70 & 9 & 36 & 60 \\
\hline Verenigd Koninkrijk & minimum premie-eis ${ }^{c}$ ) & vast bedrag & 6 & 6 & 6 \\
\hline Verenigde Staten & 6 maanden & 50 & 6 & 6 & 6 \\
\hline Zweden & 6 maanden in 1 jaar & 80 & 14 & 14 & 14 \\
\hline
\end{tabular}

a) Het gaat hier in tegenstelling tot tabel 1 en 2 om een formeel percentage (of bedrag) zonder rekening te houden met variatie tussen huishoudtypes, sociaal minimum of maximum (dag)lonen.

b) Vanaf 2006 bedraagt de maximale uitkeringsduur voor iedereen 12 maanden.

c) Over een periode van 2 jaar.

Bron: OECD, Ministerie van Sociale Zaken en Werkgelegenheid (2004)

\section{Ontslagbescherming}

Om de mate van ontslagbescherming te meten zijn door de OECD indices ontwikkeld (zie bijlage 1 voor details). De meest recente index bestaat uit drie componenten: bescherming van reguliere werknemers tegen (individueel) ontslag, specifieke regels ten aanzien van collectief ontslag en regulering van tijdelijke vormen van werkgelegenheid. Ten aanzien van de bescherming van reguliere werknemers tegen individueel ontslag gaat het om drie onderdelen. Ten eerste de moeilijkheid van ontslag, dat wil zeggen wettelijke voorwaarden die aangeven wanneer een ontslag 'gerechtvaardigd' is of 'redelijk', ten tweede om procedurele ongemakken waarmee de werkgever wordt geconfronteerd bij het begin van een ontslagprocedure en ten derde ontslagvergoedingen. Met betrekking tot collectief ontslag gaat het om sociale kosten die in vrijwel alle OECD-landen hebben geleid tot aanvullende voorzieningen. De indicator heeft betrekking op extra vertragingen en procedures boven op die van individuele ontslaggevallen. De derde component van de ontslagbeschermingindex is bedoeld om de restricties op het gebruik van tijdelijke werkgelegenheid door bedrijven te meten (type werkzaamheden waarvoor deze contracten zijn toegestaan en hun duur). In de index die door de OECD in de jaren negentig is ontwikkeld zijn regelingen met betrekking tot collectief ontslag niet verdisconteerd, in de meest recent index wel (OECD, 2004).

Analyses van de effecten van ontslagbescherming zijn vaak verricht vanuit het perspectief van de eraan verbonden additionele bedrijfskosten voor bedrijven. Naar de motivatie voor het bestaan van ontslagbescherming en naar welvaartsas- 
pecten is veel minder onderzoek verricht. Op basis van een internationaal vergelijkende studie worden in de OECD Employment Outlook van 2004 de volgende conclusies getrokken. In de eerste plaats wordt geconstateerd dat gedurende de afgelopen 15 jaar een convergentie heeft plaatsgevonden in ontslagbescherming. De convergentie is vooral toe te schrijven aan landen die hun strenge ontslagwetgeving hebben versoepeld. Desalniettemin is er nogal wat variatie tussen landen die vooral is toe te schrijven aan verschillen in wet- en regelgeving ten aanzien van tijdelijke werkgelegenheid. Voorts wordt gesteld dat ontslagbescherming aan haar doel van het beschermen van bestaande banen voldoet: de mogelijkheden van bedrijven om werknemers te ontslaan worden beperkt. Tegelijkertijd wordt geconstateerd dat ontslagbescherming het in dienst nemen van werklozen kan verminderen, omdat de kosten van een eventueel toekomstig ontslag worden verdisconteerd. Het netto-effect van ontslagbescherming op de totale werkloosheid is daarom ambigue en kan alleen via empirisch onderzoek worden bepaald. Verschillen in de mate van ontslagbescherming kunnen in belangrijke mate verklaren waarom het voorkomen van tijdelijk werk onder jongeren en laagopgeleiden in sommige landen zo is toegenomen. Voor het beoordelen van ontslagbescherming moeten kosten en baten tegen elkaar worden afgewogen. Door ontslagbescherming kan de bereidheid van werknemers om inspanning te leveren, samen te werken en opgeleid te worden toenemen. Dit kan gunstig zijn voor werkgelegenheid en economische efficiency. Een zekere mate van ontslagbescherming kan bovendien welvaartsverhogend werken, indien er een betere balans is tussen de zorgen van werknemers over hun baanzekerheid en de noodzaak van aanpassing en dynamiek. Actief arbeidsmarktbeleid kan hierbij ook een rol spelen. De precieze balans tussen ontslagbescherming, werkloosheidsuitkeringen en actief arbeidsmarktbeleid hangt af van de specifieke omstandigheden en instituties van een land. Denemarken wordt genoemd als land waarin die balans dicht bij het optimum zit (de 'gouden driehoek').

Het bovenste deel van tabel 6.4 geeft een overzicht van de ontwikkelingen in de ontslagbescherming voor de onderscheiden landen. Een hoog getal geeft een grote mate van ontslagbescherming weer. Uit de tabel blijkt dat in vrijwel alle landen de ontslagbescherming is verminderd. De uitzonderingen zijn Ierland, het Verenigd Koninkrijk en de Verenigde Staten, waar de ontslagbescherming laag is en laag is gebleven. In Denemarken is de ontslagbescherming aanzienlijk verminderd. Tussen België, Duitsland, Nederland en Zweden doen zich momenteel geen grote verschillen in ontslagbescherming voor.

Het onderste deel van tabel 6.4 geeft voor het jaar 2003 een detaillering van de ontslagbeschermingindex in de drie componenten 'regulier werk', 'tijdelijk werk' en 'collectief ontslag' weer. Het blijkt dat in Nederland in vergelijking met de andere landen de bescherming bij ontslag van werknemers met een regulier contract vrij groot is. De (aanvullende) bescherming bij collectief ontslag is daarentegen relatief laag. Alleen Ierland en het Verenigd Koninkrijk hebben een lagere aanvullende bescherming bij collectief ontslag. 
a. Ontwikkelingen eind jaren $80-2003$

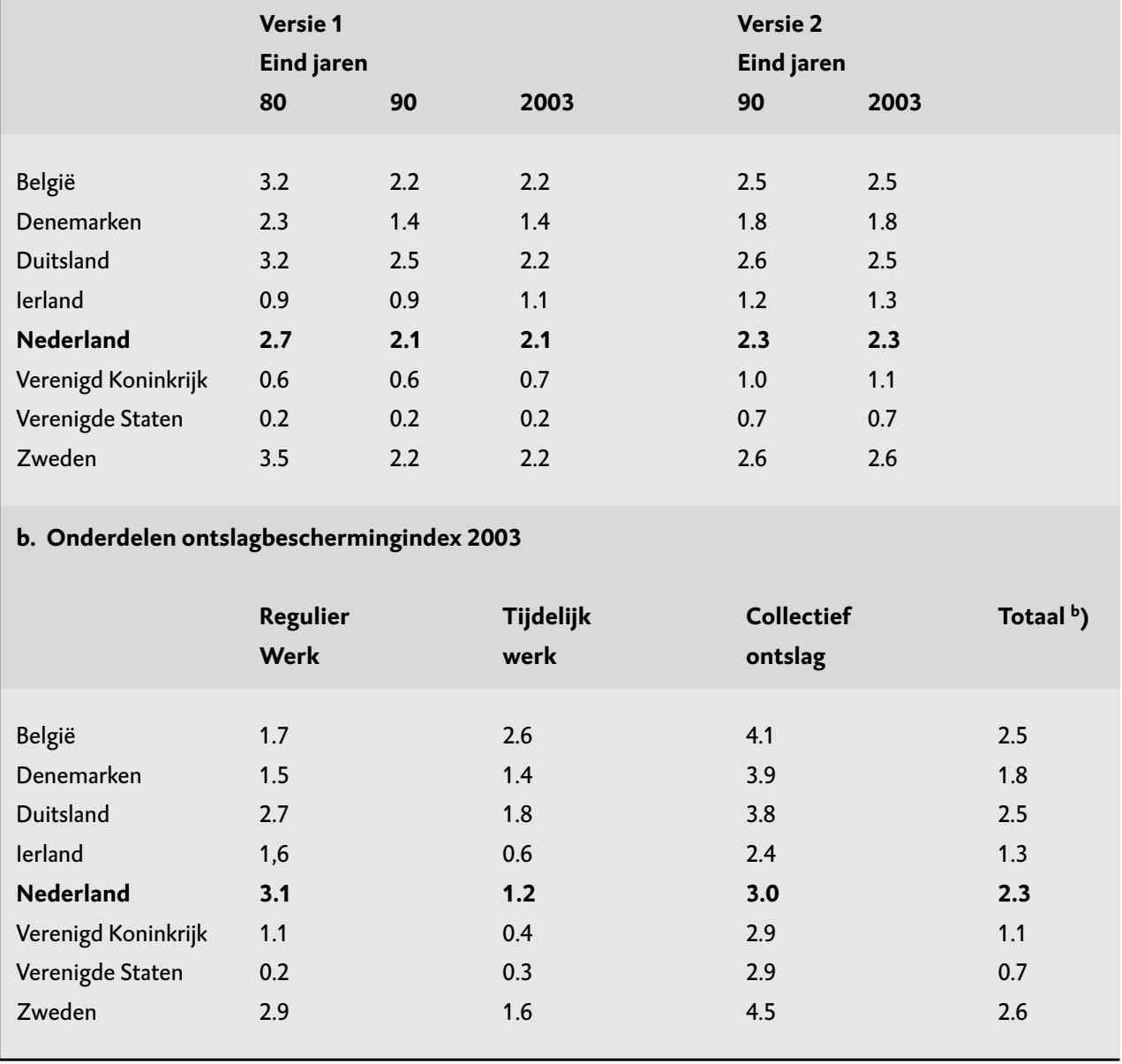

a) Versie 1: reguliere werkgelegenheid en tijdelijke werkgelegenheid; versie 2: versie 1 + collectief ontslag; voor versie 2 zijn geen gegevens beschikbaar voor eind jaren 80 .

a) $\mathrm{Bij}$ het bepalen van de totale index telt de indicator voor collectief ontslag voor 40 procent mee.

Bron: OECD Employment Outlook 2004

\section{Minimumloon}

In tabel 6.5 wordt een overzicht gegeven van informatie met betrekking tot het minimumloon in de onderscheiden landen. Nederland heeft met België, het Verenigd Koninkrijk en de Verenigde Staten gemeen dat er een wettelijk minimumloon is, terwijl in de overige landen het minimumloon tot stand komt in collectieve arbeidsovereenkomsten. De beschikbare informatie is wat verbrokkeld, maar toch kan een redelijk beeld worden verkregen van de verschillen tussen landen. Uit de tabel komt naar voren dat de verschillen in de hoogte van het minimumloon (als percentage van het gemiddelde loon) niet zo groot zijn. Uitzonderingen 
zijn hier het Verenigd Koninkrijk en de Verenigde Staten waar het minimumloon 40 procent van het gemiddelde loon bedraagt, terwijl dat in de andere landen $55-60$ procent is. Over ontwikkelingen in de tijd is niet veel informatie beschikbaar. In Nederland en België is het minimumloon gedaald, in de Verenigde Staten is het gelijk gebleven. Ten aanzien van het aantal werknemers dat werkt tegen het minimumloon is evenmin veel informatie beschikbaar. Het aandeel van de werknemers dat voor een minimumloon werkt is beperkt tot enkele procenten.

Tabel 6.5 Minimumloon

\begin{tabular}{|c|c|c|c|c|c|c|}
\hline & \multicolumn{3}{|c|}{ Hoogte minimumloon ${ }^{b}$ ) } & \multicolumn{2}{|c|}{ Situatie 1991-1994 } & \multirow[b]{2}{*}{ Werk $^{c}$ ) } \\
\hline & Type a) & 1990 & 1995 & 2000 & Hoogte ${ }^{b}$ ) & \\
\hline België & 1 & 54 & 51 & 49 & $60(1993)$ & 4.0 \\
\hline Denemarken & 2 & - & - & - & $54(1994)$ & 6.0 \\
\hline Duitsland & 2 & - & - & - & $55(1991)$ & - \\
\hline lerland & 2 & - & - & 56 & $55(1993)$ & - \\
\hline Nederland & 1 & 52 & 49 & 47 & $55(1993)$ & 3.2 \\
\hline Verenigd Koninkrijk & $\left.1^{d}\right)$ & - & - & 42 & $40(1993)$ & - \\
\hline Verenigde Staten & $\left.1^{\mathrm{e}}\right)$ & 36 & 36 & 36 & 39 (1993) & 4.0 \\
\hline Zweden & 2 & - & - & - & $52(1992)$ & 0 \\
\hline
\end{tabular}

a) Type minimumloon; 1 = wettelijk minimumloon, 2 = collectieve overeenkomst (industrie)

b) Kaitz index = minimumloon als percentage van het gemiddelde loon (jaar)

c) Percentage werknemers werkzaam tegen het minimumloon

d) Sinds 1999

e) Staatspecifiek

Bron: Hoogte minimumloon 1990-2000: OECD; Situatie 1991-94: Dolado et al. (1996)

Werkgelegenheid op het minimumniveau is niet naar rato verdeeld over sectoren. In Nederland hebben vooral de horeca en detailhandel relatief veel minimumloners. Alhoewel veel jongeren een laag inkomen hebben, zijn het niet overwegend jongeren die tegen het minimumloon werken. Een groot deel van de minimumloners heeft een deeltijdbaan (Dolado et al. 1996).

\section{Actief arbeidsmarktbeleid}

Actief arbeidsmarktbeleid beoogt werklozen sneller aan een baan te helpen door het verbeteren van het functioneren van de arbeidsmarkt. Zoals weergegeven in tabel 6.6 bestaan er nogal wat verschillen tussen landen in de omvang van het actieve arbeidsmarktbeleid met als uitersten de Verenigde Staten, waar 0,2 procent van het bbp wordt besteed aan dit beleid, en Zweden, waar in 1995 3,5 procent van het bbp werd besteed aan het actieve arbeidsmarktbeleid. Afgezien van het Verenigd Koninkrijk, waar de uitgaven ongeveer o, 5 procent van het bbp bedragen, is er tussen de overige landen niet veel verschil. Hier wordt ongeveer 0,5 procent van het bbp besteed aan actief arbeidsmarktbeleid. In Denemarken en Zweden fluctueert het percentage nogal in de tijd gezien, hetgeen samenhangt met fluctuaties in 
de werkloosheid (zie onder). In Nederland zijn in de loop van de jaren negentig de uitgaven iets toegenomen.

Tabel 6.6

Uitgaven aan actief arbeidsmarktbeleid (\% van BBP)

\begin{tabular}{|c|c|c|c|c|c|c|c|c|}
\hline & \multicolumn{3}{|l|}{ Totaal } & \multicolumn{3}{|c|}{ Gemiddeld 1985-1999 } & \multirow[b]{2}{*}{ Overig } & \multirow[b]{2}{*}{ Totaal } \\
\hline & 1990 & 1995 & 2000 & Training & $\begin{array}{l}\text { Arbeidsbe- } \\
\text { middeling }\end{array}$ & $\begin{array}{l}\text { Gesub- } \\
\text { sidieerd }\end{array}$ & & \\
\hline België & 1.2 & 1.4 & 1.3 & 0.2 & 0.2 & 0.7 & 0.2 & 1.3 \\
\hline Denemarken & 1.1 & 1.9 & 1.6 & 0.6 & 0.1 & 0.3 & 0.4 & 1.4 \\
\hline Duitsland & 0.9 & 1.3 & 1.2 & 0.4 & 0.2 & 0.3 & 0.3 & 1.2 \\
\hline lerland & 1.4 & 1.6 & - & 0.4 & 0.2 & 0.4 & 0.5 & 1.5 \\
\hline Nederland & 1.3 & 1.4 & 1.6 & 0.2 & 0.4 & 0.1 & 0.7 & 1.4 \\
\hline Verenigd Koninkrijk & 0.6 & 0.5 & $\left.0.4^{\mathrm{a}}\right)$ & 0.1 & 0.2 & 0.1 & 0.2 & 0.6 \\
\hline Verenigde Staten & 0.2 & 0.2 & 0.2 & 0.1 & 0.1 & 0.0 & 0.0 & 0.2 \\
\hline Zweden & 1.7 & 3.5 & 1.4 & 0.6 & 0.3 & 0.5 & 0.9 & 2.3 \\
\hline
\end{tabular}

a) 1999

Bron: OECD

In de OECD-statistieken over actief arbeidsmarktbeleid worden de volgende categorieën onderscheiden.

- Training van werklozen en werkenden voor wie het risico van baanverlies bestaat; omvat zowel cursuskosten als verschafte uitkeringen maar speciale programma's voor jongeren en arbeidsongeschikten behoren niet tot deze categorie.

- Gesubsidieerde werkgelegenheid gericht op het bevorderen of verschaffen van werkgelegenheid voor werklozen (maar niet jongeren of arbeidsongeschikten); het gaat hier om loonsubsidies of gesubsidieerde arbeidsplaatsen ten behoeve van werklozen.

- Arbeidsbemiddeling.

- Maatregelen voor jongeren en gehandicapten.

Tabel 6.6 geeft een overzicht van de uitgaven in deze categorieën gemiddeld over de periode 1985-1999. Terwijl in België het accent ligt op gesubsidieerde werkgelegen heid, wordt in Denemarken en Zweden meer geld besteed aan training, en ligt in Ierland en Nederland het accent op maatregelen voor jongeren en gehandicapten.

\subsection{ARBEIDSMARKTPRESTATIES}

\subsubsection{WERKGELEGENHEID EN WERKLOOSHEID}

We beginnen het overzicht van de arbeidsmarktprestaties met tabel 6.7 waarin een overzicht wordt gegeven van ontwikkelingen in de werkgelegenheidsgraad (ook wel nettoparticipatiegraad genoemd). In het bovenste deel van de tabel wordt de werkgelegenheidsgraad voor de gehele beroepsbevolking weergegeven, 
Tabel 6.7 Werkgelegenheidsgraad (werkenden als percentage van de bevolking) a)

\begin{tabular}{|c|c|c|c|c|c|c|c|c|}
\hline \multirow[b]{2}{*}{ a. 15-64 jaar } & \multicolumn{4}{|c|}{ Mannen } & \multicolumn{4}{|c|}{ Vrouwen } \\
\hline & 1990 & 1995 & 2000 & 2003 & 1990 & 1995 & 2000 & 2003 \\
\hline België & $68.1 \mid$ & 66.9 & 69.8 & 67.1 & $40.8 \mid$ & 45.4 & 51.9 & 51.4 \\
\hline Denemarken & $80.1 \mid$ & 80.7 & 80.7 & 79.7 & $70.6 \mid$ & 67.0 & 72.1 & 70.5 \\
\hline Duitsland & $75.7 \mid$ & 73.9 & 72.9 & 70.4 & $52.2 \mid$ & 55.3 & 58.1 & 58.7 \\
\hline lerland & $67.5 \mid$ & 66.3 & 75.6 & 74.5 & $36.6 \mid$ & 41.2 & 53.3 & 55.4 \\
\hline Nederland & 75.2 & 74.7 & 82.1 & 81.2 & $46.7 \mid$ & 53.4 & 63.4 & 65.8 \\
\hline Verenigd Koninkrijk & 82.1 & 76.1 & 79.1 & 79.3 & 62.8 & 62.5 & 65.5 & 66.4 \\
\hline Verenigde Staten & $80.7 \mid$ & 82.1 & 80.6 & 76.9 & 64.01 & 67.6 & 67.8 & 65.7 \\
\hline Zweden & $85.2 \mid$ & 73.5 & 76.1 & 75.6 & $81.0 \mid$ & 70.8 & 72.2 & 72.8 \\
\hline \multicolumn{9}{|l|}{ b. $25-54$ jaar } \\
\hline België & $88.5 \mid$ & 86.5 & 87.9 & 84.4 & 54.5 & 60.6 & 67.8 & 67.7 \\
\hline Denemarken & $87.4 \mid$ & 87.3 & 88.3 & 88.0 & $80.3 \mid$ & 75.9 & 80.4 & 78.9 \\
\hline Duitsland & $86.9 \mid$ & 87.3 & 87.2 & 84.2 & $59.6 \mid$ & 66.3 & 71.2 & 72.0 \\
\hline lerland & $80.9 \mid$ & 80.5 & 88.1 & 87.0 & $39.3 \mid$ & 48.6 & 62.7 & 65.1 \\
\hline Nederland & $88.8 \mid$ & 88.2 & 92.2 & 90.7 & 51.6 & 61.3 & 70.9 & 74.0 \\
\hline Verenigd Koninkrijk & 89.5 & 84.8 & 87.5 & 87.6 & 68.6 & 69.5 & 73.1 & 74.1 \\
\hline Verenigde Staten & $89.1 \mid$ & 87.6 & 89.0 & 85.9 & $70.6 \mid$ & 72.2 & 74.2 & 72.0 \\
\hline Zweden & $93.5 \mid$ & 84.0 & 85.8 & 85.3 & $89.7 \mid$ & 81.1 & 81.7 & 81.7 \\
\hline \multicolumn{9}{|l|}{ c. 55-64 jaar } \\
\hline België & $34.3 \mid$ & 34.5 & 35.1 & 38.7 & $9.4 \mid$ & 12.7 & 15.4 & 17.7 \\
\hline Denemarken & $65.6 \mid$ & 63.2 & 61.9 & 68.0 & $42.4 \mid$ & 36.1 & 46.2 & 53.1 \\
\hline Duitsland & 52.01 & 47.2 & 46.4 & 47.1 & $22.4 \mid$ & 24.4 & 29.0 & 30.9 \\
\hline lerland & 59.5 & 59.1 & 63.0 & 64.8 & $18.2 \mid$ & 19.4 & 27.1 & 33.5 \\
\hline Nederland & 44.5 & 39.9 & 49.9 & 57.4 & 15.8 & 18.0 & 25.8 & 32.2 \\
\hline Verenigd Koninkrijk & 62.4 & 56.1 & 59.8 & 65.0 & 36.7 & 39.9 & 41.4 & 46.4 \\
\hline Verenigde Staten & $65.2 \mid$ & 63.6 & 65.7 & 65.6 & $44.0 \mid$ & 47.5 & 50.6 & 54.5 \\
\hline Zweden & $74.4 \mid$ & 64.4 & 67.8 & 71.2 & $64.8 \mid$ & 59.5 & 62.4 & 66.8 \\
\hline
\end{tabular}

a) In veel landen is er sprake van een of meerdere trendbreuken in de datareeksen (aangegeven met |).

Bron: OECD Employment Outlook 1999 en 2004

in het middelste deel van de tabel de werkgelegenheidsgraad voor de leeftijdscategorie 25-54 jaar, en in het onderste deel die voor de leeftijdscategorie 55-64 jaar.

Het blijkt dat de werkgelegenheidsgraad onder mannen in Nederland fors is toegenomen in de jaren negentig, in de periode $1995-2003$ met 6,5 procent-punt. In de andere landen is hiervan - met uitzondering van Ierland - geen sprake. Het verschil tussen Nederland en Ierland is dat de toename in Nederland vooral kan worden toegeschreven aan een verhoging van de werkgelegenheidsgraad onder oudere werknemers, terwijl de toename in Ierland mede is toe te schrijven aan werkne- 
mers in de leeftijdscategorie $25-54$ jaar. Bij de vrouwen lopen de ontwikkelingen in de werkgelegenheidsgraad nogal uiteen, alhoewel er overal sprake is van een toename. In Nederland is de werkgelegenheidsgraad toegenomen met 12,4 procentpunt in de periode 1995-2003, terwijl in Zweden de toename over dezelfde periode slechts 2,o procent-punt bedroeg. Bij de vrouwen van 25-54 jaar is de toename van de werkgelegenheidsgraad in de periode 1995-2003 in Nederland 12,7 procentpunt, terwijl deze in Zweden slechts o,6 procent-punt bedroeg. Dat neemt niet weg dat de werkgelegenheidsgraad in Zweden en Denemarken nog steeds het grootste is en in Ierland en België beduidend lager is dan in de andere landen.

In de leeftijdscategorie 55-64 jaar zijn de verschillen tussen landen zowel bij mannen als vrouwen groot. Terwijl onder de mannen in deze leeftijdscategorie in Zweden in 2003 meer dan 70 procent werkte, was dat in België minder dan 40 procent. In Zweden werkte in 2003 onder de vrouwen in deze leeftijdscategorie ruim 65 procent, terwijl dit in België minder dan 20 procent was. In vrijwel alle landen is de werkgelegenheidsgraad onder de ouderen fors toegenomen sinds 1995 .

De ontwikkelingen in de werkloosheid zijn weergegeven in tabel 6.8. Ondanks de stijging van de Nederlandse werkloosheid sinds 2001 was deze in 2003 nog steeds de laagste van de weergegeven landen. De werkloosheid is in de tweede helft van de jaren negentig in elk land gedaald, het meest spectaculair in Denemarken, van 12,3 procent naar 4,6 procent. In Duitsland is de werkloosheid over dezelfde periode nagenoeg onveranderd gebleven. De eveneens in tabel 6.8 weergegeven langdurige werkloosheid is in overeenstemming met de algemene ontwikkeling: bij een daling van de werkloosheid neemt het percentage langdurig werklozen af.

Tabel 6.8 Werkloosheid; totaal en langdurig a) d)

\begin{tabular}{|c|c|c|c|c|c|c|c|c|}
\hline & \multicolumn{3}{|l|}{ Totaal } & \multicolumn{5}{|c|}{ Langdurig werklozen } \\
\hline & 1990 & 1995 & 2000 & 2003 & 1990 & 1995 & 2000 & 2003 \\
\hline België & 6.6 & 9.7 & 6.9 & 8.1 & $68.5 \mid$ & 62.4 & 51.7 & 46.3 \\
\hline Denemarken & 7.2 & 6.8 & 4.4 & 5.6 & $29.9 \mid$ & 27.9 & 20.0 & 19.9 \\
\hline Duitsland & - & 8.0 & 7.8 & 9.3 & $46.8 \mid$ & 48.7 & 51.5 & 50.0 \\
\hline lerland & 13.4 & 12.3 & 4.3 & 4.6 & $66.0 \mid$ & 61.4 & $33.1 b)$ & 35.4 \\
\hline Nederland & 5.9 & 6.6 & 2.9 & 3.8 & $49.3 \mid$ & $46.8 \mid$ & 26.7c) & 29.2 \\
\hline Verenigd Koninkrijk & 6.9 & 8.5 & 5.4 & 5.0 & 34.4 & 43.7 & 28.0 & 23.0 \\
\hline Verenigde Staten & 5.6 & 5.6 & 4.0 & 6.0 & 5.5 & $9.7 \mid$ & 6.0 & 11.8 \\
\hline Zweden & 1.7 & 8.8 & 5.6 & 5.6 & 26.4 & 27.8 & 26.4 & 17.8 \\
\hline
\end{tabular}

a) Totale werkloosheid als percentage van de beroepsbevolking; langdurig werkloosheid: meer dan 1 jaar werkloos als percentage van de totale werkloosheid

b) 2001 i.p.v. 2000

c) 2002 i.p.v. 2000

d) Trendbreuken zijn aangegeven met |

Bron: OECD Employment Outlook 2004 


\subsubsection{GROEI, BAANCREATIE EN BAANVERNIETIGING}

Een overzicht van de economische groei en de werkgelegenheidsgroei sinds het begin van de jaren negentig wordt gegeven in tabel 6.9. Hierin is duidelijk te zien dat Ierland een uitzonderlijke sterke economische groei heeft gekend evenals een hiermee samenhangende groei van de werkgelegenheid. In de jaren negentig bedroeg de jaarlijkse economische groei in Ierland 7,7 procent, terwijl die in Nederland en het Verenigd Koninkrijk 2,8 procent bedroeg, en in de Verenigde Staten 3,3 procent. Voor de overige landen geldt dat de economische groei 2-2,4 procent per jaar bedroeg in de jaren negentig. Inmiddels is de groei fors verminderd. Nederland is met Duitsland het enige land dat in 2003 een negatieve groei kende. Qua werkgelegenheidgroei is Nederland na Ierland de snelste groeier, met 2 procent per jaar in de jaren negentig. In 2003 kenden alleen Ierland, het Verenigd Koninkrijk en de Verenigde Staten nog een positieve werkgelegenheidsgroei.

Tabel 6.9 Economische groei (reëel BBP) en werkgelegenheidsgroei (\%/jaar)

\begin{tabular}{|c|c|c|c|c|c|c|}
\hline & \multicolumn{3}{|c|}{$\begin{array}{l}\text { Economische groei } \\
1991-\end{array}$} & \multicolumn{3}{|c|}{$\begin{array}{l}\text { Werkgelegenheidsgroei } \\
\text { 1991- }\end{array}$} \\
\hline België & 2.0 & 0.7 & 1.1 & 0.7 & -0.3 & -0.4 \\
\hline Denemarken & 2.4 & 1.0 & 0.4 & 0.3 & 0.4 & -0.1 \\
\hline Duitsland & 2.0 & 0.2 & -0.1 & 0.4 & -0.6 & -1.1 \\
\hline lerland & 7.7 & 6.9 & 1.4 & 4.2 & 1.4 & 1.2 \\
\hline Nederland & 2.8 & 0.2 & -0.7 & 2.0 & 1.1 & -0.6 \\
\hline Verenigd Koninkrijk & 2.8 & 1.6 & 2.2 & 0.6 & 0.7 & 0.9 \\
\hline Verenigde Staten & 3.3 & 2.2 & 3.1 & 1.5 & -0.3 & 0.9 \\
\hline Zweden & 2.2 & 2.1 & 1.6 & -0.4 & 0.1 & -0.2 \\
\hline
\end{tabular}

Bron: OECD Employment Outlook 2004

Een andere manier om ontwikkelingen in de werkgelegenheid weer te geven is met behulp van indicatoren voor baancreatie en baanvernietiging. Baancreatie en baanvernietiging zijn indicatoren die ontleend zijn aan baanmobiliteit. Op bedrijfsniveau is baanmobiliteit gelijk aan de nettoverandering van de werkgelegenheid tussen twee tijdstippen. Op landelijk niveau is baanmobiliteit gelijk aan de som van de absolute werkgelegenheidsveranderingen op bedrijfsniveau.

Baancreatie en baanvernietiging zijn beide indicatoren die gemeten worden op geaggregeerd niveau, een sector of een land. Baancreatie is gelijk aan de som van de positieve werkgelegenheidsveranderingen op bedrijfsniveau. Baanvernietiging is gelijk aan de absolute som van de negatieve werkgelegenheidsveranderingen op bedrijfsniveau. De som van baancreatie en baanvernietiging is per definitie gelijk aan de baanreallocatie. Het verschil tussen baancreatie en baanvernietiging is per definitie gelijk aan de verandering in de werkgelegenheid. 
In formulevorm geldt voor sector $s$ en jaar $t$ wanneer $n_{i t}$ de werkgelegenheid in onderneming $i$ in jaar $\mathrm{t}$ is, $s^{+}\left(s^{-}\right)$het deel van de sector $s$ met een positieve (negatieve) werkgelegenheidsontwikkeling is, en $\Delta$ het symbool is voor verandering:

Baancreatie: $B C_{s t}=\Sigma_{f \in s}{ }^{+} \Delta n_{f t} /\left(\Sigma_{i \in s}\left(n_{i, t}+n_{i, t-1}\right) / 2\right)$

Baanvernietiging: $B D_{s t}=\Sigma_{i \in s}{ }^{-}\left|\Delta n_{i t}\right| /\left(\Sigma_{i \in s}\left(n_{i t}+n_{i, t-1}\right) / 2\right)$

Baanrealloctie: $B D_{s t}=B C_{s t}+B D_{s t}$

Werkgelegenheidsgroei: $\Delta e_{s t}=B C_{s t}-B D_{s t}$

Tabel 6.10 Jaarlijkse baancreatie (BC), baanvernietiging (BD), baanreallocatie (BR) en werkgelegenheidsgroei $(\Delta e)^{\text {a) }}$

\begin{tabular}{|c|c|c|c|c|c|c|c|c|}
\hline & \multicolumn{3}{|c|}{ Jaren $80^{b}$ ) } & \multicolumn{3}{|c|}{ Jaren $90^{c}$ ) } & \multirow[b]{2}{*}{ BR } & \multirow[b]{2}{*}{$\Delta \mathbf{e}$} \\
\hline & BC & BD & BR & $\Delta \mathbf{e}$ & BC & BD & & \\
\hline België & 7.7 & 7.5 & 15.2 & 0.2 & 5.2 & 3.8 & 9.0 & 1.4 \\
\hline Denemarken & 9.9 & 8.8 & 18.7 & 1.1 & 6.2 & 3.3 & 9.5 & 2.9 \\
\hline Duitsland & 6.5 & 5.6 & 12.1 & 0.9 & 4.4 & 3.7 & 8.1 & 0.7 \\
\hline lerland & 6.1 & 8.1 & 14.1 & -2.0 & 8.5 & 3.1 & 11.5 & 5.4 \\
\hline Nederland & 8.2 & 7.2 & 15.4 & 1.0 & 6.5 & 4.3 & 10.8 & 2.2 \\
\hline Verenigd Koninkrijk & 6.0 & 2.7 & 8.7 & 3.3 & 6.6 & 4.4 & 11.0 & 2.2 \\
\hline Verenigde Staten & 4.6 & 3.1 & 7.7 & 1.5 & - & - & - & - \\
\hline Zweden & 8.0 & 9.6 & 17.6 & -1.6 & 8.1 & 3.6 & 11.7 & 4.5 \\
\hline
\end{tabular}

a) Percentage van de werkgelegenheid

b) Jaren 80 ondernemingen die blijven bestaan: België (alle ondernemingen; 1983-85), Denemarken (1983-89), Duitsland (West-Duitsland 1983-1990), lerland (industrie; 1984-85), Nederland (industrie alle ondernemingen; 1984-91), Verenigd Koninkrijk (1985-91), Zweden (1985-92)

c) Jaren 90: Duitsland, lerland, Nederland (1994-2000), België (1992-2000), Denemarken (1996-2001), Verenigd Koninkrijk (1992-2000), Zweden (1998-2001)

Bron: OECD Employment Outlook 1996; Gomez-Salvador et al. (2004)

In tabel 6.10 zijn de niveaus van deze indicatoren op landelijk niveau weergegeven voor de jaren tachtig en de jaren negentig. Beide perioden zijn niet zonder meer met elkaar vergelijkbaar. De gegevens uit de jaren tachtig zijn samengesteld door de OECD (1996) op basis van een groot aantal studies met onderling een soms sterk verschillende methodiek en informatiebestanden. De gegevens uit de jaren negentig zijn afkomstig uit een redelijk uniform databestand (GomezSalvador 2004), die het beter mogelijk maakt om verschillen tussen landen te bestuderen. Zowel voor de jaren tachtig als voor de jaren negentig gaat het om gegevens over gevestigde bedrijven. ${ }^{2}$ We beperken ons commentaar daarom tot verschillen tussen landen zoals gemeten in de jaren negentig. Duidelijk is te zien dat in de jaren negentig de baancreatie het grootst is geweest in Ierland en Zweden, met ruim 8 procent per jaar. ${ }^{3}$ De onderlinge verschillen in baancreatie zijn verder niet zo groot. Alleen Duitsland wijkt ongunstig naar beneden af; hier 
bedroeg de jaarlijkse baancreatie 4,4 procent. In termen van baanvernietiging zijn de verschillen tussen landen nog kleiner. De grootste baanvernietiging had het Verenigd Koninkrijk met 4,4 procent per jaar, de kleinste baanvernietiging vond plaats in Ierland, met 3,1 procent op jaarbasis. De baanreallocatie loopt uiteen van 8,1 tot 11,7 procent, de werkgelegenheidsgroei van 0,7 procent tot 5,4 procent.

Tabel 6.11 Instroom in en uitstroom uit werkgelegenheid (percentage totale werkgelegenheid)

\begin{tabular}{lllll} 
& Periode & Instroom & Uitstroom & $\begin{array}{l}\text { Werknemers } \\
\text { reallocatie }\end{array}$ \\
België & 1985 & 21.9 & 19.9 & 41.8 \\
Denemarken & $1984-91$ & 29.0 & 29.0 & 58.0 \\
Duitsland & $1985-90$ & 31.6 & 30.4 & 62.0 \\
lerland & - & - & - & - \\
Nederland & $1988-90$ & 11.9 & 10.1 & 22.0 \\
Verenigd Koninkrijk & $1967-85$ & 37.2 & 37.6 & 74.8 \\
Verenigde Staten & $1985-93$ & - & - & 96.0 \\
Zweden & $1977-81$ & 16.8 & 17.8 & 34.6 \\
\hline
\end{tabular}

Bron: Layard en Nickell (1999)

In tabel 6.11 worden gegevens gepresenteerd over de instroom in en de uitstroom uit de werkgelegenheid. Het gaat hierbij om werknemersmobiliteit. Per definitie is de instroom naar een baan gelijk aan de som van baancreatie en de mobiliteit van baan naar baan, terwijl de uitstroom van een baan per definitie gelijk is aan de som van baanvernietiging en de mobiliteit van baan naar baan. Gegevens met betrekking tot werknemersreallocatie zijn nogal gevoelig voor de gehanteerde meetmethode, vooral voor het al dan niet meetellen van korte dienstverbanden. Indien een werknemer in een jaar 5 keer van baan veranderd telt hij of zij 10 keer mee in de werknemersreallocatie. Internationaal vergelijkbare recente informatie over werknemersmobiliteit is helaas niet beschikbaar. Aangezien bovendien geldt dat de gegevens op een niet-uniforme manier zijn verzameld, dienen de gegevens in tabel 6.11 als niet meer dan indicatief beschouwd te worden.

Tot slot worden in tabel 6.12 voor Nederland gegevens gepresenteerd over baanreallocatie en werknemersreallocatie naar leeftijdscategorie. Zoals te verwachten is zijn vooral jongeren en banen voor jongeren mobiel. In 1995 bedroeg de baancreatie onder werknemers tot 30 jaar 15 procent en baandestructie 5 procent; in datzelfde jaar begon 31 procent aan een nieuwe baan en vertrok 21 procent van hun oude baan. In totaal bedroeg de toename van de werkgelegenheid onder deze leeftijdscategorie 10 procent. In het jaar 2000 was dit zelfs 15 procent. Een vergelijking tussen de jaren 1995 en 2000 geeft ook enige indicatie hoe de situatie op de arbeidsmarkt mobiliteit en baancreatie beïnvloeden. Zoals eerder weergegeven was in 1995 de arbeidsmarkt ruim en in 2000 krap. De sterkere groei van de werkgelegenheid in 2000 komt vooral tot stand doordat er meer banen voor jongeren 
Tabel 6.12 Baanreallocatie en werknemersreallocatie naar leeftijdscategorie; Nederland; 1995 en 2000

\begin{tabular}{|c|c|c|c|c|c|c|c|c|c|}
\hline & & 1995 & & & & 2000 & & & \\
\hline & Leeftijd & $<30$ & $30-49$ & $\Delta \mathbf{5 0}$ & Gem. & $<30$ & $30-49$ & $\Delta 50$ & Gem. \\
\hline \multirow[t]{3}{*}{ Banen } & Creatie & 15 & 4 & 1 & 6.0 & 19 & 3 & 1 & 6.6 \\
\hline & Destructie & 5 & 3 & 11 & 4.4 & 4 & 4 & 9 & 4.3 \\
\hline & Reallocatie & 20 & 7 & 12 & 10.4 & 23 & 7 & 10 & 10.9 \\
\hline \multirow[t]{3}{*}{ Werknemers } & Instroom & 31 & 10 & 4 & 15.7 & 41 & 11 & 4 & 20.3 \\
\hline & Uitstroom & 21 & 9 & 14 & 14.1 & 26 & 12 & 12 & 18.0 \\
\hline & Reallocatie & 52 & 19 & 18 & 29.8 & 67 & 23 & 16 & 38.3 \\
\hline$\Delta \mathrm{e}$ & & 10 & 1 & -10 & 1.6 & 15 & -1 & -8 & 2.3 \\
\hline
\end{tabular}

Bron: Gielen en Van Ours (2004)

worden gecreëerd en minder banen voor ouderen worden vernietigd. De instroom van vijftigplussers in een nieuwe baan is in beide jaren ongeveer 4 procent.

De uitstroom van vijftigplussers was 14 procent in 1995 en 12 procent in 2000.

\subsubsection{ARBEIDSMARKTINSTITUTIES EN ARBEIDSMARKTPRESTATIES}

Uit het voorgaande overzicht is duidelijk geworden dat er tussen landen nogal wat verschillen bestaan in combinaties van instituties. De relevante dimensies waarop arbeidsmarktinstituties beoordeeld kunnen worden zijn: hoogte en duur van de werkloosheidsuitkering, ontslagbescherming (regulier werk), minimumloon, actief arbeidsmarktbeleid. Om enige ordening aan te kunnen brengen delen we elk land in volgens het criterium 'laag' en 'hoog' volgens elk van deze vijf dimensies. In principe zou dit kunnen leiden tot 32 mogelijke combinaties, in de praktijk is het aantal combinaties aanmerkelijk geringer. Het grote onderscheid is tussen het Verenigd Koninkrijk en de Verenigde Staten enerzijds en de overige landen anderzijds. Het VK en de vs hebben een lage werkloosheidsuitkering, een laag minimumloon en geringe uitgaven aan actief arbeidsmarktbeleid. De overige landen hebben een hoge werkloosheidsuitkering, een hoog minimumloon en hoge uitgaven aan actief arbeidsmarktbeleid. Verschillen binnen de laatstgenoemde groep van landen doen zich voor ten aanzien van de duur van de uitkering en de ontslagbescherming. In tabel 6.13 wordt een schematisch overzicht gegeven.

Ten opzichte van Ierland, Zweden en Duitsland heeft Nederland een lange werkloosheidsuitkering vooral vanwege de sterke samenhang met de leeftijd van de werkloze. Ten opzichte van Ierland, België en Denemarken heeft Nederland een hoge mate van ontslagbescherming in geval van reguliere banen.

Ten aanzien van de dynamiek op de arbeidsmarkt, in het bijzonder de mobiliteit van werknemers en de reallocatie van banen, doet zich het probleem voor dat er niet of nauwelijks data beschikbaar zijn voor een goede internationale vergelij- 
Tabel 6.13 Combinaties van arbeidsmarktinstituties

\begin{tabular}{|c|c|c|c|c|c|}
\hline $\begin{array}{l}\text { Niveau uitkering } \\
\text { Actief arbeidsm. beleid } \\
\text { Minimumloon }\end{array}$ & Laag & \multicolumn{4}{|c|}{ Hoog } \\
\hline Duur uitkering & Laag & \multicolumn{2}{|c|}{ Laag } & \multicolumn{2}{|c|}{ Hoog } \\
\hline Ontslagbescherming ${ }^{\text {a) }}$ & Laag & Laag & Hoog & Laag & Hoog \\
\hline Landen & $\begin{array}{c}\text { Verenigd Koninkrijk } \\
\text { Verenigde Staten }\end{array}$ & lerland & $\begin{array}{l}\text { Zweden } \\
\text { Duitsland }\end{array}$ & $\begin{array}{c}\text { België } \\
\text { Denemarken }\end{array}$ & Nederland \\
\hline
\end{tabular}

a) Reguliere banen

king. Voor wat betreft de indicatoren voor arbeidsmarktprestaties zijn er meer gegevens beschikbaar, maar het is geen eenvoudige zaak die te koppelen aan de dynamiek op de arbeidsmarkt. Qua werkgelegenheidsgraad voor mannen in de leeftijd van 25-64 jaar zijn er geen grote verschillen tussen landen, in 2003 waren de extremen 84,2 procent in Duitsland en 9o,7 procent in Nederland. In termen van werkgelegenheidsgraad van vrouwen, ouderen en in termen van langdurige werkloosheid doen zich wel grotere verschillen voor tussen landen. Hiernaast bestaan er verschillen in groei van de werkgelegenheid vooral in de jaren negentig van de vorige eeuw. We beoordelen de landen op drie dimensies: werkgelegenheidsgroei, langdurige werkloosheid en werkgelegenheidsgraad onder ouderen (54-65 jaar), en maken weer een - arbitrair - onderscheid tussen 'hoog' en 'laag'. Een overzicht wordt gegeven in tabel 6.14.

Aldus ingedeeld zijn Nederland en de Verenigde Staten de twee landen met een zeer goede arbeidsmarktprestatie; de werkgelegenheidsgroei was hoog, de langdurige werkloosheid laag en de werkgelegenheidsgraad onder ouderen hoog. Ierland heeft ook uitstekende arbeidsmarktprestaties, maar de werkgelegenheidsgraad onder ouderen is nog laag.

Tabel 6.14 Combinaties van arbeidsmarktprestaties

\begin{tabular}{|l|c|c|c|c} 
Werkgelegenheidsgroei & Laag & Hoog & \\
Langdurige werkloosheid & Hoog & Laag & Hoog \\
\hline Werkgelegenh. graad ouderen & Laag & Hoog & Laag \\
\hline Landen & $\begin{array}{c}\text { België } \\
\text { Duitsland }\end{array}$ & $\begin{array}{c}\text { Venendand } \\
\text { Verengd Koninkrijk } \\
\text { Zweden }\end{array}$ & Verenigde Staten \\
\hline
\end{tabular}


Wanneer we de landenindeling in tabel 6.14 vergelijken met die in tabel 6.13, is het duidelijk dat er niet een eenduidige relatie bestaat tussen arbeidsmarktinstituties en arbeidsmarktprestaties. Nederland en de Verenigde Staten bevinden zich qua arbeidsmarktinstituties aan de uiteinden van de verdeling, terwijl beide landen qua arbeidsmarktprestatie sterk overeenkomen. Qua arbeidsmarktinstituties verschillen België en Nederland niet zoveel, terwijl beide landen qua arbeidsmarktprestatie sterk verschillen.

\subsection{ARBEIDSMARKTINSTITUTIES - THEORETISCH EN EMPIRISCH ONDERZOEK}

Een belangrijke beleidsmatige vraag is of de huidige arbeidsmarktinstituties het goed functioneren van de Nederlandse arbeidsmarkt belemmeren. Het zou kunnen zijn dat de arbeidsmarktinstituties de aanpassingssnelheid van de economie verminderen. Verschillen in arbeidsmarktinstituties tussen landen worden wel als verklaring gegeven voor verschillen in de omvang van de werkloosheid tussen landen (zie bijvoorbeeld Belot en Van Ours 2004; Blanchard en Wolfers 2000; Nickell et al. 2005). Layard en Nickell (1999) onderzoeken de relatie tussen arbeidsmarktinstituties, werkloosheid en economische groei. Zij concluderen onder andere dat vooral de sociale zekerheid een institutie is met een grote invloed op het functioneren van de arbeidsmarkt. Activerend arbeidsmarktbeleid is naar hun mening van groot belang, terwijl daarentegen tijd besteed aan het zich zorgen maken over ontslagbescherming en minimumloon grotendeels 'verspilde tijd' is.

De relatie tussen arbeidsmarktinstituties en baanreallocatie is minder duidelijk. Verschillende indicatoren van reallocatie laten bijvoorbeeld geen grote verschillen zien tussen de Europese landen en de Verenigde Staten (OESO 1996; Bertola en Rogerson 1997). De omvang van reallocatie is in alle landen groot. Tot voor kort was het echter moeilijk om een goed inzicht te krijgen in de rol van instituties hierin. Zoals aangegeven in het vorige hoofdstuk is de onderlinge vergelijkbaarheid van informatie over baancreatie en baanvernietiging, zeker waar het oudere gegevens over bijvoorbeeld de jaren tachtig betreft, niet groot. Inmiddels zijn verschillende recente studies gebaseerd op betere internationaal vergelijkbare data en dit heeft geleid tot interessante nieuwe inzichten wat betreft de rol van uit arbeidsmarktinstituties voortvloeiende rigiditeiten in het reallocatieproces.

In dit hoofdstuk geven we een overzicht van de theoretische en empirische effecten van instituties op de arbeidsmarktdynamiek. Arbeidsmarktdynamiek zien we in termen van baan- en arbeidsreallocatie, transitie tussen werkloosheid en werkgelegenheid, en toe- en uittreding van bedrijven. Gezien het grote belang van arbeidsmarktdynamiek voor economische groei, bestuderen we in hoeverre de relatie tussen instituties en deze dynamiek bepalend is voor de prestaties van een land: we plaatsen de discussie in een bredere context, waarbij we ingaan op de relatie tussen instituties en een efficiënte inzet van middelen. 


\subsubsection{AFZONDERLIJKE INSTITUTIES EN REALLOCATIE}

\section{Ontslagbescherming en werkloosheidsuitkeringen}

Werkloosheidsuitkeringen en ontslagbescherming zijn de basisingrediënten van een optimaal systeem van arbeidsmarktinstituties (Blanchard en Tirole 2004a en 2004b). Ontslagbescherming en werkloosheidsuitkeringen zijn twee vormen van een verzekering tegen inkomensfluctuaties. Beide instituties hebben een direct effect op de mobiliteit tussen banen (Bertola 2004) en introduceren inefficiënties in het proces van 'creatieve destructie'.

In financiële termen bestaat ontslagbescherming meestal uit twee componenten. Ten eerste vindt er veelal een financiële overdracht plaats van de werkgever naar de werknemer (zoals een ontslagvergoeding of gouden handdruk). Ten tweede omvat ontslagbescherming directe kosten betaald door de werkgever in het geval van ontslag (administratieve kosten, enz.). Beide componenten kunnen verschillend uitwerken op de arbeidsdynamiek. De financiële overdracht is equivalent aan een belasting op ontslag en heeft een direct negatief effect op reallocatie: laagproductieve banen blijven inefficiënt lang bestaan en de creatie van nieuwe banen wordt ontmoedigd door de ontslagkosten (bijvoorbeeld Bentolila en Bertola 1990; Mortensen en Pissarides 1999). Men verwacht hierdoor dus een negatief verband tussen ontslagbescherming en reallocatie. Het netto-effect op het niveau van werkgelegenheid is echter onzeker. Rekenexercities op basis van theoretische modellen voorspellen vaak een negatief netto-effect (Mortensen en Pissarides 1999).

Een ontslagvergoeding kan hetzelfde effect hebben zolang lonen niet geheel flexibel zijn. Echter, Lazear (1990) beargumenteert dat als lonen wel flexibel zijn, een ontslagvergoeding geen effect heeft. Werknemers zullen lagere lonen accepteren in ruil voor de mogelijke toekomstige ontslagvergoeding. Bentolila en Bertola (1990) stellen dat ontslagbescherming de cyclische fluctuaties van werkgelegenheid vermindert. In goede tijden zullen er minder mensen aangenomen worden, en in slechte tijden worden minder mensen ontslagen.

Naast ontslagbescherming leiden ook werkloosheidsuitkeringen tot een inefficiënte allocatie van middelen. Hiervoor zijn twee belangrijke oorzaken aan te geven. In de eerste plaats verbeteren werkloosheidsuitkeringen de onderhandelingspositie van werknemers waardoor lonen en loonkosten omhoog gaan, de creatie van nieuwe banen wordt ontmoedigd en de vernietiging van banen met een relatief lage productiviteit wordt gestimuleerd. In de tweede plaats verminderen werkloosheidsuitkeringen de kosten van werkloosheid en daarmee de prikkels om een baan te zoeken. Bij dit effect zijn zowel de duur van de uitkering als het proces van toezicht en sanctionering van belang.

Op basis van de bestaande empirische en theoretische literatuur komen Fredriksson en Holmlund (2003) tot de conclusies dat de optimale werkloosheidsuitkering afneemt met de duur van de werkloosheid en dat toezicht en sancties op het 
zoekgedrag een positief effect hebben op de uitstroom van werkloosheid naar een baan, zowel ex ante (vóórdat de sanctie wordt toegepast, zie Boone en Van Ours 200o) als ex post (zie bijvoorbeeld Van den Berg et al. 2004).

De theorie verwacht dus een negatief effect van werkloosheidsuitkeringen op baancreatie en een positief effect op baanvernietiging. Garibaldi, Konings en Pissarides (1999) kijken naar een eenvoudige correlatie tussen de generositeit van de werkloosheidsuitkeringen (een indicator die voorgesteld is door Burda 1988) en baanreallocatie, en vinden een negatief verband. Met andere woorden, het effect op baancreatie domineert het effect op baanvernietiging. Het negatieve verband is vooral te vinden tussen de duur van uitkeringen en baanreallocatie. Wanneer uitkeringen langer worden verstrekt, worden er minder banen gecreëerd. Kortom, de verwachting is dat werkloosheidsuitkeringen een negatief effect hebben op de arbeidsmarktdynamiek, maar de grootte van de effecten hangt sterk af van de specifieke kenmerken van de uitkering in termen van niveau, duur en toezicht.

Omdat instituties weinig veranderen over de tijd, kunnen de effecten van instituties op de arbeidsmarktdynamiek alleen worden geanalyseerd door landen met elkaar te vergelijken. Tot voor kort was er echter een gebrek aan internationaal vergelijkbare data omtrent arbeidsmarktdynamiek. Verschillen in definities, steekproefkader en dergelijke maakten het onmogelijk om naar verschillende landen tegelijk te kijken. Het was daarom niet mogelijk om de effecten van instituties op de arbeidsmarktdynamiek vast te stellen. Hoewel niet alle problemen qua internationale vergelijkbaarheid zijn opgelost, is er een grote vooruitgang geboekt. We geven hier een overzicht van de bevindingen van recente studies wat betreft de rol van instituties op de arbeidsmarktdynamiek.

Blanchard en Portugal (2001) vergelijken de arbeidsmarktdynamiek in Portugal en in de Verenigde Staten. Die twee landen bevinden zich aan de twee uiteinden van het spectrum van ontslagbescherming. Terwijl de regelingen soepel zijn in de vs, heeft Portugal een van de strengste regelingen. De puzzel is dat ondanks dit grote verschil, de omvang van de jaarlijkse baanreallocatie op geaggregeerd niveau vergelijkbaar is in beide landen. Blanchard en Portugal laten zien dat dit niet meer het geval is wanneer er gegevens met een hogere tijdsfrequentie worden gebruikt. De omvang van de baanreallocatie gemeten over een kwartaal is in Portugal substantieel lager dan in de vs. Blijkbaar vindt er in de vs veel 'compenserende' baanreallocatie plaats. ${ }^{4}$ Het langetermijnproces van creatieve destructie wordt minder verstoord door ontslagbescherming.

Wolfers (2004) gaat dieper in op het argument van Blanchard en Portugal (2001) en presenteert een model waarin de effecten van ontslagbescherming verschillend zijn in het geval van tijdelijke schokken in de economie dan van die in het geval van permanente schokken in de economie. Ontslagbescherming vermindert de aanpassing van bedrijven aan tijdelijke schokken. Hij gebruikt geaggregeerde landelijke kwartaaldata over de omvang van baanreallocatie in de drie sectoren en OECD-informatie over de mate van ontslagbescherming in de ver- 
schillende landen. Het blijkt dat de correlatie tussen de mate van ontslagbescherming en baanreallocatie duidelijker is bij kwartaalgegevens dan bij jaargegevens. Bovendien is het negatieve verband sterker in de landbouw en in de verwerkende industrie dan in de dienstensector, waar de omvang van seizoenafhankelijke reallocatie kleiner is.

Om meer inzicht te krijgen in de rol van instituties in baanreallocatie is het noodzakelijk om studies met minder geaggregeerde data in beschouwing te nemen. Salvanes (1997) is een van de eerste empirische studies die de effecten van institutionele regulering (waaronder arbeidsmarktinstituties) op baanreallocatie onderzoekt. Hij gebruikt jaarlijkse data op bedrijfsniveau (2-digit ISIC) in de verwerkende industrie voor zeven verschillende landen: Noorwegen, Denemarken, de Verenigde Staten, Canada, Nederland, Duitsland en Italië voor verschillende jaren (de periode varieert tussen landen 5 ). Hij ontleedt de variantie in baanreallocatie in een sectorspecifiek deel en een landspecifiek deel. Het sectorspecifieke deel wordt gerelateerd aan sectorspecifieke technologieën en het landspecifieke deel wordt gerelateerd aan institutionele reguleringen. De instituties waarnaar gekeken wordt zijn het niveau van ontslagbescherming, de mate van centralisatie in loononderhandelingen en de omvang van subsidies aan de industrie. Hij vindt dat landspecifieke effecten ongeveer 40 procent van de variantie in reallocatie verklaren. Institutionele verschillen lijken dus een belangrijke rol te spelen in reallocatie. Ontslagbescherming heeft een significant negatief effect op baancreatie. Het totale effect op reallocatie is eveneens negatief, maar niet significant.

Gómez et al. (2004) kijken naar de effecten van arbeidsmarktinstituties op baancreatie en baanvernietiging in 13 Europese landen over de periode 1992-2001, op basis van data op bedrijfsniveau (van de zogenaamde Amadeus dataset; zie ook tabel 6.10). De data omvatten zowel sectoren in de verwerkende als in de nietverwerkende industrie. In het bijzonder is het interessant om data te hebben over de dienstensector, aangezien de mate van baanreallocatie daar gemiddeld groter is dan in de verwerkende industrie. Gómez et al. kijken naar het effect van institutionele verschillen op baancreatie, baanvernietiging en totale baanreallocatie. De instituties die ze in beschouwing nemen zijn het niveau van ontslagbescherming (een indicator die over de tijd varieert), werkloosheidsuitkeringen (een indicator van de duur van uitkeringen) en arbeidsbelastingen (de WIG). Ze controleren voor bedrijfsspecifieke kenmerken (grootte, leeftijd) en sectorspecifieke effecten (met behulp van dummy's). Ze vinden dat zowel de duur van de werkloosheidsuitkeringen als ontslagbescherming een negatief effect heeft op baanreallocatie. Beide instituties blijken vooral effecten te hebben op baancreatie. Het effect op baanvernietiging is daarentegen kleiner en niet altijd significant. Ze concluderen dat baanvernietiging waarschijnlijk meer afhangt van idiosyncratische schokken dan van instituties.

Scarpetta et al. (2002) bestuderen het effect van verschillende instituties (waaronder ontslagbescherming) op het proces van toe- en uittreding van bedrijven en op de productiviteit. Ze kijken in detail naar het gedrag van bedrijven in termen 
van toetreding, uitbreiding en bijdrage aan de geaggregeerde productiviteit. Ze vinden interessante verschillen tussen de vs en de Europese landen, die deels te verklaren zijn met behulp van institutionele verschillen. De nieuwe bedrijven in de vs zijn gemiddeld kleiner, hebben een lagere productiviteit ten opzichte van het gemiddelde van de industrie en breiden zich sneller uit in de eerste jaren. Ze vinden dat ontslagbescherming een sterk negatief effect heeft op de toetreding van kleine en middelgrote bedrijven.

Het nadeel van de weergegeven empirische studies is dat ze alleen kijken naar baanreallocatie, met andere woorden naar nettoveranderingen in werkgelegenheid op bedrijfsniveau, en niet naar de totale mobiliteit van werknemers binnen en tussen bedrijven (arbeidsreallocatie). Stel dat twee werknemers wisselen tussen twee bedrijven, dan heeft dit geen gevolgen voor de mate van baanreallocatie, maar wel voor de mate van arbeidsreallocatie.

De literatuur noemt het verschil tussen baanreallocatie en arbeidsreallocatie churning. Churning bestaat uit de reallocatie van werknemers tussen bestaande functies. Doordat werknemers en banen heterogeen zijn en omdat er imperfecte informatie is over de kwaliteit van een potentiële match, worden inefficiënte matches gevormd. We zouden daarom kunnen verwachten dat bedrijven tegelijkertijd mensen ontslaan en nieuwe mensen aannemen. ${ }^{6}$

Burgess et al. (200o) laten zien dat de relatie tussen de arbeidsreallocatie en baanreallocatie complex is. Terwijl baanreallocatie negatief gecorreleerd is met de geaggregeerde economische cyclus (meer reallocatie in recessies dan in booms), is arbeidsreallocatie positief gecorreleerd met de economische cyclus. Het lijkt profitabeler om werknemers te herverdelen in goede dan in slechte tijden.

Baanreallocatie heeft dus direct te maken met creatieve destructie (sommige banen verdwijnen omdat ze niet meer productief zijn, en nieuwe banen worden gecreëerd in meer productieve sectoren) en churning heeft te maken met de mate van fricties op de arbeidsmarkt. Instituties spelen een belangrijke rol in beide, omdat ze een direct effect hebben op de mobiliteit van werknemers op de arbeidsmarkt.

Omdat er weinig vergelijkbare informatie tussen landen is over de indienstnemingbeslissingen en ontslagbeslissingen, en over de interne mobiliteit van werknemers, is het tot nu toe niet mogelijk geweest om de effecten van instituties op de totale arbeidsreallocatie te meten. De empirische literatuur heeft echter veel aandacht besteed aan de mobiliteit van mensen tussen werkloosheid en werkgelegenheid. In een recente studie van de OECD (Employment Outlook 2004) worden geaggregeerde data op landniveau gebruikt om de effecten van verschillende instituties te bestuderen. Het gaat hierbij onder andere om de effecten van ontslagbescherming en werkloosheidsuitkeringen op de instroom in en uitstroom uit de werkloosheid. Ze gebruiken data voor 19 landen (waaronder Nederland), over de periode 1985-2002. De institutionele indicatoren variëren tussen 
landen en over de tijd, zodat de effecten van de recente institutionele hervormingen meegenomen kunnen worden. Een samenvattend overzicht van de resultaten wordt gegeven in tabel 6.15.7 Ontslagbescherming heeft een negatief effect op de instromen en uitstromen. Het effect op uitstromen is veel groter dan op instromen. Het is daarom niet verassend dat het effect op het aandeel van langdurige werkloosheid in de totale werkloosheid positief en significant is. Landen met een strengere ontslagregulering hebben relatief meer langdurige werkloosheid.

\section{Tabel 6.15 Schattingsresultaten}

\begin{tabular}{l|c|c|c} 
& $\begin{array}{c}\text { Instroom in } \\
\text { werkloosheid }\end{array}$ & $\begin{array}{c}\text { Uitstroom uit } \\
\text { werkloosheid }\end{array}$ & $\begin{array}{c}\text { Aandeel langdurig } \\
\text { werklozen }\end{array}$ \\
Ontslagbescherming & $-*$ & $-*$ & $+*$ \\
Werkloosheidsuitkeringen & & $+^{*}$ & * $^{*}$ \\
Actief arbeidsmarktbeleid & & - $^{*}$ & \\
\hline
\end{tabular}

*: Coëfficiënt is statistisch significant. Zie OECD, Employment Outlook 2004 voor details over de andere variabelen zoals aard en type vakbondsonderhandelingen, belasting et cetera.

Bron: OECD (2004)

Om het effect van werkloosheidsuitkeringen te meten, gebruiken ze een samenvattende indicator van hun niveau voor verschillende types werklozen (familiesituatie, leeftijd, enz.) en verschillende lengtes van werkloosheidsduur (zie voor een overzicht tabel 6.1 hierboven). Ze vinden een positief en significant effect van deze indicator op langdurige werkloosheid. Het actieve arbeidsmarktbeleid daarentegen heeft een positief effect op uitstroom en een negatief effect op langdurige werkloosheid.

Op basis van de huidige literatuur concluderen we dat ontslagbescherming en werkloosheidsuitkeringen een negatief effect hebben op de arbeidsmarktdynamiek, met name op baancreatie en op de transities tussen werkloosheid en werkgelegenheid.

\section{Minimumloon}

In theorie hebben minimumlonen een vergelijkbare invloed op baancreatie en baanvernietiging als een werkloosheidsuitkering. Een hoog minimumloon ontmoedigt de creatie van laagproductieve banen en stimuleert de vernietiging van laagproductieve banen. Door het negatieve effect op baancreatie en het positieve effect op baanvernietiging wordt er een duidelijk negatief effect op de werkgelegenheid verwacht.

Eventuele effecten van het minimumloon zullen zich vooral manifesteren voor (potentiële) werknemers met een laag loon. Omdat jongere werknemers vaak een laag loon hebben, heeft de empirische literatuur veel aandacht voor de effecten van het minimumloon op jeugdwerkgelegenheid. Een voorbeeld hiervan is de 
studie van de hand van Neumark en Wascher (1999). Ze gebruiken data voor 15 OESO-landen, over de periode 1975-1997. Ze schatten twee elasticiteiten van werkgelegenheid in relatie tot het minimumloon: voor tieners (15-19) en voor jongere werknemers $(15-24)$. De elasticiteit houdt rekening met andere instituties (interactie-effecten met het niveau van ontslagbescherming en de publieke uitgaven voor het actief arbeidsmarktbeleid als percentage van het bbp).

De belangrijkste bevindingen van Dolado et al. (2002) zijn de volgende.

- Het minimumloon heeft een significant negatief effect op jeugdwerkgelegenheid in 7 OECD-landen, waaronder Nederland.

- De elasticiteiten zijn (in absolute termen) bijna allemaal kleiner dan 1. Alleen Zweden heeft systematisch elasticiteiten groter dan 1. Dit betekent dat voor de meeste landen het netto-inkomenseffect voor de groepen in kwestie positief is.

- Nederland heeft een vrij hoge elasticiteit (in absolute termen) ter vergelijking met andere oEso-landen.

Tabel 6.16 geeft een overzicht van de resultaten voor de voor ons relevante landen.

Tabel 6.16 Schattingsresultaten elasticiteit van de werkgelegenheid in relatie tot het minimumloon

\begin{tabular}{|lcc} 
& $\begin{array}{c}\text { Jongeren } \\
(\mathbf{1 5 - 2 4} \text { jaar })\end{array}$ & $\begin{array}{c}\text { Tieners } \\
\mathbf{( 1 5 - 1 9 ~ j a a r ) ~}\end{array}$ \\
België & 0.13 & 0.92 \\
Denemarken & -0.28 & -0.19 \\
Duitsland & $-0.49 *$ & -0.42 * \\
lerland & - & - \\
Nederland & $-\mathbf{0 . 4 9 *}$ & $-\mathbf{0 . 9 7}$ * \\
Verenigd Koninkrijk & 0.36 & 1.02 * \\
Verenigde Staten & 0.13 & 0.42 \\
Zweden & -1.26 * & -2.08 * \\
\hline
\end{tabular}

* = Significant verschillend van 0

Bron: Dolado et al. (2002)

Minimumlonen hebben dus wel een negatief effect op de jeugdwerkgelegenheid, maar het effect op de totale looninkomsten van de bevolking is positief (immers, de procentuele daling van de werkgelegenheid is kleiner dan de procentuele stijging van het loon). Verder vinden ze ook dat het effect van het minimumloon sterk afhangt van andere arbeidsmarktinstituties. Actief arbeidsmarktbeleid vermindert het negatieve effect van minimumlonen substantieel. Jeugdspecifieke minima blijken ook het negatieve effect te verminderen.

Daarnaast is er ook de vraag in welke mate veranderingen in het minimumloon effecten hebben op de rest van de loonverdeling. Dit hangt af van het systeem van 
arbeidsverhoudingen. In sommige landen is de causaliteit omgekeerd (bijvoorbeeld in Frankrijk): het niveau van het minimumloon hangt van het gemiddelde loon af, zodat als het gemiddelde loon toeneemt, ook het minimumloon toeneemt.

\section{Actief arbeidsmarktbeleid}

Actief arbeidsmarktbeleid heeft als doel het functioneren van de arbeidsmarkt te verbeteren. Er is een brede variëteit van programma's die onder het actief arbeidsmarktbeleid vallen. Zoals eerder aangegeven, kunnen we drie belangrijke types programma's onderscheiden: verbetering van het matchingproces, bijscholing en productiviteitsgerichte programma's, subsidies op baancreatie in de private sector en directe baancreatie in de publieke sector. Sommige programma's zijn gericht op specifieke groepen (jongeren, gehandicapten) en betreffen meerdere categorieën.

De literatuur heeft veel aandacht besteed aan de evaluatie van actief arbeidsmarktbeleid. Een deel van de literatuur kijkt naar de effecten van de programma's op de participanten zelf (micro-evaluaties). De vraag die wordt gesteld is of de arbeidsmarktprestaties van de participanten verbeterd zijn door hun deelname aan het programma. De uitdaging in deze studies is om het effect van de behandeling (treatment effect) te isoleren van andere aspecten, zoals de individuele - vaak niet waarneembare - kenmerken van de participanten (zie Heckman et al. 1999 voor een overzicht van de problemen en methoden).

Martin (2001) komt op basis van een analyse van relevante evaluatiestudies tot de volgende conclusies. Trainingsprogramma's zijn het duurst, terwijl sommige programma's weinig tot geen effect hebben. Voor zover de programma's werken doen ze dat wel voor sommige categorieën (volwassen vrouwen), maar niet voor andere categorieën (mannen van 25-50 jaar, jongeren). Volgens Martin moeten scholingsprogramma's aan vier criteria voldoen om effectief te kunnen zijn: goede selectie van deelnemers, relatief kleinschalig, resulterend in een kwalificatie die door de markt wordt erkend en met een sterke baancomponent (goede banden met lokale werkgevers). Assistentie bij het zoeken naar een baan is meestal het goedkoopst, maar moet worden gecombineerd met het monitoren van zoekgedrag en toepassing van sanctiebeleid. Werkgelegenheidssubsidies gaan vaak gepaard met grote substitutie-effecten. Rechtstreekse baancreatie voor werklozen is weinig succesvol gebleken als het gaat om het vinden van reguliere banen. Voor zover effectief gaat het volgens Martin vooral om kortdurende banen.

Kluve en Schmidt (2002) gebruiken de uitkomsten van 53 recente evaluatiestudies om een analyse te verrichten waarbij elke studie 1 'datapunt' vertegenwoordigt. Op basis van deze analyse concluderen ze dat werkgelegenheidssubsidies en baancreatie in de publieke sector er meestal niet in slagen werklozen aan een reguliere baan te helpen. Programma's met een sterke trainingscomponent lijken succesvoller te zijn. 
Calmfors (1994) beargumenteert dat arbeidsmarktbeleid algemene evenwichtseffecten met zich meebrengt waar we rekening mee moeten houden. De macroeconomische evaluatie van deze programma's moet met name rekening houden met de effecten op de 'niet-behandelde' groepen. Volgens Calmfors gaat het in het bijzonder om effecten op arbeidsvraag, zoekgedrag en loonkosten. Actief arbeidsmarktbeleid zou een positief effect moeten hebben op de arbeidsvraag. Verbeteringen in het matchingproces verlagen de rekruteringskosten van bedrijven. De literatuur heeft veel aandacht besteed aan de mogelijke welvaartsverliezen en substitutie-effecten. Een welvaartsverlies ontstaat wanneer een baan ook gecreëerd zou zijn in de afwezigheid van het programma. Substitutie-effecten ontstaan wanneer de arbeidsmarktprestaties van participanten verbeterd worden ten koste van andere groepen; met andere woorden, wanneer programma's beïnvloeden wie wordt aangenomen in plaats van hoeveel mensen worden aangenomen. De empirische studies (bijvoorbeeld De Koning et al. 1992 voor Nederland) laten zien dat deze effecten substantieel kunnen zijn: bij tussen de 70 en 90 procent van de nieuwe banen gaat het om substitutie-effecten en welvaartsverliezen. Het effect van actief arbeidsmarktbeleid op het zoekgedrag van participanten is minder duidelijk. Afhankelijk van het type programma zou het kunnen zijn dat participanten hun zoekintensiteit verlagen tijdens de deelname (denk bijvoorbeeld aan een bijscholingsprogramma). Het vooruitzicht op deelname zou zelfs ex ante een negatief effect kunnen hebben op het zoekgedrag. Deze effecten worden niet meegenomen in de micro-evaluatiestudies. Tot slot zou volgens Calmfors actief arbeidsmarktbeleid tot lagere lonen moeten leiden: Het is voor bedrijven gemakkelijker om werknemers aan te trekken (gezien de verbetering in het matchingproces), terwijl ook de concurrentie tussen outsiders en insiders sterker wordt, hetgeen een loondrukkend effect heeft. Aan de andere kant vormen de programma's een deel van de outside option van werknemers in loononderhandelingen. Via hetzelfde mechanisme als werkloosheidsuitkeringen zouden de beloningen in programma's de onderhandelingspositie van werknemers kunnen verbeteren.

Studies die algemeen evenwichtseffecten van actief arbeidsmarktbeleid meenemen in de analyse zijn zeldzaam. Wel zijn er studies die het effect van uitgaven aan actief arbeidsmarktbeleid onderzoeken op verschillende indicatoren op macroniveau, zoals de werkloosheid, langdurige werkloosheid en stromen in en uit de werkloosheid. Layard en Nickell (1999) vinden bijvoorbeeld dat de totale uitgaven aan actief arbeidsmarktbeleid een significant negatief effect hebben op de omvang van de werkloosheid in OECD-landen. Actief arbeidsmarktbeleid heeft ook een positief effect op de uitstroom uit de werkloosheid en daarmee een negatief significant effect op langdurige werkloosheid. Boone en Van Ours (2004) concluderen op basis van een analyse voor 20 OECD-landen dat arbeidsmarkttraining het effectiefste programma is om de werkloosheid te verlagen en de werkgelegenheidsgraad te verhogen, terwijl het subsidiëren van werkgelegenheid niet effectief is. Training is waarschijnlijk vooral effectief vanwege het effect op de baanduur: werklozen die een training hebben gevolgd zijn beter in staat om hun nieuwe baan te behouden dan werklozen die geen training hebben gevolgd. 


\subsubsection{COMBINATIE VAN INSTITUTIES}

De recente literatuur (Coe and Snower 1997; Belot en Van Ours 2004) stelt dat het totale effect van de combinatie van instituties sterker is dan de som van de effecten van de afzonderlijke instituties. Anders gezegd, bepaalde instituties hebben vooral in combinatie met andere instituties een negatief effect of een positief effect op de arbeidsmarktprestaties.

Wat betreft het effect op baancreatie en baanvernietiging is het duidelijk dat de effecten van instituties elkaar kunnen compenseren of juist verergeren. Bijvoorbeeld, ontslagbescherming leidt ertoe dat laagproductieve banen inefficiënt blijven bestaan, terwijl een minimumloon of werkloosheidsuitkering precies het tegenovergestelde doet: laagproductieve banen worden vernietigd terwijl ze nog efficiënt zijn. Dit betekent dat ontslagbescherming de negatieve gevolgen van een minimumloon of werkloosheidsuitkering in termen van efficiëntie zou kunnen compenseren. Blanchard en Tirole (2004a en 2004b) laten zien dat een positieve ontslagbelasting optimaal is.

Cahuc en Zylberberg (1999) concluderen dat twee landen met verschillende niveaus van ontslagbescherming dezelfde omvang van baanvernietiging zouden kunnen hebben als hun niveaus van minimumlonen verschillen. Ze laten ook zien dat het effect van ontslagbescherming, en in het bijzonder van ontslagvergoedingen, sterk afhangt van de flexibiliteit van lonen (zie Lazear 1990). Minimumlonen, bijvoorbeeld, maken het onmogelijk voor werknemers om lagere lonen te accepteren in ruil voor ontslagbescherming. In hun model heeft de ontslagvergoeding een negatief effect op baanreallocatie (baancreatie en baanvernietiging) als er een bindend minimumloon bestaat.

Bertola en Rogerson (1997) beargumenteren dat het systeem van loononderhandelingen deels kan compenseren voor de negatieve effecten van ontslagbescherming op arbeidsreallocatie en baanreallocatie. In landen waar loononderhandelingen meer gecentraliseerd zijn, hebben de bedrijven minder ruimte om zich aan te passen in het geval van economische schokken. Ze kunnen de lonen niet verlagen en moeten daarom relatief meer mensen ontslaan dan in landen waar lonen flexibel zijn (zoals in de Verenigde Staten). Hun argument is dat dit zou kunnen verklaren waarom de omvang van baanreallocatie vergelijkbaar is tussen Europese landen en de vs. Echter, dit argument is in strijd met het argument van Blanchard en Portugal (2001) en Wolfers (2004), die wel laten zien dat de omvang van baanreallocatie over een jaarkwartaal aanzienlijk lager is in landen waar ontslagbescherming groter is. De twee argumenten kunnen misschien gecombineerd worden als we veronderstellen dat bedrijven ook beperkt zijn om op korte termijn de werkgelegenheid aan te passen. Dit komt terug bij het argument van Bentolila en Bertola (1990) wanneer ze laten zien dat de werkgelegenheid minder in recessies en booms fluctueert wanneer ontslagbescherming groot is. 
Ten slotte, Freeman (1996) stelt dat de combinaties van instituties de oorspronkelijke functie van die instituties teniet kunnen doen. Hij concludeert dat het minimumloon negatieve gevolgen kan hebben voor de laagbetaalde bevolking wanneer de omvang van reallocatie klein is, en wanneer de gemiddelde werkloosheidsduur lang is. Het minimumloon offert een deel van de laagbetaalde bevolking op om daarmee hun totale inkomsten te verhogen. De laagbetaalde bevolking wordt dan verdeeld in 'gelukkige winnaars', die wel aan een baan komen en 'ongelukkige verliezers', die niet aan een baan komen. De inkomstenwinsten worden alleen verdeeld over de laagbetaalde bevolking wanneer de mobiliteit op de arbeidsmarkt hoog is. Wanneer de mobiliteit laag is, dus wanneer de omvang van reallocatie klein is, zou het minimumloon wel langdurige negatieve effecten hebben voor een gedeelte van de laagbetaalde bevolking. Dit suggereert dat minimumlonen wellicht een belangrijke herverdelingsfunctie vervullen, maar niet vallen te combineren met andere rigiditeiten.

\subsubsection{INSTITUTIES, ARBEIDSMARKTDYNAMIEK EN WELVAART}

Instituties beïnvloeden de arbeidsmarktdynamiek en kunnen leiden tot een inefficiënte allocatie van economische middelen: door ontslagbescherming blijven laagproductieve banen op een inefficiënte wijze bestaan. Werkloosheidsuitkeringen verminderen de prikkels voor werklozen om een baan te zoeken. Het minimumloon verhindert de creatie van laagproductieve banen. Het is daarom verleidelijk om te concluderen dat minder instituties en meer arbeidsflexibiliteit wenselijk zijn. Die conclusie is echter voorbarig. Ten eerste is het niet duidelijk dat meer reallocatie beter is dan minder. Meerdere studies laten bijvoorbeeld zien dat ontslagbescherming vooral kortetermijnfluctuaties vermindert, wat suggereert dat het effect van ontslagbescherming op het dynamische proces van creatieve destructie niet noodzakelijkerwijs negatief is. Ten tweede zijn deze instituties ontworpen met een specifiek doel en zouden zelfs welvaartsverbeterend kunnen zijn. In een wereld met imperfecties vervullen deze instituties een functie, tenminste in de tijd waarin ze ontworpen zijn. Sommige instituties treden op als second-best om deze imperfecties te corrigeren. Ten slotte, deze instituties corresponderen met maatschappelijke keuzes die ooit zijn gemaakt. De politieke economie die achter het ontstaan van instituties zit, is door de literatuur bestudeerd (zie Saint-Paul 200o). We concentreren ons op de welvaartstheoretische beschouwingen.

De arbeidsmarktliteratuur onderscheidt twee redenen waarom instituties welvaartsverbeterend kunnen zijn. Ten eerste in het geval van externe maatschappelijke effecten wanneer de maatschappelijke waarde van een baan hoger is dan de private waarde. Ten tweede wanneer instituties als second-best instrumenten optreden in een wereld met imperfecties. Er is sprake van positieve externe maatschappelijke effecten wanneer de maatschappelijke waarde van een baan hoger is dan zijn private waarde (de waarde voor de werkgever en werknemer). Werkgevers en werknemers houden geen rekening met de additionele maatschappelijke effecten (externe effecten) in hun beslissingen. Reallocatiebe- 
slissingen zijn daarom inefficiënt. Blanchard en Tirole (2004a en 2004b) beargumenteren dat zonder ontslagbescherming er vanuit een maatschappelijk uitzicht te veel mensen worden ontslagen. Dit komt omdat werkgevers geen rekening houden met de maatschappelijke kosten van werkloosheid. Om dit te voorkomen zou een positieve belasting op ontslag optimaal zijn. Ze bediscussiëren zelfs een systeem waarin bedrijven de kosten van de werkloosheidsuitkeringen betalen een zogenoemd 'experience-rating' systeem, zoals in de Verenigde Staten. Nederland heeft een soortgelijk systeem ingevoerd voor de WAO-regelingen. Bedrijven moeten nu meebetalen aan de kosten. Een ander voorbeeld van maatschappelijke externe effecten is wanneer er een herverdelingssysteem bestaat. Lonen worden belast en de belastingen worden gebruikt om bijvoorbeeld werkloosheidsuitkeringen te financieren. Werkgevers en werknemers hechten geen waarde aan het belaste gedeelte, en kijken alleen naar nettowinsten en lonen. Belot et al. (2002) laten zien dat in deze context de ontslagbeslissingen ook inefficiënt zijn. Banen worden vernietigd terwijl ze nog een positieve maatschappelijke waarde hebben. Wederom, ontslagbescherming vermindert deze inefficiëntie.

Arbeidsmarktinstituties kunnen ook imperfecties op de arbeidsmarkt corrigeren en zo leiden tot welvaartsverbetering. We bespreken drie belangrijke imperfecties op de arbeidsmarkt en laten zien hoe instituties deze imperfecties kunnen corrigeren. De eerste belangrijke imperfectie betreft de verzekerbaarheid van werkloosheid. Werknemers kunnen zich om verschillende redenen moeilijk verzekeren tegen inkomensfluctuaties. De financiële markten hebben geen perfecte informatie over de kwaliteit van de werknemers en kunnen het gedrag van werklozen moeilijk monitoren (bijvoorbeeld hoe hard ze zoeken naar een andere baan). In deze context is een systeem van publieke werkloosheidsuitkeringen en ontslagvergoedingen optimaal (zie Pissarides 2001; Blanchard en Tirole 2004). De tweede belangrijke imperfectie is de imperfecte informatie over bestaande vacatures en werklozen. Werkgevers en werknemers moeten naar elkaar zoeken en elkaar vinden. Het kost tijd om een geschikte baan te vinden. Acemoglu en Shimer (1998) laten zien dat werkloosheidsuitkeringen tot positieve welvaartseffecten kunnen leiden, omdat werklozen kieskeuriger kunnen zijn in hun keuze van een baan. Bedrijven zullen daarop reageren en hogere productiviteitsbanen creëren. De gemiddelde productiviteit van nieuwe matches wordt daardoor verhoogd. De derde belangrijke imperfectie betreft de contracteerbaarheid van specifieke investeringen. Specifieke investeringen verhogen de productiviteit van een baan. Echter, als deze investeringen niet contracteerbaar zijn, omdat ze moeilijk te observeren zijn (denk bijvoorbeeld aan de inspanning van de werknemer), bestaat de kans dat degene die de kosten van de investering draagt de vruchten ervan niet zal plukken. Belot et al. (2002) laten zien dat ontslagbescherming welvaartsverhogend kan zijn indien specifieke investeringen worden gestimuleerd. Het effect op specifieke investeringen domineert bij lage niveaus van ontslagbescherming, terwijl het negatieve effect op baancreatie domineert bij hoge niveaus van ontslagbescherming. 


\subsection{PERSPECTIEF OP INSTITUTIES EN DYNAMIEK}

De vraag die in dit preadvies centraal staat is of het systeem van Nederlandse arbeidsmarktinstituties robuust is, in het bijzonder of het systeem bestand is tegen een toenemende dynamiek en een vergrijzende beroepsbevolking. Het gaat hierbij om vier belangrijke arbeidsmarktinstituties: werkgelegenheidsuitkeringen, ontslagbescherming, minimumloon en actief arbeidsmarktbeleid. Deze instituties oefenen elk een eigen invloed uit op het functioneren van de arbeidsmarkt, en kunnen daarnaast in verschillende combinaties andersoortige effecten hebben. Het preadvies is gebaseerd op internationale vergelijking van arbeidsmarktinstituties en arbeidsmarktpresentaties en een inventarisatie van relevante theoretische en empirische literatuur.

Arbeidsmarktinstituties vervullen een belangrijke functie. Ze kunnen mobiliteit en flexibiliteit verminderen, maar het is niet zonder meer duidelijk dat dit altijd negatief beoordeeld moet worden. De vormgeving van instituties speelt een belangrijke rol bij het minimaliseren van de negatieve effecten op reallocatie en creatieve destructie.

Vanuit een dynamisch perspectief is het minimumloon de minst relevante institutie. De invloed van het minimumloon op het niveau van de werkgelegenheid is al onduidelijk en ten aanzien van de invloed op de dynamiek is dit niet veel beter. Bovendien is het minimumloon relevant voor een beperkt deel van de arbeidsmarkt, zowel kwantitatief als kwalitatief. Werkloosheidsuitkeringen en ontslagbescherming zijn van meer belang, terwijl de rol van het actieve arbeidsmarktbeleid vooral faciliterend is.

We concluderen dat ontslagbescherming een negatief effect heeft op de stromen tussen werkloosheid en werkgelegenheid en leidt tot meer langdurige werkloosheid. Op korte termijn leidt ontslagbescherming tot minder reallocatie, maar op het langetermijnproces van baancreatie en baanvernietiging ('creatieve destructie') lijkt de invloed beperkt te zijn. Werkloosheidsuitkeringen hebben vooral een negatief effect op baancreatie door hun negatief effect op het zoekgedrag van werklozen. Vooral waar het gaat om de duur van de uitkeringen in relatie tot de leeftijd van de werklozen neemt Nederland een uitzonderingspositie in. Tegen de achtergrond van de vergrijzende beroepsbevolking kan het wenselijk zijn de lange duur van de werkloosheidsuitkeringen kritisch te bezien. Tot slot kan actief arbeidsmarktbeleid behulpzaam zijn bij het sneller terugbrengen van werklozen naar een reguliere baan indien dit wordt ondersteund door een actief sanctiebeleid. 


\section{NOTEN}

1

2

In deze netto-nettomaatstaf zijn ook andere uitkeringen zoals huursubsidies verdisconteerd.

Bedrijven die ontstaan of verdwijnen worden buiten beschouwing gelaten. Hierbij dient opgemerkt te worden dat de informatie voor Zweden afkomstig is uit een betrekkelijk korte periode toen er een sterke economische groei was in Zweden.

Een voorbeeld kan dit verduidelijken. Indien er twee bedrijven A en B zijn en er in het eerste half jaar bij bedrijf $\mathrm{A} 1$ werknemer wordt aangenomen en in bedrijf $\mathrm{B}$ 1 werknemer wordt ontslagen, dan is de baanreallocatie in het eerste half jaar gelijk aan 2. Indien vervolgens in het tweede half jaar bij bedrijf A 1 werknemer wordt ontslagen en in bedrijf $\mathrm{B} 1$ werknemer wordt aangenomen, dan is de baanreallocatie in het tweede half jaar gelijk aan 2. Indien we zouden meten over het gehele jaar, dan is de werkgelegenheid constant zowel in bedrijf $\mathrm{A}$ als in bedrijf $\mathrm{B}$ en zou de baanreallocatie gelijk aan nul zijn.

5 Canada en vs: 1973-1986, Denemarken: 1980-1991 en 1995, Nederland: 1975199o, Duitsland: 1984-1989, Italië: 1987-1989, Noorwegen: 1976-1992.

6 Hamermesh, Hassink en Van Ours (1996) presenteren interessante informatie over de arbeidsdynamiek binnen bedrijven in Nedeland (ze gebruiken informatie over twee jaren: 1988 en 1990) en komen tot de volgende conclusies.

1) Bedrijven die zich uitbreiden ontslaan ook mensen, en bedrijven die inkrimpen nemen ook nieuwe mensen aan. De veranderingen in nettowerkgelegenheid op bedrijfsniveau weerspiegelen maar een gedeelte van de totale mobiliteit van werknemers.

2) Tweederde van de banen waar werknemers ontslagen worden blijven bestaan en worden ingevuld door nieuwe werknemers. Weinig nieuwe werknemers worden aangenomen in nieuwe functies.

3) Interne mobiliteit is laag: de meeste werknemers komen op hun functie van buiten het bedrijf.

Zie OECD Employment Outlook 2004, tabel 2.2, blz. 79. 


\section{LITERATUUR}

Acemoglu, D. en R. Shimer (200o) Productivity gains from unemployment insurance, European Economic review 44: 1195-1224.

Belot, M. en J.C. van Ours (2001) Unemployment and labour market institutions: an empirical analysis, Journal of Japanese and International Economies, 15, 4: 403-418.

Belot, M. en J.C. van Ours (2004) Does the recent success of some OECD countries in lowering their unemployment rates lie in the clever design of their labour market reforms?, Oxford Economic Papers 56: 621-642.

Belot, M., J. Boone en J.C. van Ours (2002) Welfare improving employment protection, CentER, Universiteit van Tilburg, Discussion Paper CentER, nr. 2002-2048.

Bentolila, S. en G. Bertola (1990) Firing costs and labour demand: How bad is Eurosclerosis? Review of Economic Studies 57: 381-402.

Bertola, G. en R. Rogerson (1997) Institutions and labour reallocation, European Economic Review 41, 6: 1147-1171.

Bertola, G. (2004) Labor market institutions in a changing world, Moneda y Credito 218: 61-8.

Blanchard, O. en J. Tirole (2004a) Redesigning the employment protection system, De Economist 152, 1: 1-20.

Blanchard, O. en J. Tirole (2004b) The optimal design of unemployment insurance and employment protection: A First Pass, MIT Department of Economics Working Paper, nr. 04-15.

Blanchard, O. en J. Wolfers (200o) The role of shocks and institutions in the rise of European unemployment: The aggregate evidence, Economic Journal 110: 1-33.

Blanchard, O. en P. Portugal (2001) What hides behind an unemployment rate: Comparing Portuguese and us labor markets, American Economic Review 91, 1: 187-207.

Boone, J. en J.C. van Ours (200o) Modeling financial incentives to get unemployed Back To Work, CEPR Discussion Papers 2361.

Boone, J. en J.C. van Ours (2004) Efficient active labor market policies, CEPR Discussion Papers 4708.

Burda, M. (1988) Wait unemployment in Europe, Economic Policy 7: 391-426.

Burgess, S., J. Lane en D. Stevens (2000) Job flows, worker flows and churning, Journal of Labor Economics 18, 3: 473-502.

Cahuc, P. en A. Zylberberg (1999) Job protection, minimum wage and unemployment, IZA Discussion Paper, nr. 95.

Calmfors (1994) Active labour market policy and unemployment - A framework for the analysis of crucial design features, OECD Economic Studies, nr. 22.

Coe, D. en D. Snower (1997) Policy complementarities: the case for fundamental labour market reform, CEPR Discussion Paper 1585.

Dolado J.J., F. Kramarz, S. Machin, A. Manning, D. Margolis en C. Teulings (1996) The economic impact of the minimum wages, Economic Policy 23: 319-370.

Dolado J.J., F. Felgueroso en J.F. Jimeno (2002) The role of the minimum wage in the welfare state: an appraisal, Swiss Journal of Economics and Statistics 136: 1-33.

Fredriksson, P. en B. Holmlund (2003) Improving incentives in unemployment insurance: A review of recent research, IFAU Working Paper 2003: 5. 
Freeman, R. (1996) The minimum wage as a redistributive tool, Economic Journal 106, 436: 639-649.

Garibaldi, P., J. Konings en C. Pissarides (1997) Gross job reallocation and labour market Policy, in Snower, Dennis and Guillermo de la Dehesa, Unemployment Policy, Cambridge University Press.

Gielen, A.C. en J.C. van Ours (2004) Age-specific cyclical effects in job reallocation and labor mobility, mimeo.

Grubb, D. (2000) Eligibility criteria for unemployment benefits, OECD Economic Studies, nr. 31 .

Gómez-Salvador, R., J. Messina en G. Vallanti (2004) Gross job flows and institutions in Europe, Labour Economics 11: 469-485.

Hamermesh, D.S., W.H.J. Hassink en J.C. van Ours (1996) Job turnover and labor turnover: A taxonomy of employment dynamics, Annales d'economie et de Statistique 41/42: 21-40.

Heckman J., R. LaLonde en J. Smith (1999) The economics and econometrics of active labor market programs, in Handbook of Labor Economics, Eds O. Ashenfelter en Card D., Volume 3A, North-Holland.

Kluve, J. en C.M. Schmidt (2002) Can training and employment subsidies combat European unemployment?, Economic Policy, 410-448.

Koning, J. de, J.H. Gravesteijn-Ligthelm, N. 't Hoen en A. Verkaik (1992) Does the KRA work properly? An interim review and monitoring KRA 1991, Centraal Bestuur Arbeidsvoorziening, OAV-report 92-o9, Rijswijk.

Layard, R. en S. Nickell (1999), Labor market institutions and economic performance, in Handbook of Labor Economics, Eds O. Ashenfelter en Card D., Volume 3A, North-Holland.

Lazear, E.P. (1990) Job security provisions and employment, Quarterly Journal of Economics, $699-726$.

Martin, J.P. (2000) What works among active labour market policies: evidence from OECD countries experience, OECD Economic Studies, 30.

Ministerie van Sociale Zaken en Werkgelegenheid (2004) Toekomstverkenning WW, Den Haag.

Mortensen, D.T. en C. Pissarides (1999) New developments in models of search in the labor market, in Ashenfelter, O. en D. Card, Handbook of Labor Economics, Amsterdam, North-Holland, 2567-2627.

Neumark, D. en W. Wascher (2003) Minimum wages, labor market institutions and youth unemployment: a cross-national analysis, no. 2003-23, Finance and Economics Discussion Series from Board of Governors of the Federal Reserve System.

Nickell, S.J., L. Nunziata en W. Ochel (2005) Unemployment in the OECD since the 1960s; what do we know?, Economic Journal, forthcoming.

OECD (1996) Employment Outlook, Paris 1996.

OECD (2002) Employment Outlook, Paris 2002.

OECD (2004) Employment Outlook, Paris 2004.

Pissarides, C.A. (2001) Employment protection, Labour Economics 8, 2: 131-159.

Saint-Paul, G. (2000) The political economy of labour market institutions, Oxford: Oxford University Press. 
Salvanes, K.G. (1997) Market rigidities and labour market flexibility: an international comparison, Scandinavian Journal of Economics 99, 2: 315-333.

Scarpetta, S., P. Hemmings, T. Tressel en J. Woo (2002) The role of policy and institutions for productivity and firm dynamics: Evidence from micro and industry data, OECD Economics Department Working Paper, no. 329.

Van den Berg, G., B. van der Klaauw en J.C. van Ours (2004) Punitive sanctions and the transition rate from welfare to work, Journal of Labor Economics 22, 1: 211-210.

Wolfers, J. (2004) Employment protection and job flows: Evidence from seasonal cycles, Mimeo. 


\section{BIJLAGE 6.1:}

\section{DETAILS OVER DE OECD-ONTSLAGBESCHERMINGSINDEX}

De constructie van de ontslagbeschermingsindex is gebaseerd op 18 indicatoren: 8 indicatoren voor individueel ontslag van werknemers met een regulier contract, 6 indicatoren voor tijdelijk werk en 4 indicatoren voor collectief ontslag. De indicatoren zijn de volgende.

- Indicatoren individueel ontslag werknemers met regulier contract: aanzeggingsprocedure, periode voordat aanzegging kan beginnen, duur van de aanzeggingprocedure, ontslagbetaling, definitie van (on)gerechtvaardigd ontslag, duur van de proefperiode, compensatie in geval van ongerechtvaardigd ontslag, mogelijkheid van indienstneming na ongerechtvaardigd ontslag.

- Indicatoren voor tijdelijk werk: voorwaarden voor aanstelling met bepaalde duur, maximum aantal opeenvolgende tijdelijke contracten, maximum gecumuleerde duur opeenvolgende tijdelijke contracten, typen arbeid waarvoor gebruik van uitzendbureaus legaal is, wel of geen restricties op aantal vernieuwingen, maximum gecumuleerde duur van uitzendarbeid.

- Indicatoren voor collectief ontslag: definitie collectief ontslag, aanvullende eisen aan ontslagaanzegging, aanvullende vertraging alvorens aanzegging kan beginnen, overige speciale kosten voor werkgevers. 


\section{OVER DE AUTEURS}

Mr. A. Baris is promovenda bij de Juridische faculteit van de Universiteit van Amsterdam. Het onderwerp van haar dissertatie is 'De grondslag van de ontslagvergoeding'.

Dr. M.V.K. Belot is als lecturer verbonden aan de Economische faculteit van de Universiteit van Essex. Zij promoveerde in 2003 aan de Universiteit van Tilburg.

Drs. A. Gelderblom is onderzoeker en projectleider bij SEOR, onderzoeksbureau op sociaal-economisch gebied voor de Erasmus Universiteit Rotterdam.

Prof. dr. J. de Koning is directeur bij SEOR, onderzoeksbureau op sociaal-economisch gebied voor de Erasmus Universiteit Rotterdam.

Dr. M.J.S.M. van der Meer is als universitair hoofddocent verbonden aan het Amsterdams Instituut voor ArbeidsStudies. Tevens is hij projectleider bij het Centrum voor Sociale Innovatie.

Prof. dr. J.C. van Ours is hoogleraar aan de faculteit Economie en Bedrijfswetenschappen, Universiteit van Tilburg.

Dr. D. Scheele is wetenschappelijk medewerker van de Wetenschappelijke Raad voor het Regeringsbeleid.

Mr. A. S.M.I.B. Vandenberghe is gepromoveerd op de economische analyse van het contractenrecht toegepast op arbeidsovereenkomsten. Momenteel is zij werkzaam aan de Utrecht School of Economics.

Prof. mr. E. Verhulp is hoogleraar aan de Universiteit van Amsterdam, faculteit der Rechtsgeleerdheid.

Prof. dr. J. Visser is wetenschappelijk directeur en hoogleraar Empirische Sociologie aan het Amsterdams Instituut voor ArbeidsStudies.

Dr. G.J.M. de Vries is wetenschappelijk medewerker van de Wetenschappelijke Raad voor het Regeringsbeleid.

Prof. dr. J.J.M. Theeuwes is raadslid van de Wetenschappelijke Raad voor het Regeringsbeleid. Tevens is hij directeur van SEO Economisch Onderzoek en hoogleraar aan de Universiteit van Amsterdam. 


\section{RAPPORTEN AAN DE REGERING}

\section{Eerste raadsperiode (1972-1977)}

Europese Unie

2 Structuur van de Nederlandse economie

3 Energiebeleid

Gebundeld in één publicatie (1974)

$4 \quad$ Milieubeleid (1974)

5 Bevolkingsgroei (1974)

6 De organisatie van het openbaar bestuur (1975)

7 Buitenlandse invloeden op Nederland: Internationale migratie (1976)

8 Buitenlandse invloeden op Nederland: Beschikbaarheid van wetenschappelijke en technische kennis (1976)

9 Commentaar op de Discussienota Sectorraden (1976)

10 Commentaar op de nota Contouren van een toekomstig onderwijsbestel (1976)

11 Overzicht externe adviesorganen van de centrale overheid (1976)

12 Externe adviesorganen van de centrale overheid (1976)

13 Maken wij er werk van? Verkenningen omtrent de verhouding tussen actieven en niet-actieven (1977)

14 Interne adviesorganen van de centrale overheid (1977)

15 De komende vijfentwintig jaar - Een toekomstverkenning voor Nederland (1977)

16 Over sociale ongelijkheid - Een beleidsgerichte probleemverkenning (1977)

Tweede raadsperiode (1978-1982)

17 Etnische minderheden (1979)

A. Rapport aan de Regering

B. Naar een algemeen etnisch minderhedenbeleid?

18 Plaats en toekomst van de Nederlandse industrie (1980)

19 Beleidsgerichte toekomstverkenning

Deel 1: Een poging tot uitlokking (1980)

Democratie en geweld. Probleemanalyse naar aanleiding van de gebeurtenissen in Amsterdam op 30 april 1980

21 Vernieuwingen in het arbeidsbestel (1981)

22 Herwaardering van welzijnsbeleid (1982)

23 Onder invloed van Duitsland. Een onderzoek naar gevoeligheid en kwetsbaarheid in de betrekkingen tussen Nederland en de Bondsrepubliek (1982)

Samenhangend mediabeleid (1982)

\section{Derde raadsperiode (1983-1987)}

Beleidsgerichte toekomstverkenning

Deel 2: Een verruiming van perspectief (1983)

Waarborgen voor zekerheid. Een nieuw stelsel van sociale zekerheid in hoofdlijnen (1985)

27 Basisvorming in het onderwijs (1986)

28 De onvoltooide Europese integratie (1986)

Ruimte voor groei. Kansen en bedreigingen voor de Nederlandse economie in de komende tien jaar (1987)

Op maat van het midden- en kleinbedrijf (1987)

Deel 1: Rapport aan de Regering

Deel 2: Pre-adviezen 


\section{Vierde raadsperiode (1988-1992)}

35

Activerend arbeidsmarktbeleid (1987)

Rechtshandhaving (1988)

Allochtonenbeleid (1989)

Van de stad en de rand (1990)

Technologie en overheid (1990)

De onderwijsverzorging in de toekomst (1991)

\section{Vijfde raadsperiode (1993-1997)}

44 Duurzame risico's. Een blijvend gegeven (1994)

46 Besluiten over grote projecten (1994)

47 Hoger onderwijs in fasen (1995)

De financiering van de Europese Gemeenschap. Een interimrapport (1987)

Overheid en toekomstonderzoek. Een inventarisatie (1988)

Een werkend perspectief. Arbeidsparticipatie in de jaren '90 (1990)

Milieubeleid. Strategie, instrumenten en handhaafbaarheid (1992)

Grond voor keuzen. Vier perspectieven voor de landelijke gebieden in de Europese Gemeenschap (1992)

Ouderen voor ouderen. Demografische ontwikkelingen en beleid (1993)

45 Belang en beleid. Naar een verantwoorde uitvoering van de werknemersverzekeringen (1994)

48 Stabiliteit en veiligheid in Europa. Het veranderende krachtenveld voor het buitenlands beleid (1995)

49 Orde in het binnenlands bestuur (1995)

50 Tweedeling in perspectief (1996)

51 Van verdelen naar verdienen. Afwegingen voor de sociale zekerheid in de 21e eeuw (1997)

52 Volksgezondheidszorg (1997)

53 Ruimtelijke-ontwikkelingspolitiek (1998)

54 Staat zonder land. Een verkenning van bestuurlijke gevolgen van informatie- en communicatietechnologie (1998)

\section{Zesde raadsperiode (1998-2002)}

55 Generatiebewust beleid (1999)

56 Het borgen van publiek belang (2000)

57 Doorgroei van arbeidsparticipatie (2000)

58 Ontwikkelingsbeleid en goed bestuur (2001)

$59 \quad$ Naar een Europabrede Unie (2001)

60 Nederland als immigratiesamenleving (2001)

61 Van oude en nieuwe kennis. De gevolgen van ICT voor het kennisbeleid (2002)

62 Duurzame ontwikkeling. Bestuurlijke voorwaarden voor een mobiliserend beleid (2002)

63 De toekomst van de nationale rechtsstaat (2002)

64 Beslissen over biotechnologie (2003)

65 Slagvaardigheid in de Europabrede Unie (2003)

66 Nederland handelsland. Het perspectief van de transactiekosten (2003)

67 Naar nieuwe wegen in het milieubeleid (2003) 


\section{Zevende raadsperiode (2003-2007)}

Waarden, normen en de last van het gedrag (2003)

69 De Europese Unie, Turkije en de islam (2004)

70 Bewijzen van goede dienstverlening (2004)

71 Focus op functies. Uitdagingen voor een toekomstbestendig mediabeleid (2005)

72 Vertrouwen in de buurt (2005)

73 Dynamiek in islamitisch activisme. Aanknopingspunten voor democratisering en mensenrechten (2006)

$74 \quad$ Klimaatstrategie - tussen ambitie en realisme (2006)

75 Lerende overheid. Een pleidooi voor probleemgerichte politiek (2006)

76 De verzorgingsstaat herwogen. Over verzorgen, verzekeren, verheffen en verbinden (2006)

77 Investeren in werkzekerheid (2007)

Rapporten aan de Regering nrs $1 \mathrm{t} / \mathrm{m} 67$ en publicaties in de reeks Voorstudies en achtergronden zijn niet meer leverbaar. Alle studies van de WRR zijn beschikbaar via de website www.wrr.nl.

Rapporten aan de Regering nrs $68 \mathrm{t} / \mathrm{m} 77$ zijn verkrijgbaar in de boekhandel of via Amsterdam University Press, Herengracht 221, 1016 BC Amsterdam (www.aup.nl). 


\section{VERKENNINGEN}

\section{Zevende raadsperiode (2003-2007)}

1 Jacques Pelkmans, Monika Sie Dhian Ho en Bas Limonard (red.) (2003) Nederland en de Europese grondwet

2 P.T. de Beer en C.J.M. Schuyt (red.) (2004) Bijdragen aan waarden en normen

3 G. van den Brink (2004) Schets van een beschavingsoffensief. Over normen, normaliteit en normalisatie in Nederland

4 E.R. Engelen en M. Sie Dhian Ho (red.) (2004) De staat van de democratie. Democratie voorbij de staat

5 P.A. van der Duin, C.A. Hazeu, P. Rademaker en I.J. Schoonenboom (red.) (2004) Vijfentwintig jaar later. De Toekomstverkenning van de WRR uit 1977 als leerproces

6 H. Dijstelbloem, P.L. Meurs en E.K. Schrijvers (red.) (2004) Maatschappelijke dienstverlening. Een onderzoek naar vijf sectoren

7 W.B.H.J. van de Donk, D.W.J. Broeders en F.J.P. Hoefnagel (red.) (2005) Trends in het medialandschap. Vier verkenningen

8 G. Engbersen, E. Snel en A. Weltevrede (2005) Sociale herovering in Amsterdam en Rotterdam. Eén verhaal over twee wijken

9 D.J. Wolfson (2005) Transactie als bestuurlijke vernieuwing. Op zoek naar samenhang in beleid en uitvoering

10 Nasr Abu Zayd (2006) Reformation of Islamic Thought. A Critical Historical Analysis

11 J.M. Otto (2006) Sharia en nationaal recht. Rechtssystemen in moslimlanden tussen traditie, politiek en rechtsstaat

12 P.L. Meurs, E.K. Schrijvers en G.H. de Vries (red.) (2006) Leren van de praktijk. Gebruik van lokale kennis en ervaring voor beleid

13 W.B.H.J. van de Donk, A.P. Jonkers, G.J. Kronjee en R.J.J.M. Plum (red.) (2006) Geloven in het publieke domein. Verkenningen van een dubbele transformatie

Alle Verkenningen zijn verkrijgbaar in de boekhandel of via Amsterdam University Press, Herengracht 221, 1016 BG Amsterdam (www.aup.nl) 


\section{WEBPUBLICATIES}

\section{Zevende raadsperiode (2003-2007)}

WP 01 Opvoeding, onderwijs en jeugdbeleid in het algemeen belang

WP 02 Ruimte voor goed bestuur: tussen prestatie, proces en principe

WP 03 Lessen uit corporate governance en maatschappelijk verantwoord ondernemen

WP 04 Regulering van het bestuur van maatschappelijke dienstverlening: eenheid in verscheidenheid

WP 05 Een schets van het Europese mediabeleid

WP 06 De regulering van media in internationaal perspectief

WP 07 Beleid inzake media, cultuur en kwaliteit: enkele overwegingen

WP 08 Geschiedenis van het Nederlands inhoudelijk mediabeleid

WP 09 Buurtinitiatieven en buurtbeleid in Nederland anno 2004: analyse van een veldonderzoek van 28 casussen

WP 10 Geestelijke gezondheid van adolescenten: een voorstudie

WP 11 De transitie naar volwassenheid en de rol van het overheidsbeleid: een vergelijking van insitutionele arrangementen in Nederland, Zweden, Groot-Brittannië en Spanje

WP 12 Klassieke sharia en vernieuwing

WP 13 Sharia en nationaal recht in twaalf moslimlanden 